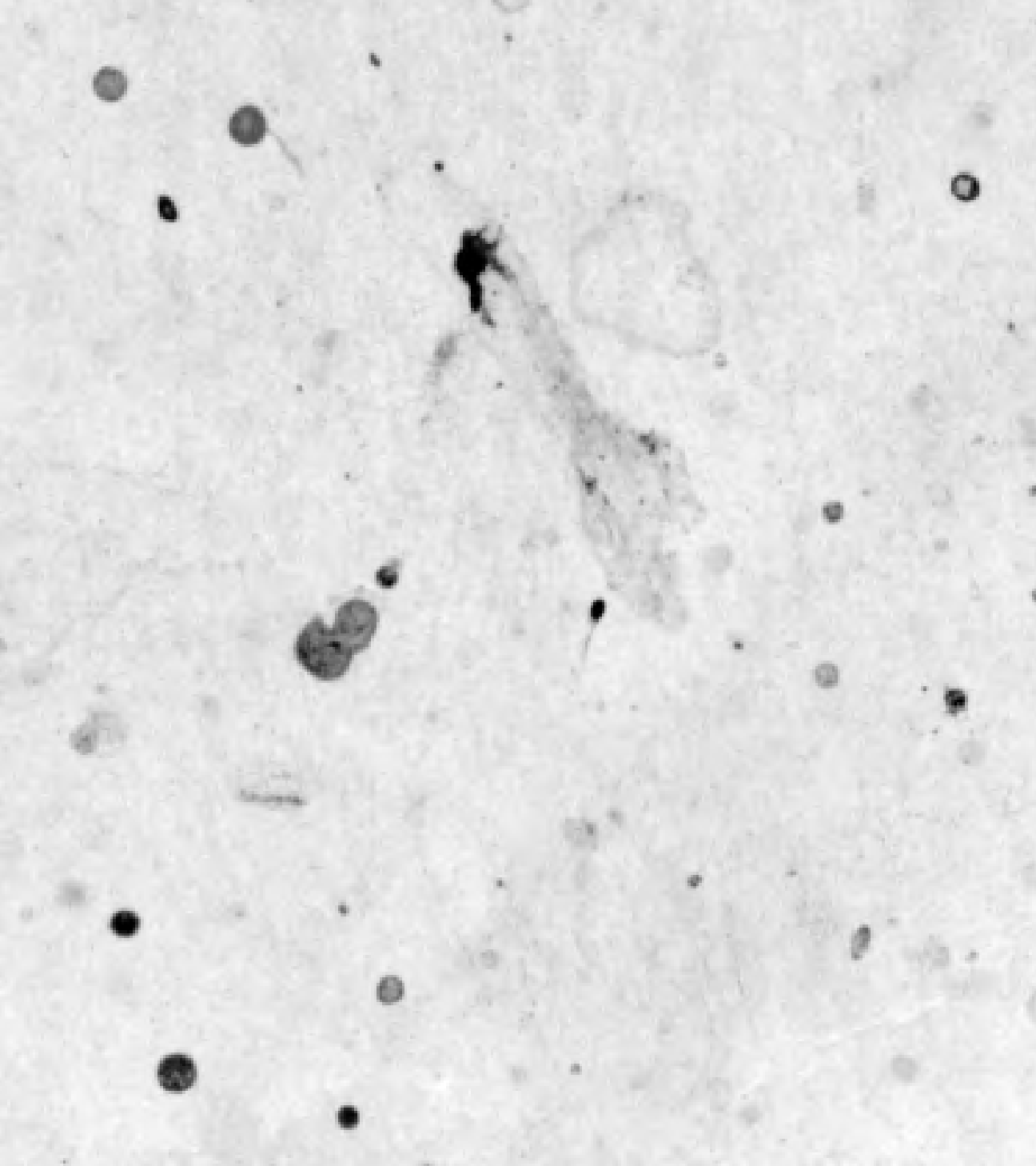

a if

ह3. त ?

$\rightarrow$

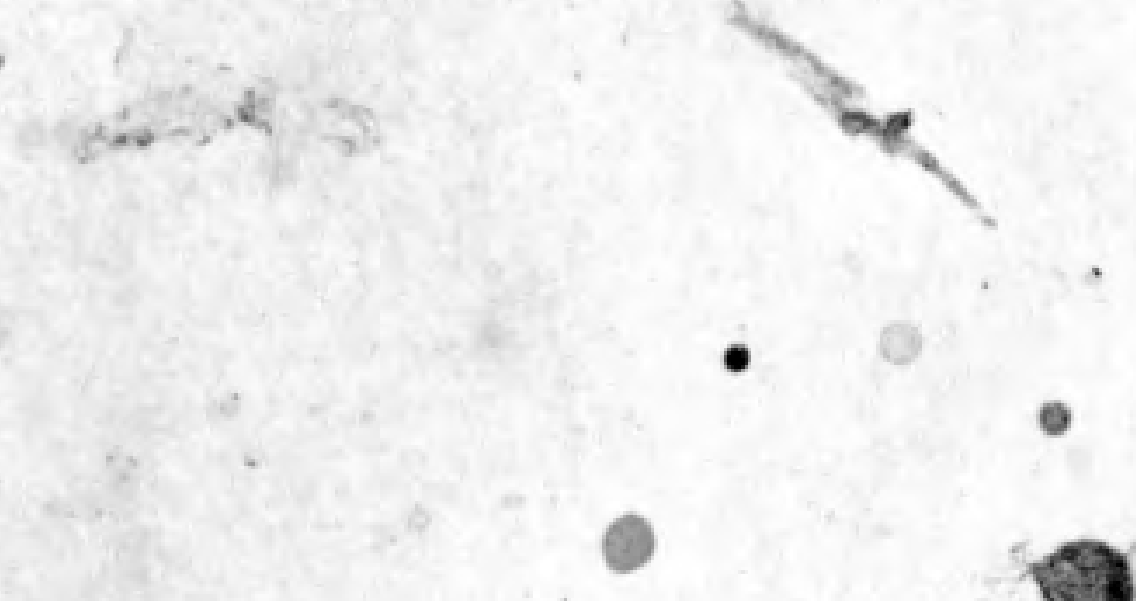

$\therefore$
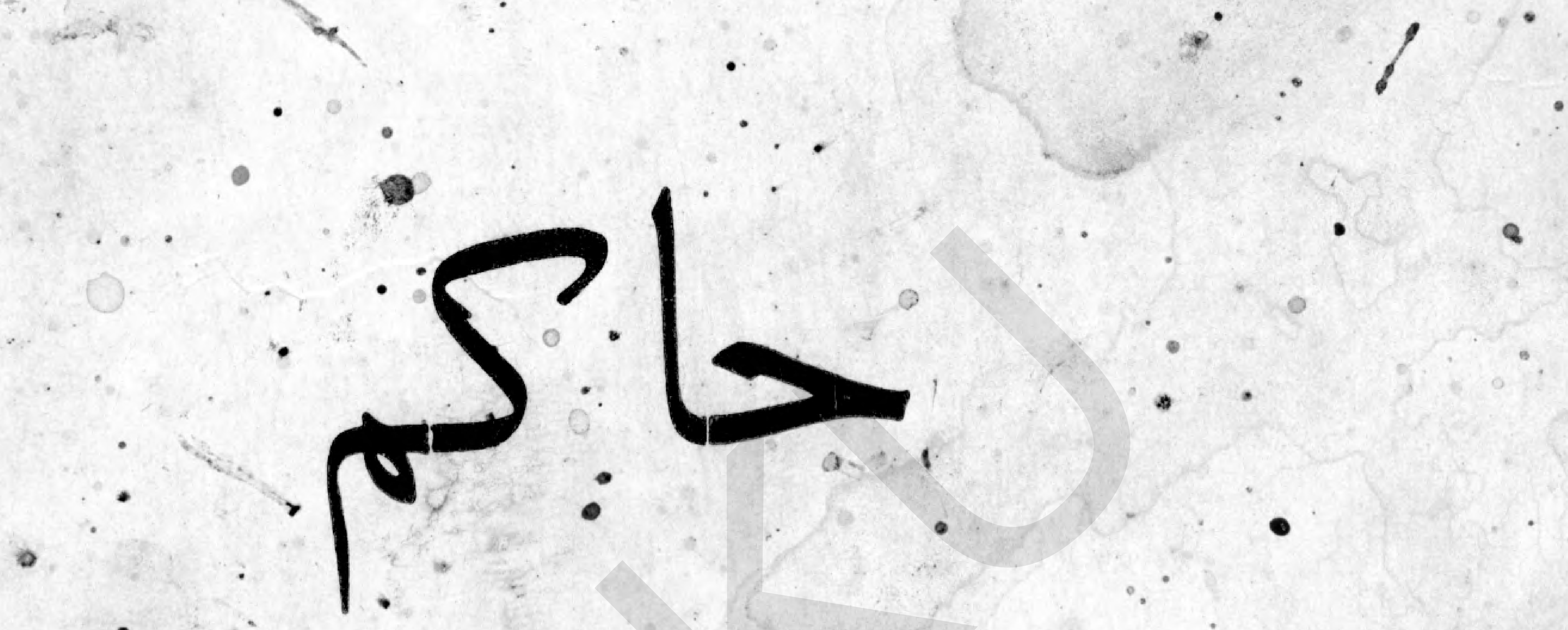

-

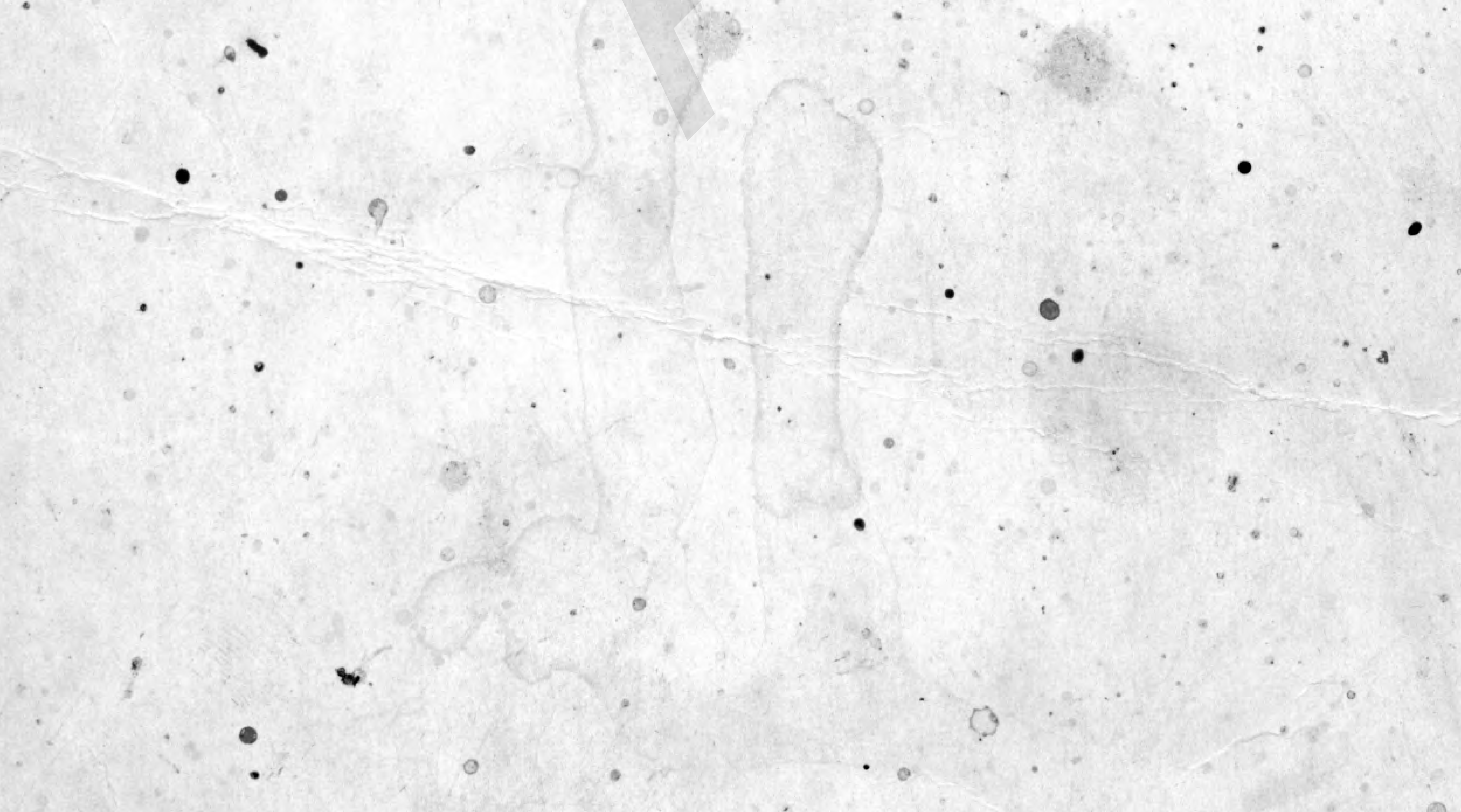

نويسله: محمد شفيع رهگذر 

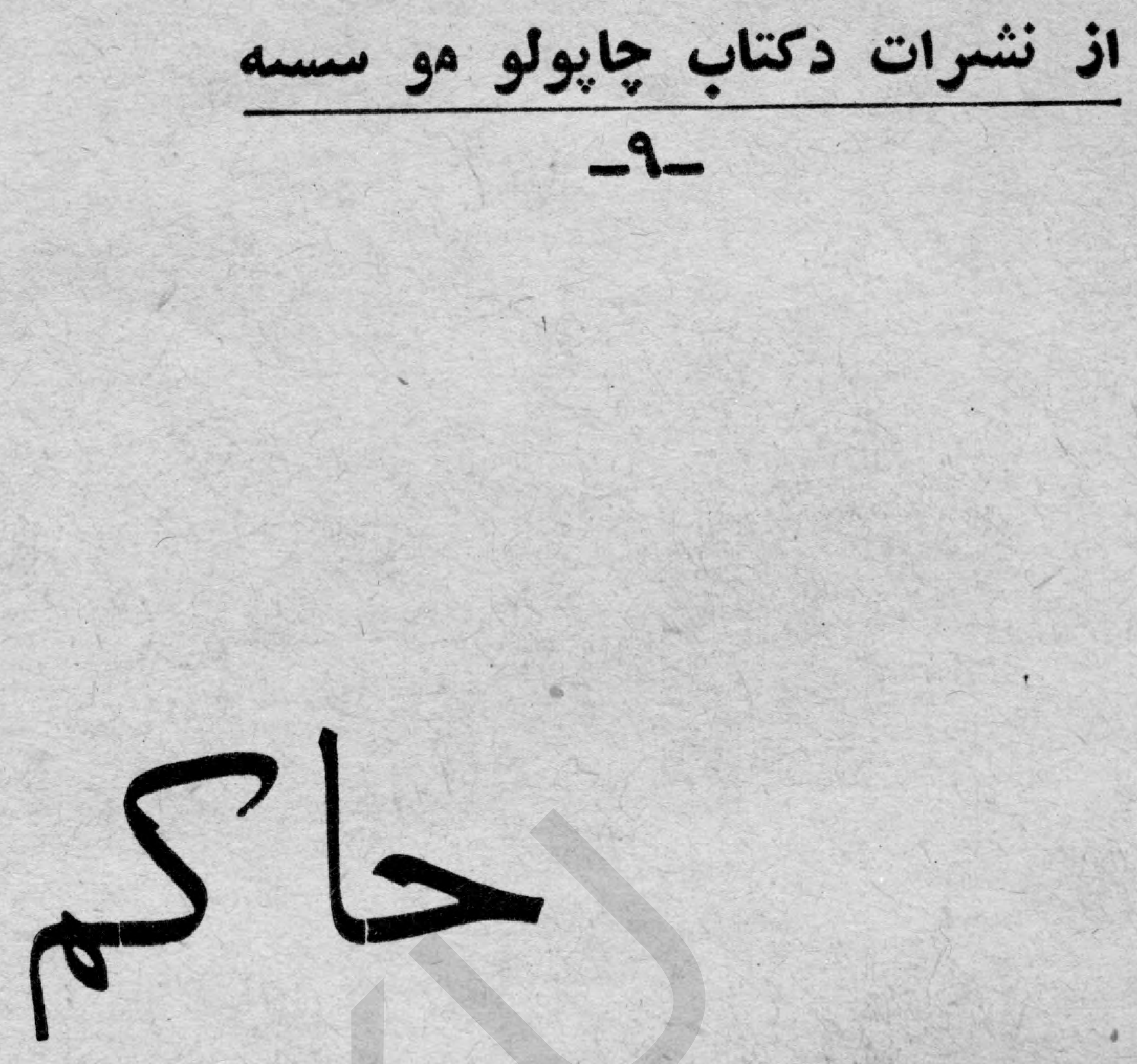

برندة جايزه ابنسينا سال عس

نويسنده : محمد شفيع "رهكذر)"

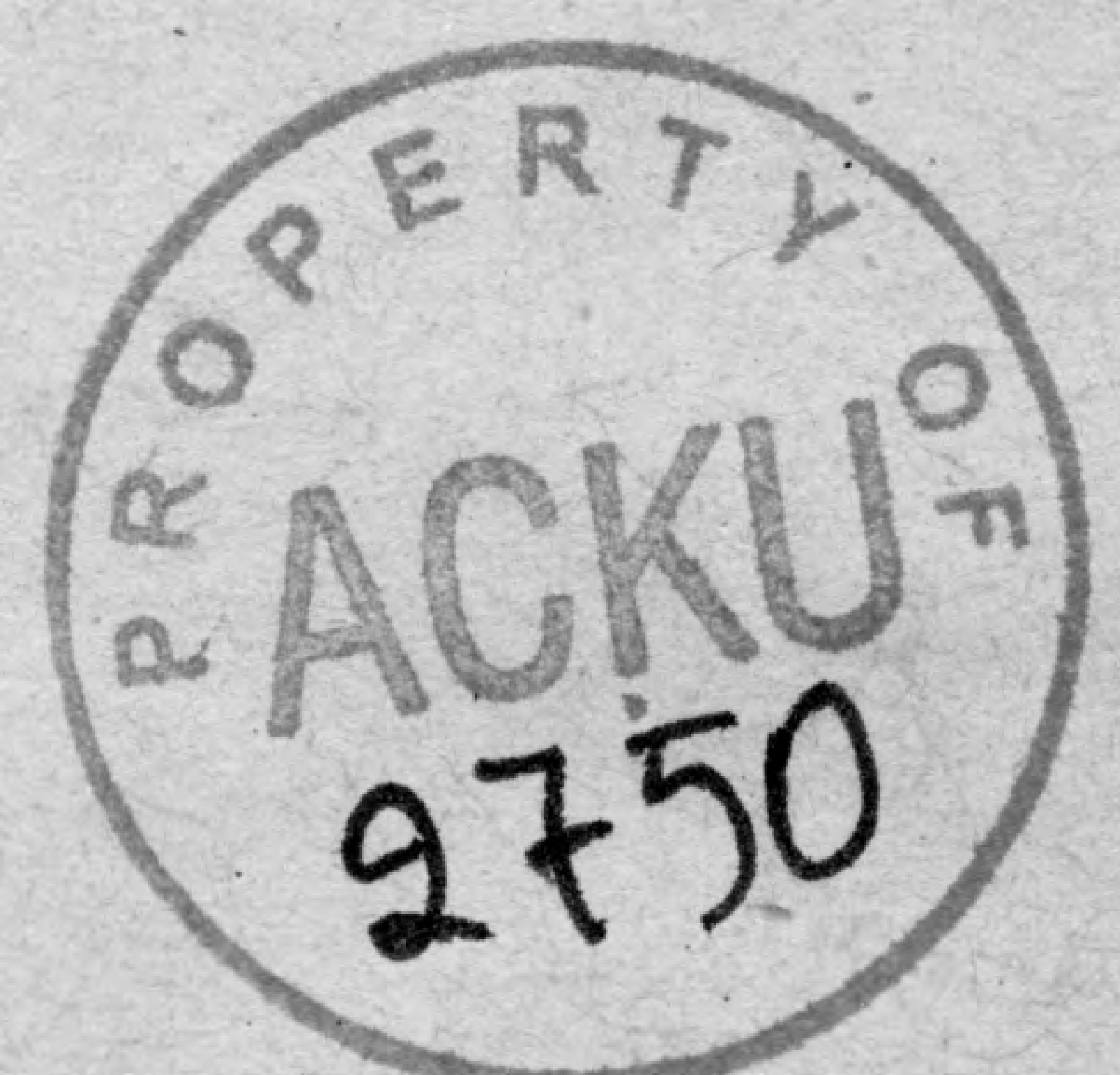

حمل

طبح دوم 


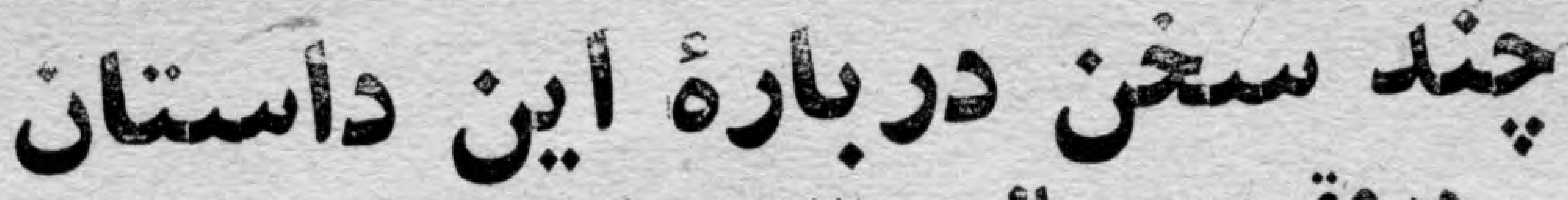

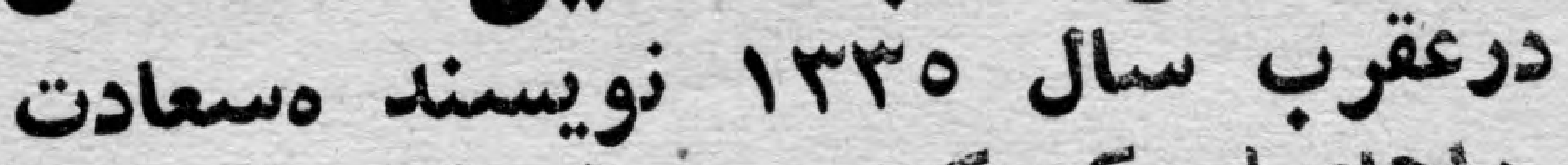

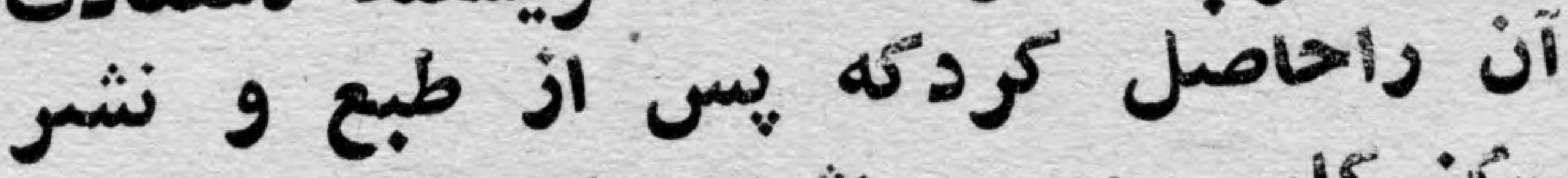

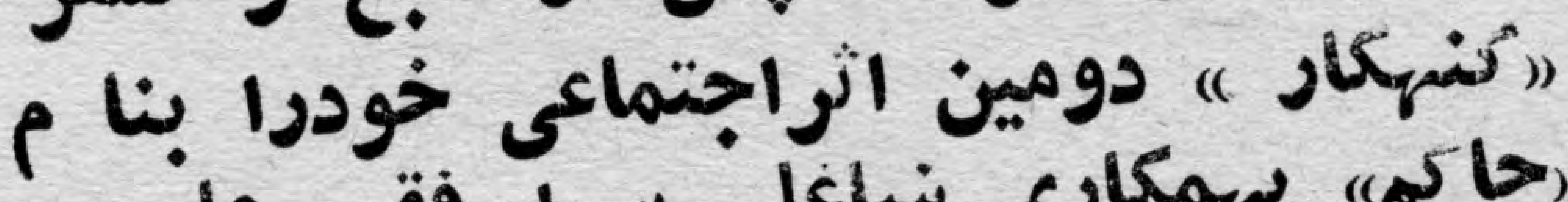

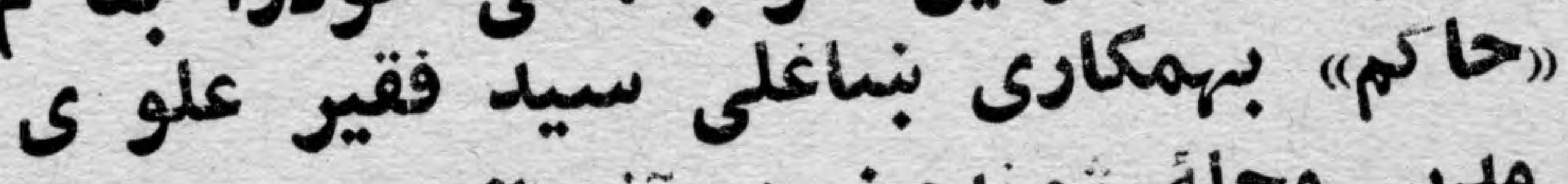

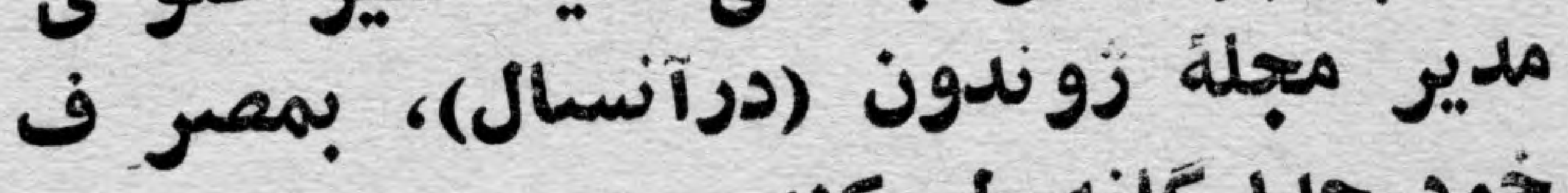

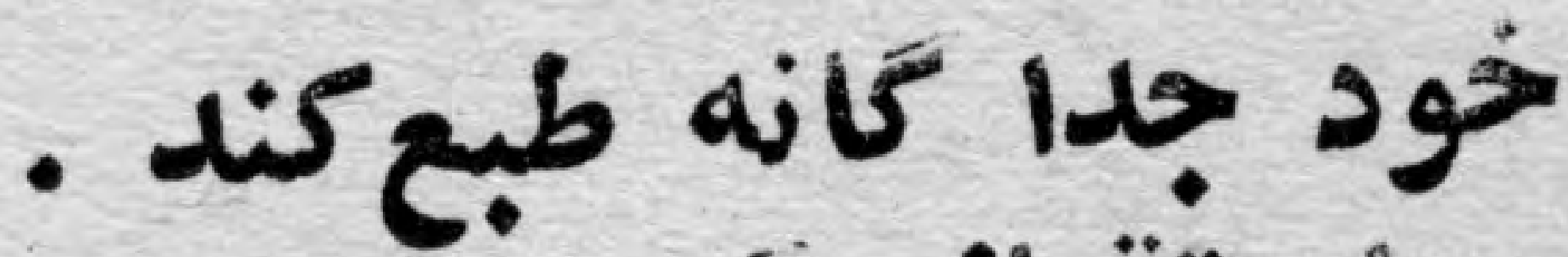

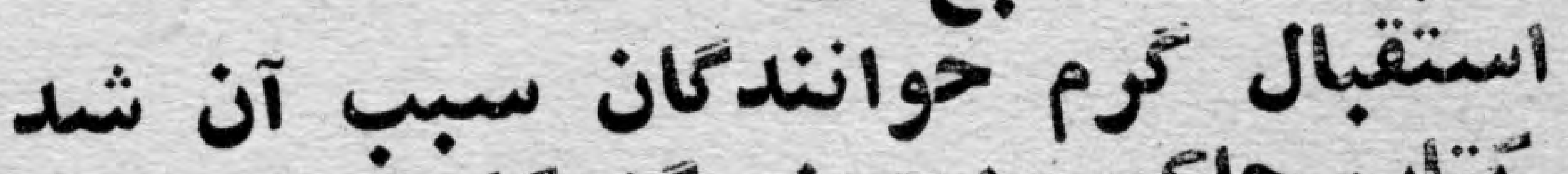

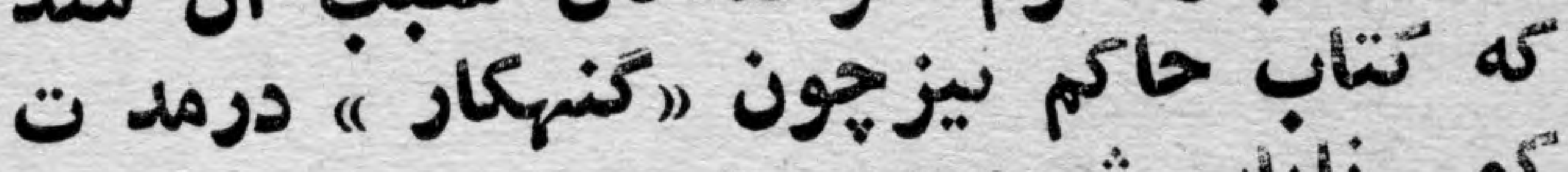

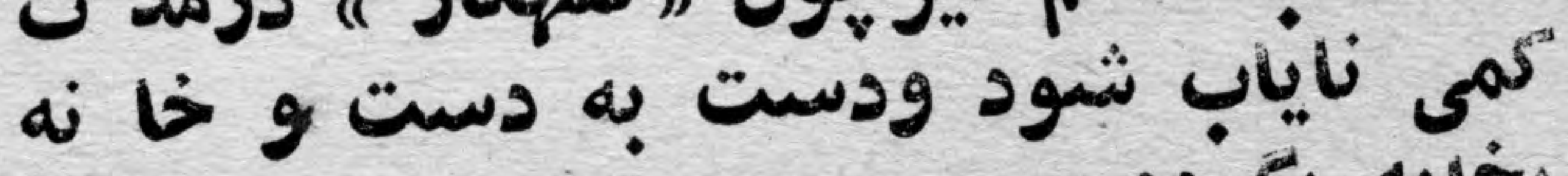

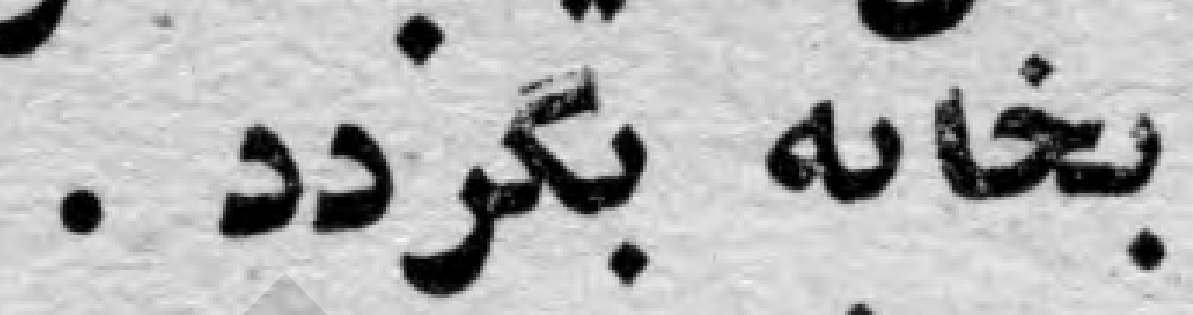

خريدأران كتاب حاكم را بيشتر دم ود

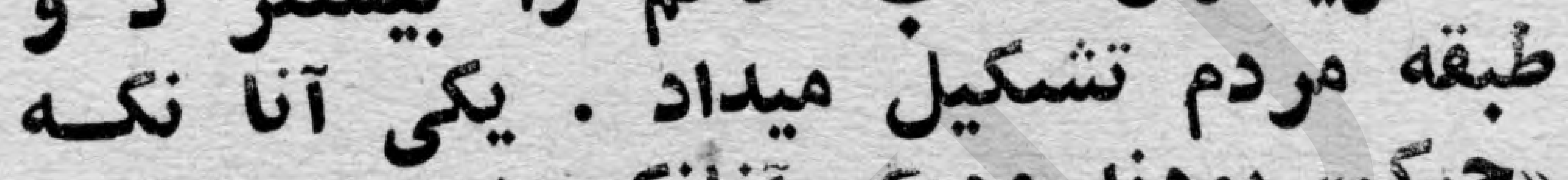

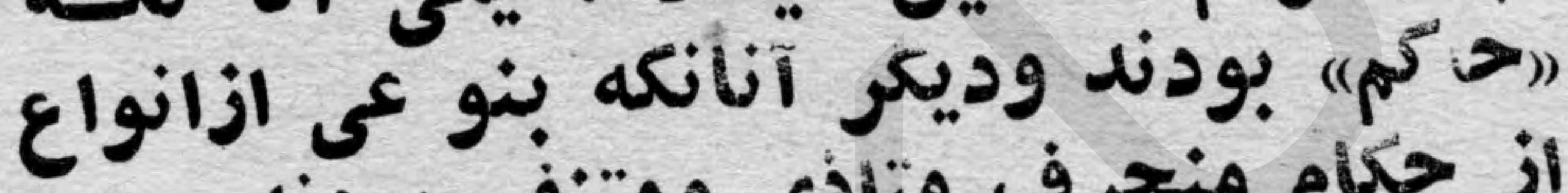

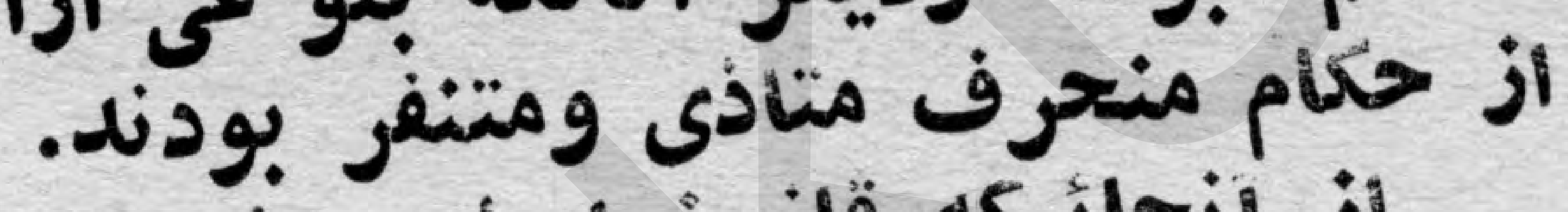

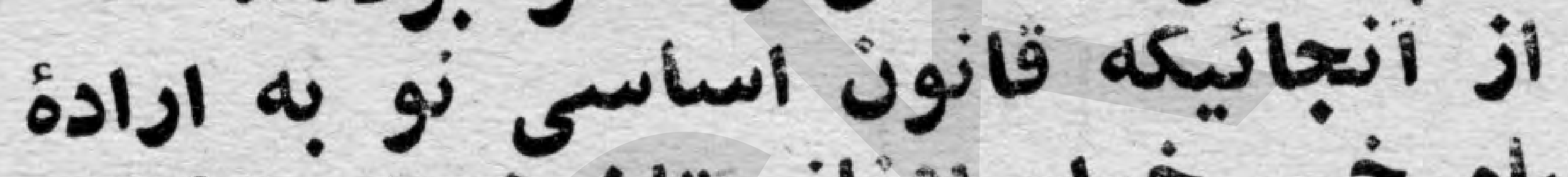

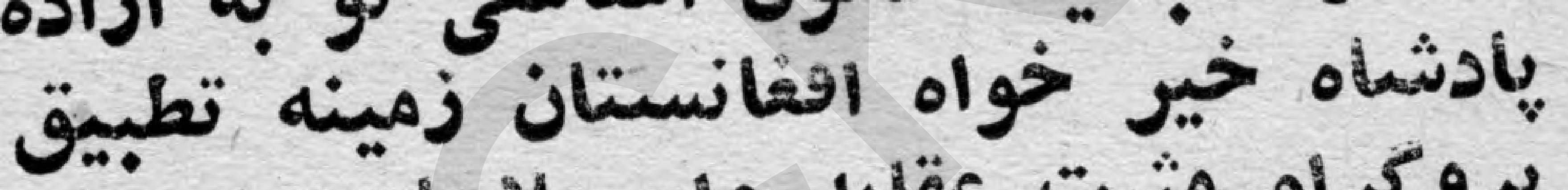

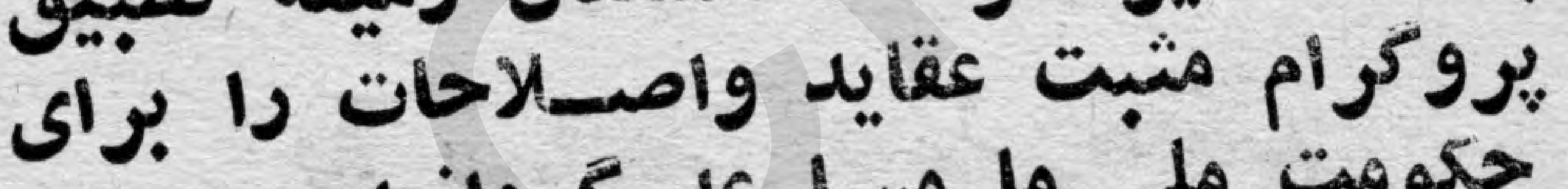

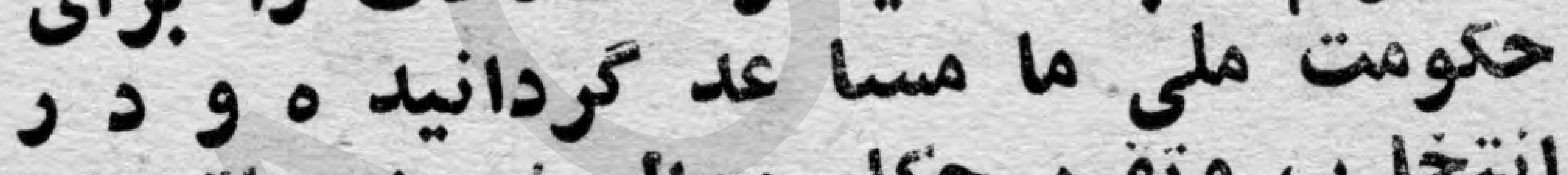
انتخا ب ونغرد حكام وواليها يعنى حلقههاى

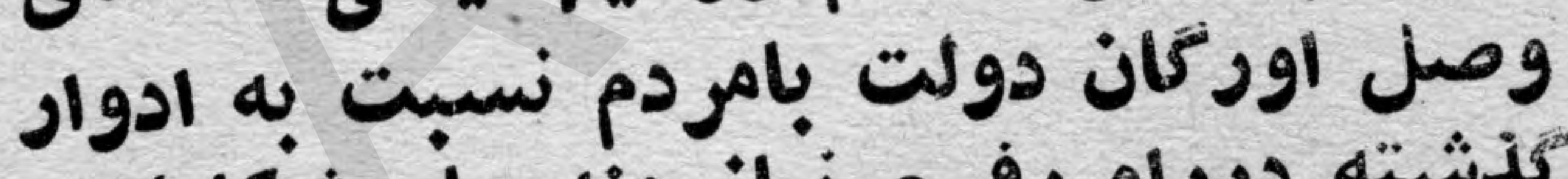

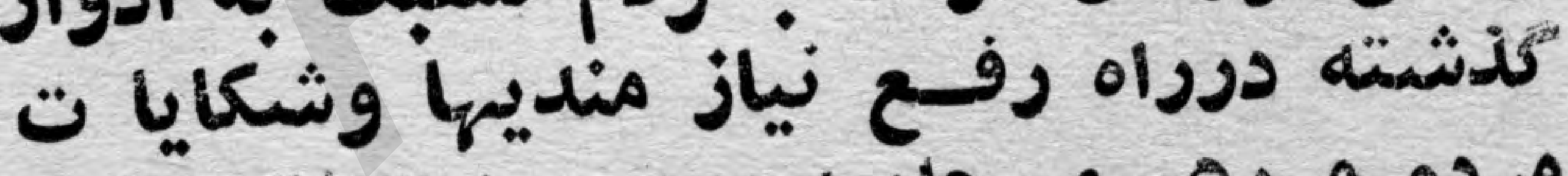

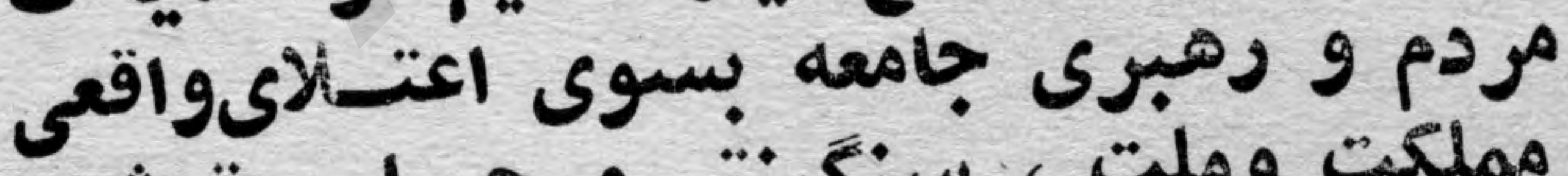
مملكت وملت ، سنغينتر و و حساس ترشيده

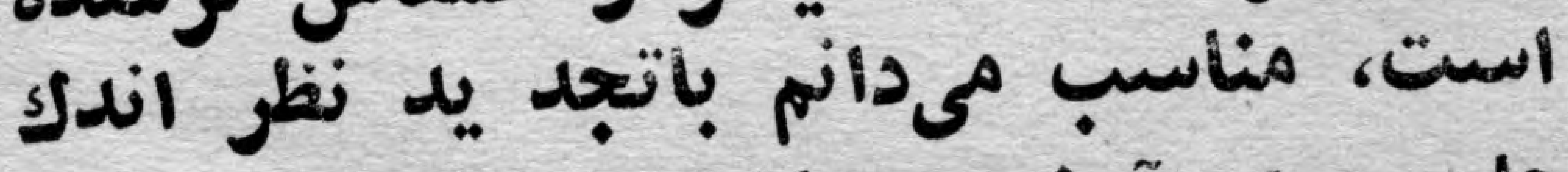

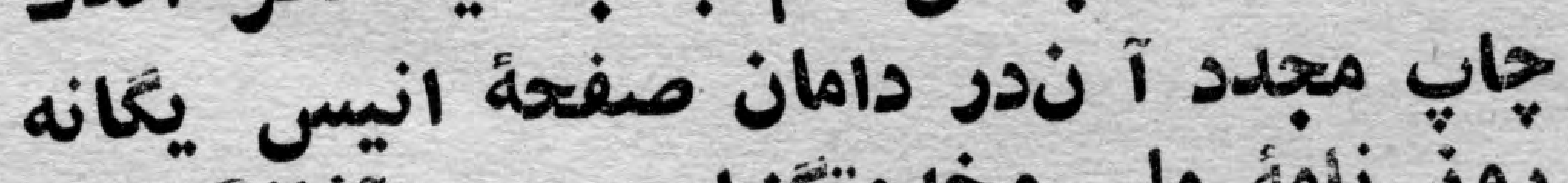

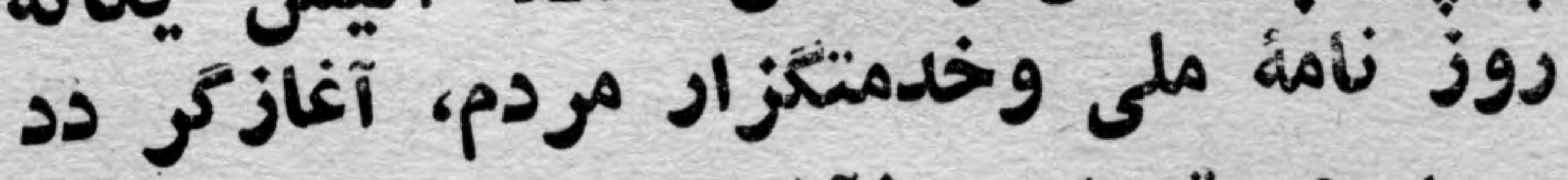

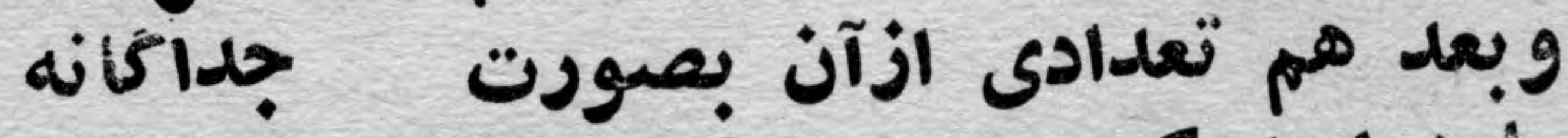

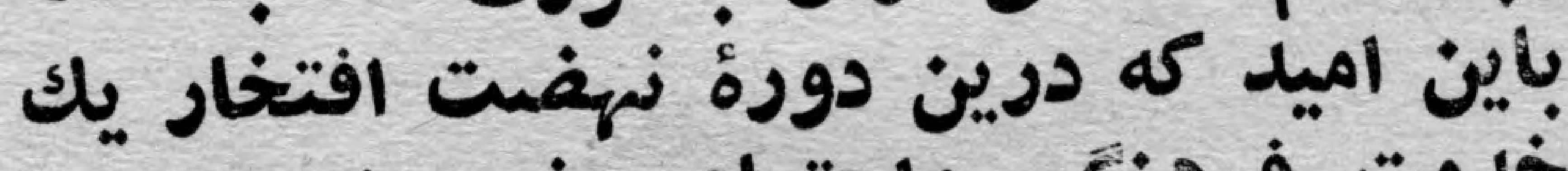

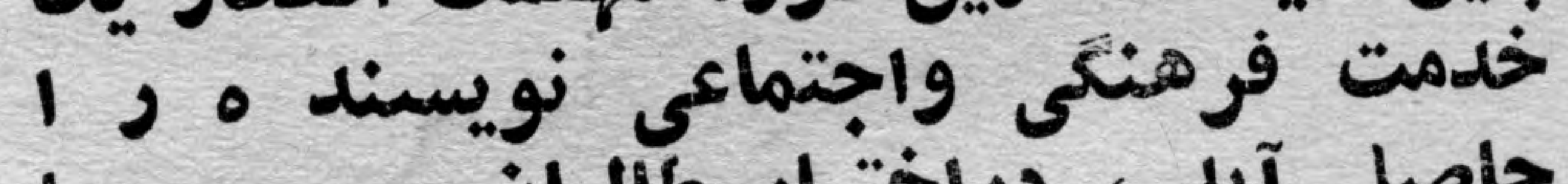

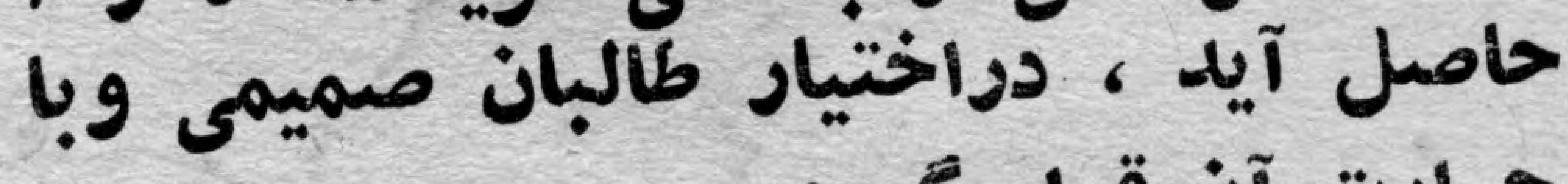

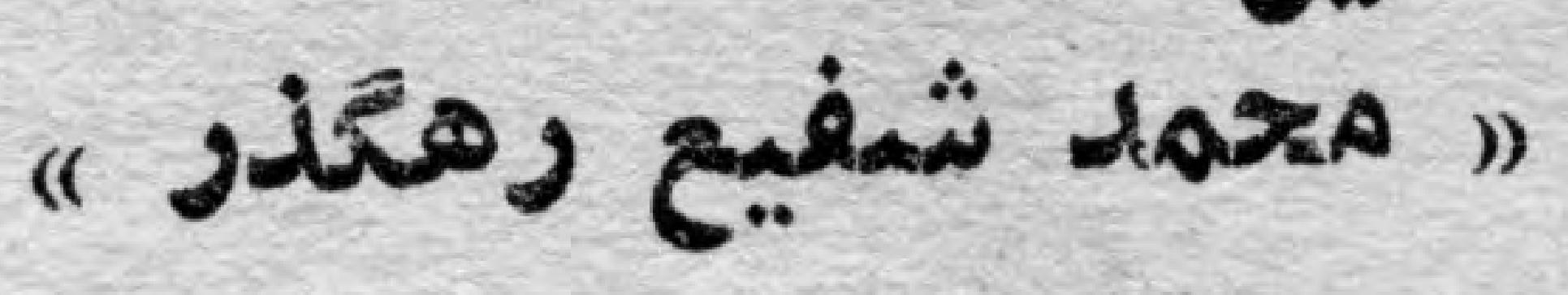

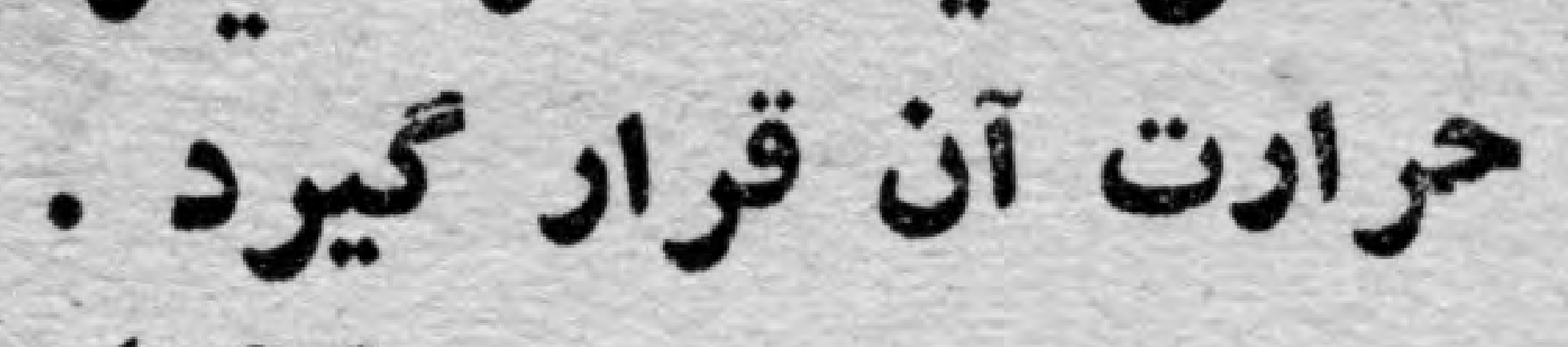




\section{مقدمهُ نأنَر}

برجاب اول كتاب حاكم

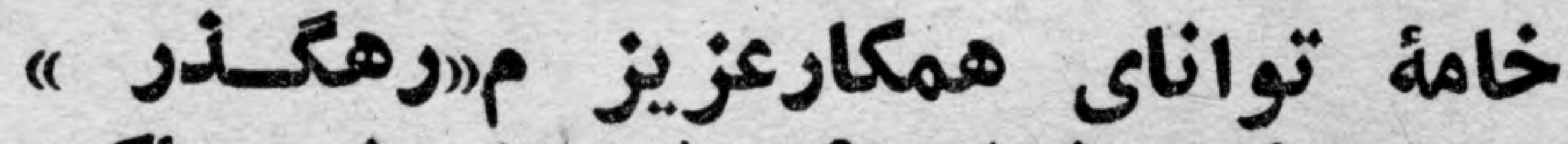

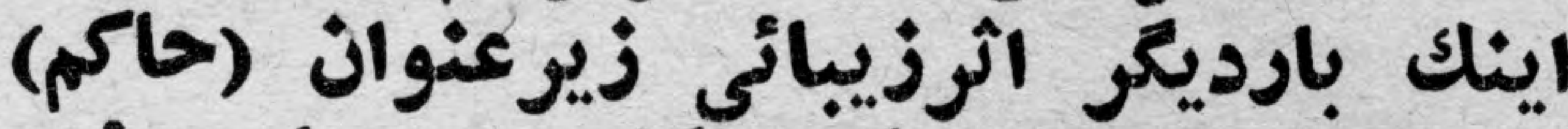

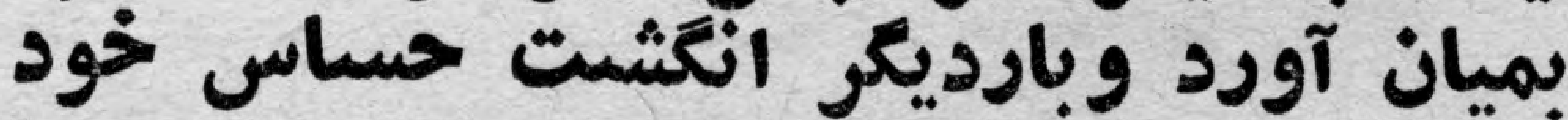

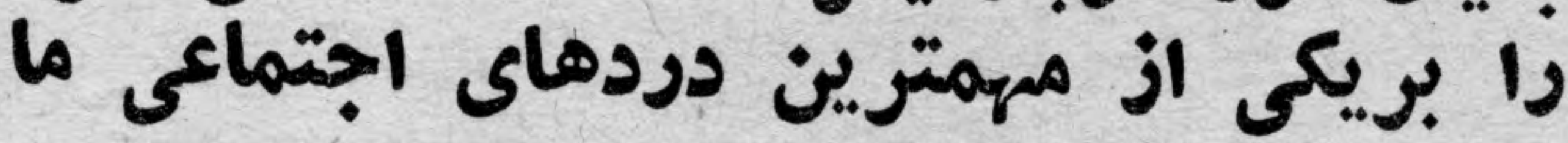

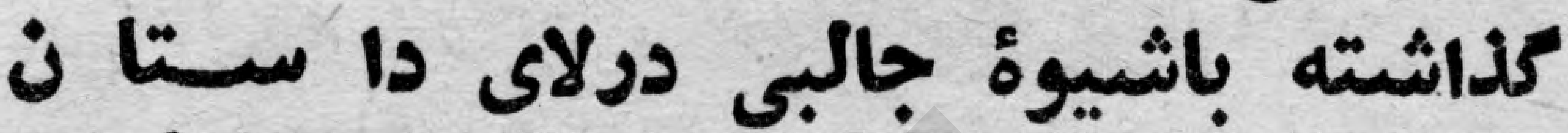

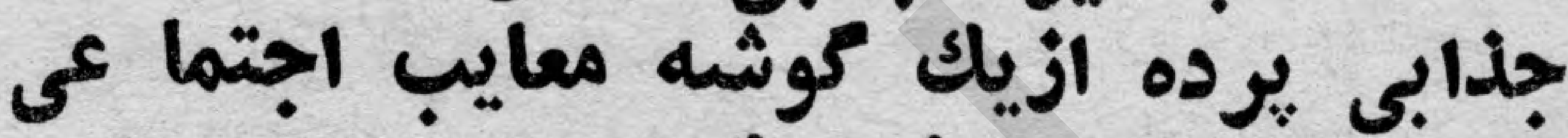

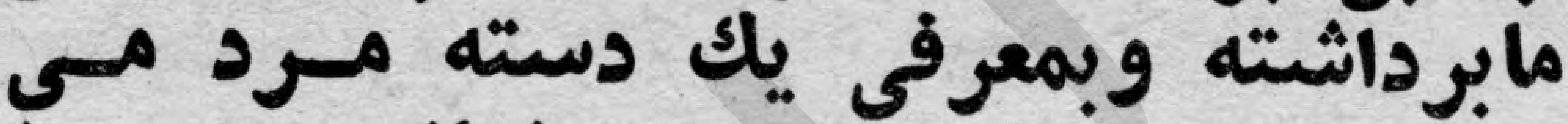

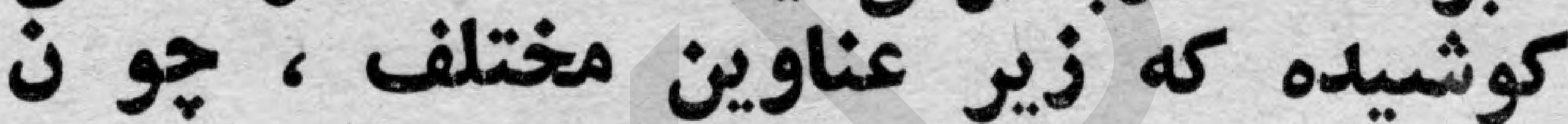

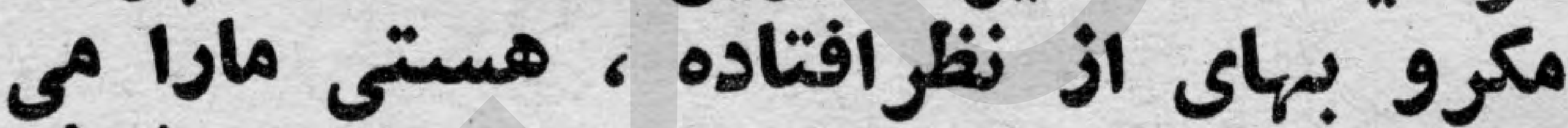

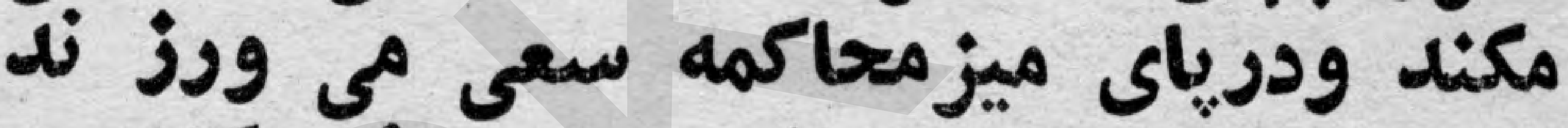

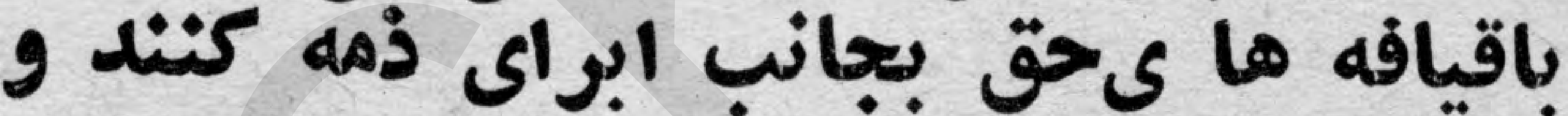
بار مسئوليت رابدوش كسا نسي تحم تحميـل

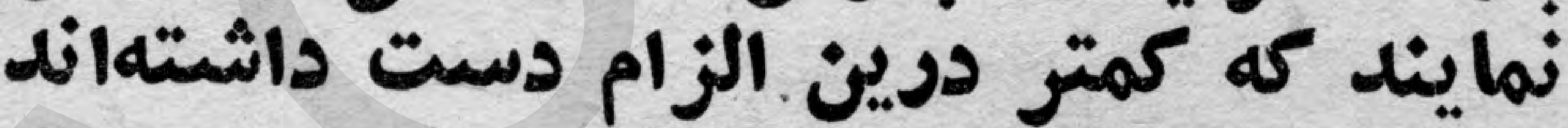

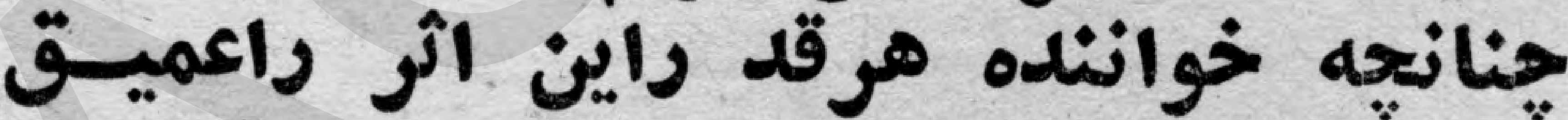

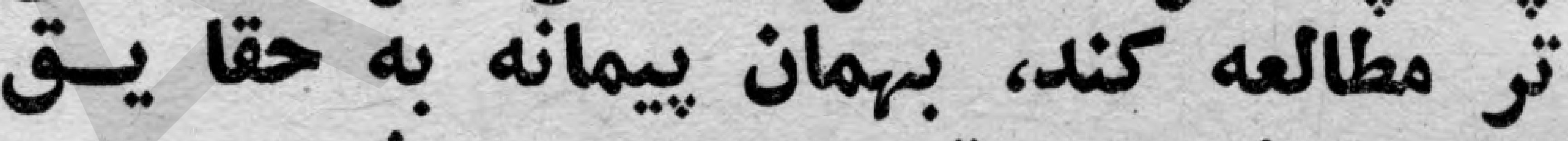

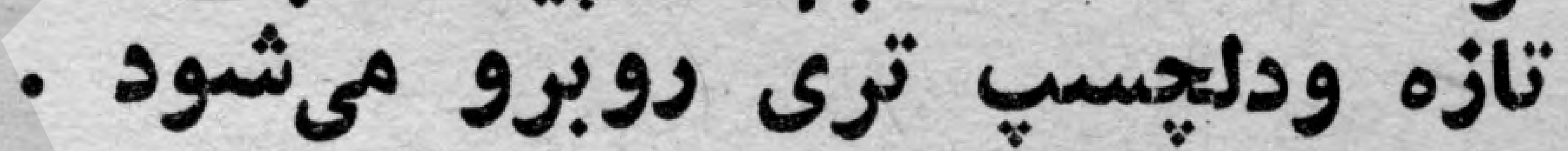

هون جوانان مادرعصر حاضر بيش از بازئ

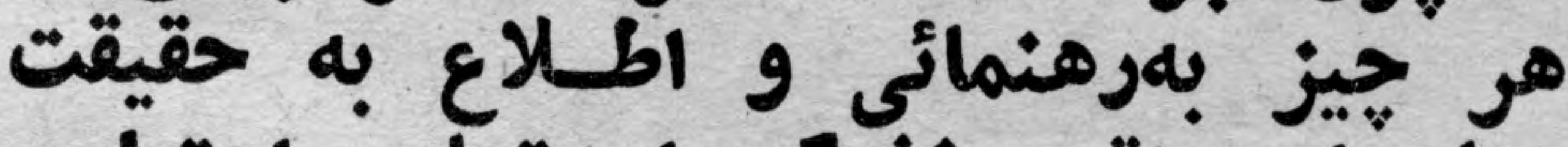

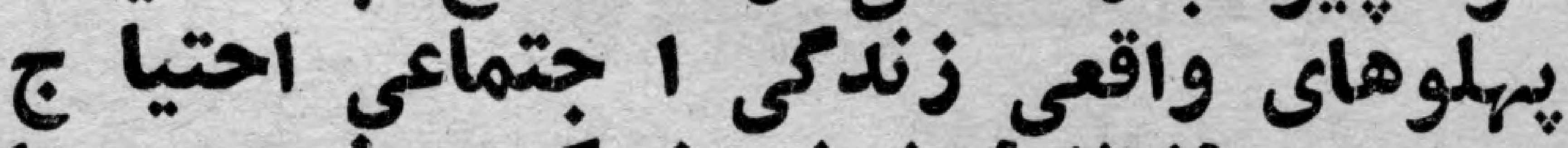

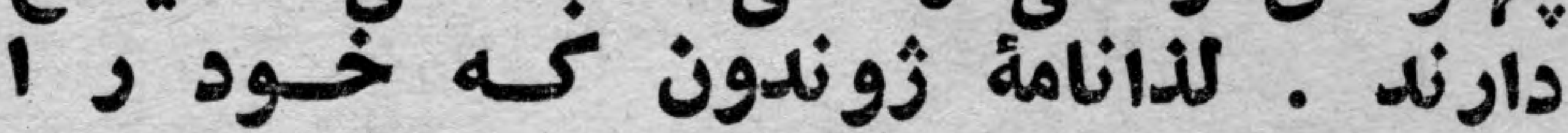

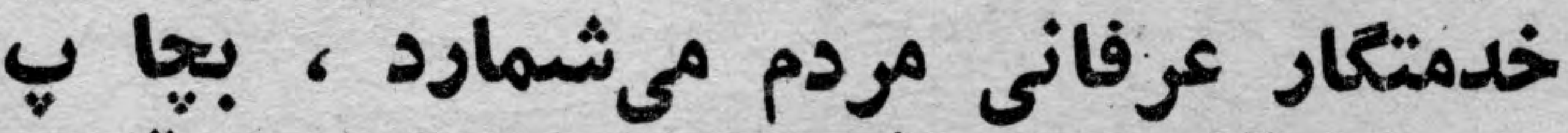

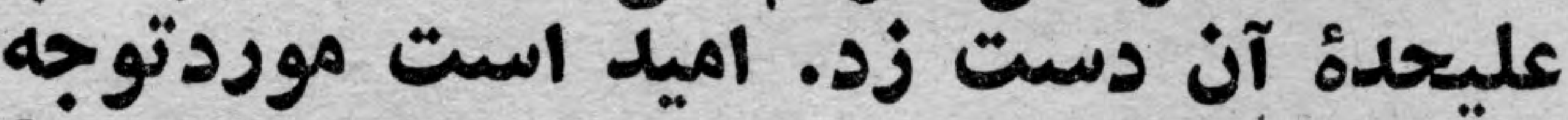

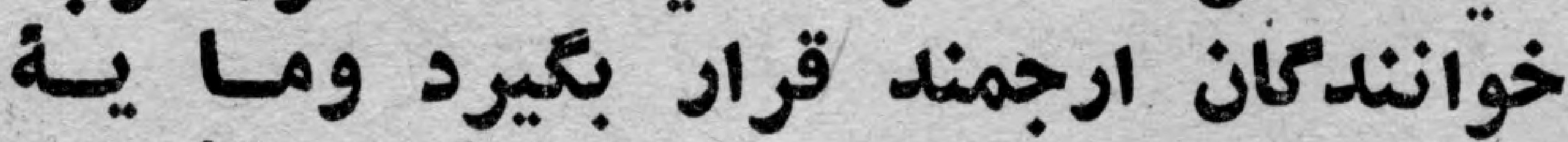

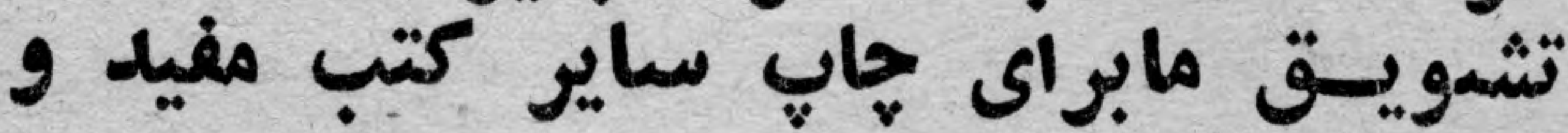
" (سيدفقير علوى ")

$$
\text { خواندنى كردد . }
$$




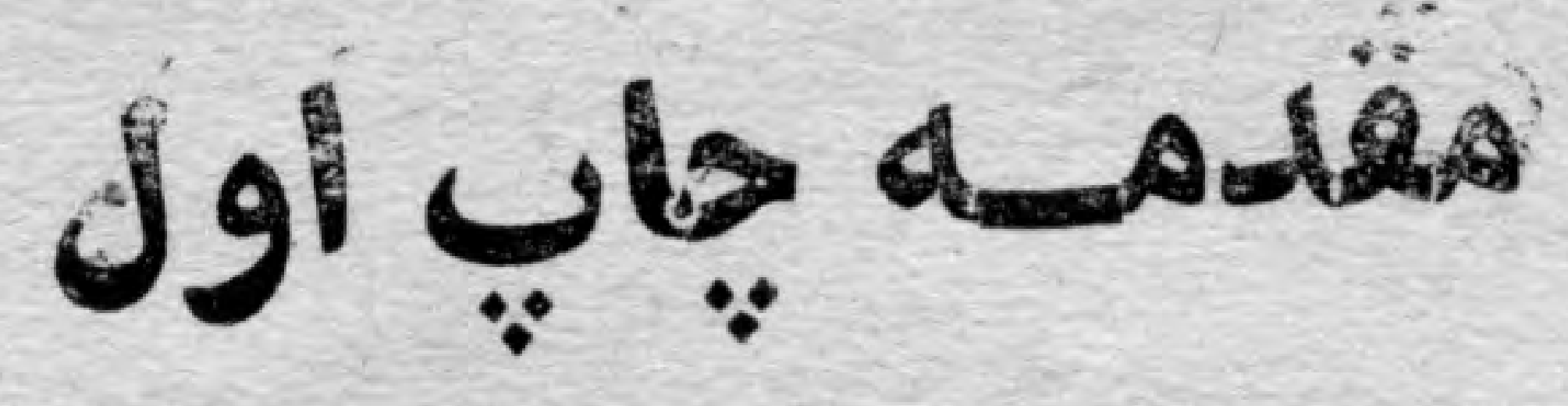

ترازيدى نارساى حاكم واكه تاكيلو تئي

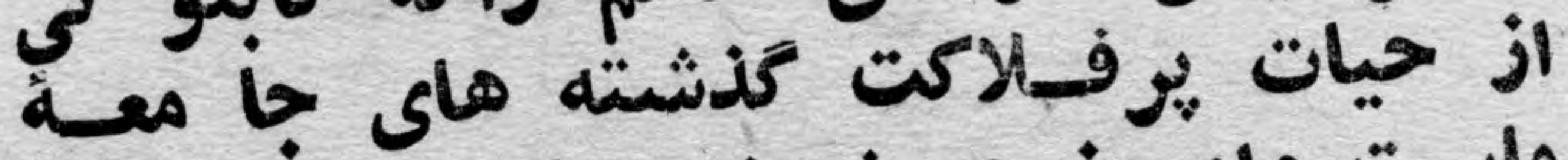

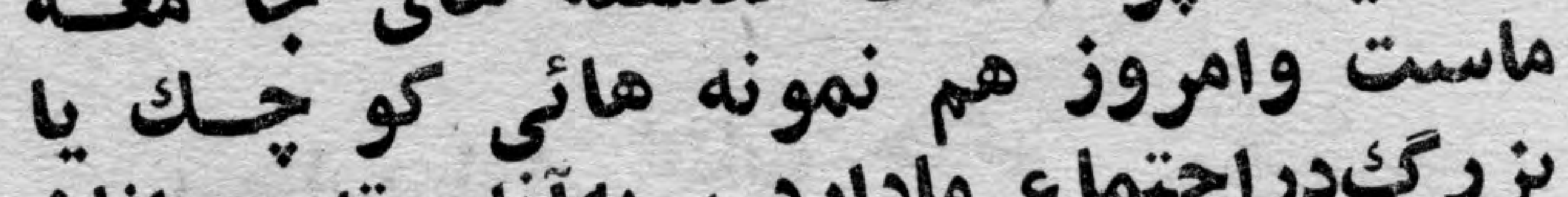

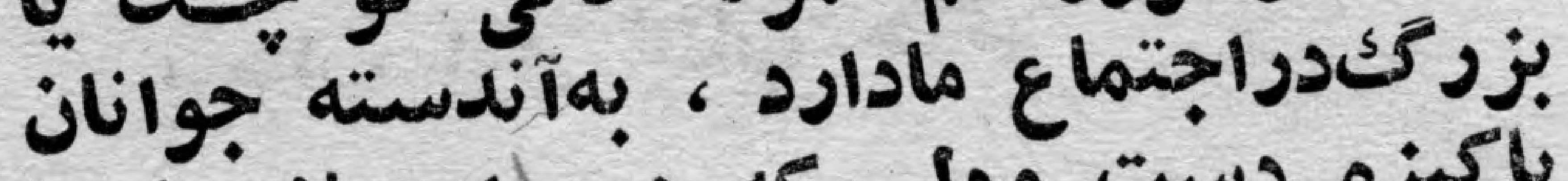

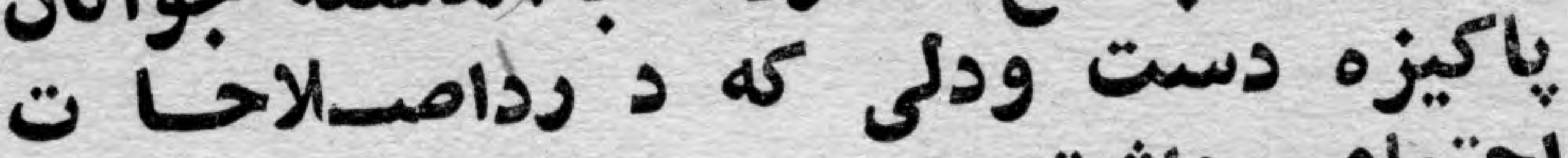

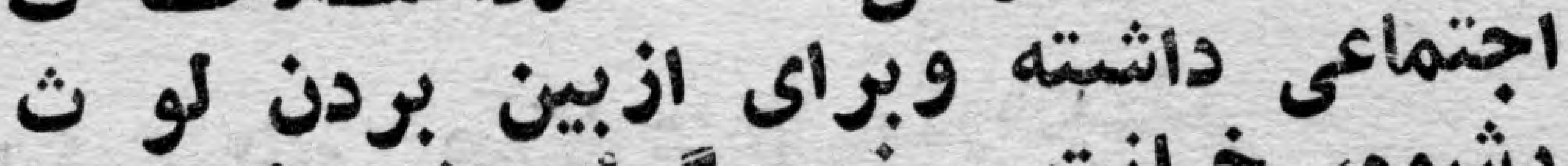

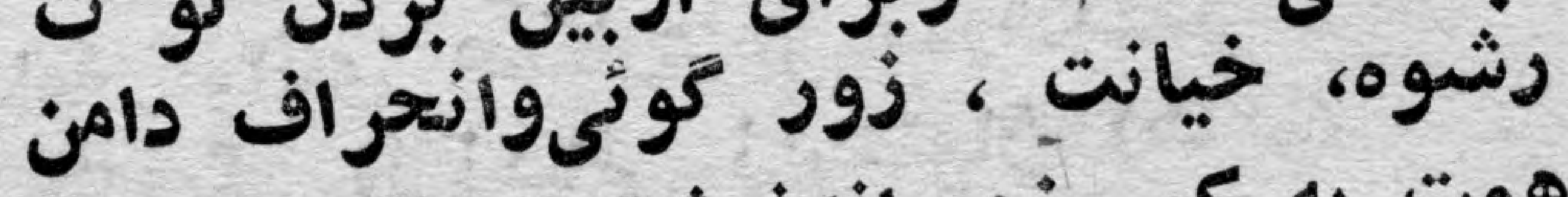

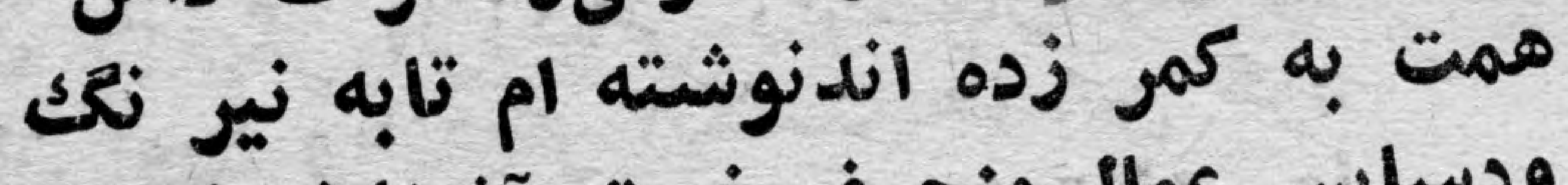

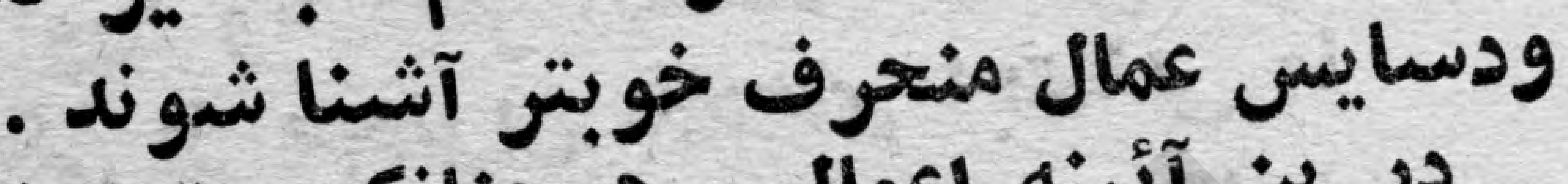

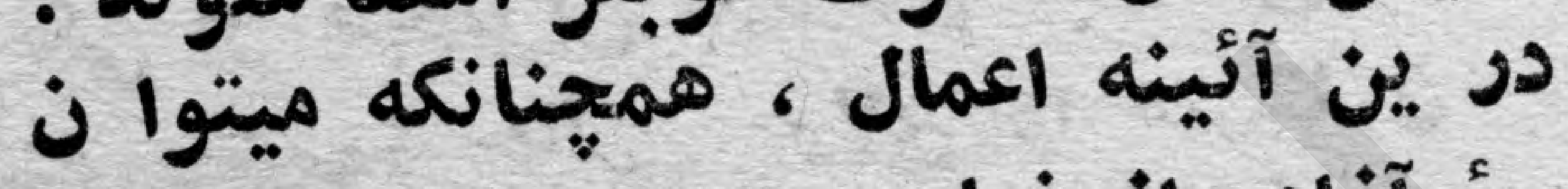

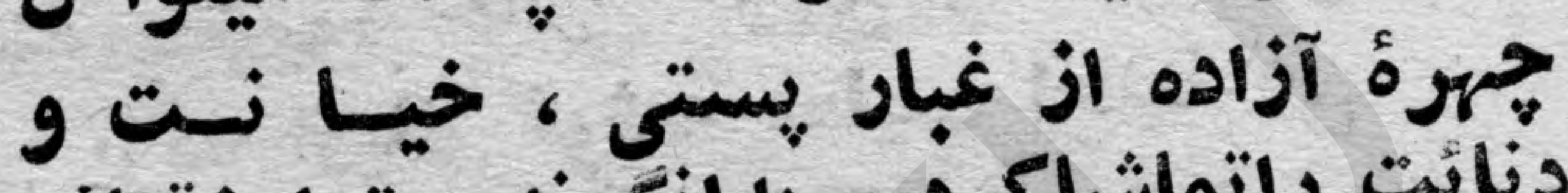

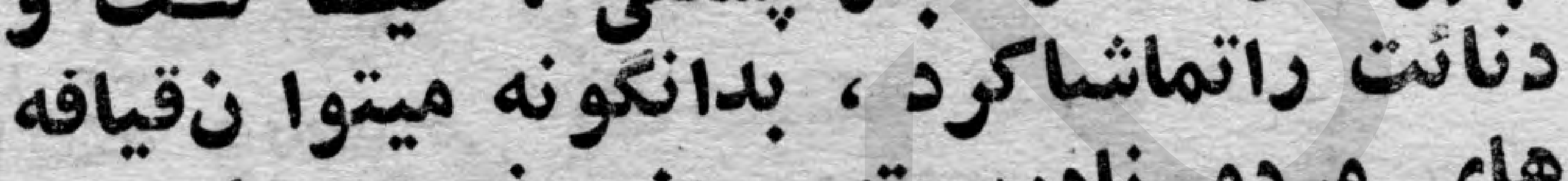

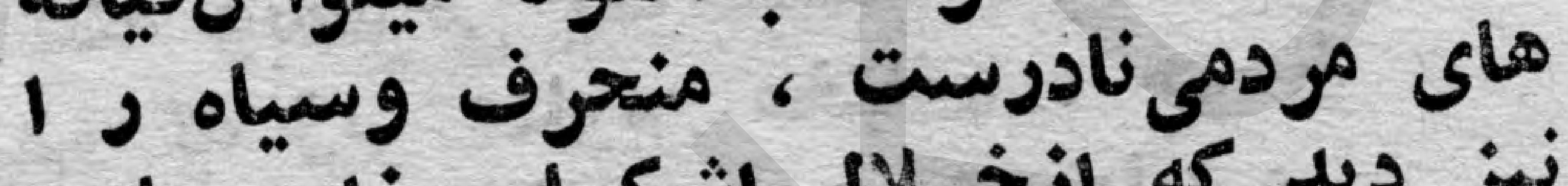

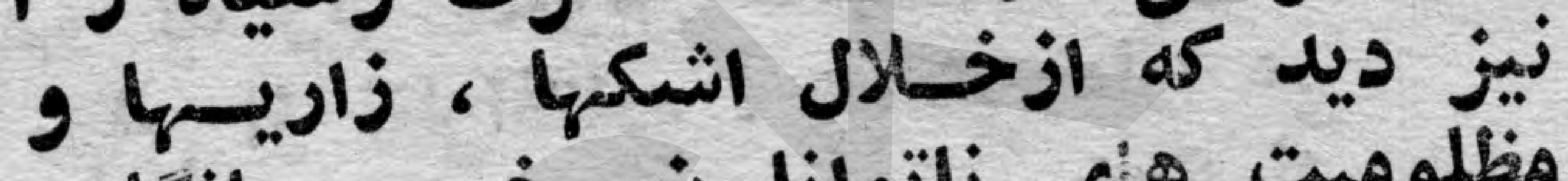

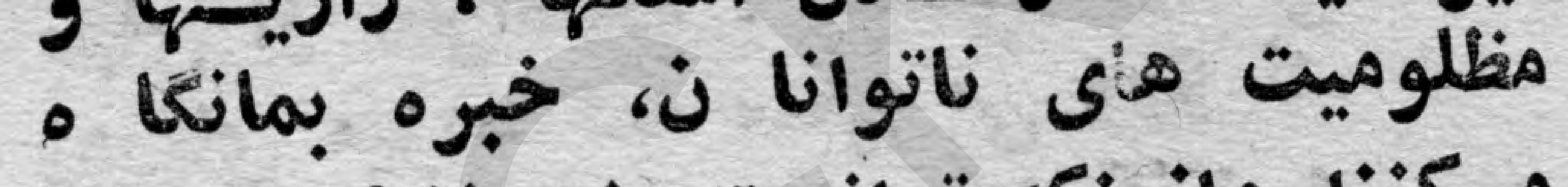

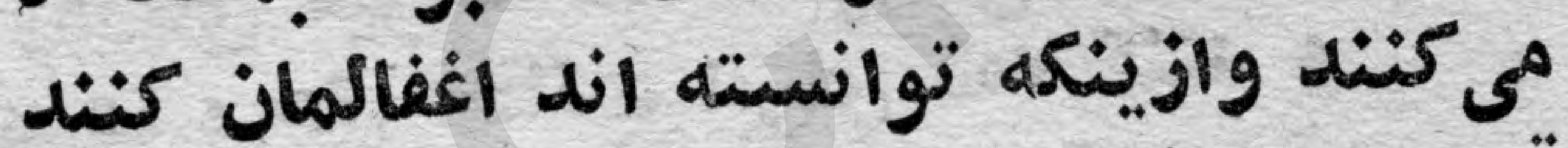

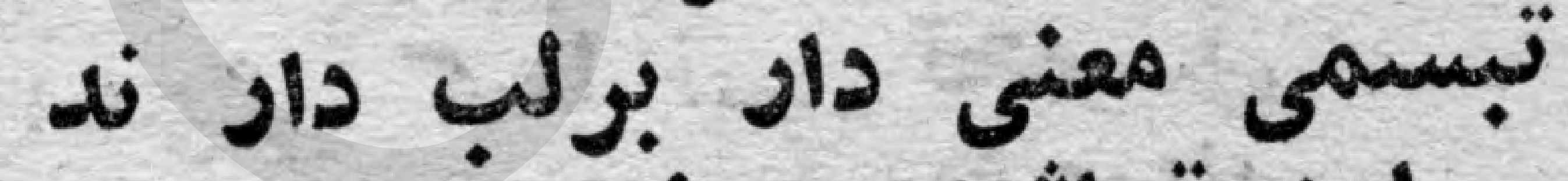

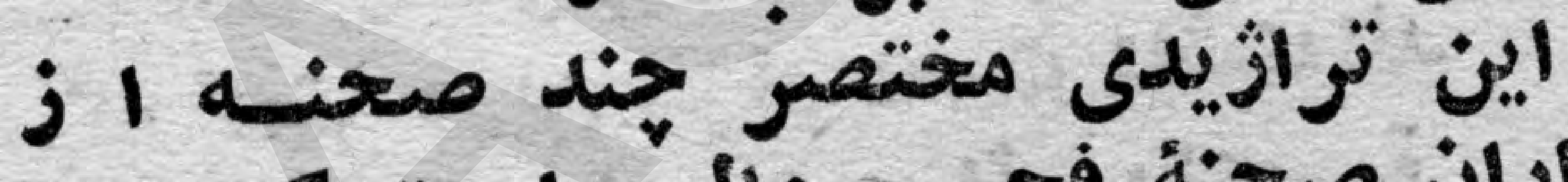

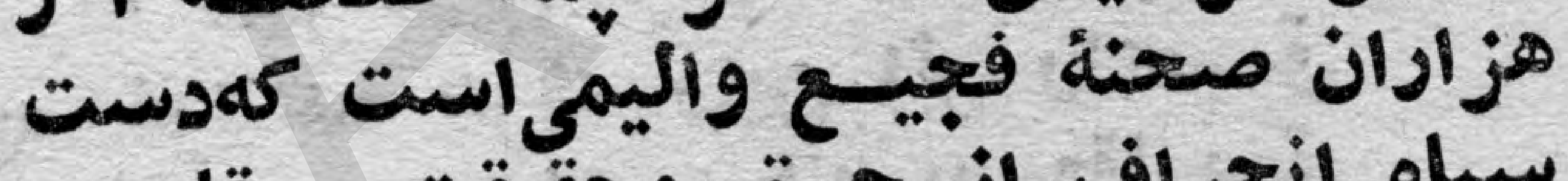

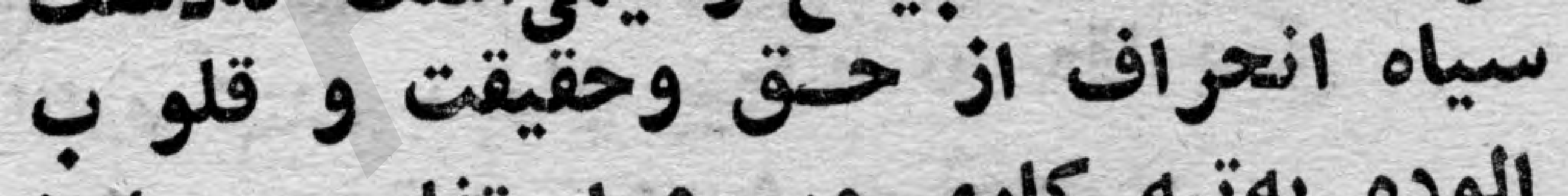

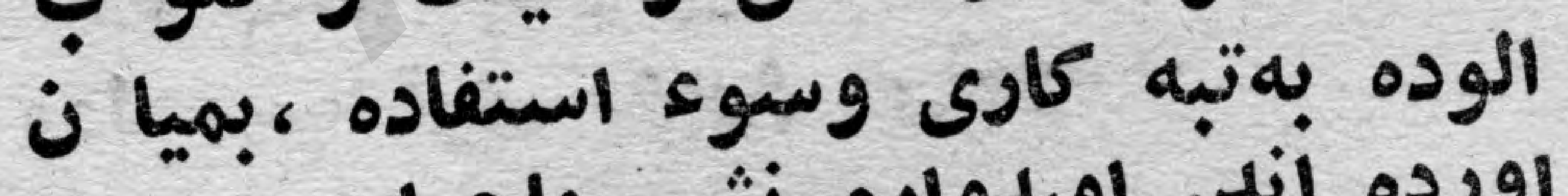

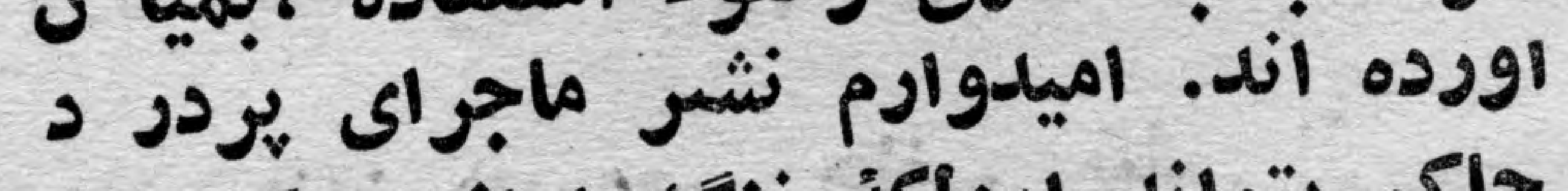

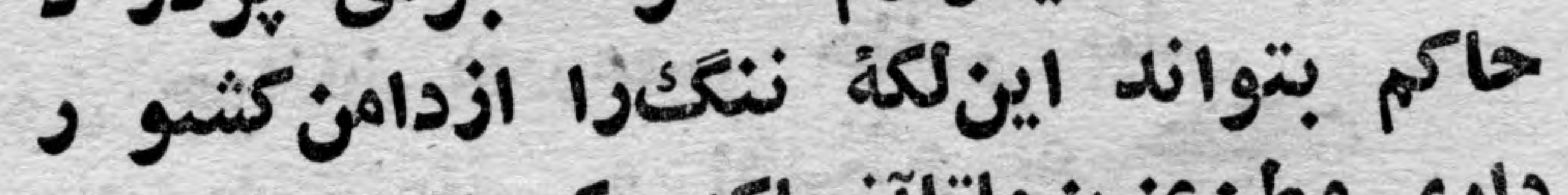

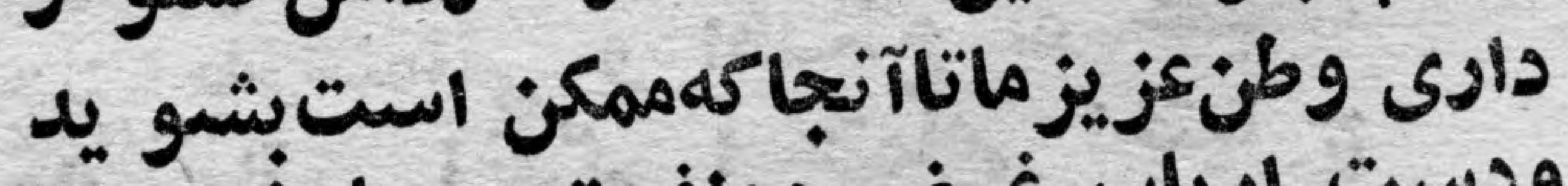

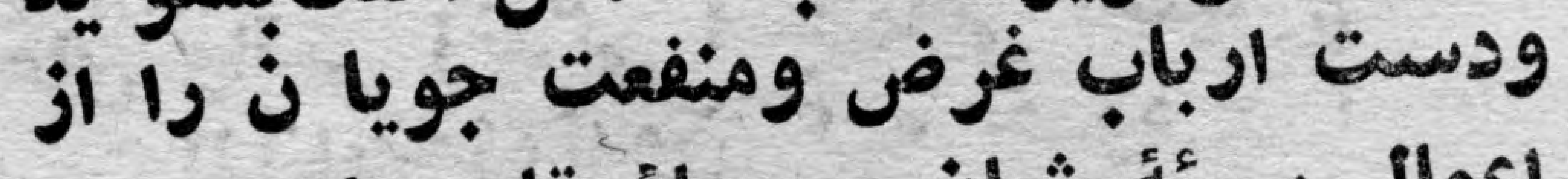

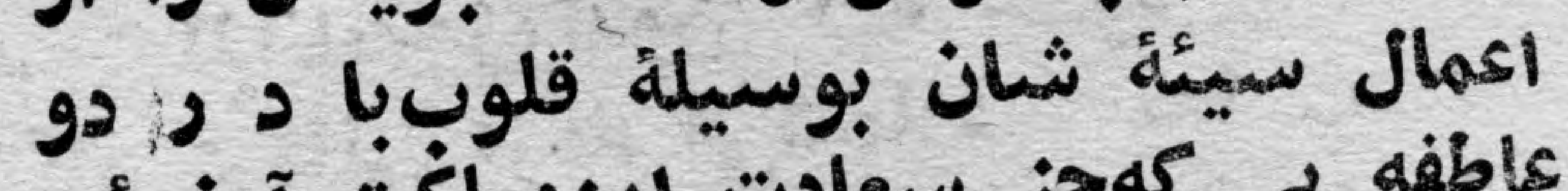

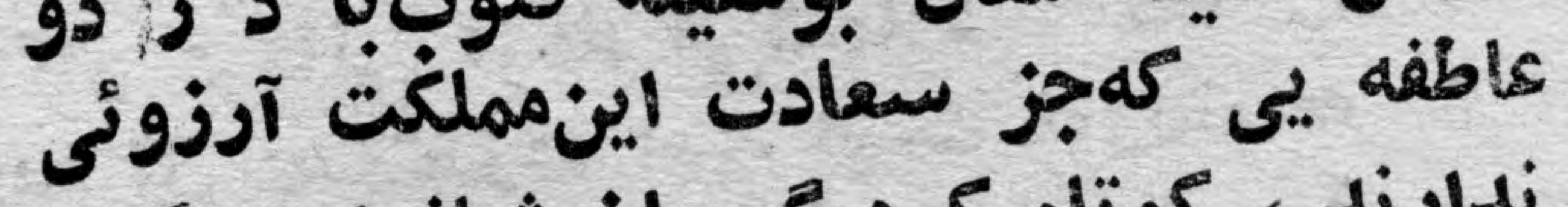

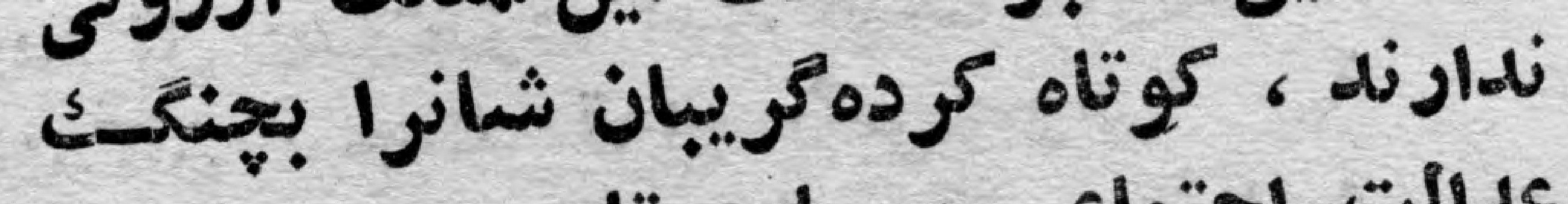

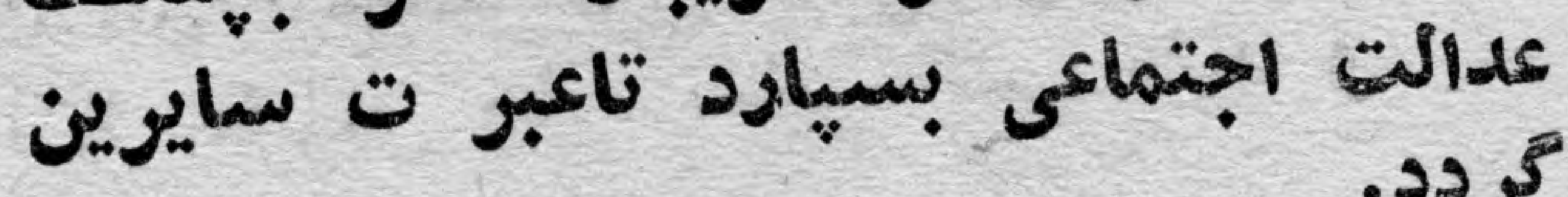
نابود باد خائن ومنترف كرد 


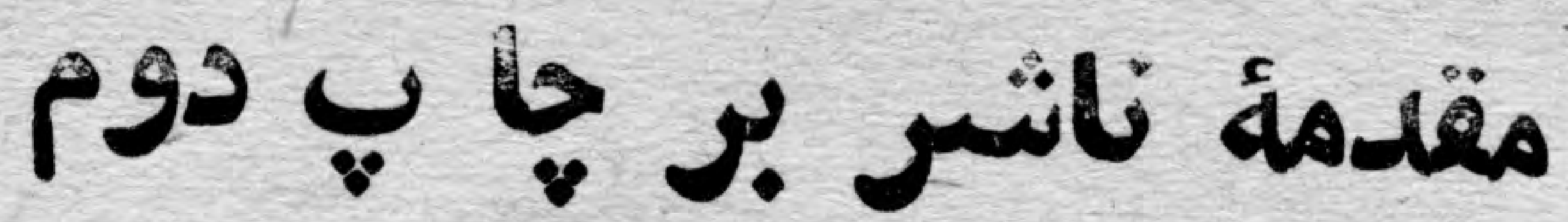

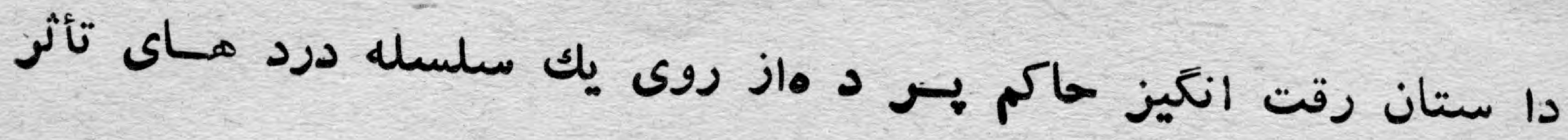

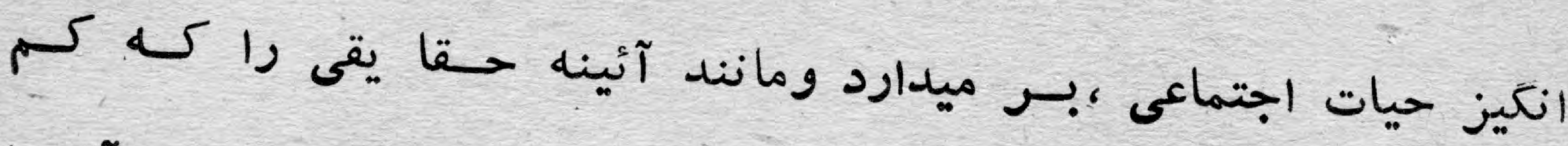

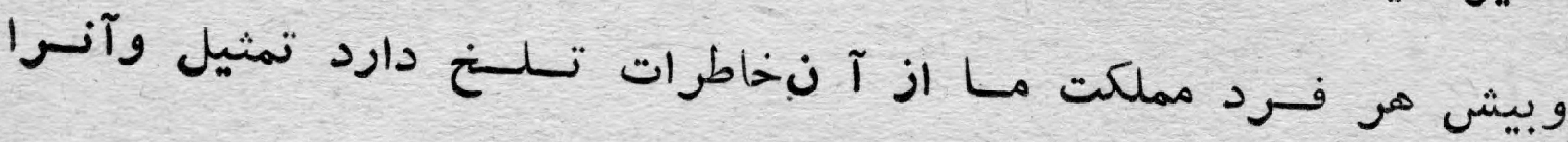

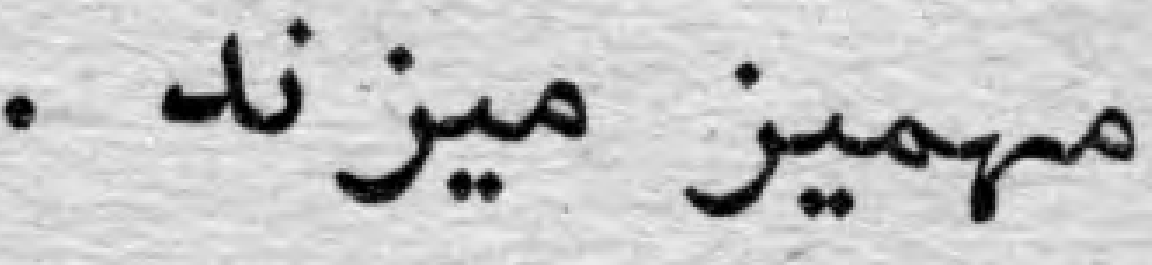

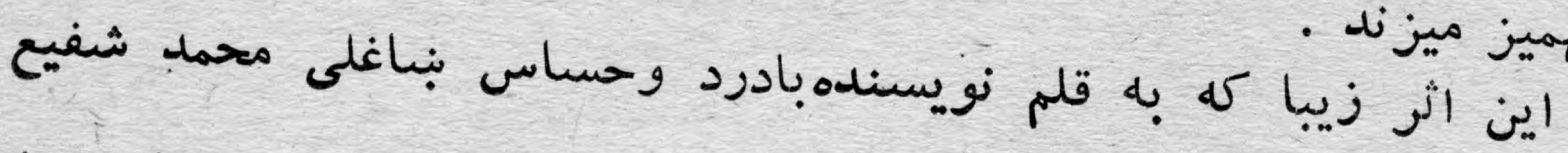
رهكذر نغارش يافته است جناسمالقبل روى صفحاتمجله وزينزوندون

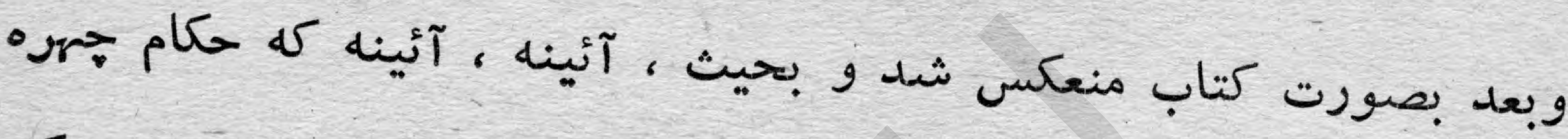

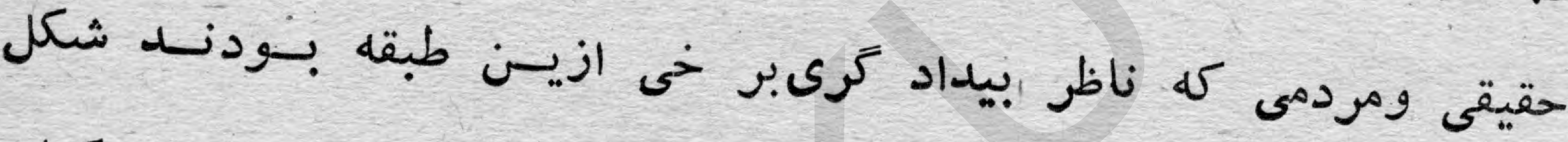

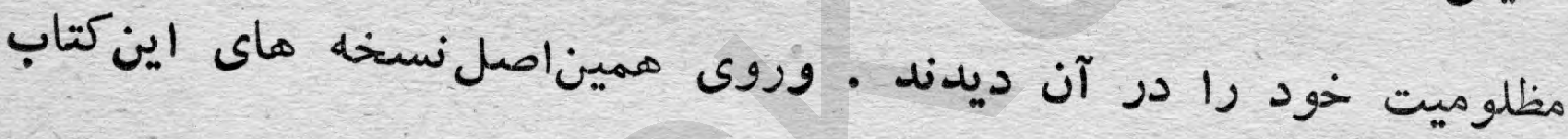

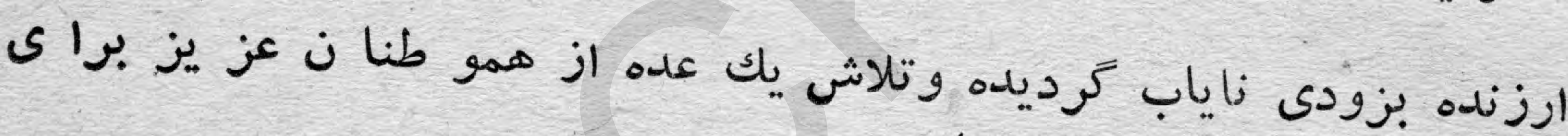

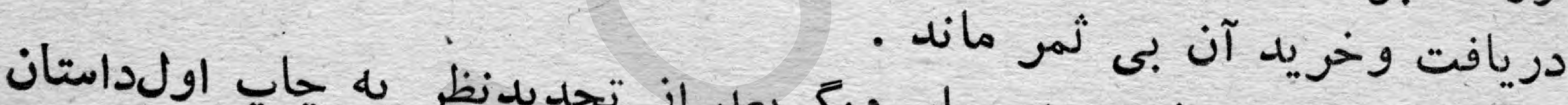

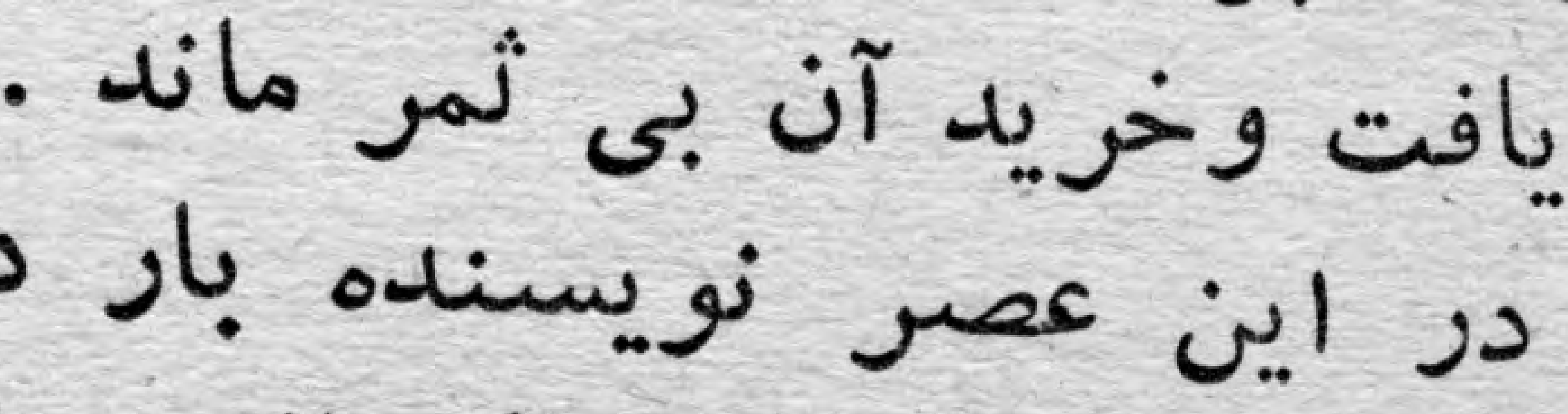

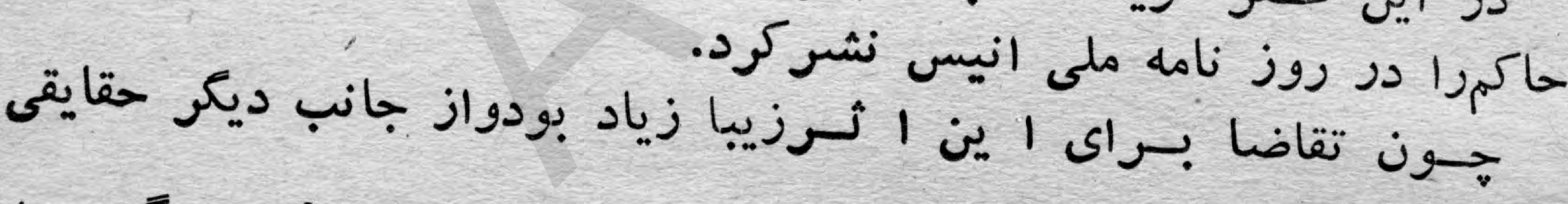

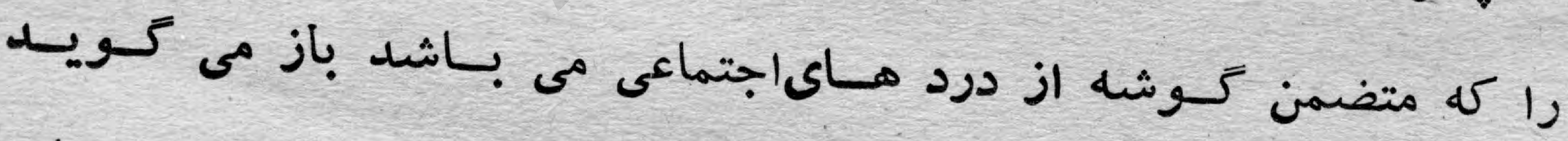

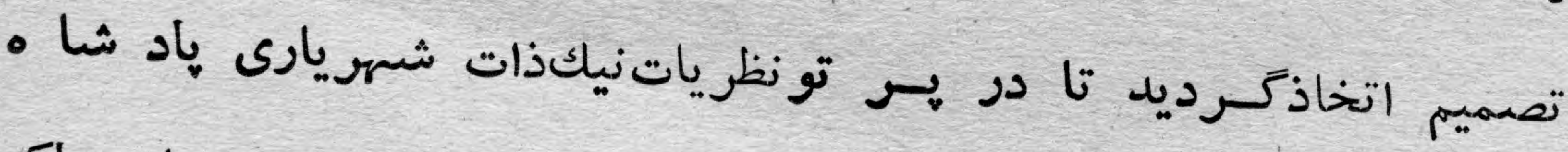

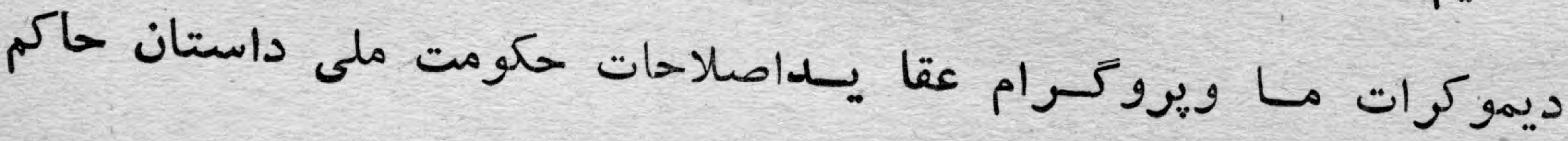

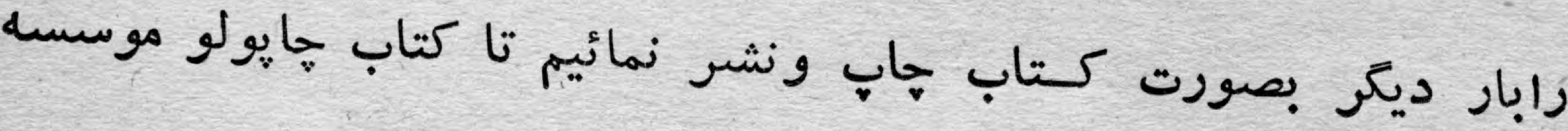
بنوبه خود قدمى براىقلعوقمع عناصرفاسد ومنفعتجوبر داشتهوازجانب

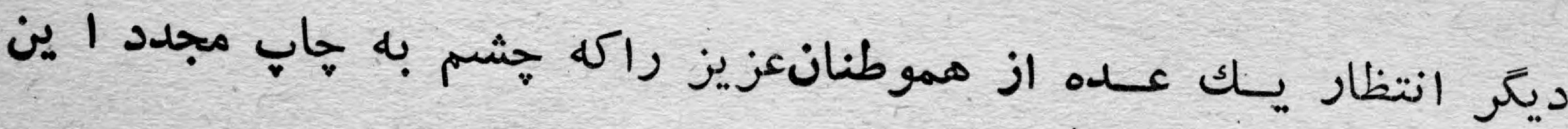
اثر دا شتند مر تفع نمايد. 
بسوى ماموريت

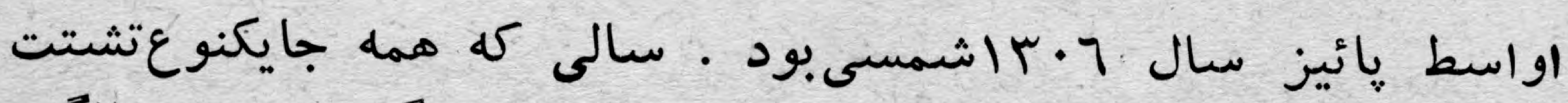

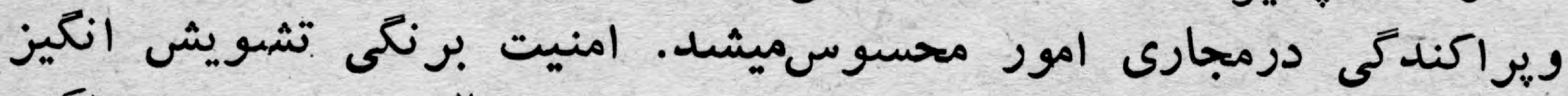

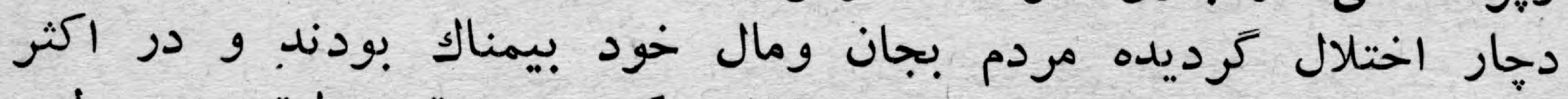

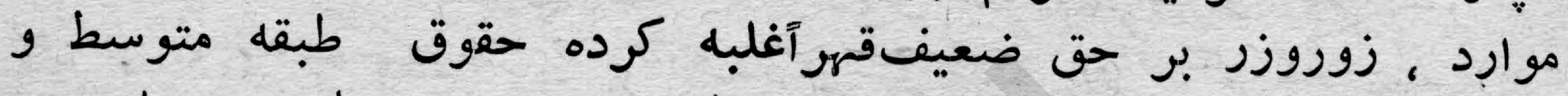

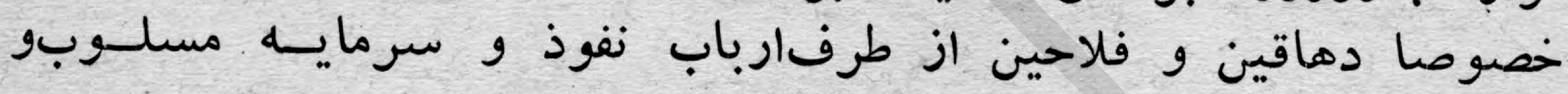

مغصوب بودو.

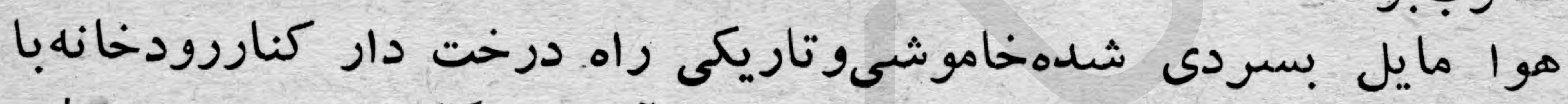

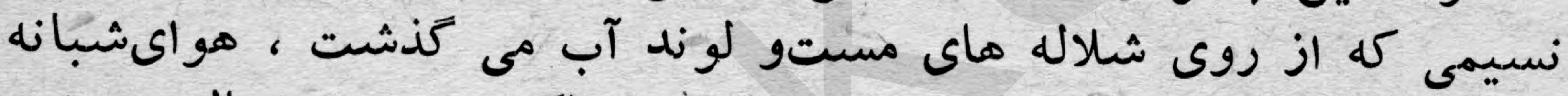

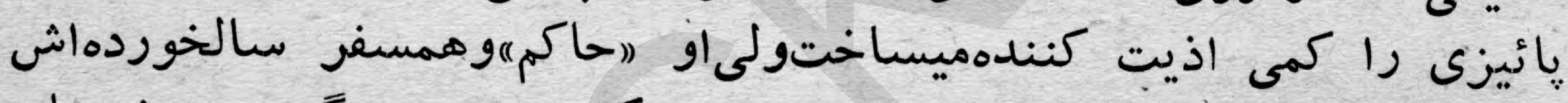

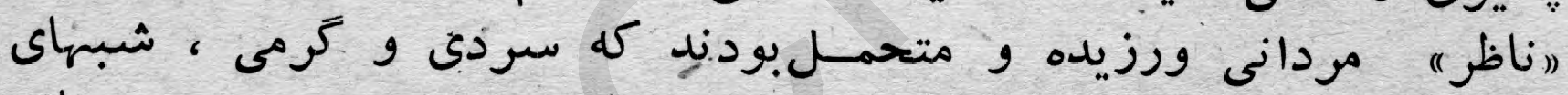

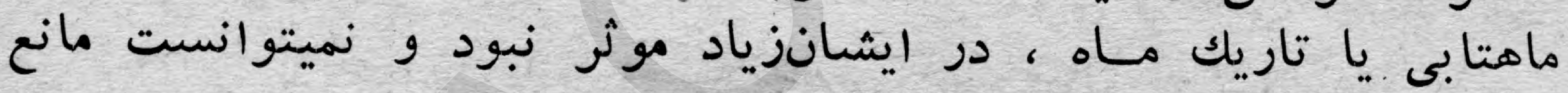

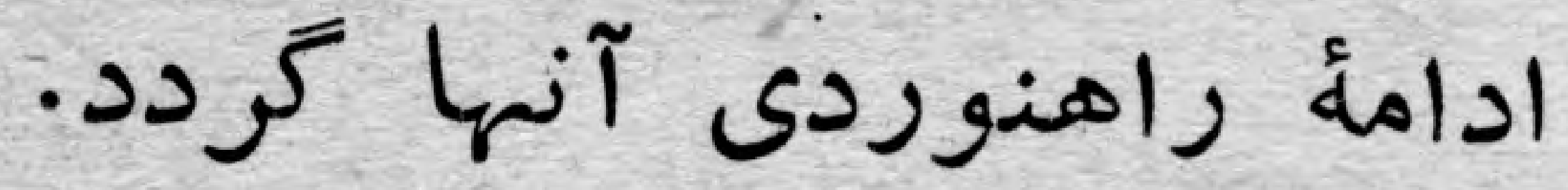

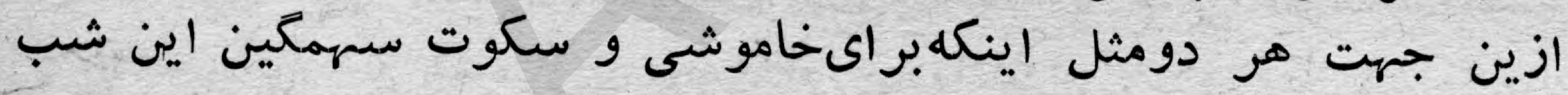

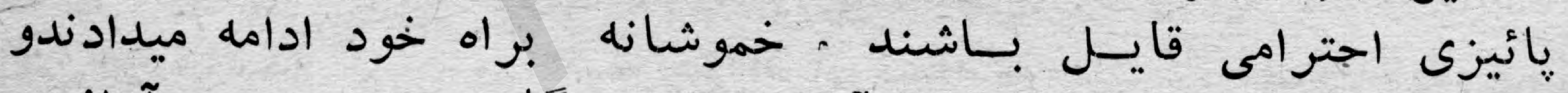

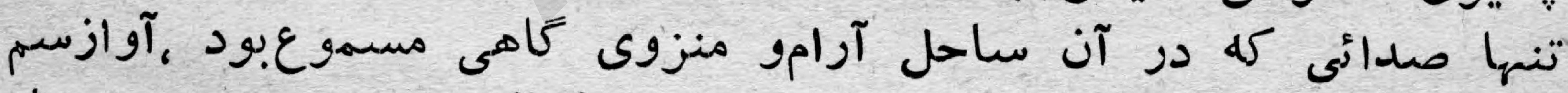

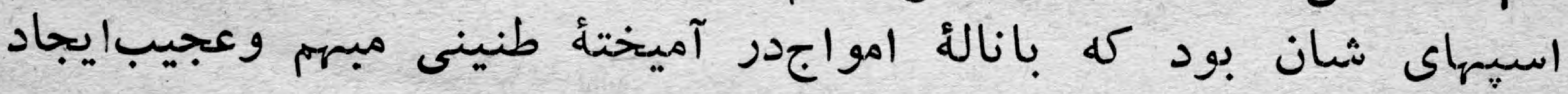

ميكرد.

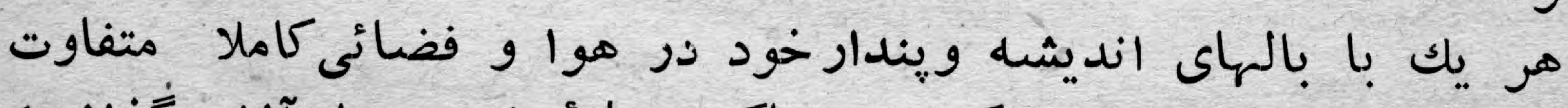

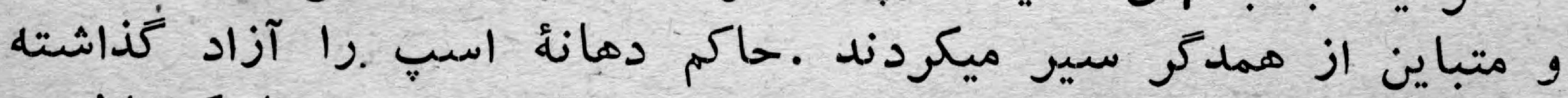

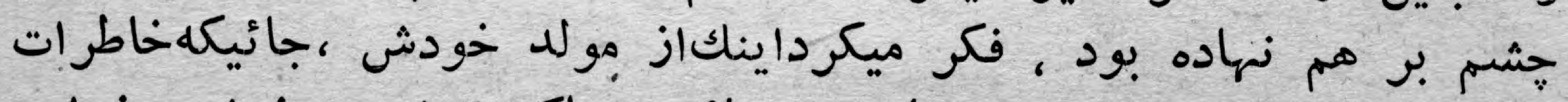

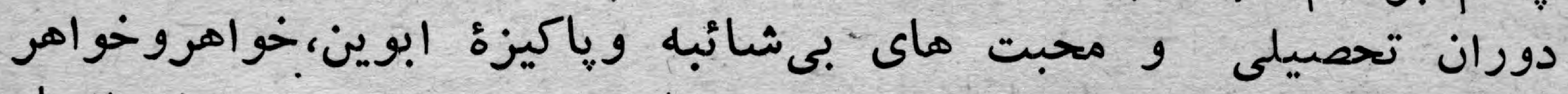

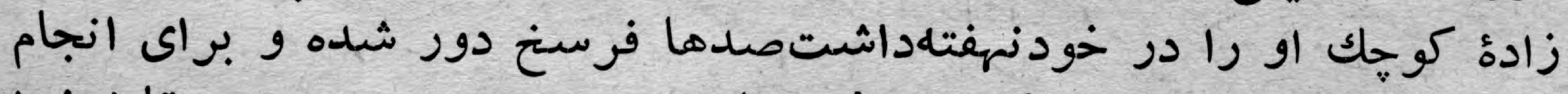

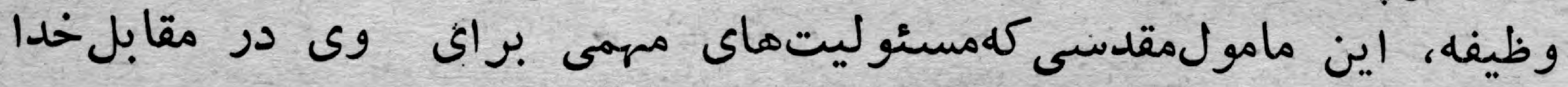

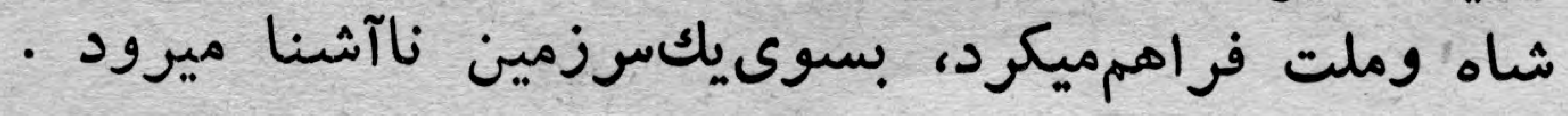




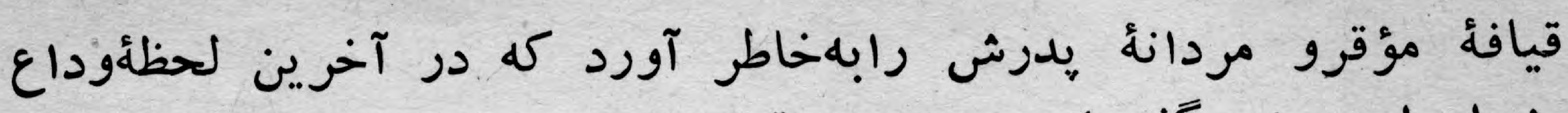

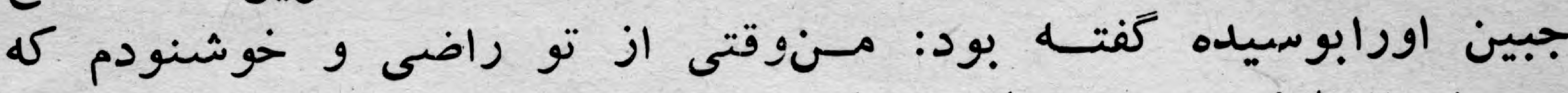

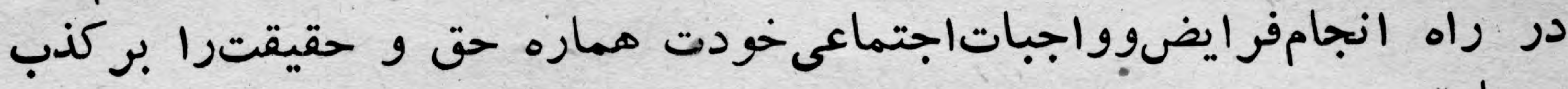

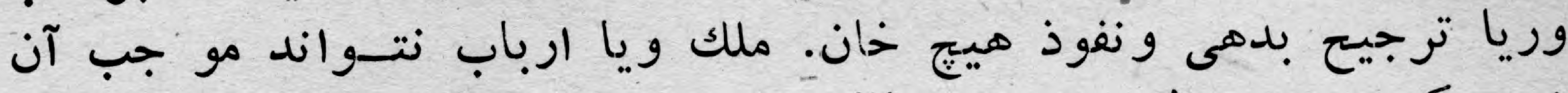

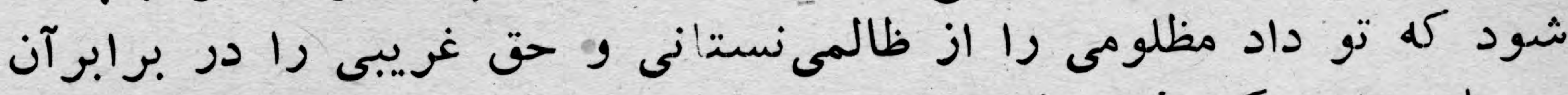

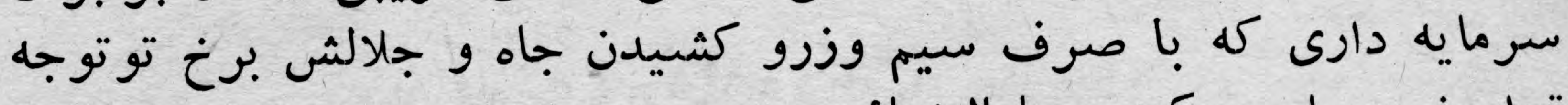

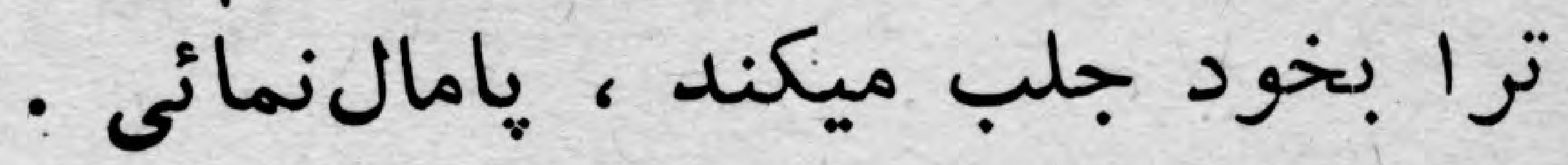

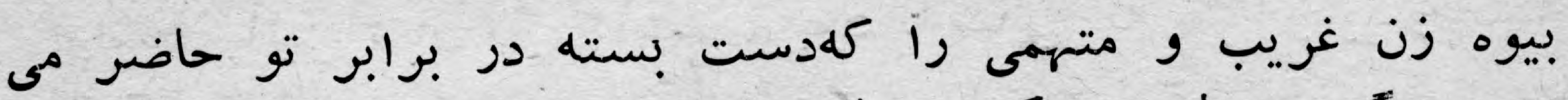

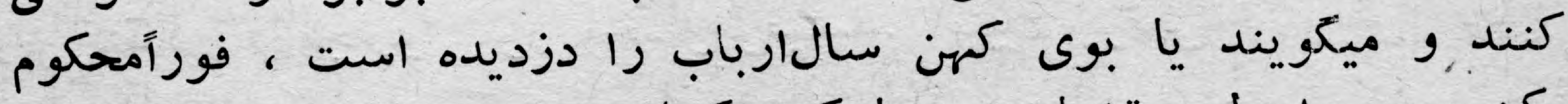

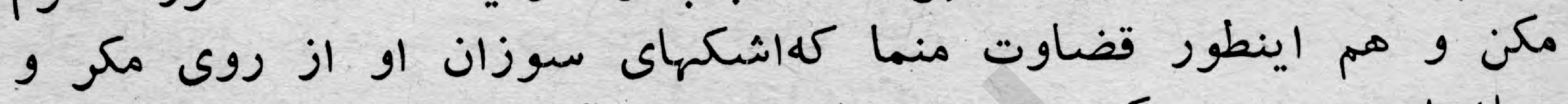

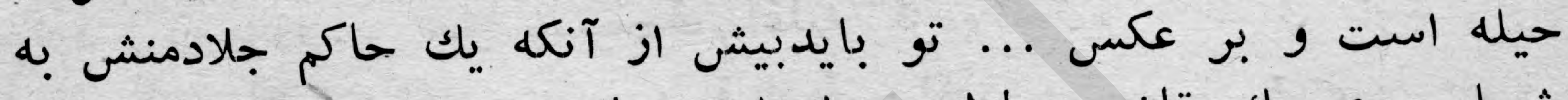

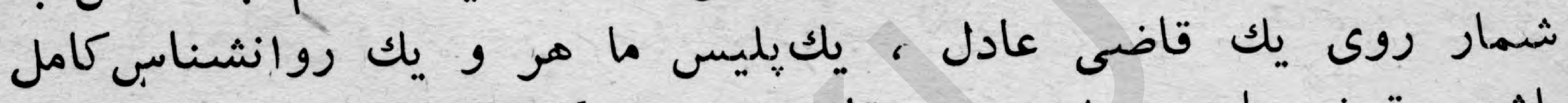

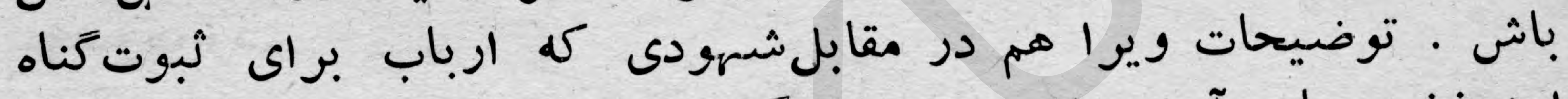

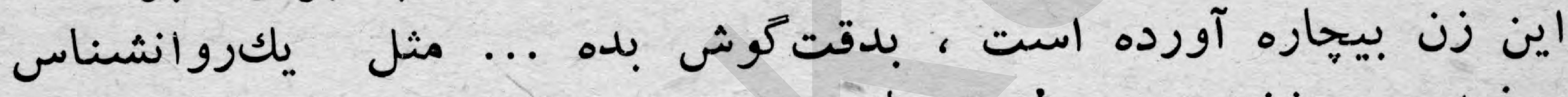

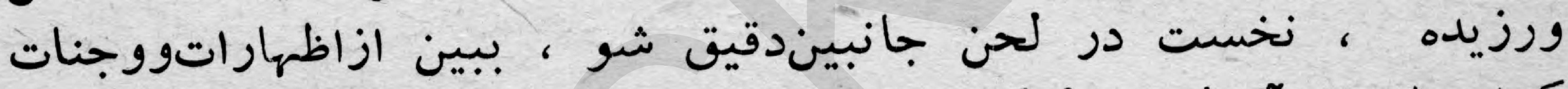

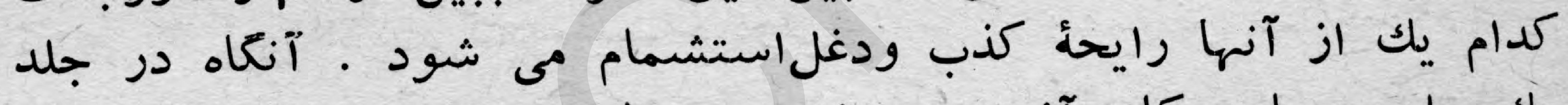

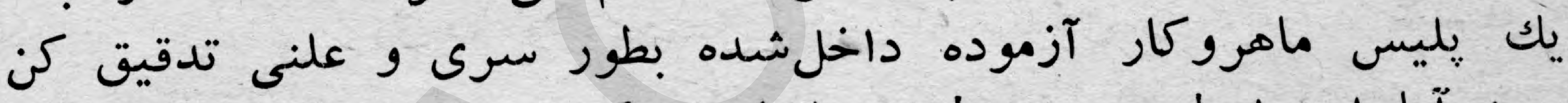

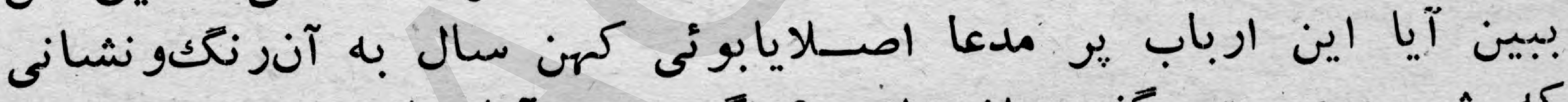

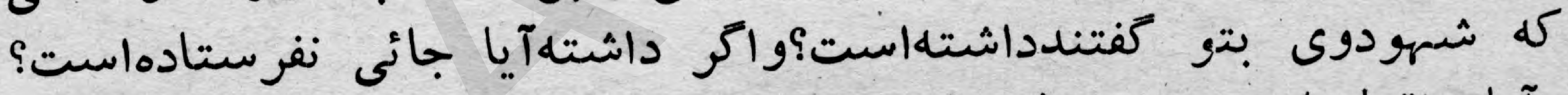

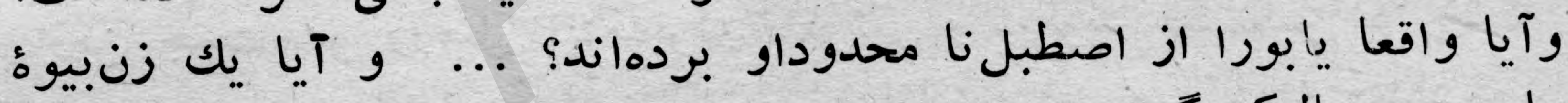

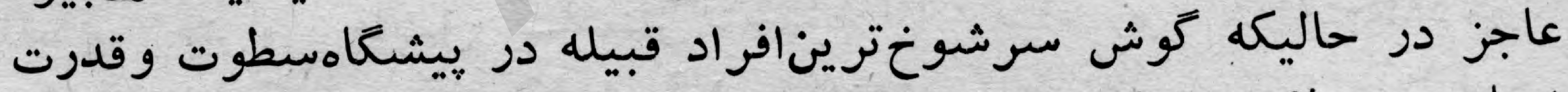

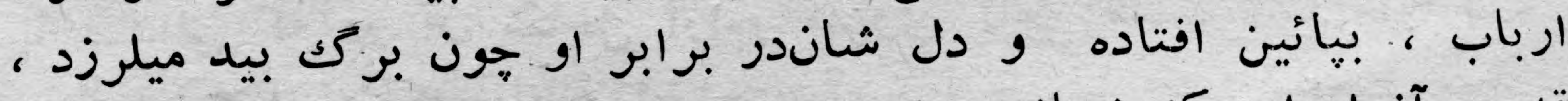

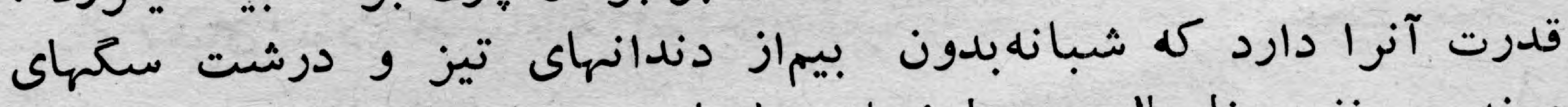

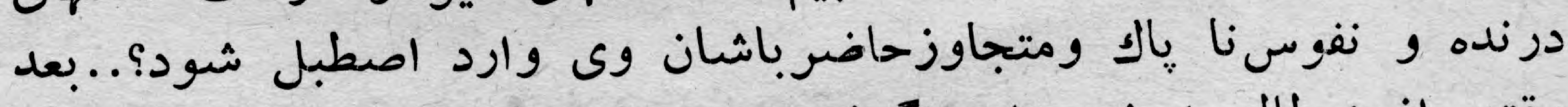

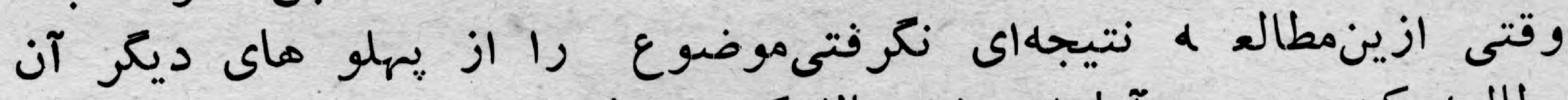

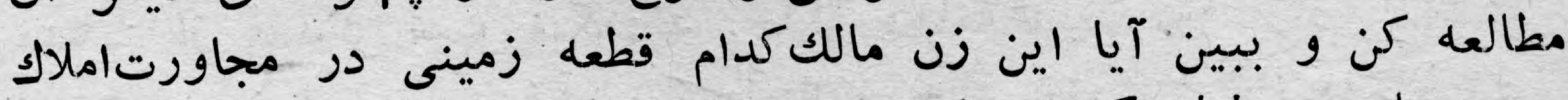

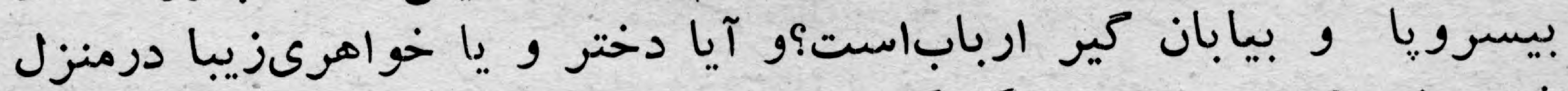

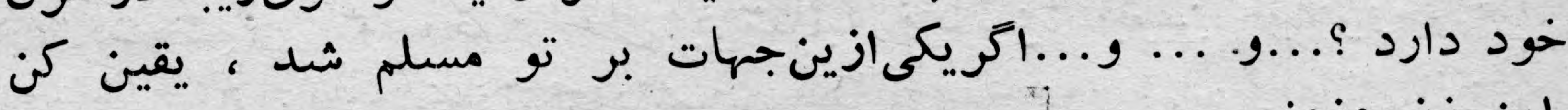
ارباب باصرف نفوذ اين توطئلراترتيب دادهو اين شهود رالجيركرده 
تا اينزن عفيف و بينوا را كه يـانخواسته خواهر و دخترش راشبى زئل

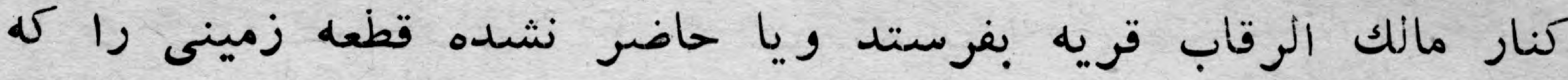

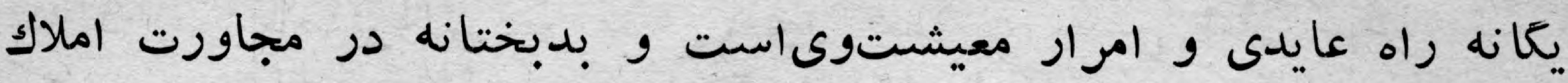

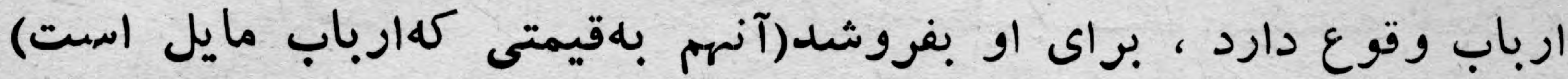

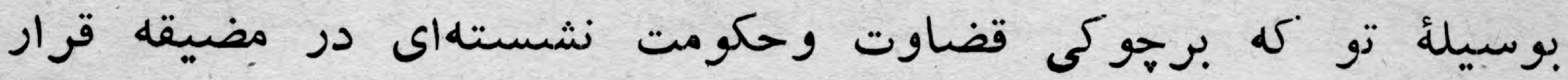

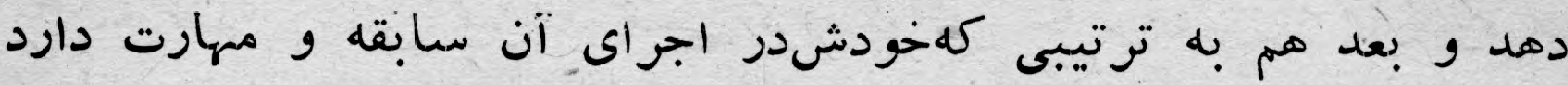

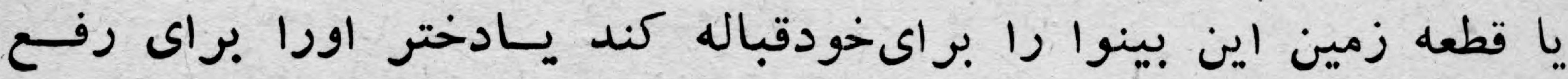

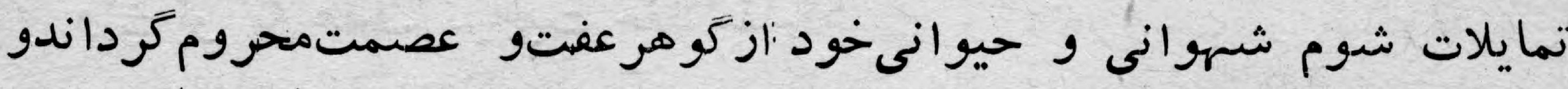

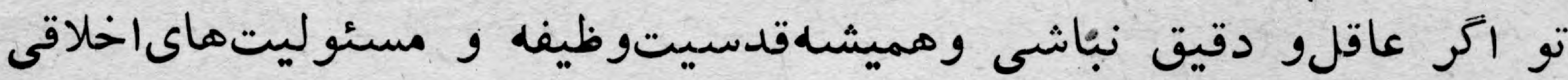

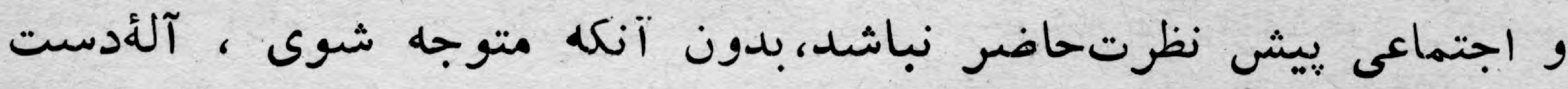

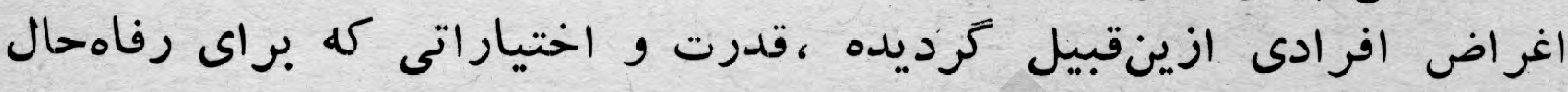

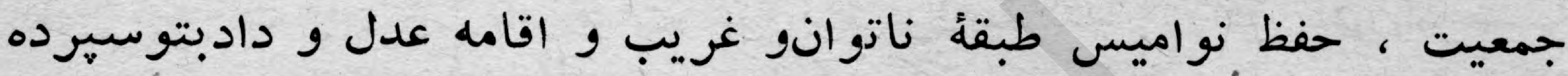

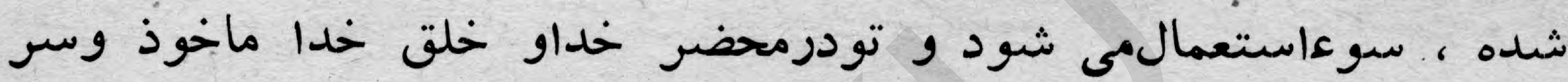

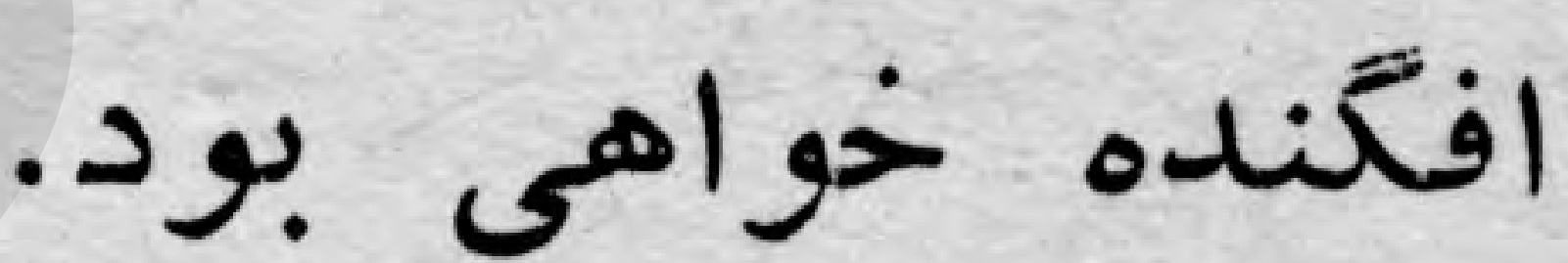

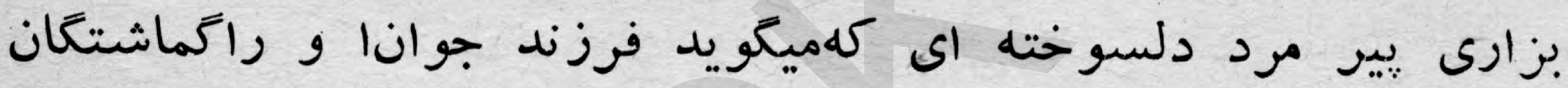

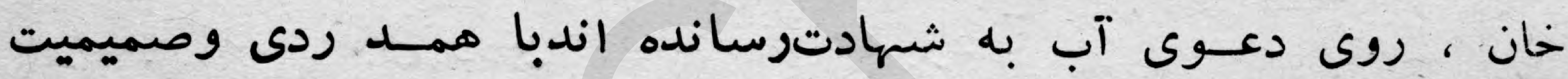

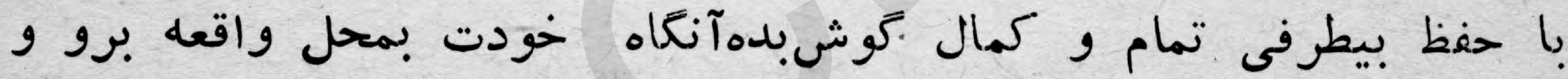

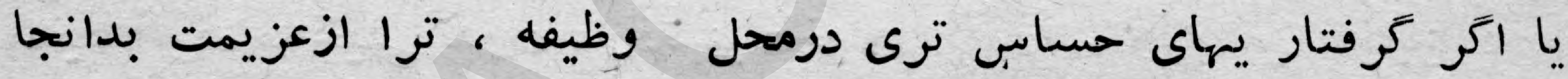

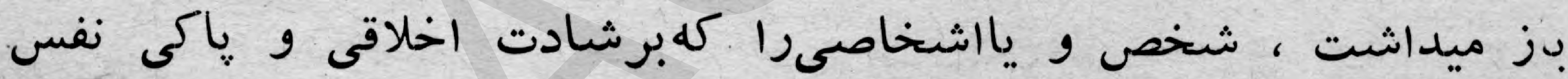

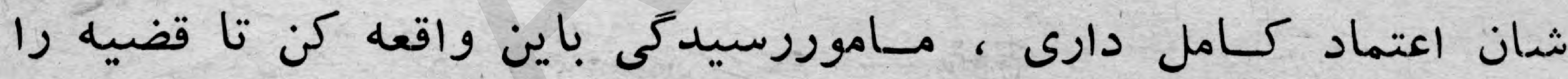

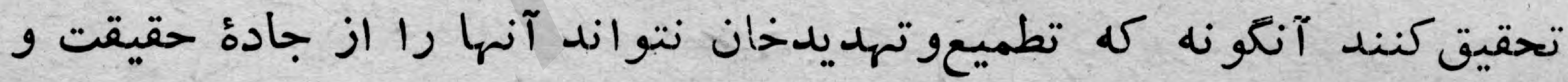

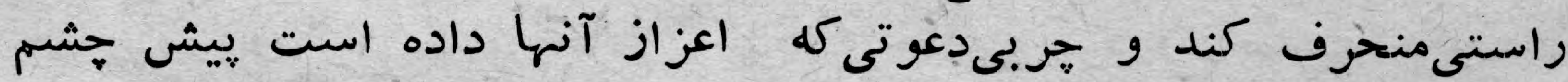

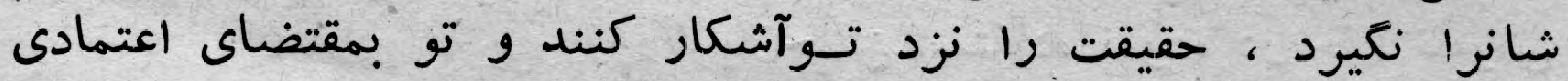

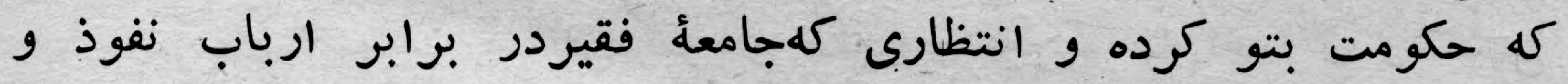

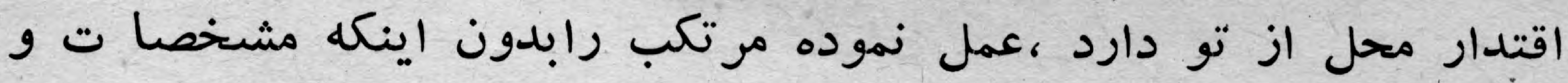

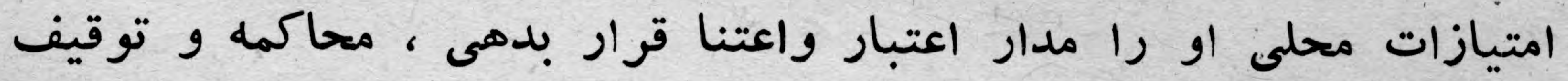

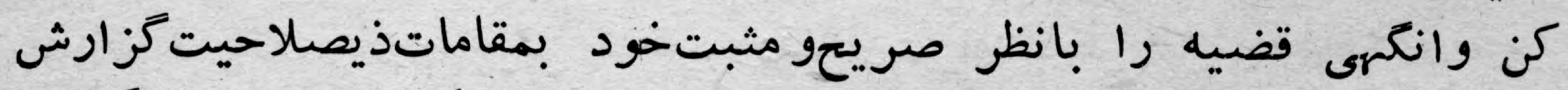

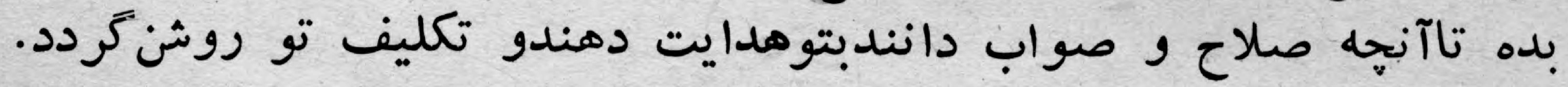

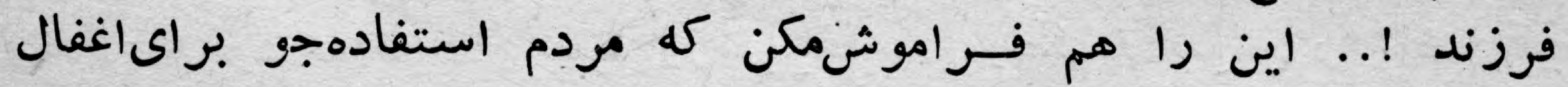

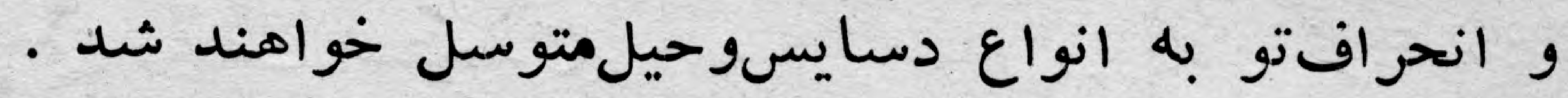
ary 
مثلا وقتى ديدند تو حاضر نيستىرشوه بكيرى يا وظيفه را در مر مقابز

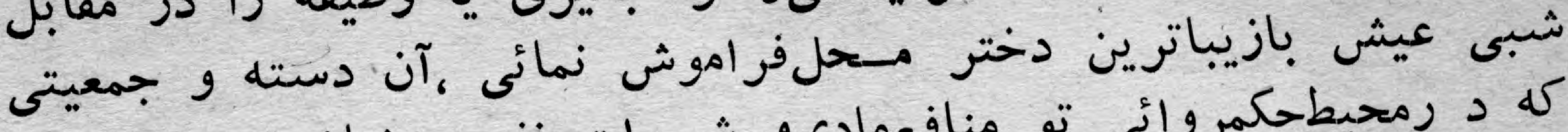

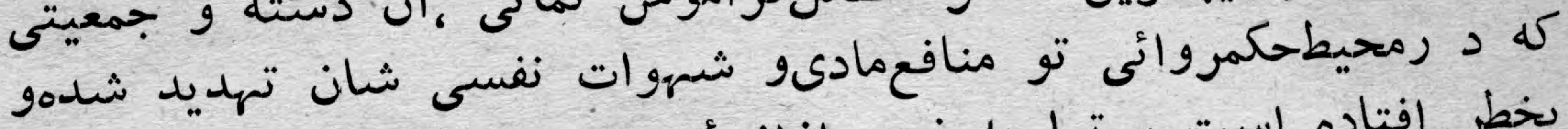

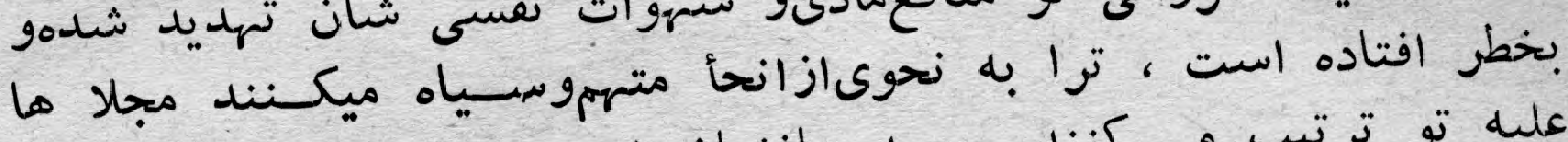

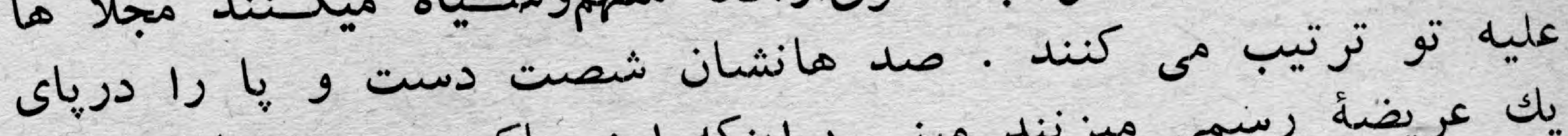

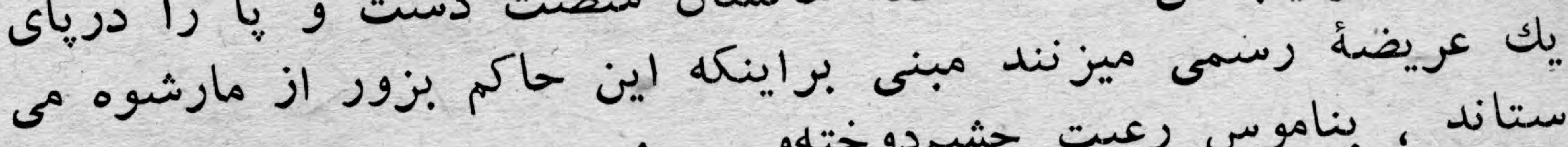

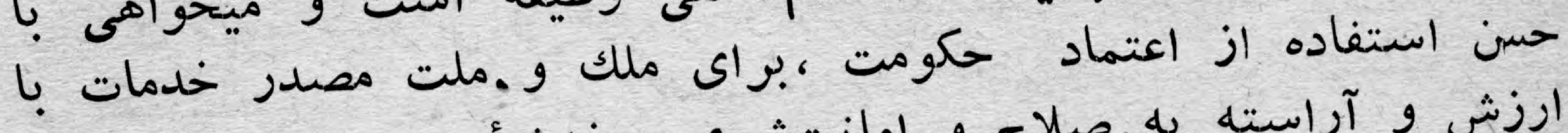

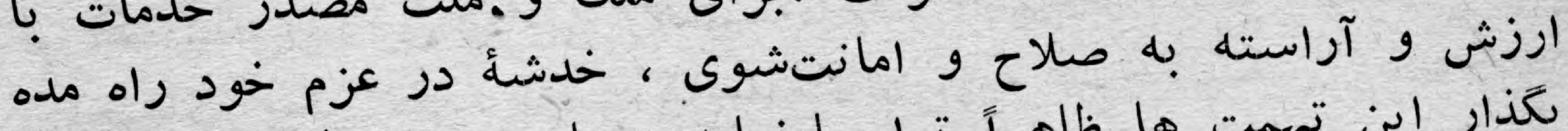

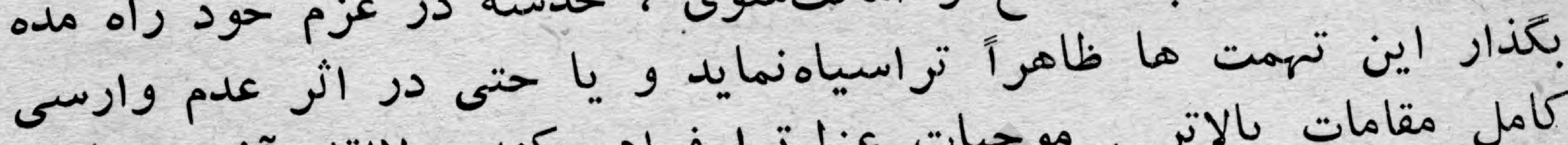

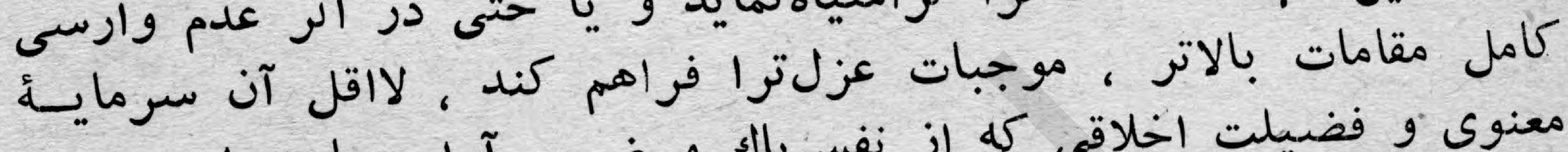

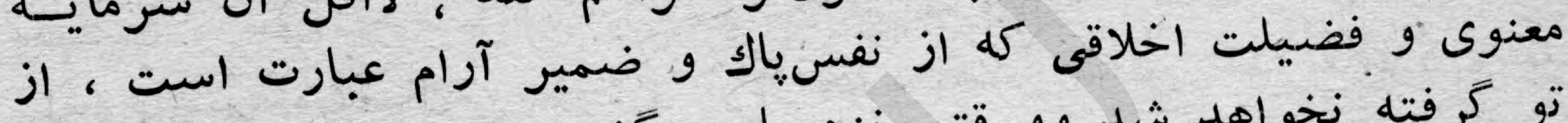

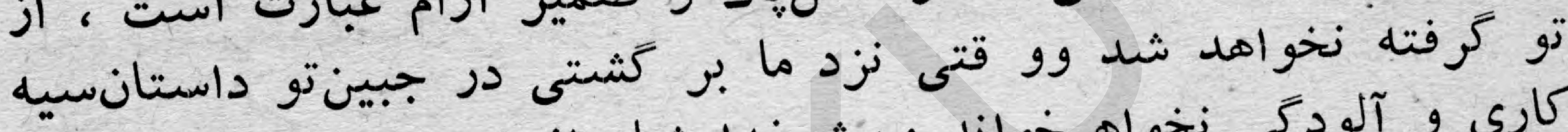

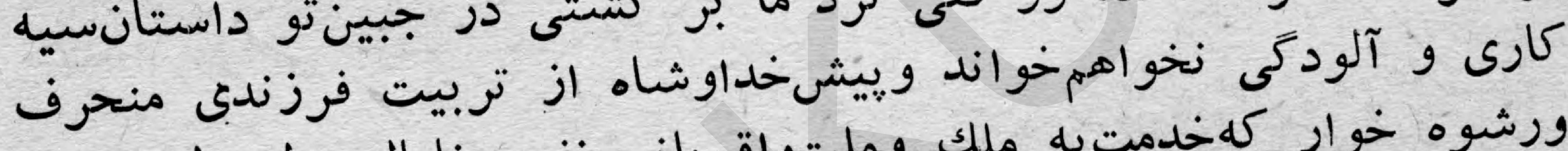

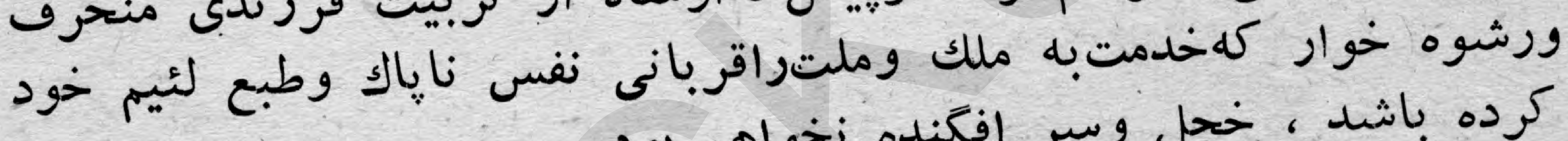

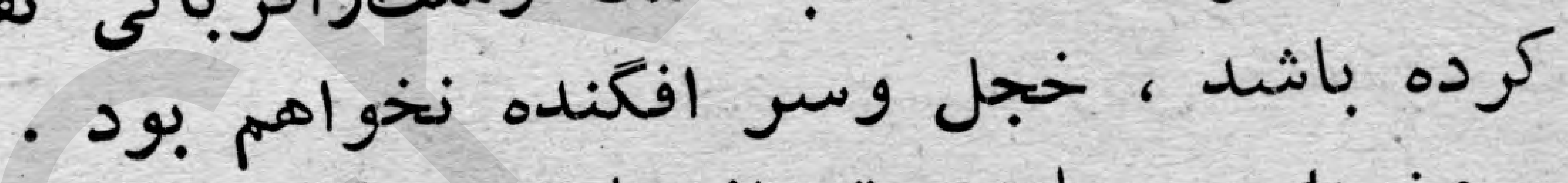

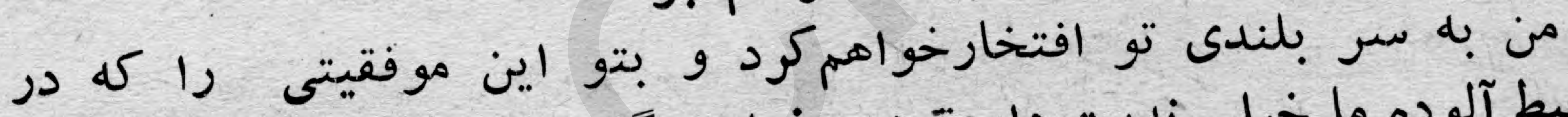

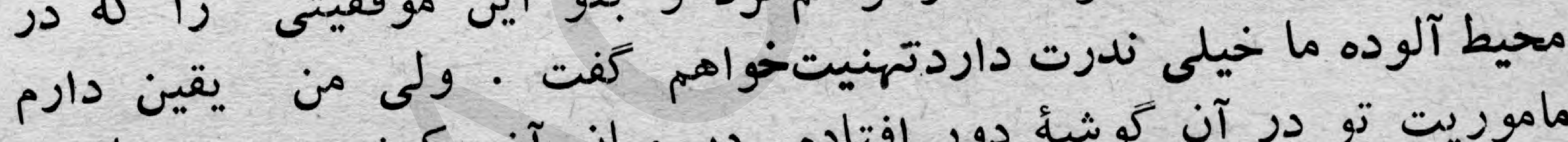

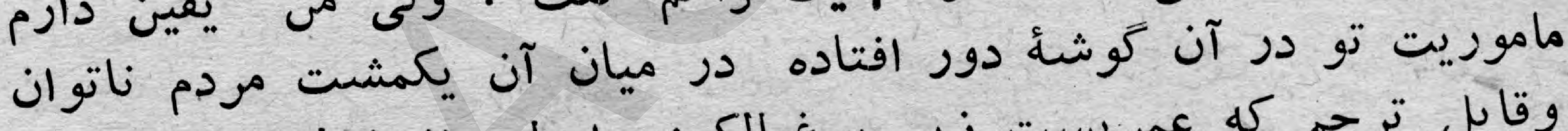

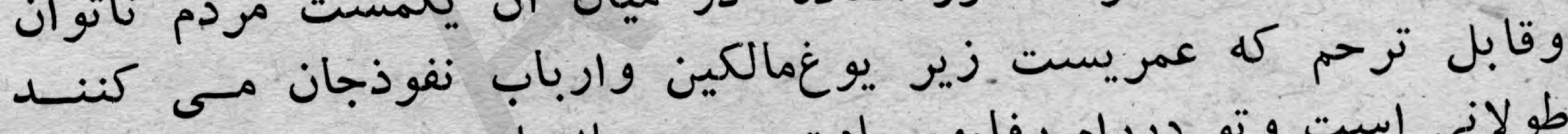

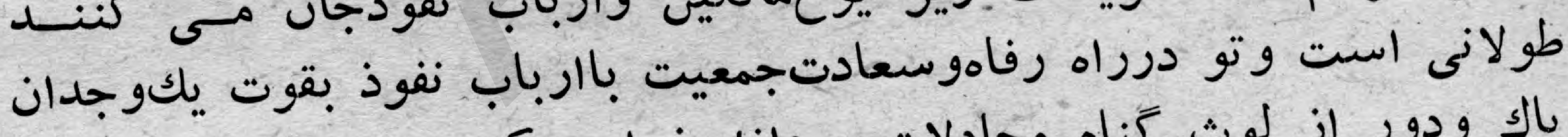

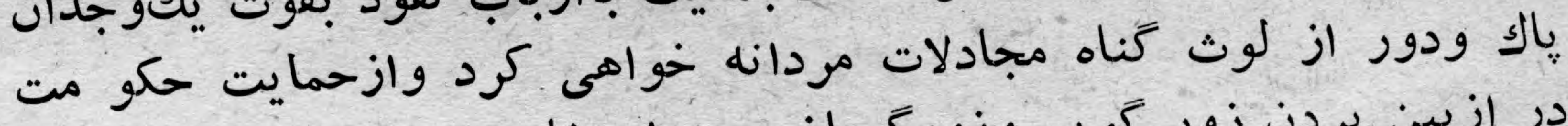

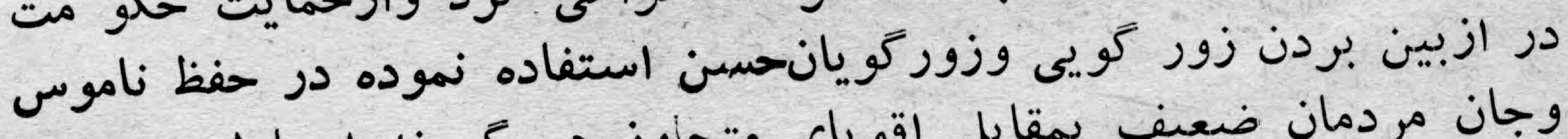

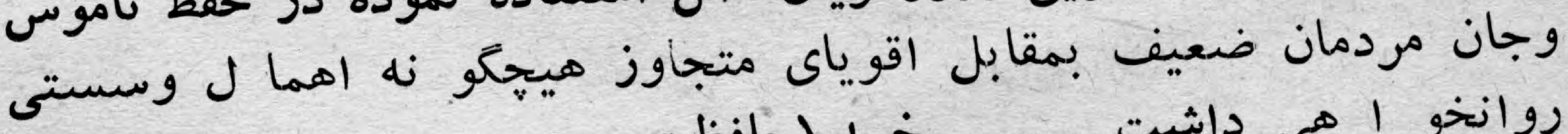

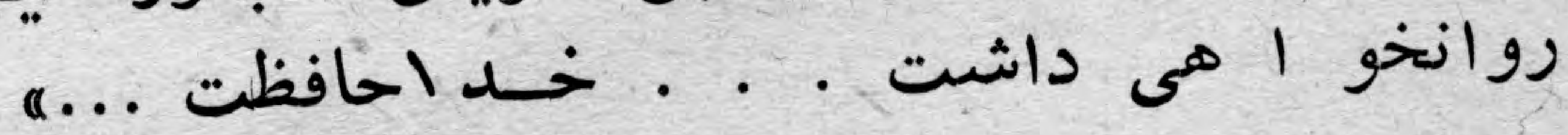

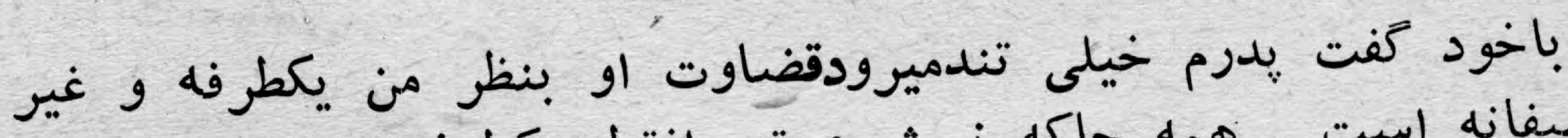

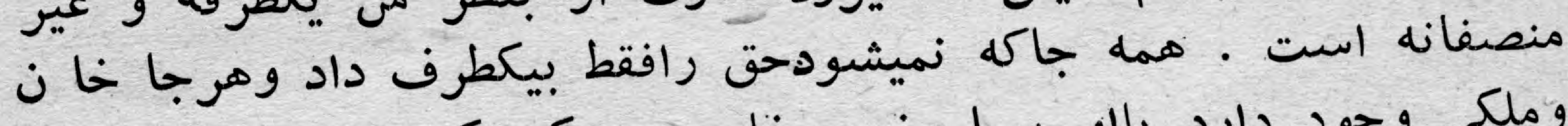

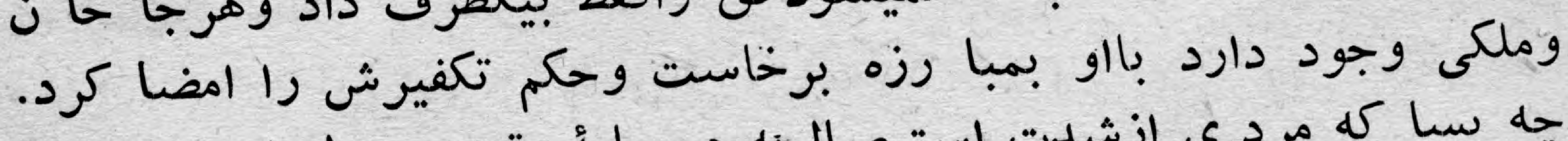

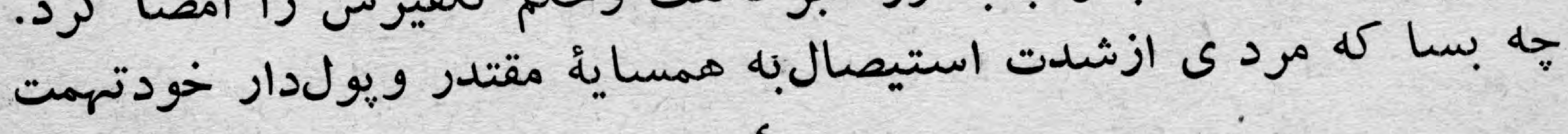
(घ)" 


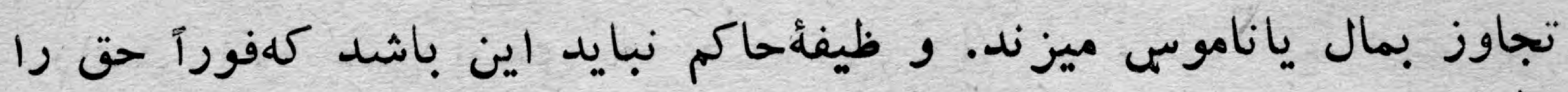

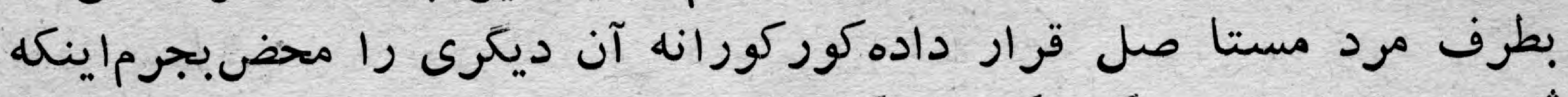

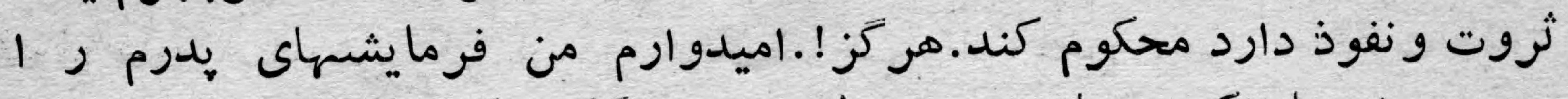

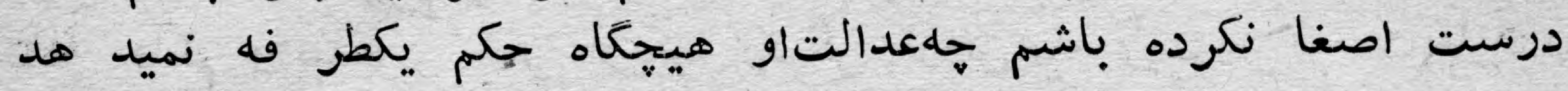

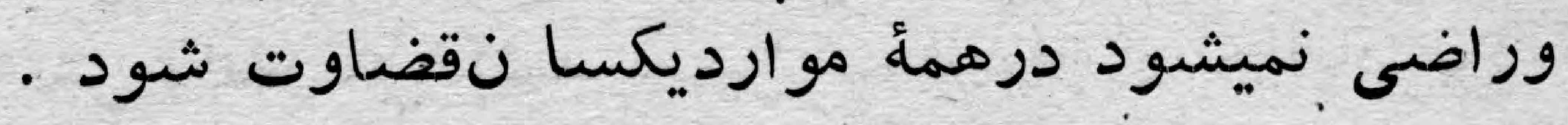

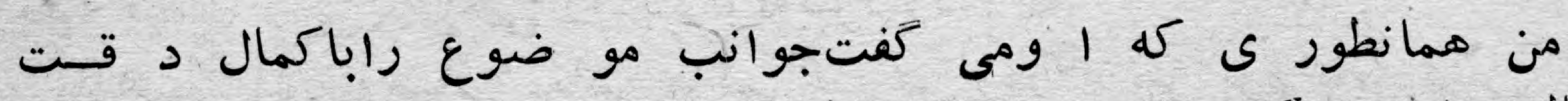

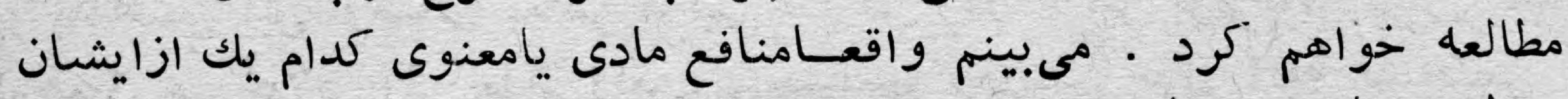

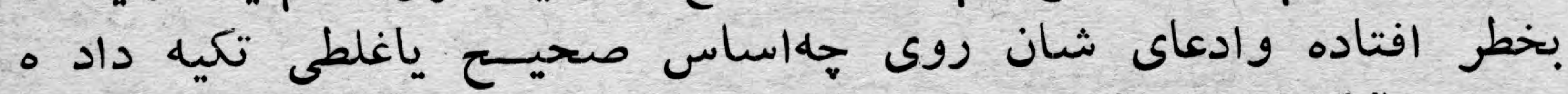

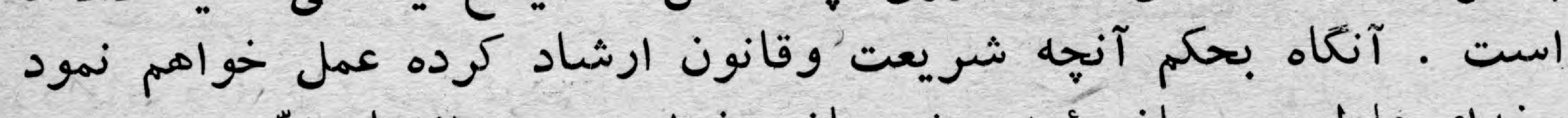

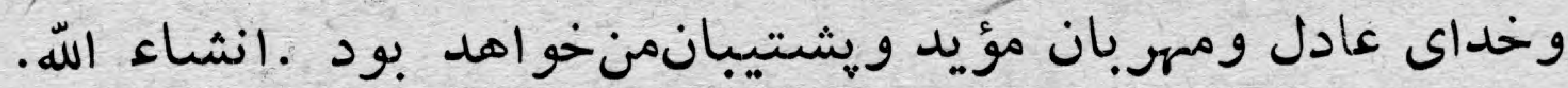

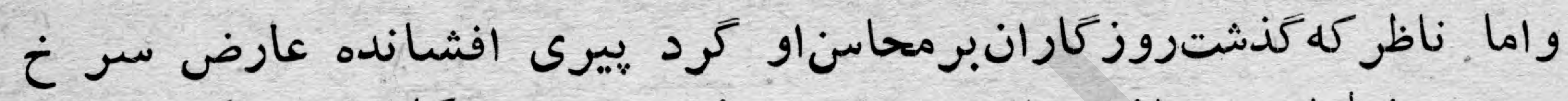

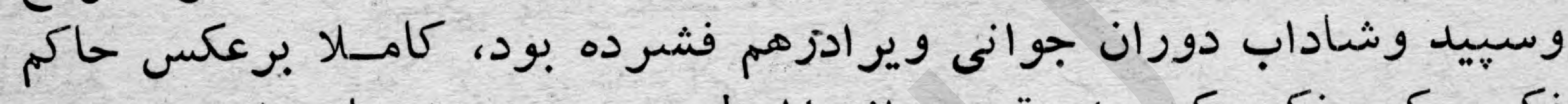

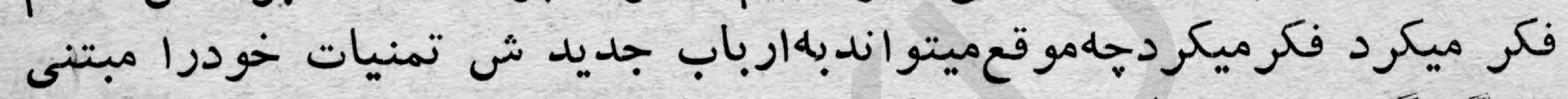

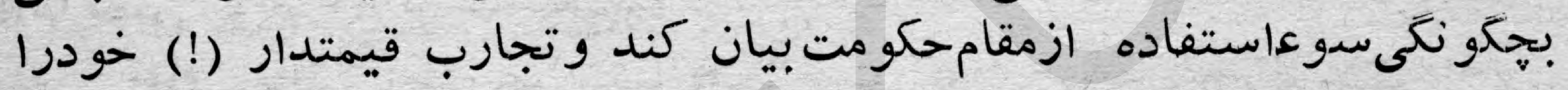

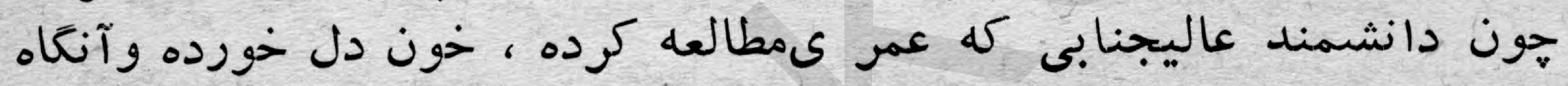

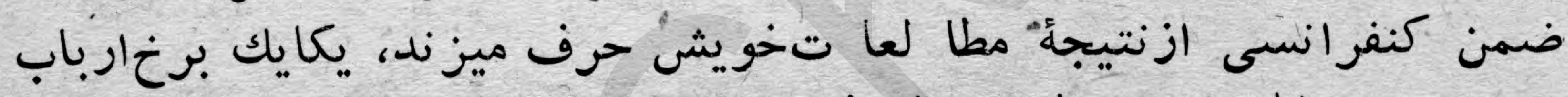

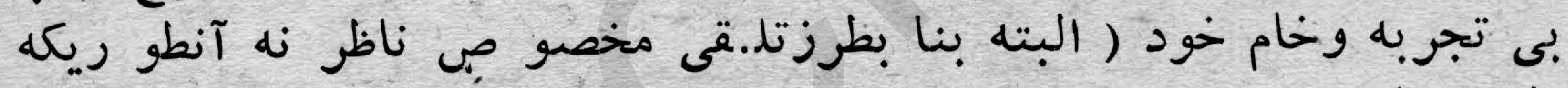

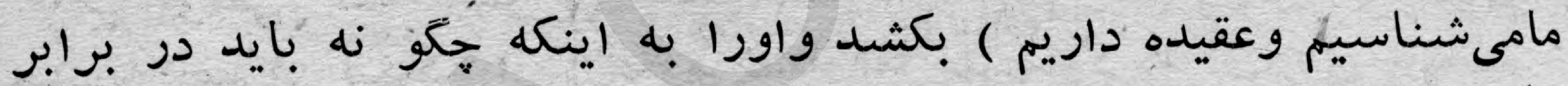

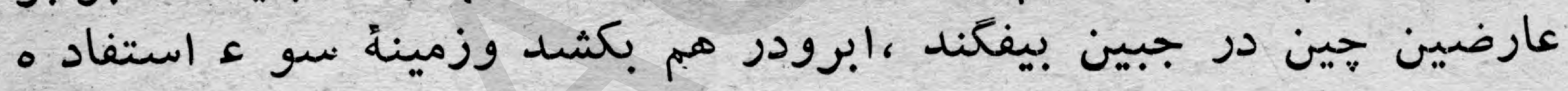

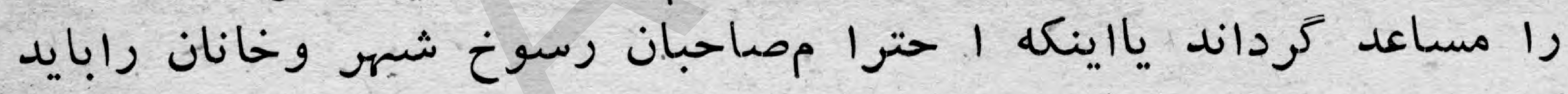

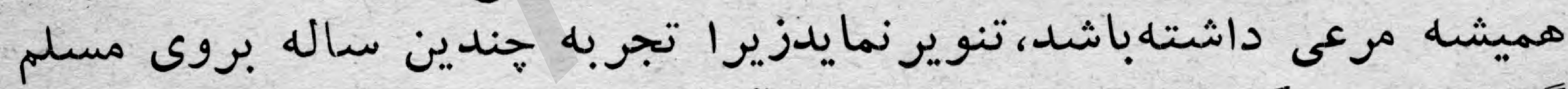

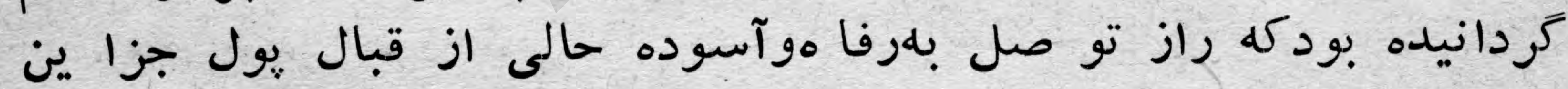

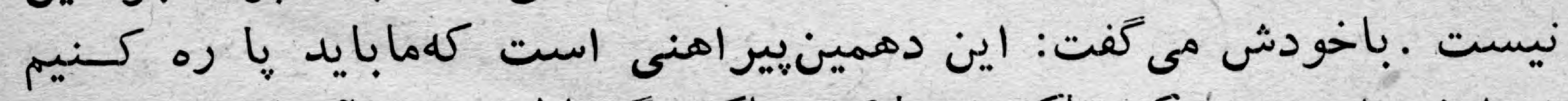

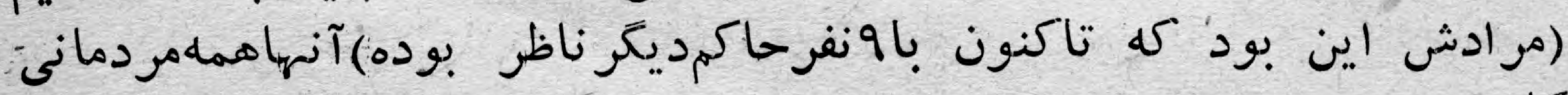

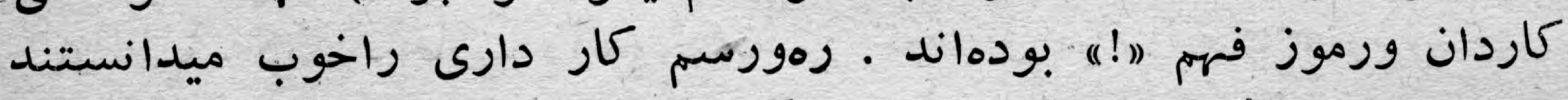

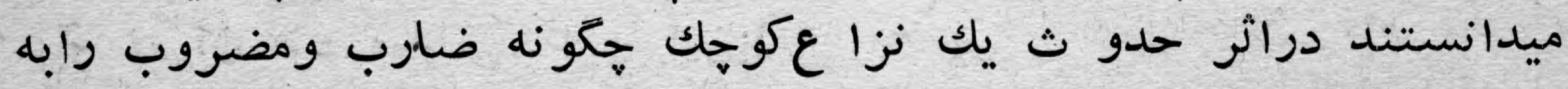

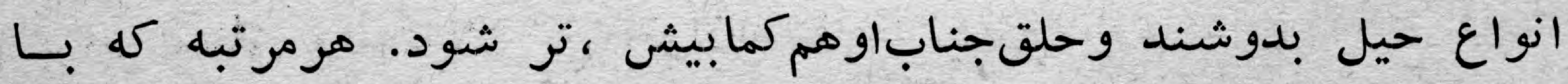

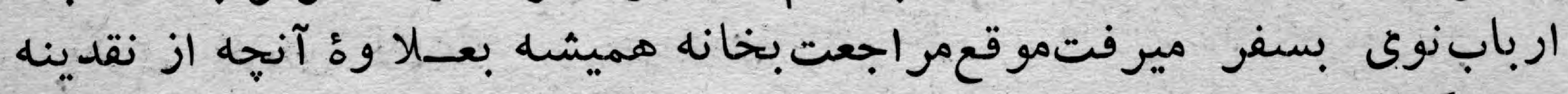

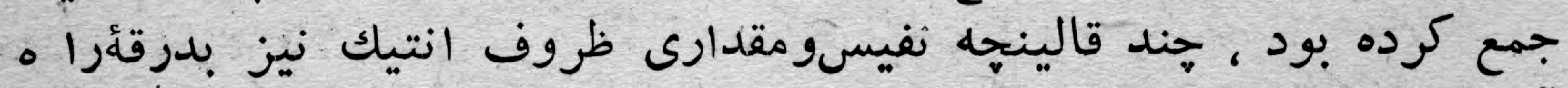

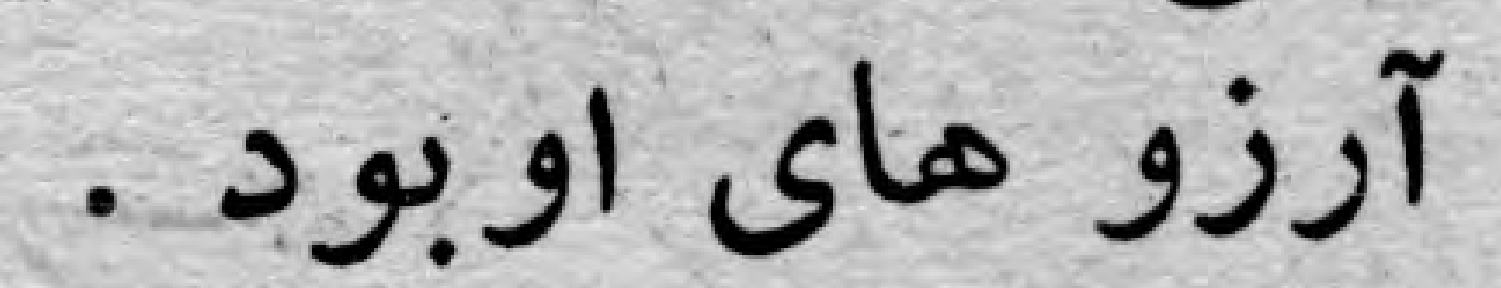




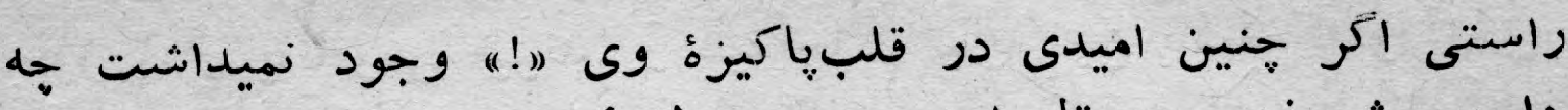

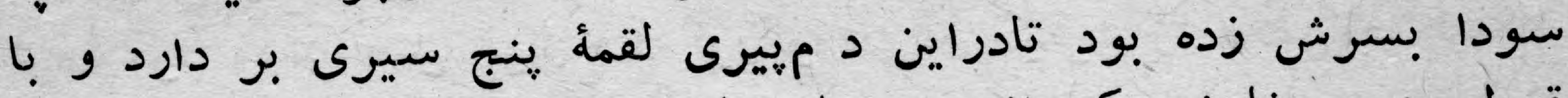

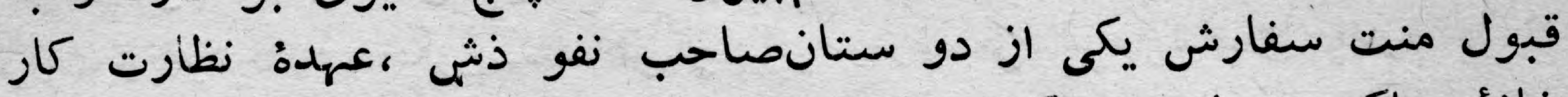

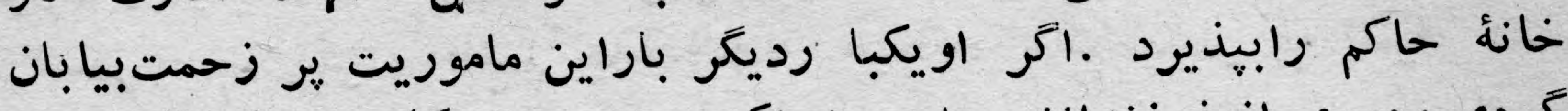

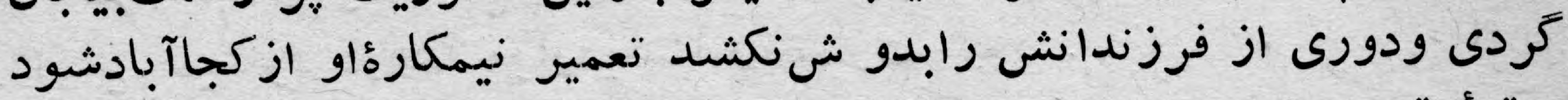

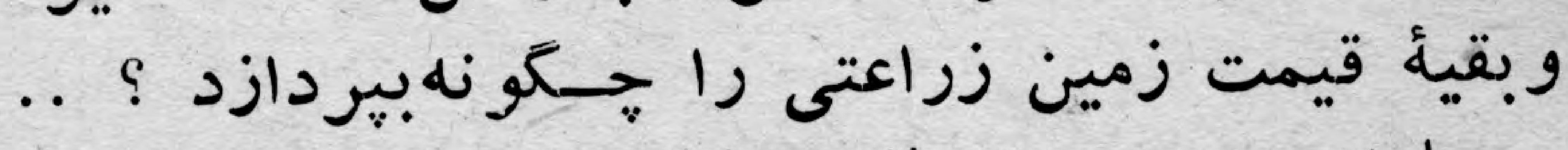

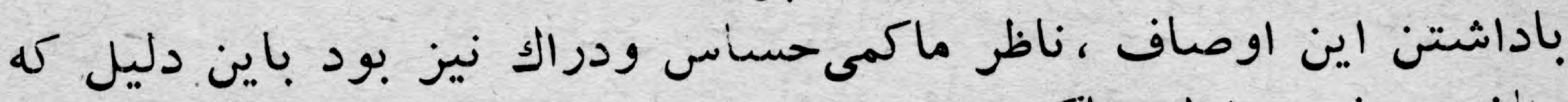

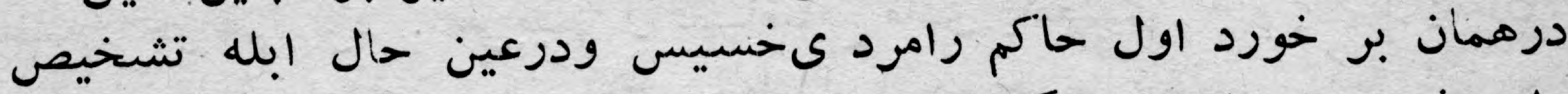

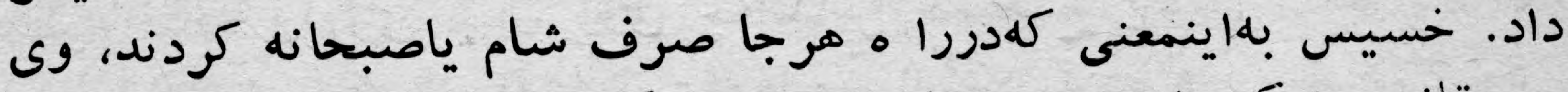

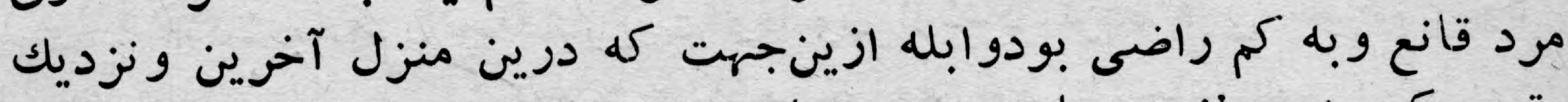

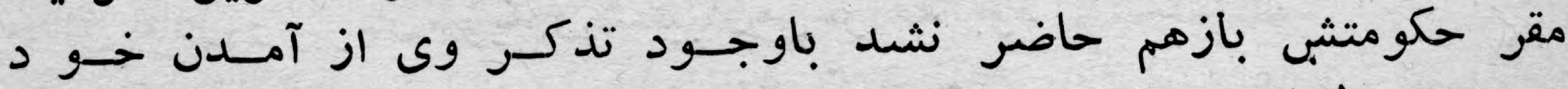

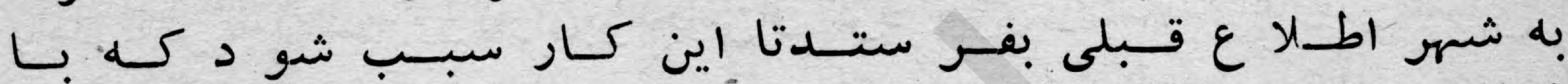

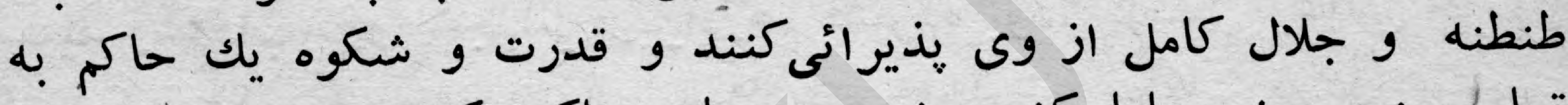

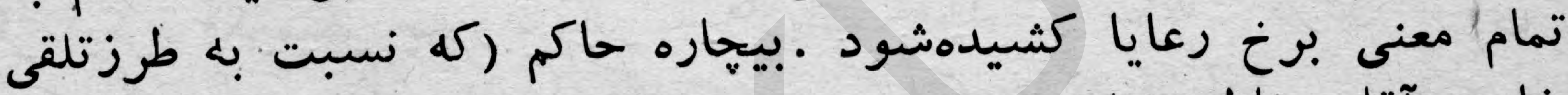

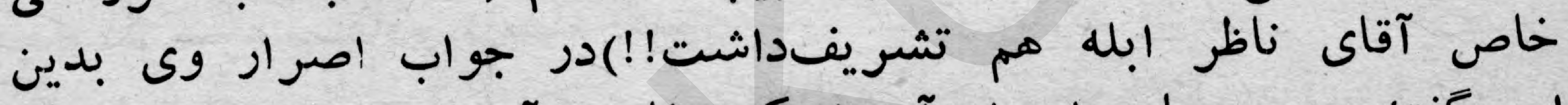

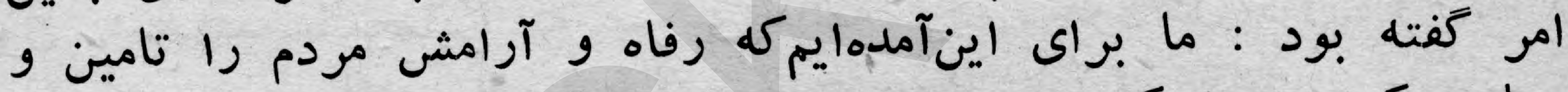

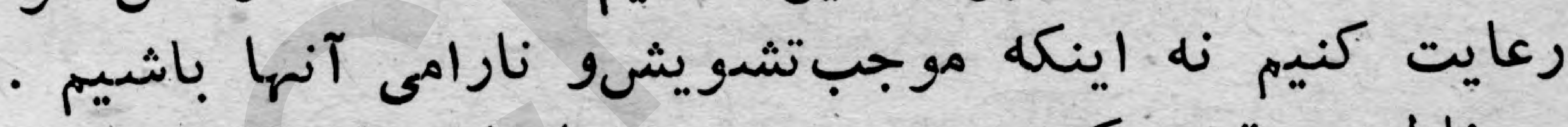

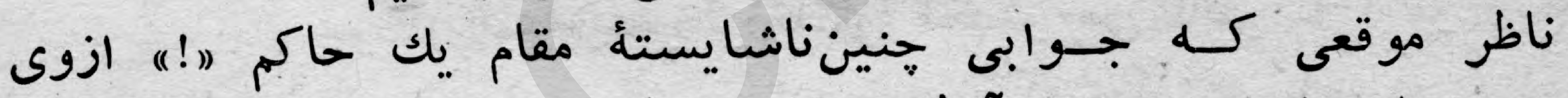

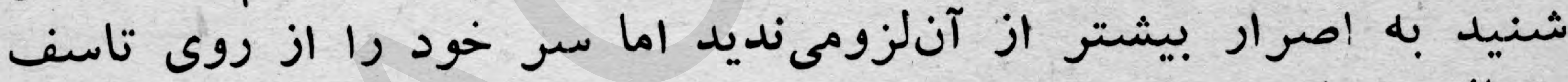

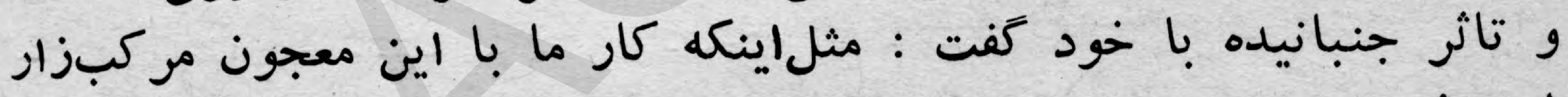

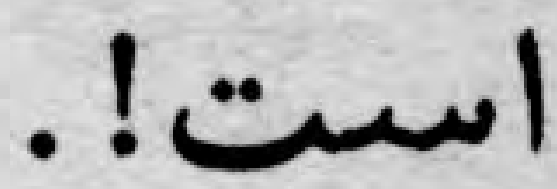

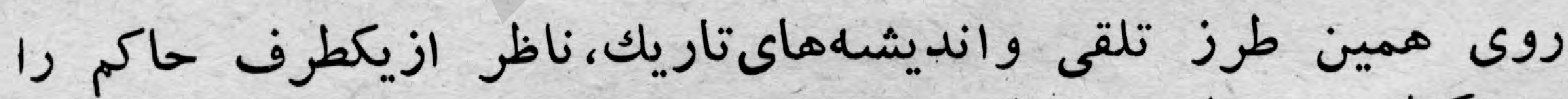

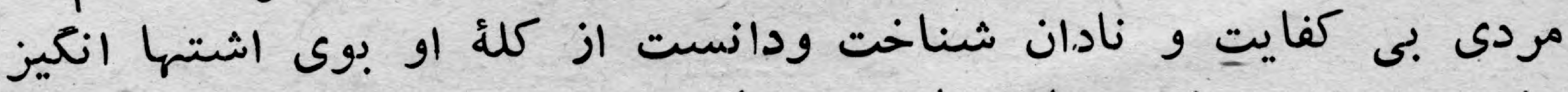

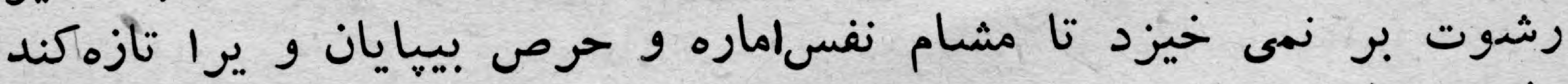

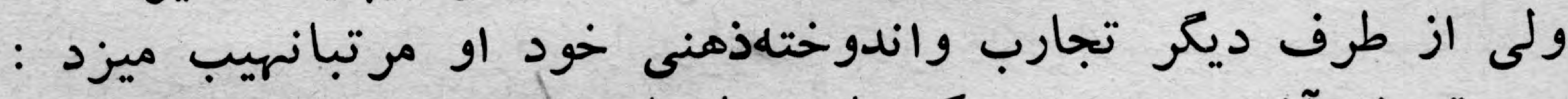

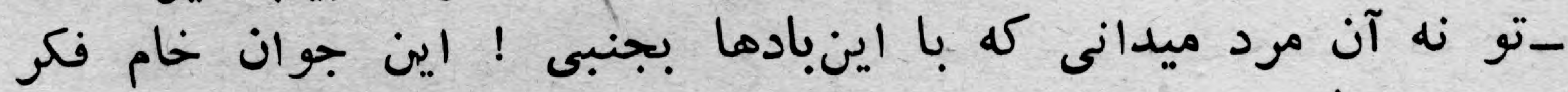

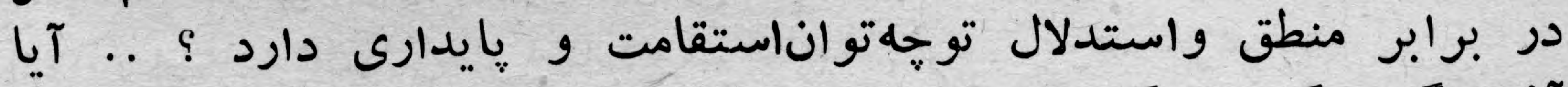

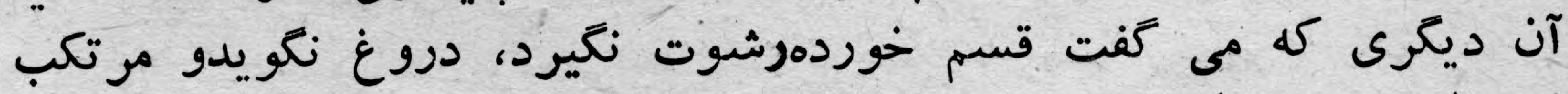

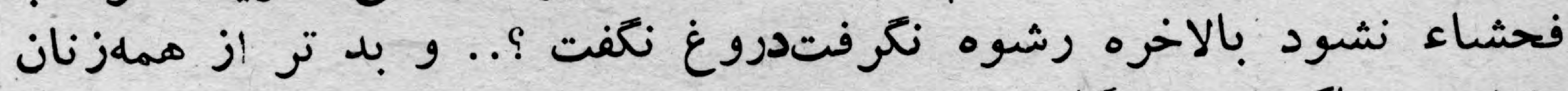

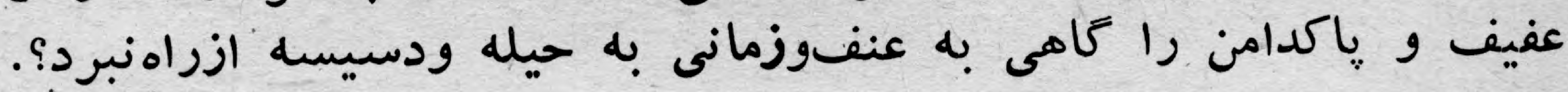

\section{a.}




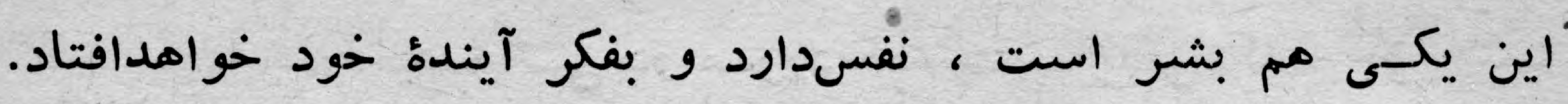

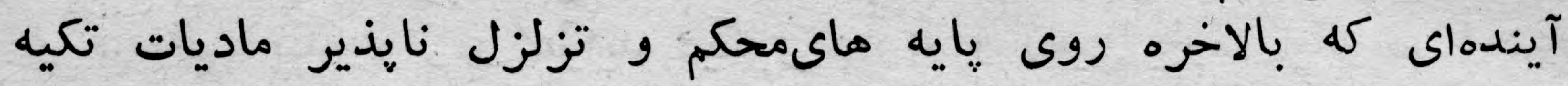

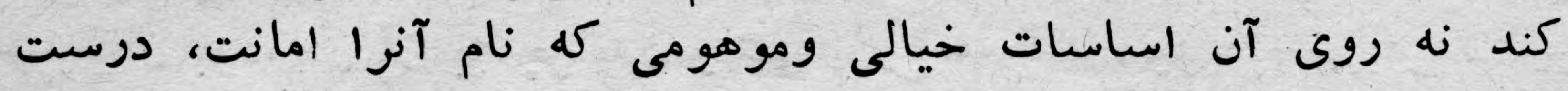

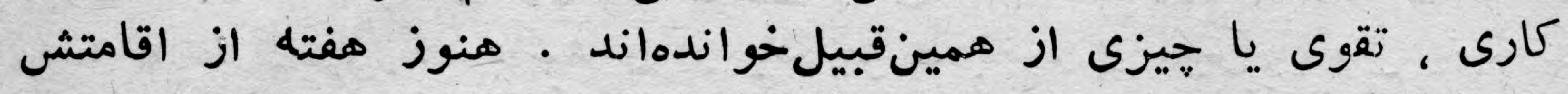

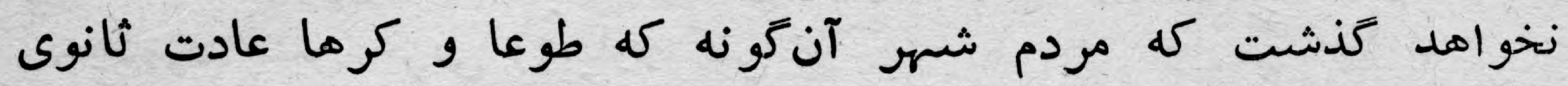

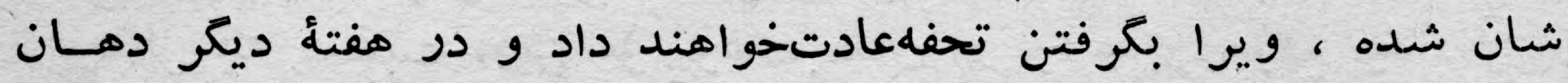

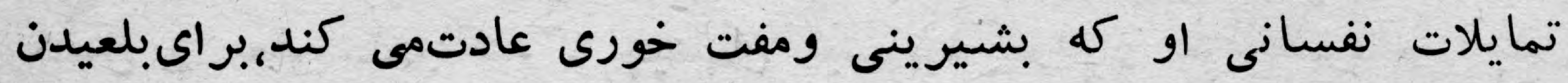

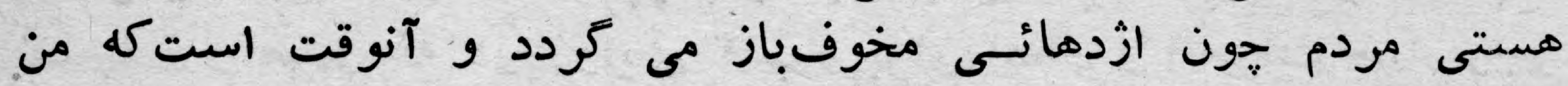

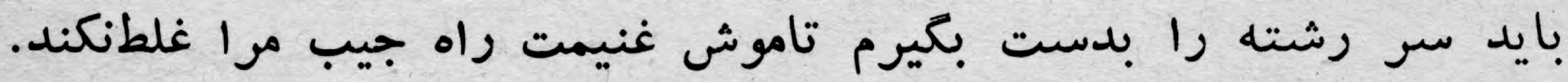

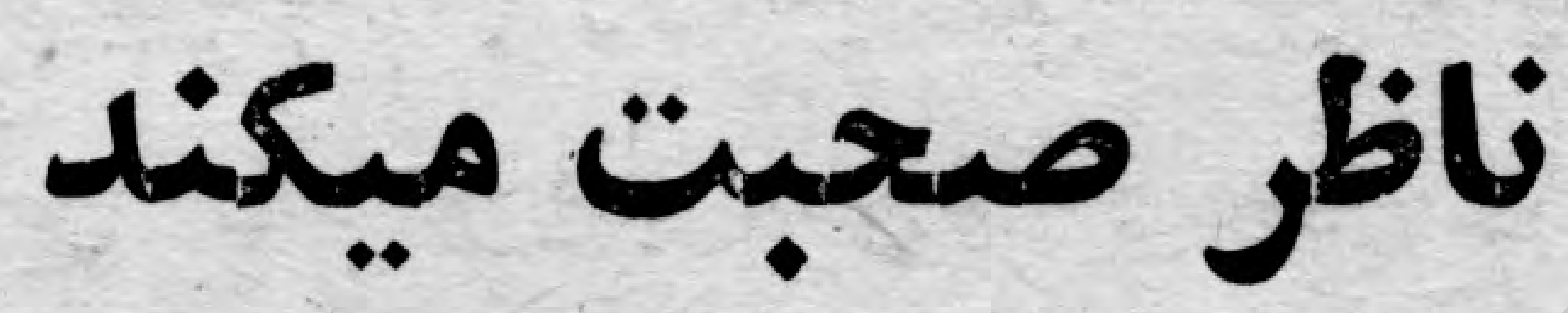

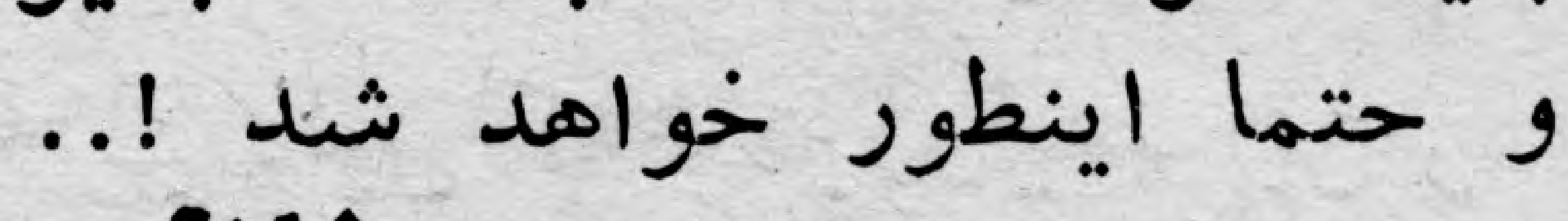

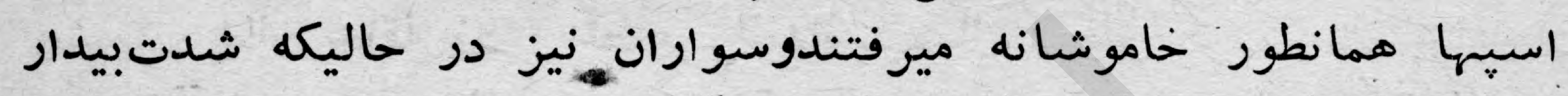

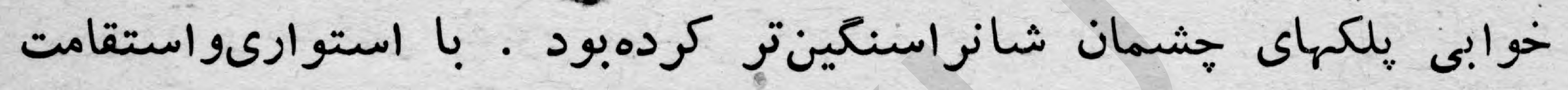

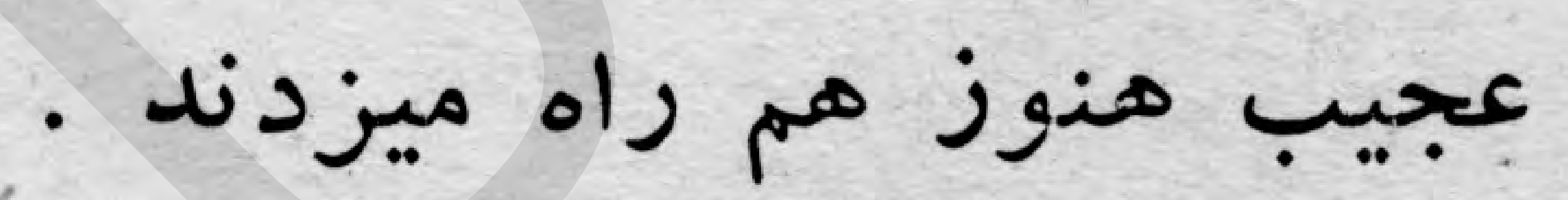

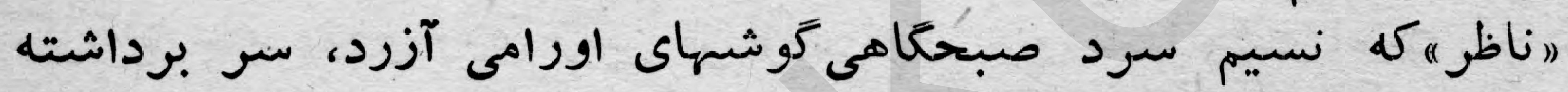

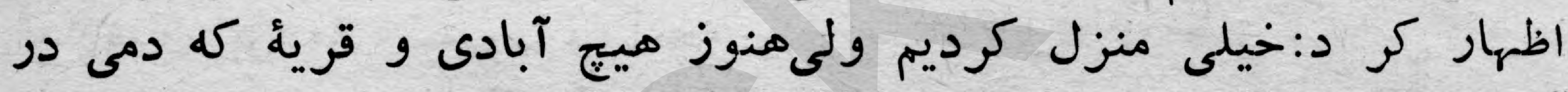

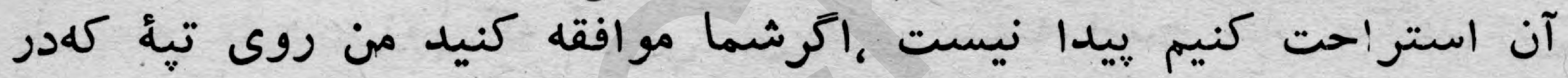

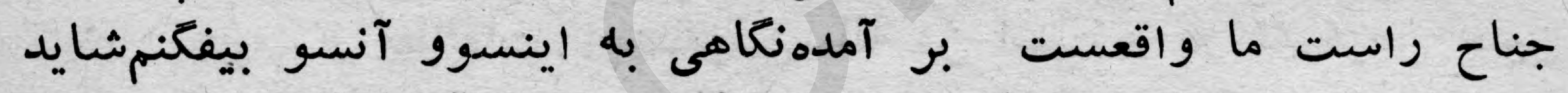

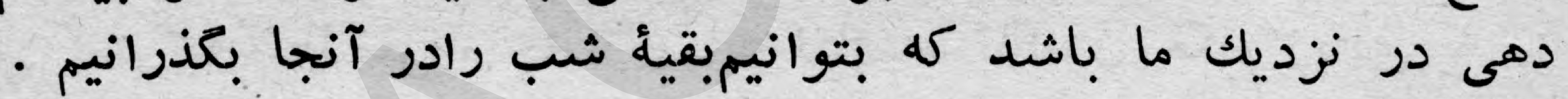

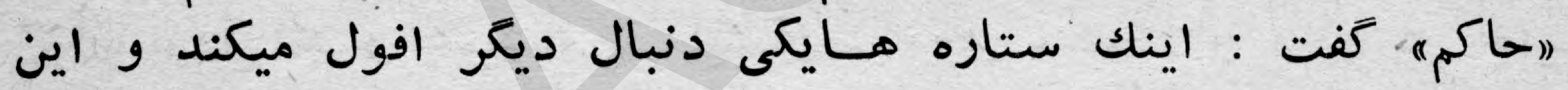

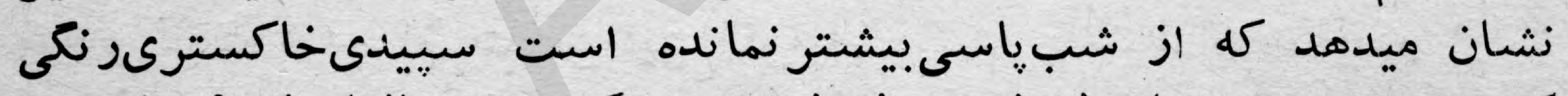

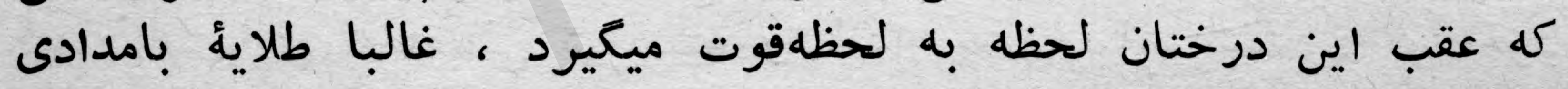

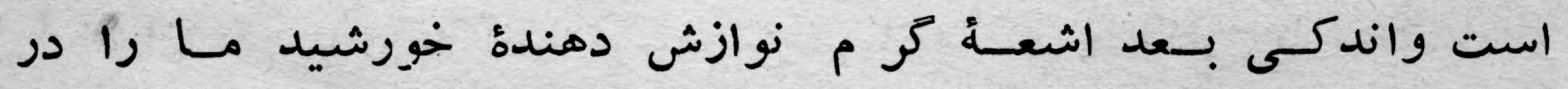

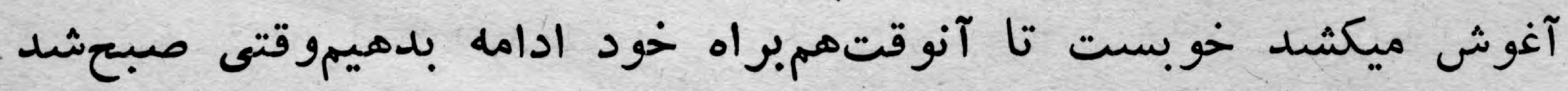

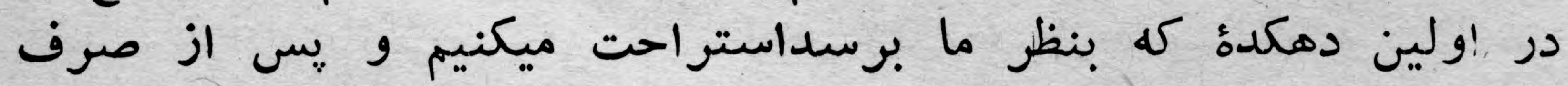

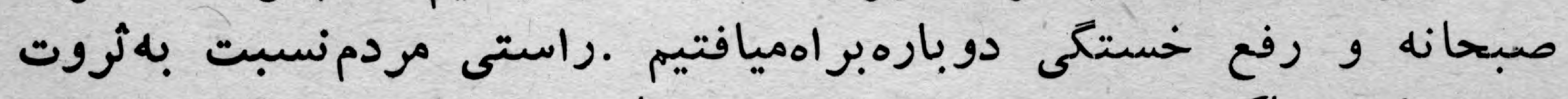

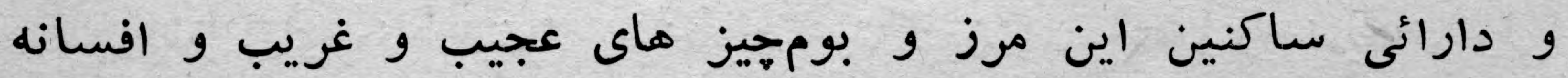

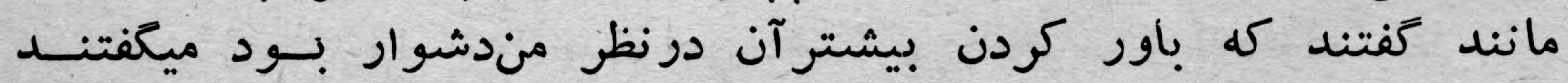

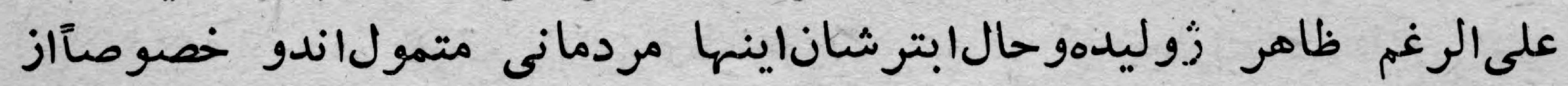

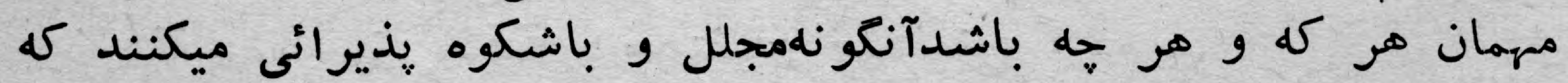
كيج كننده است كل 


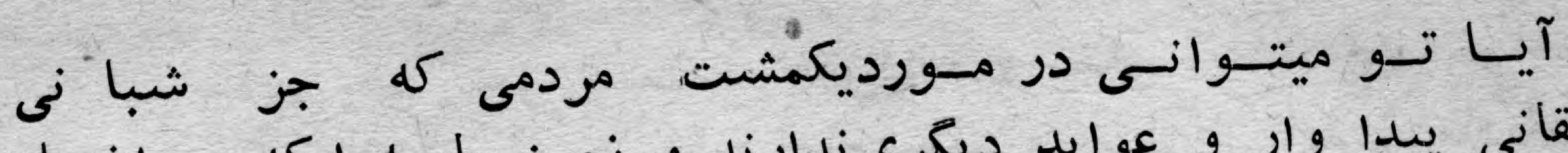

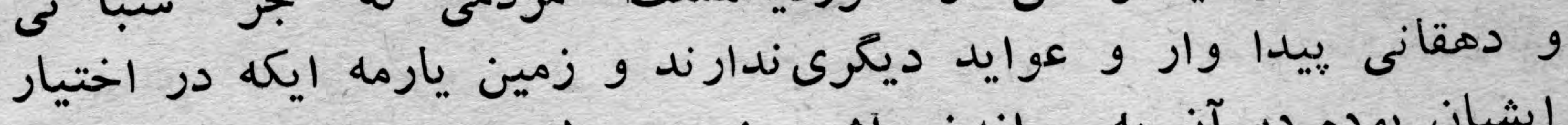

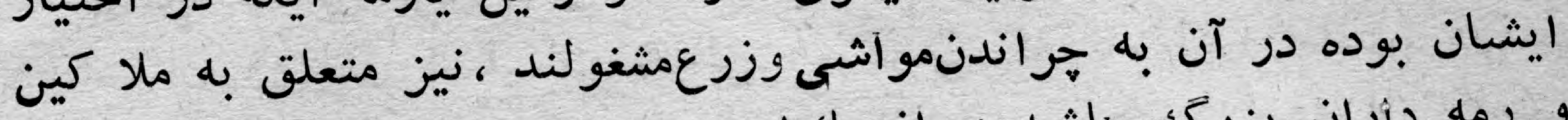

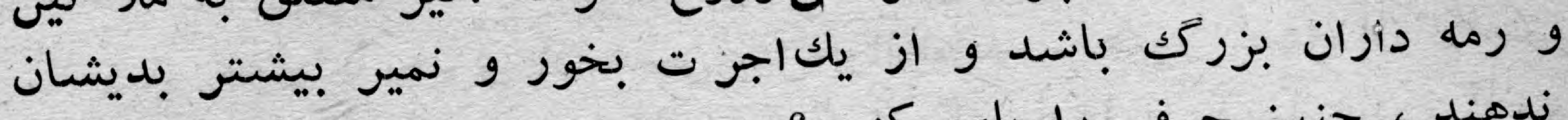

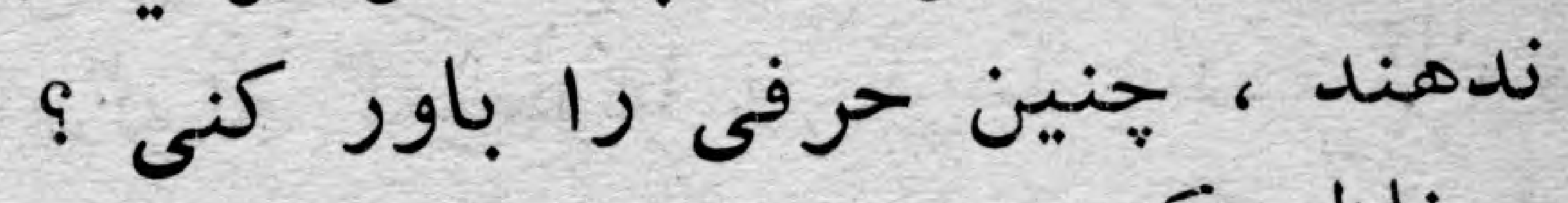

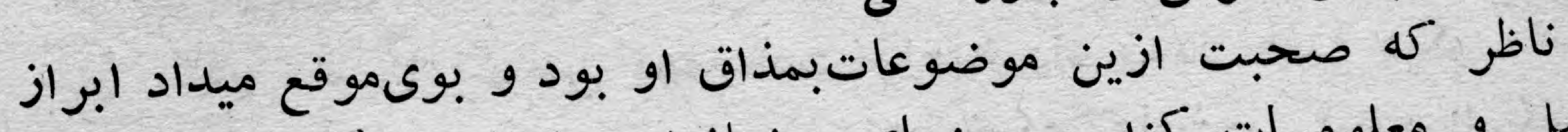

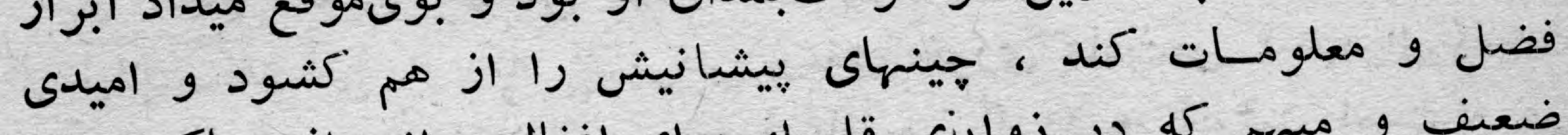

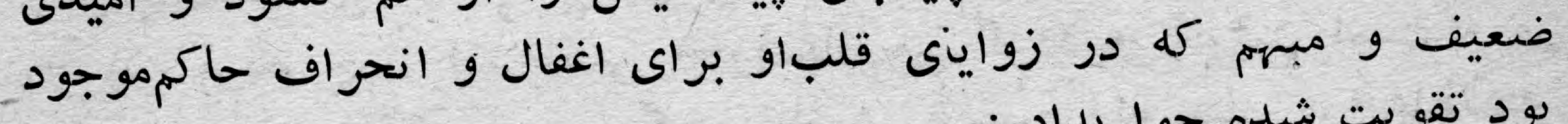

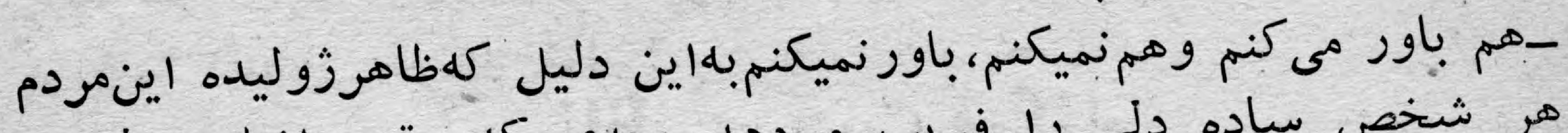

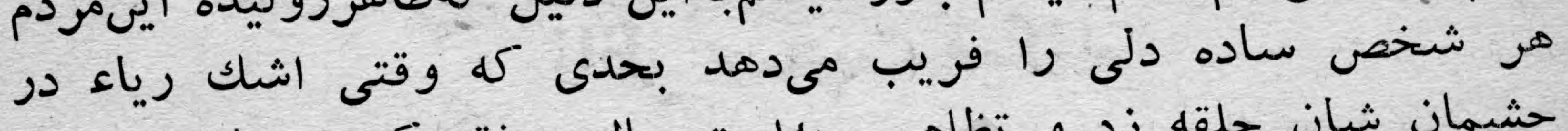

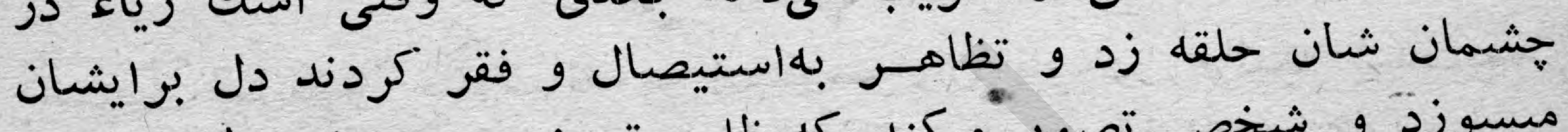

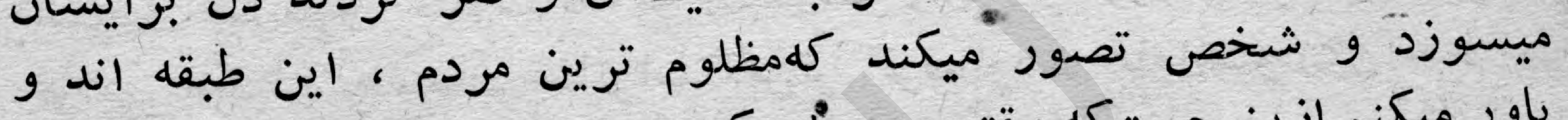

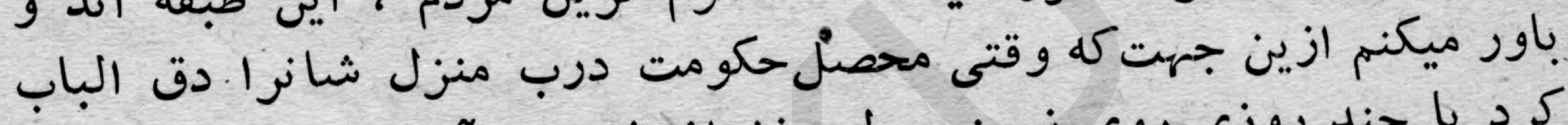

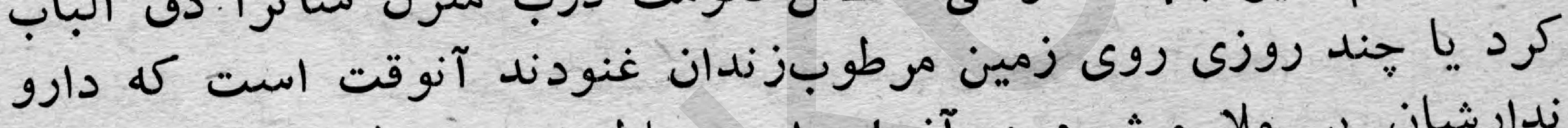

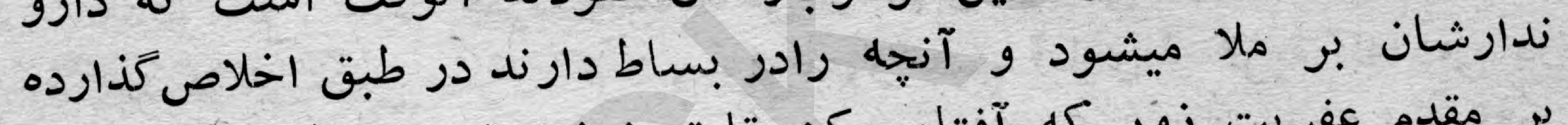

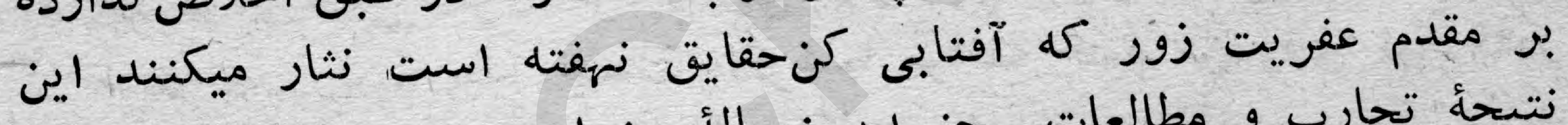

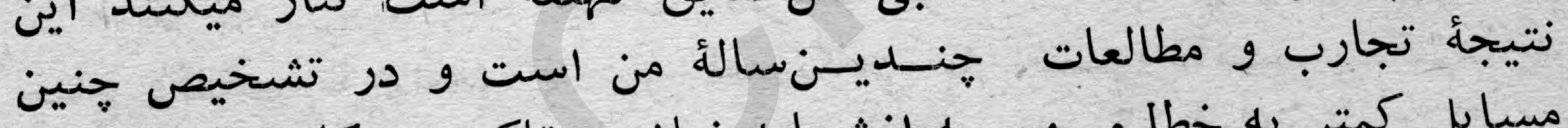

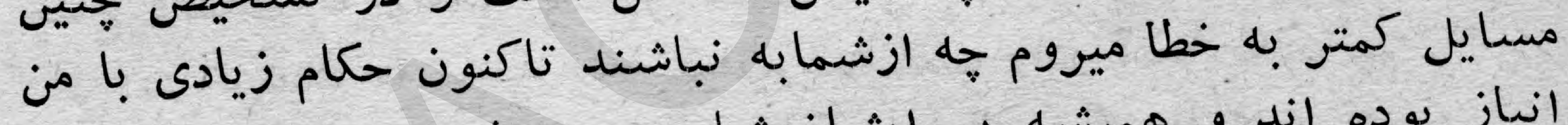

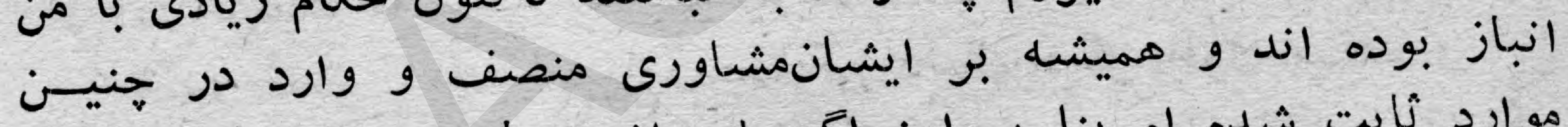

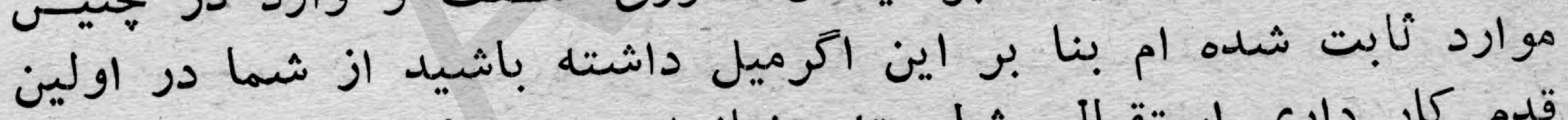

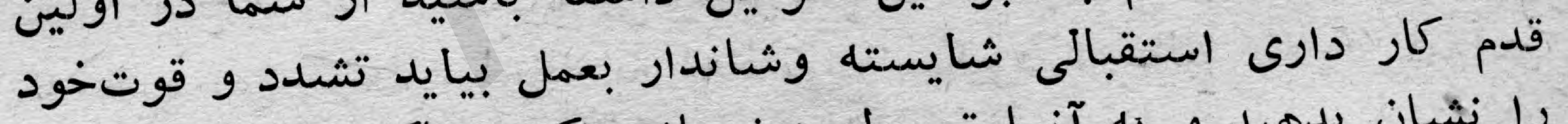

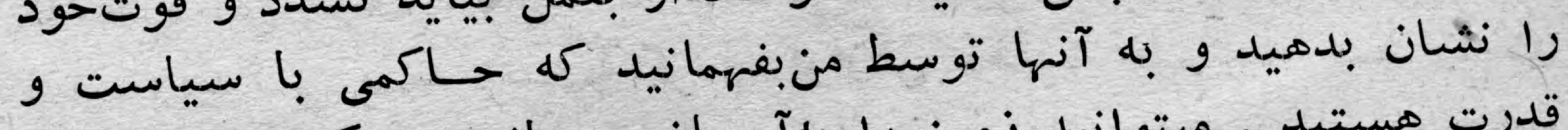

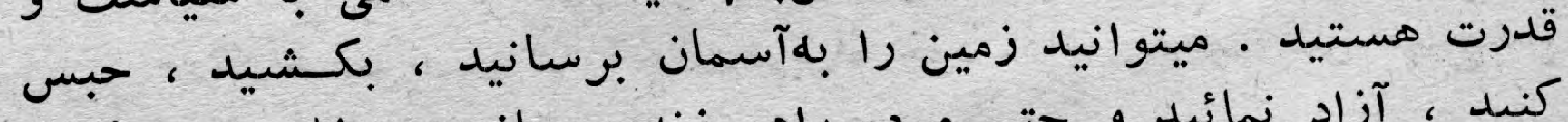

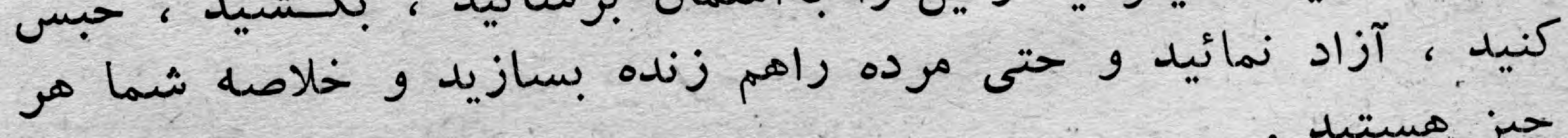

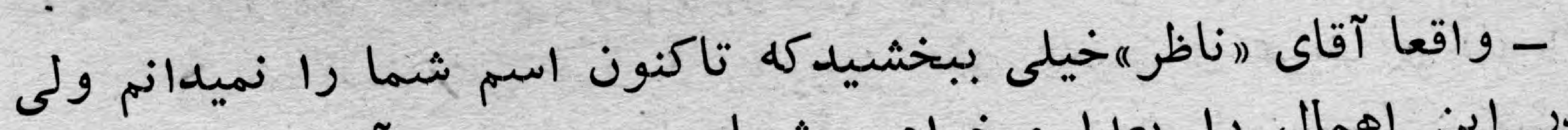

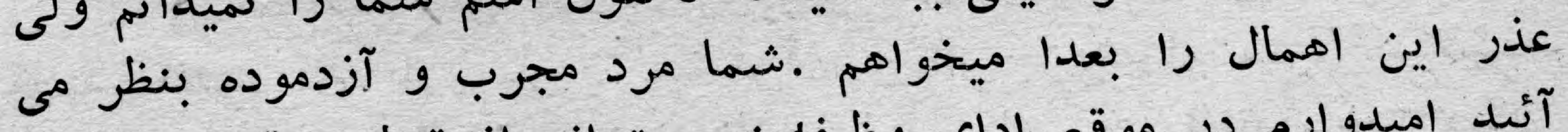

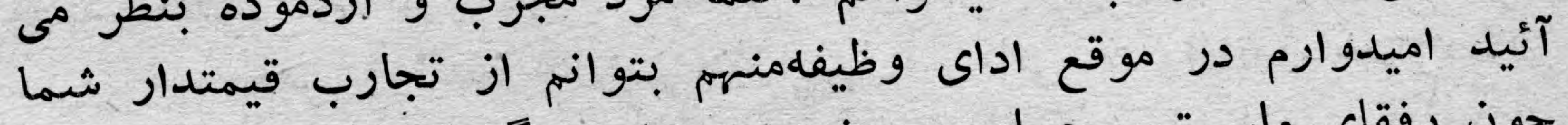

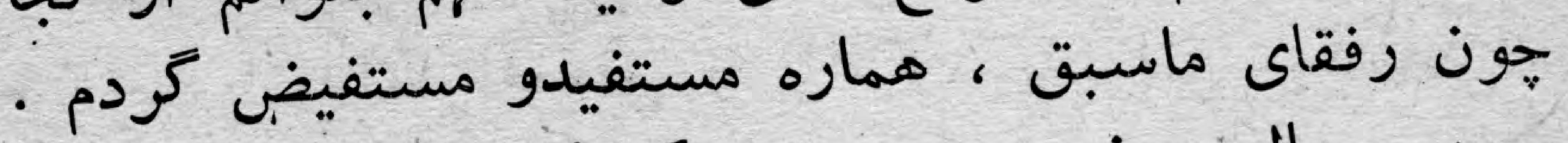

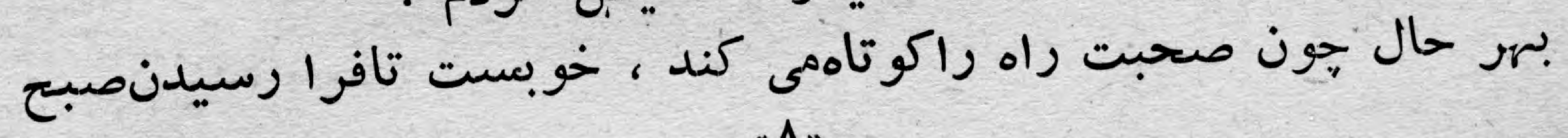
(A) 
روى يكى دو نكته از اظهنرات شماتوقف كنيم و شما در آنمورد مسرا

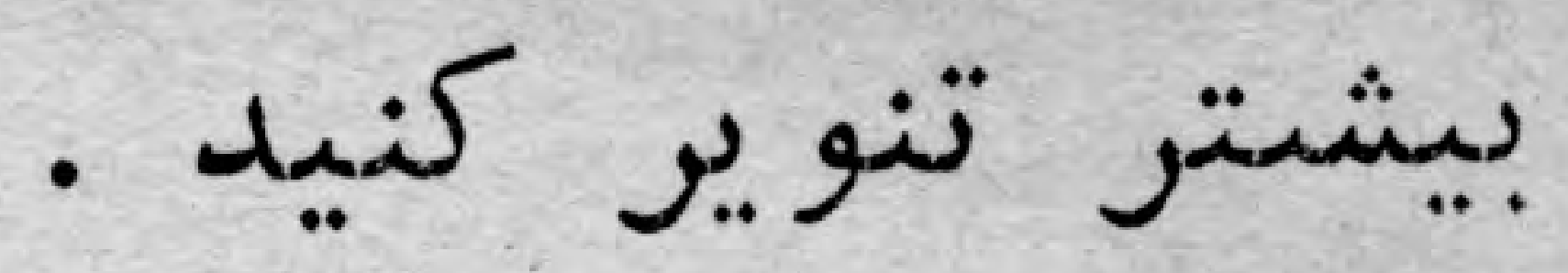

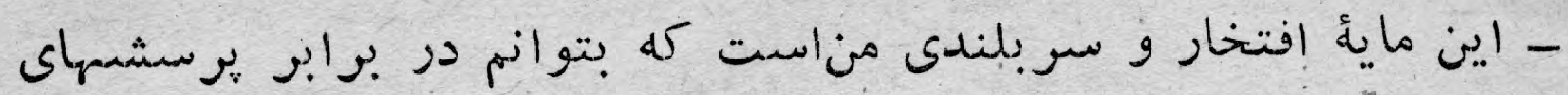

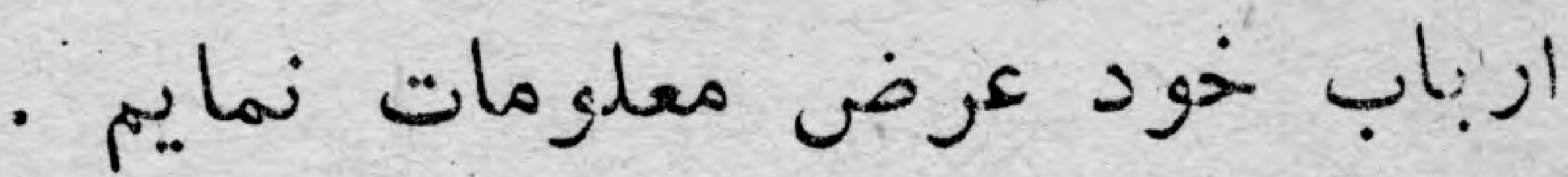

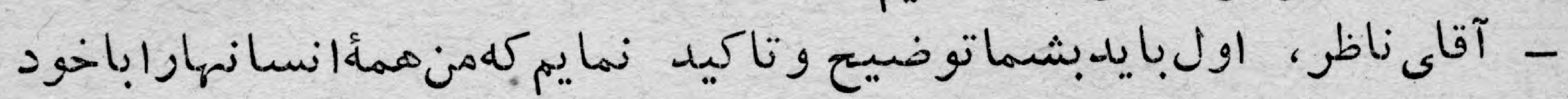

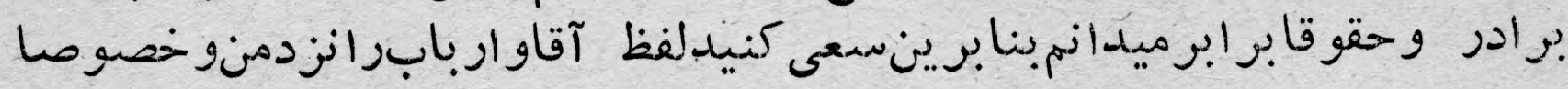

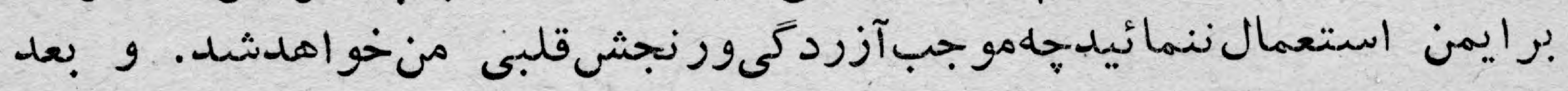

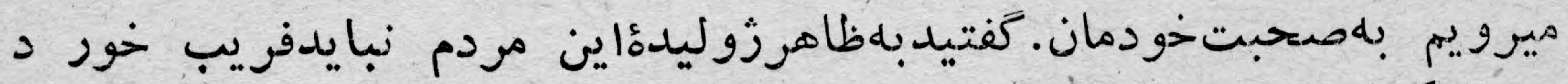

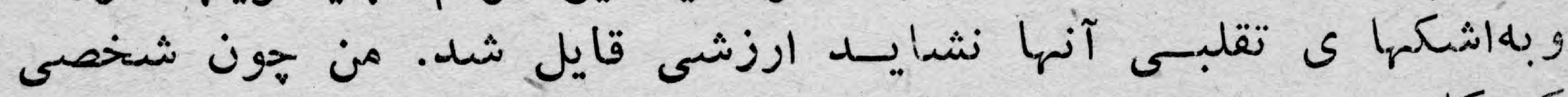

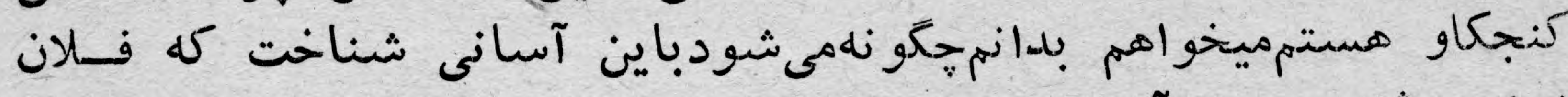

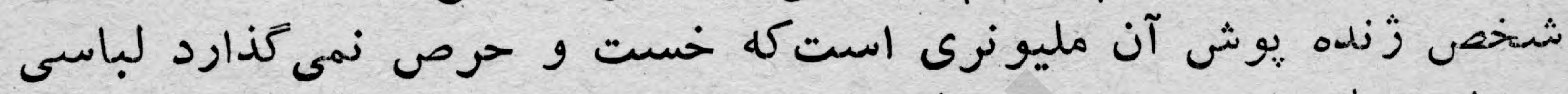

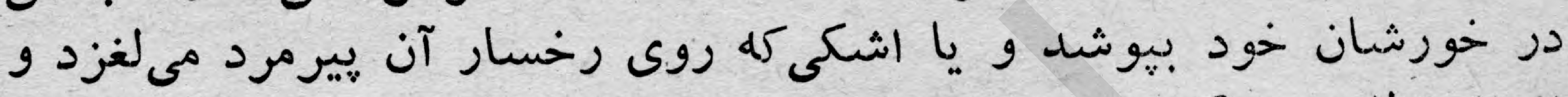

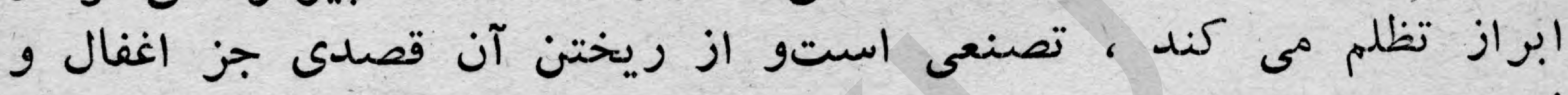

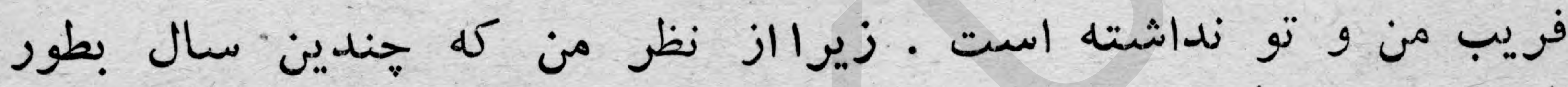

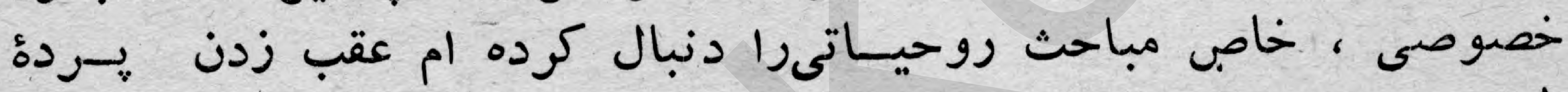

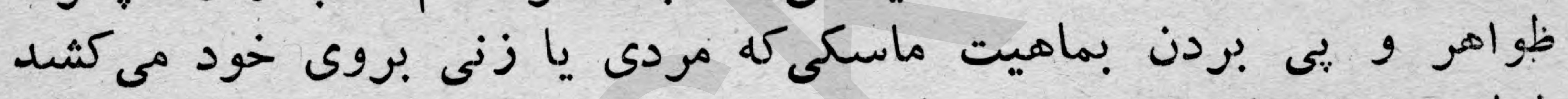

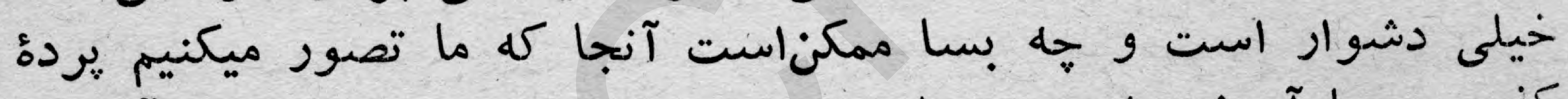

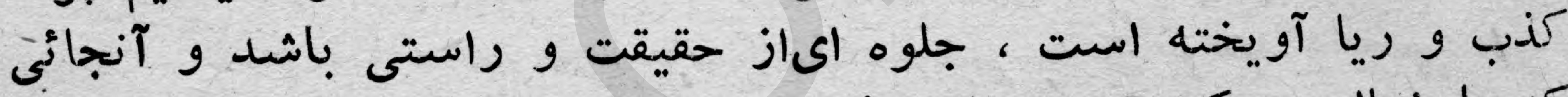

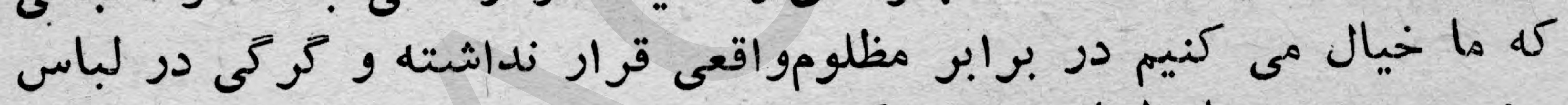

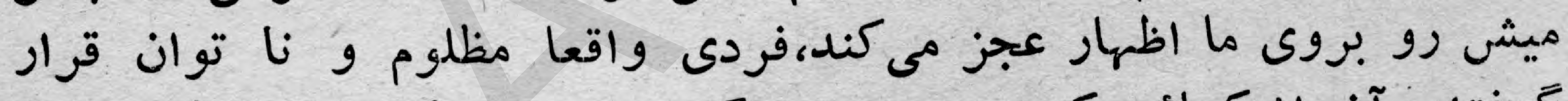

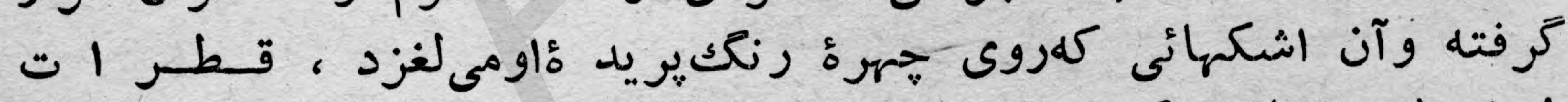

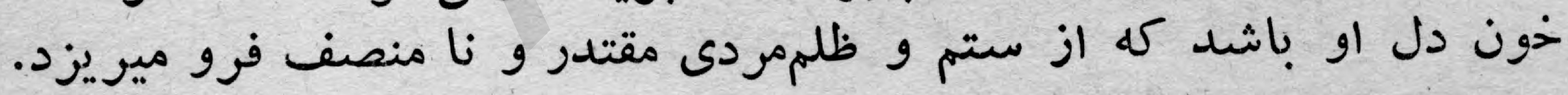

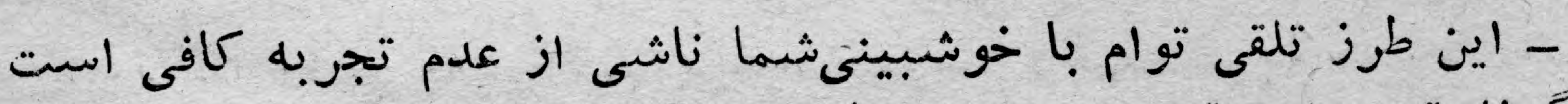

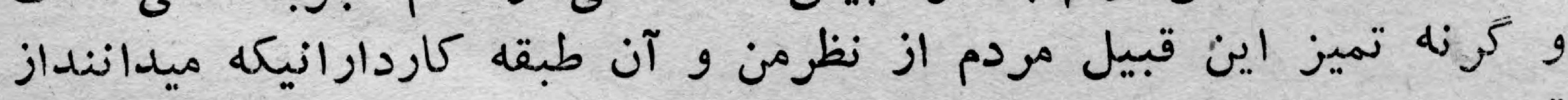

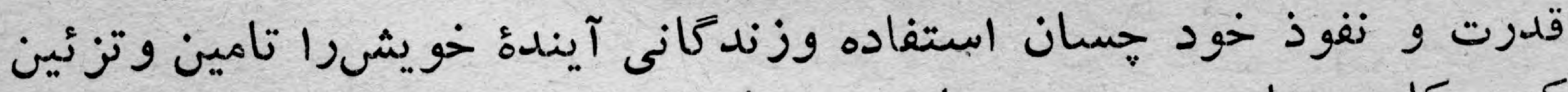

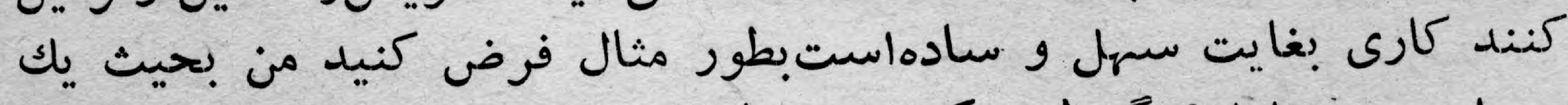
1)

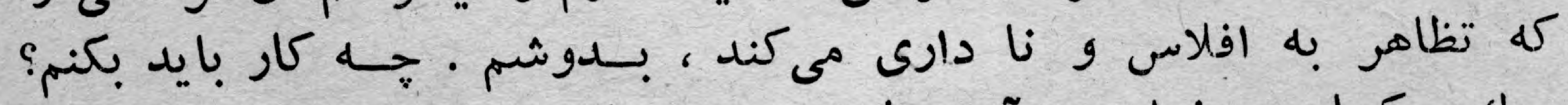

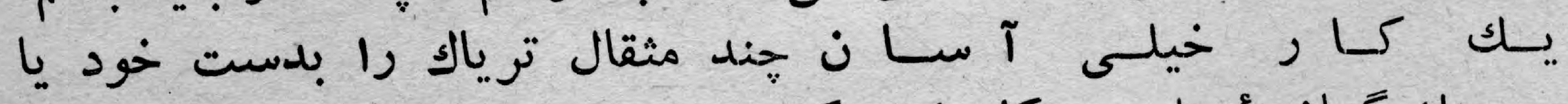

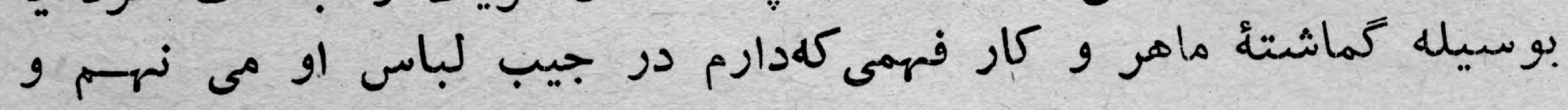




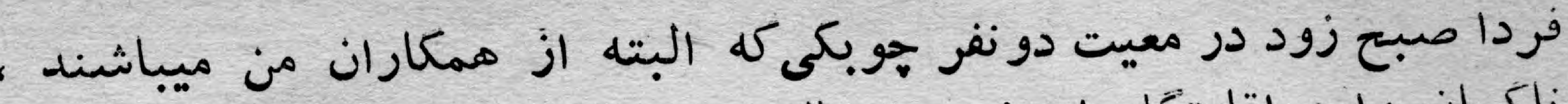

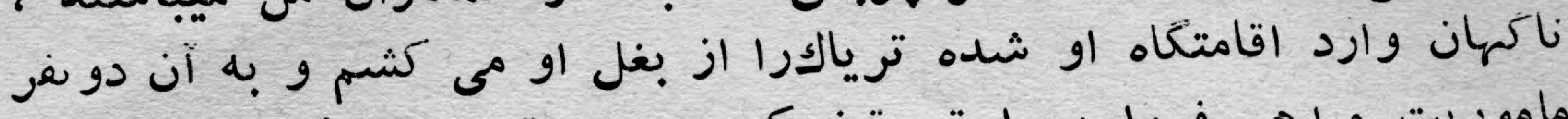

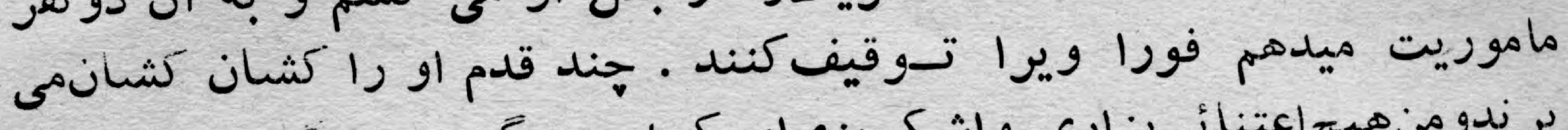

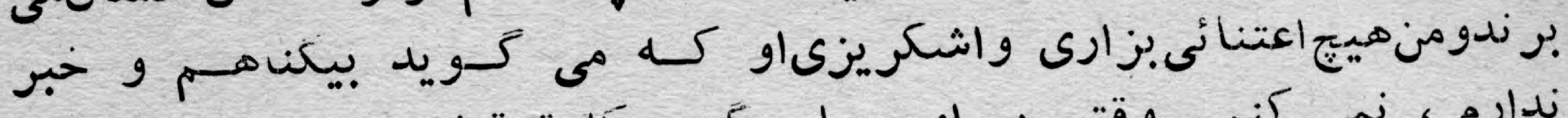

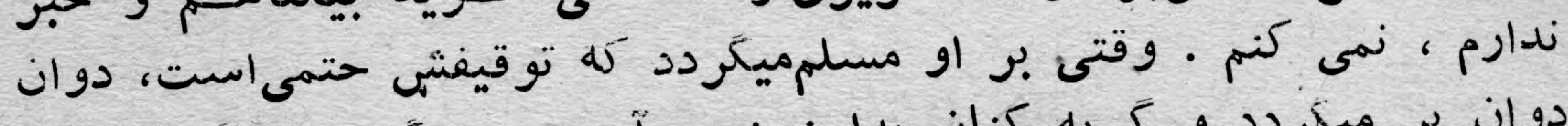

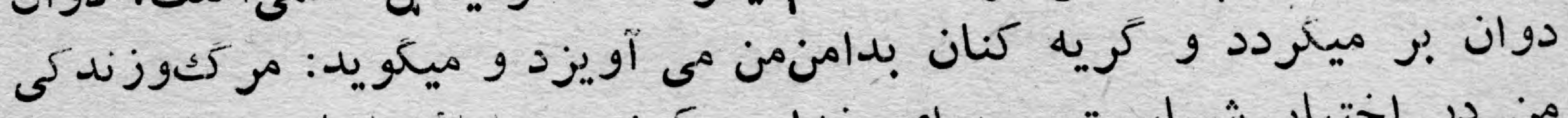

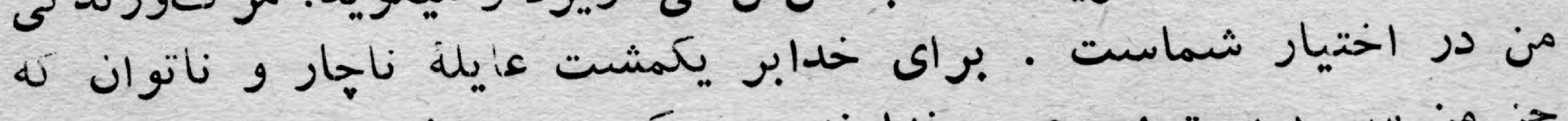

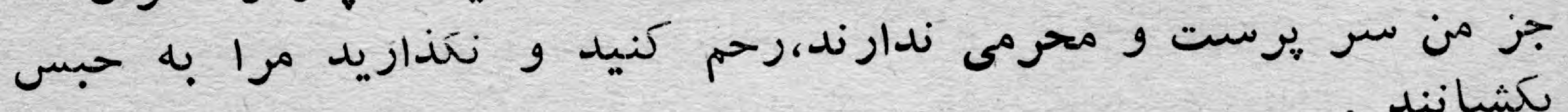
بكانند

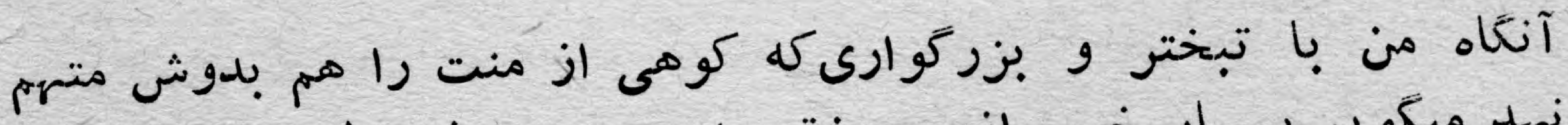

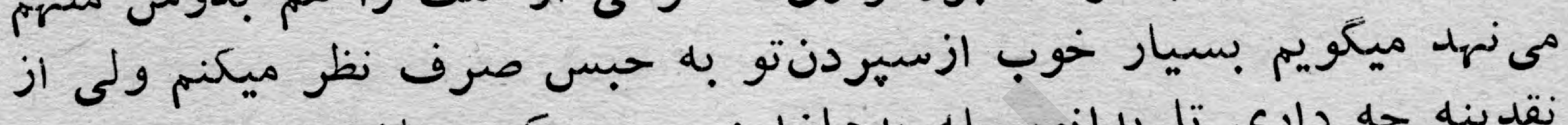

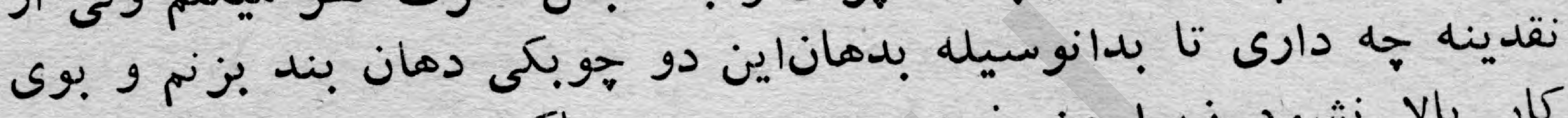

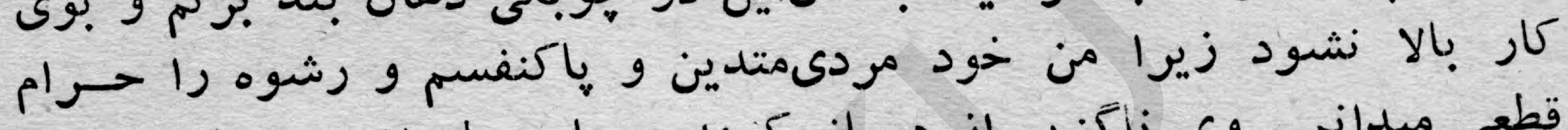

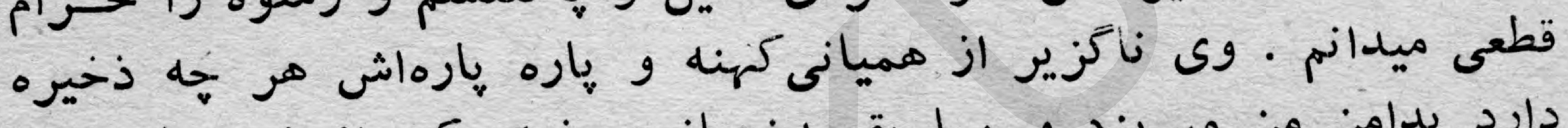

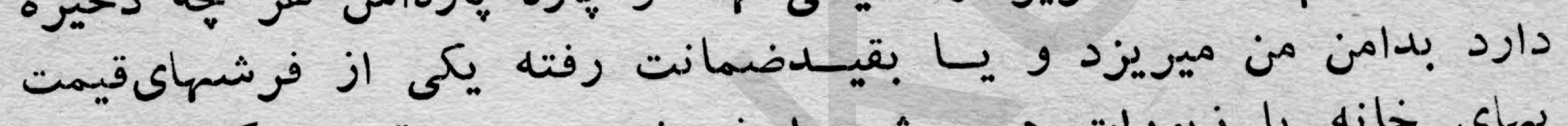

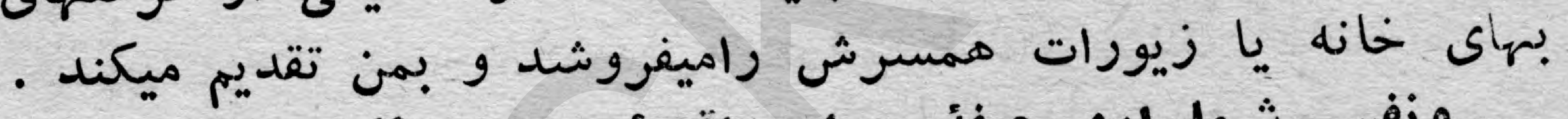

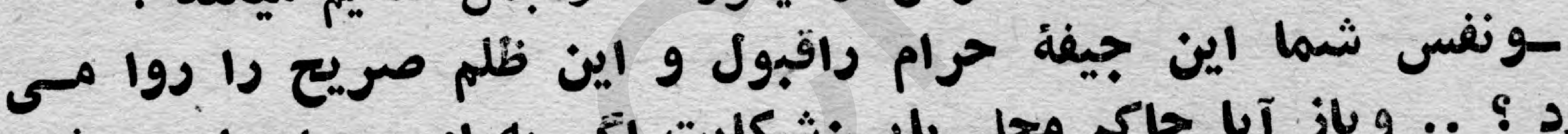

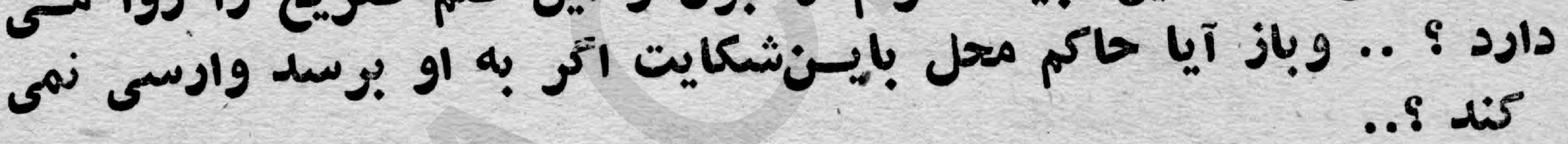
كند ؟..

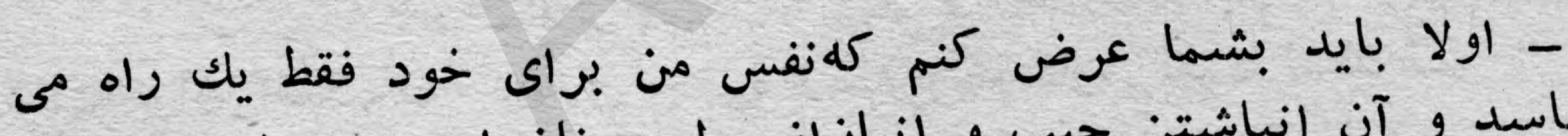

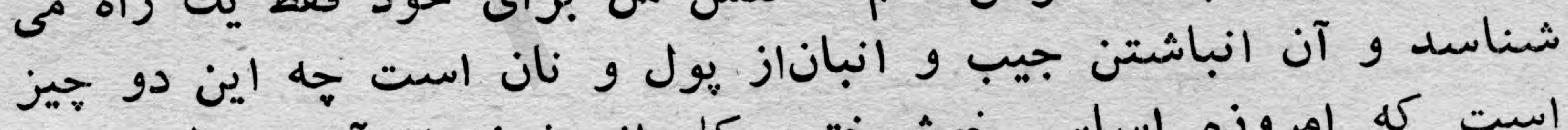

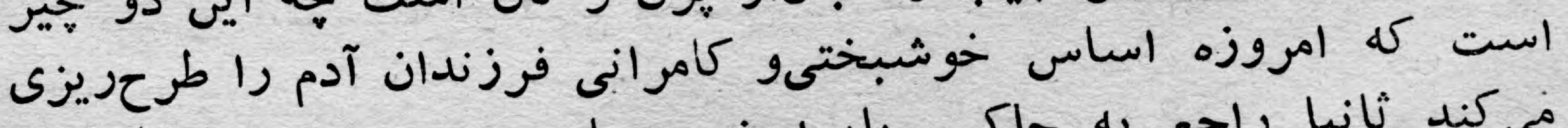

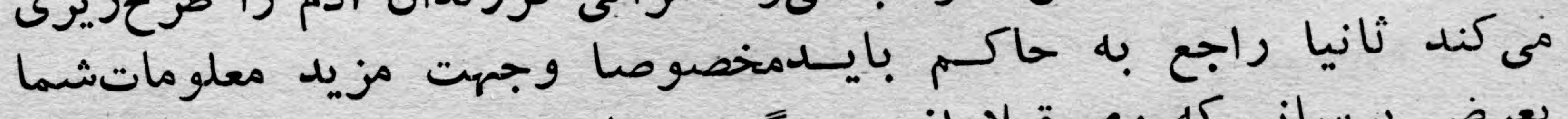

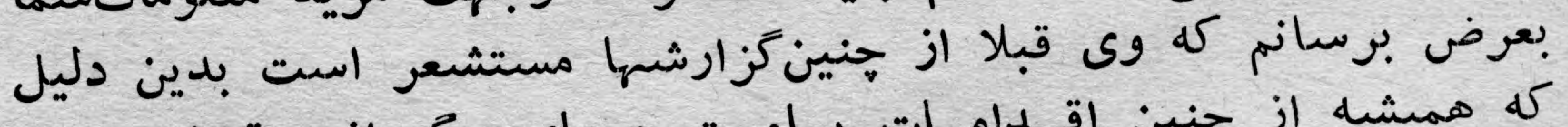

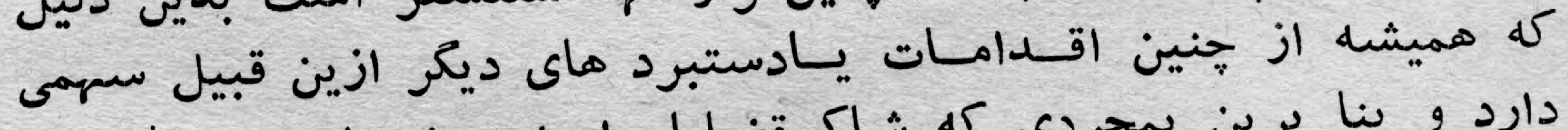

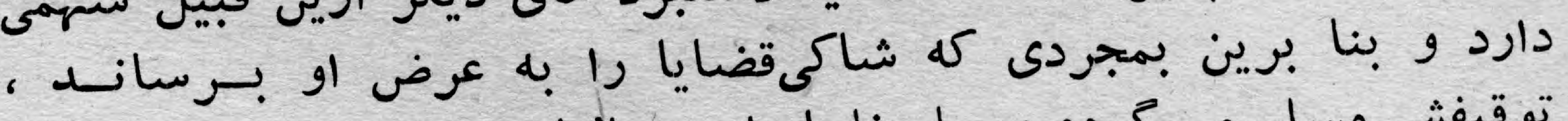

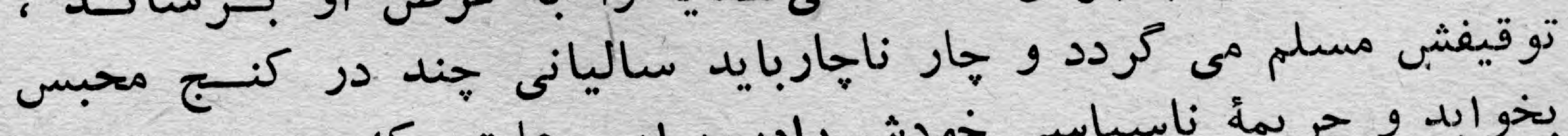

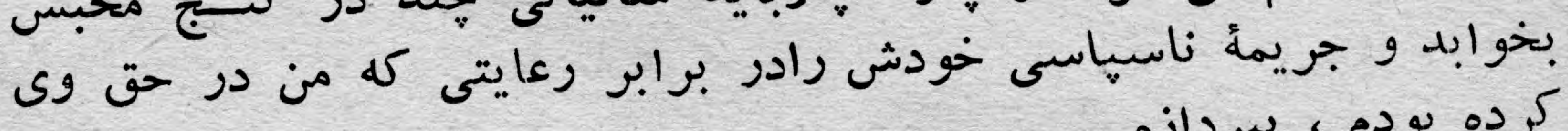

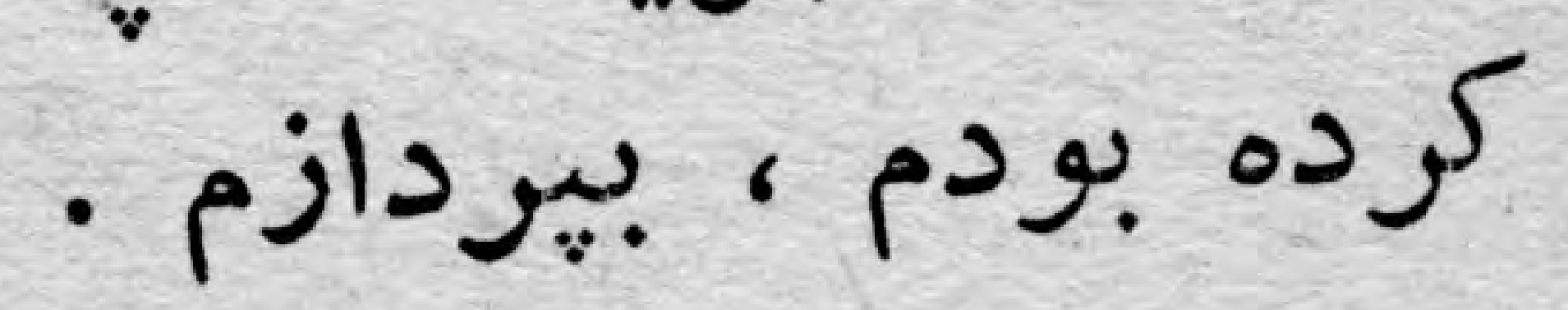
روى همين اصل است كه كسى كيرئت نداردبروى من يا كماشتعانى 


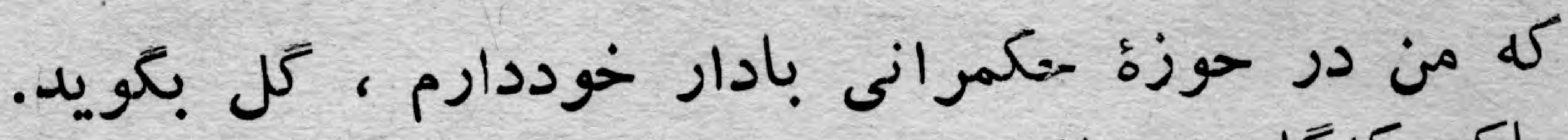

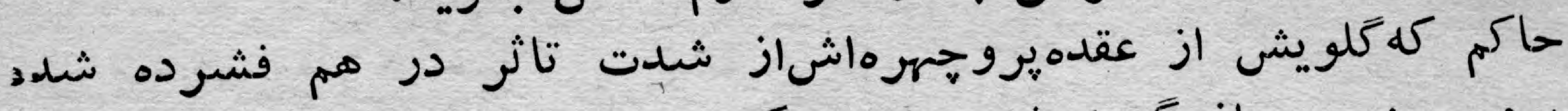

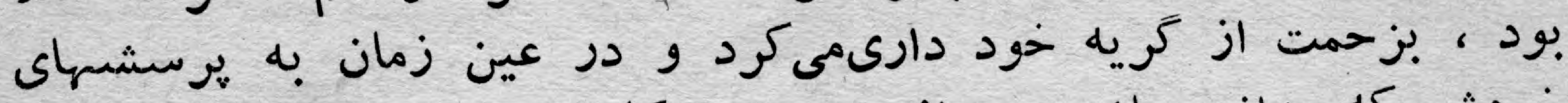

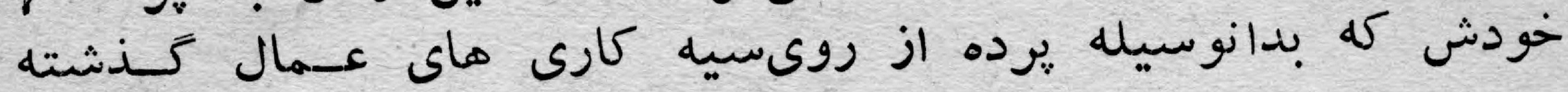

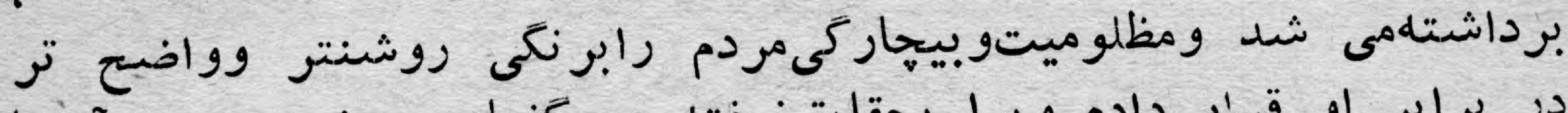

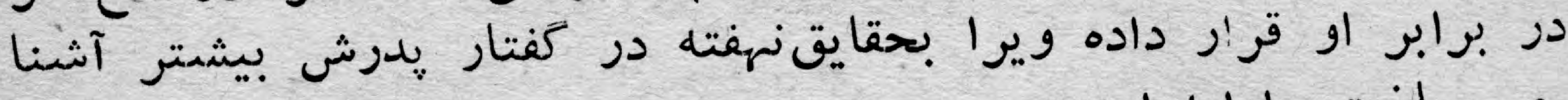
مى ساخت ، ادامهداد:

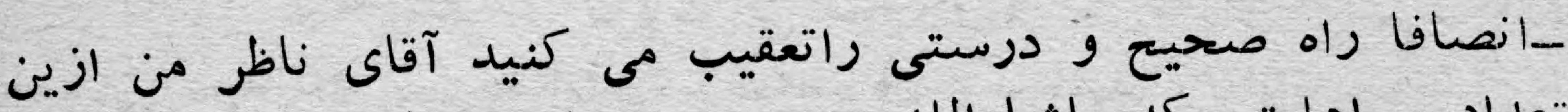

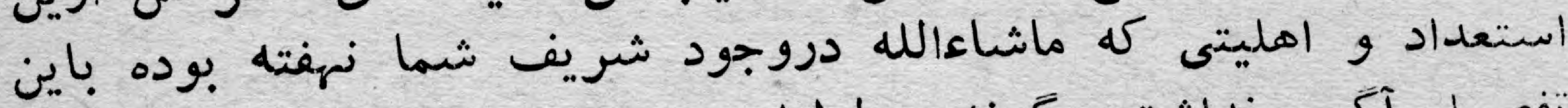

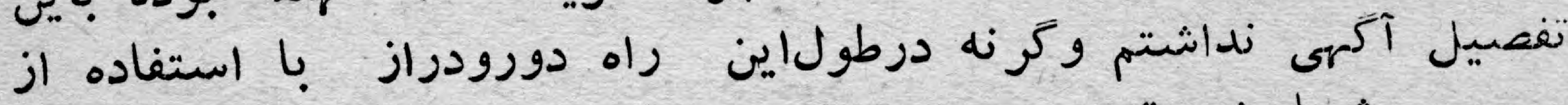

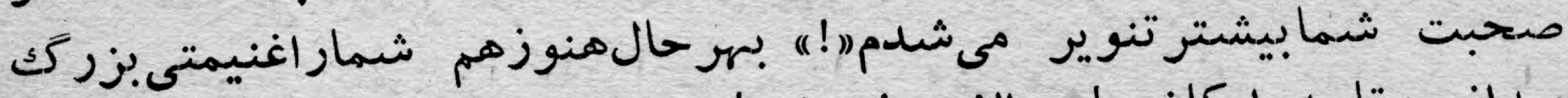

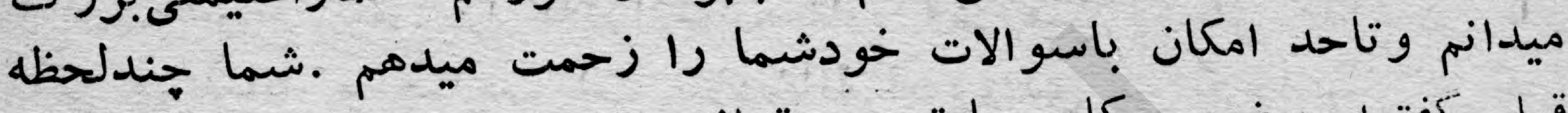

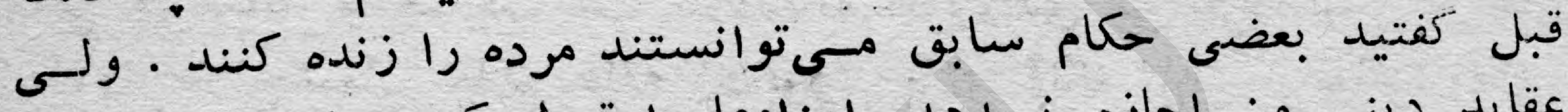

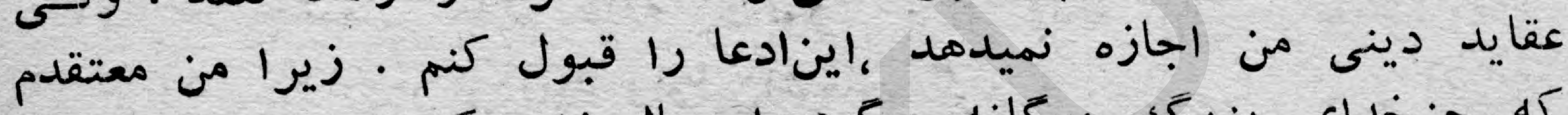

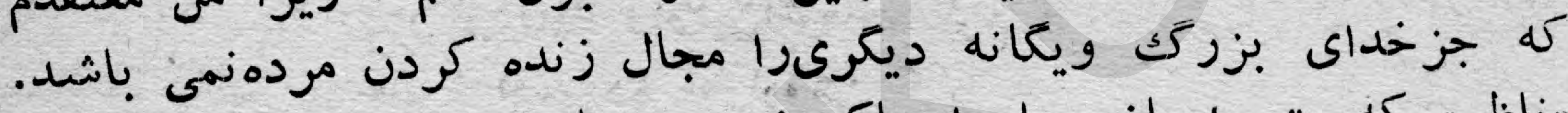

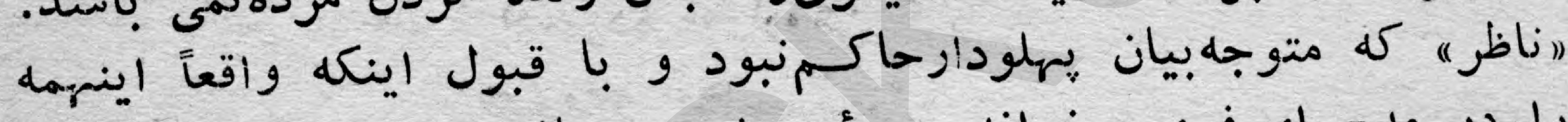

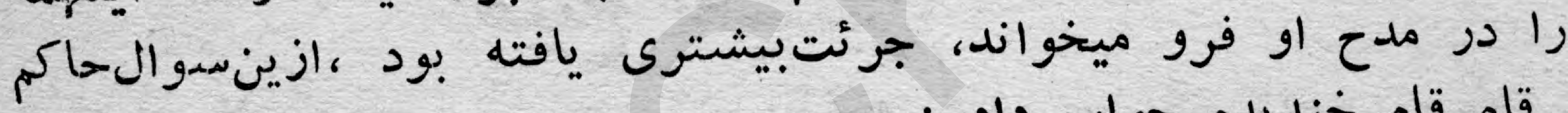

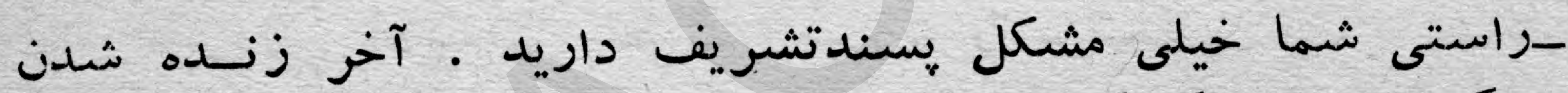

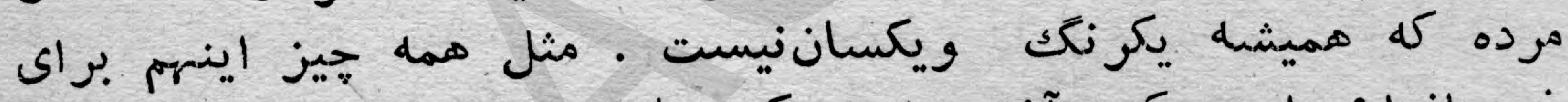

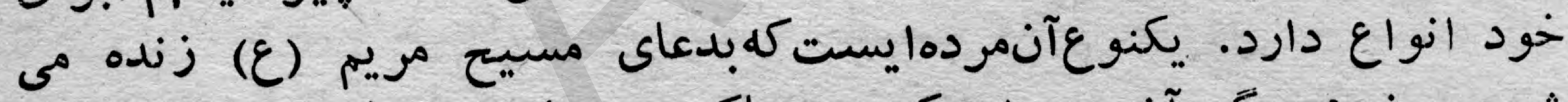

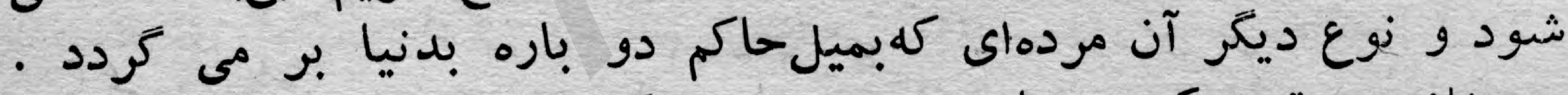

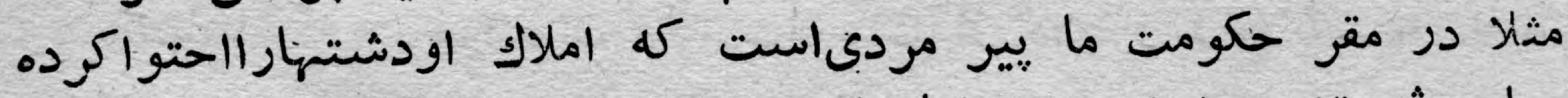

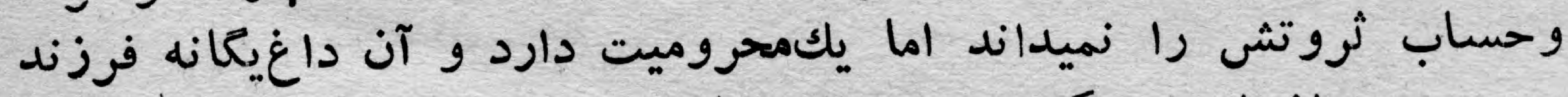

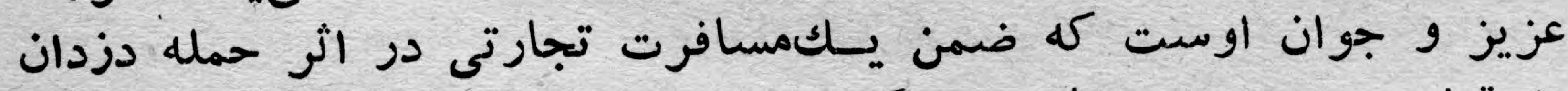

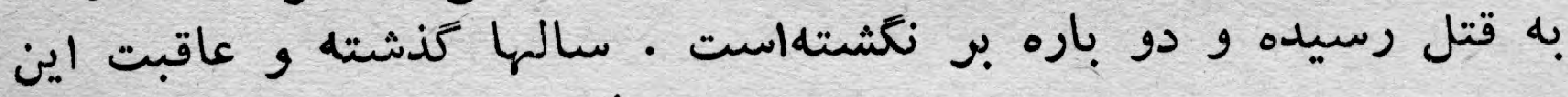

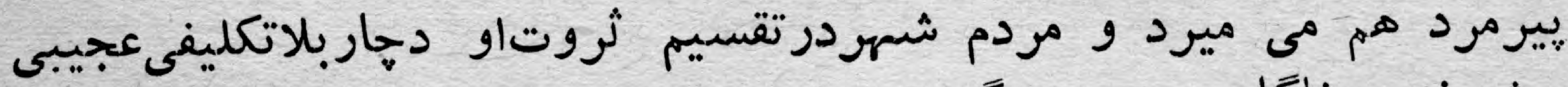

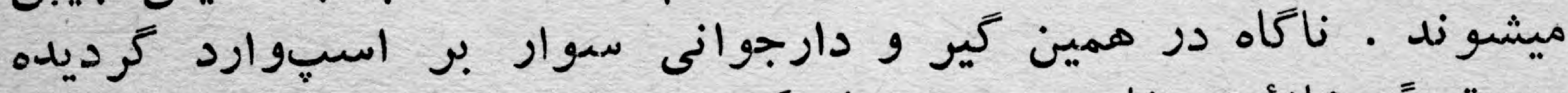

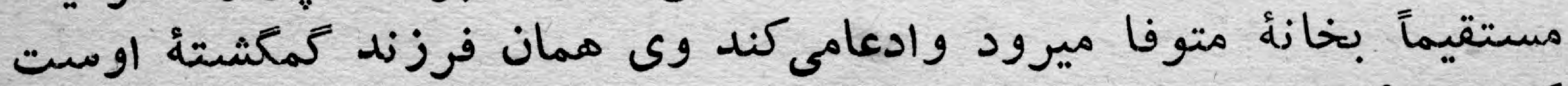

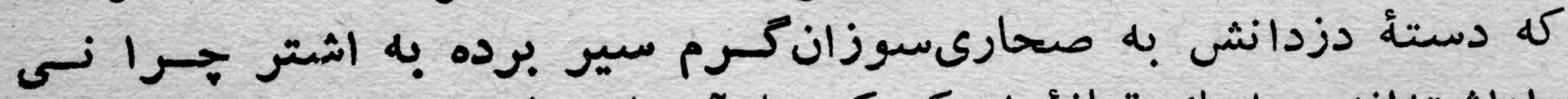

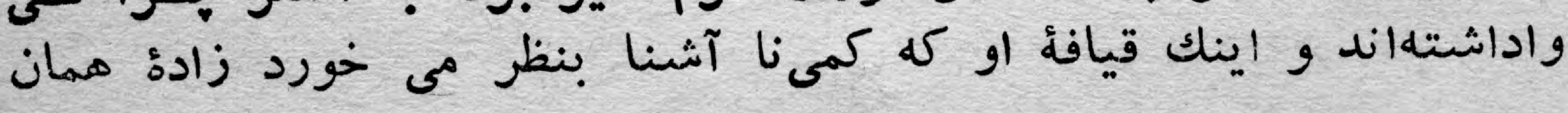




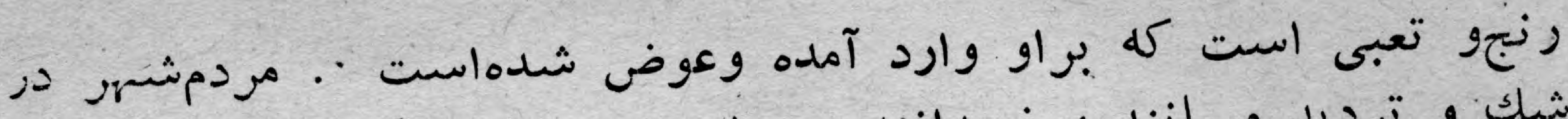

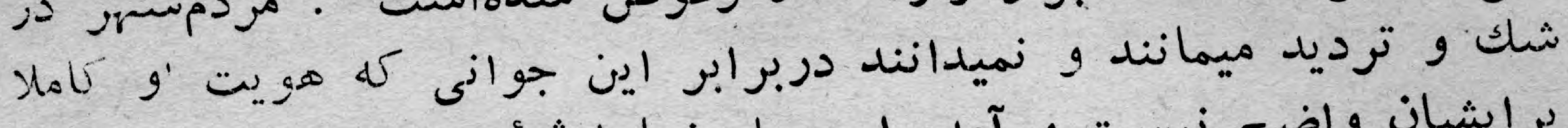

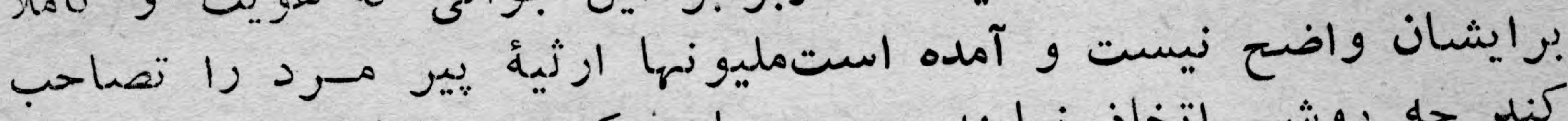

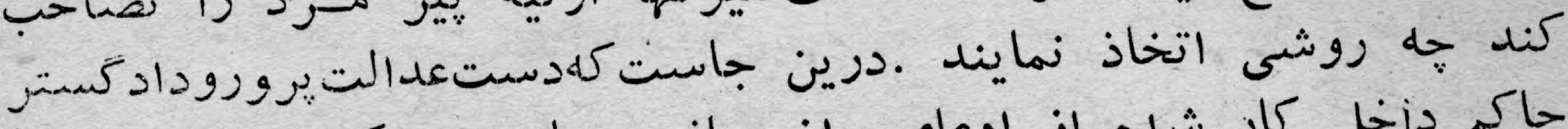

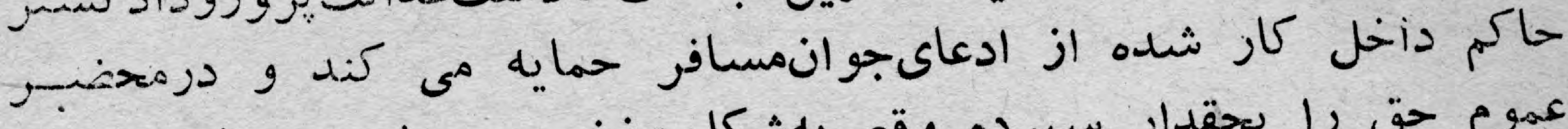

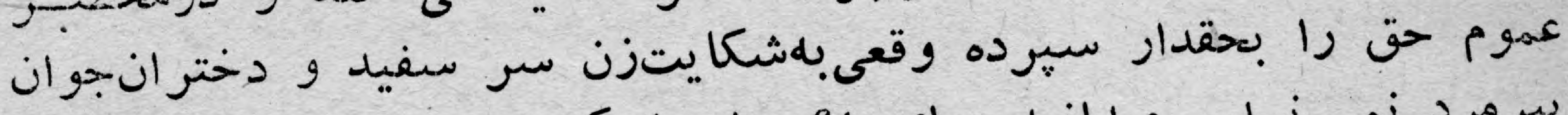

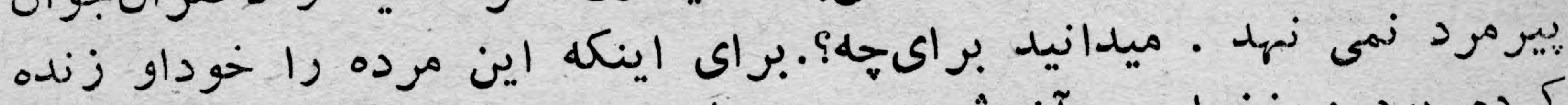

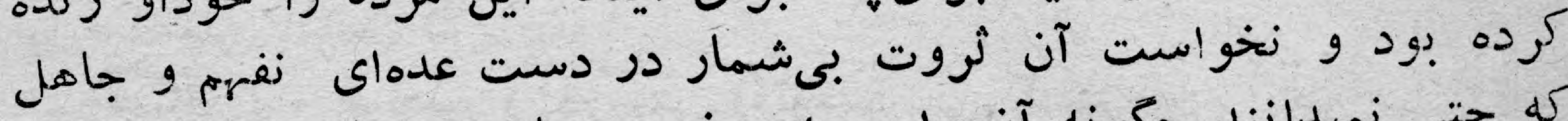

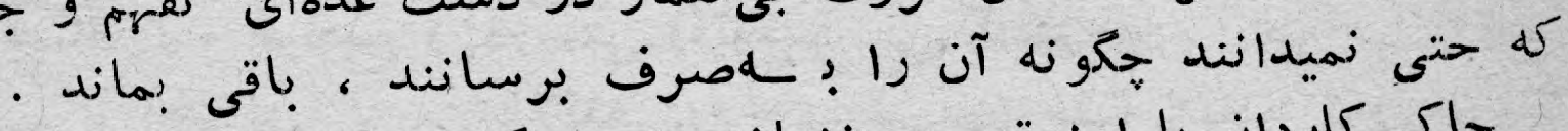

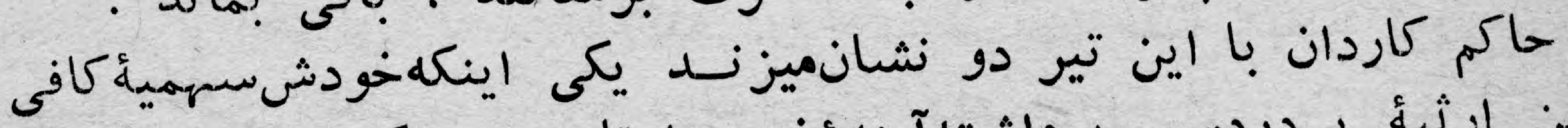

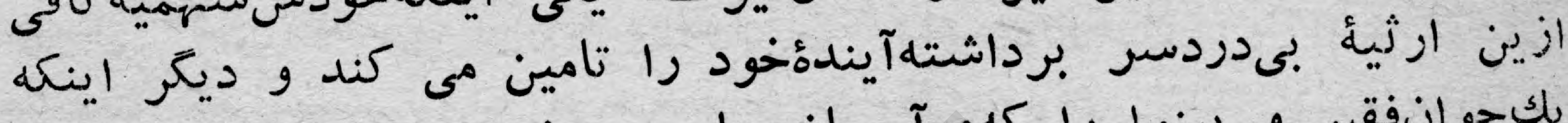

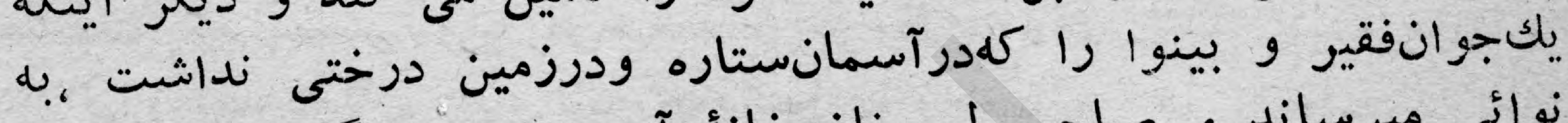

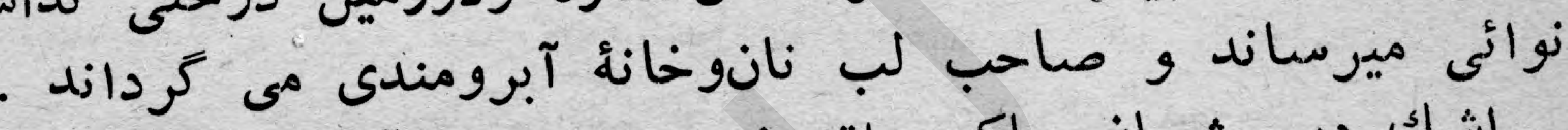

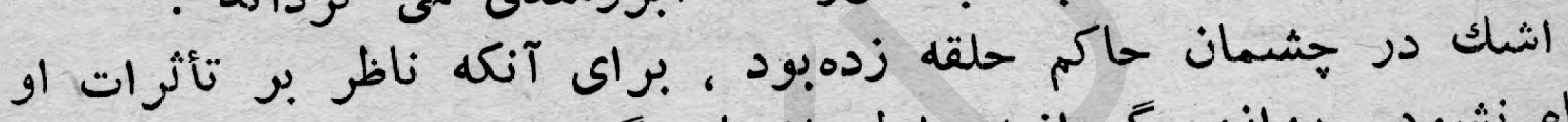

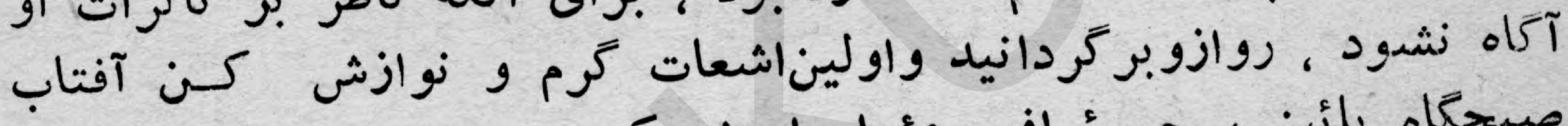

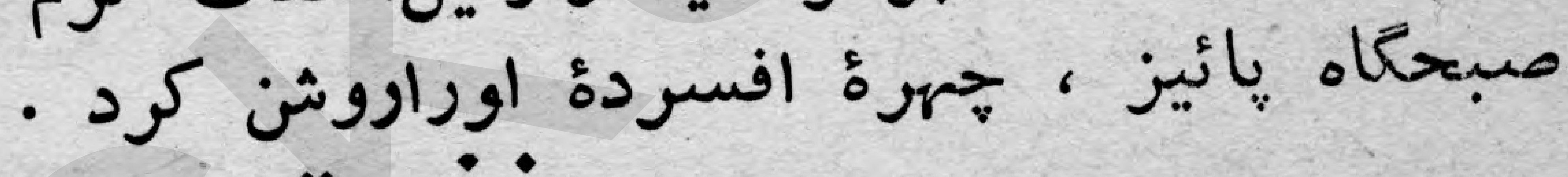

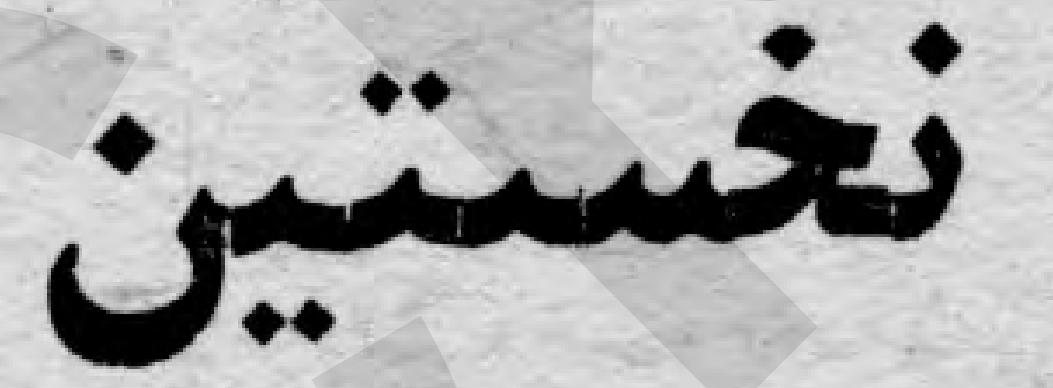

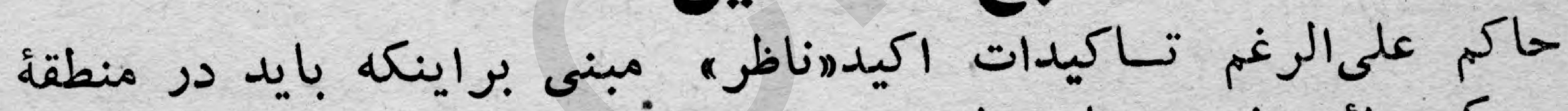

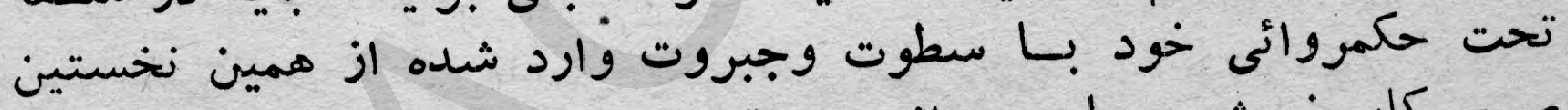

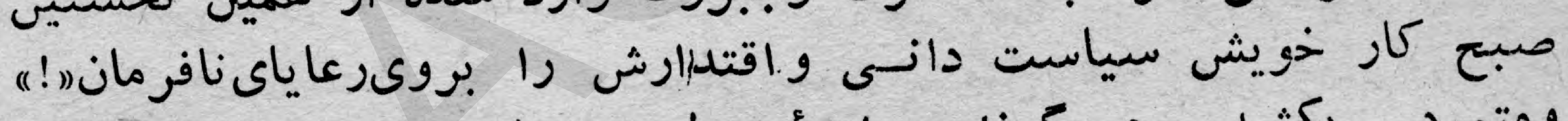

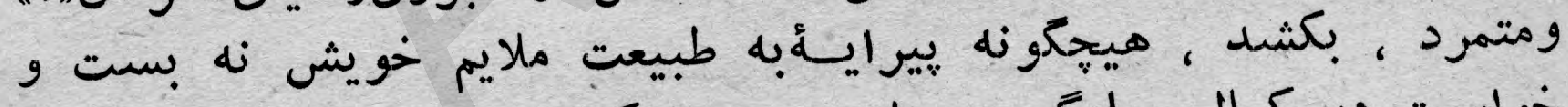

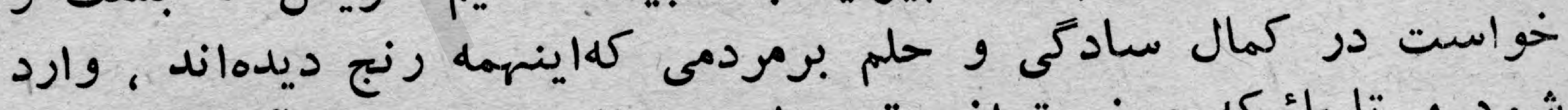

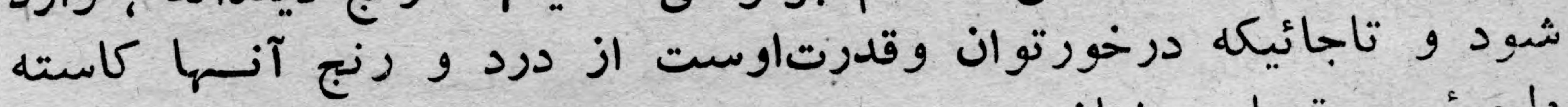

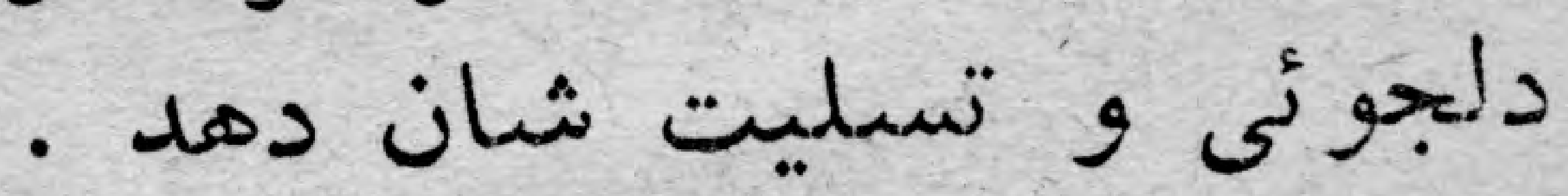

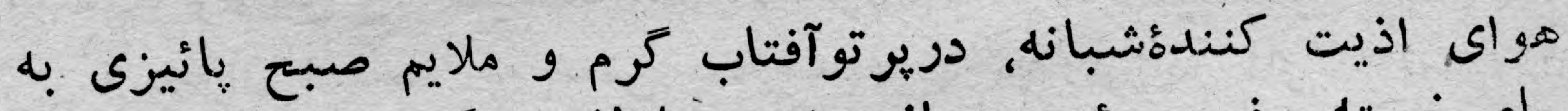

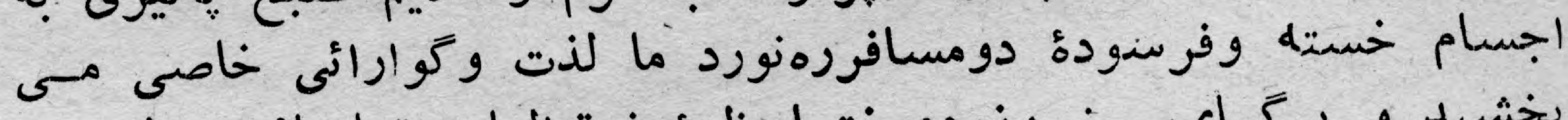

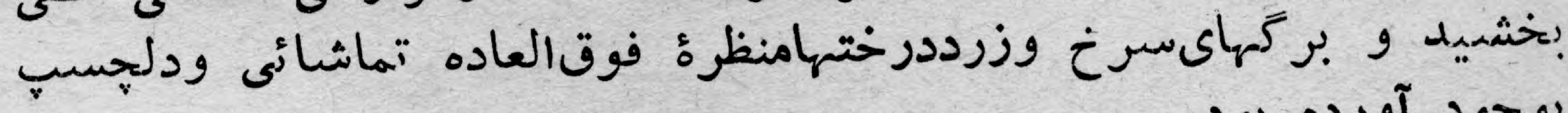
•

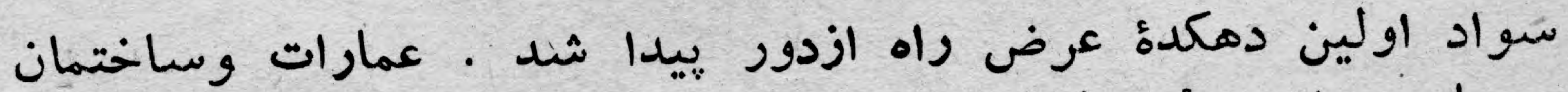

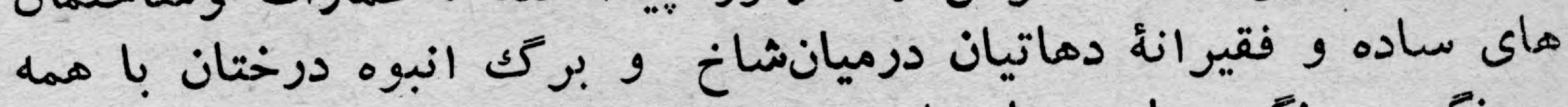

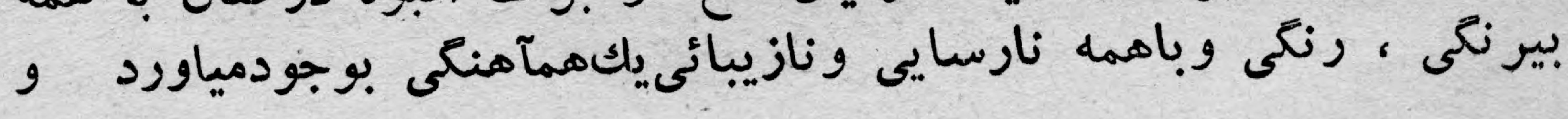


يير ايه بهم ميرساند.اين فاصله رالسبهاى تندر ست وتواناىمسافرين

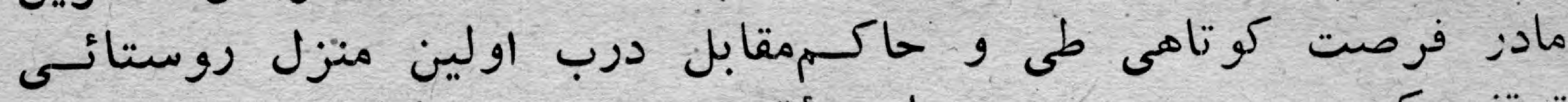

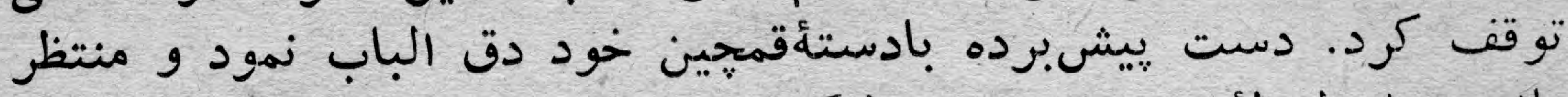

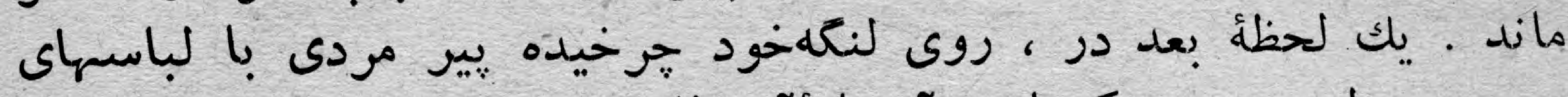

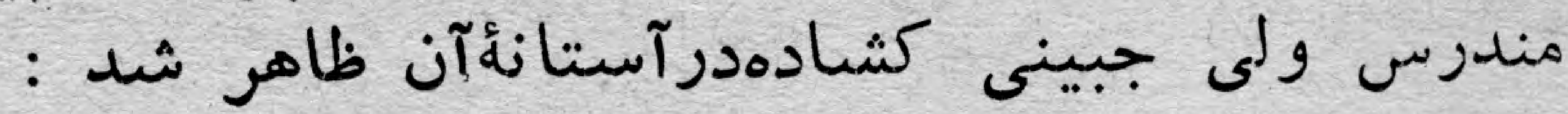

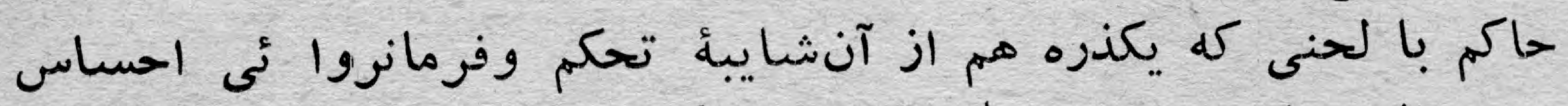

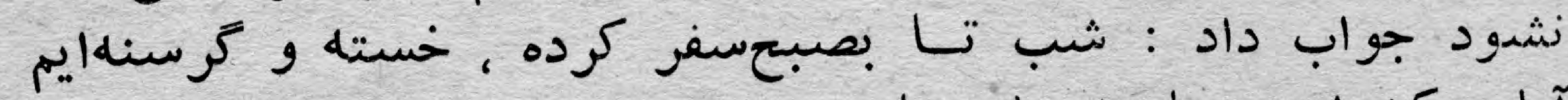

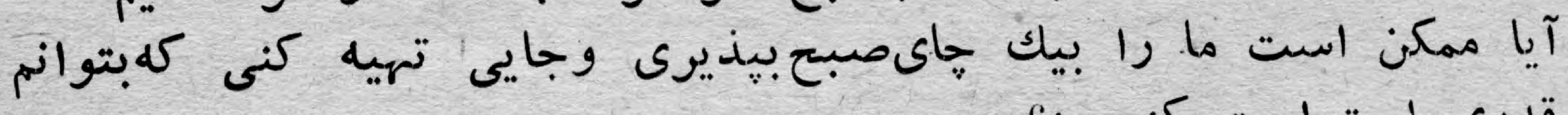

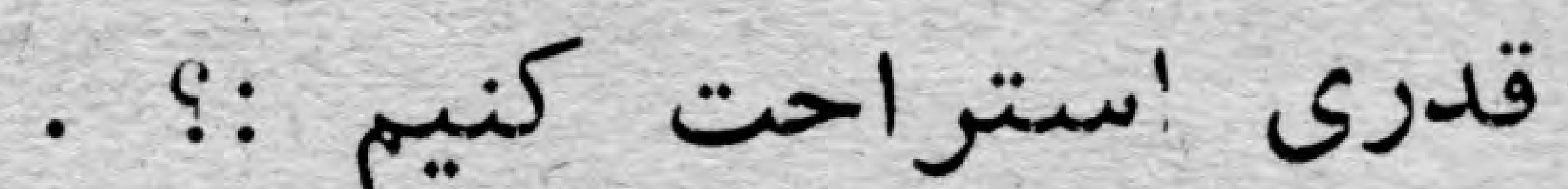

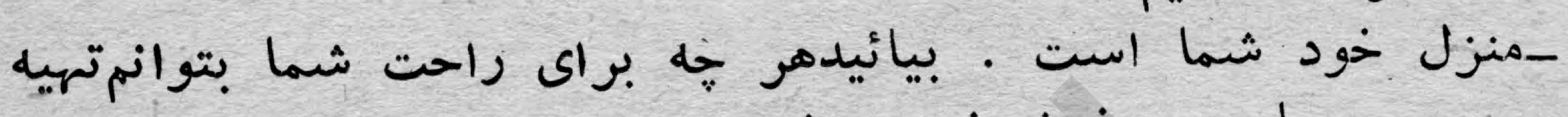

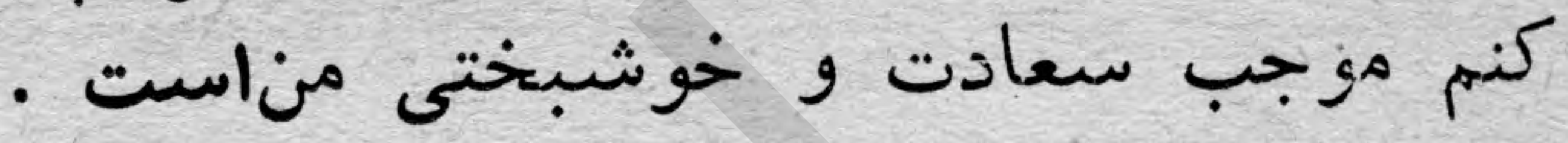

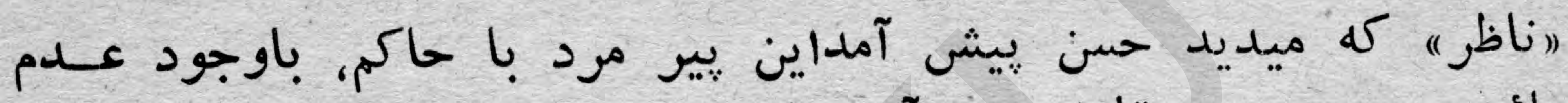

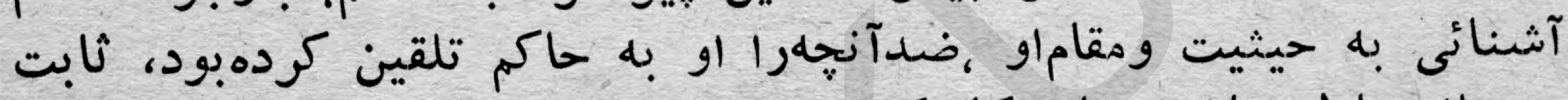

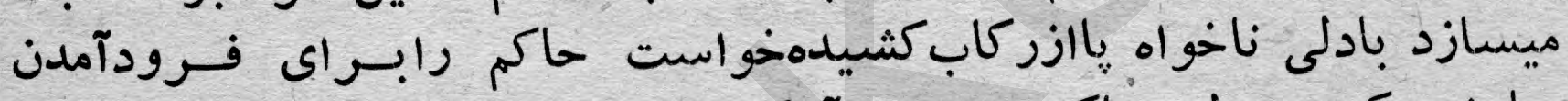

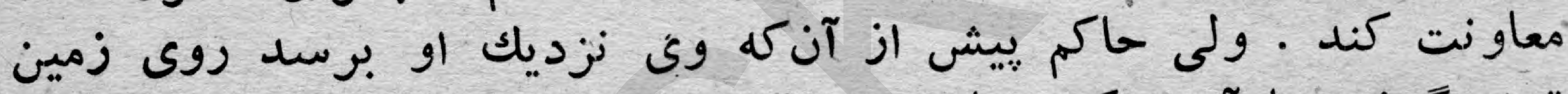

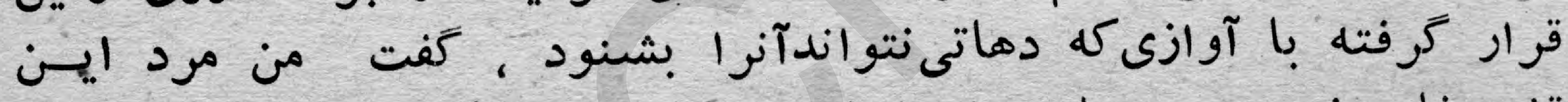

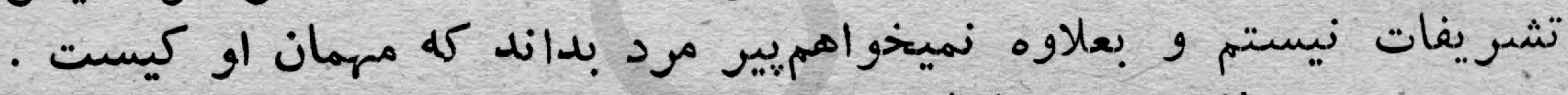

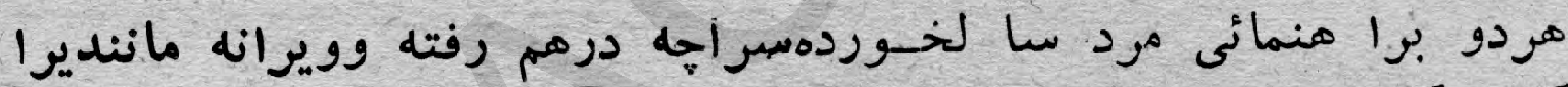

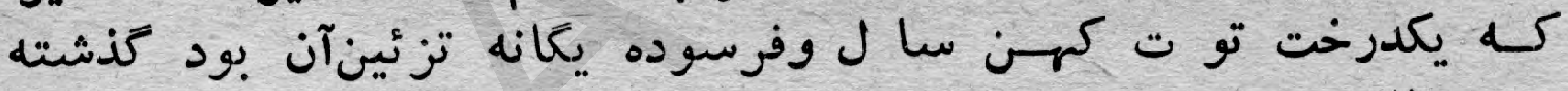

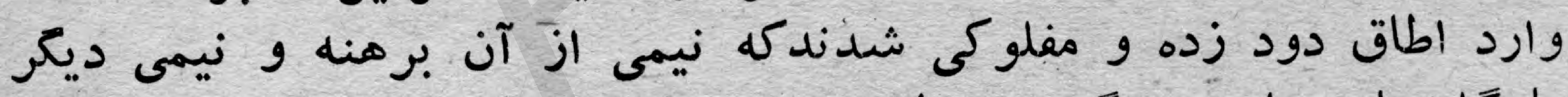

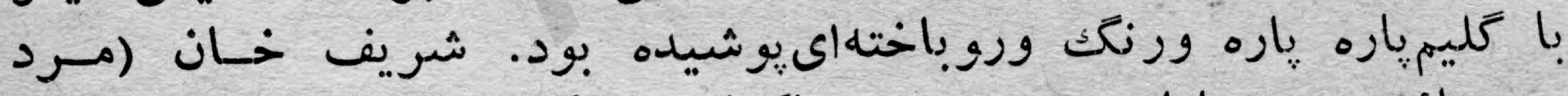

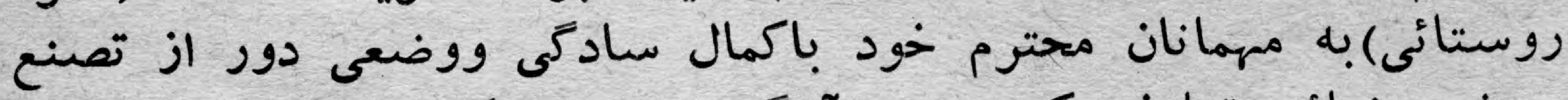

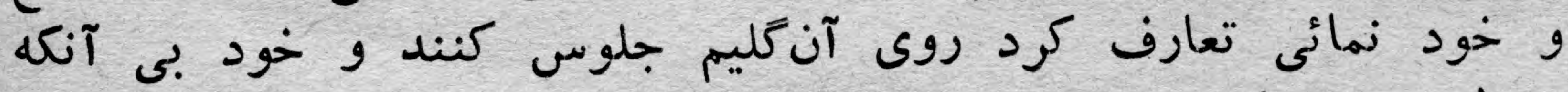

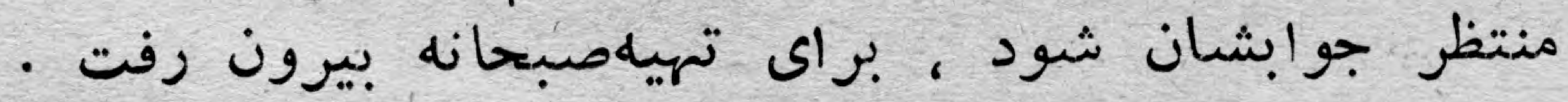

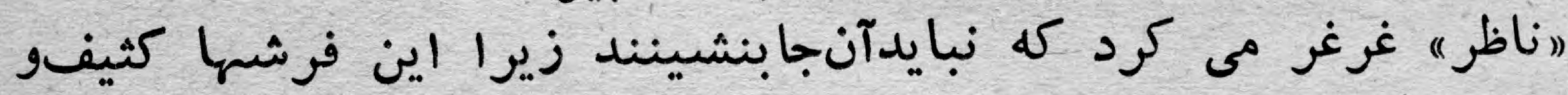

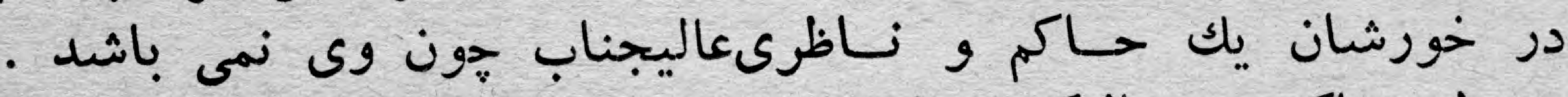

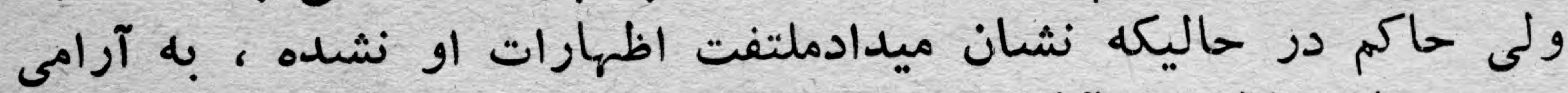

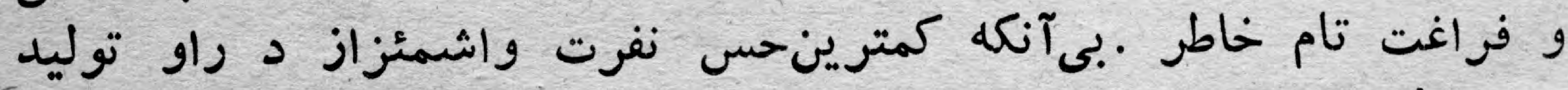

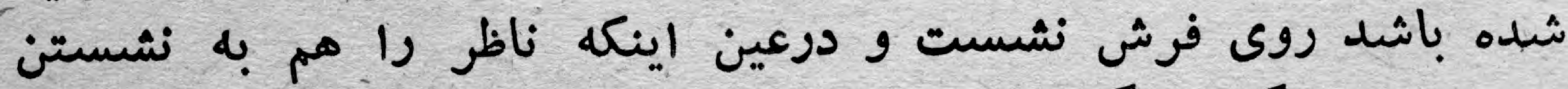

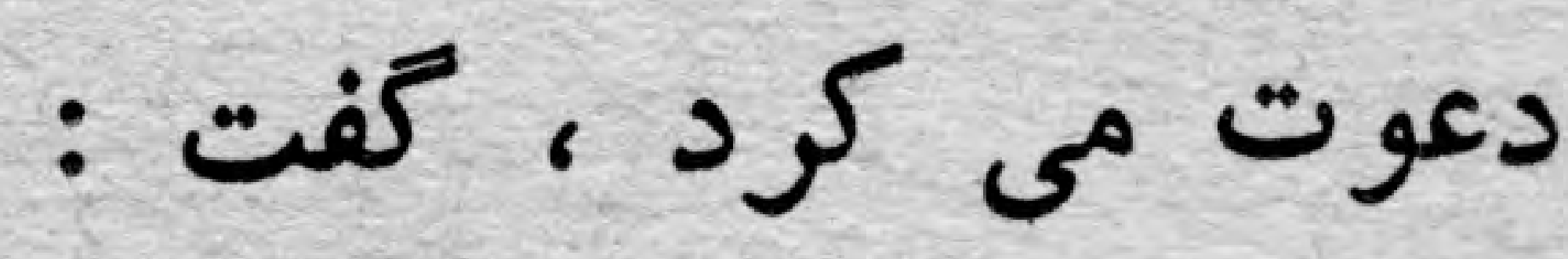




\section{شلغم يخته به ز نقره خـام}

\section{در بيا بان فقيه كر سنــه را}

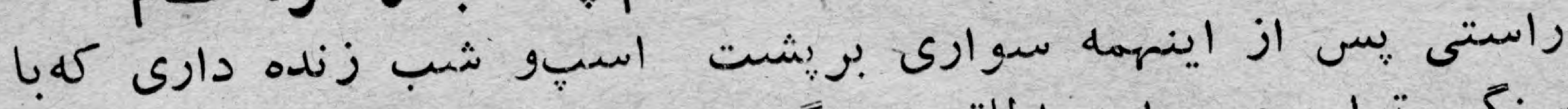

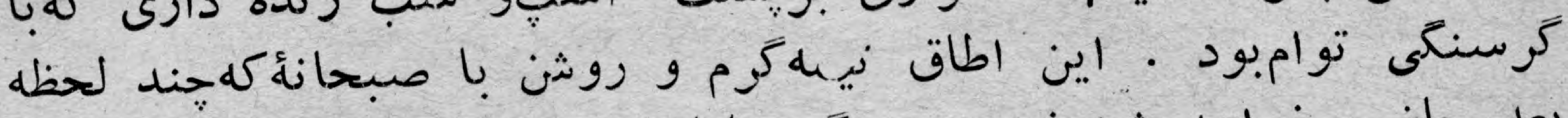

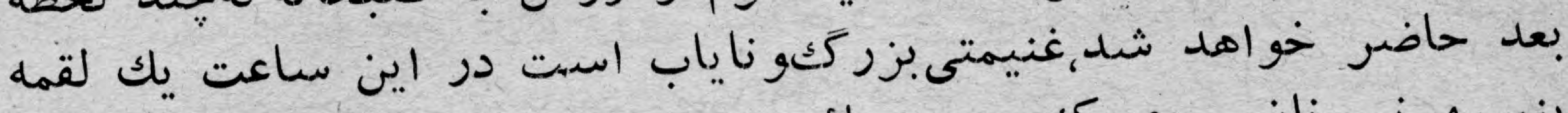

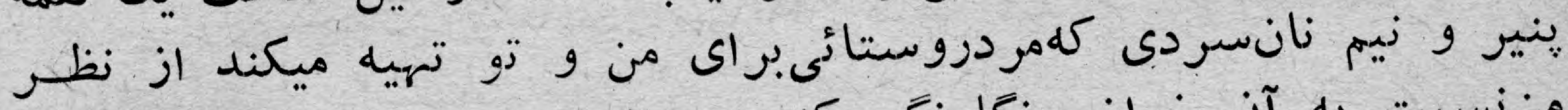

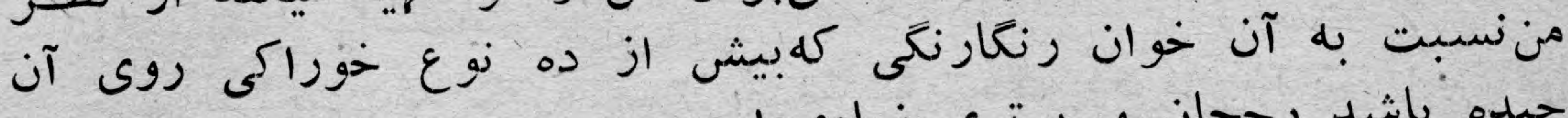

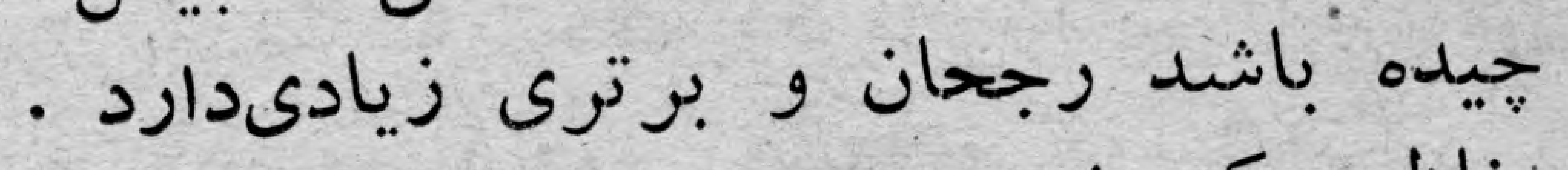

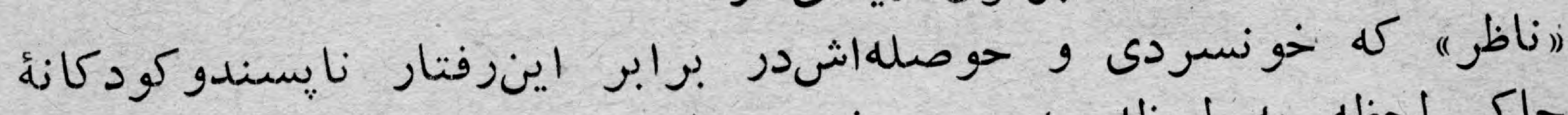

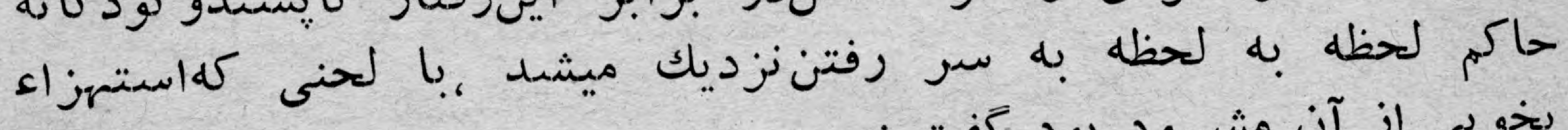

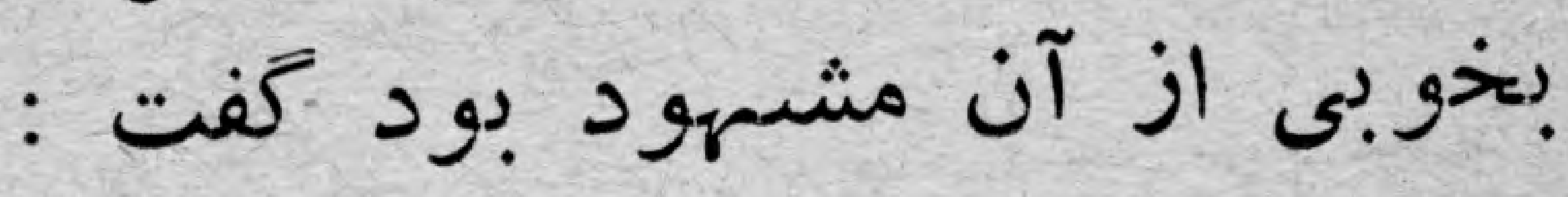

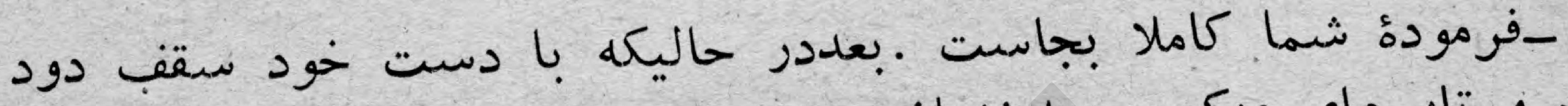

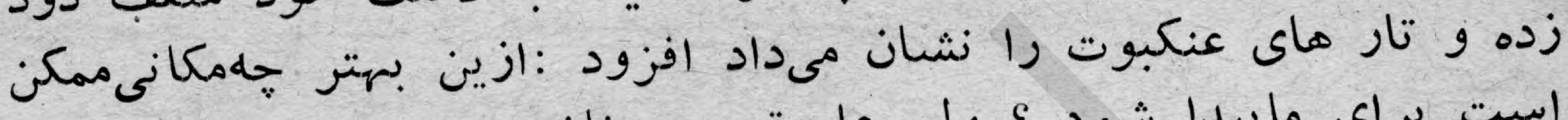

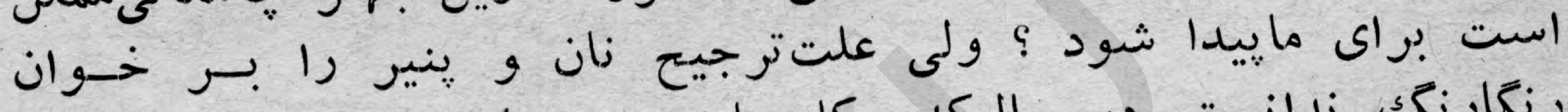

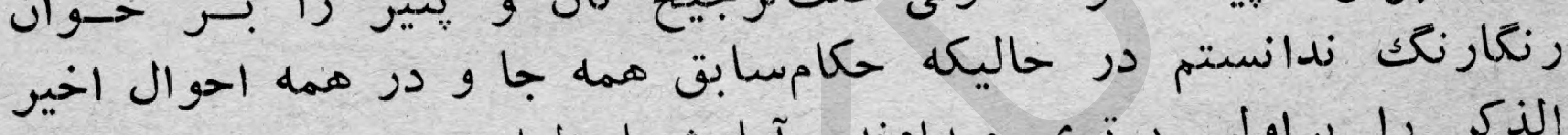

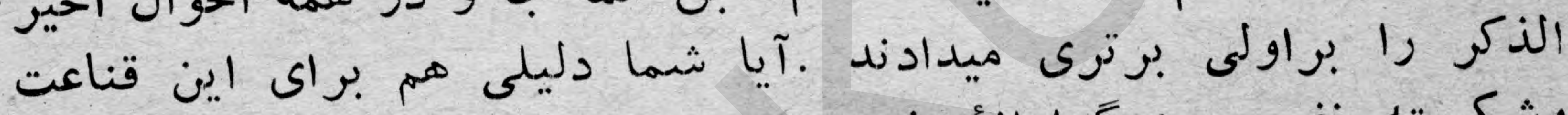

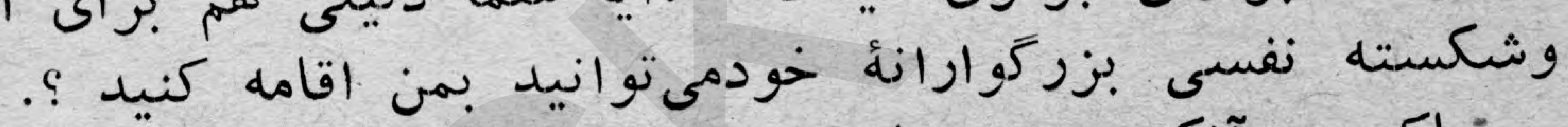

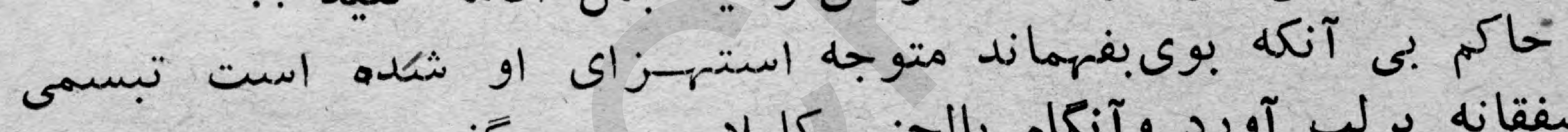

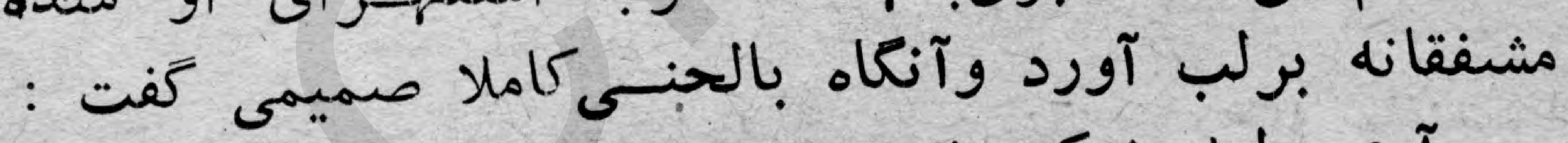

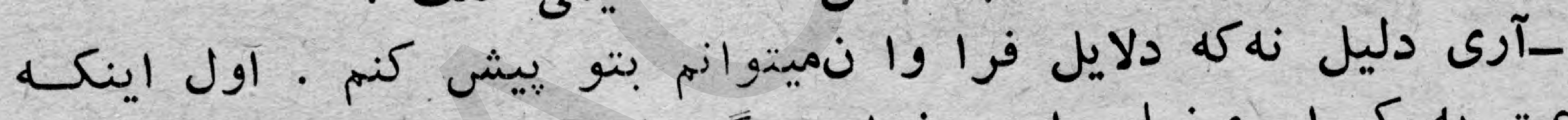

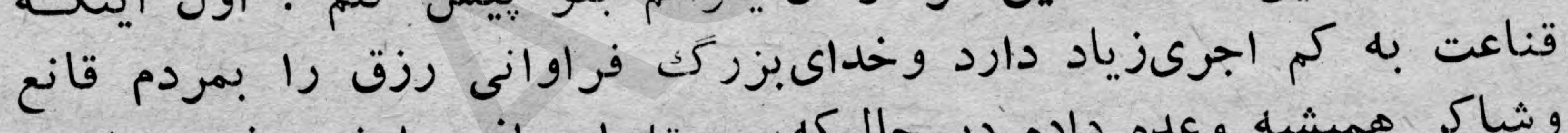

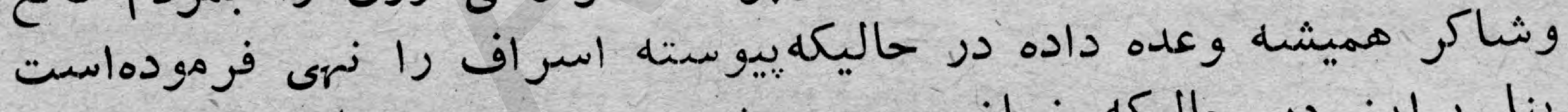

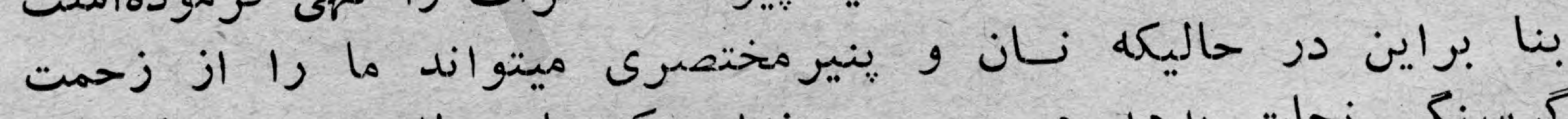

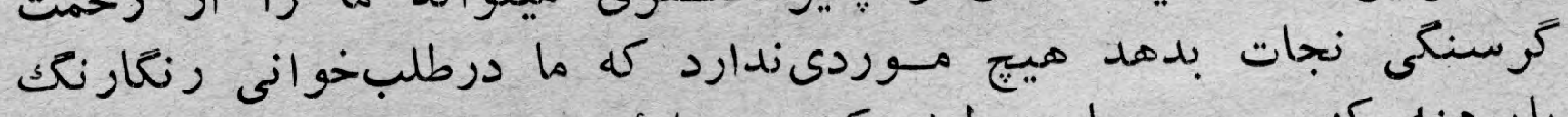

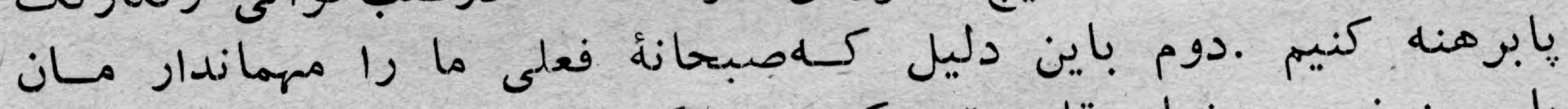

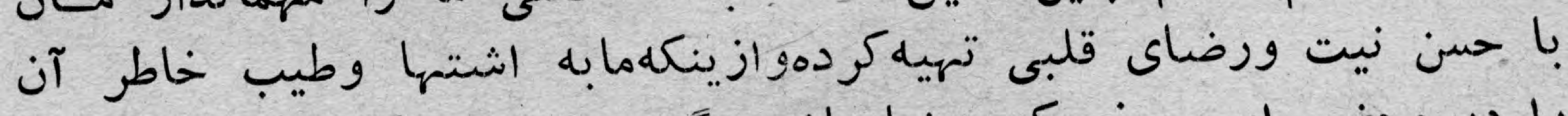

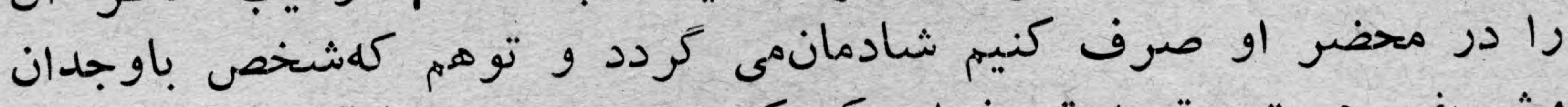

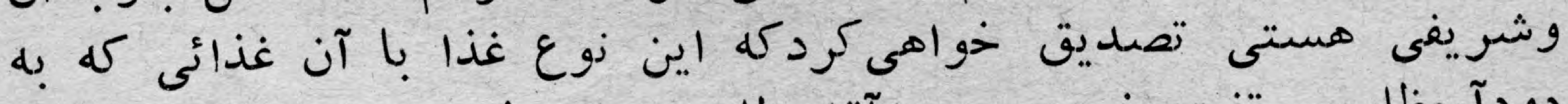

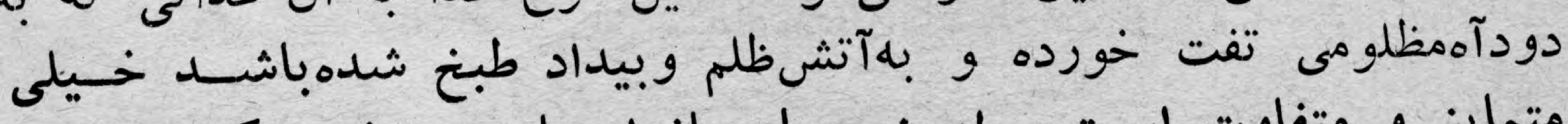

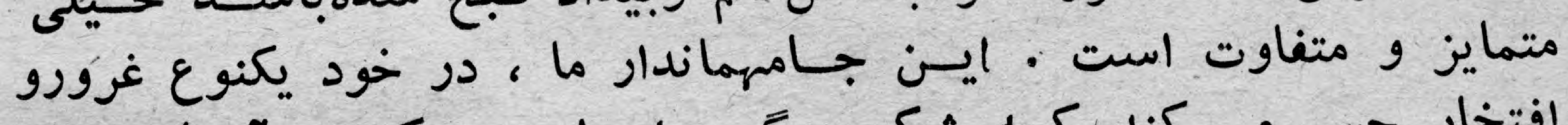

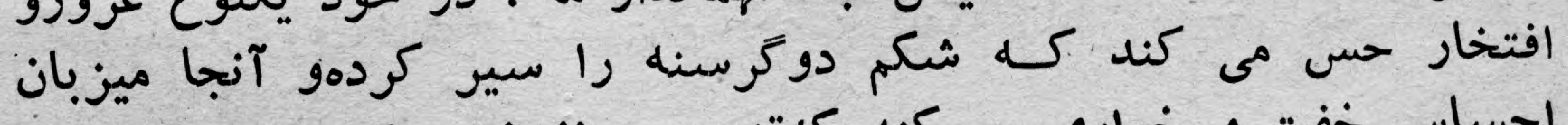

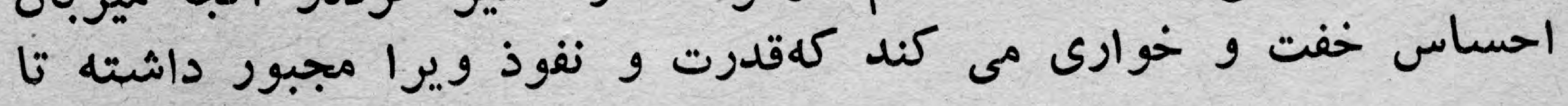




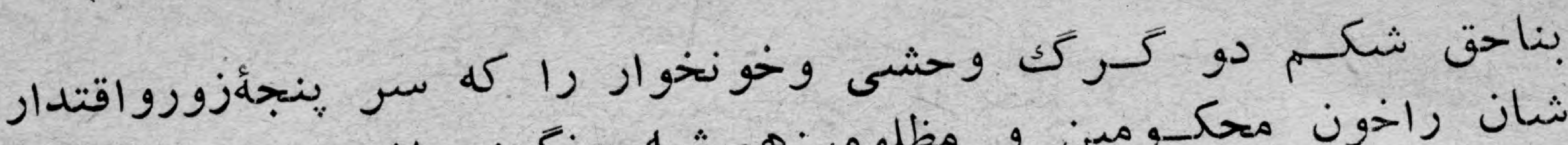

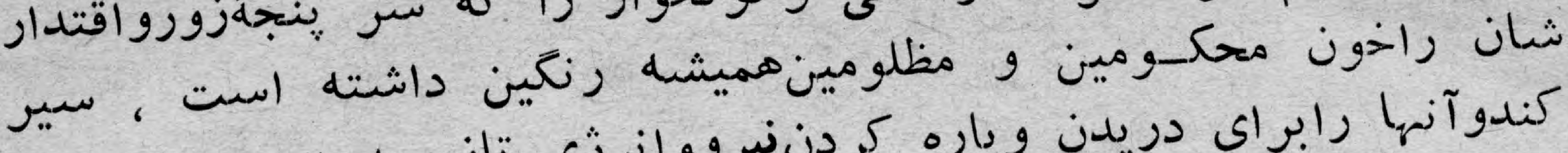

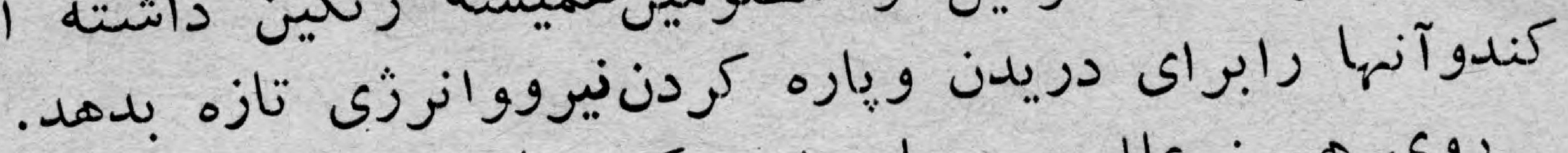

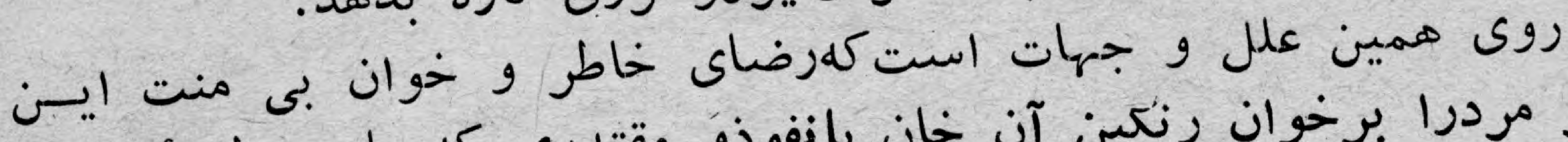

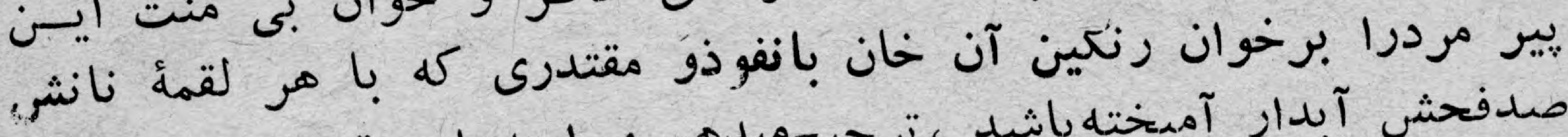

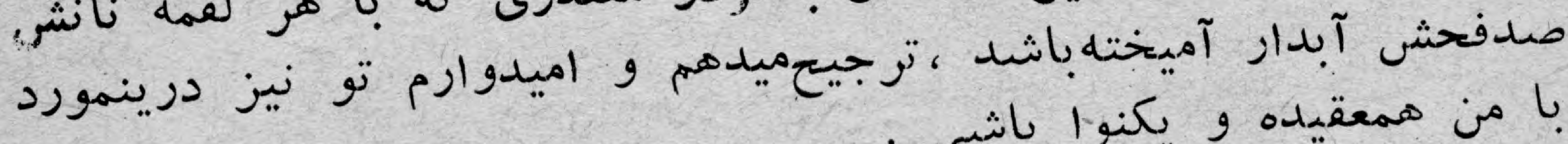

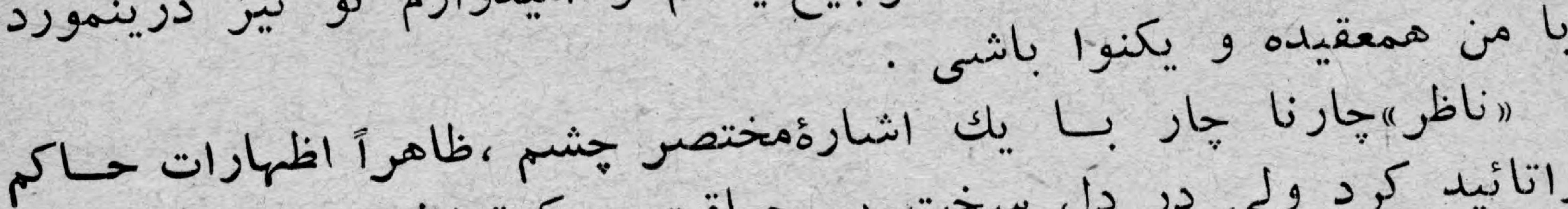

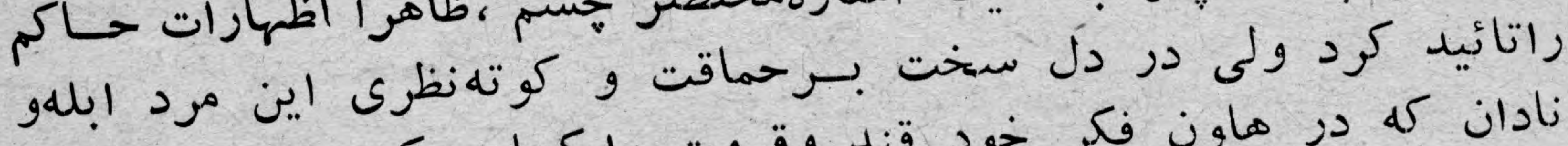

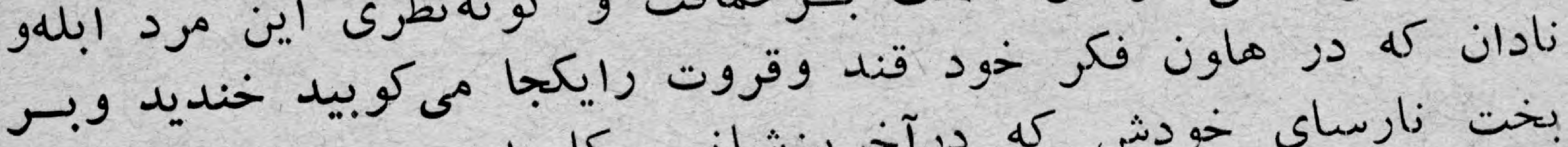

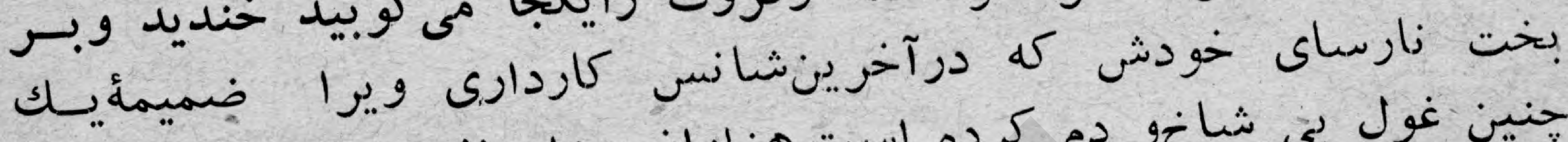

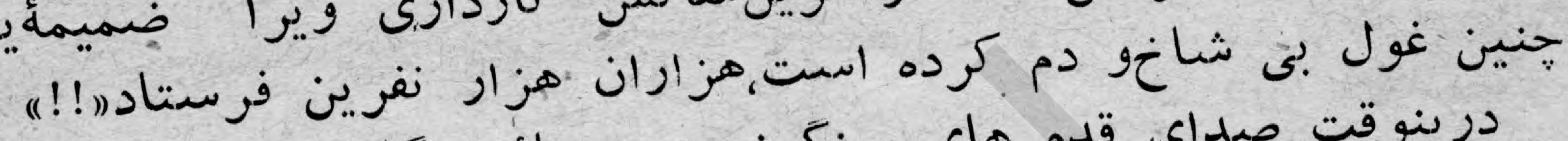

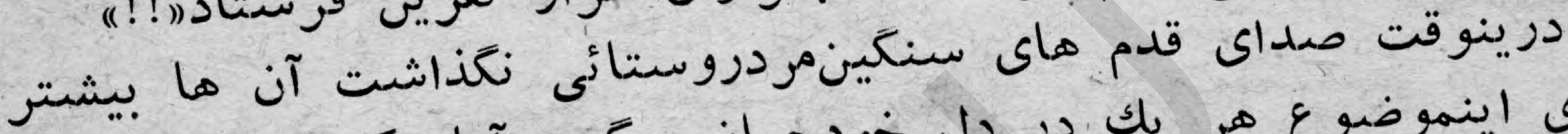

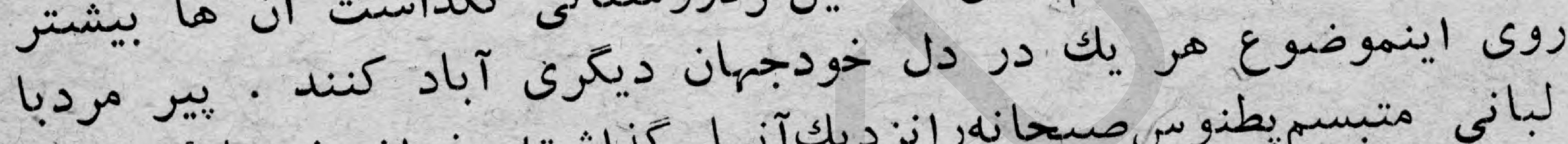

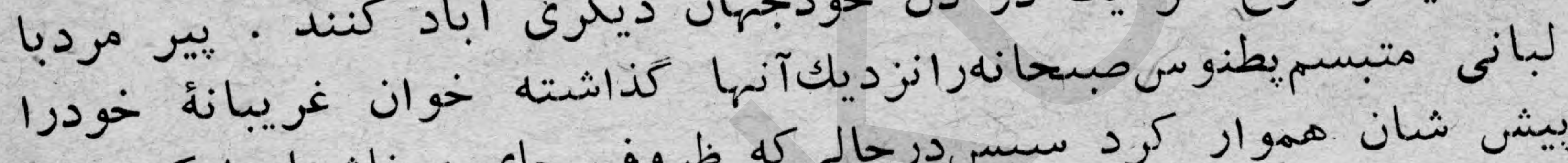

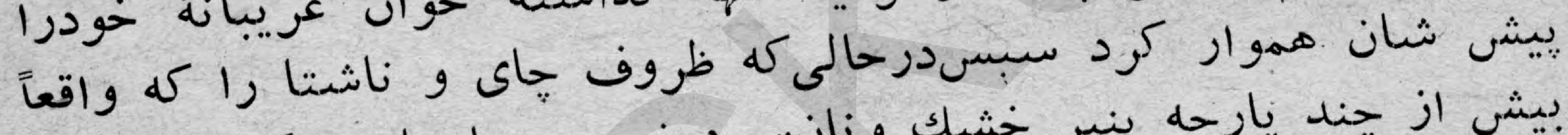

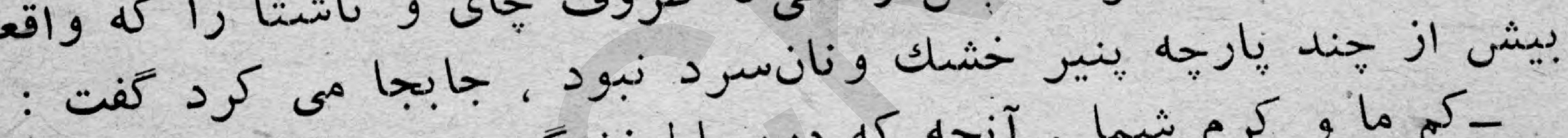

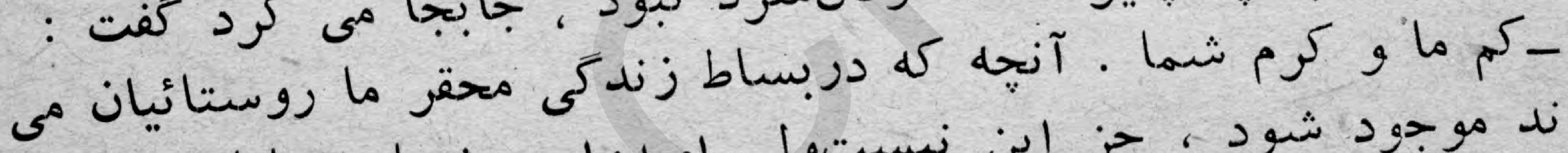

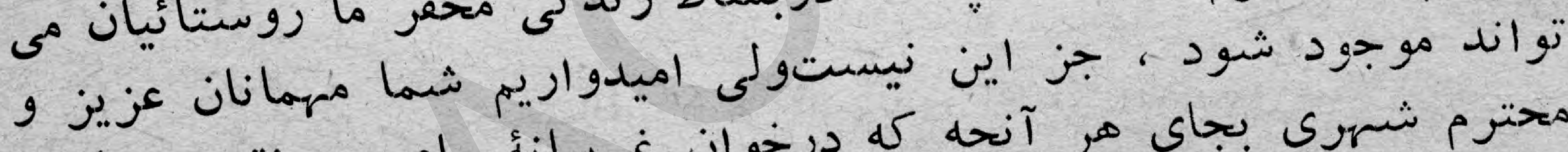

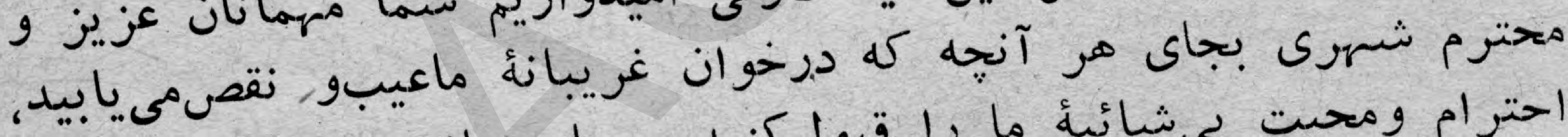

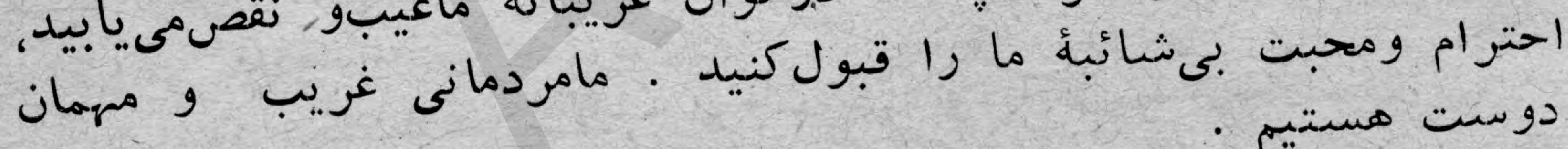

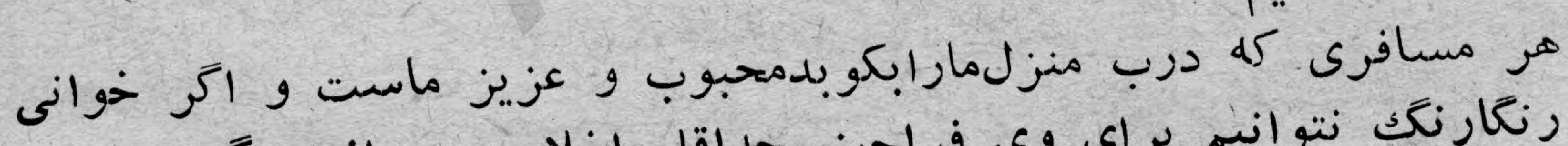

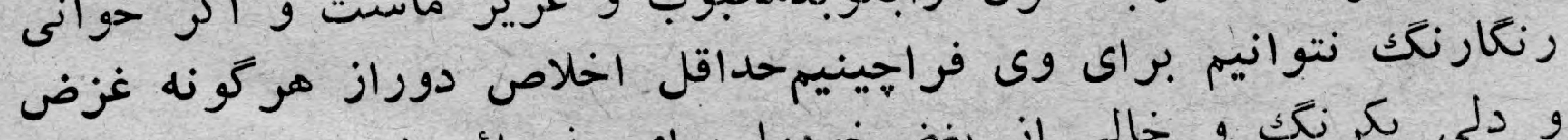

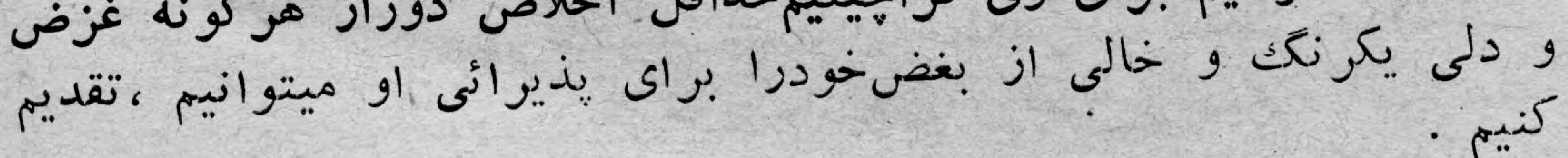

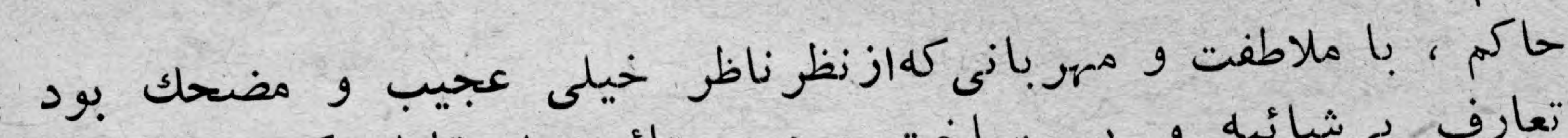

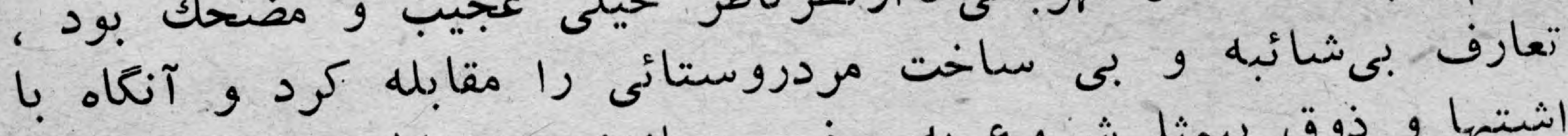

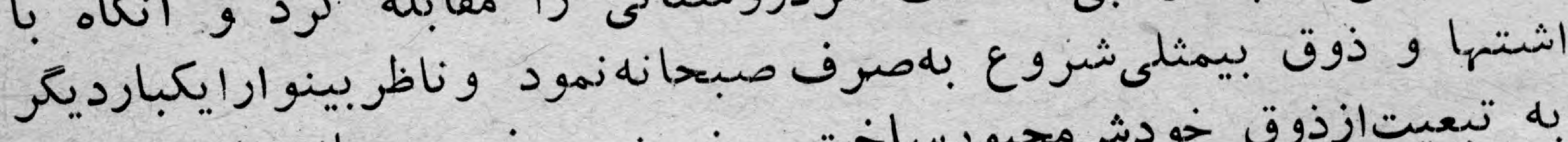

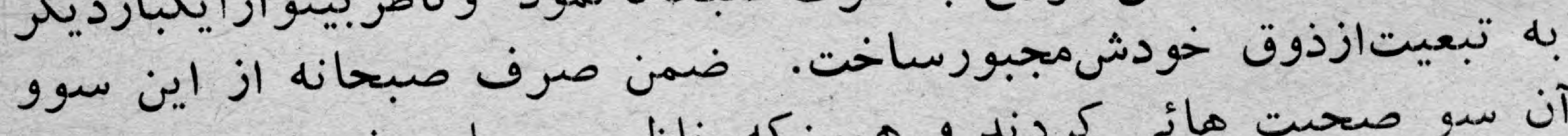

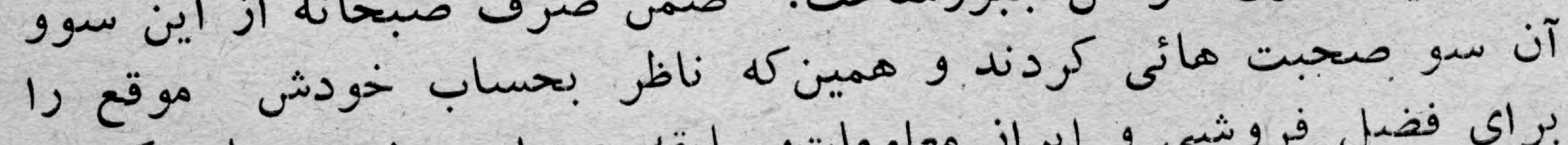

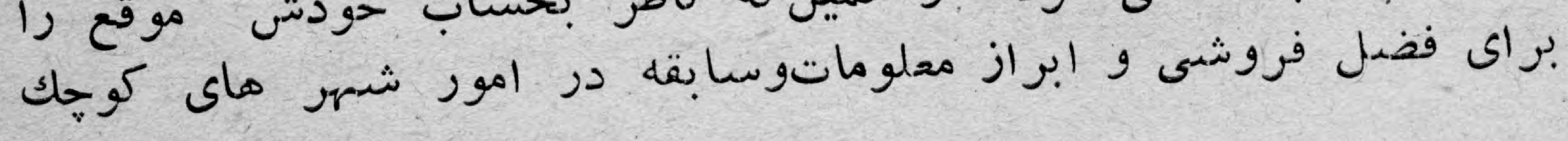


مناسب يافت . از تير مرد ميزبانراجع به تهو نكى وضع مالدارانو

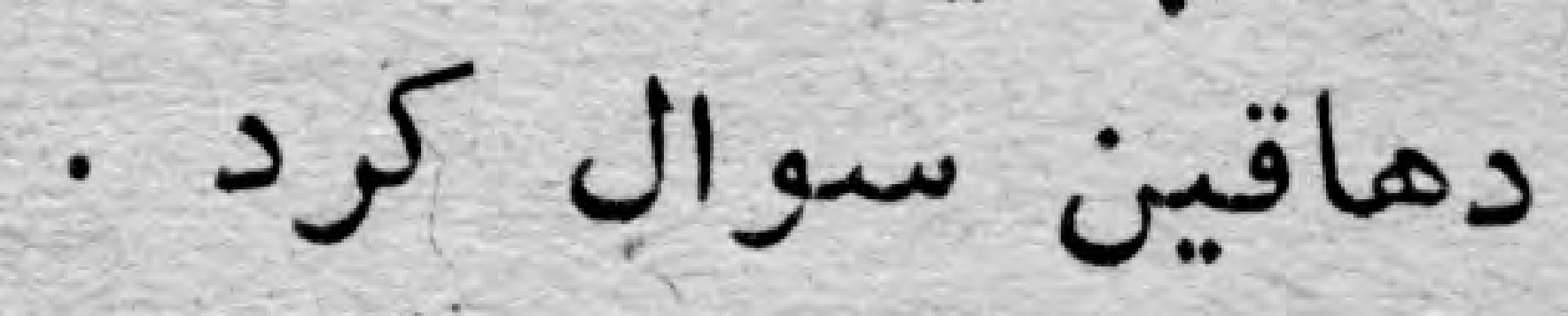

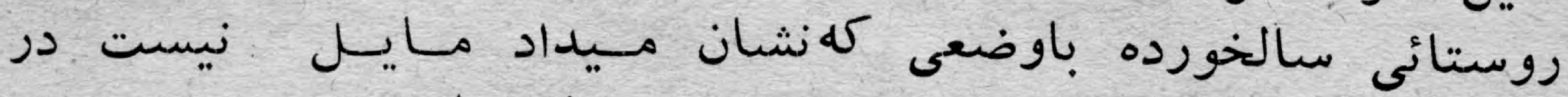

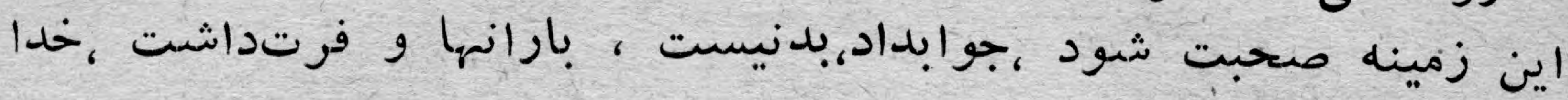

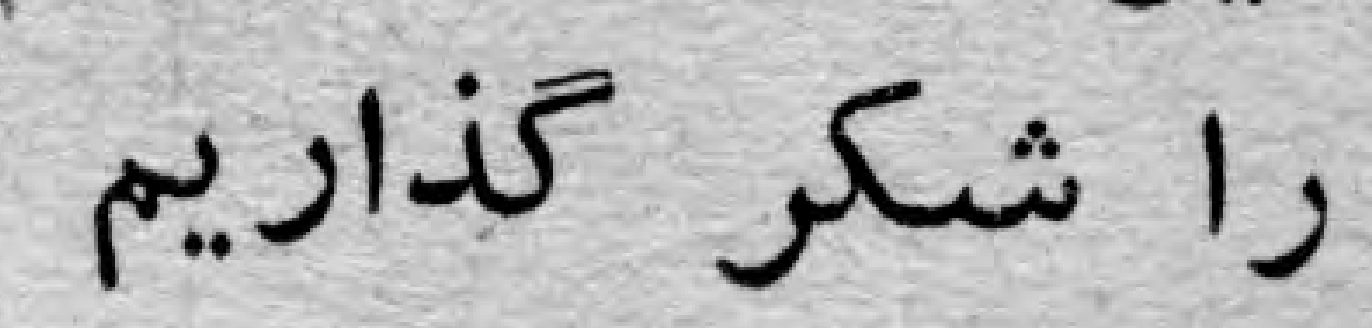

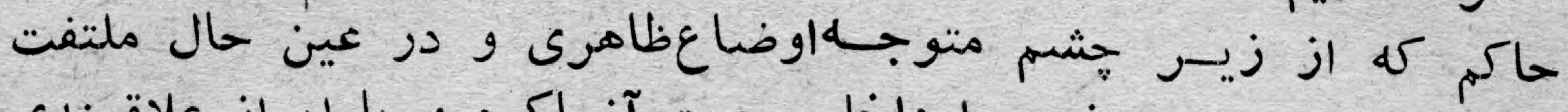

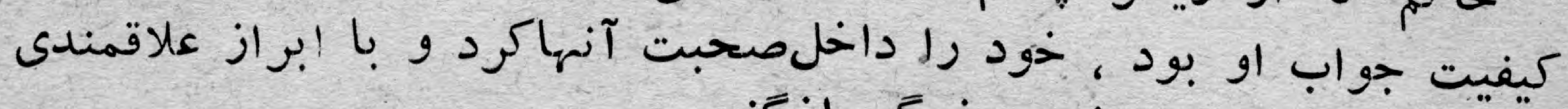

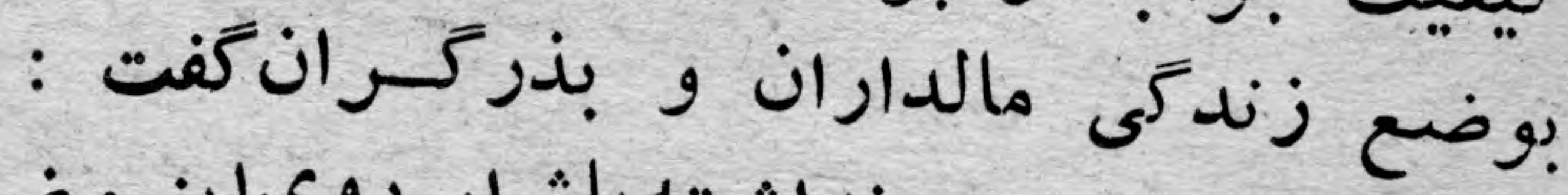

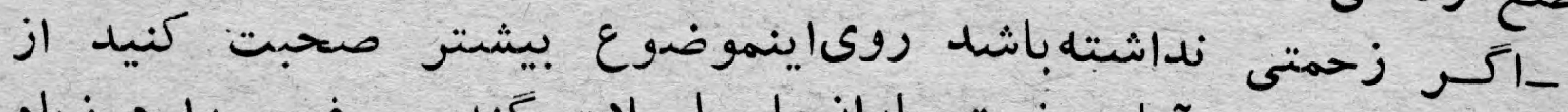

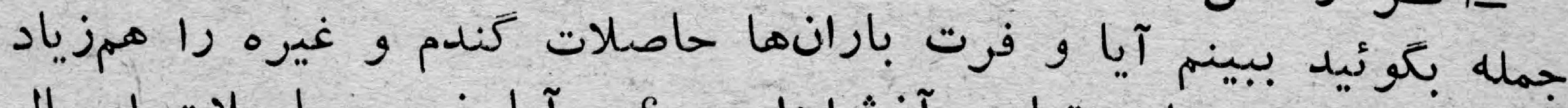

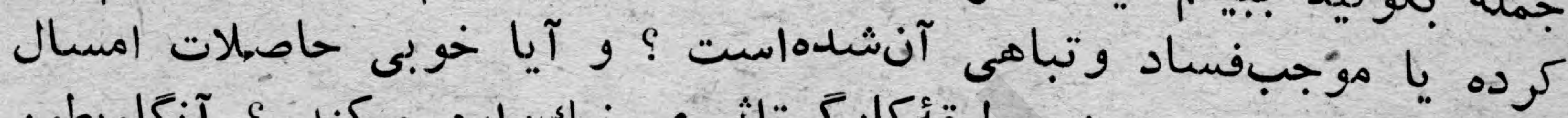

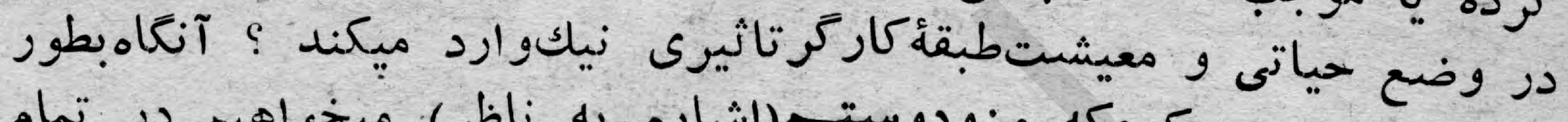

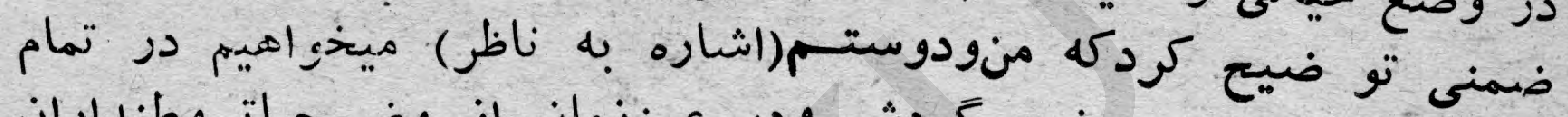

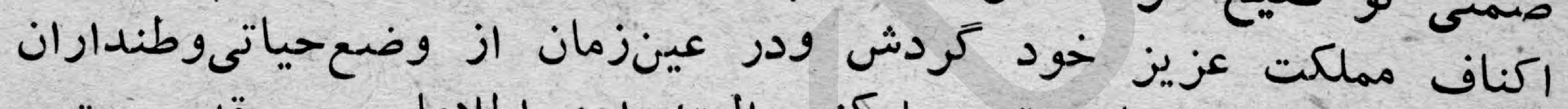

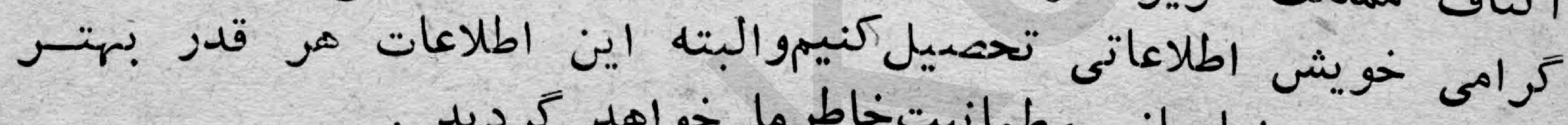

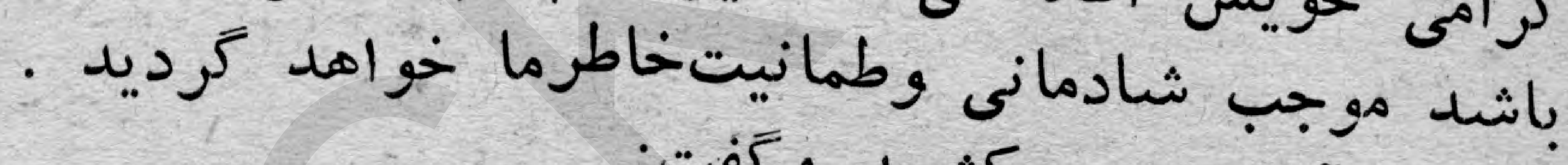

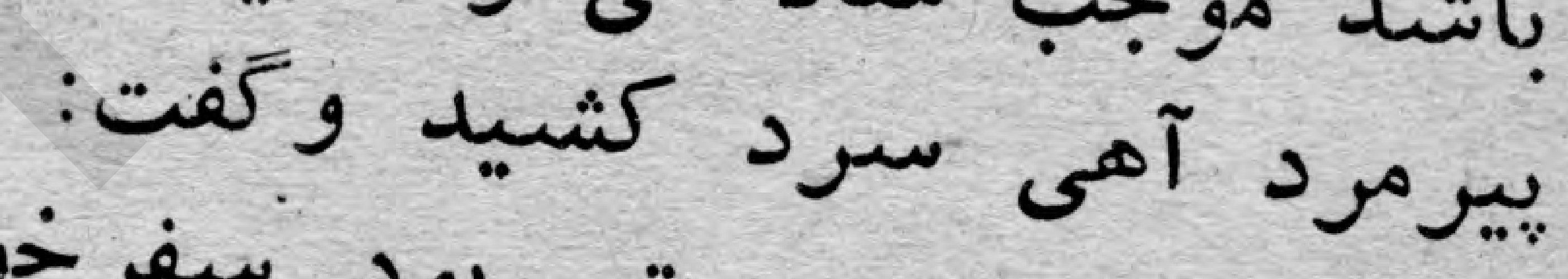

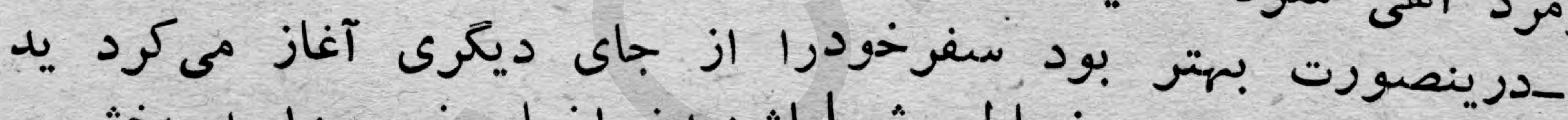

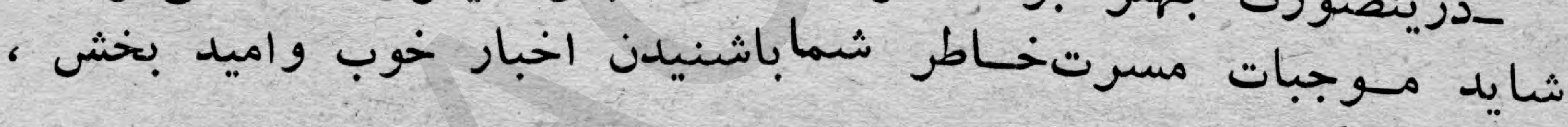

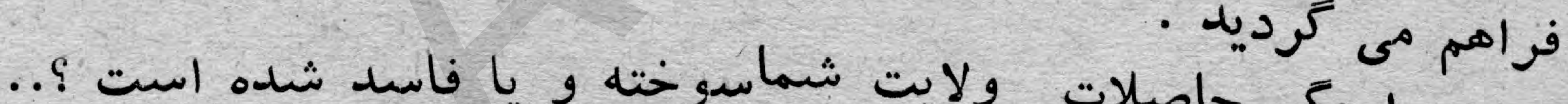

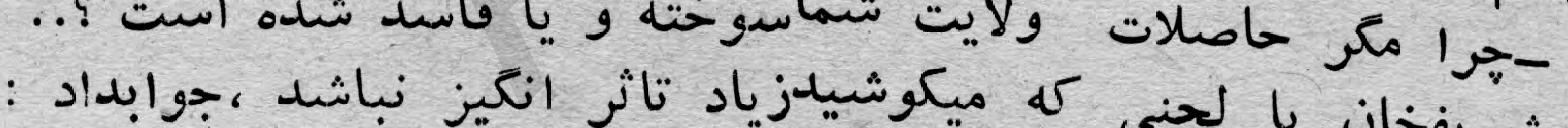

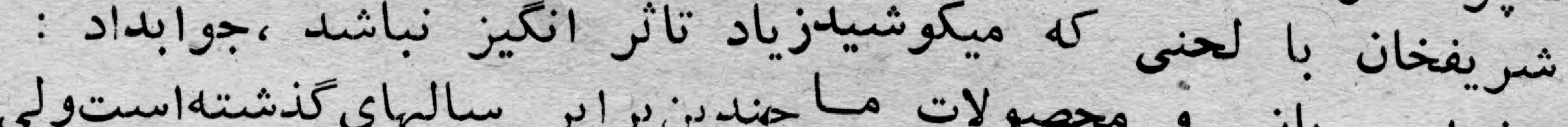

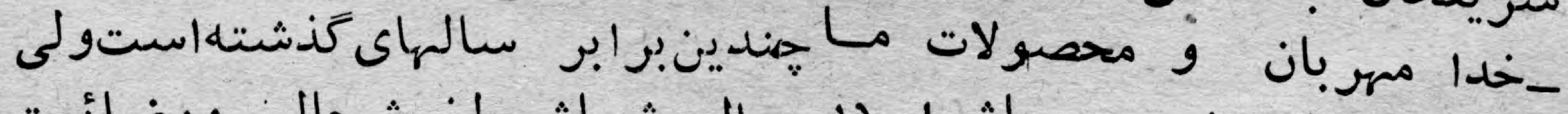

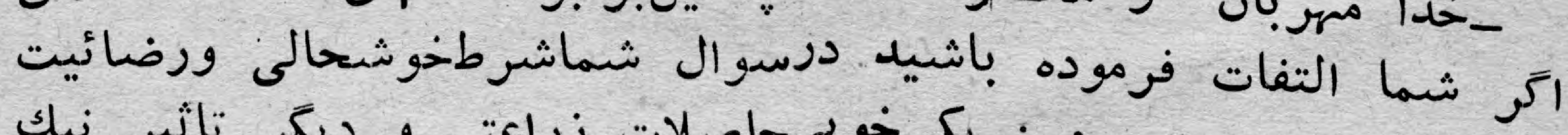

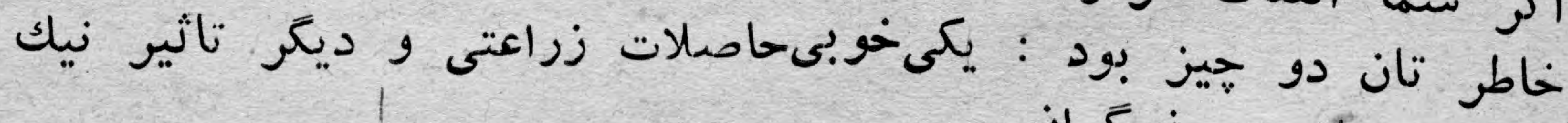

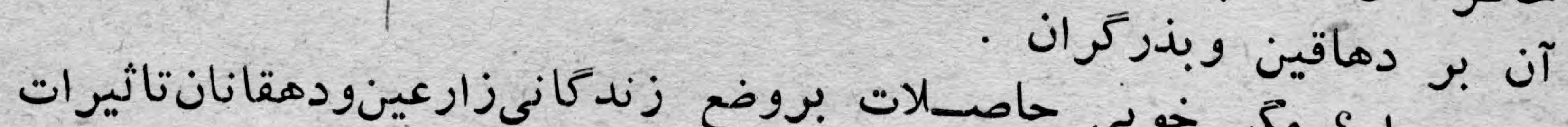

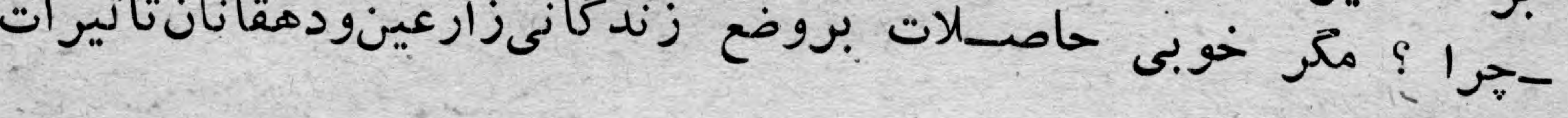

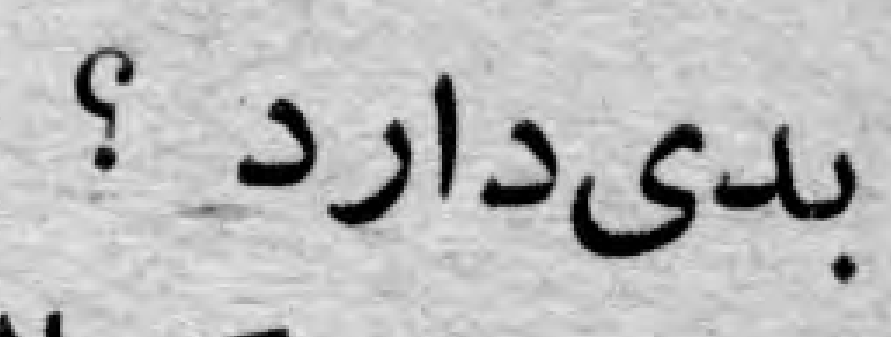

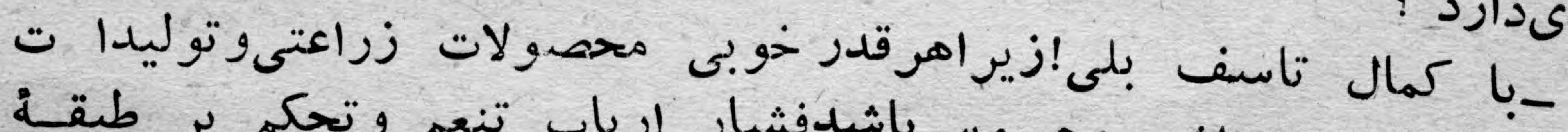

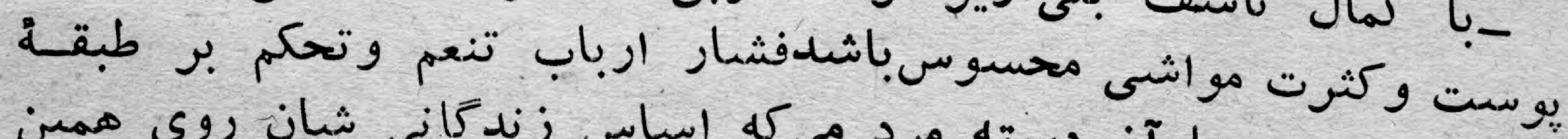

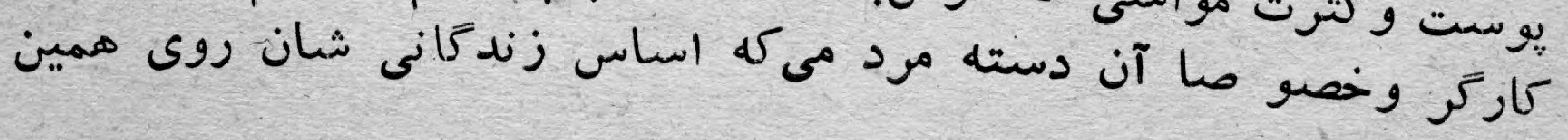


توليدات زراعتى و فـالاحتى متكسى است بيشتر وبيشتر ميكردد تا آنجا

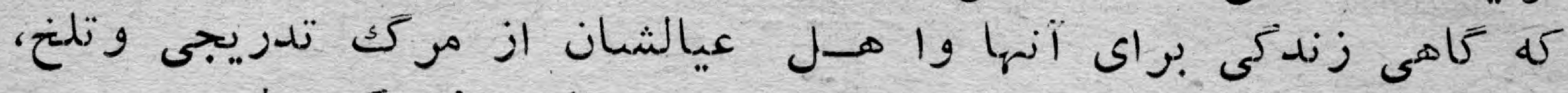

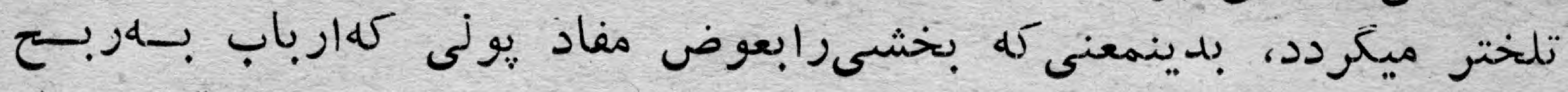

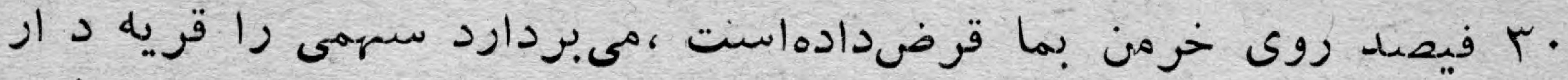

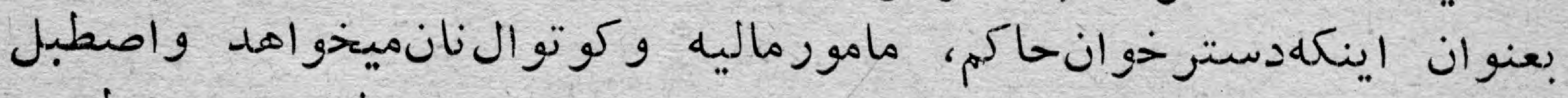

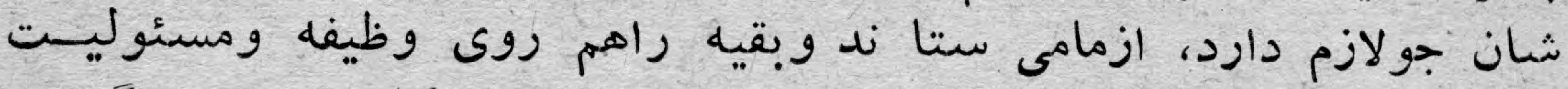

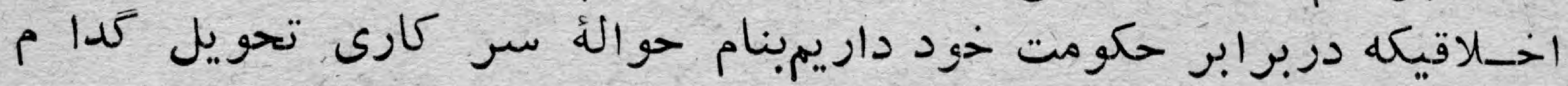

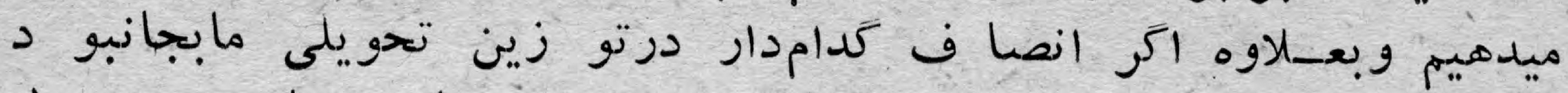

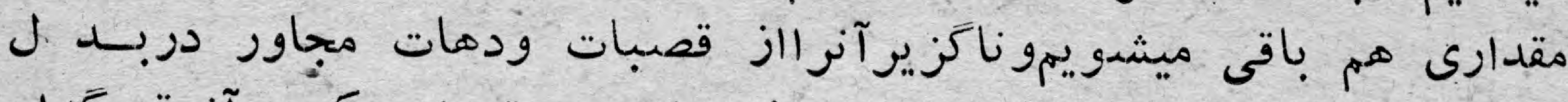

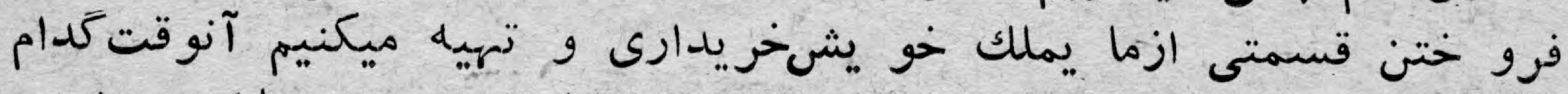

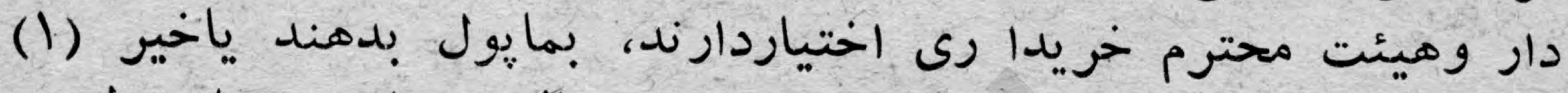

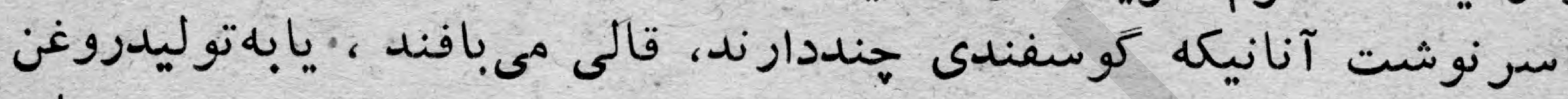

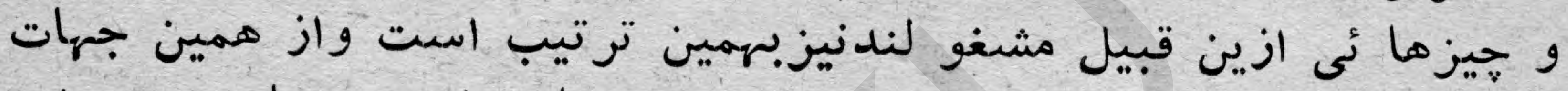

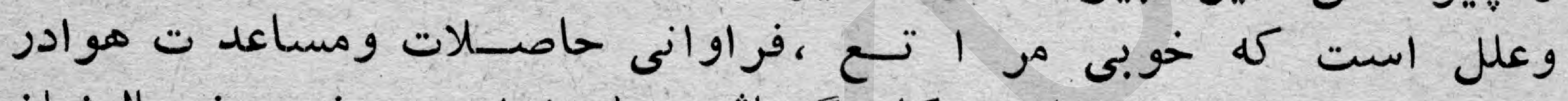

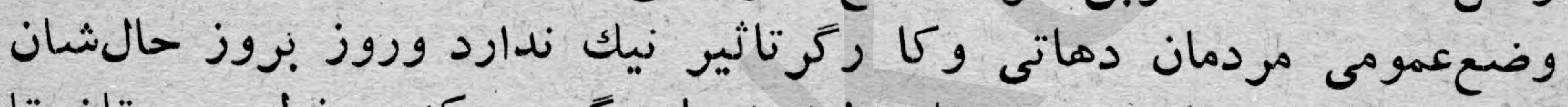

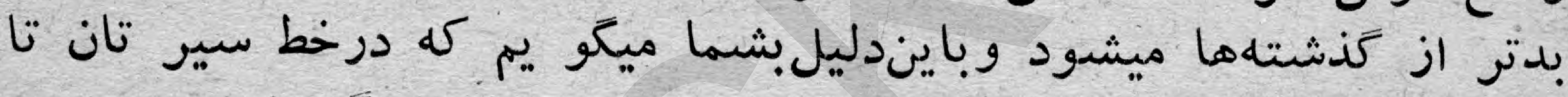

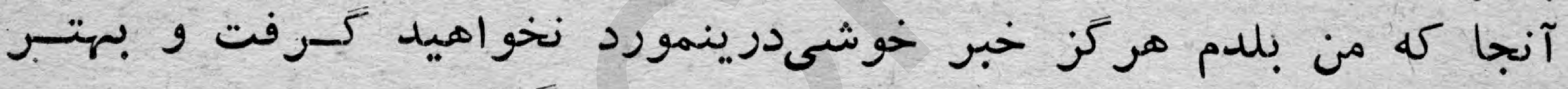

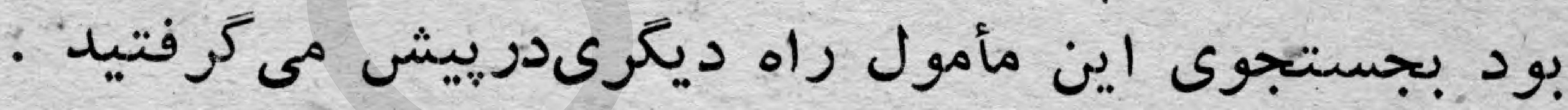

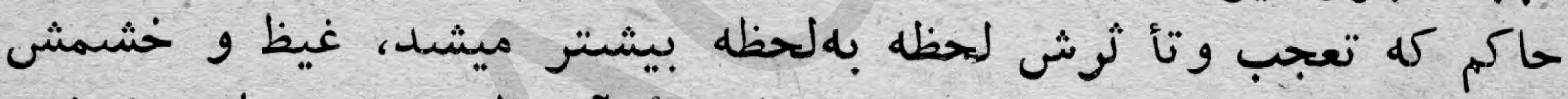

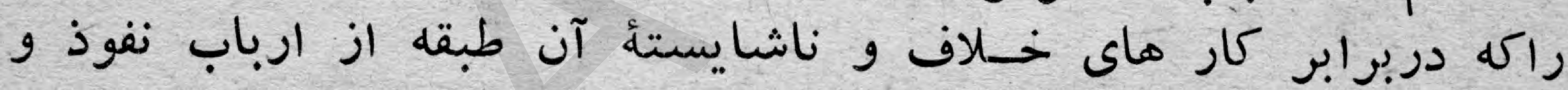

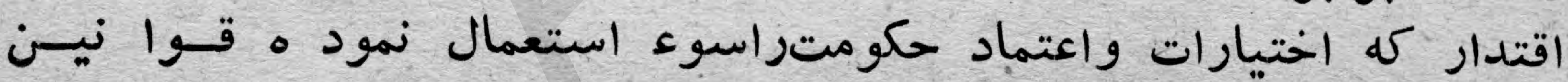

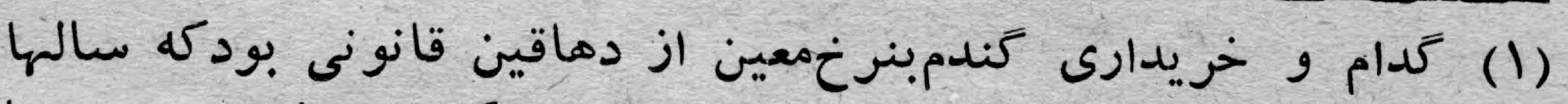

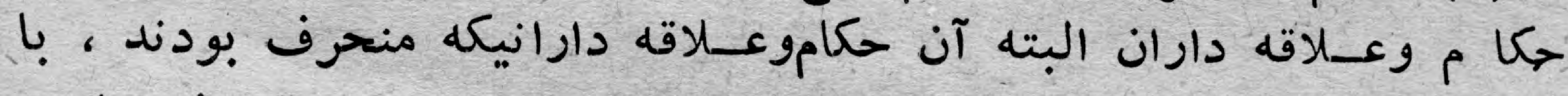

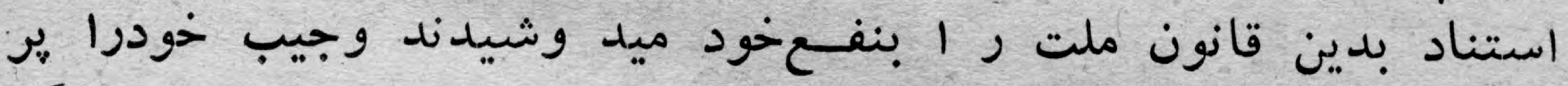

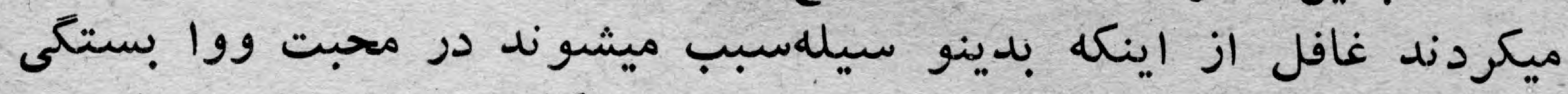

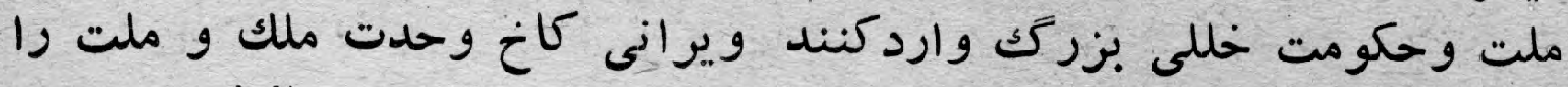

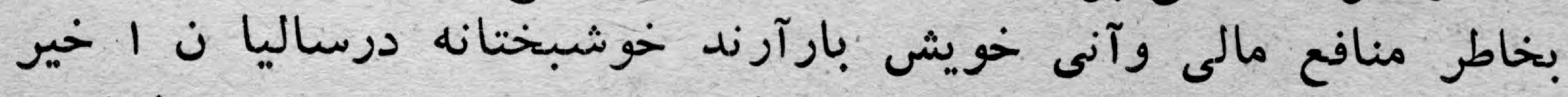

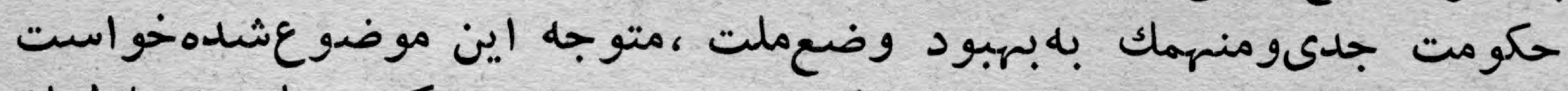

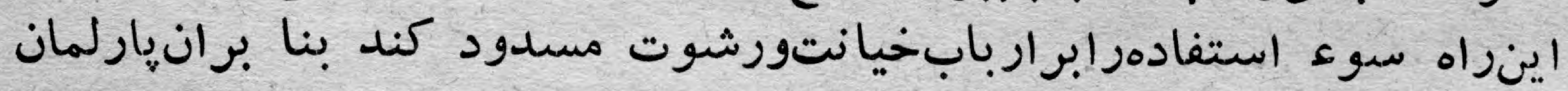

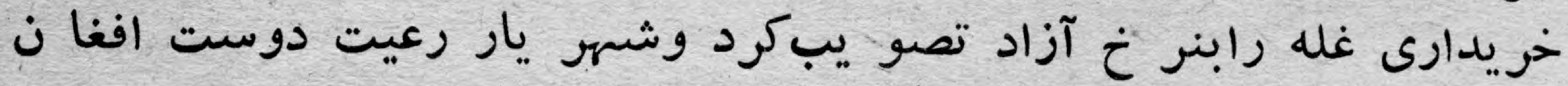

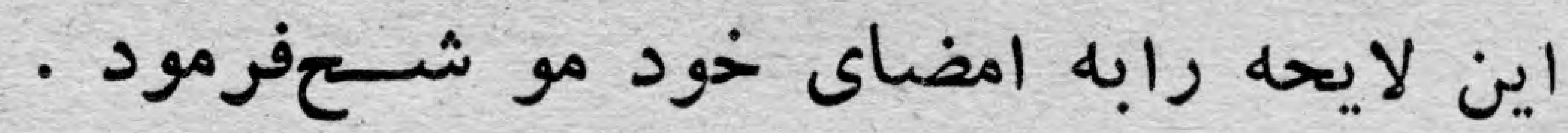




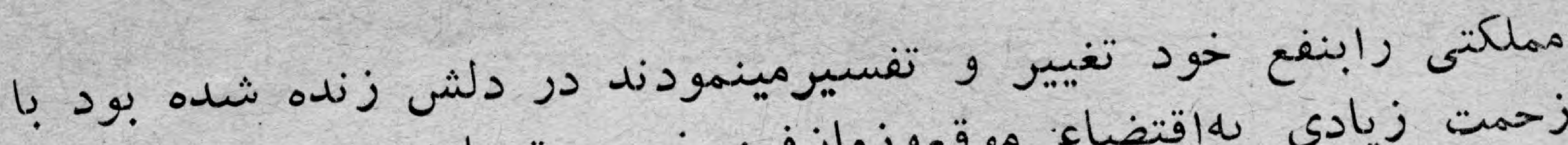

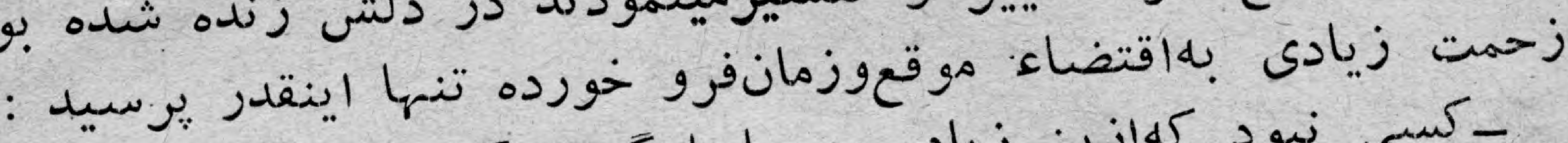

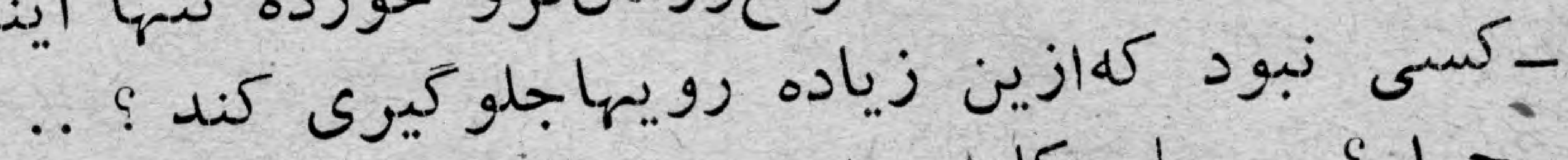

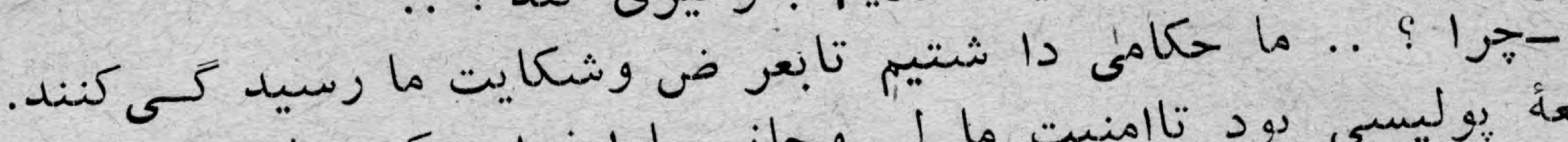

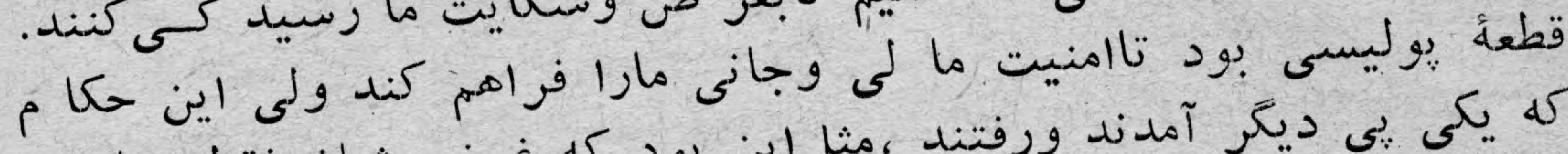

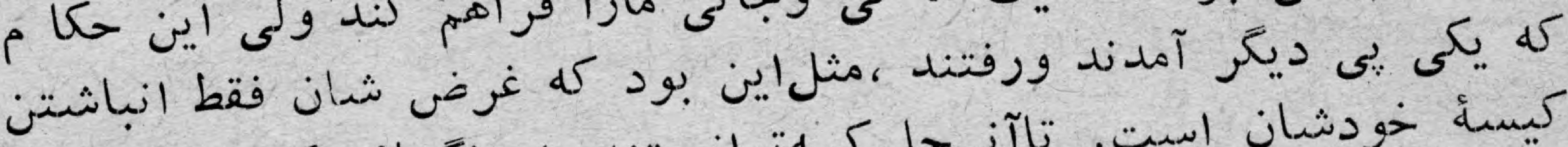

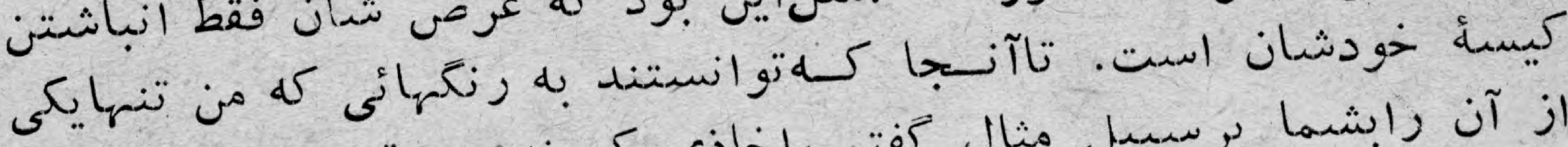

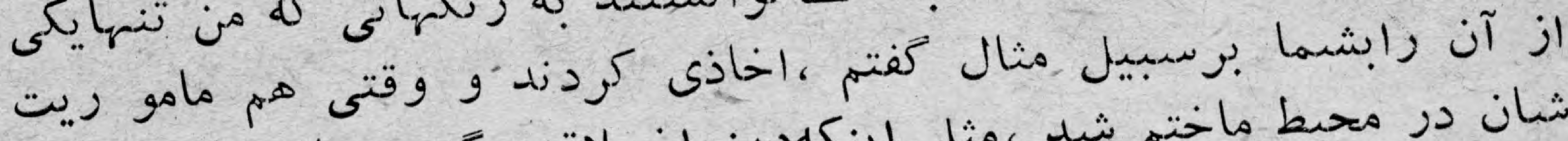

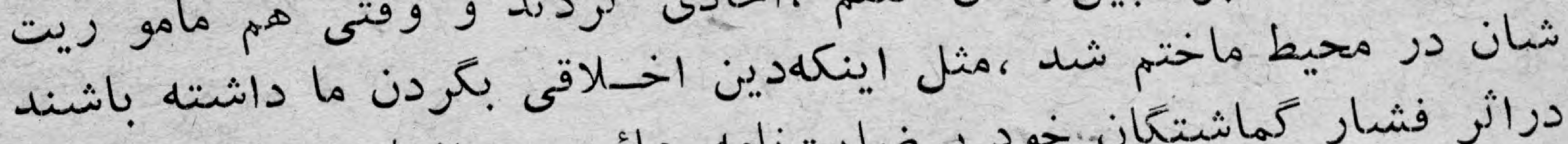

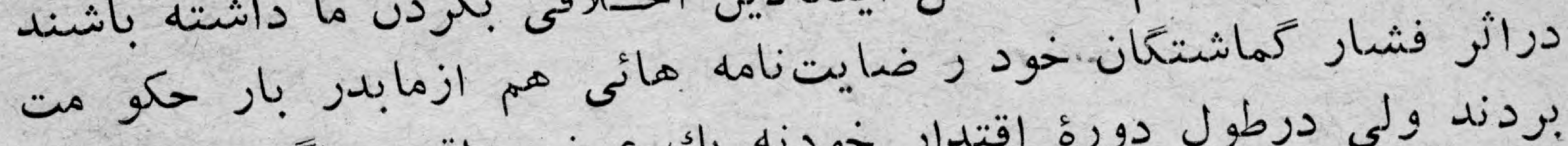

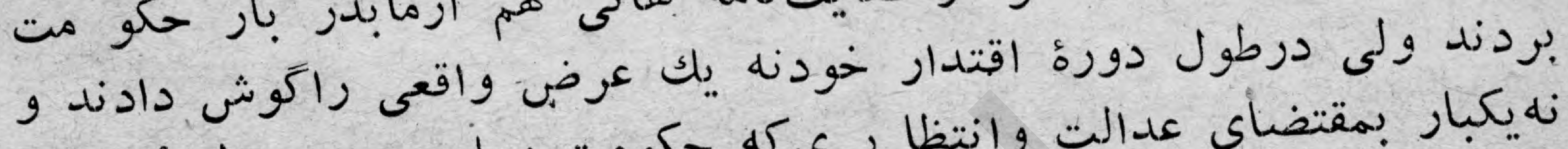

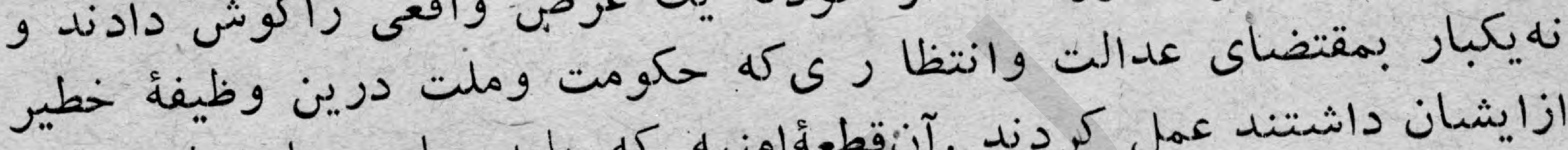

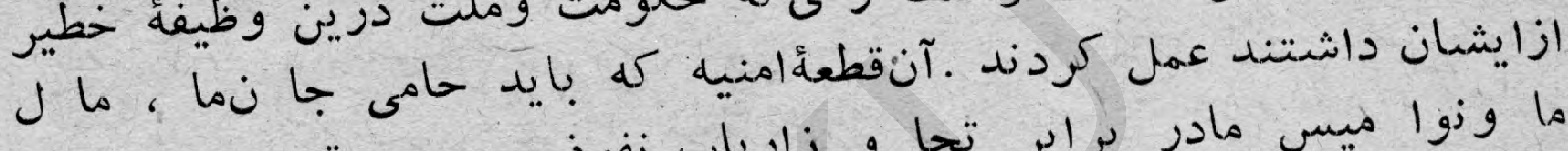

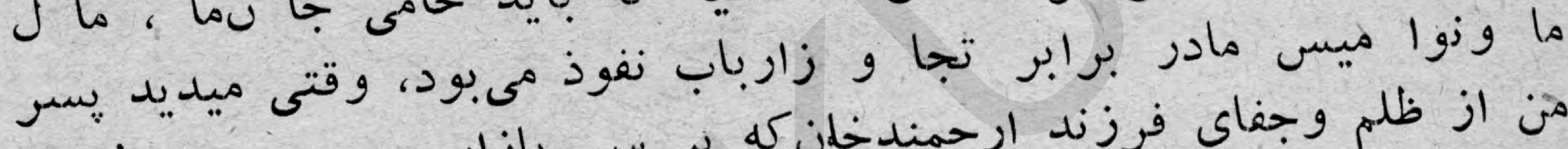

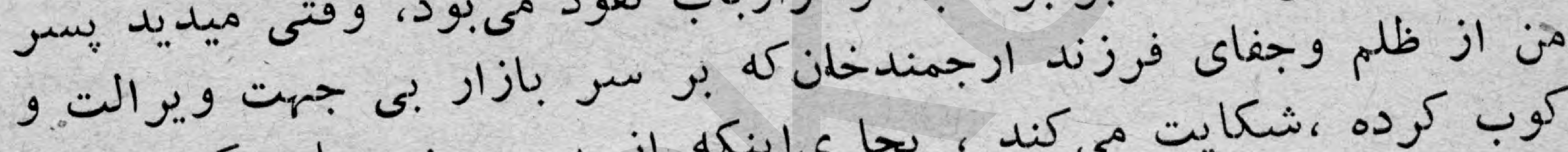

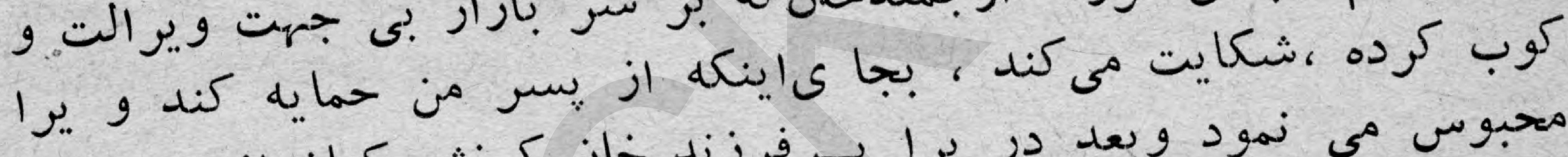

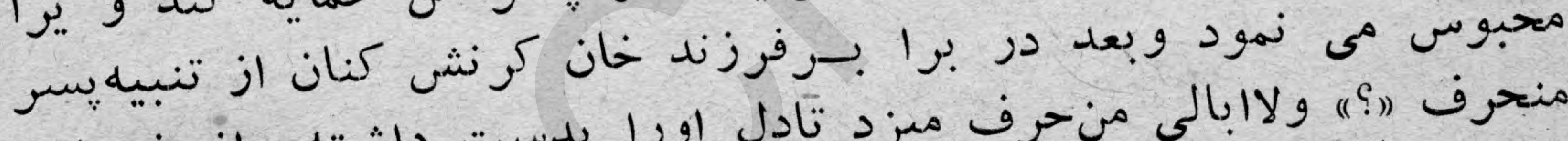

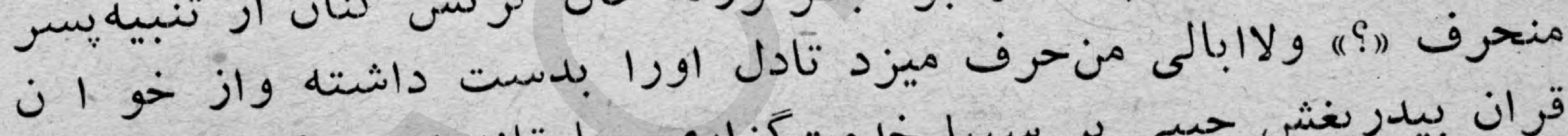

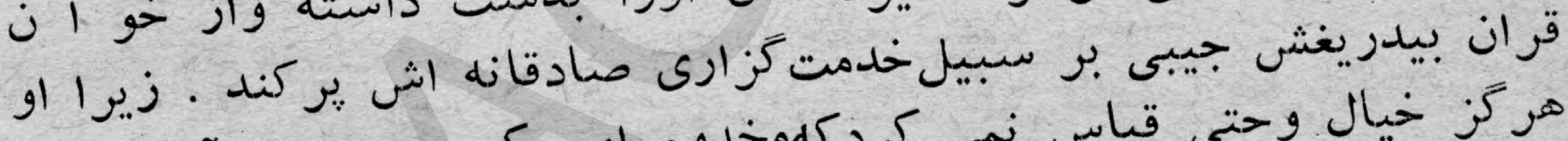

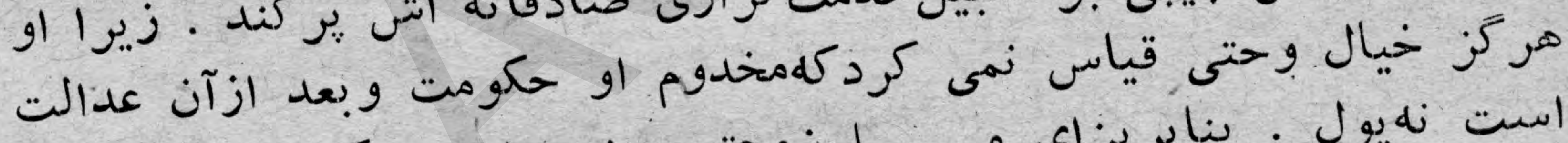

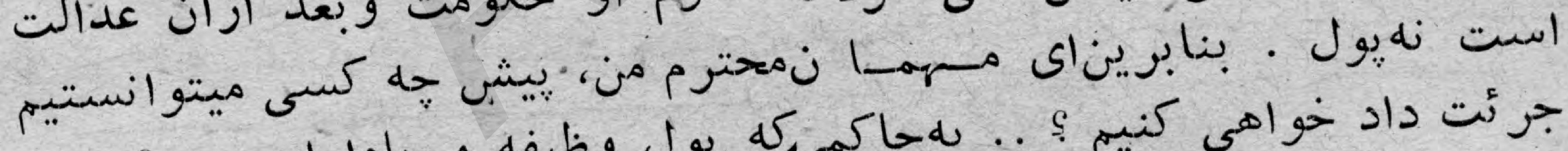

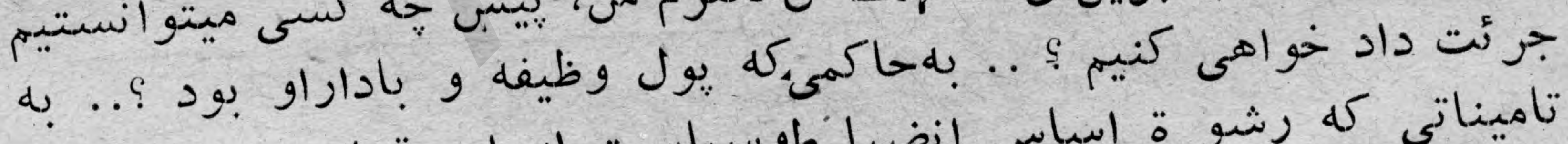

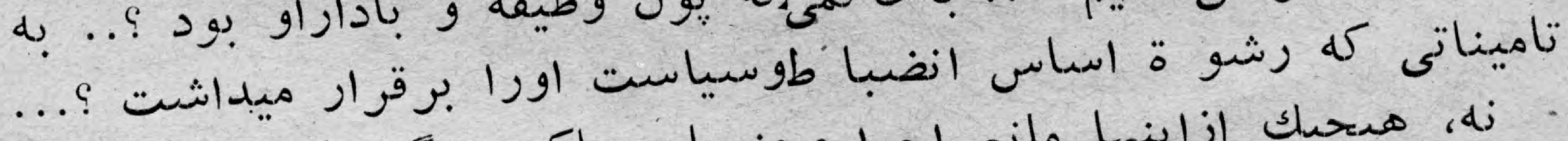

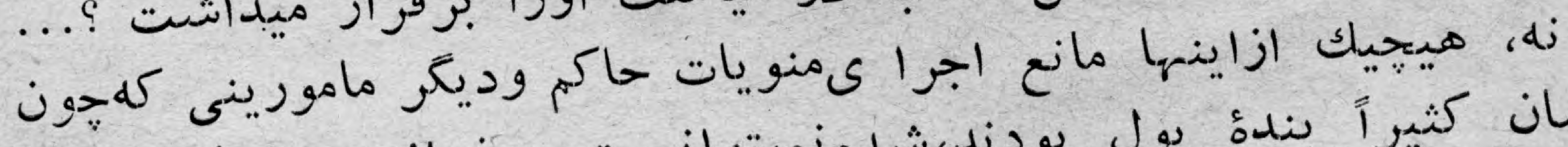

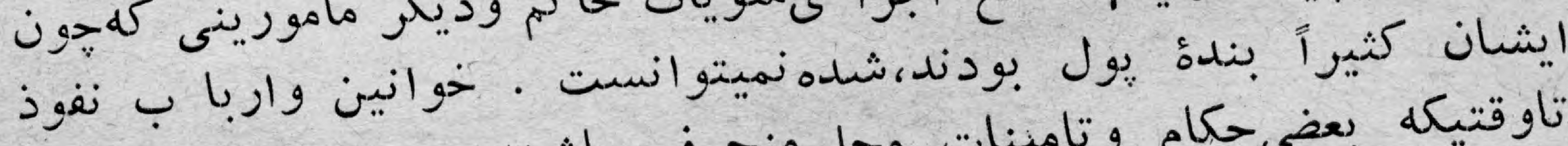

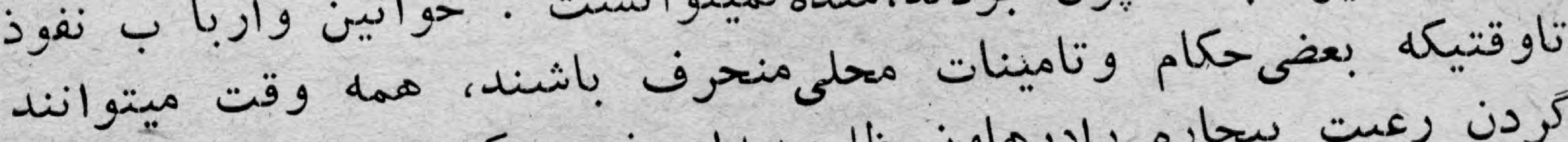

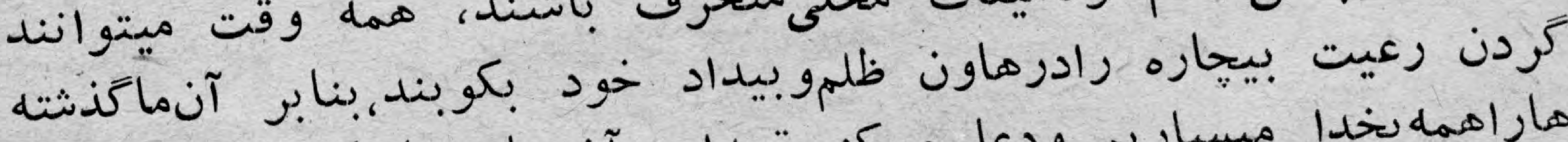

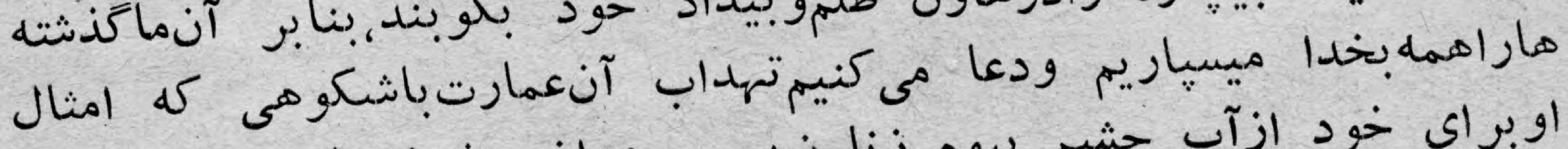

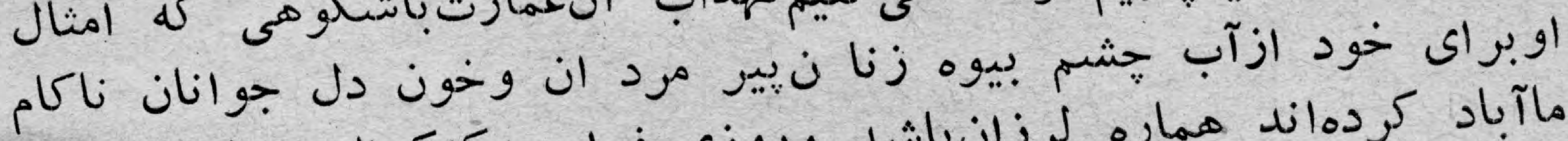

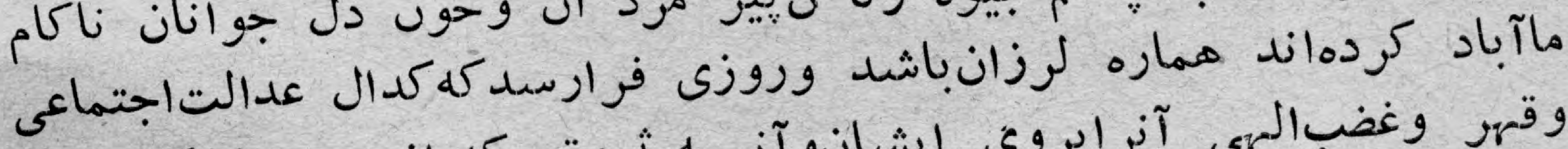

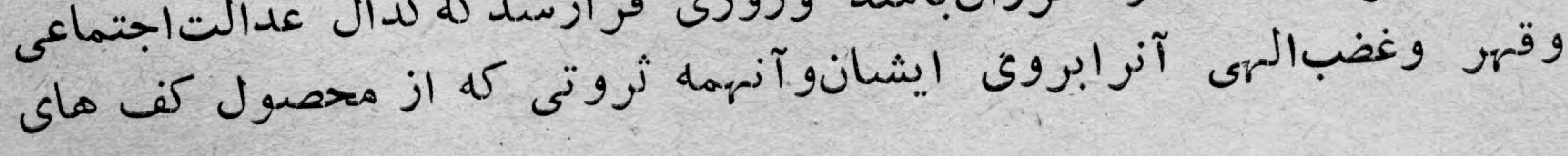


ير آبله دست مابنا حهق اندو ختهاند فرو ريزد ووارونه كند ! انشاء

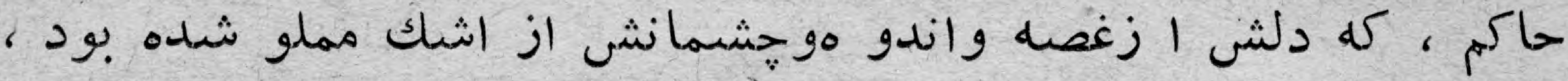

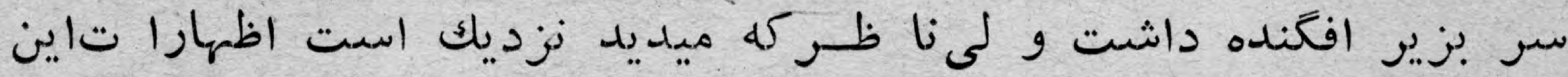

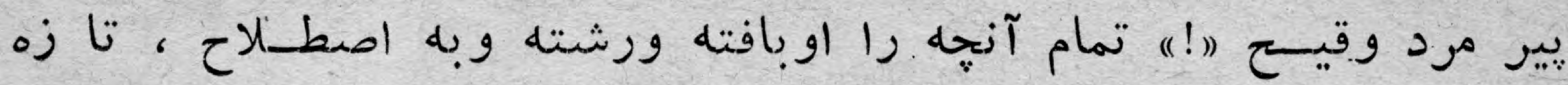

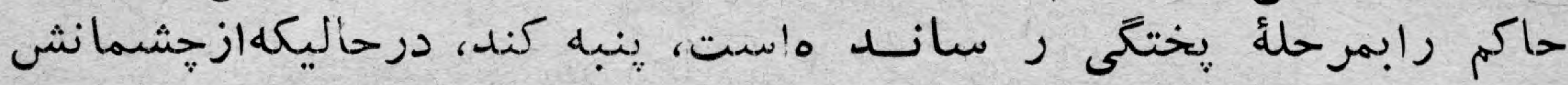

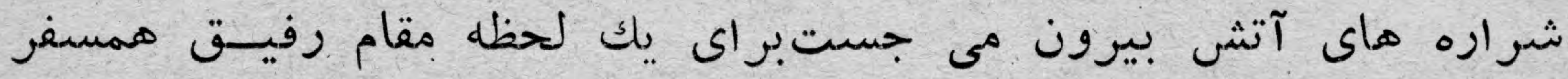

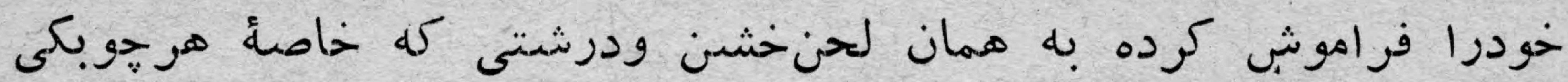

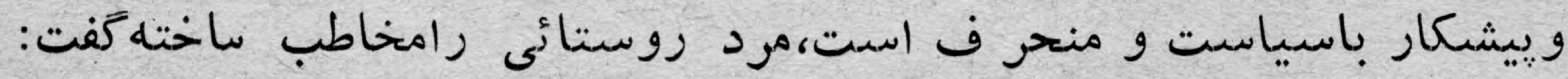

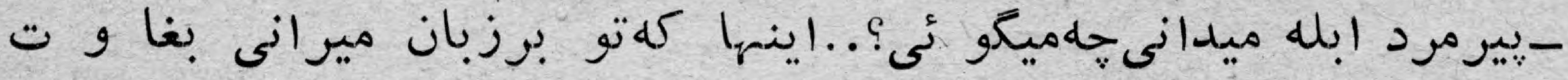

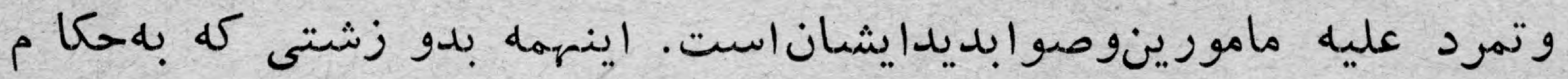

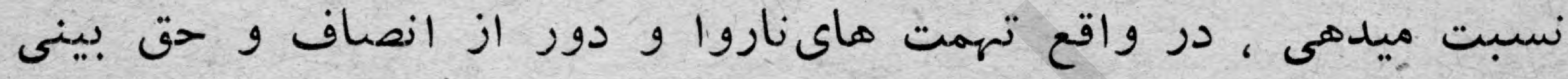

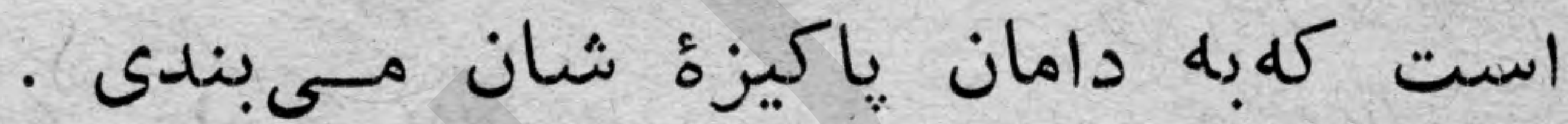

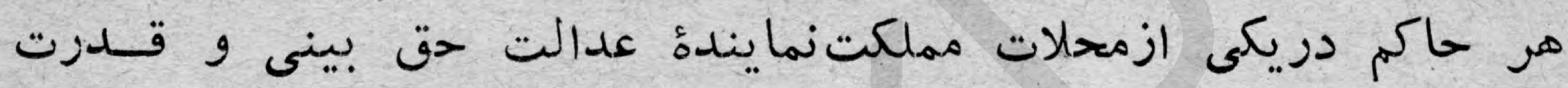

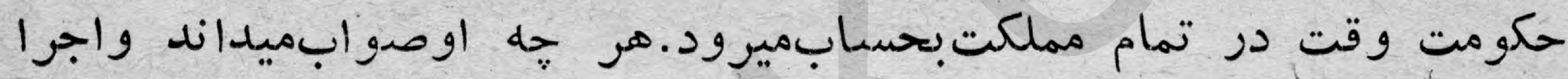

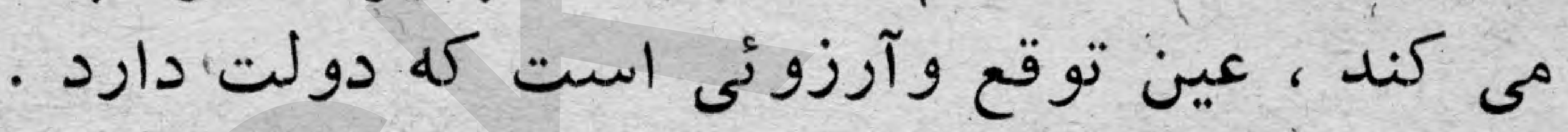

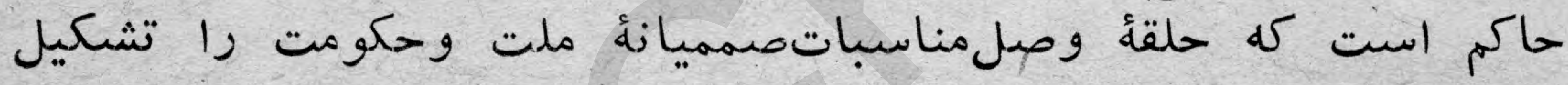

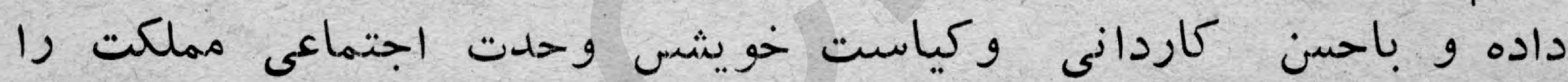

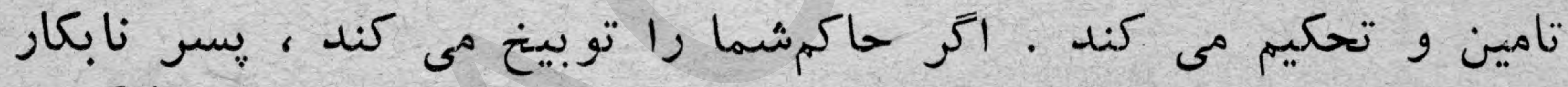

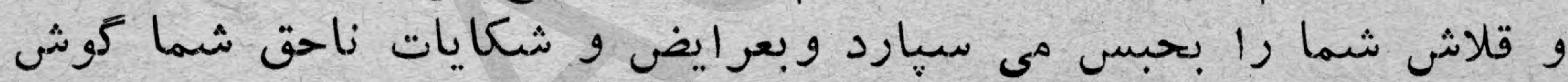

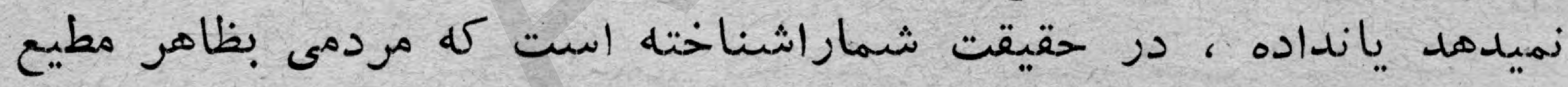

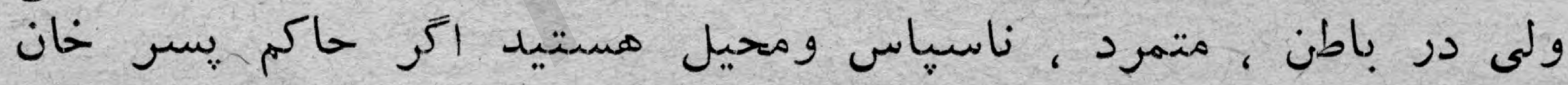

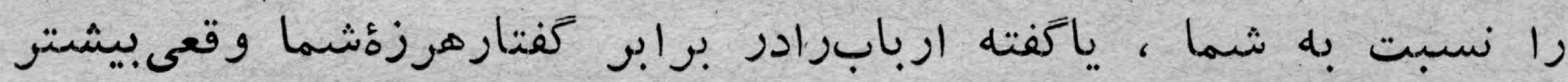

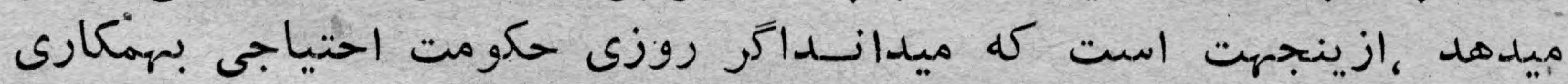

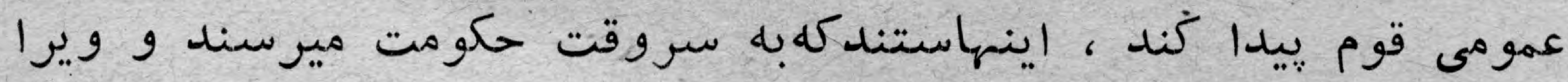

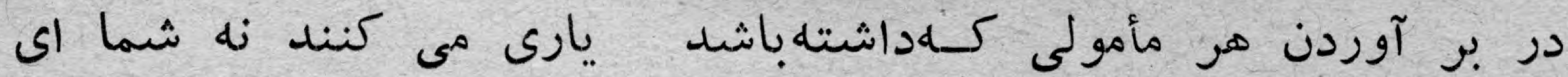

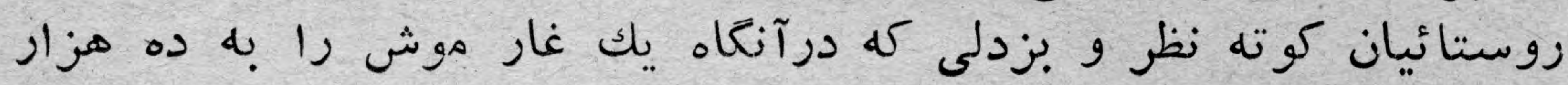

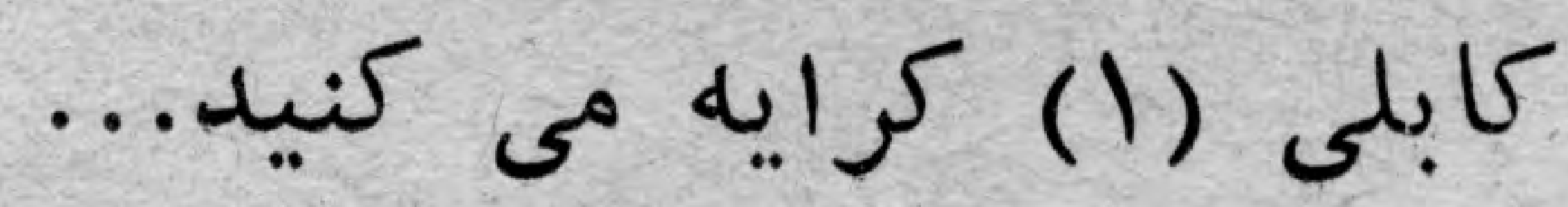

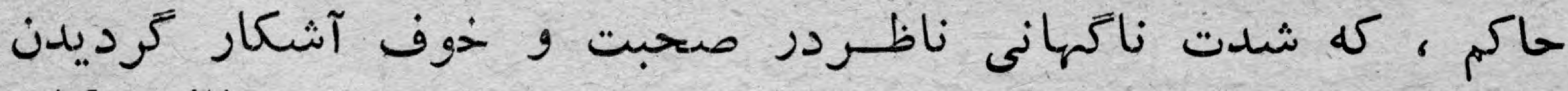

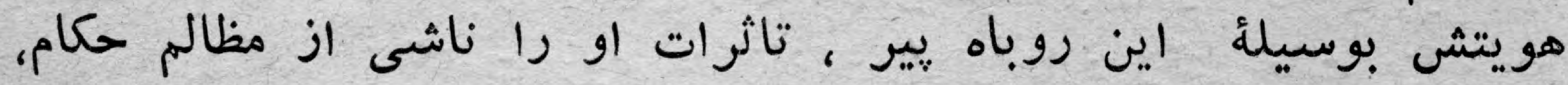

(1)يكى از مسكو كات رايج درنيم قرن قبل افغانستان (نويسنده) 


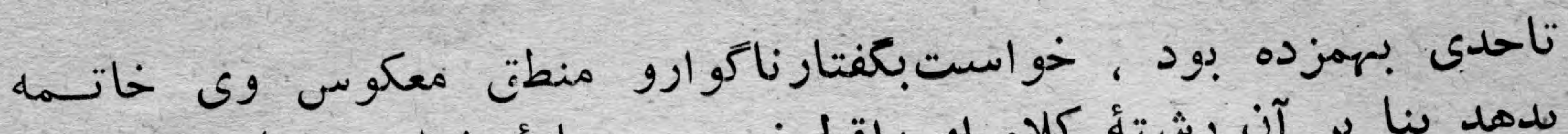

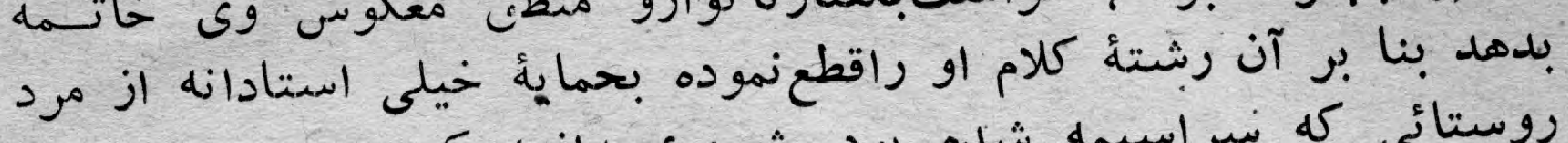

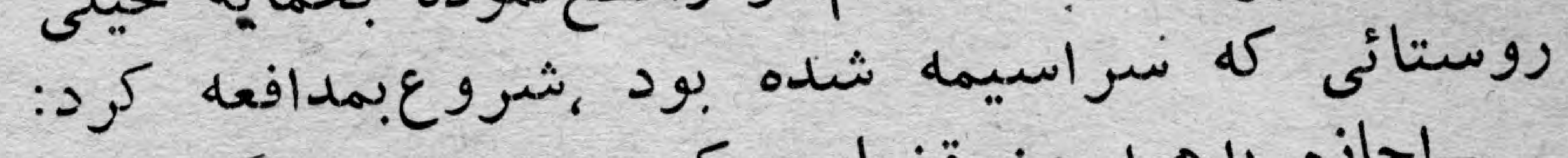

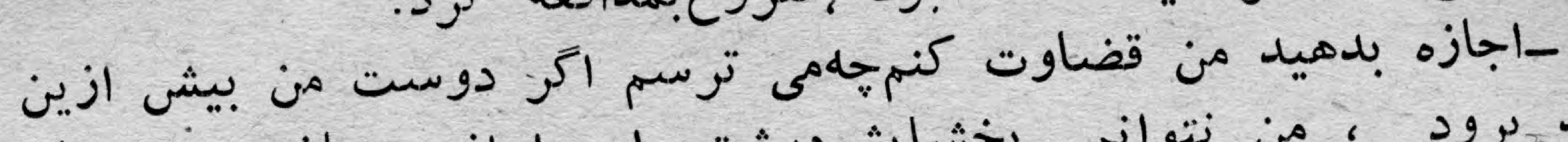

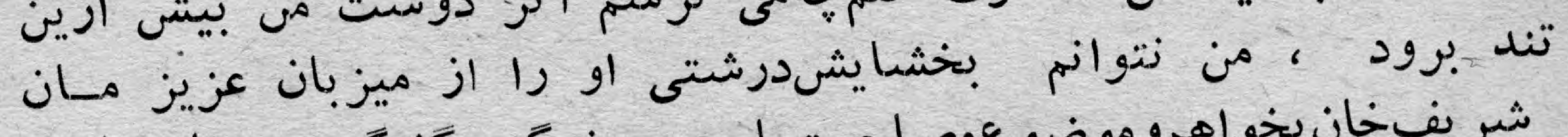

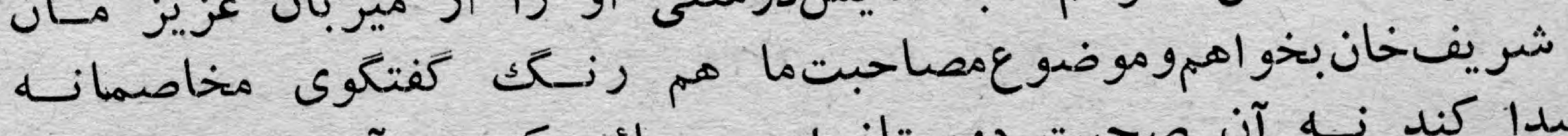

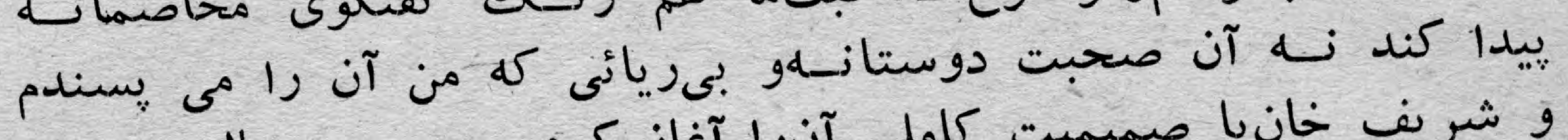

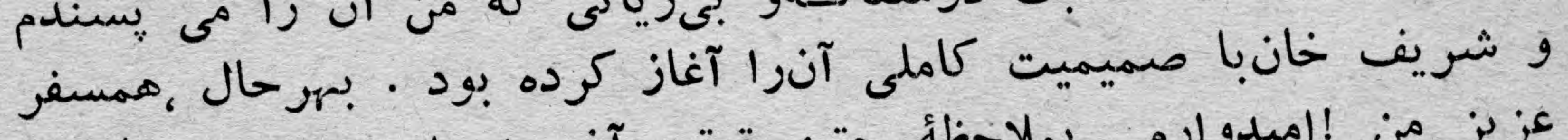

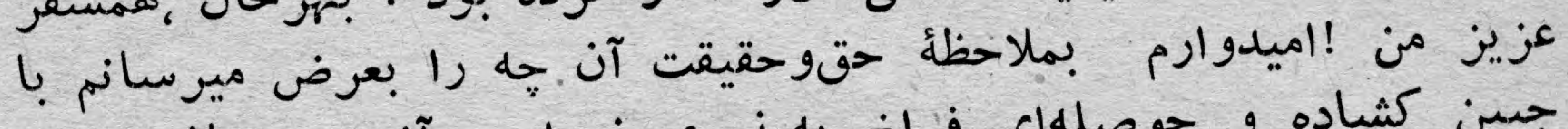

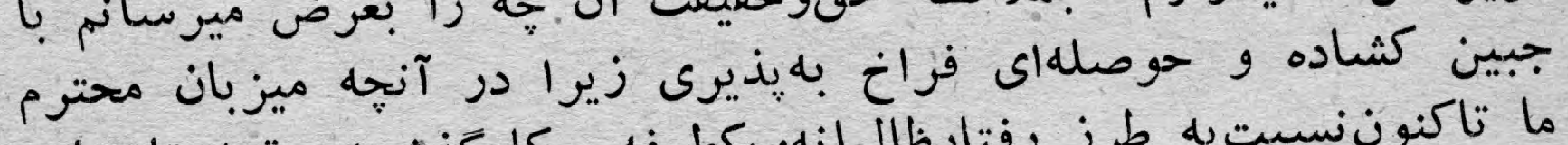

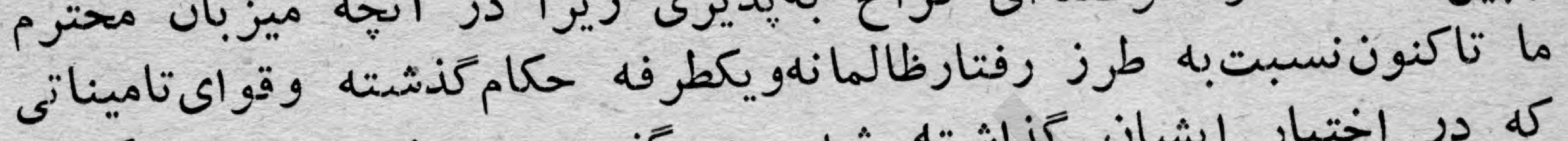

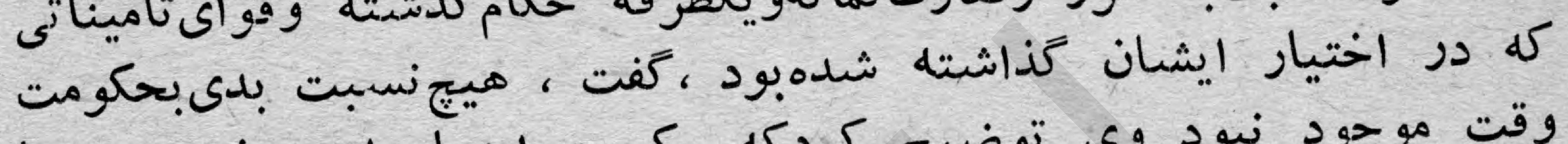

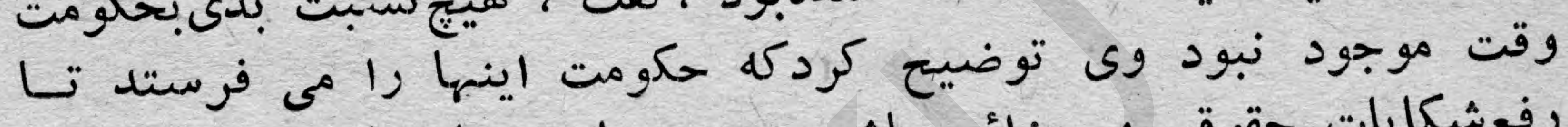

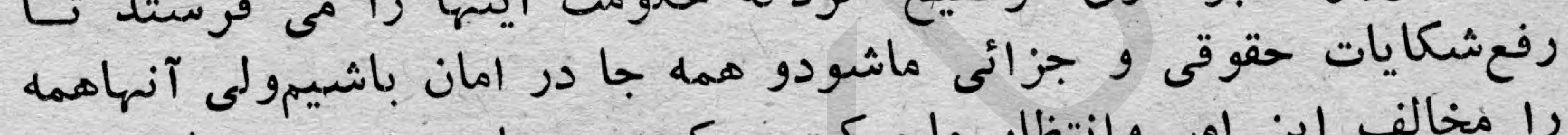

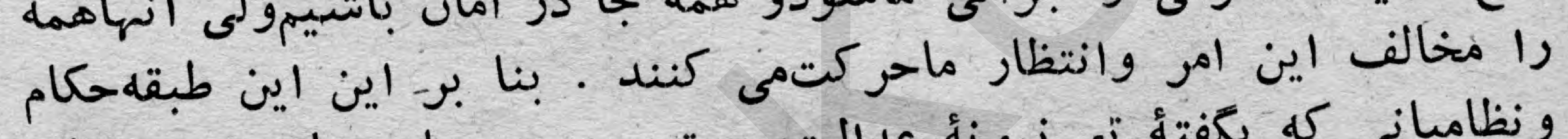

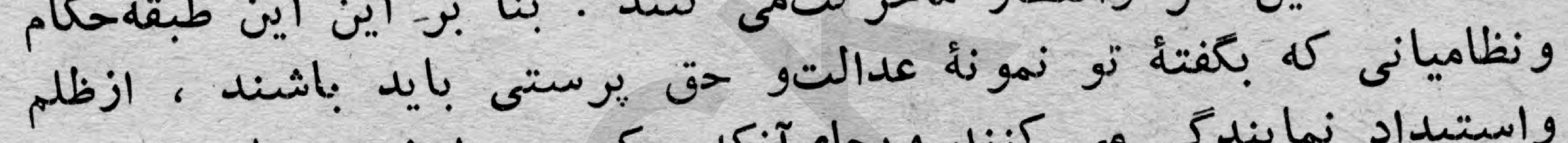

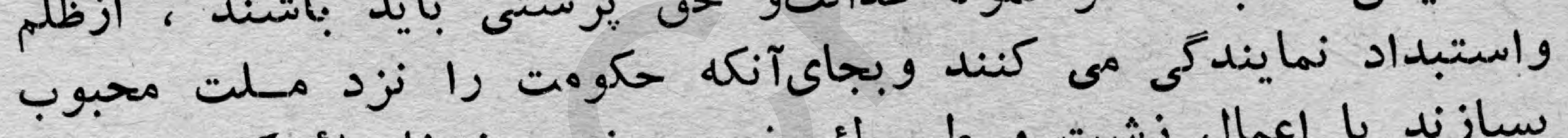

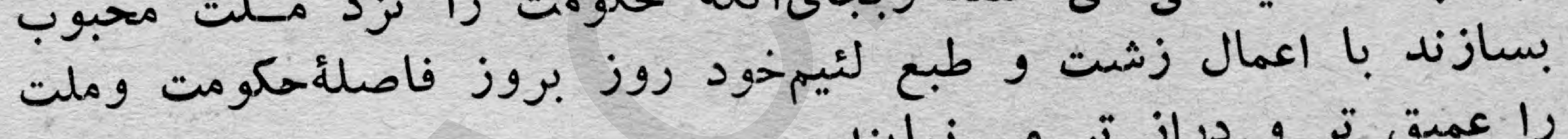

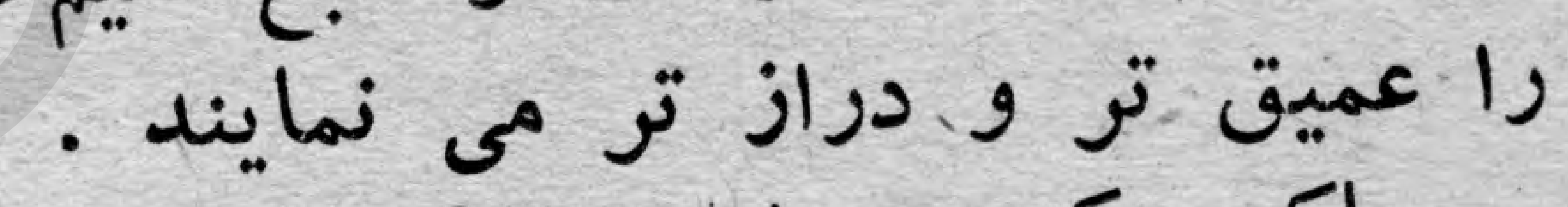

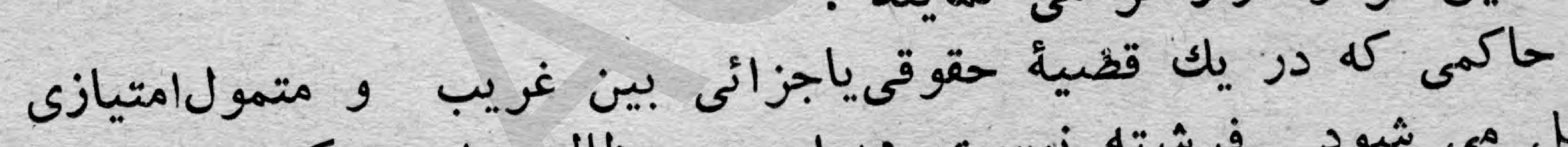

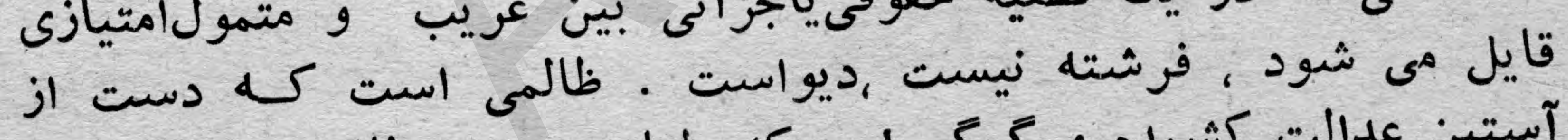

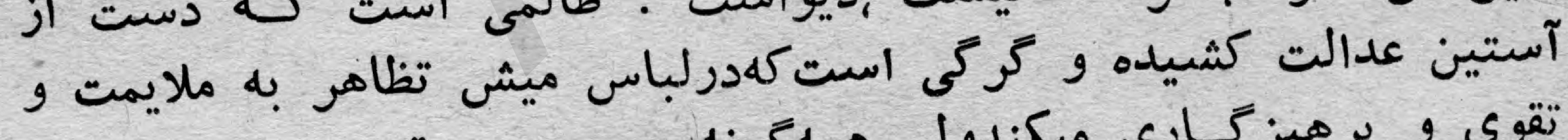

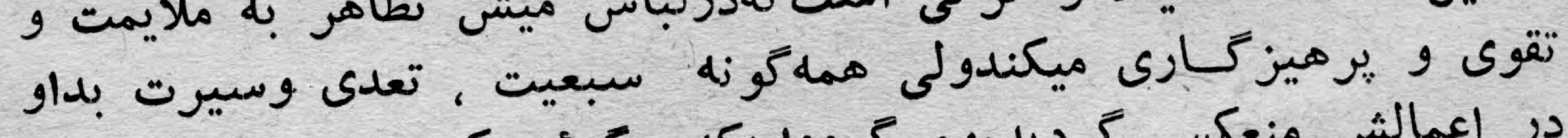

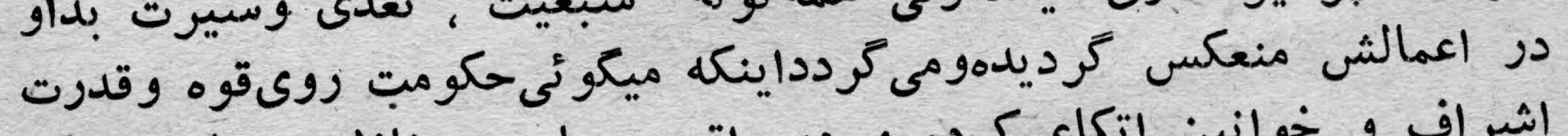

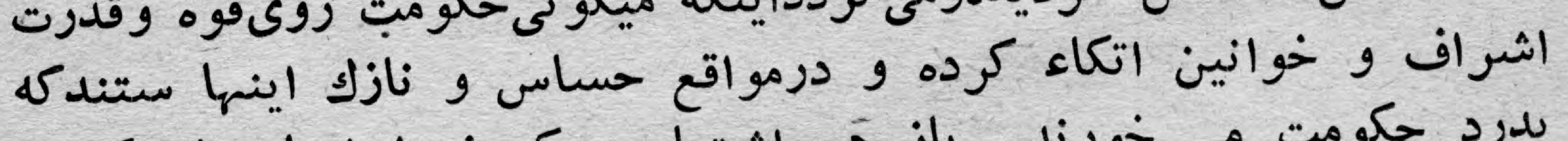

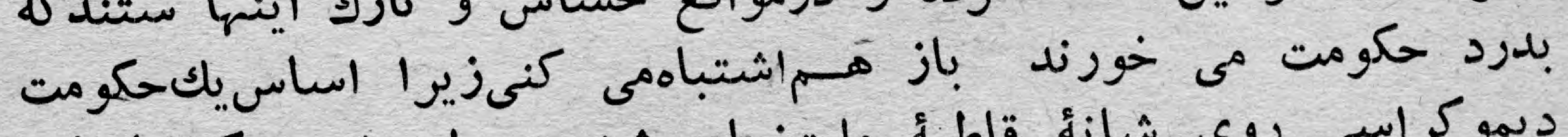

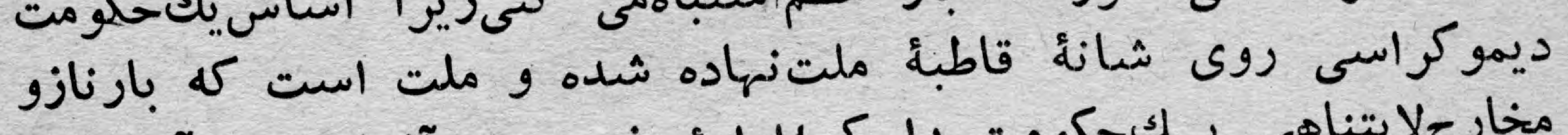

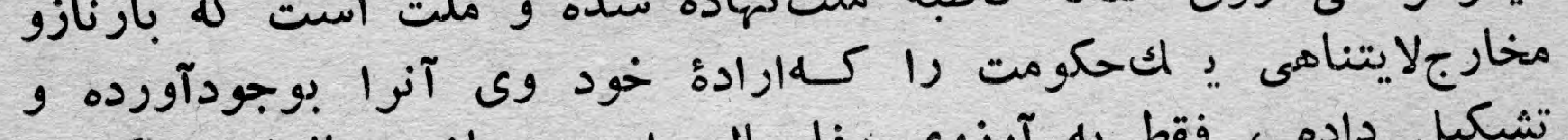

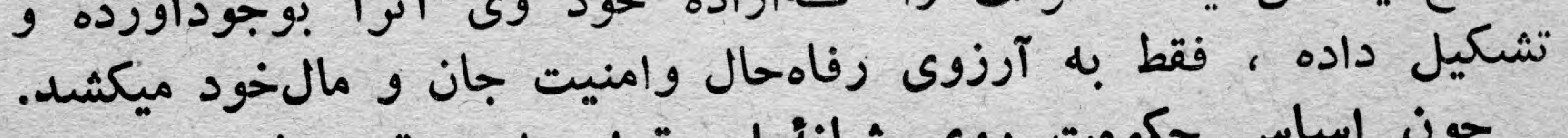

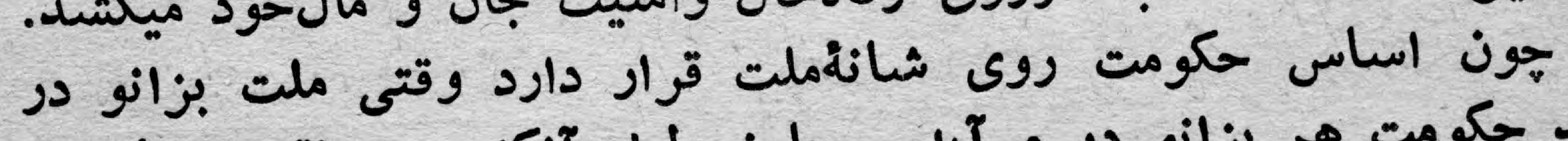

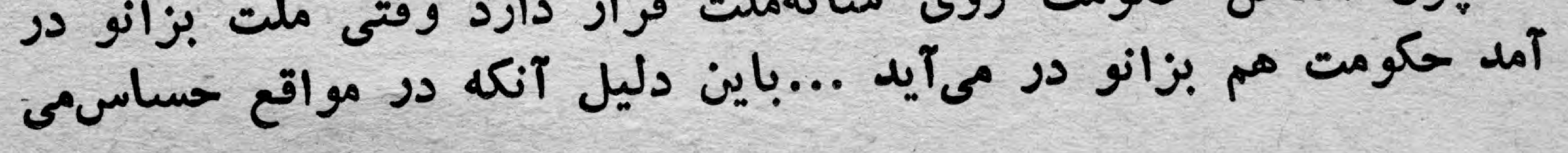

ar. 


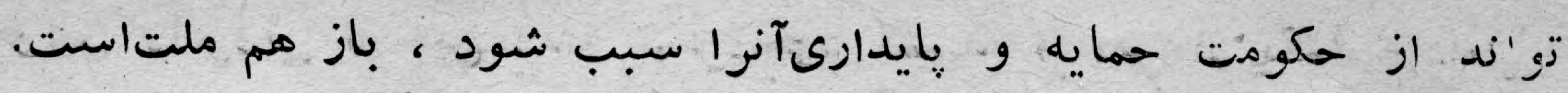

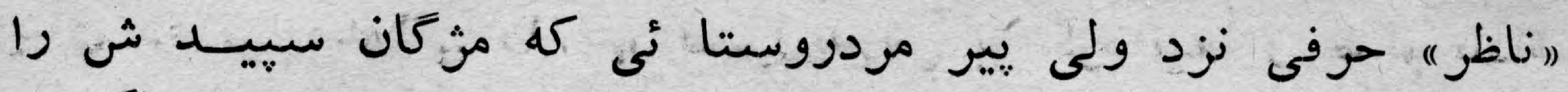

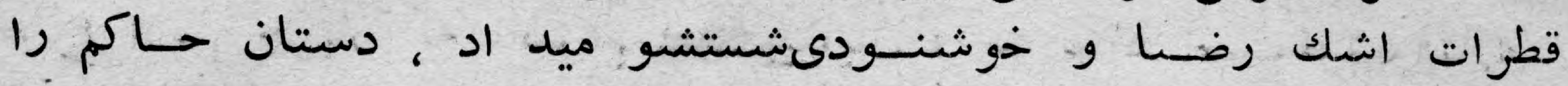

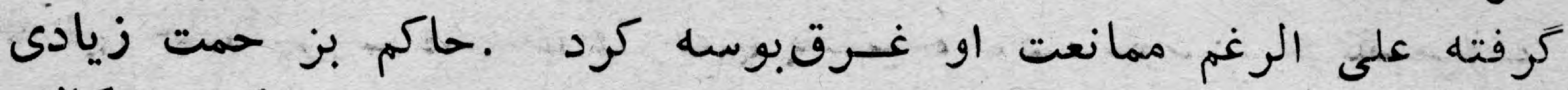

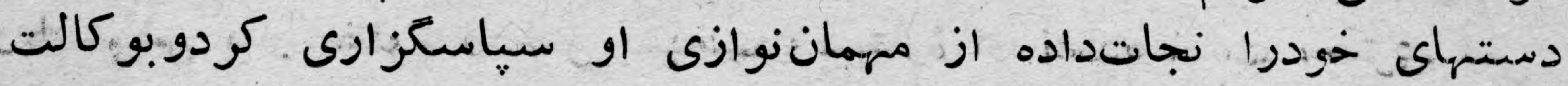

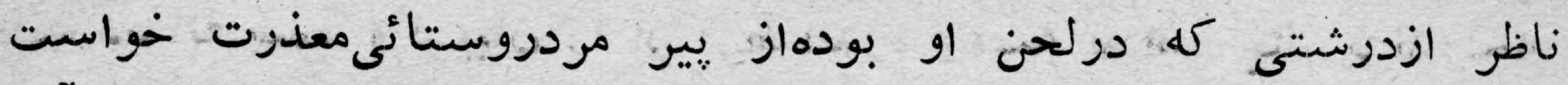

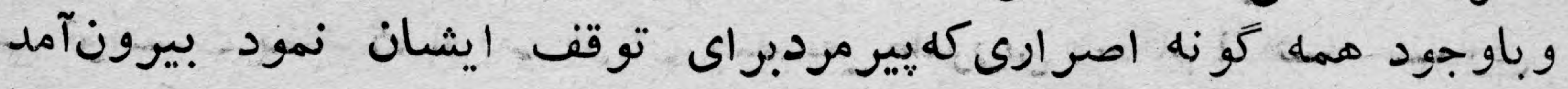

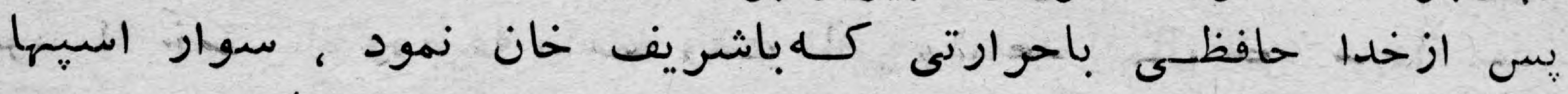

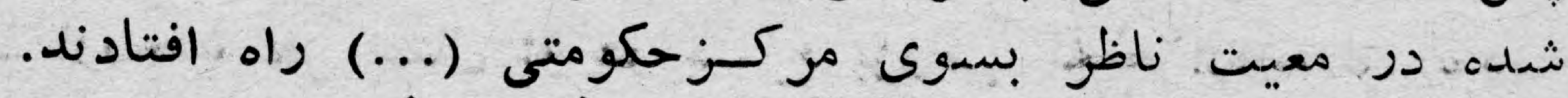

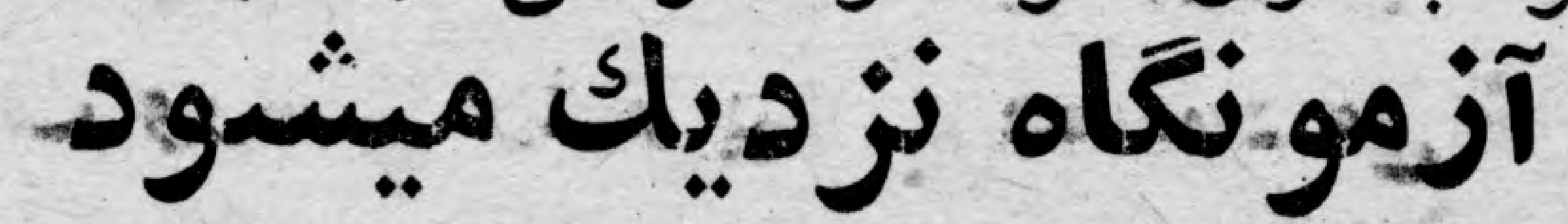

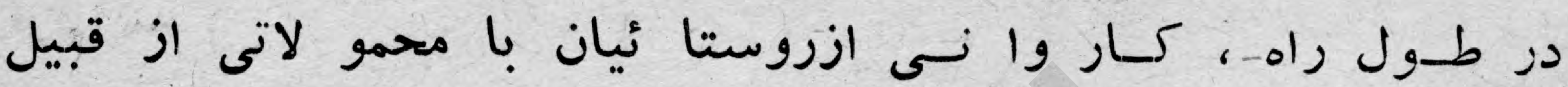

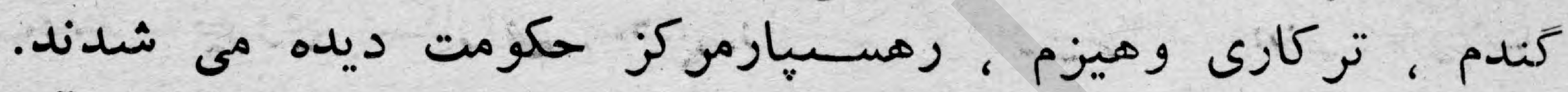

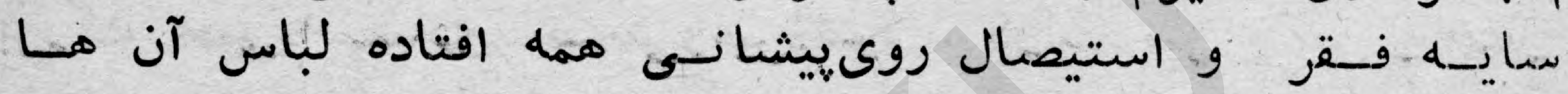

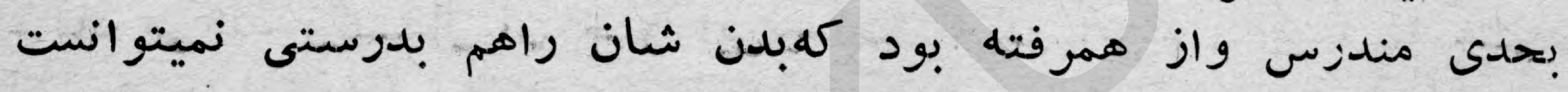
ستر كند.

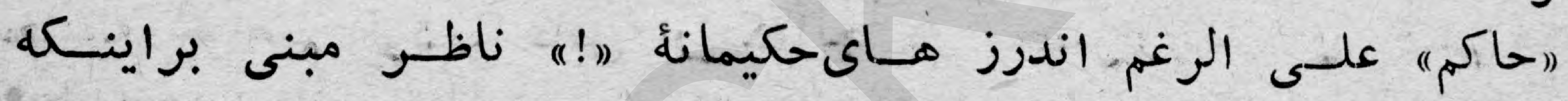

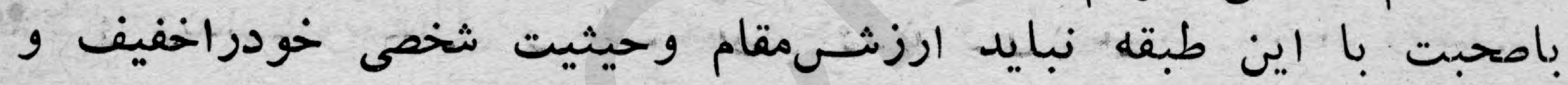

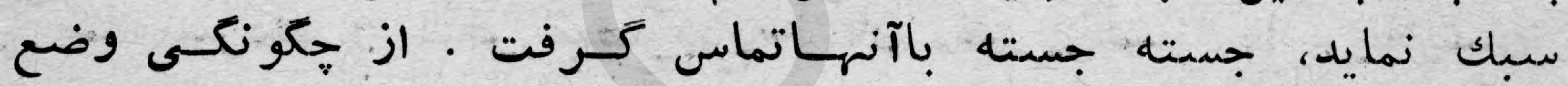

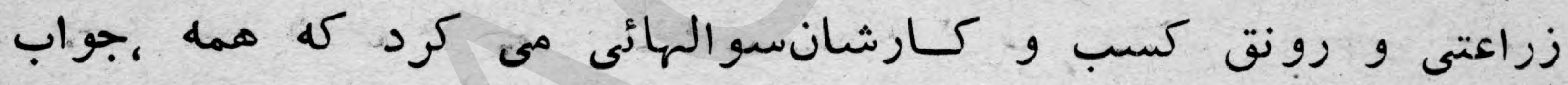

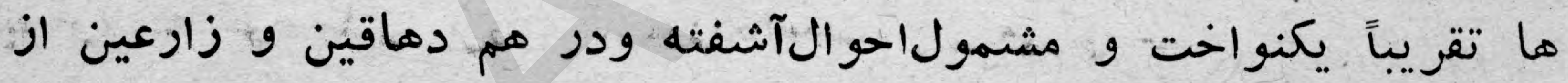

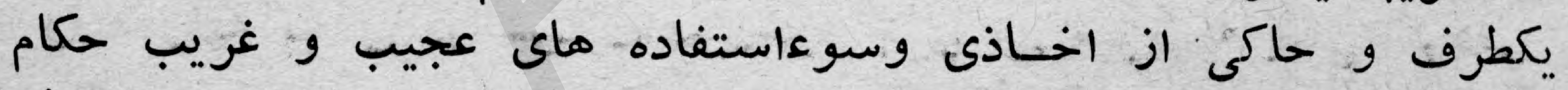

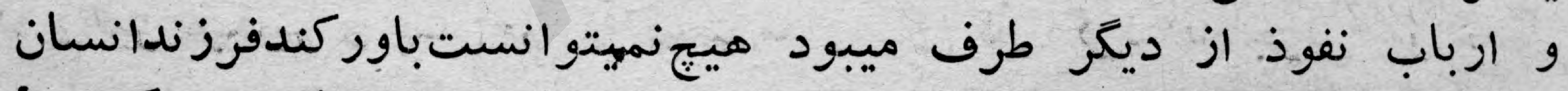

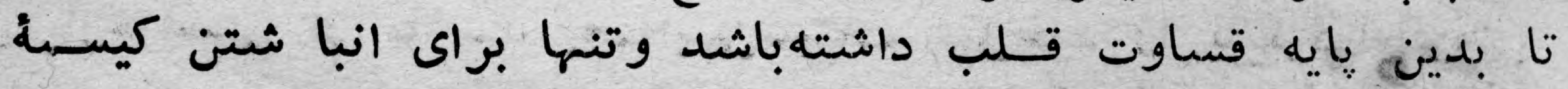

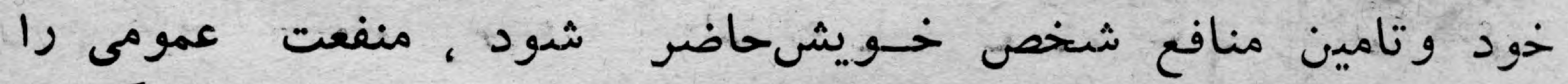

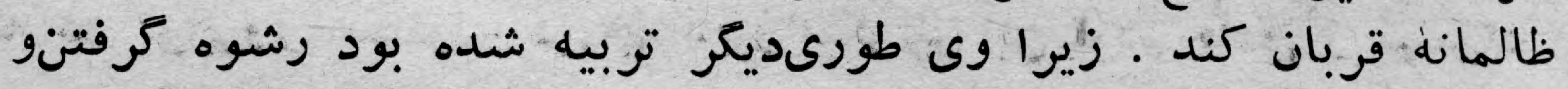

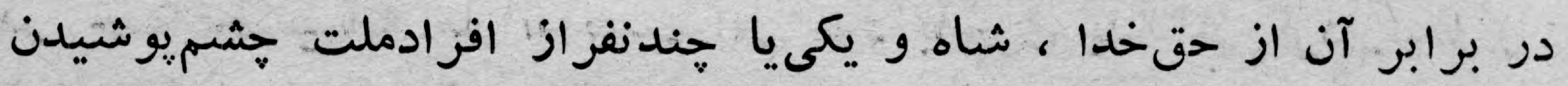

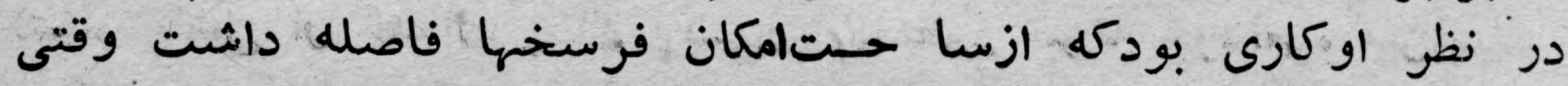

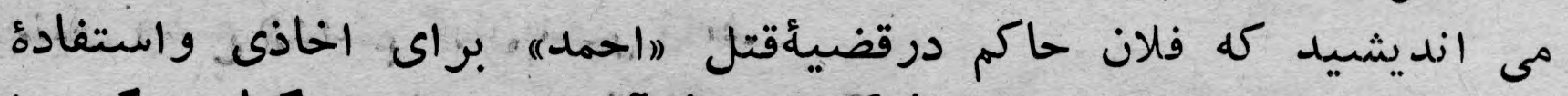

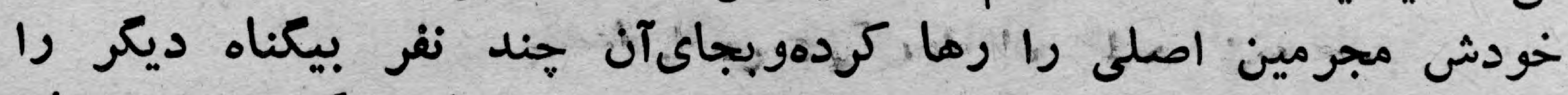

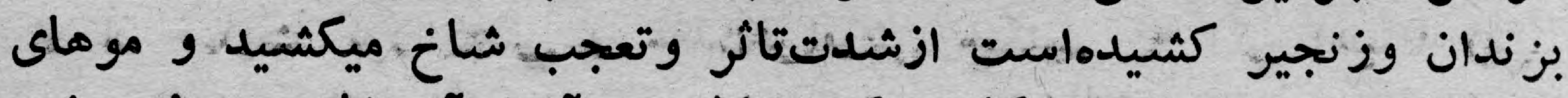

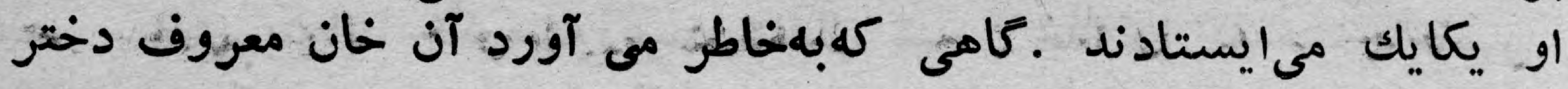

EID 


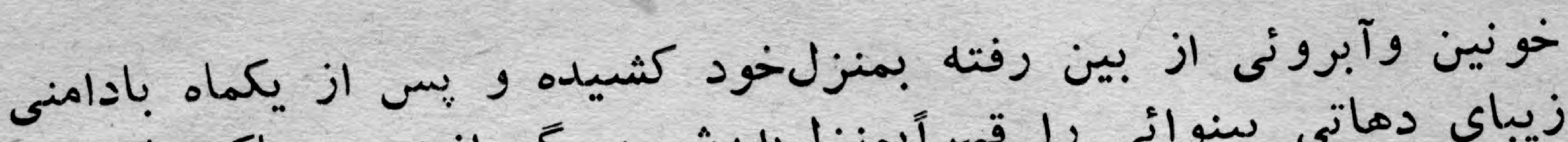

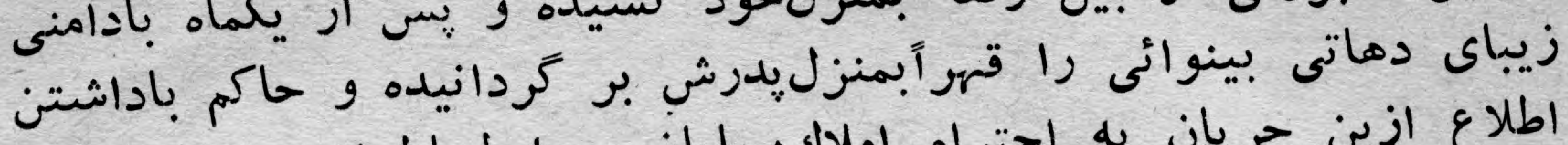

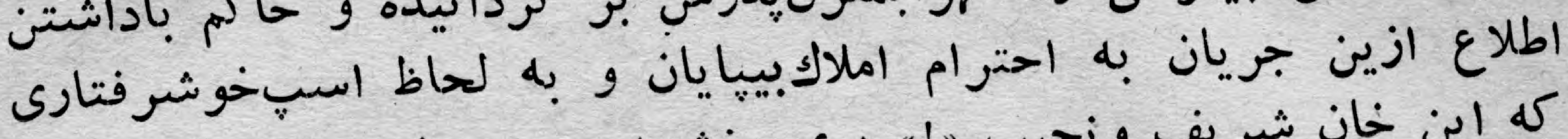

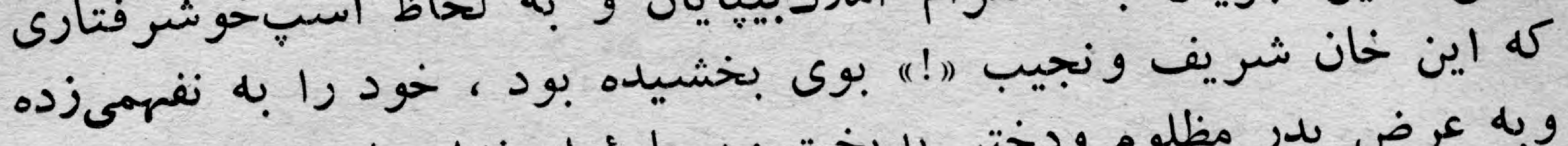

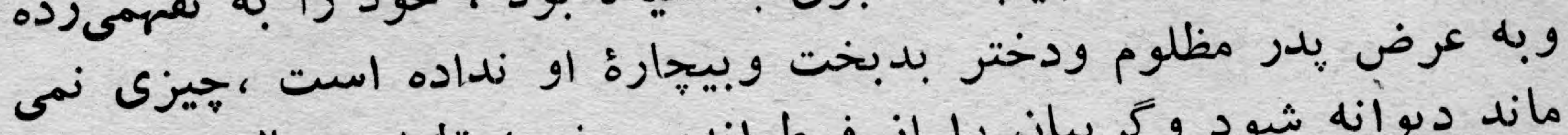

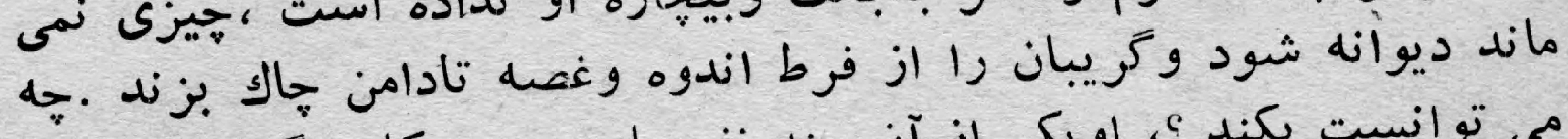

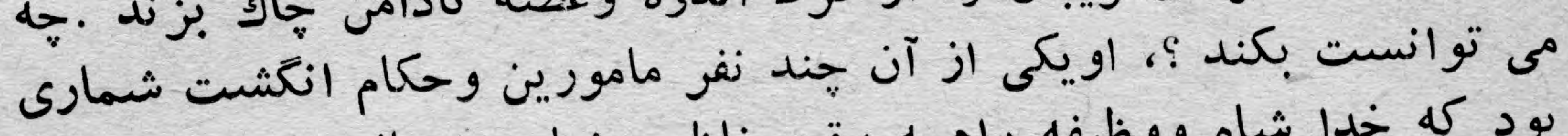

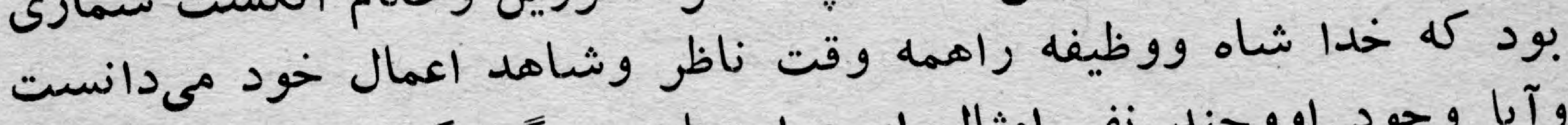

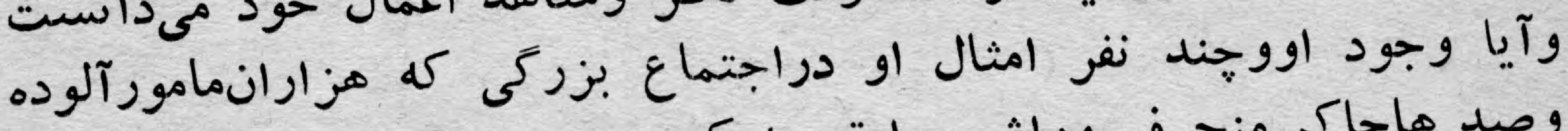

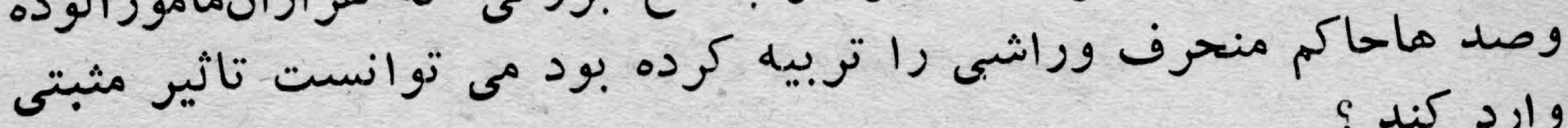
وارد كند ؟ و باكي

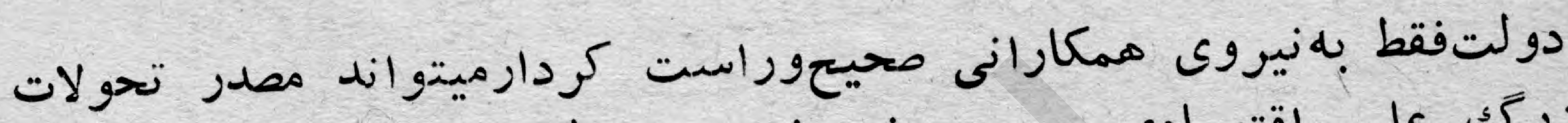

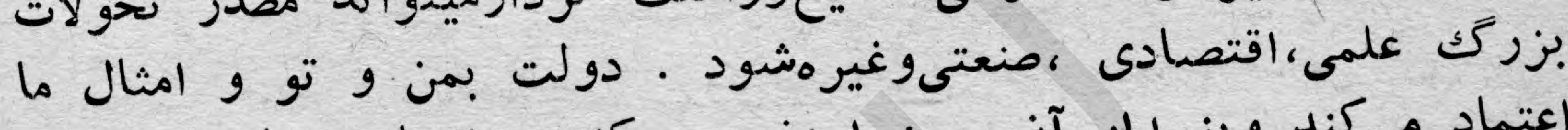

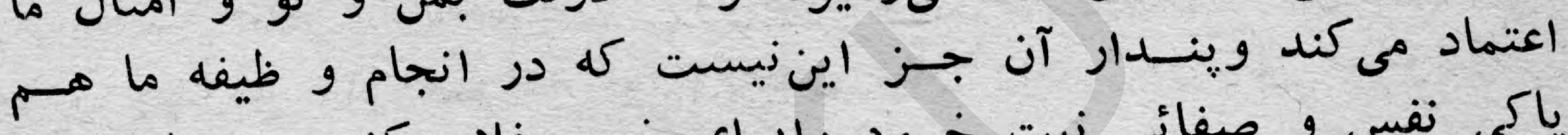

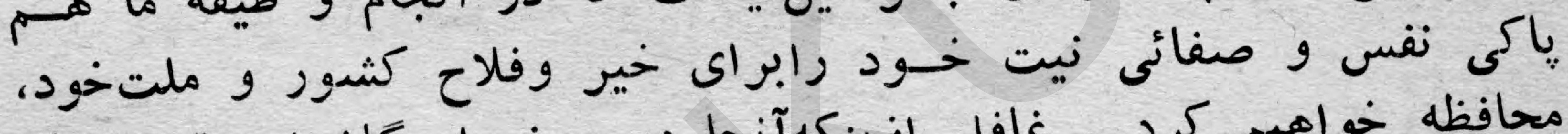

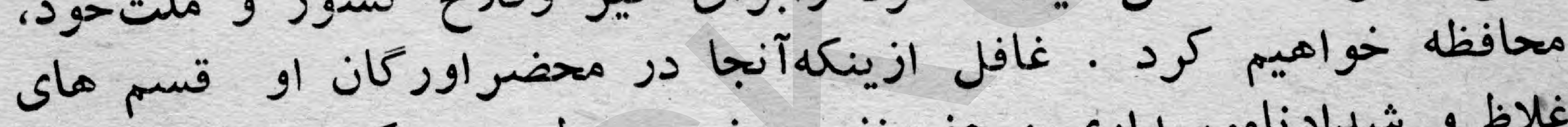

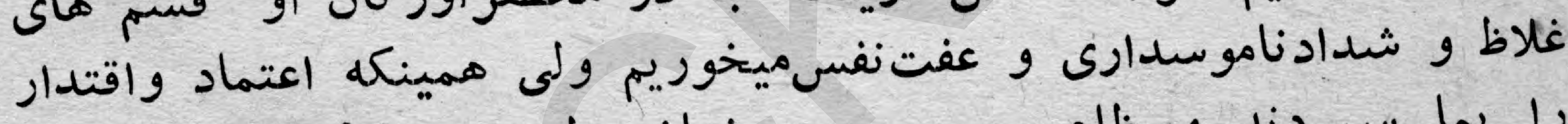

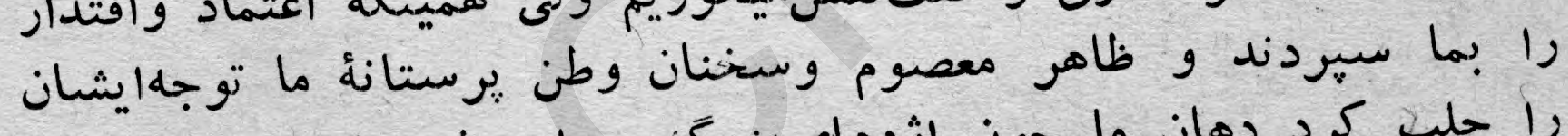

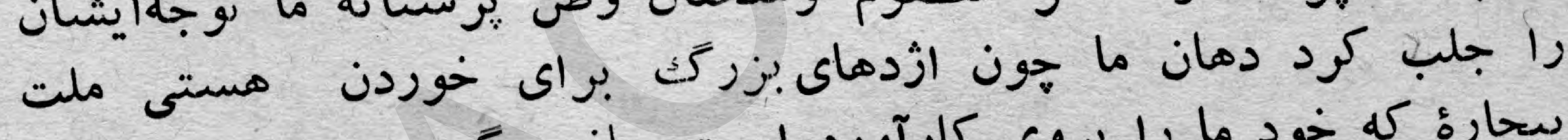

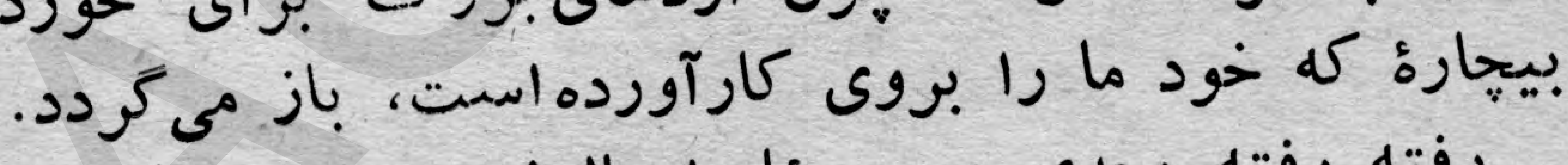

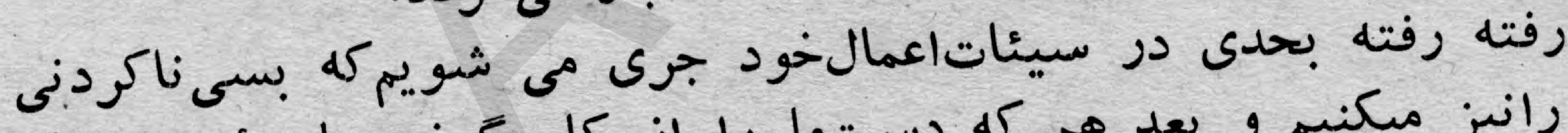

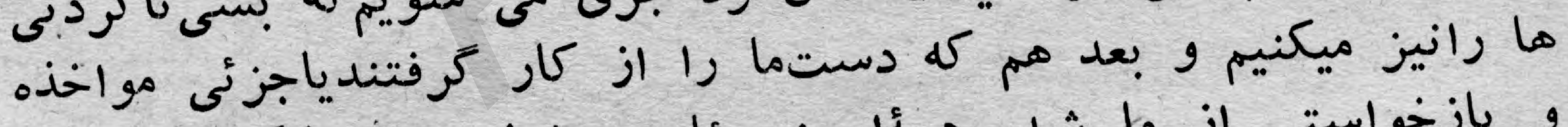

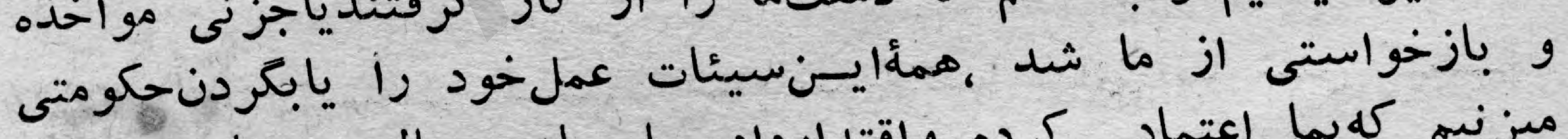

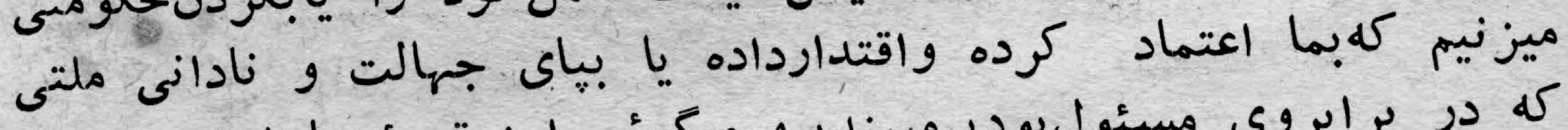

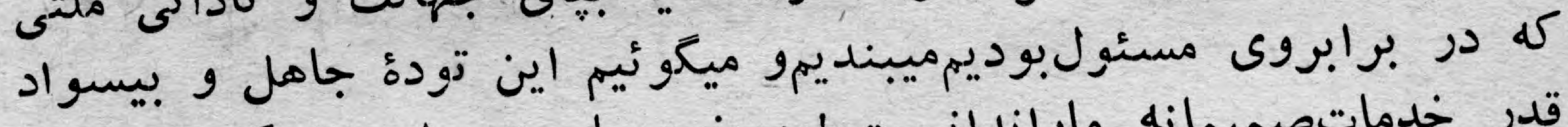

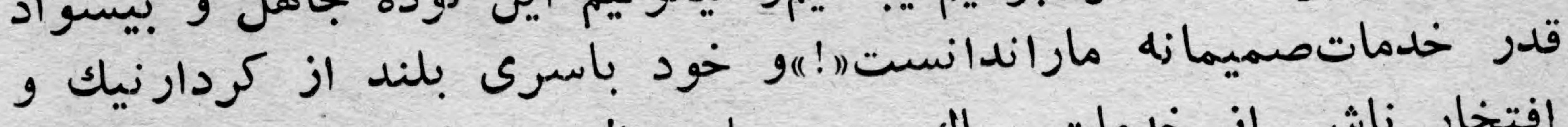

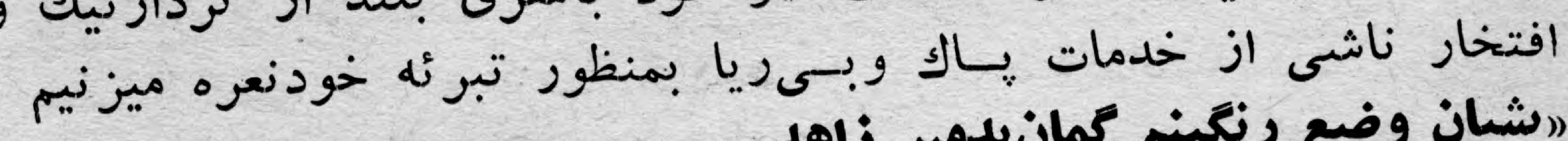
"افشان وضع رنكينم كمانبدمبر زات واهد

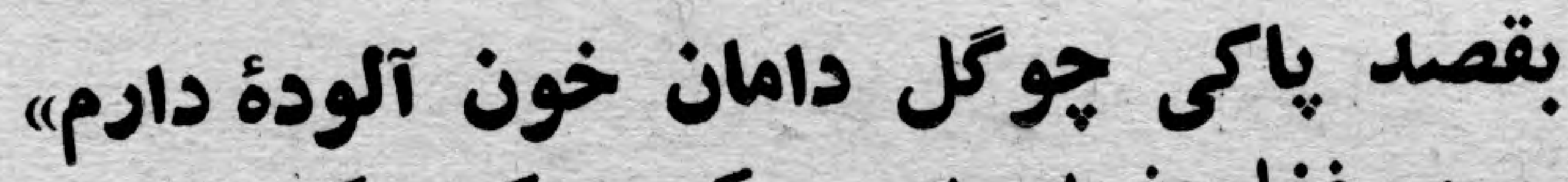

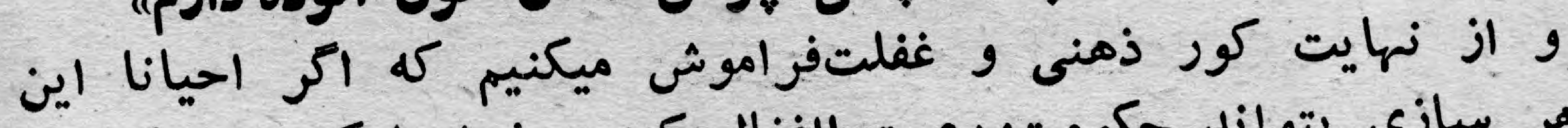

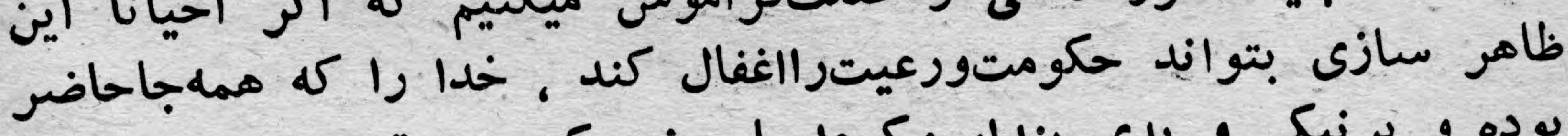

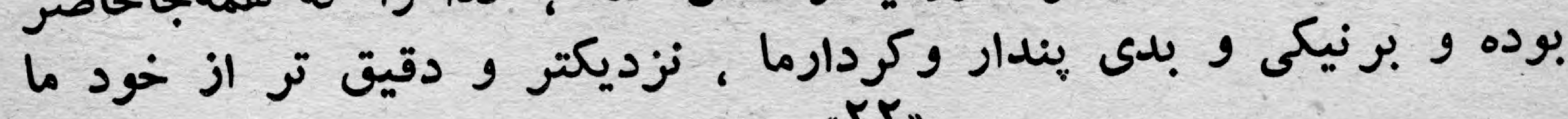
art" 


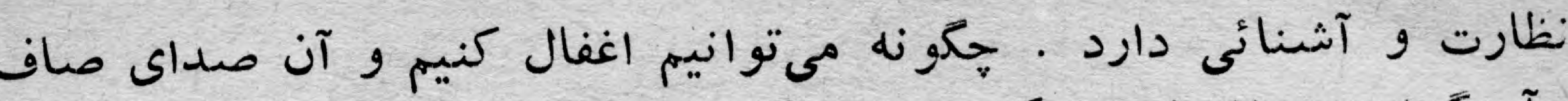

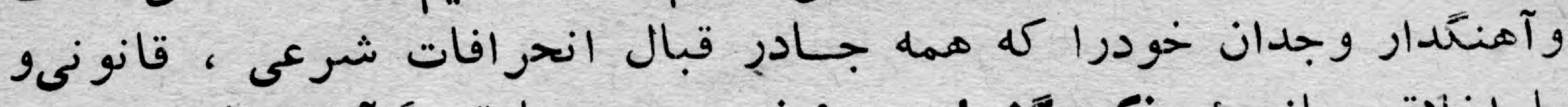

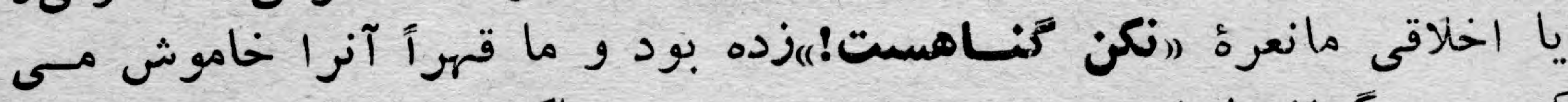

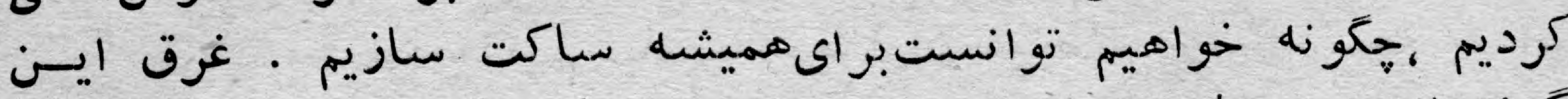

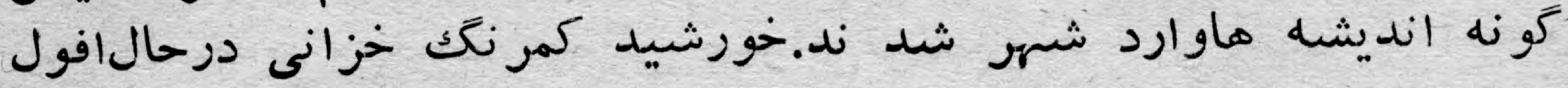

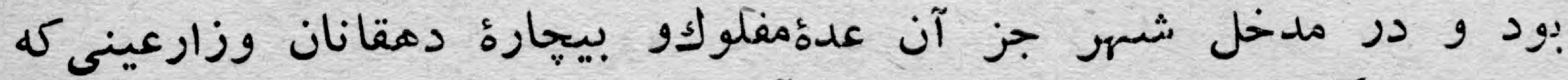

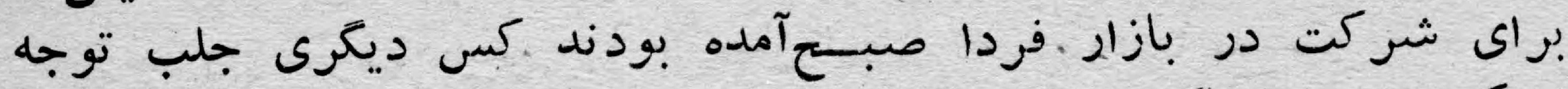

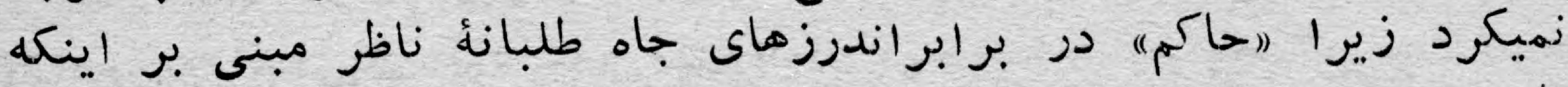

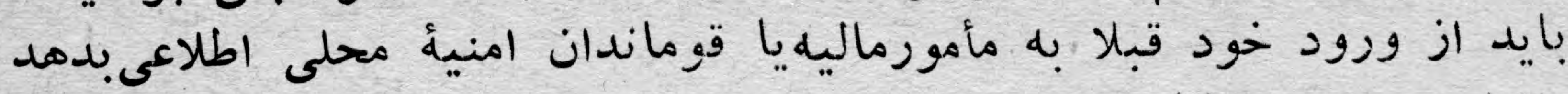

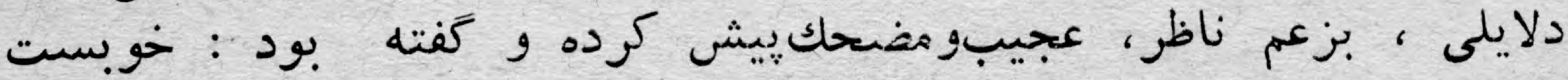

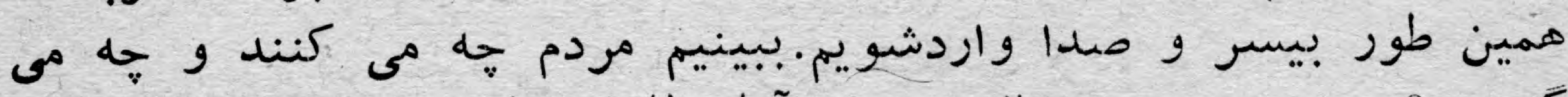

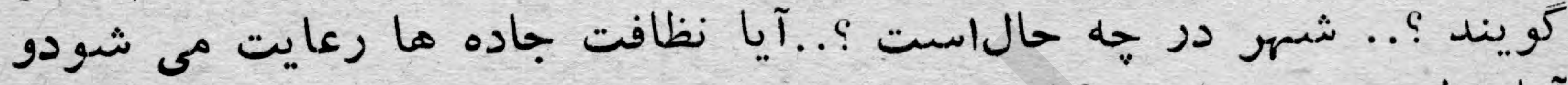

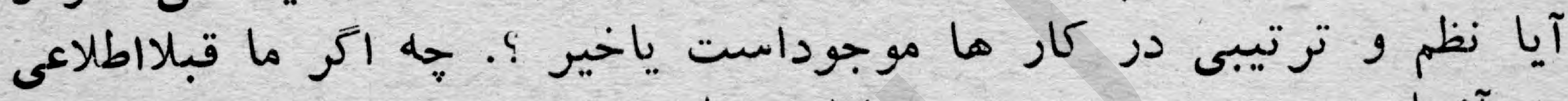

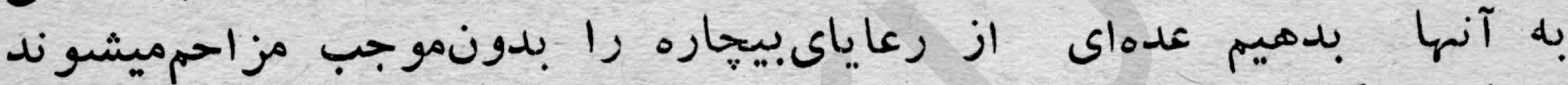

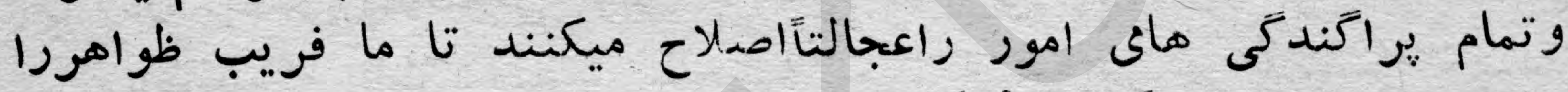

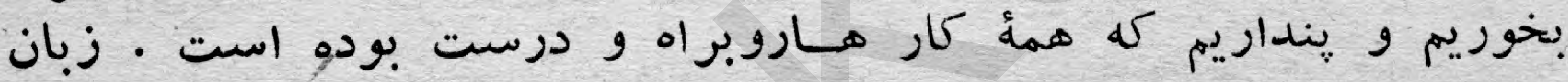

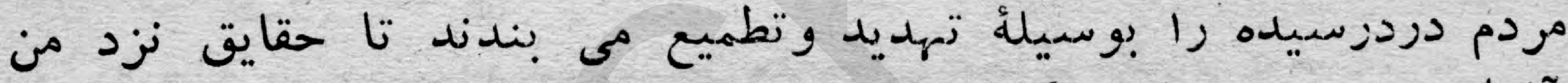

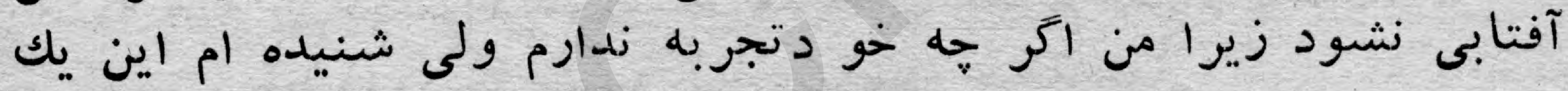

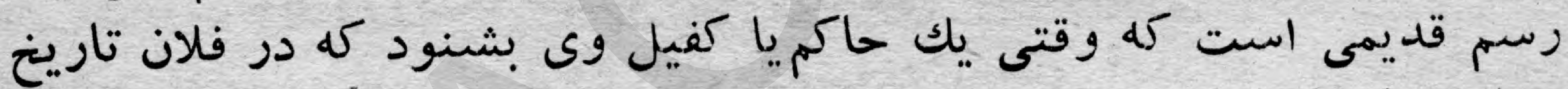

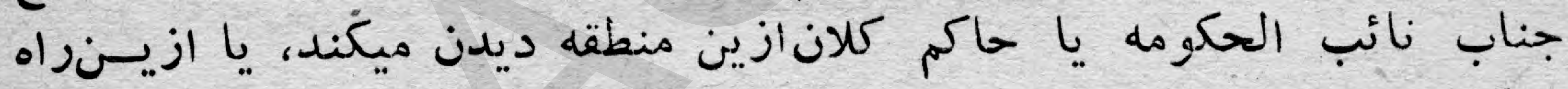

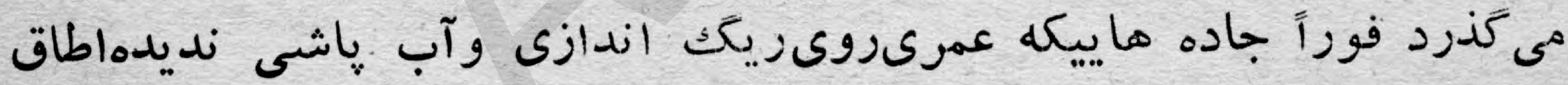

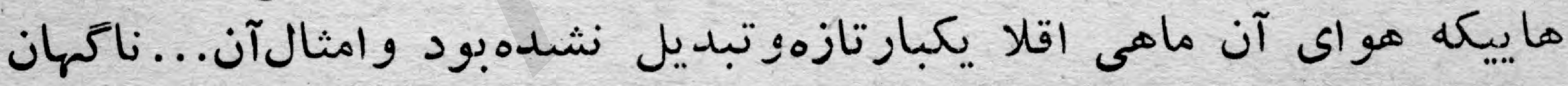

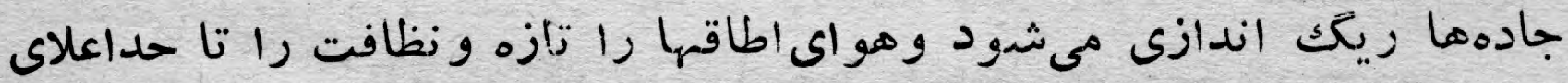

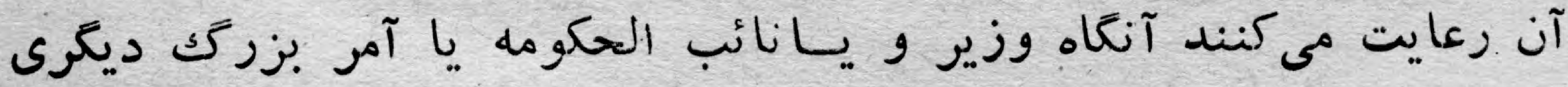

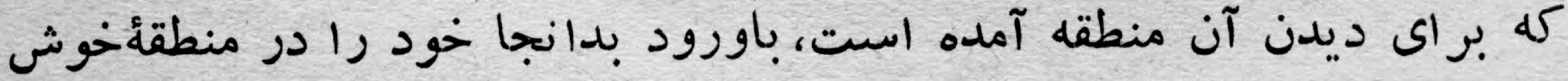

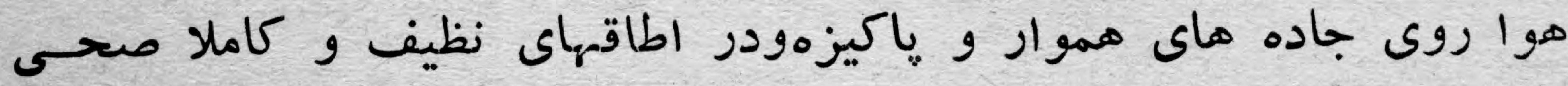

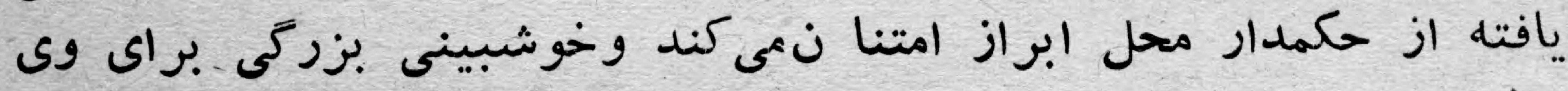

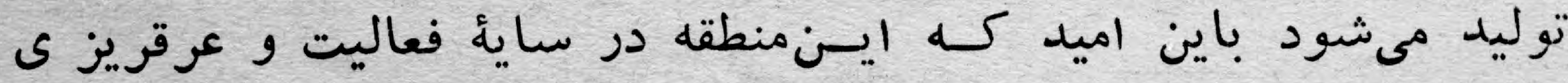

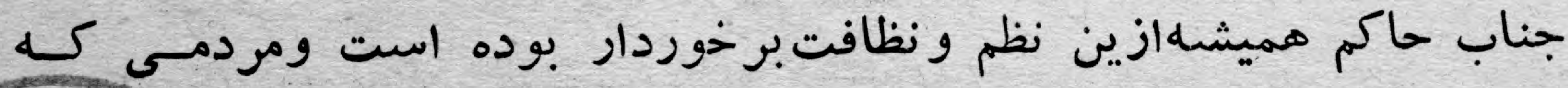

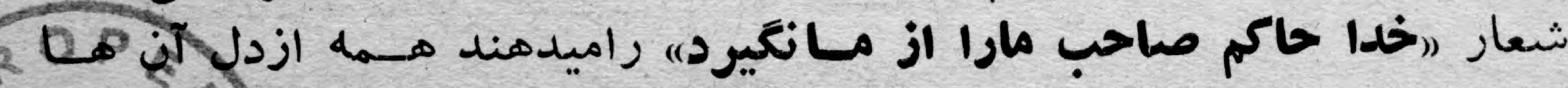

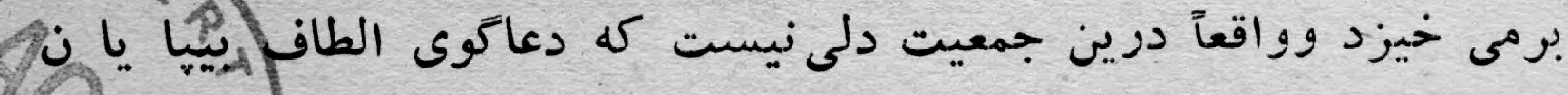




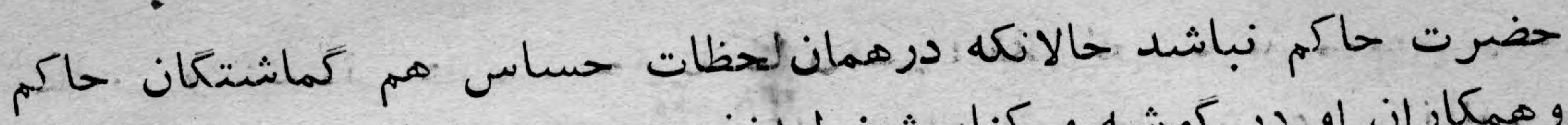

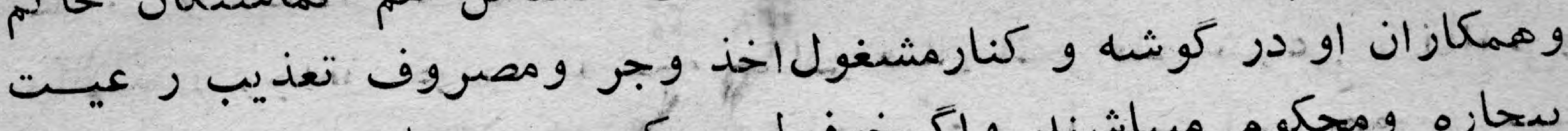

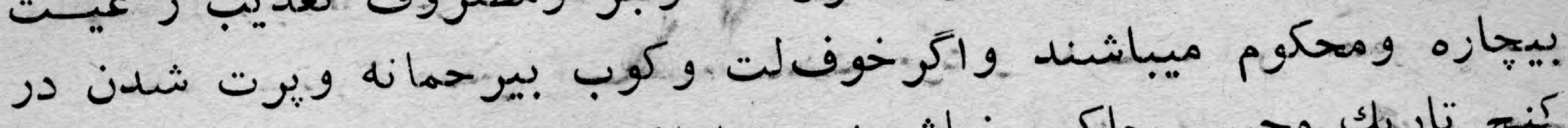

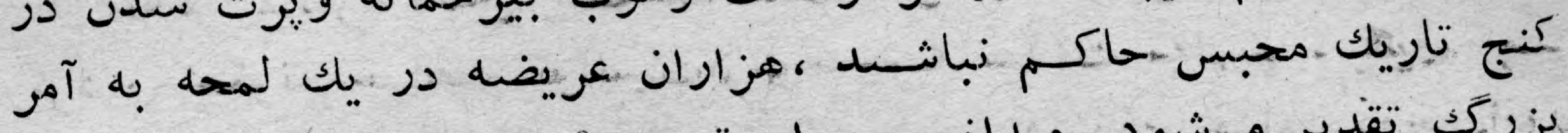

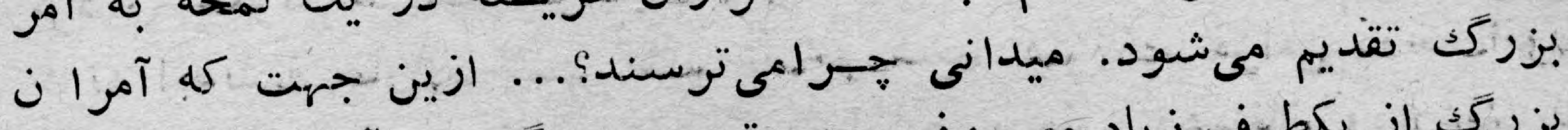

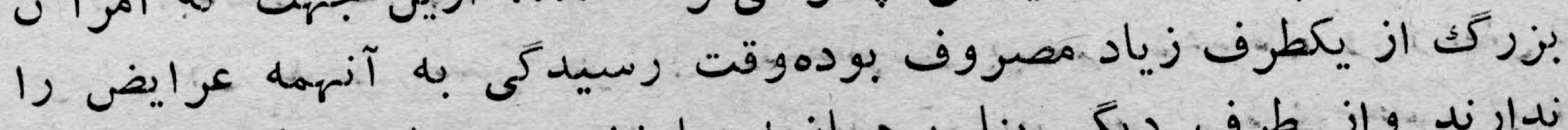

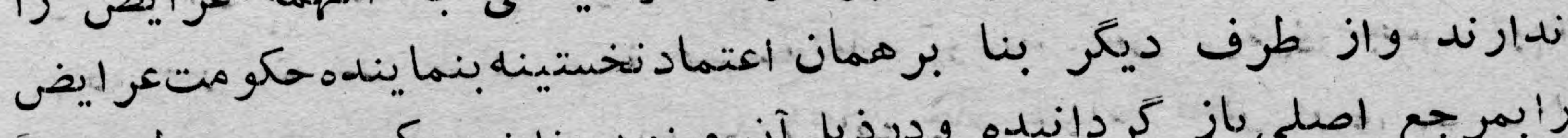

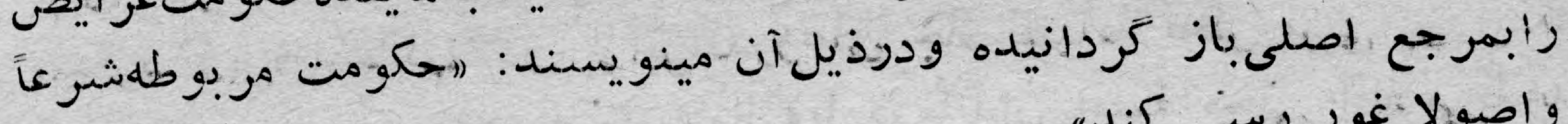

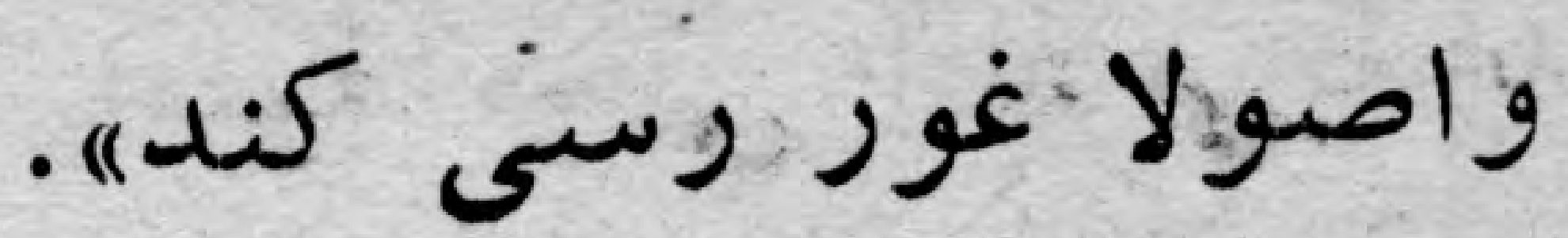

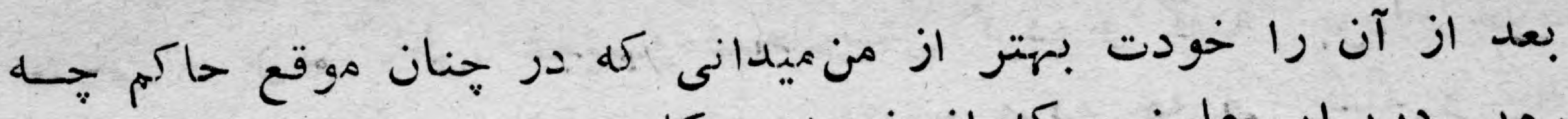

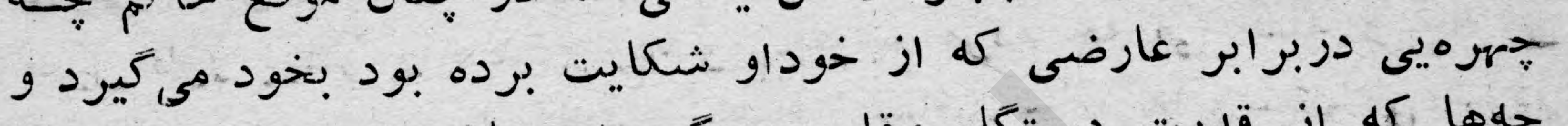

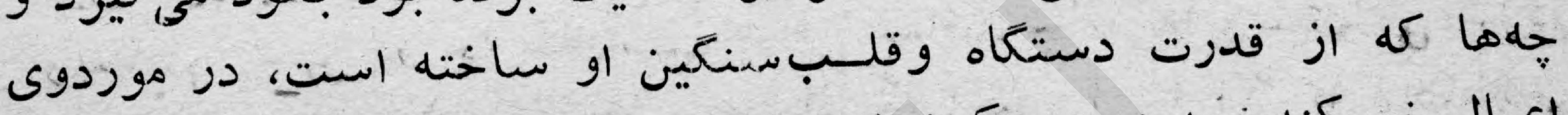

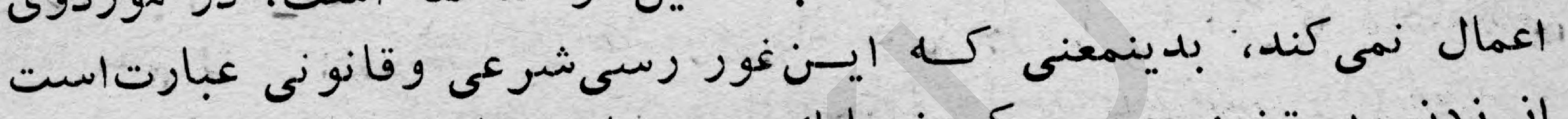

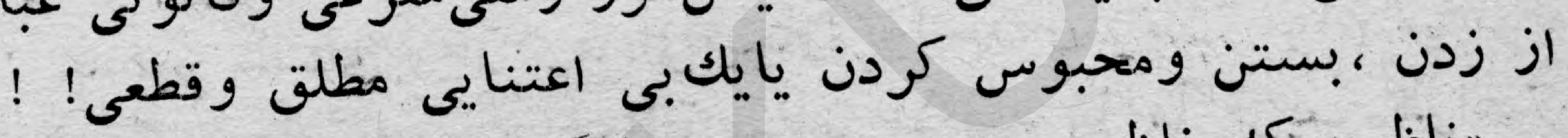

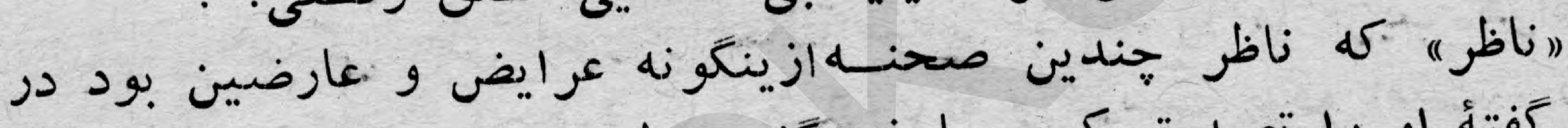

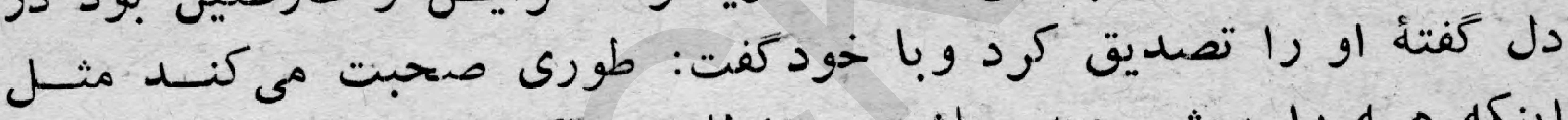

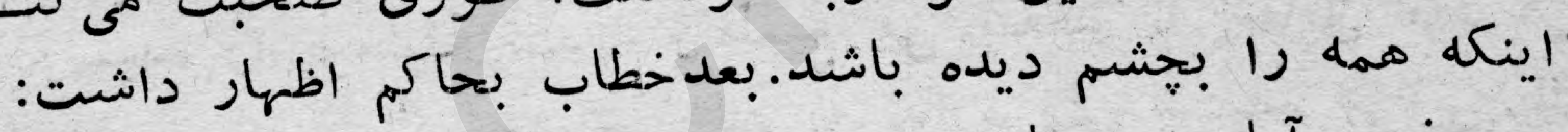

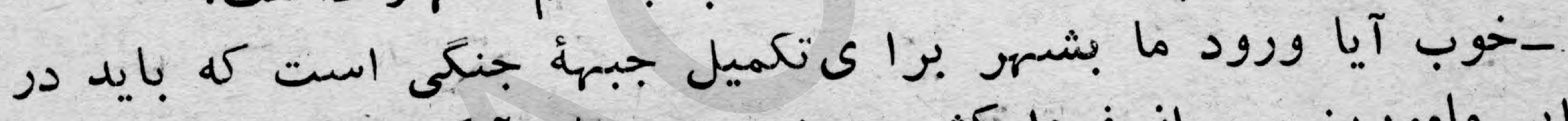

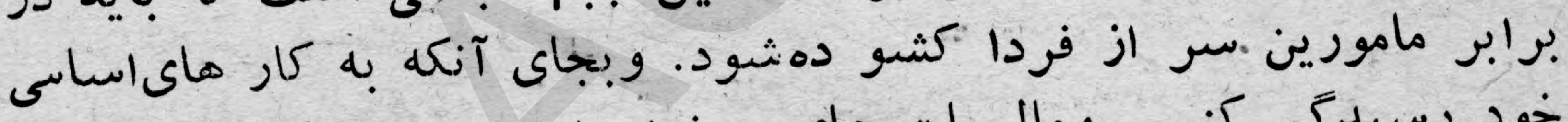

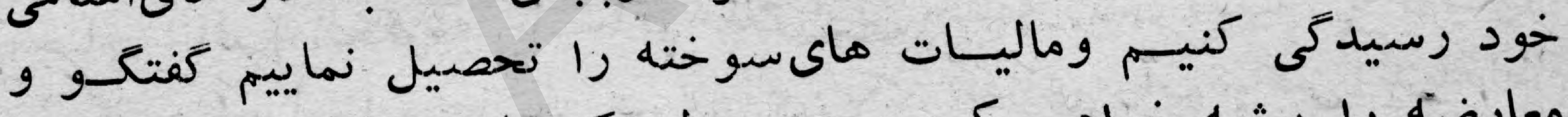

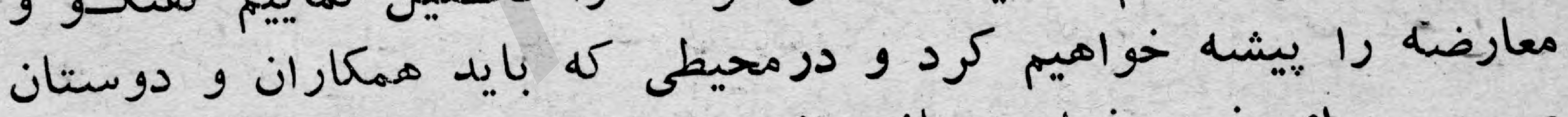

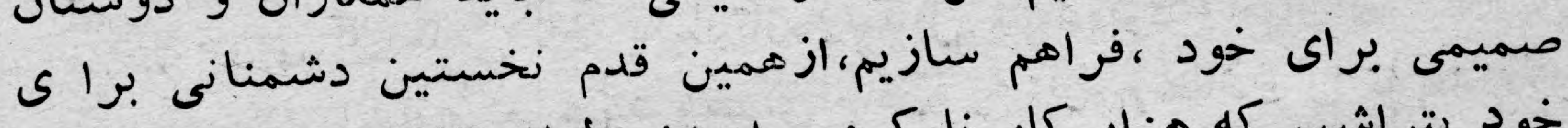

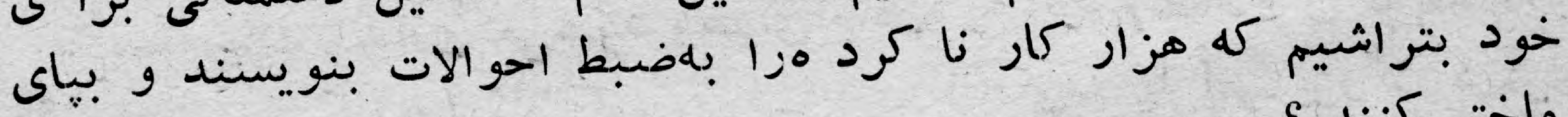

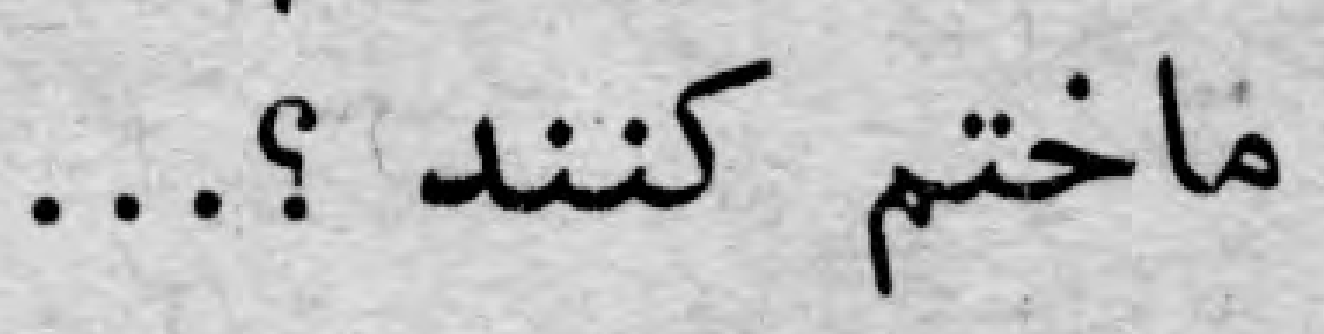

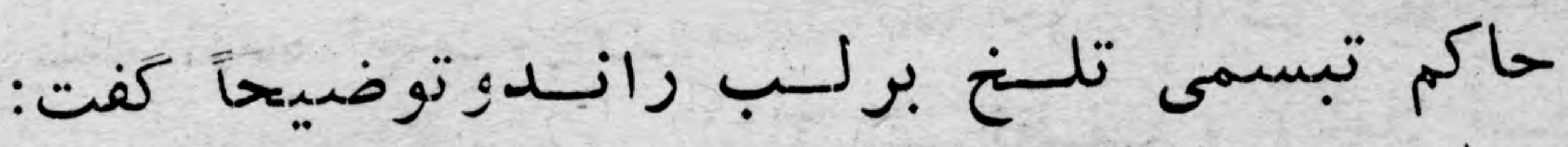

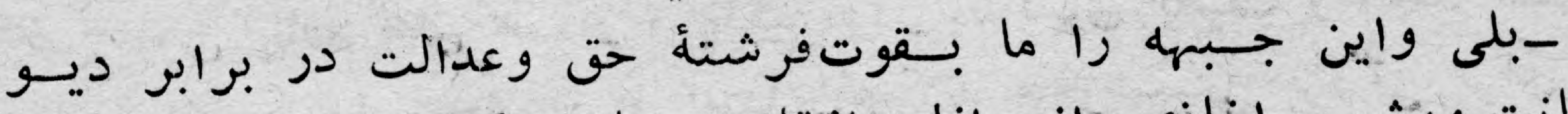

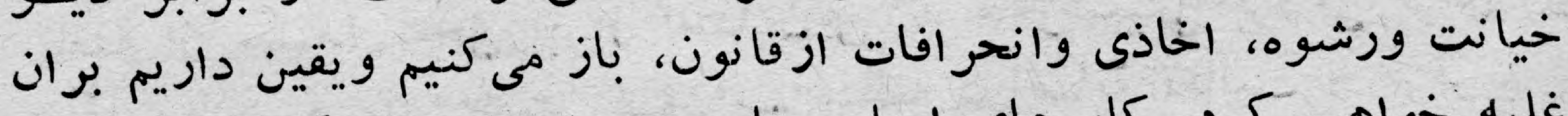

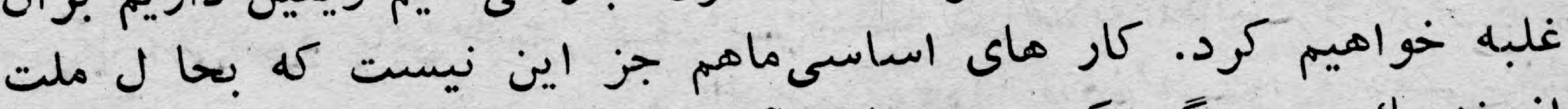

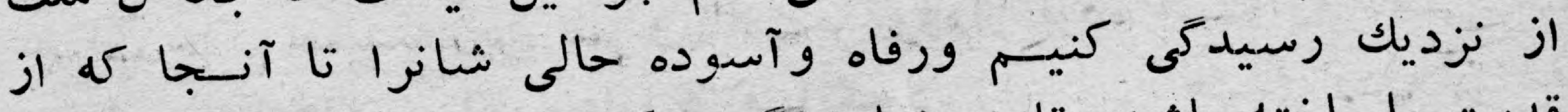

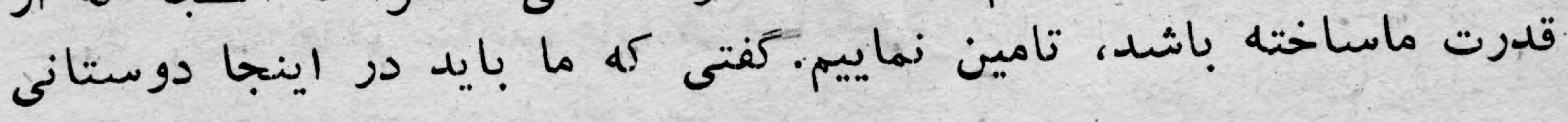




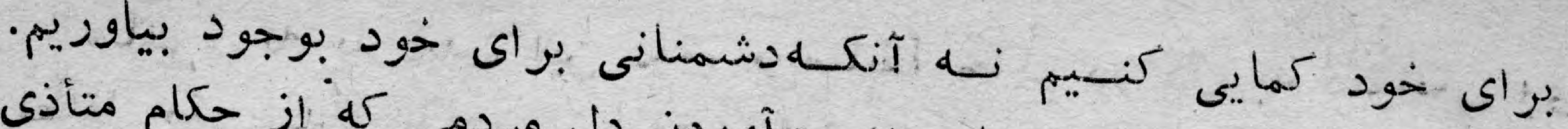

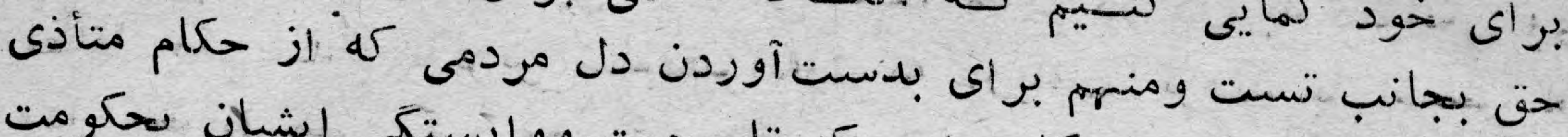

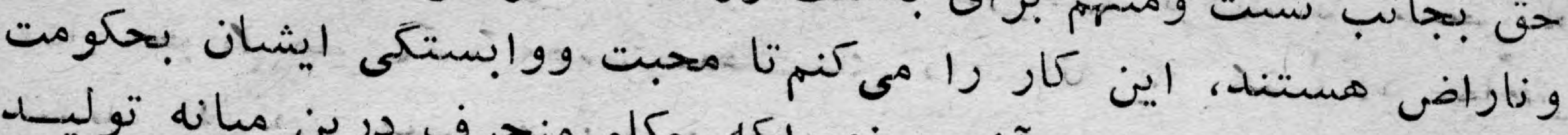

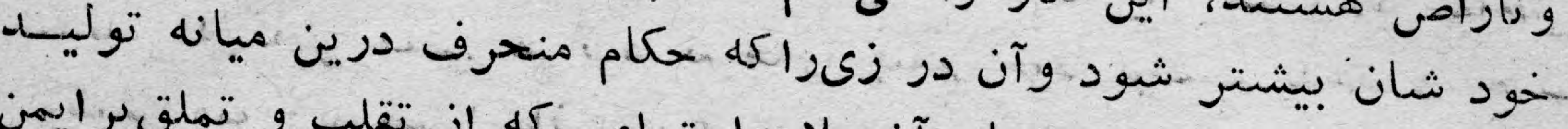

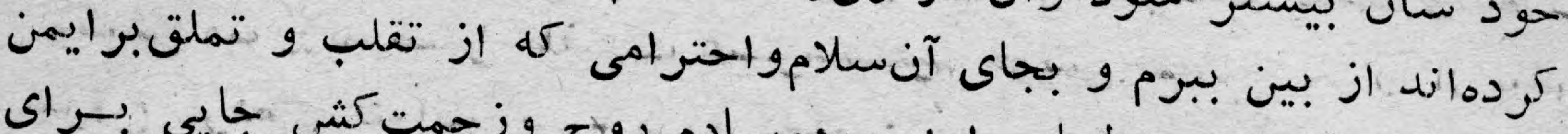

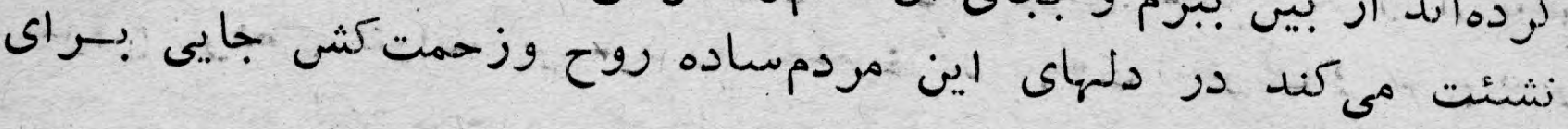
خود باز كنم.

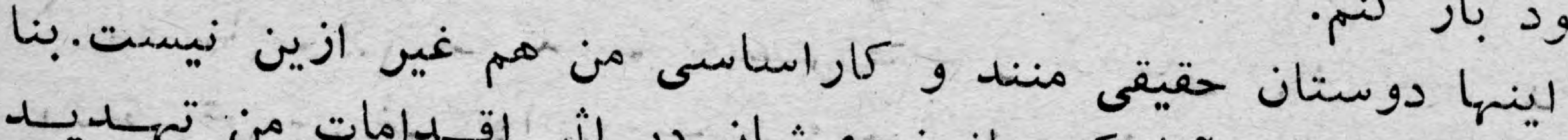

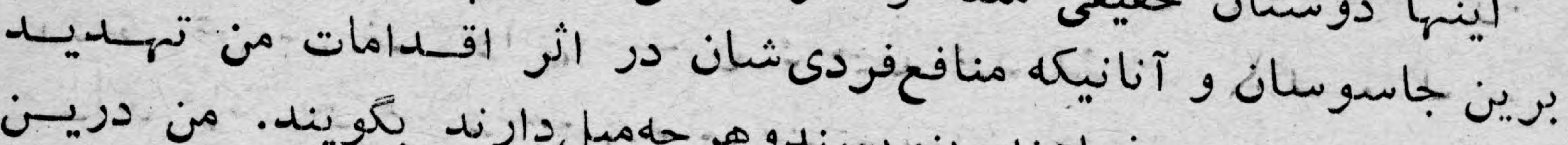

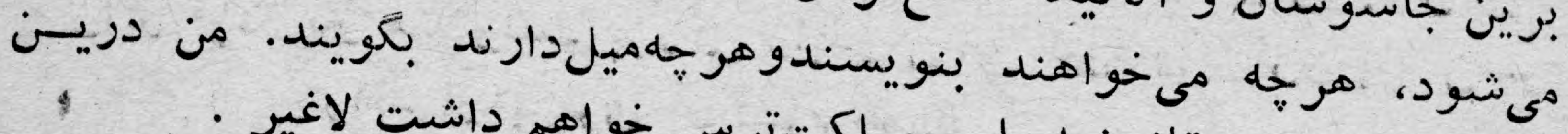

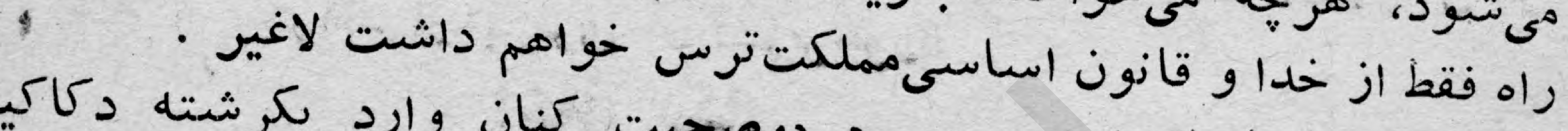

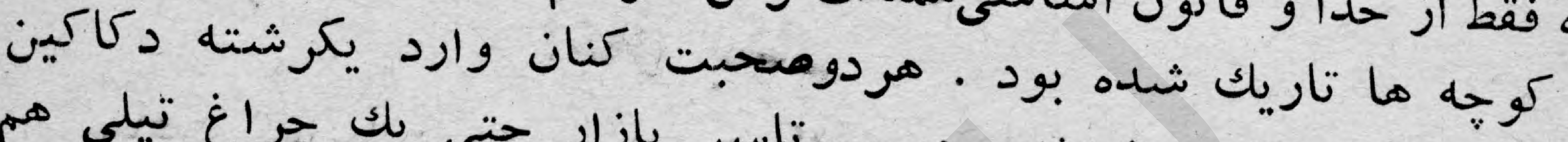

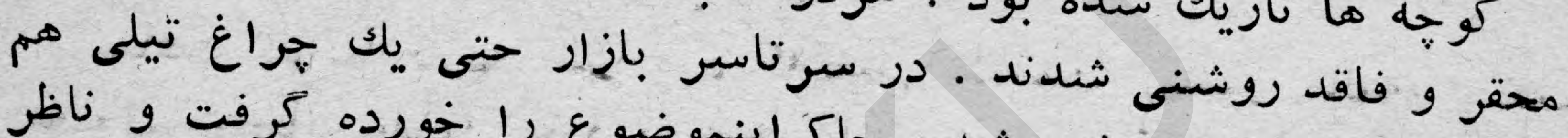

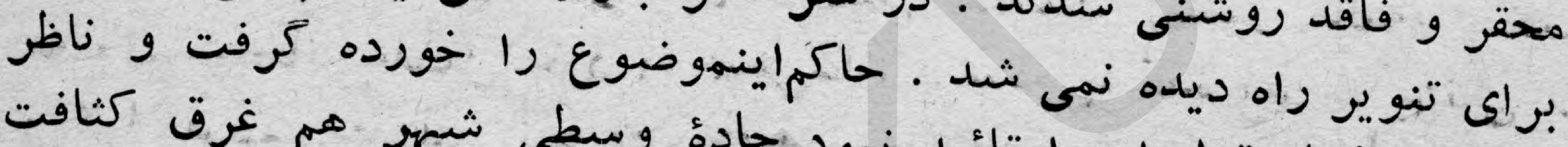

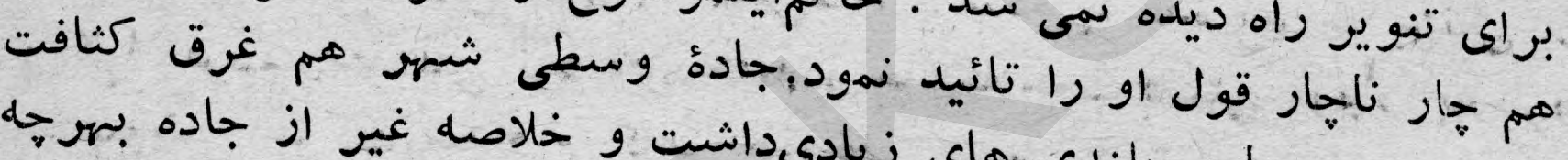

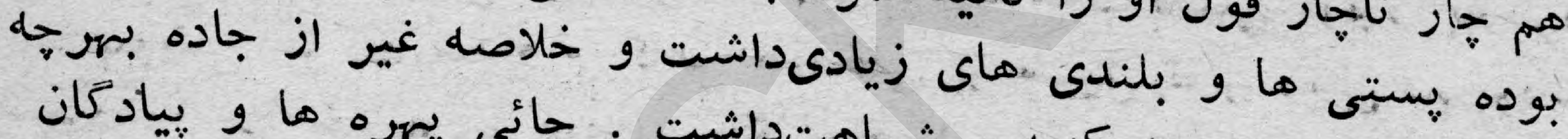

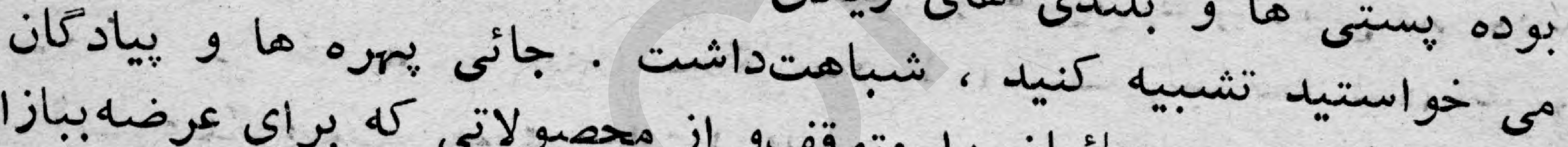

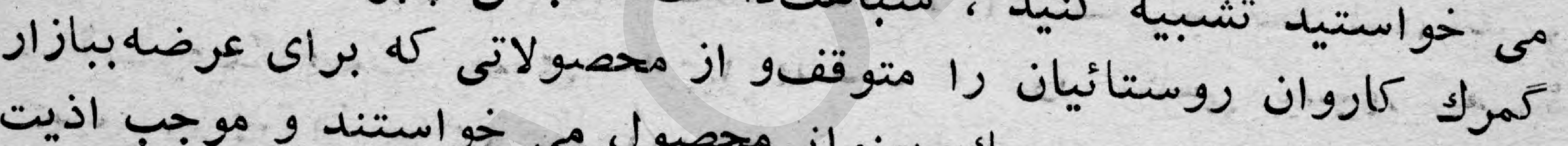

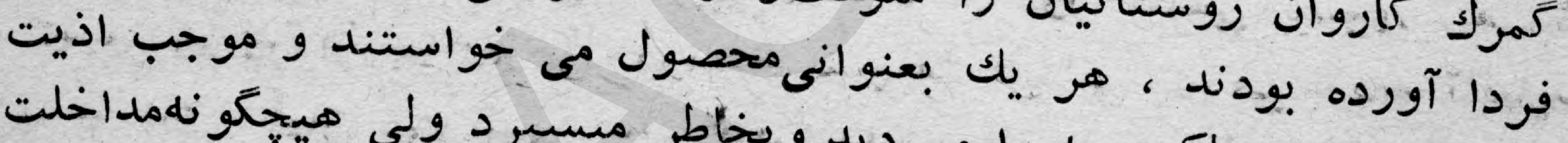

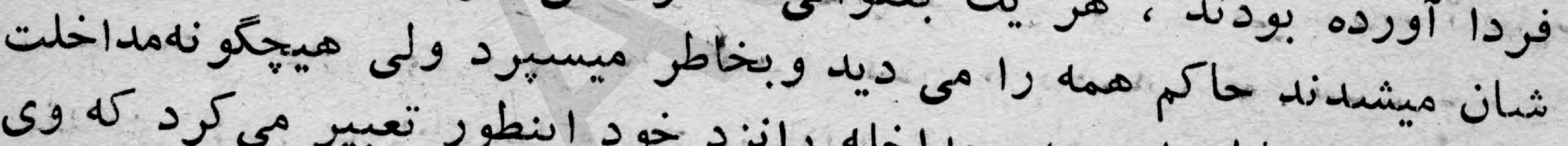

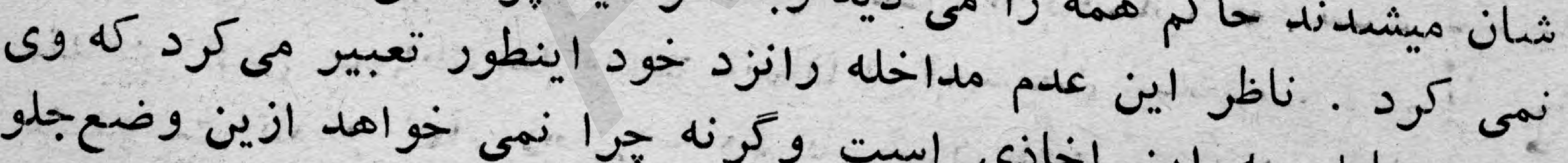

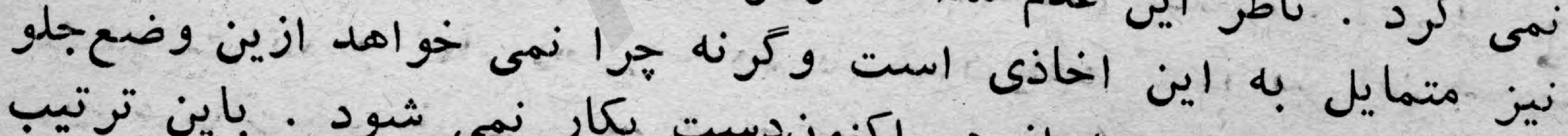

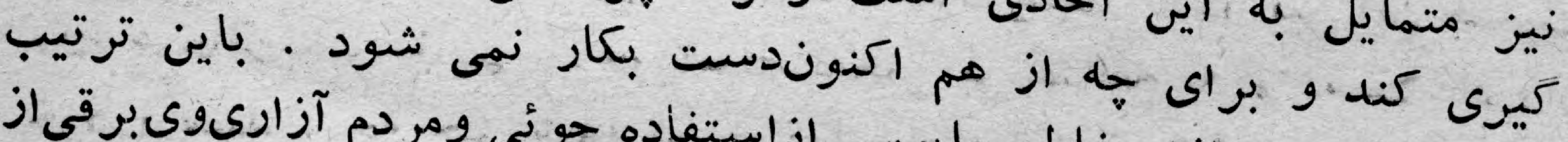

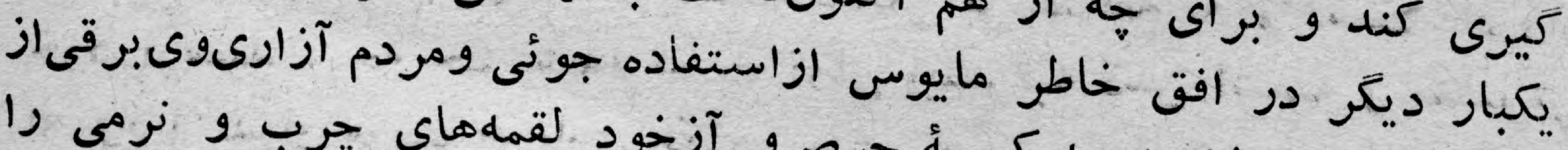

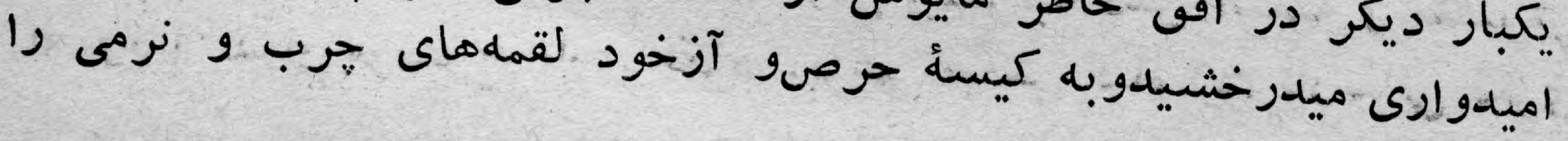

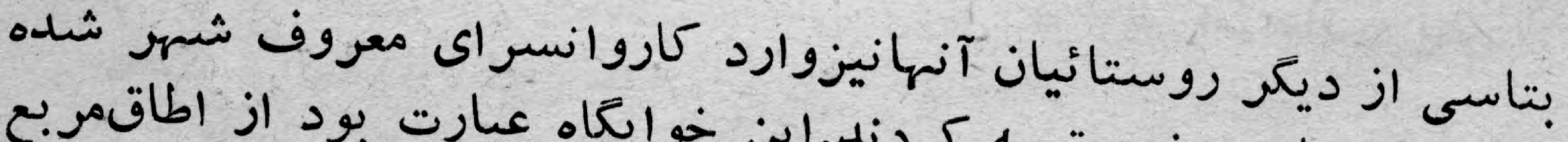

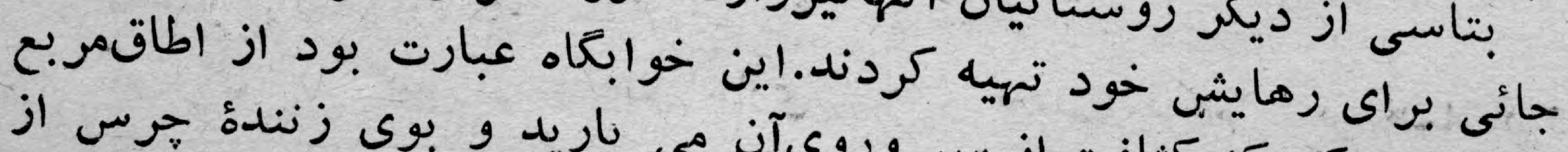

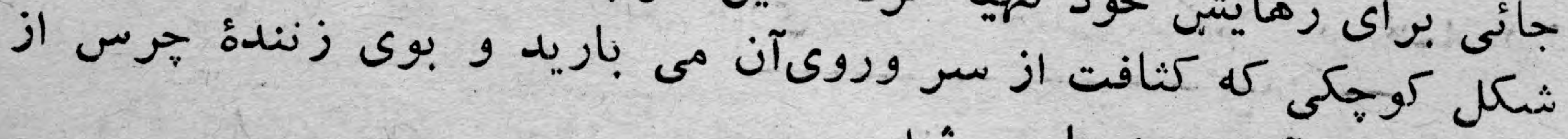

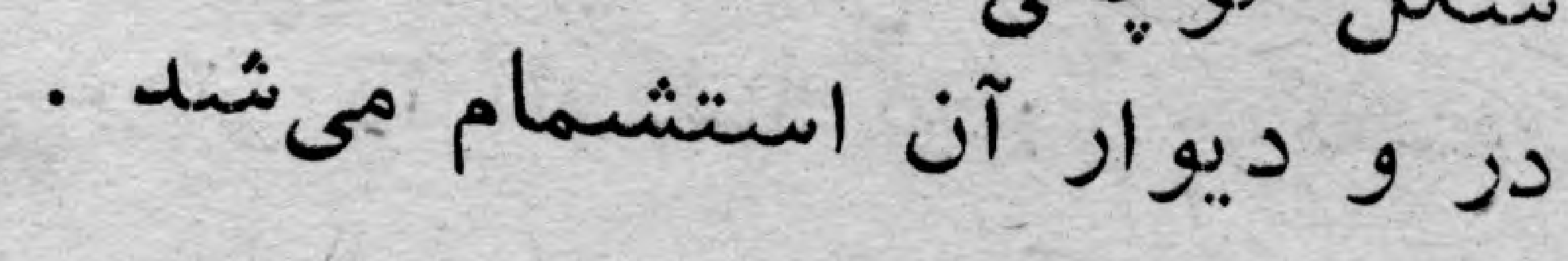




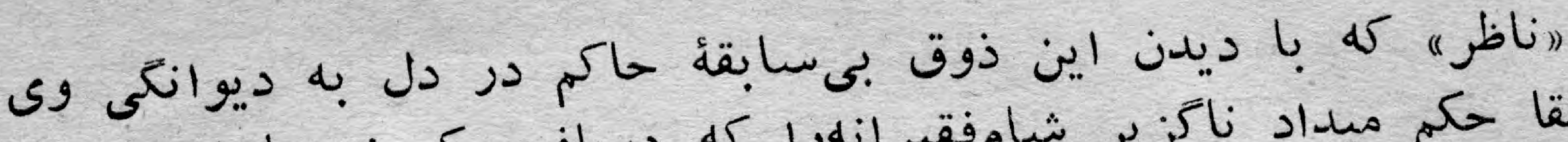

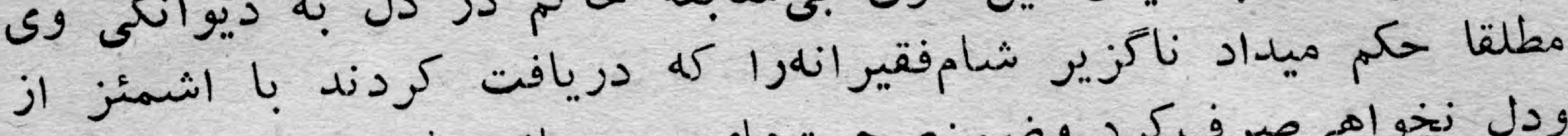

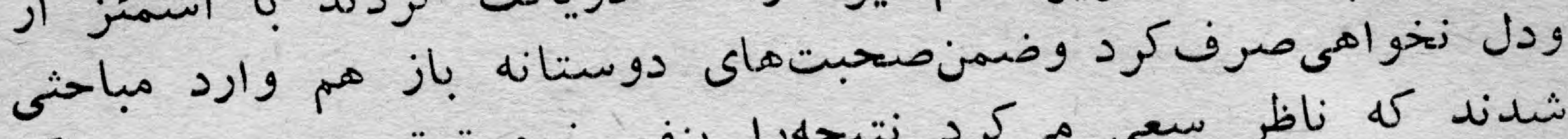

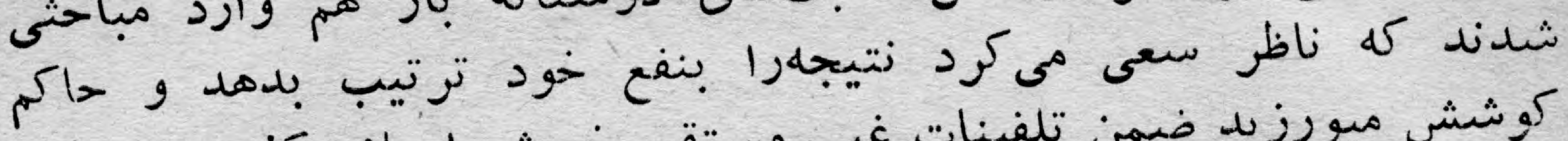

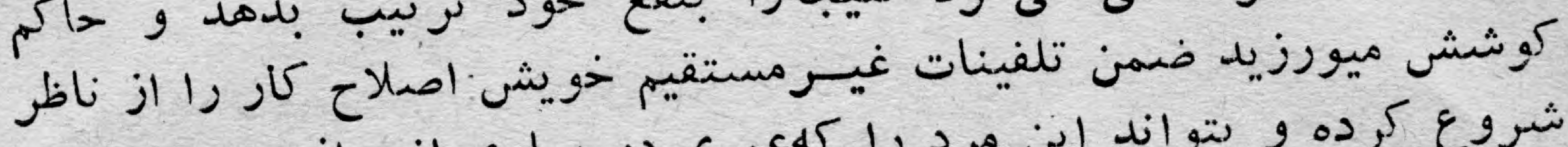

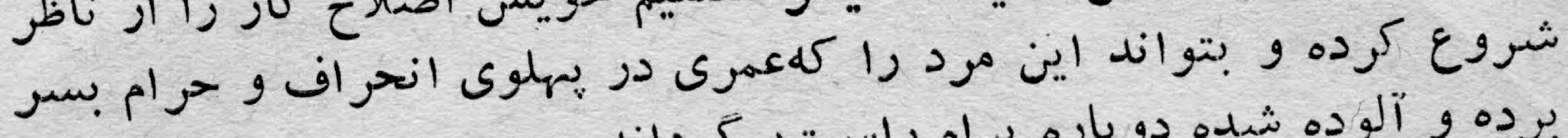

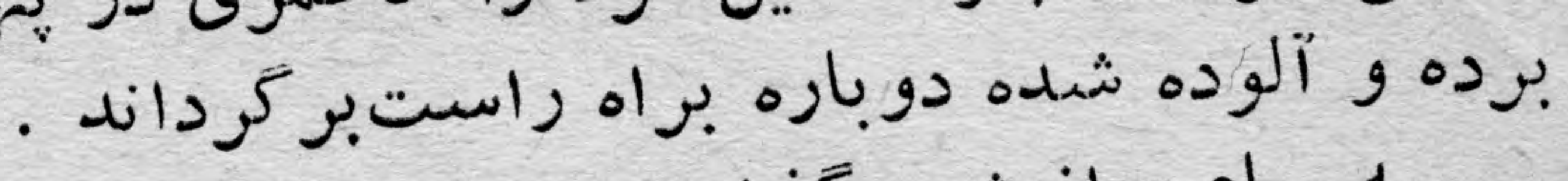

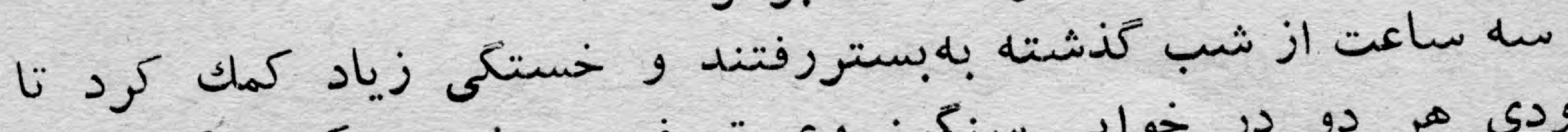

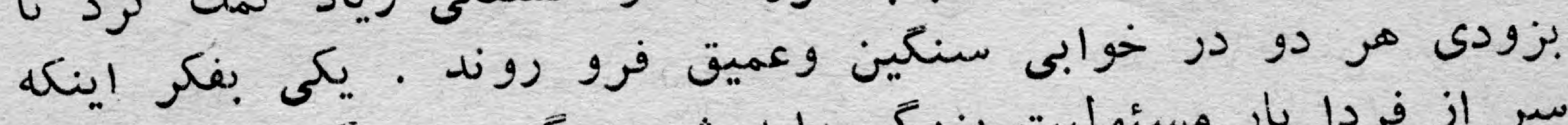

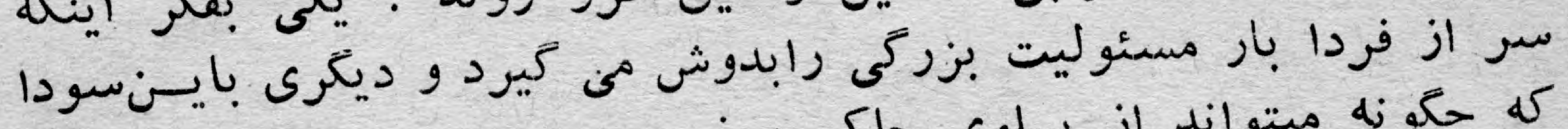

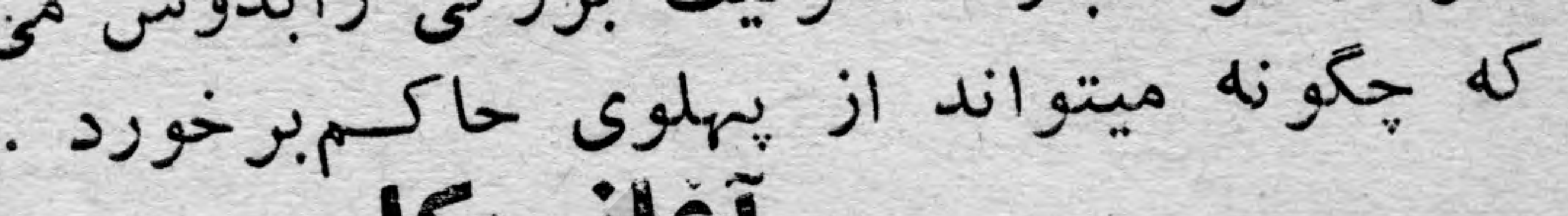

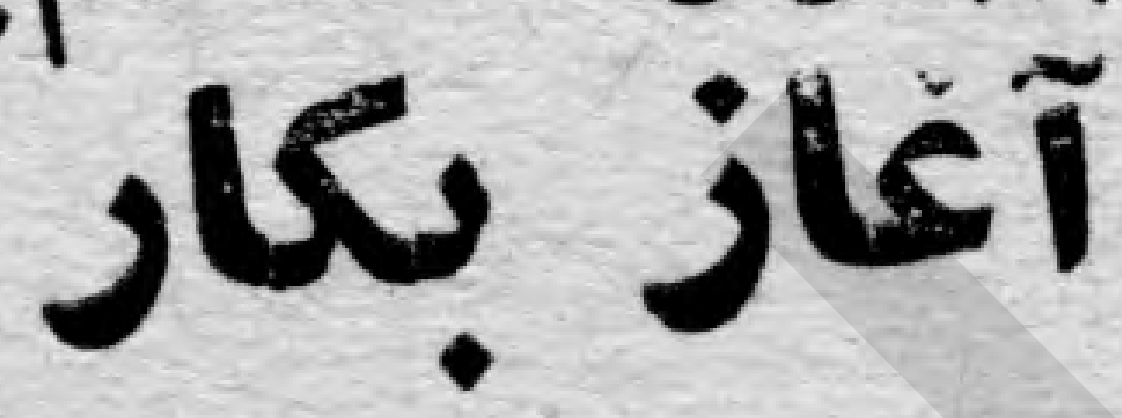

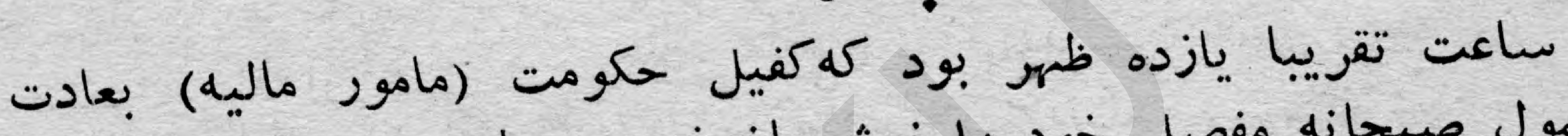

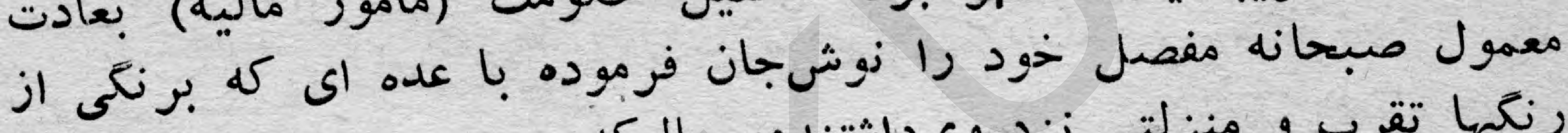

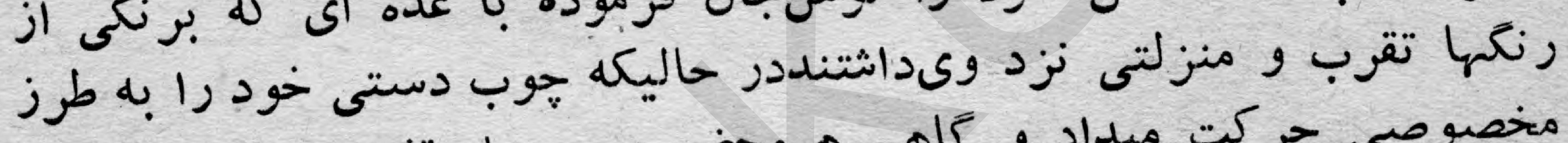

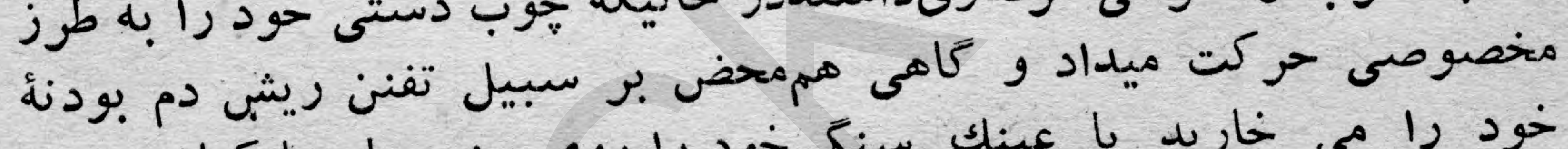

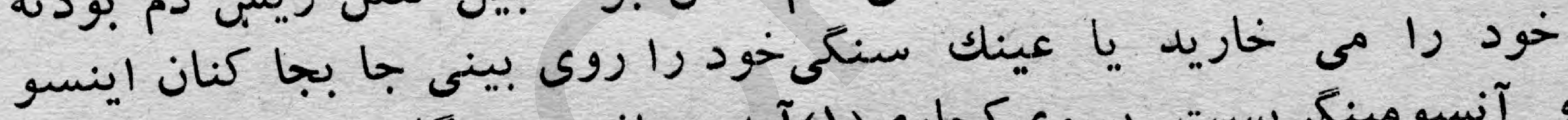

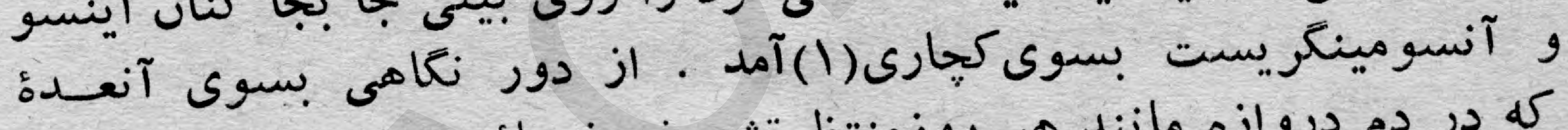

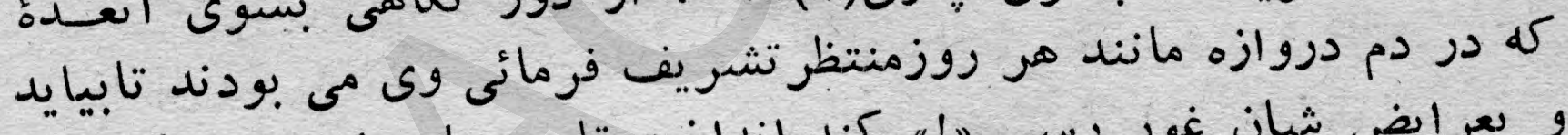

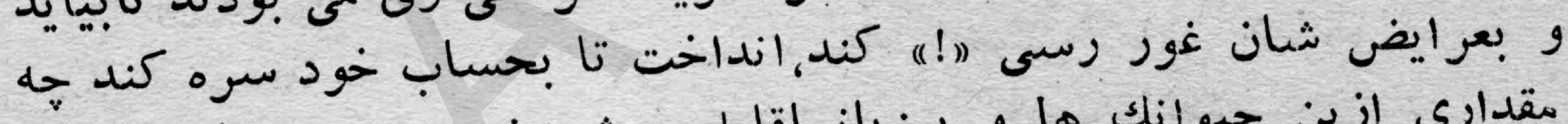

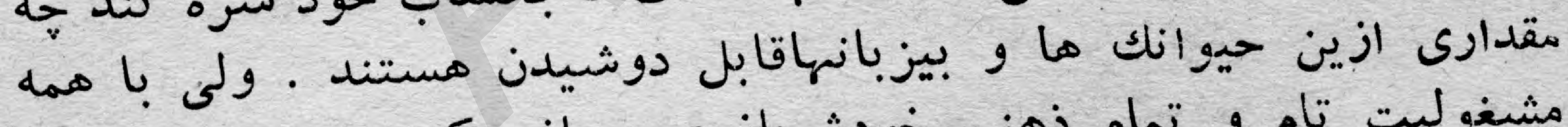

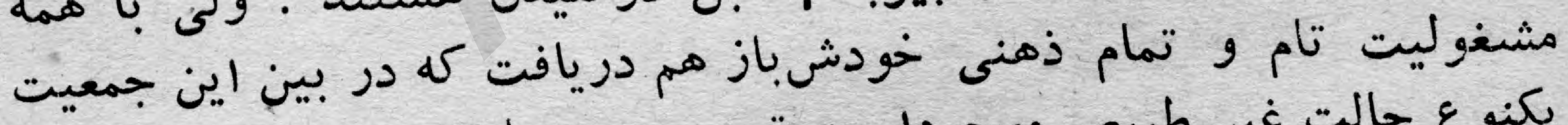

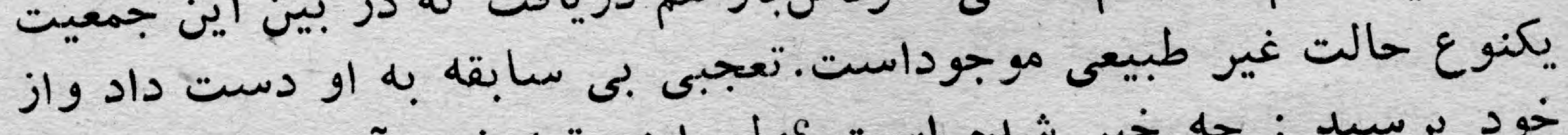

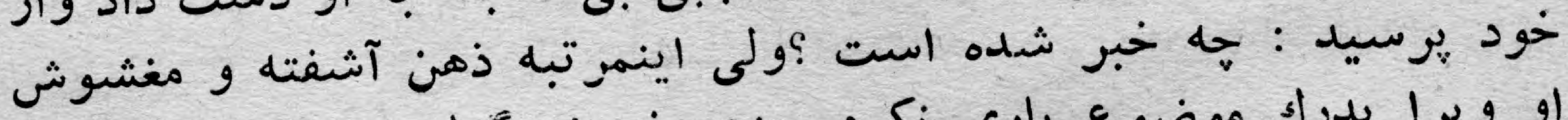

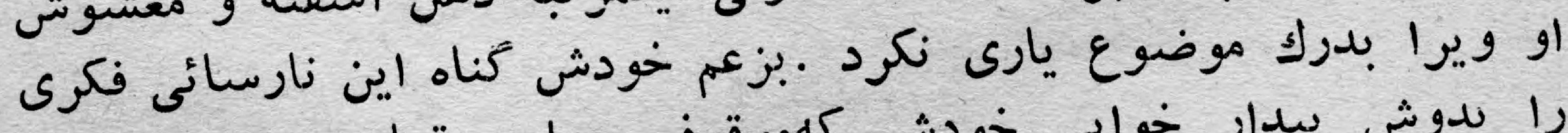

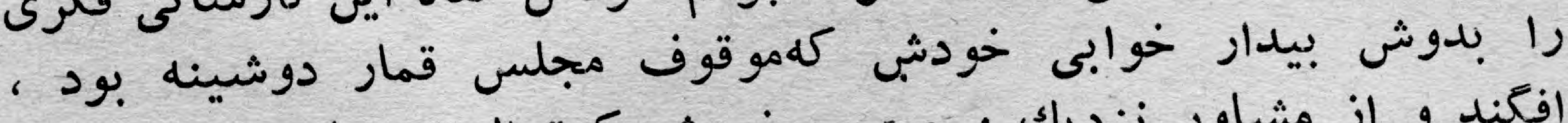

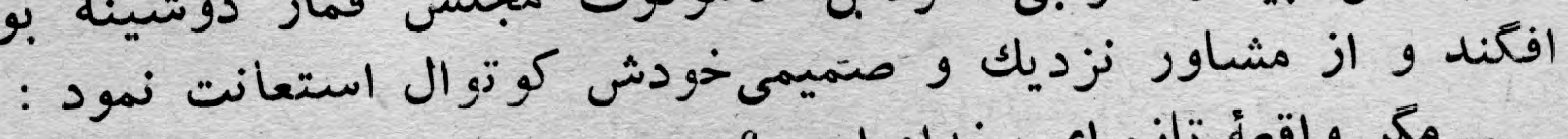

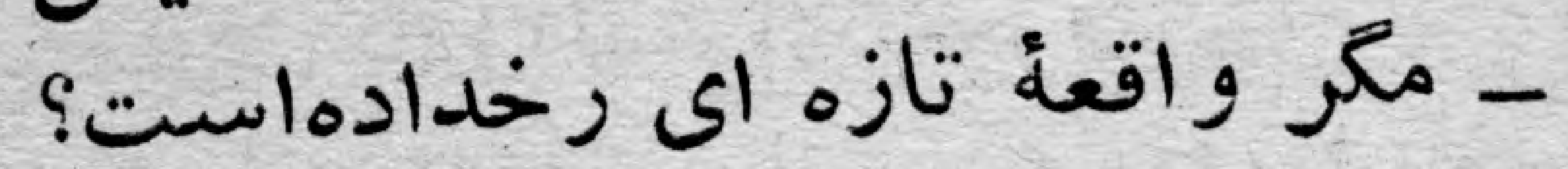
كوتوال كل غير از وقايع جارىشهيه وخدادهات امنيت مردم ، بر همه كونه

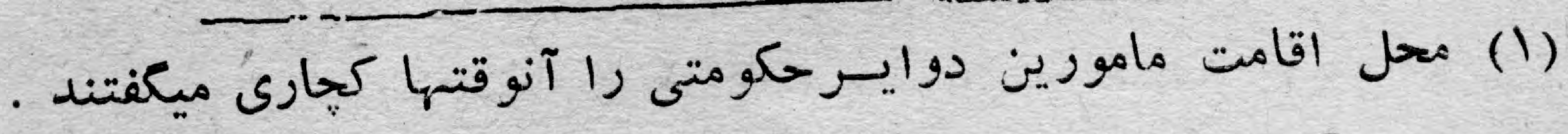




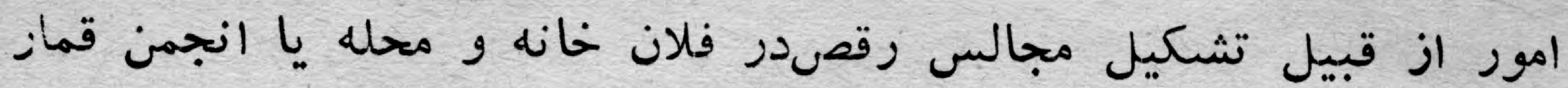

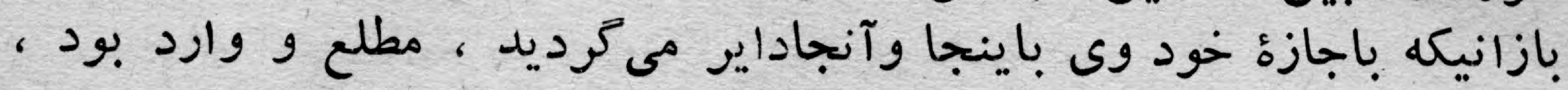

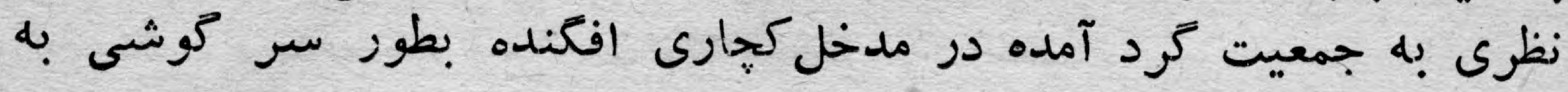

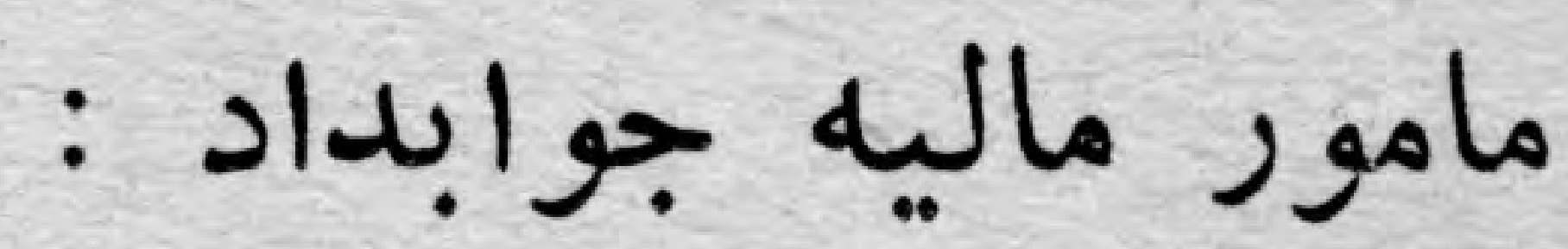

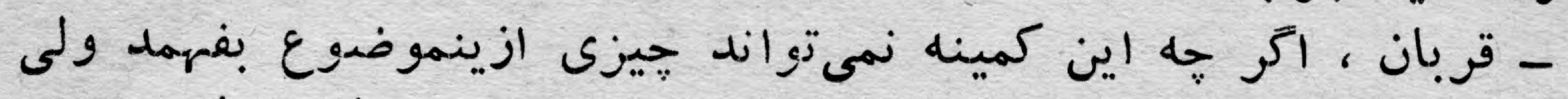

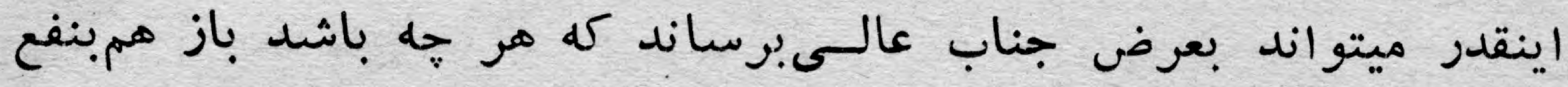
ماست قربان أنفعر ميتو اند

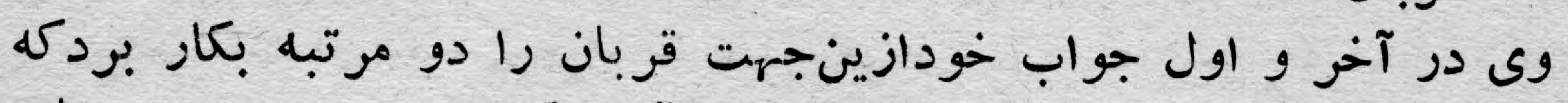

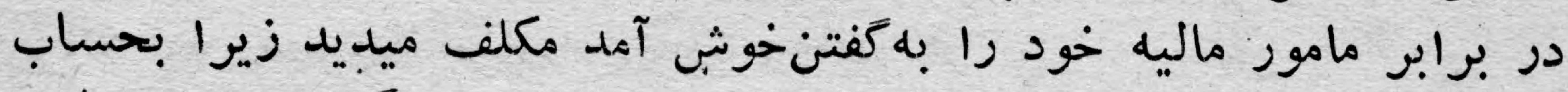

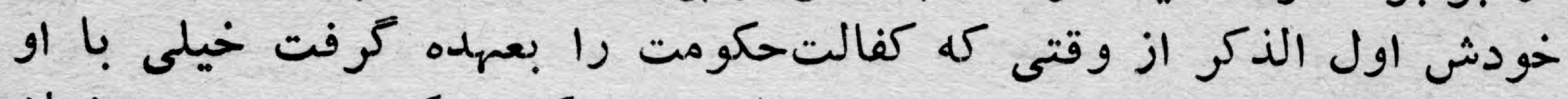

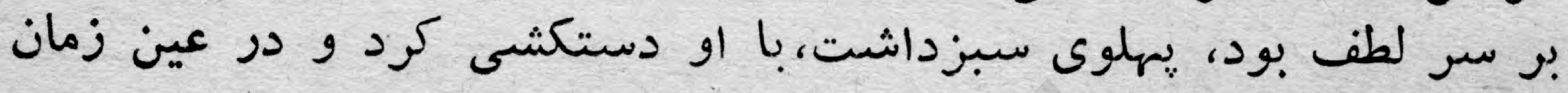

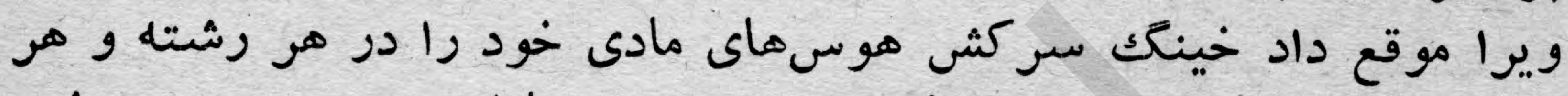

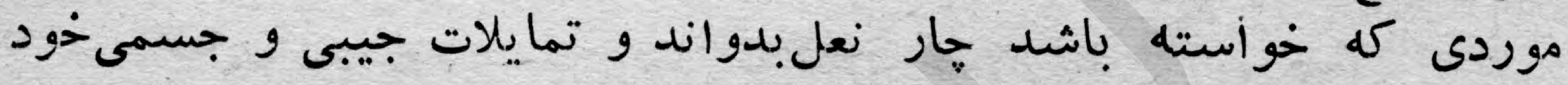

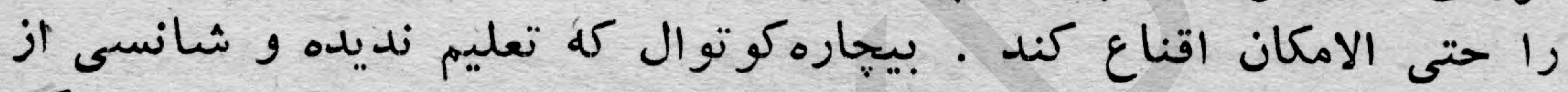

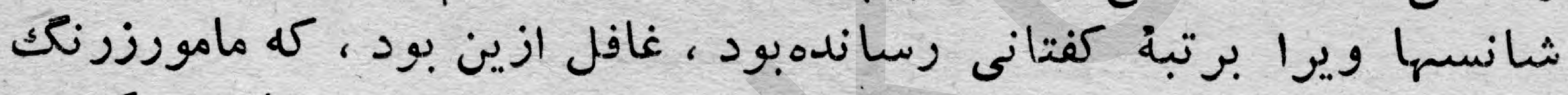

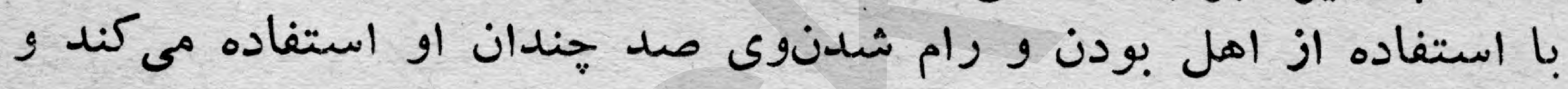

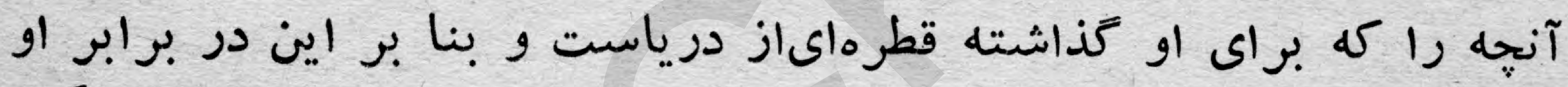

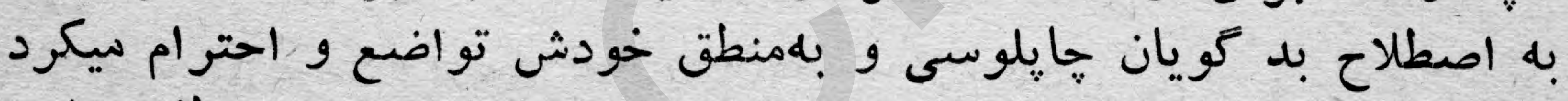

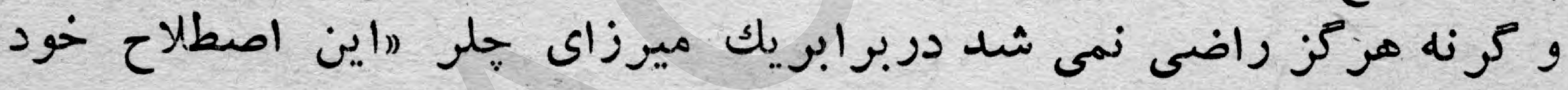

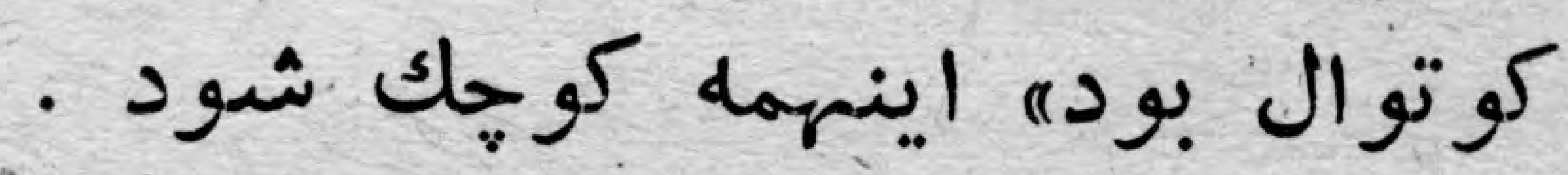

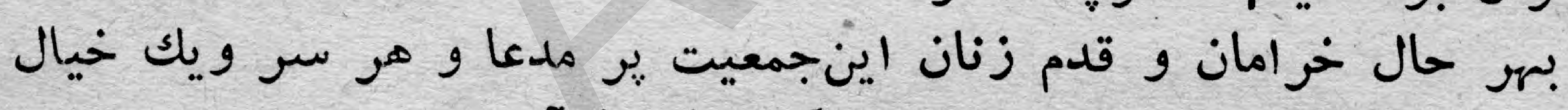

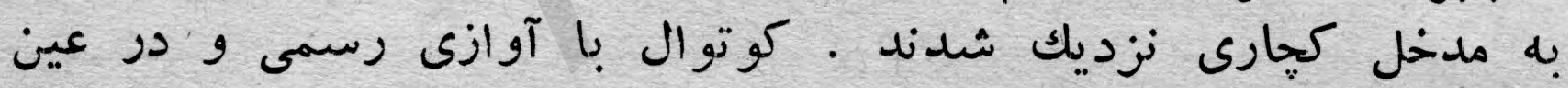

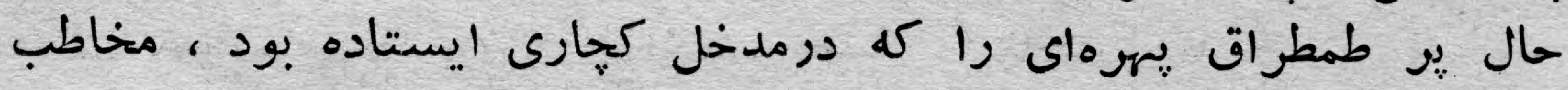

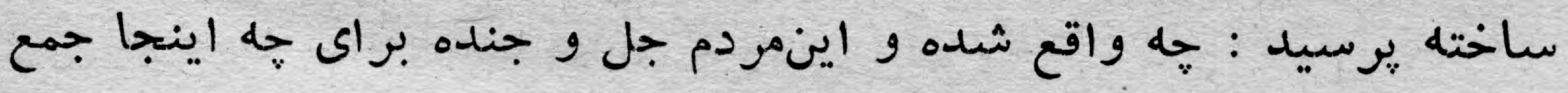
شدهاند

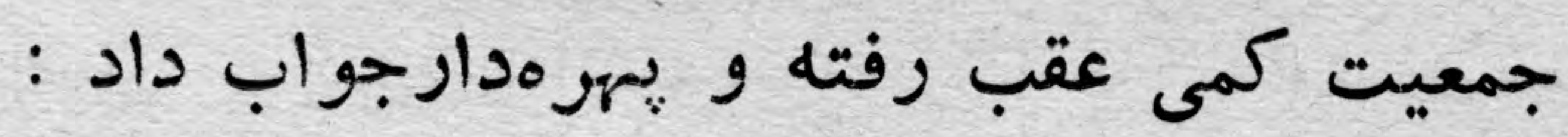

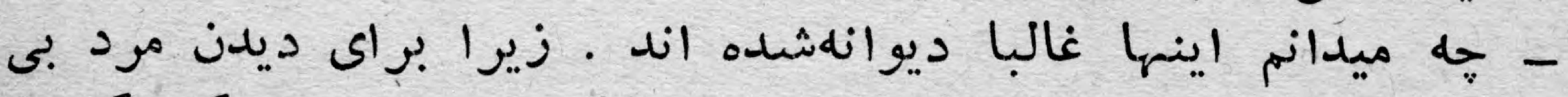

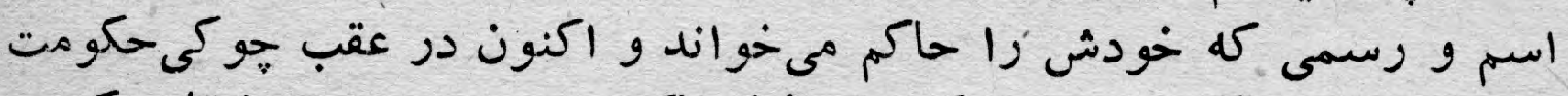

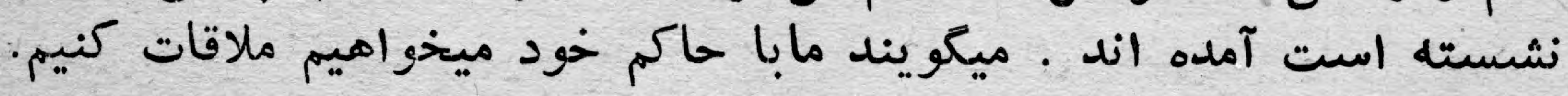

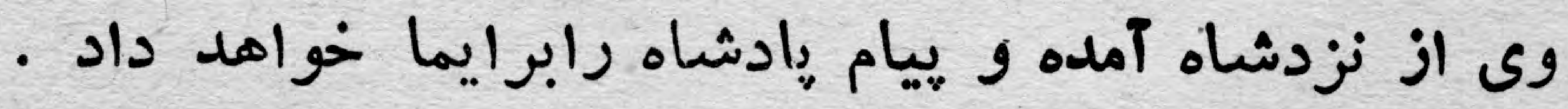

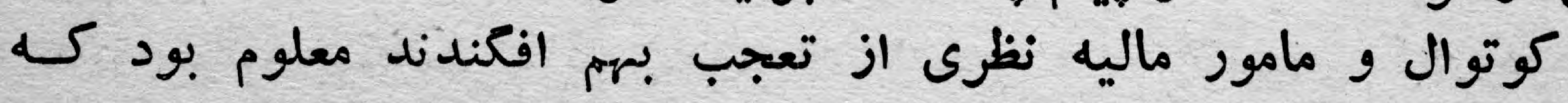
arVo 


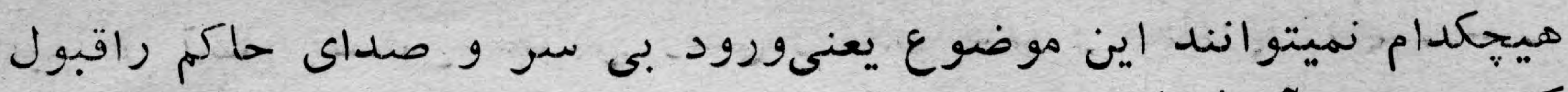

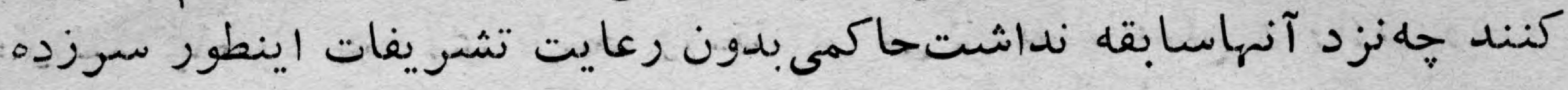

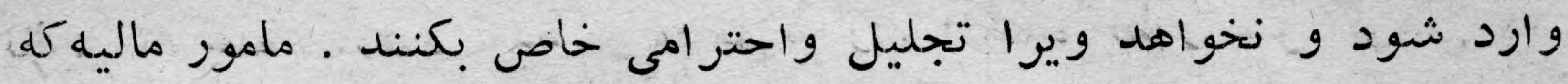

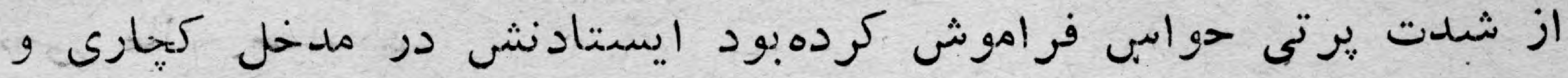

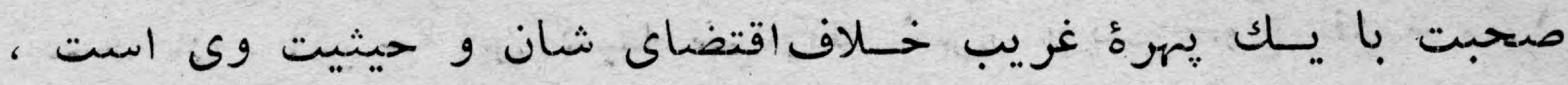

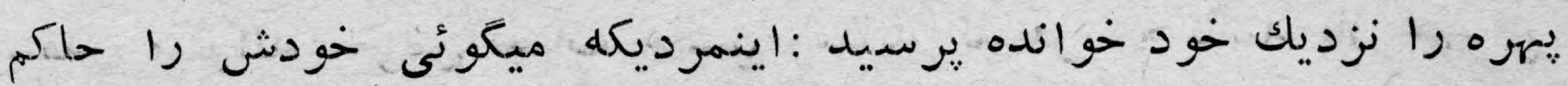

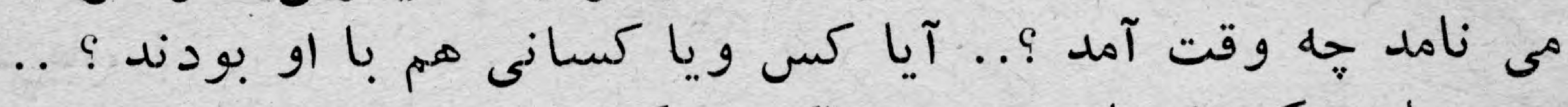

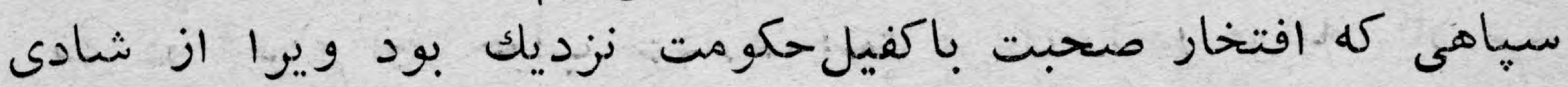

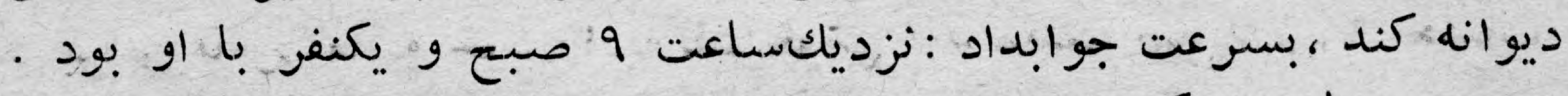

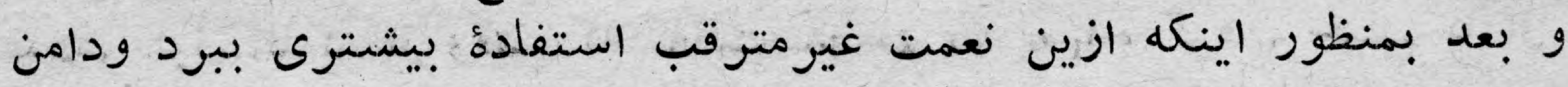

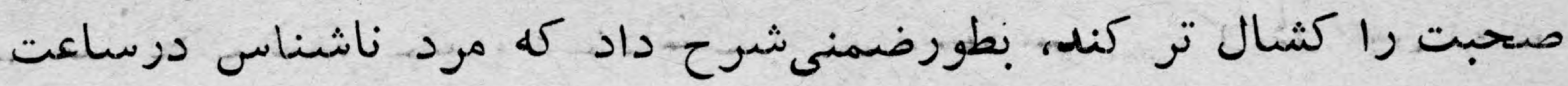

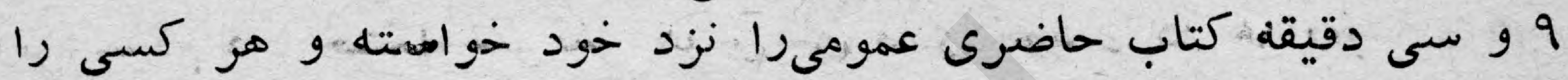

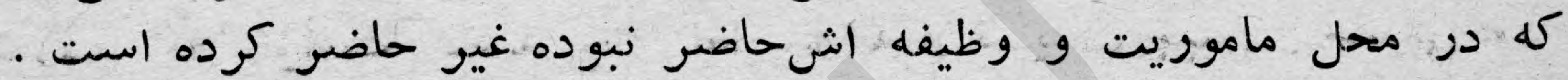

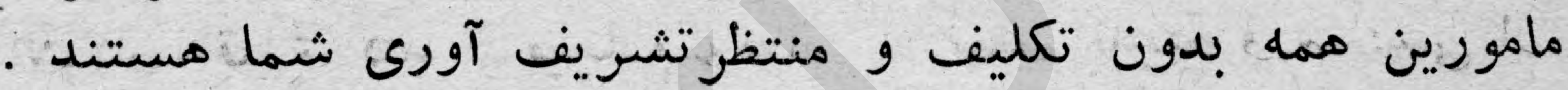

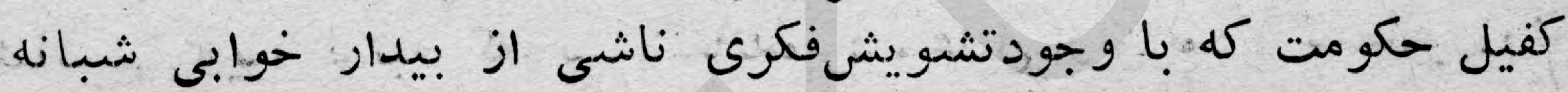

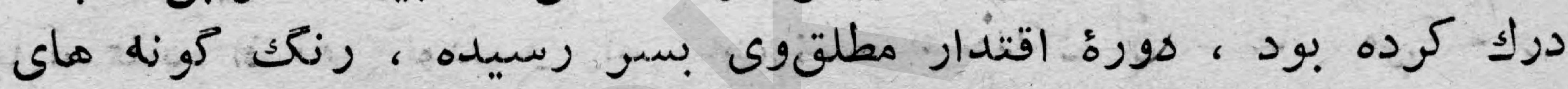

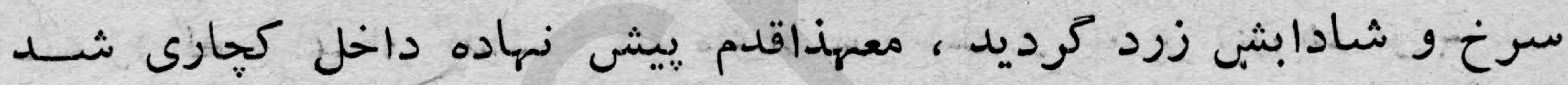

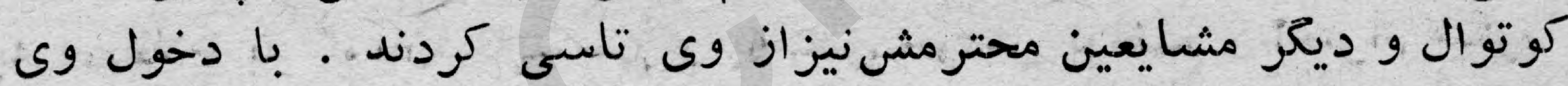

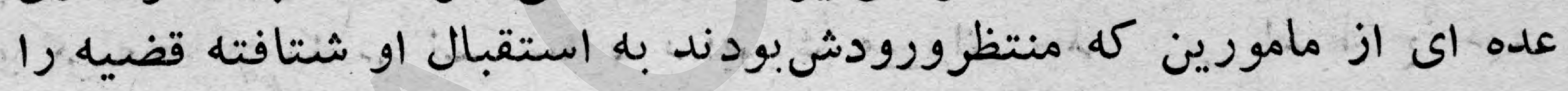

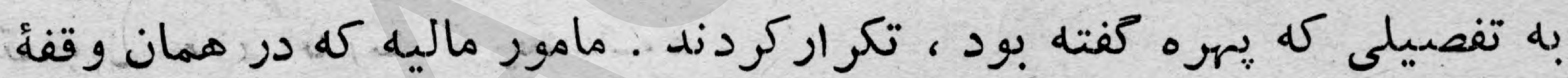

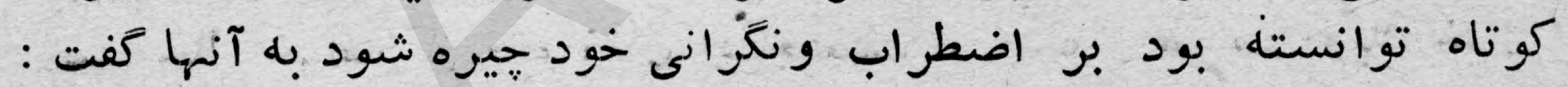

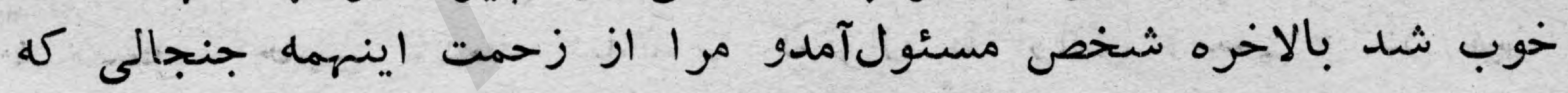

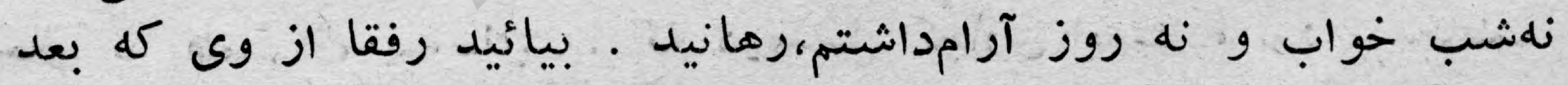

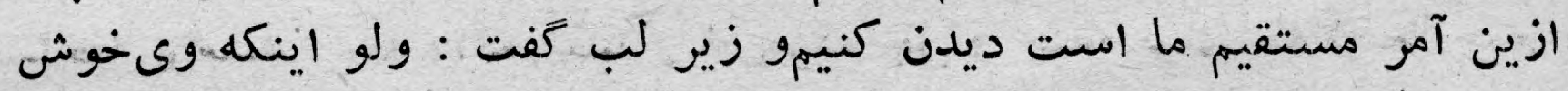

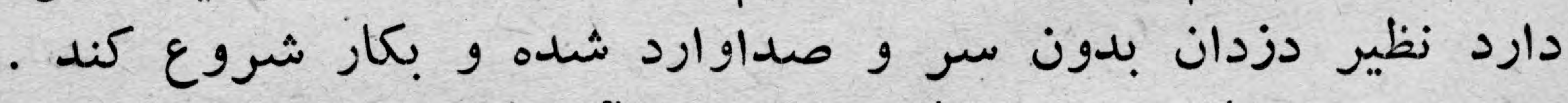

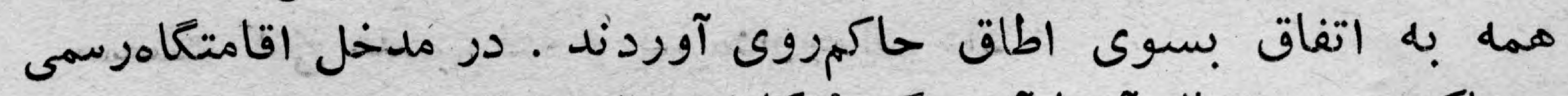

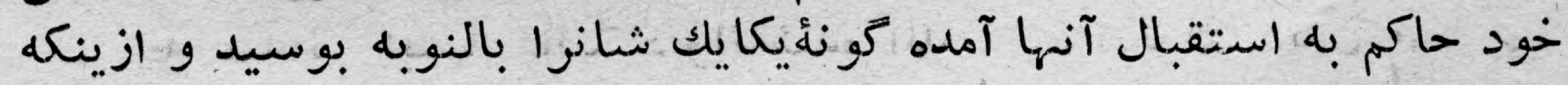

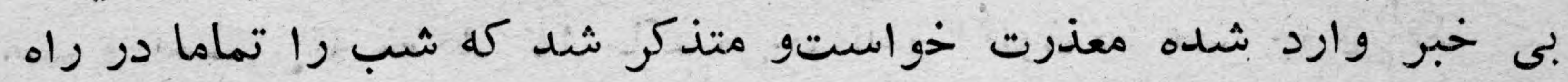

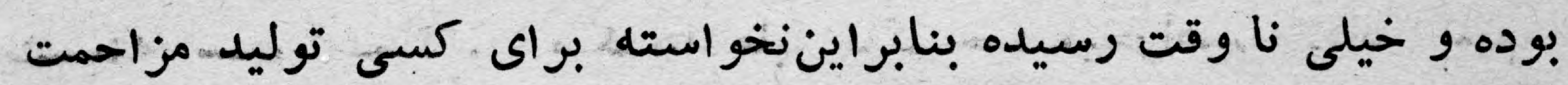
مامور ماليه بو كالت سايوين وروداو را خيو مقدم كفت و يكبار ديكر 


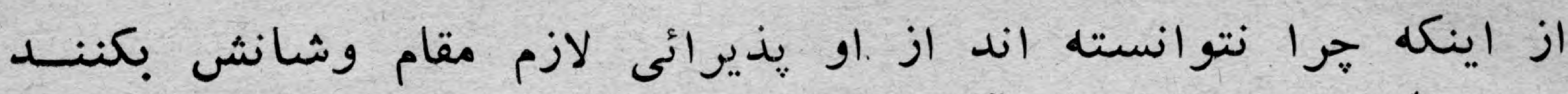

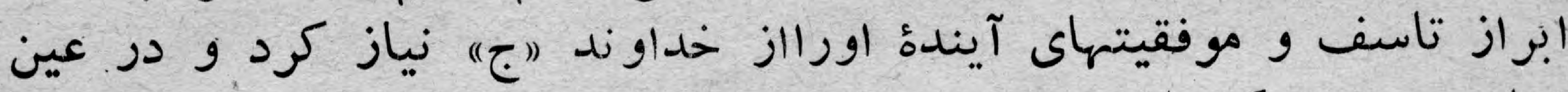

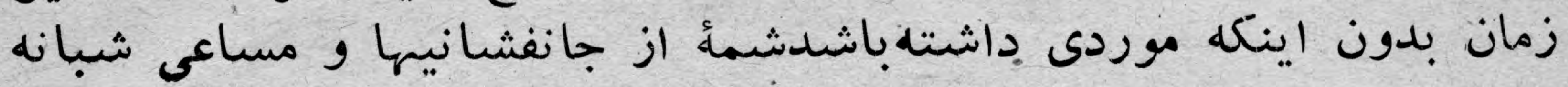

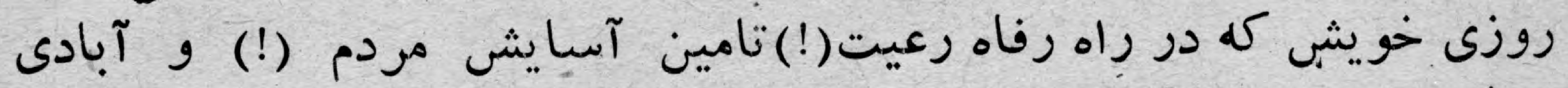

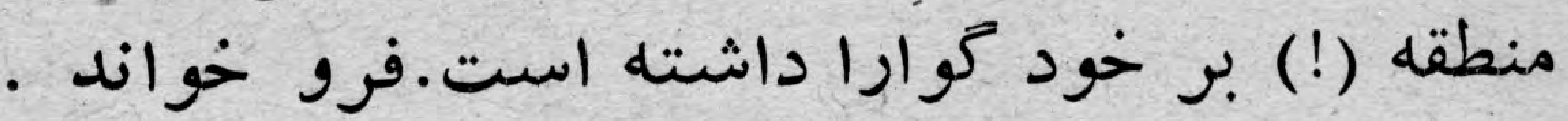

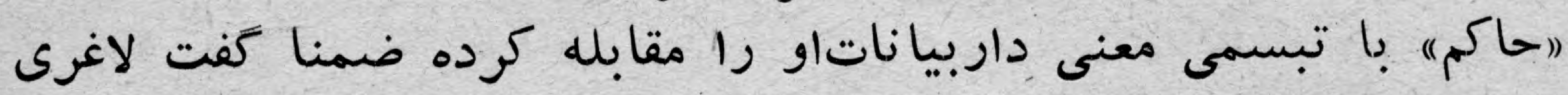

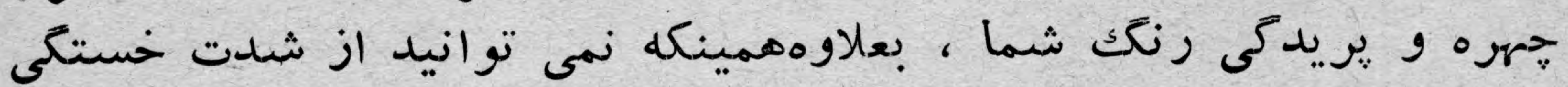

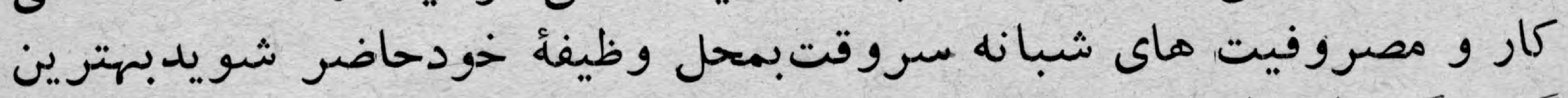

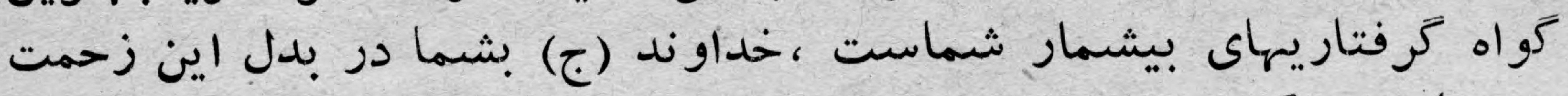

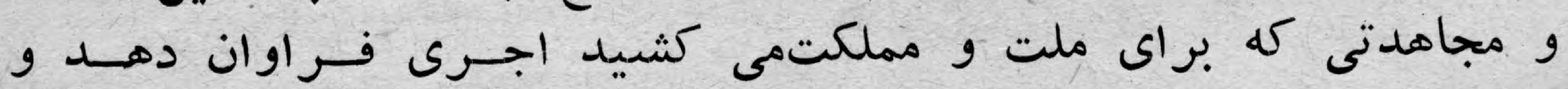

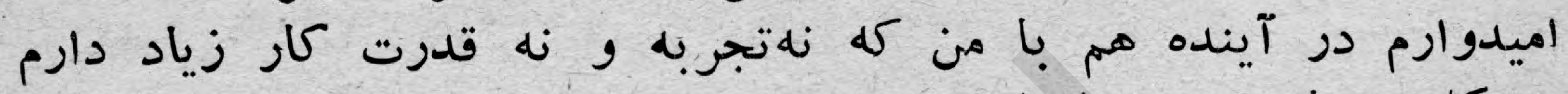

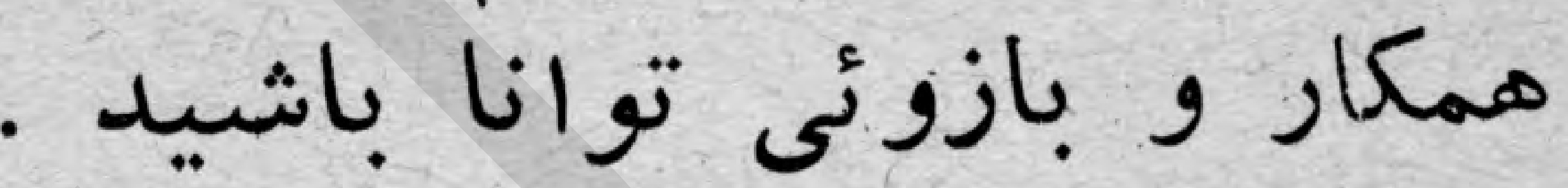

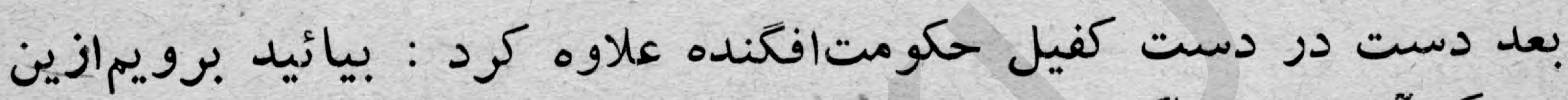

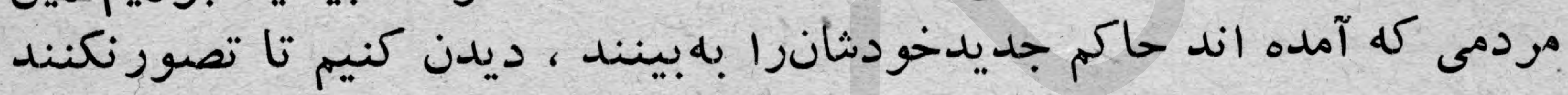

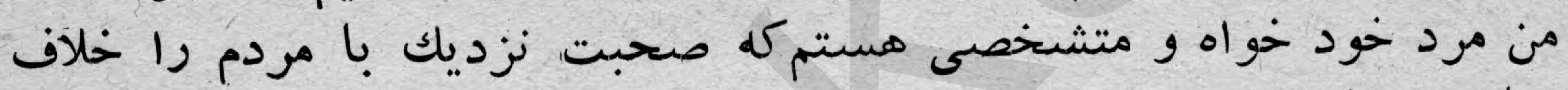

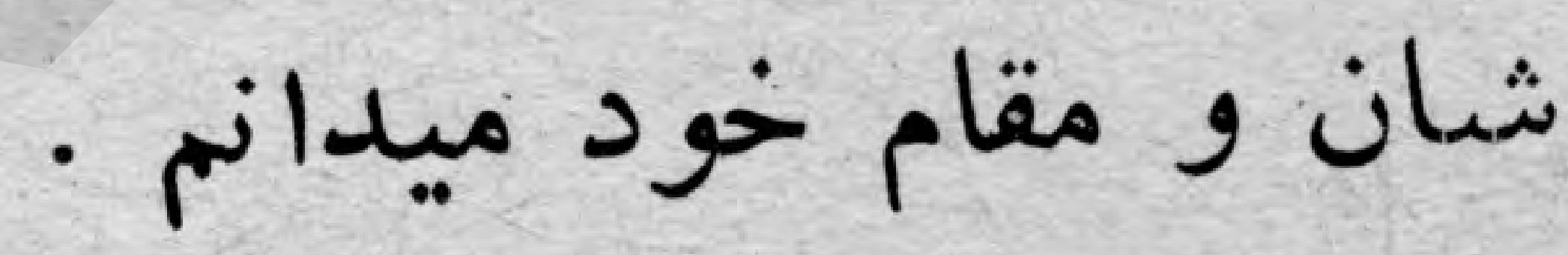

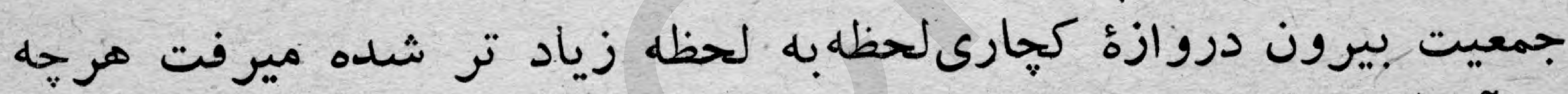

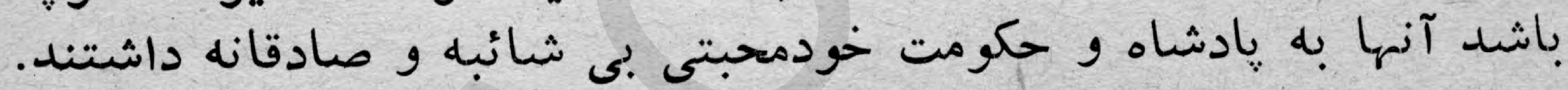

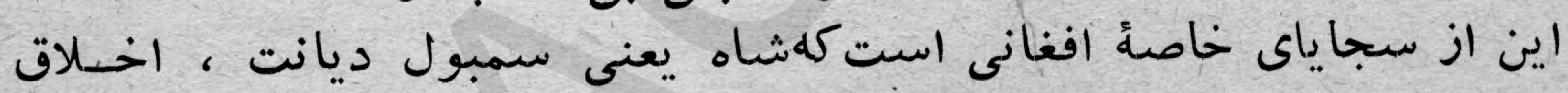

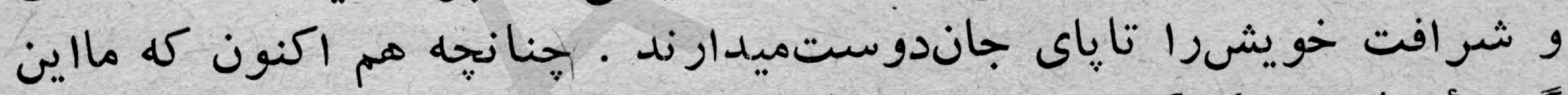

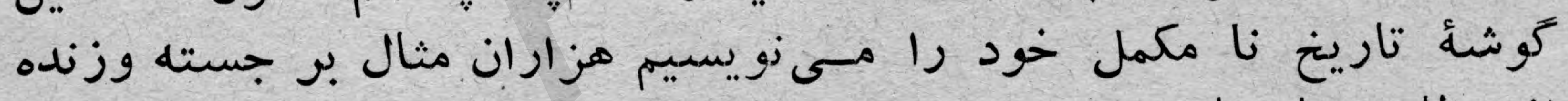

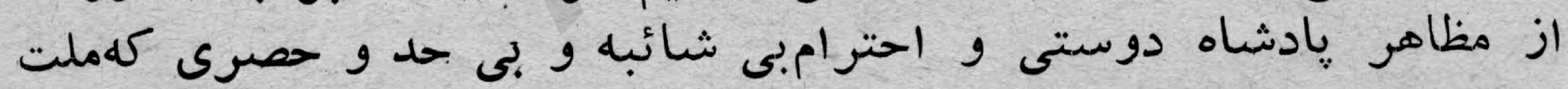

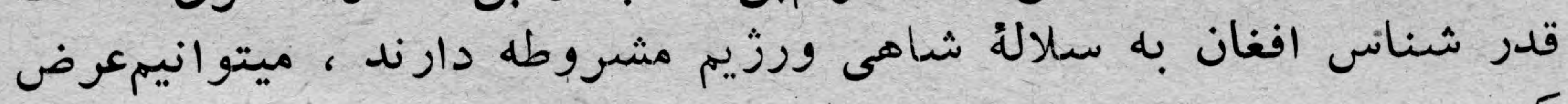

كني阝

روى اين اصل بود كه وقتى قيافهُملايم و بشاش حاكم از مد مدخل كجارى

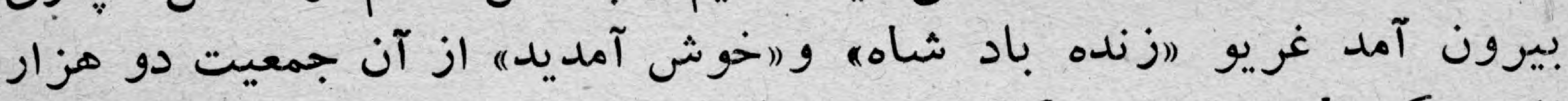

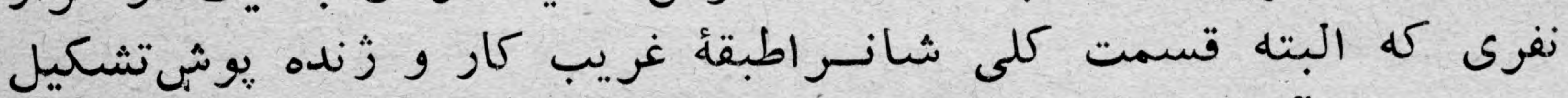

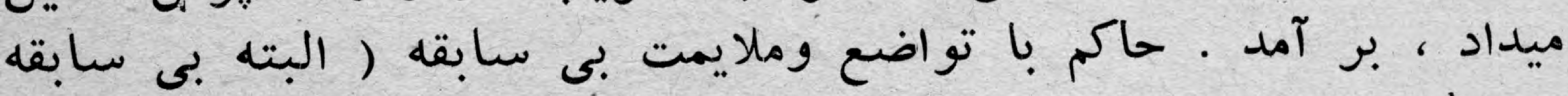

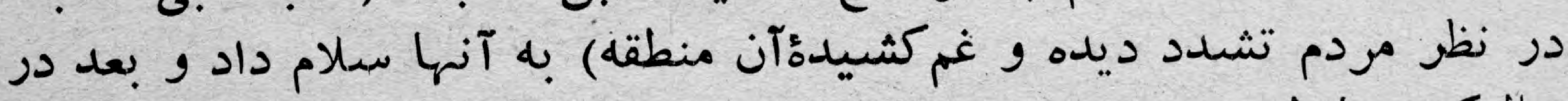

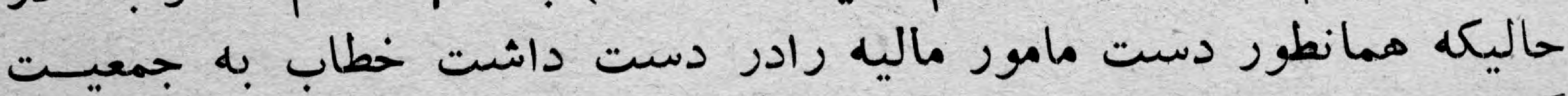

كفت :

"र १" 


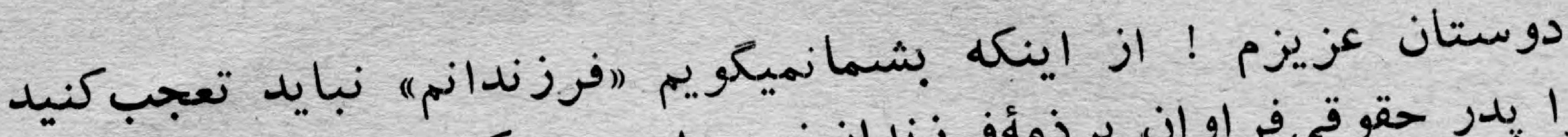

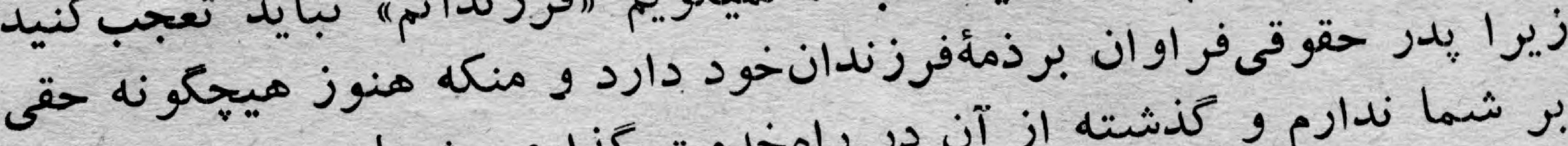

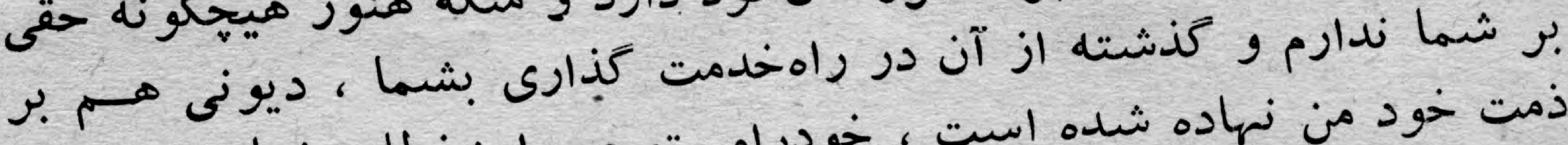

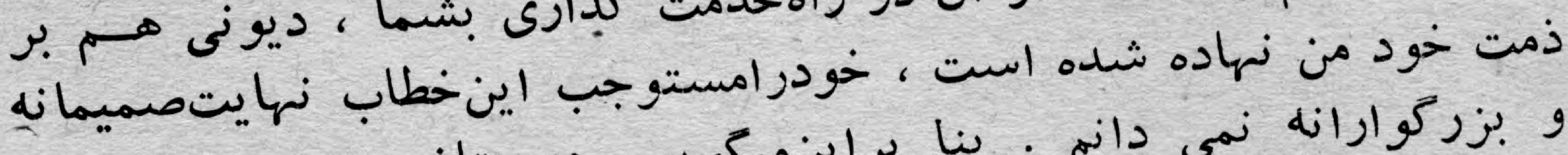

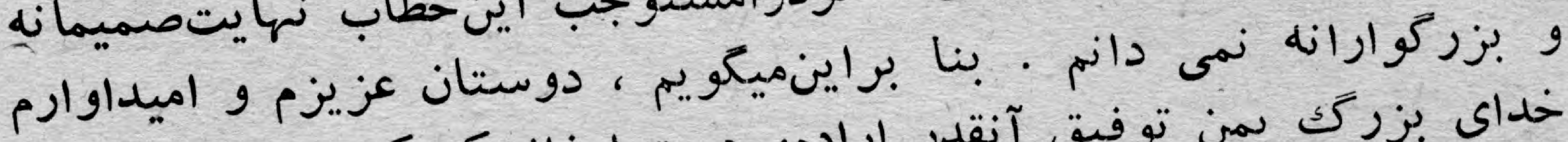

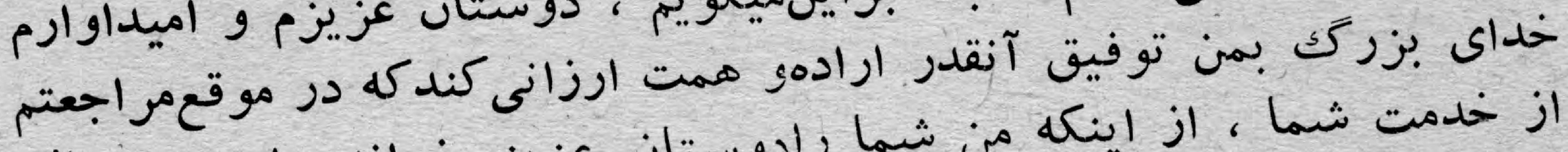

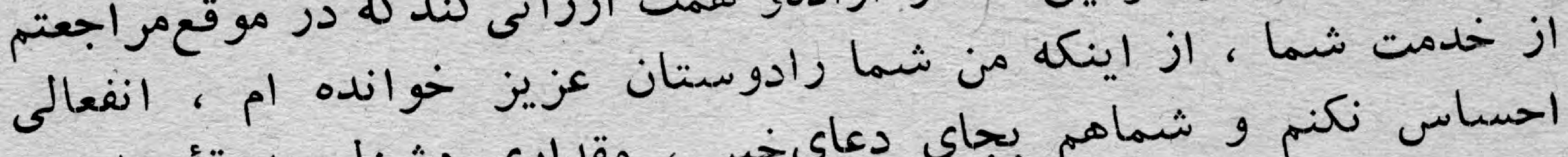

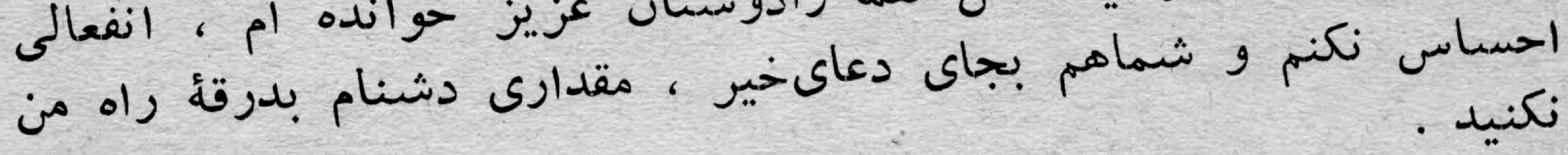

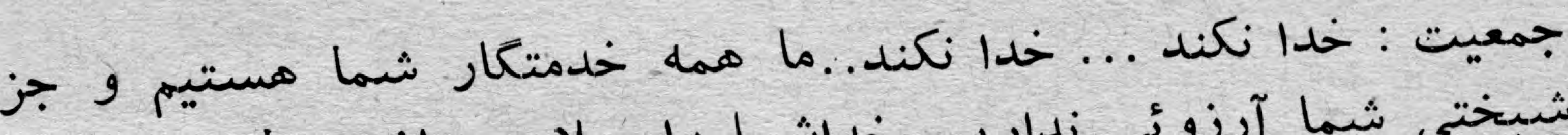

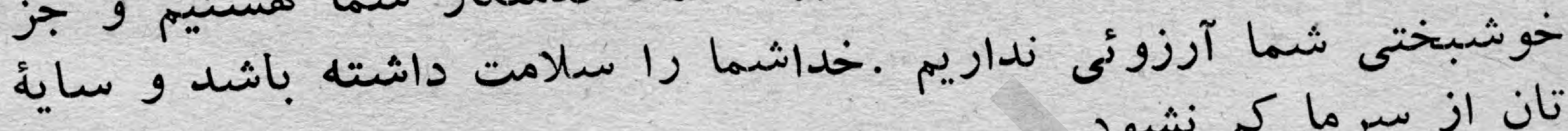

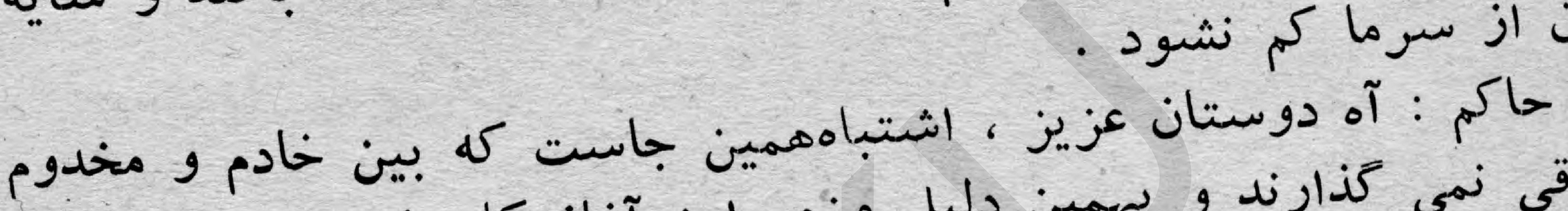

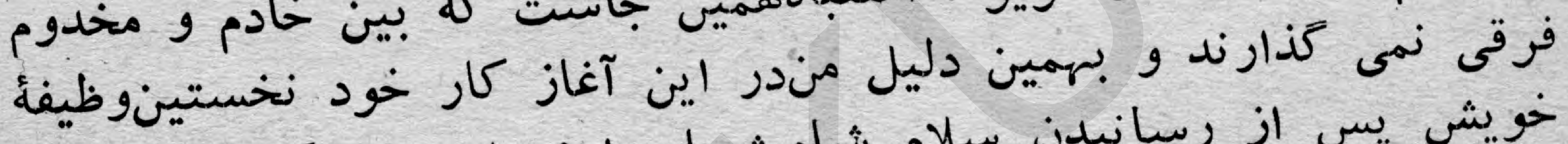

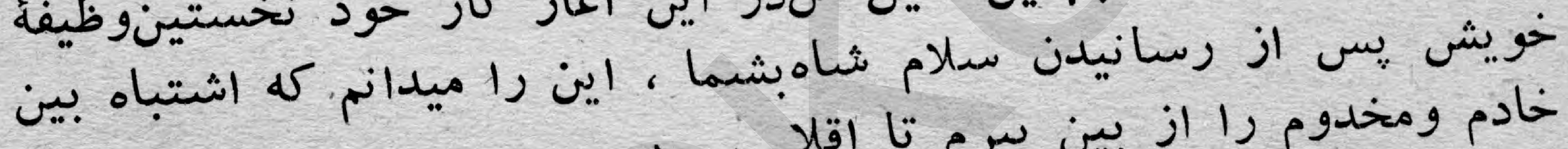

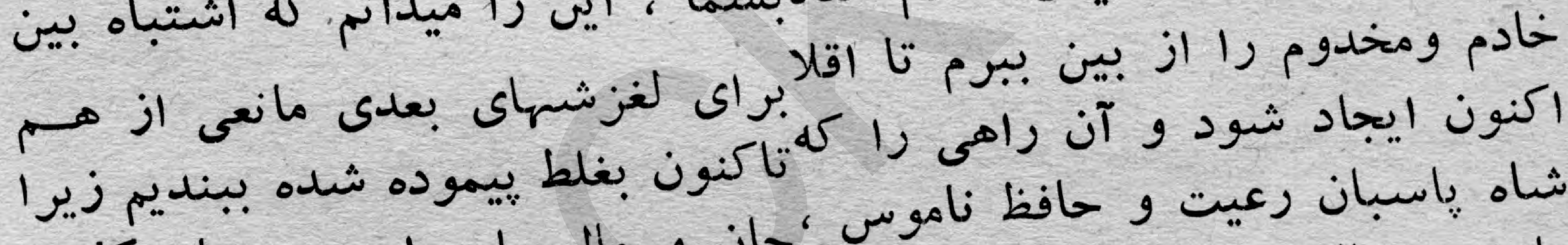

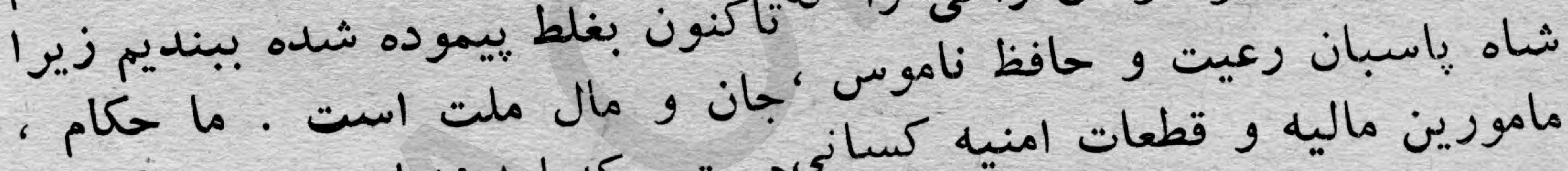

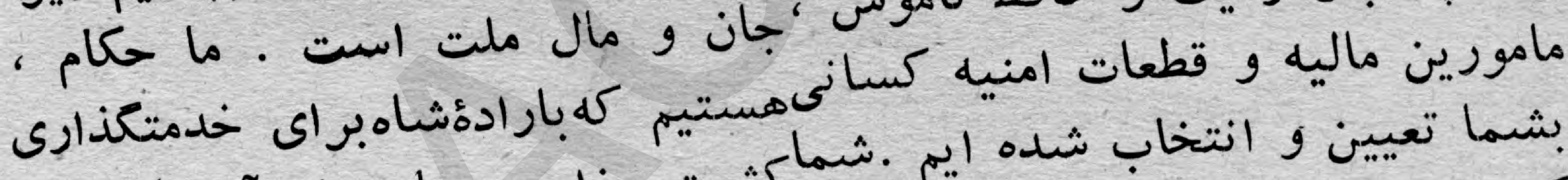

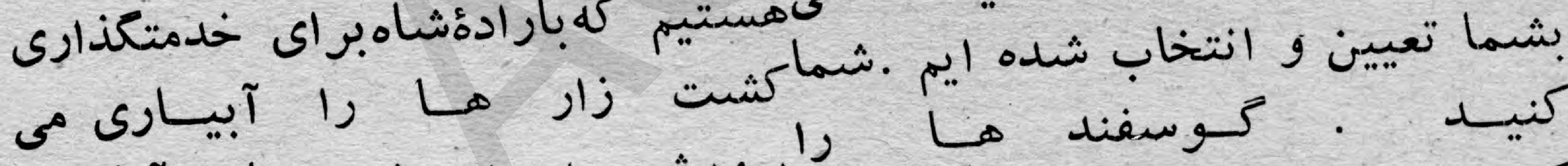

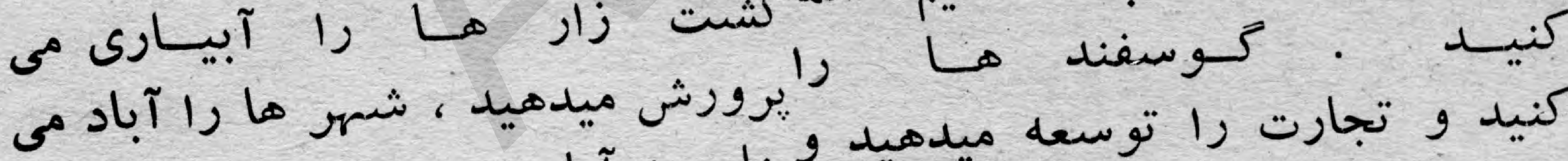

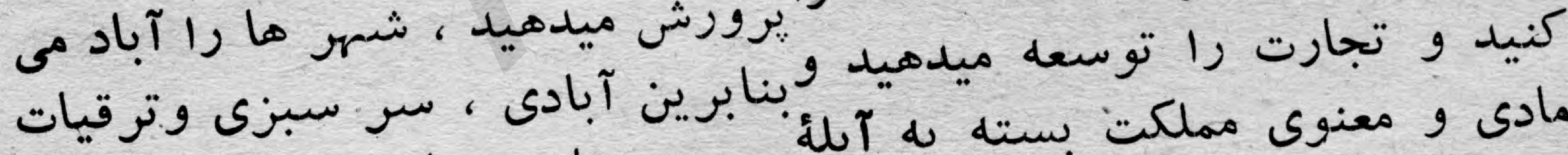

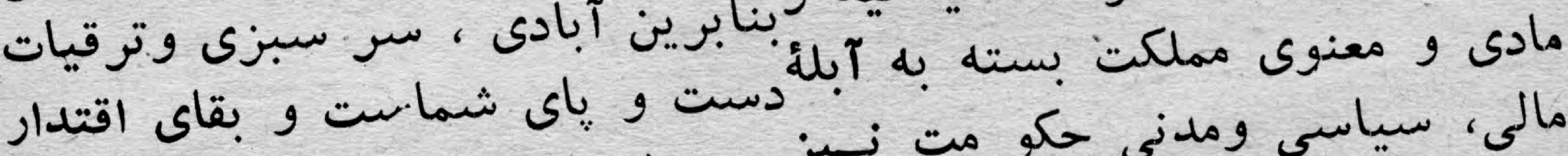

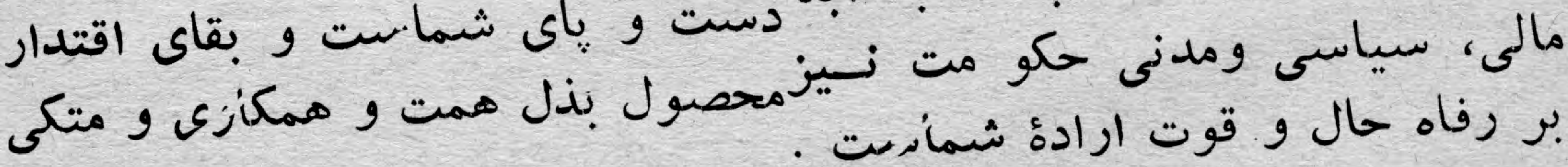

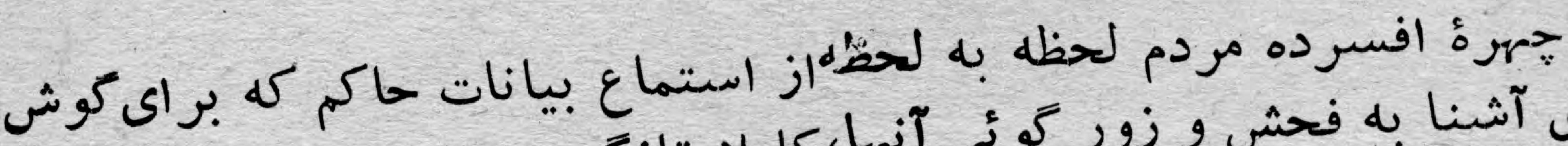

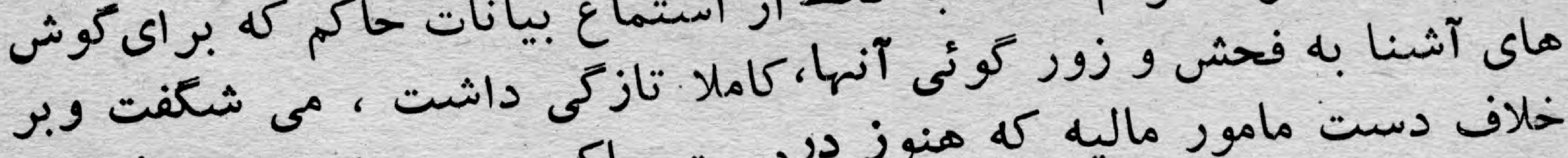

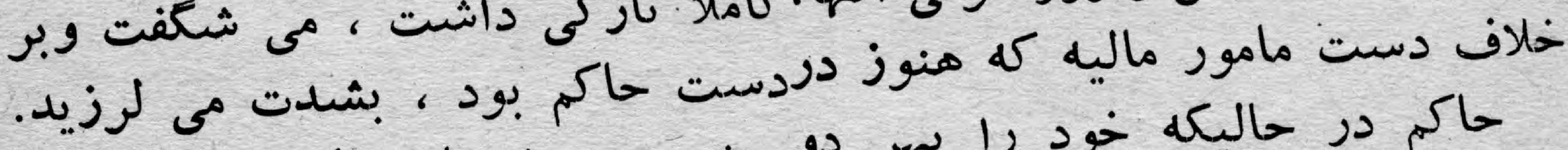

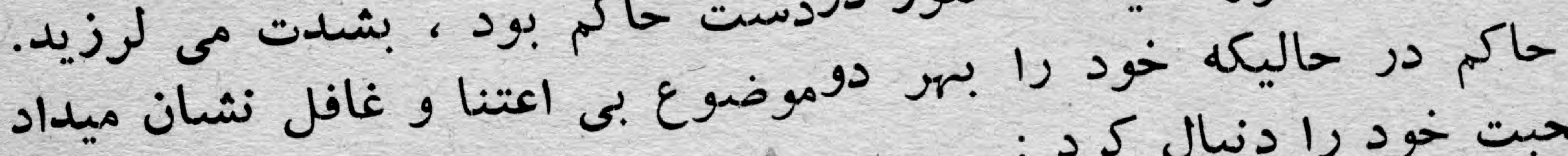

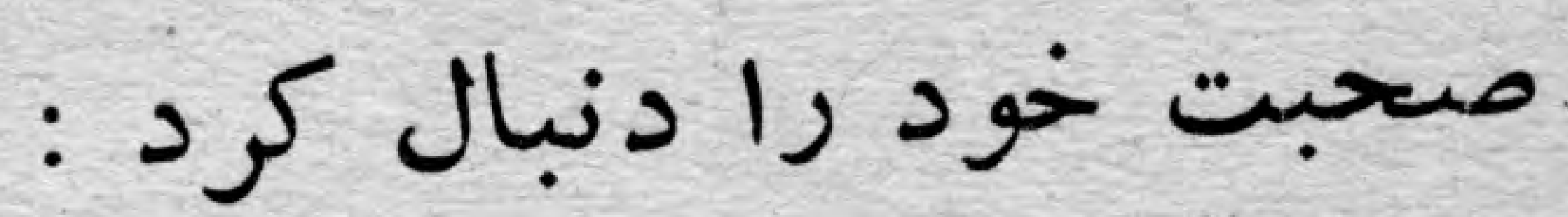

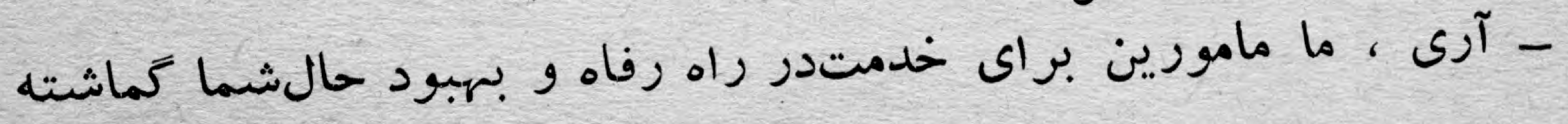




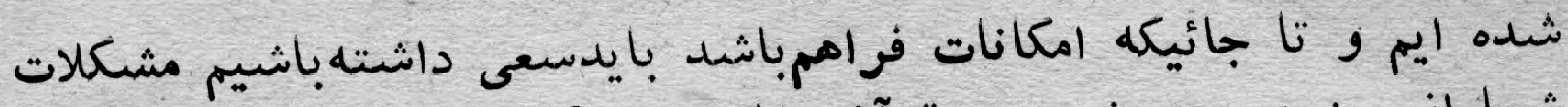

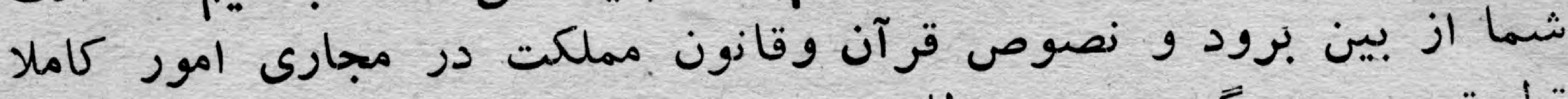

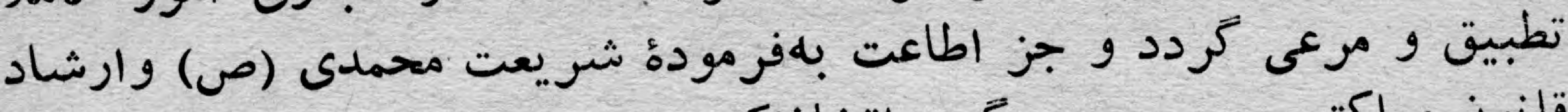

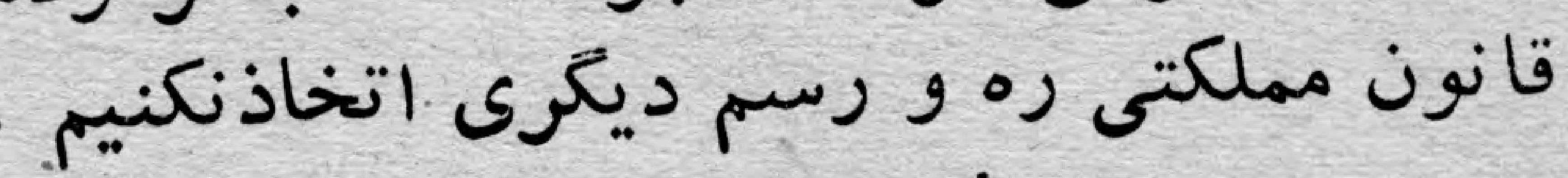

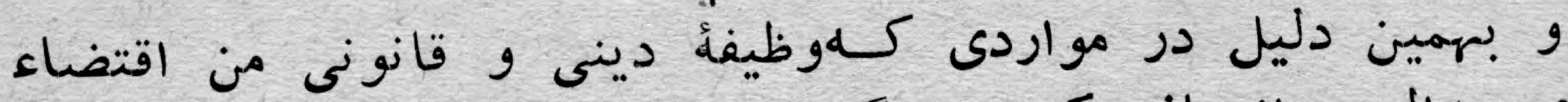

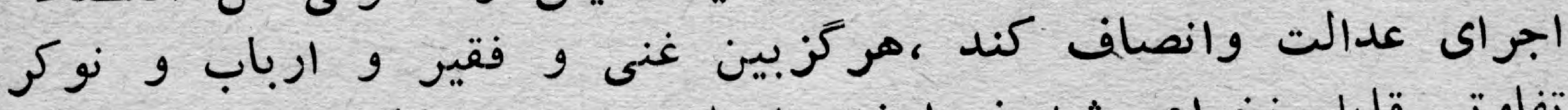

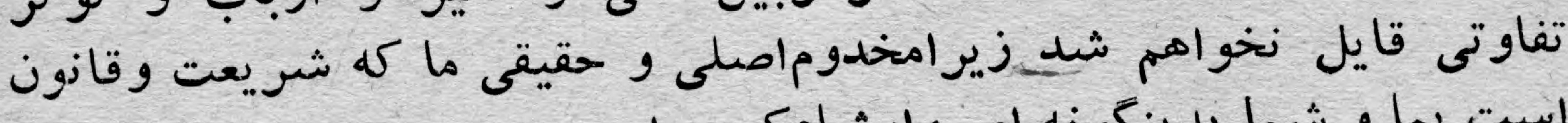

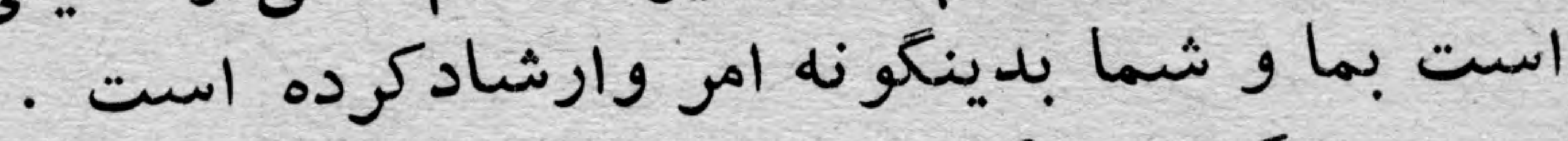

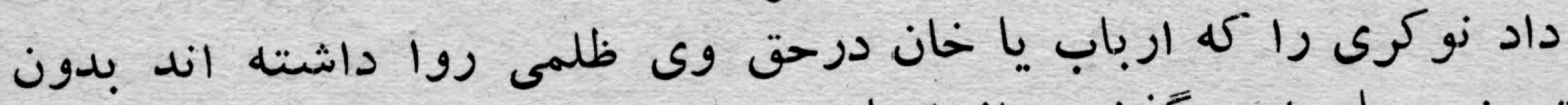

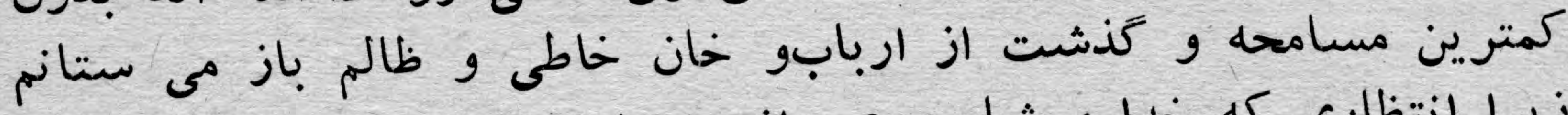

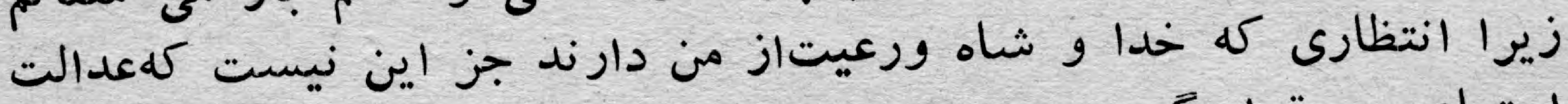

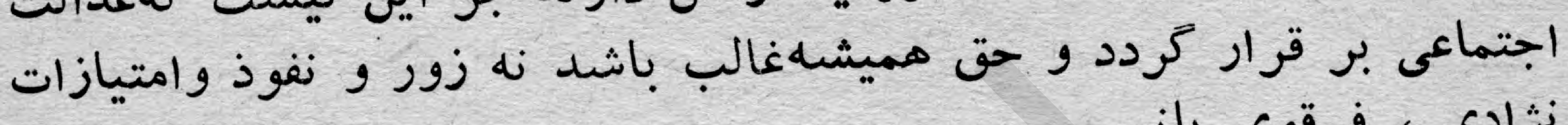

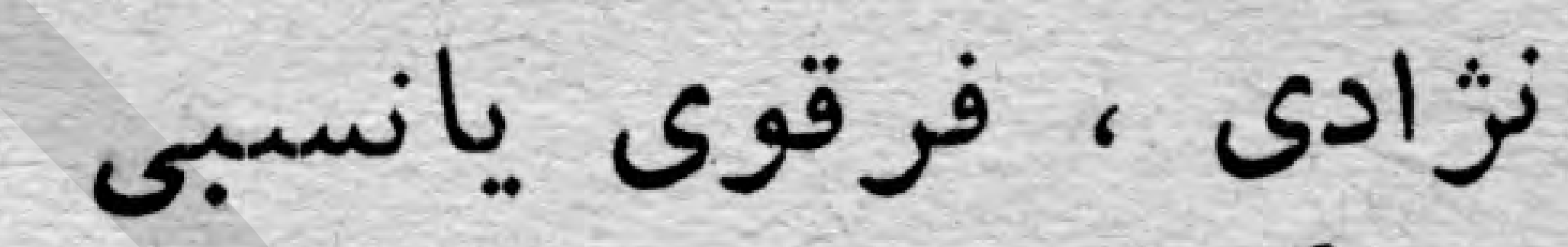

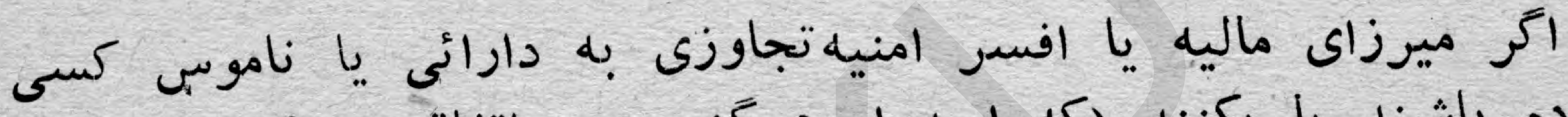

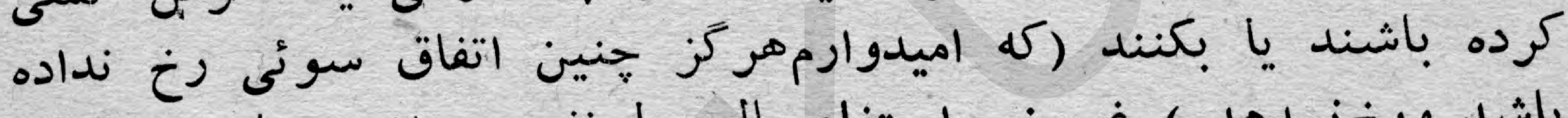

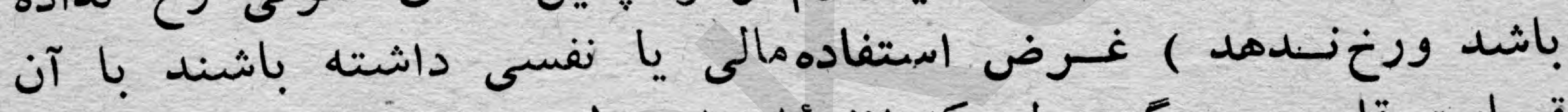

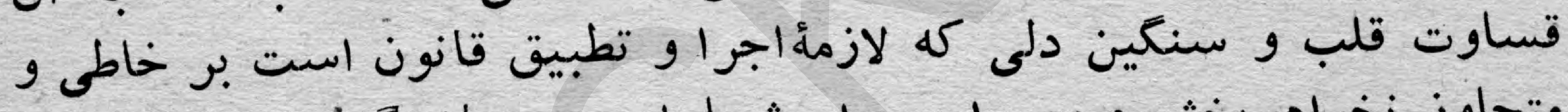

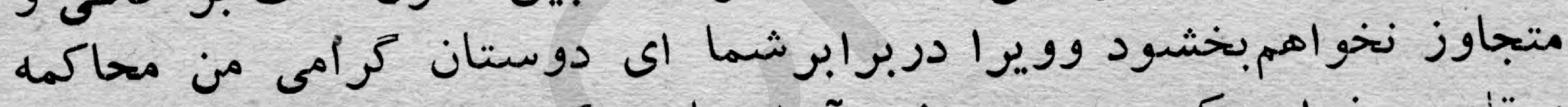

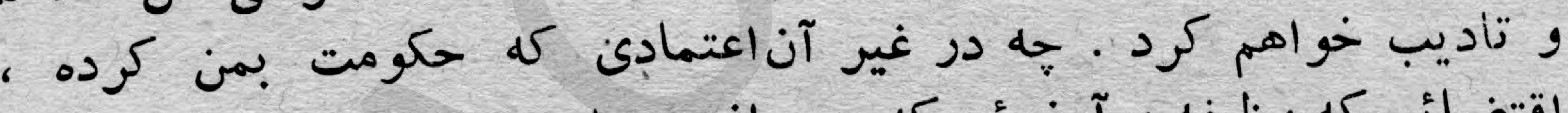

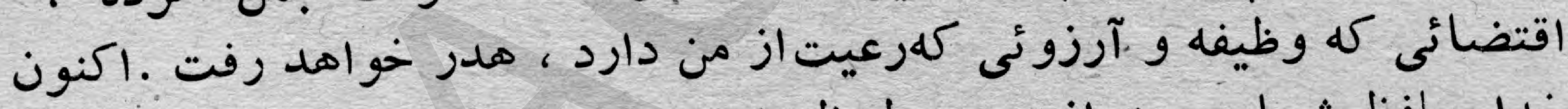

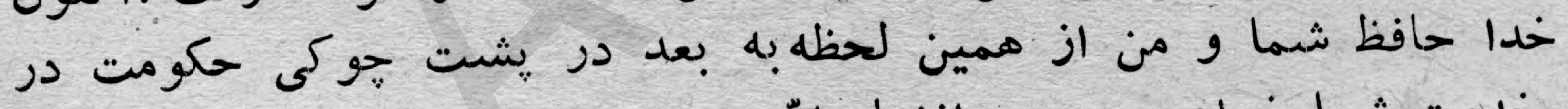
خدمي شما خو اهم بود ... انشاء الهاء

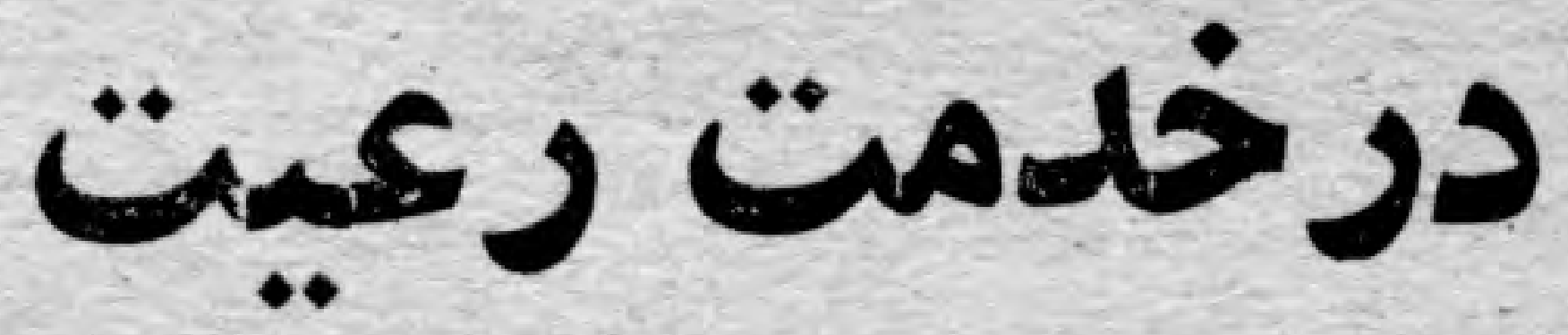

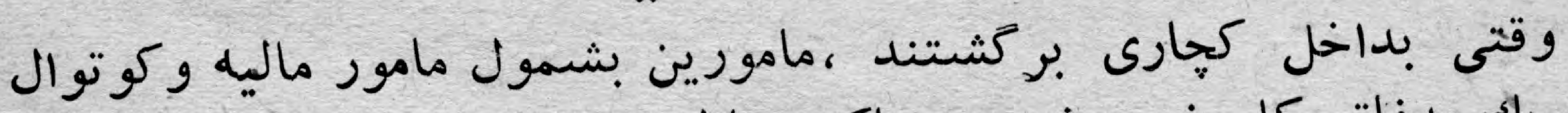

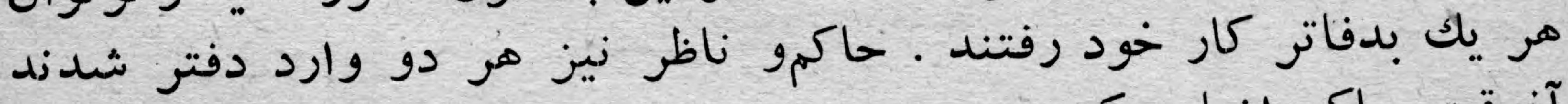

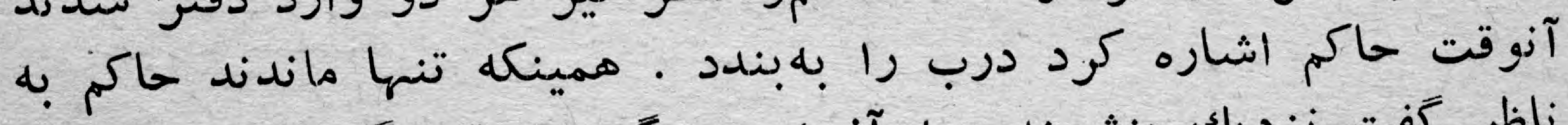

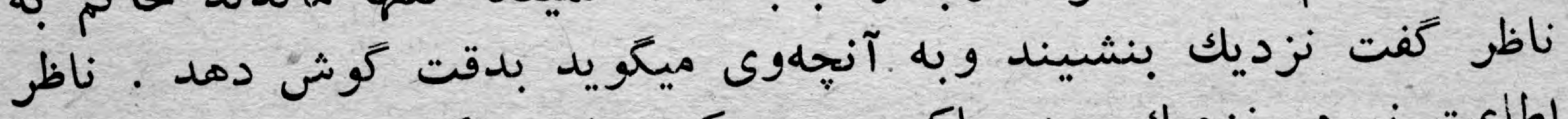

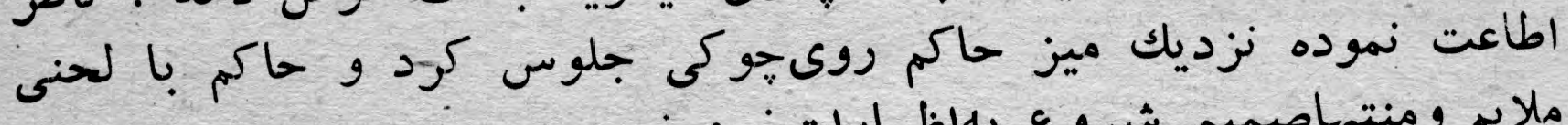

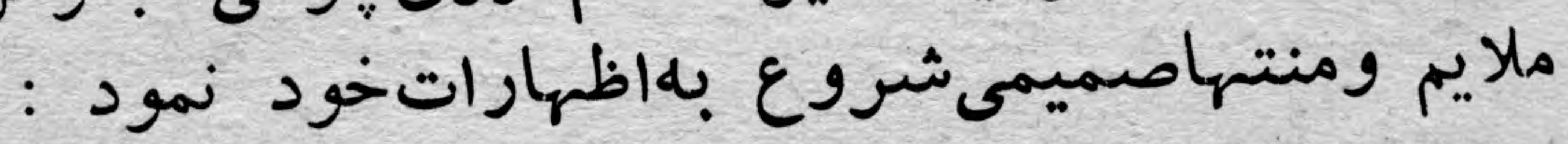

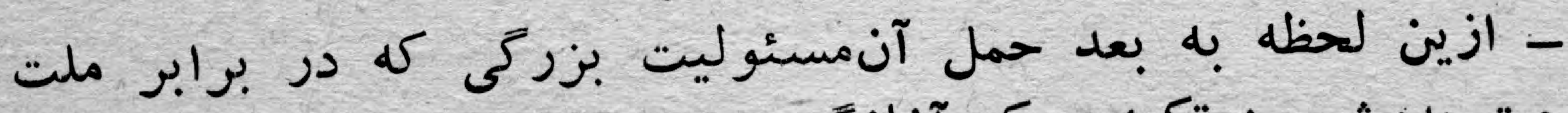

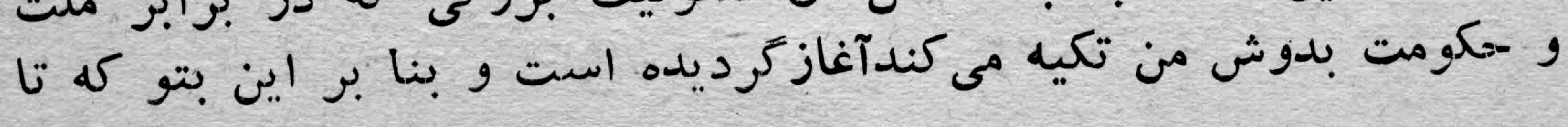




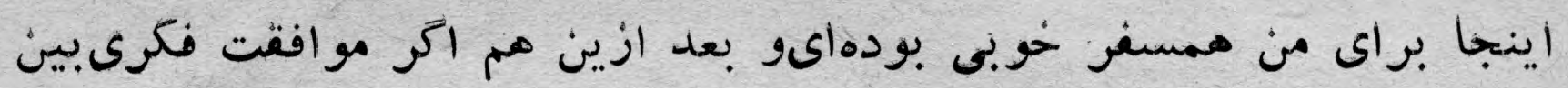

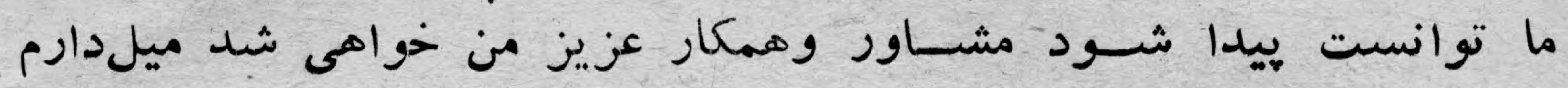

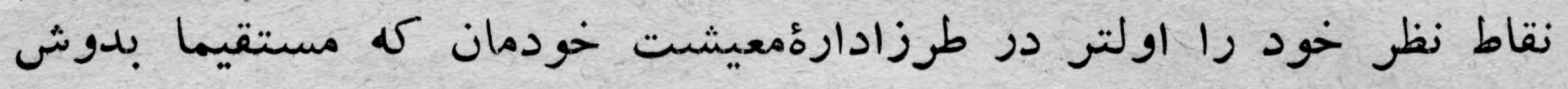

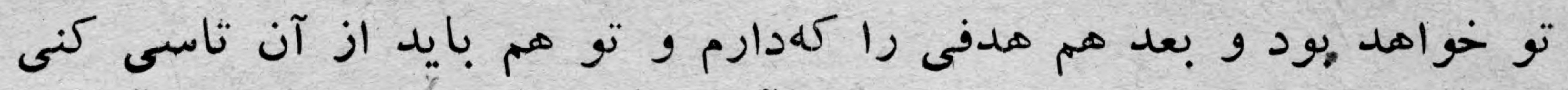

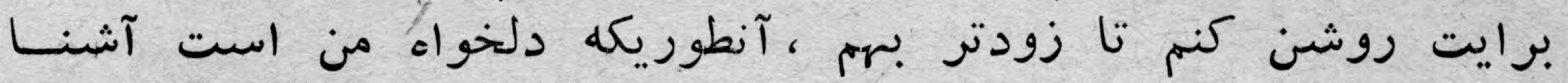

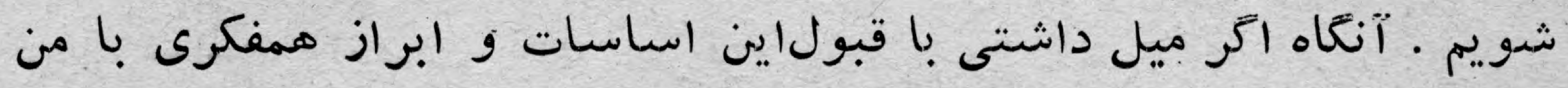

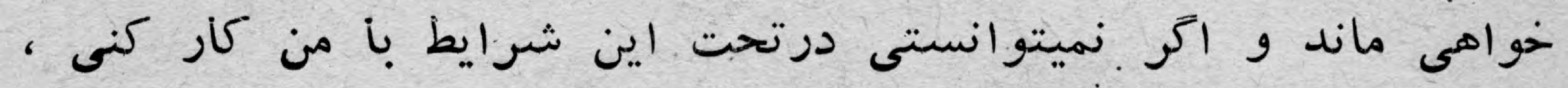

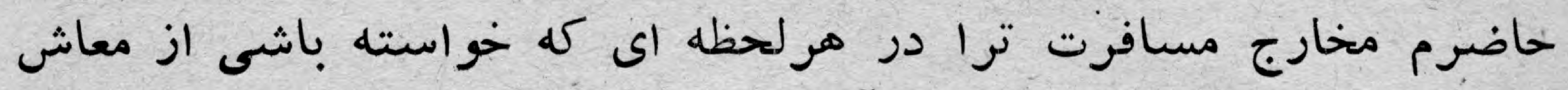

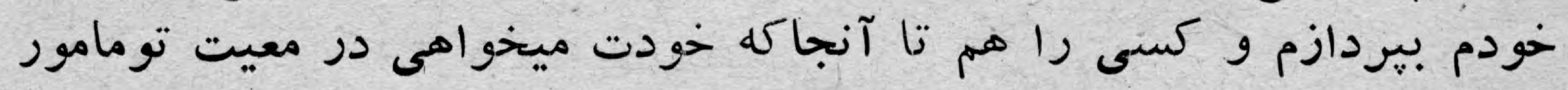

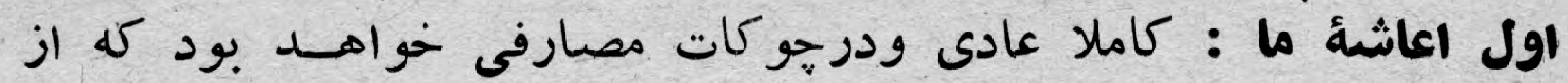

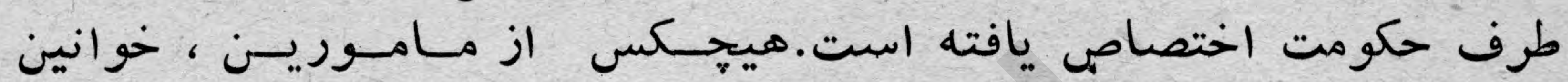

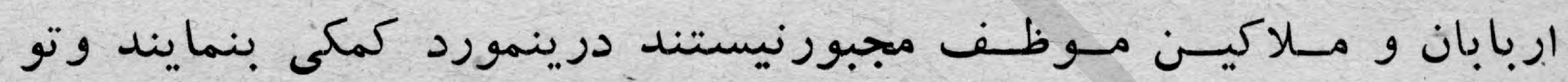

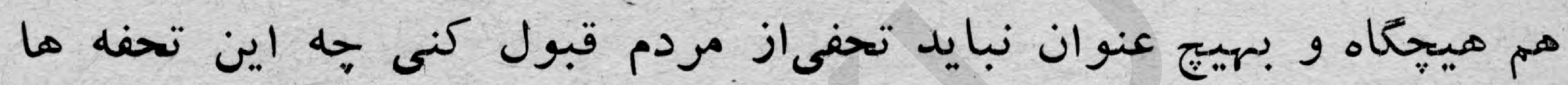

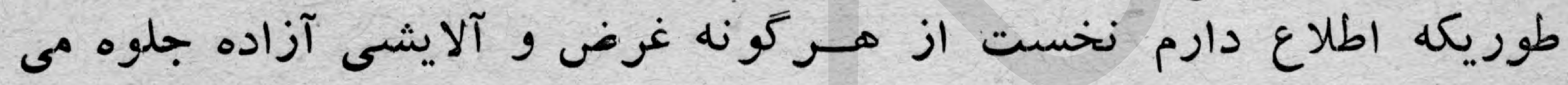

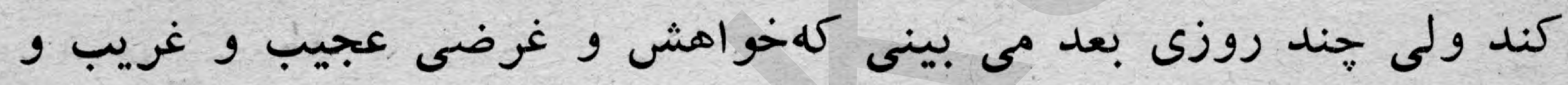

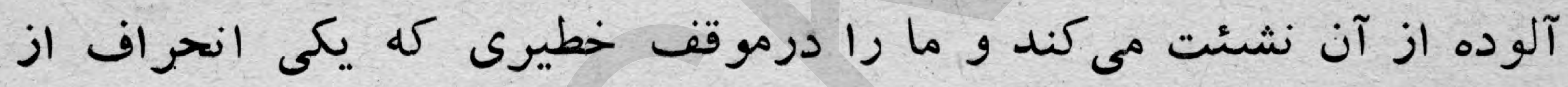

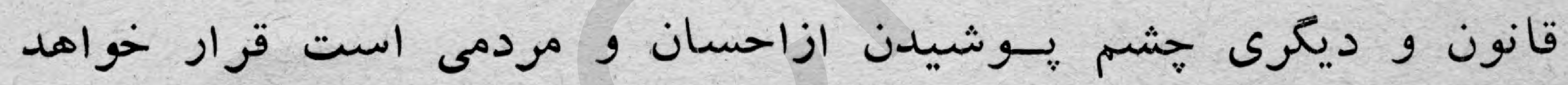

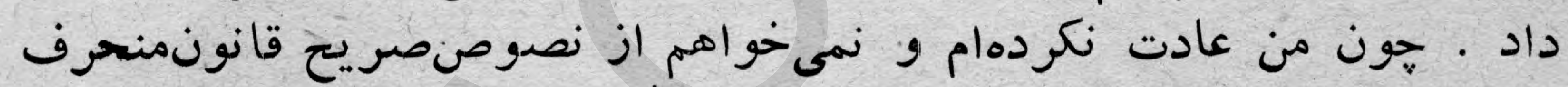

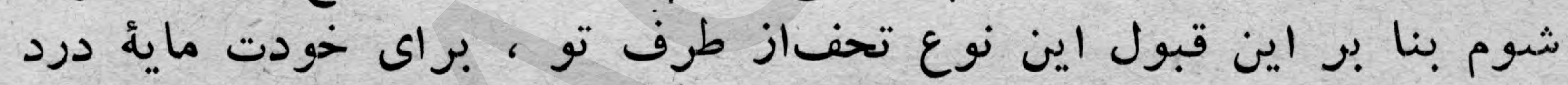

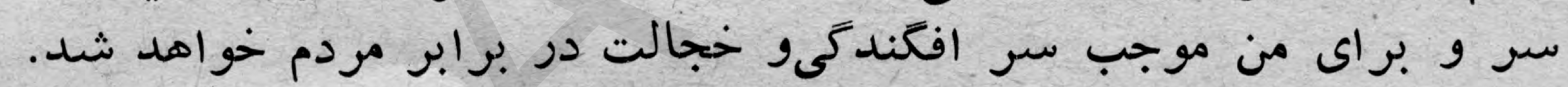

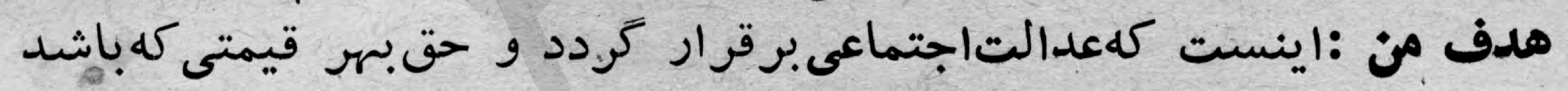

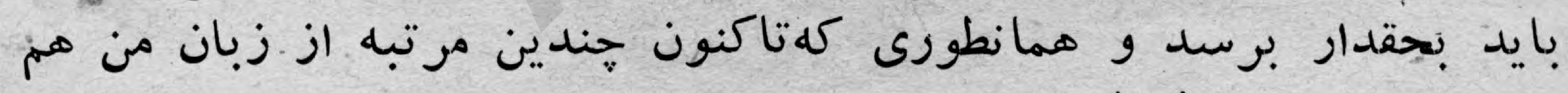

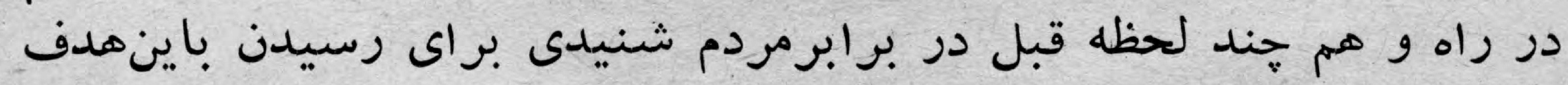

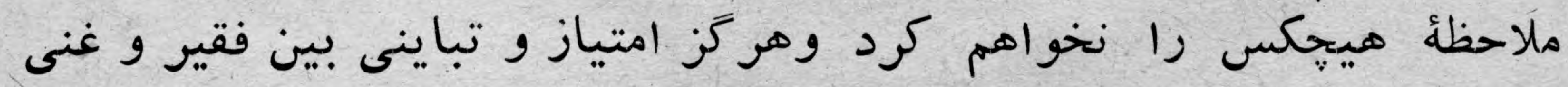

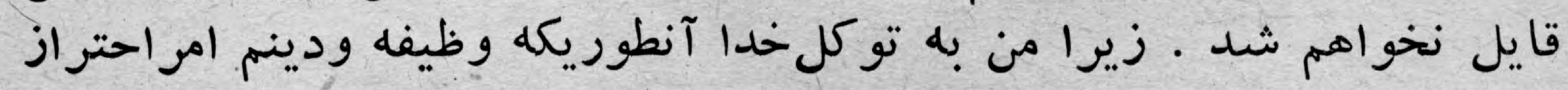

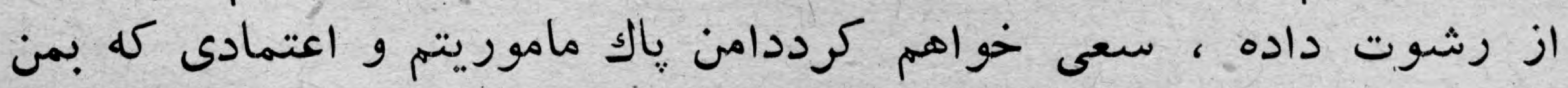

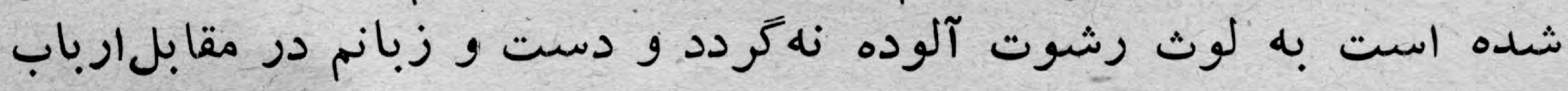

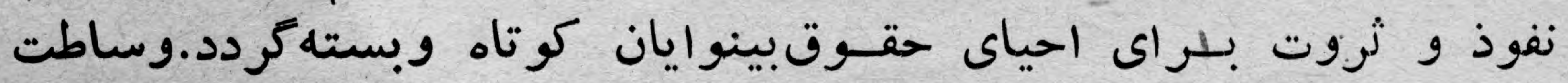

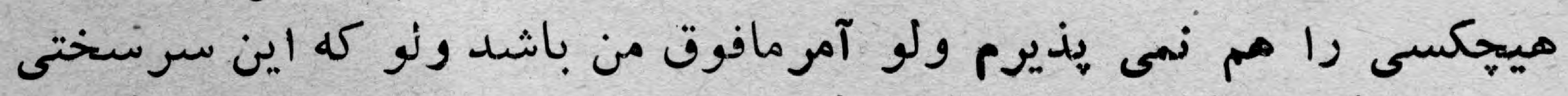

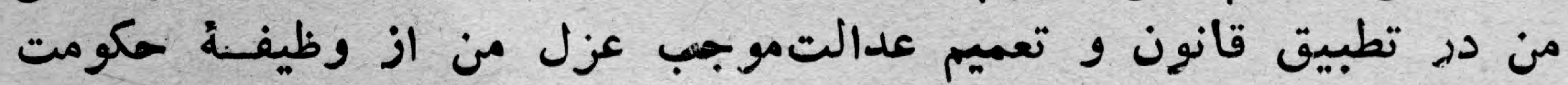
"Tr" 


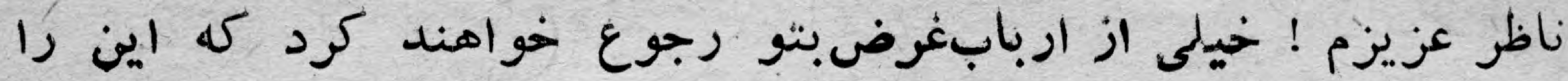

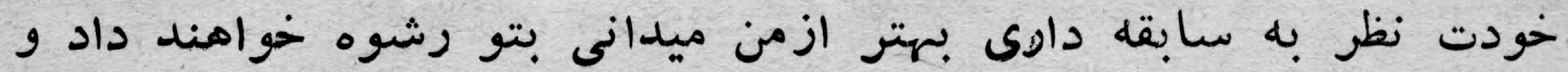

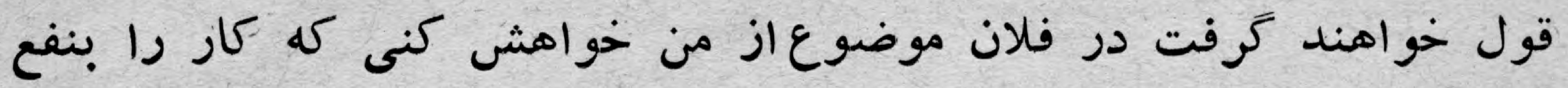

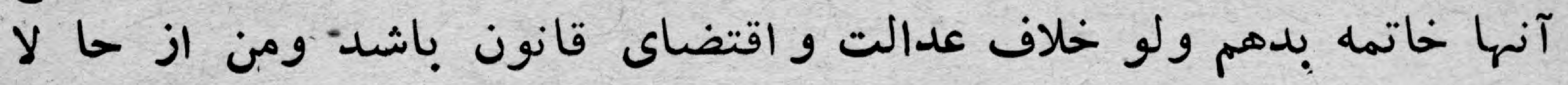

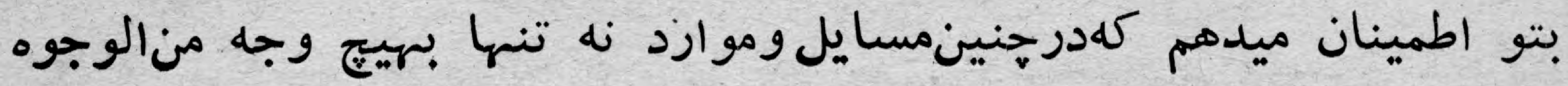

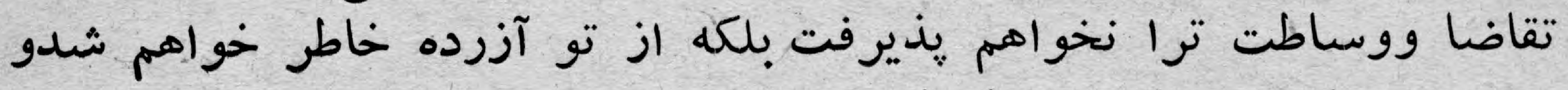

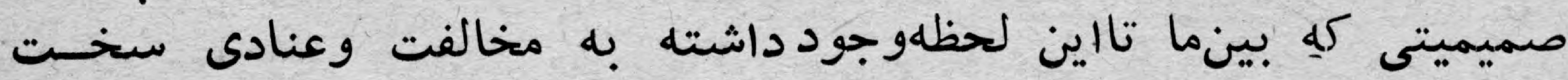

$$
\text { تبديل مى مردد. }
$$

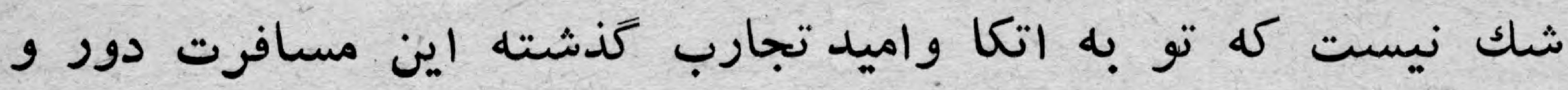

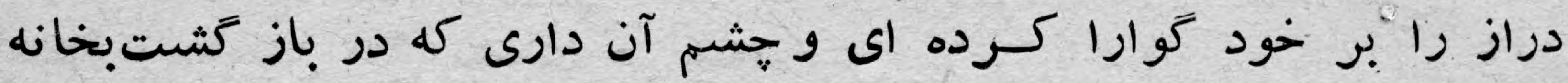

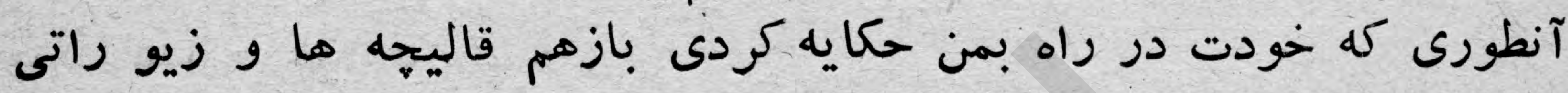

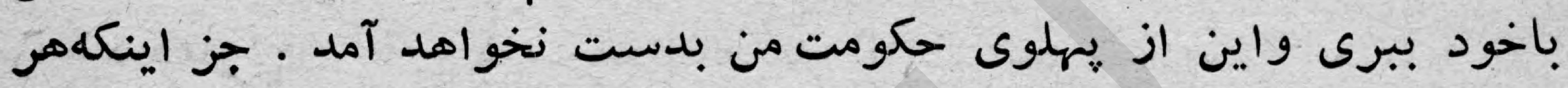

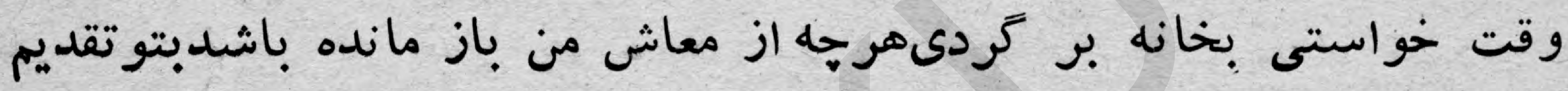

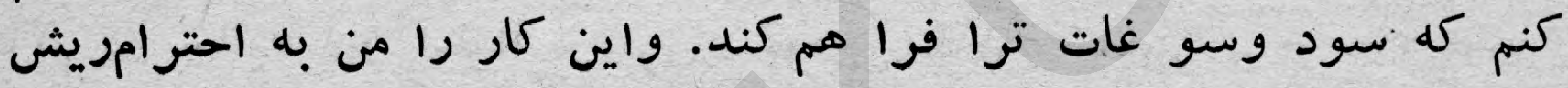

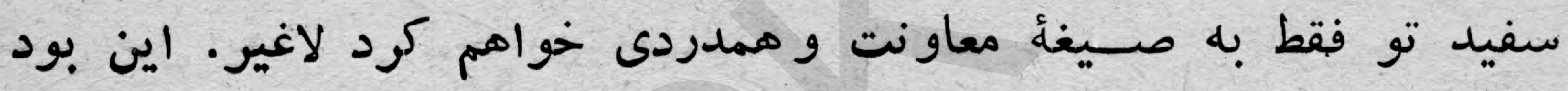

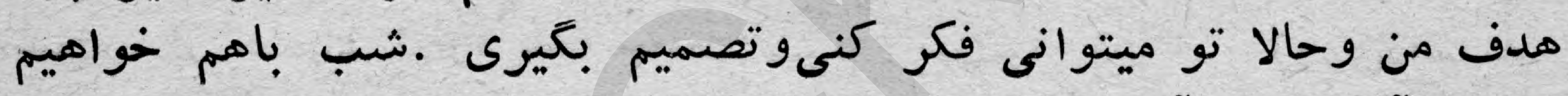

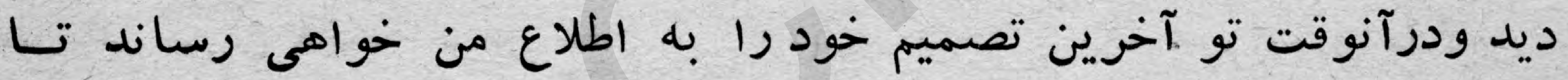

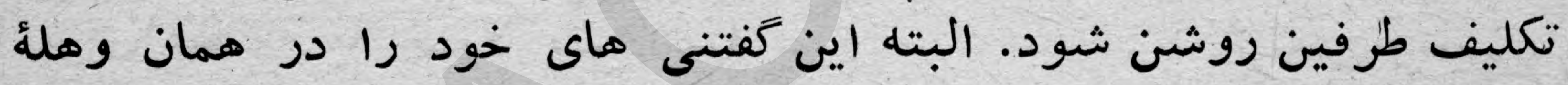

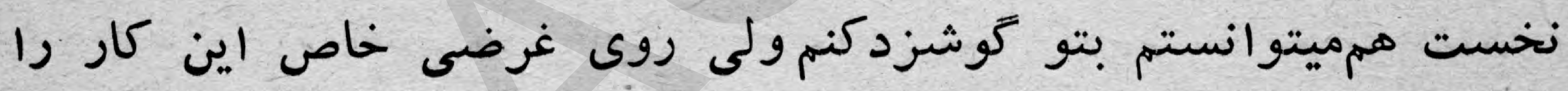

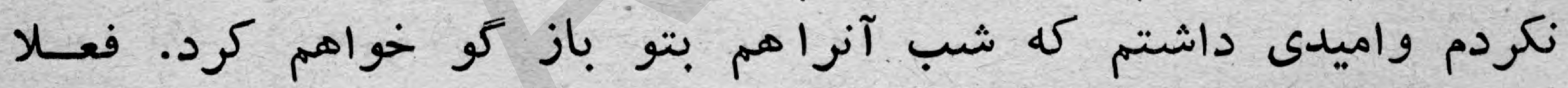

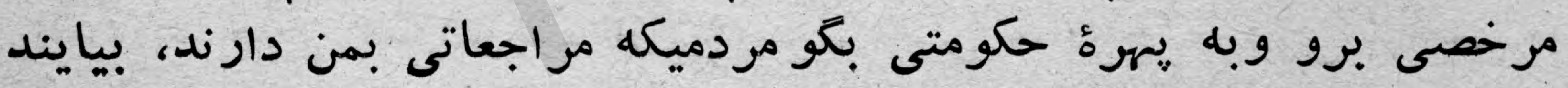

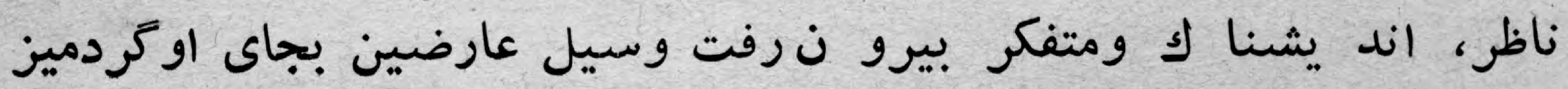

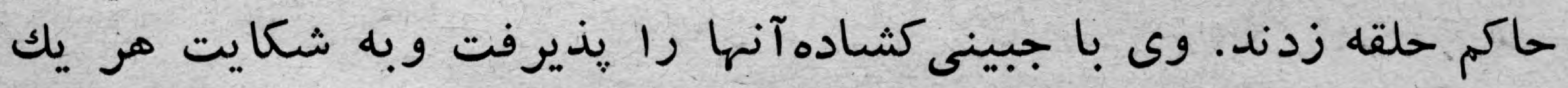

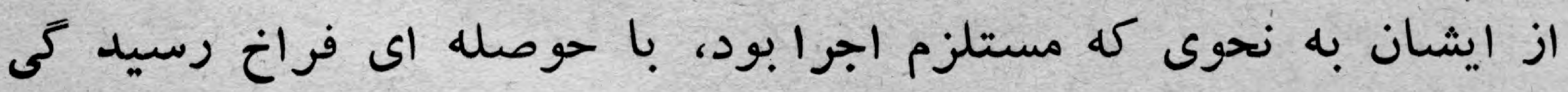

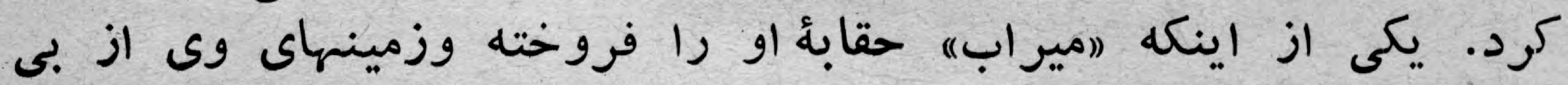

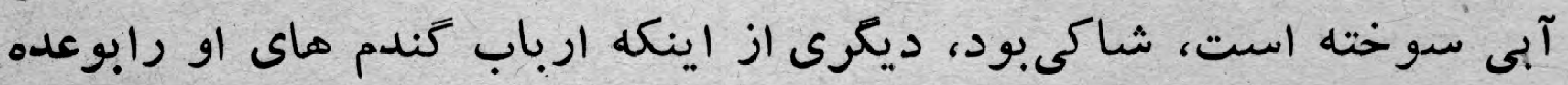

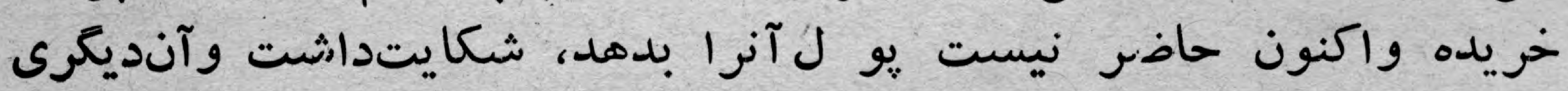

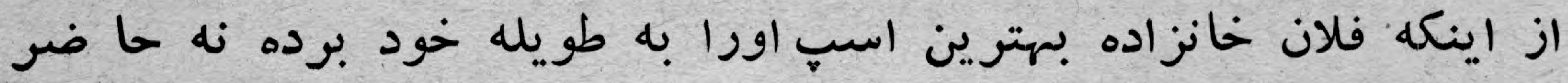

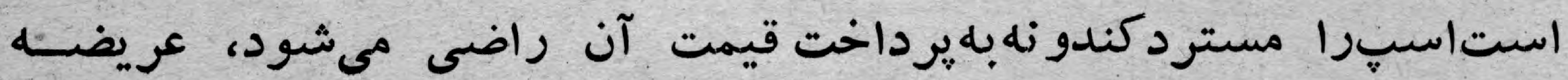

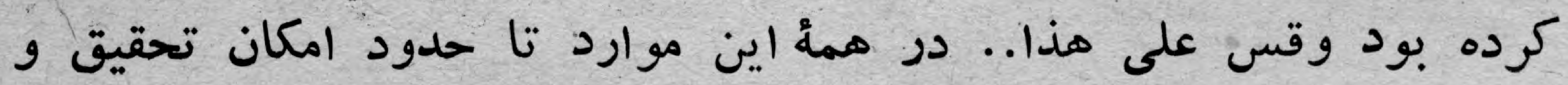


يس آن از مسلم كردانيدن حقوت شا نحق رابحقدار سيرد. آخرينعريضهاى

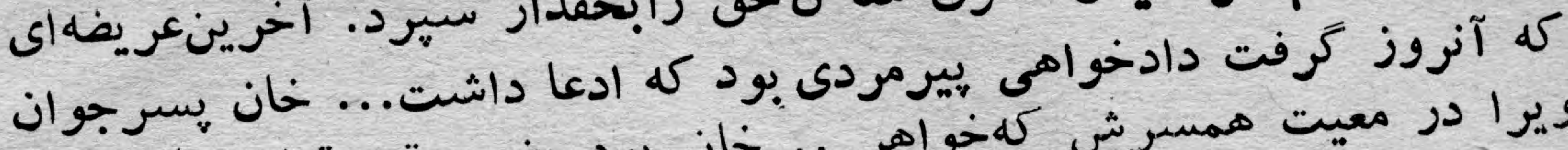

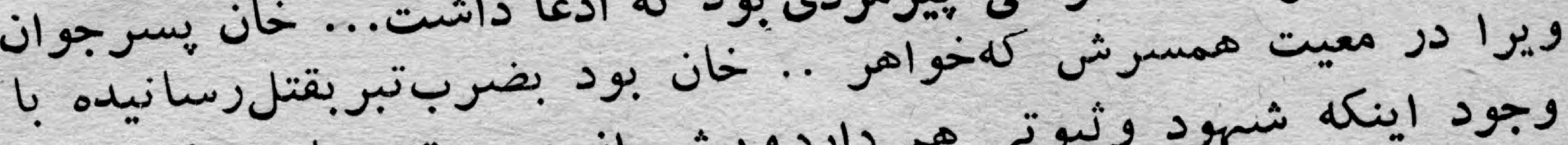

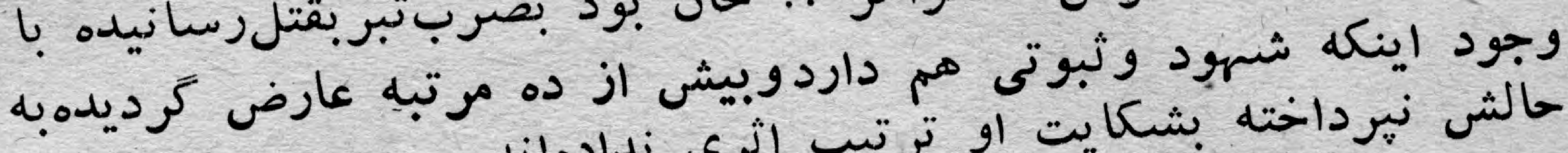

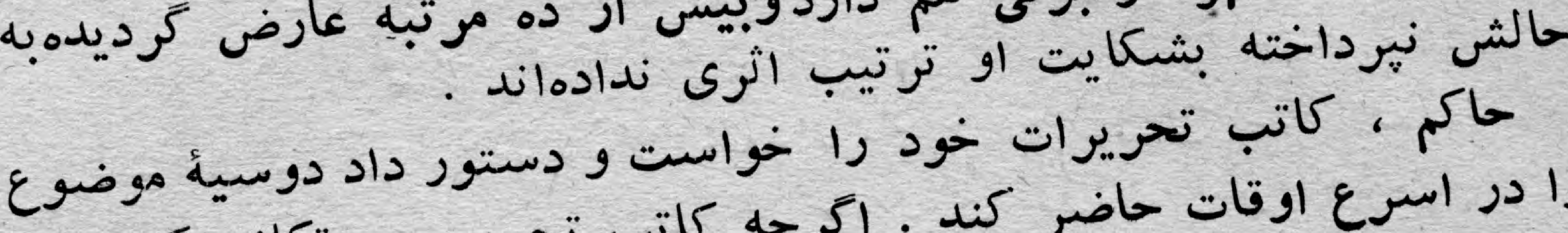

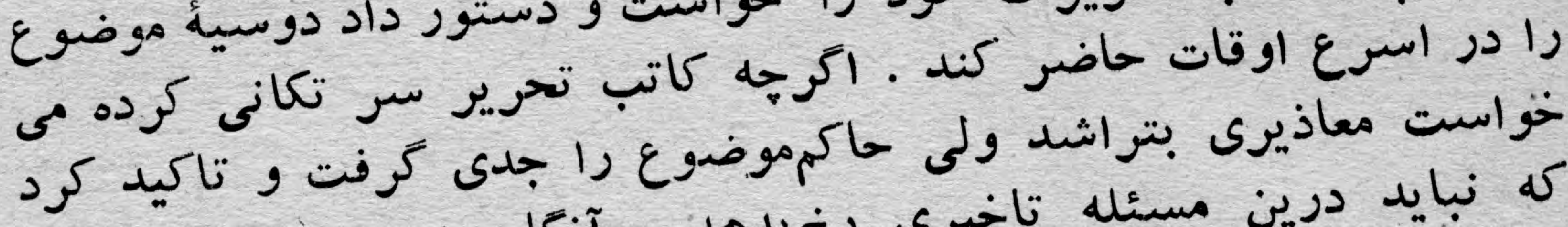

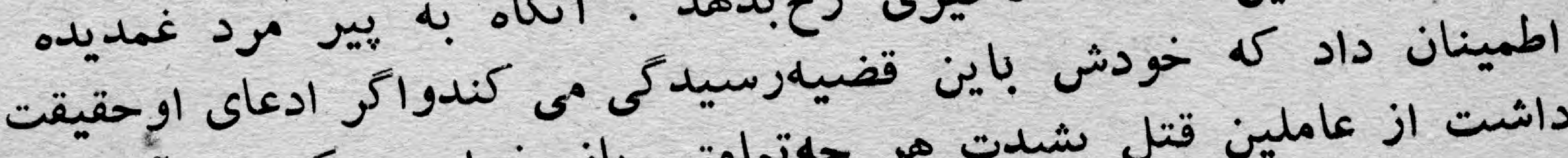

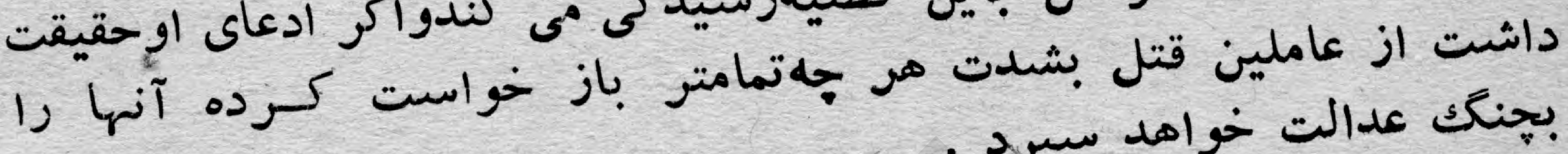

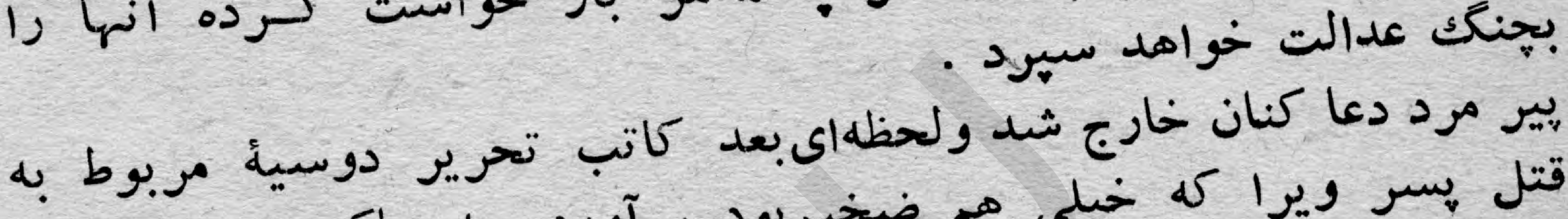

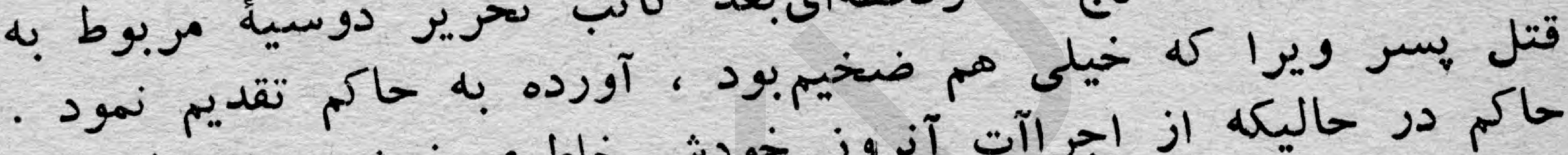

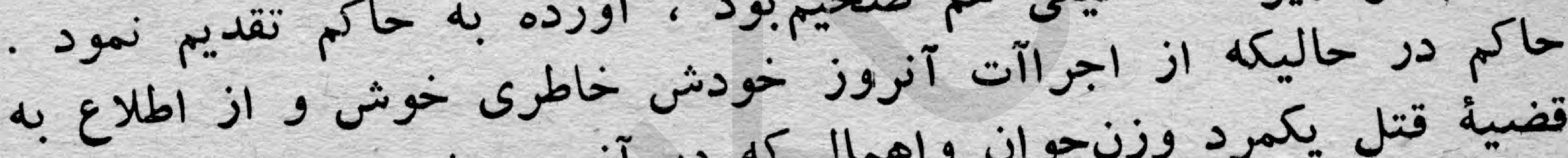

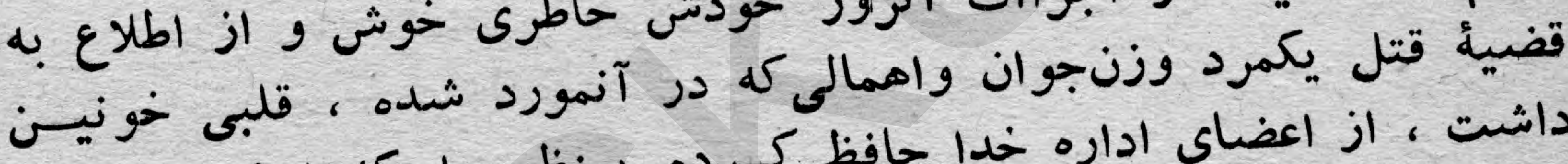

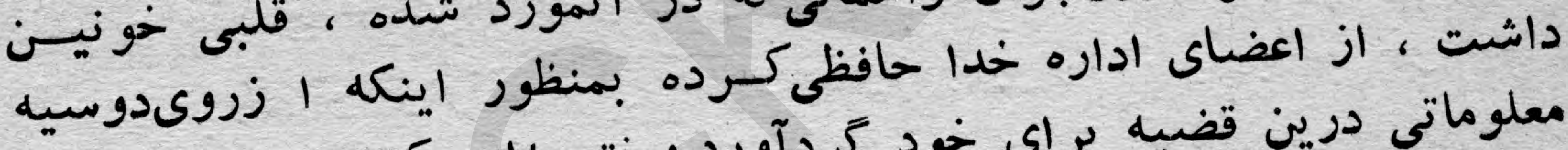

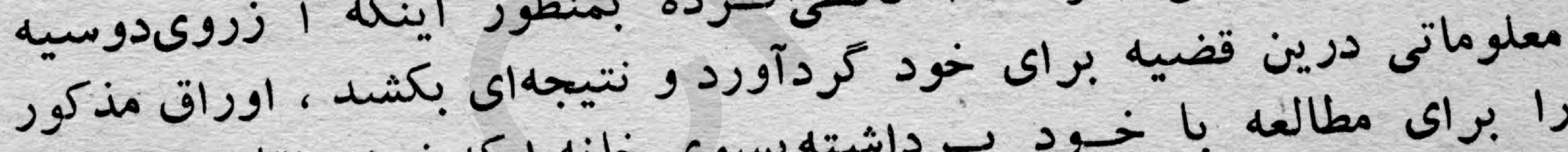

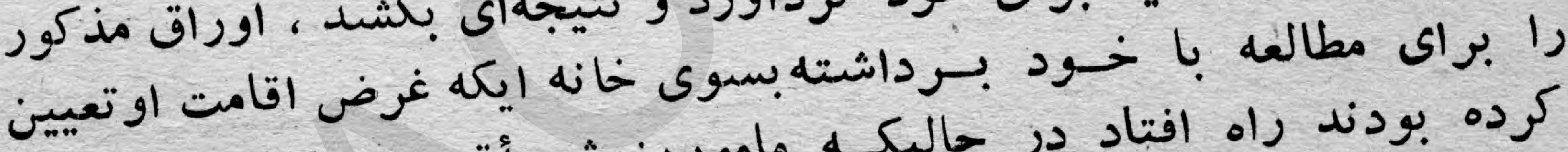

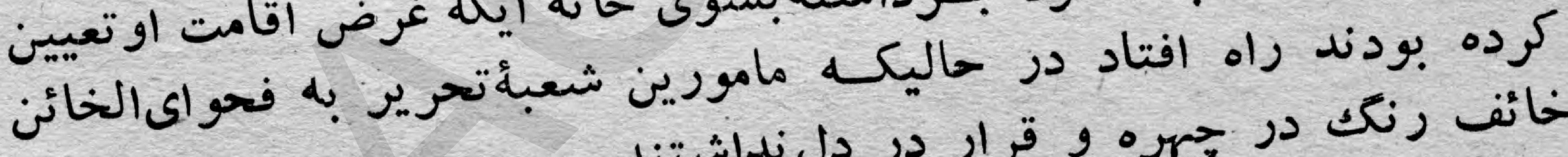

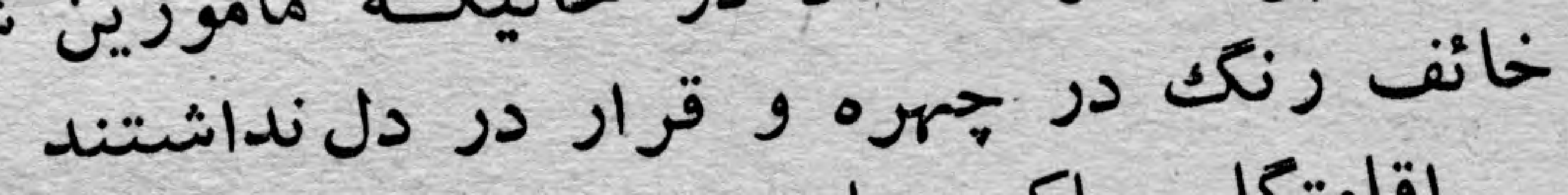

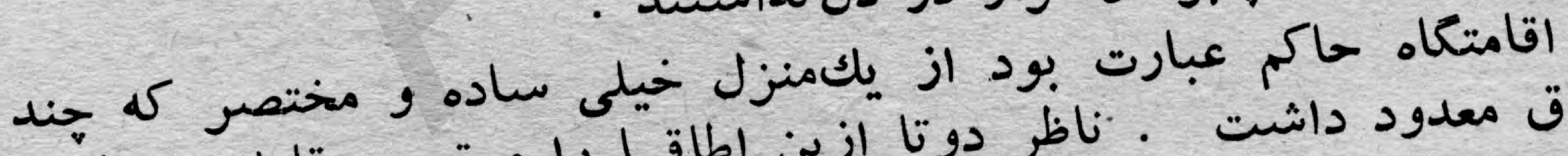

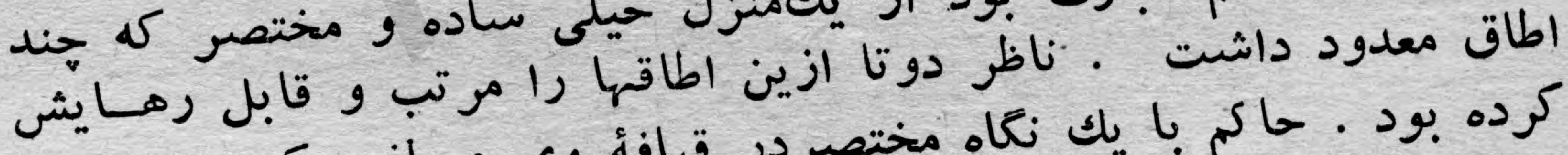

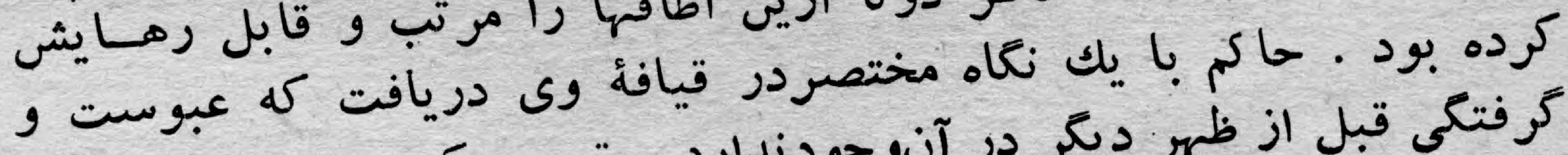

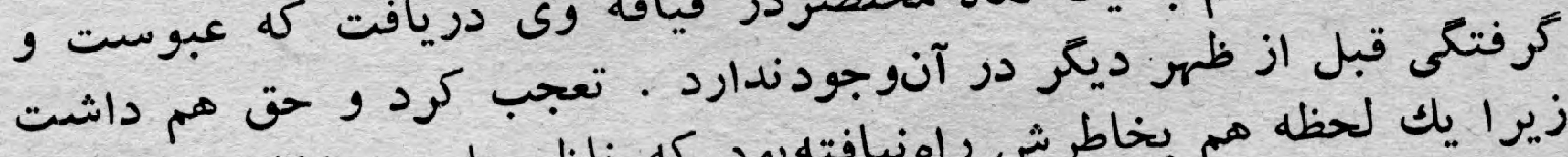

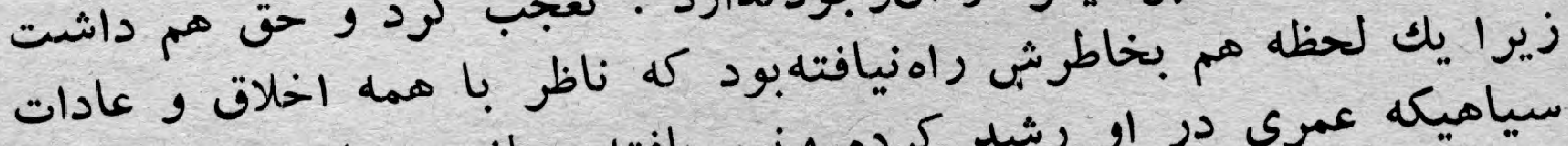

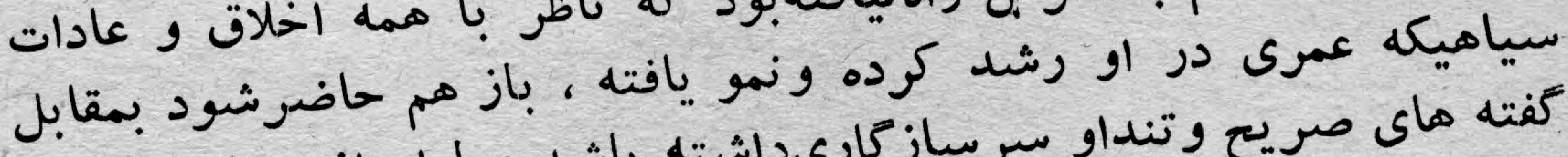

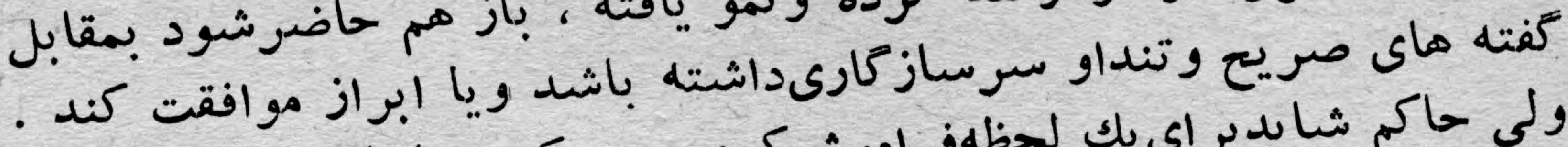

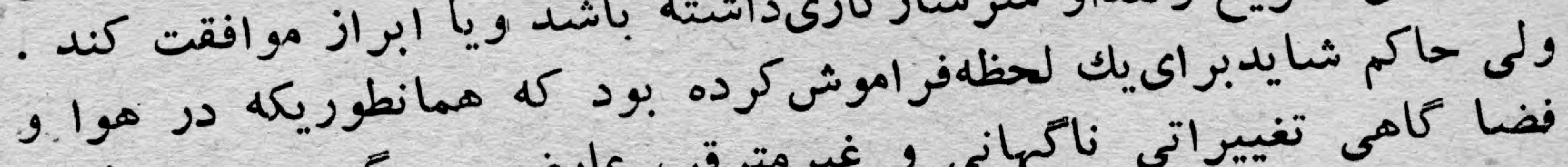

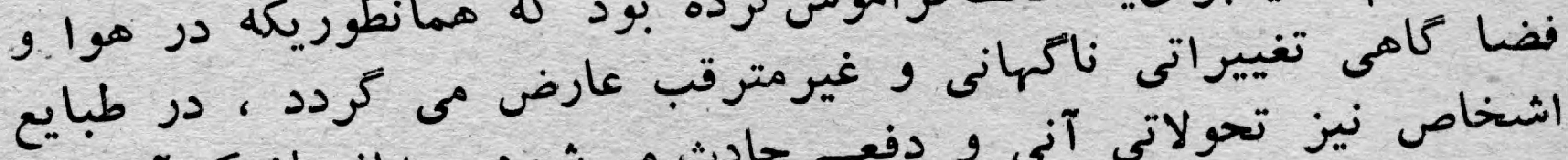

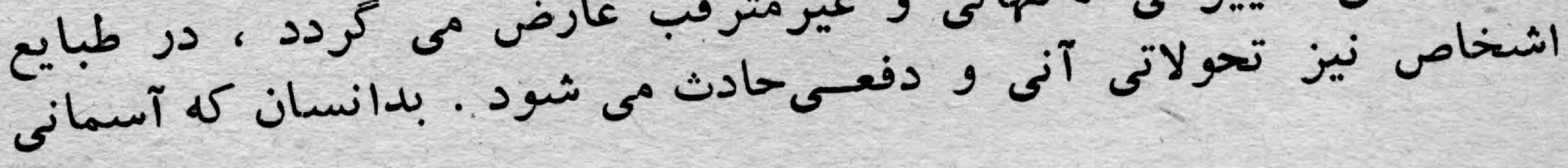


صاف و بى ابر ناكهان خشمكين شدهو در اواسط تابستان بوف و و و برو باران

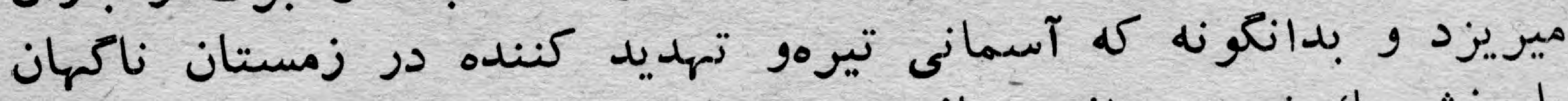

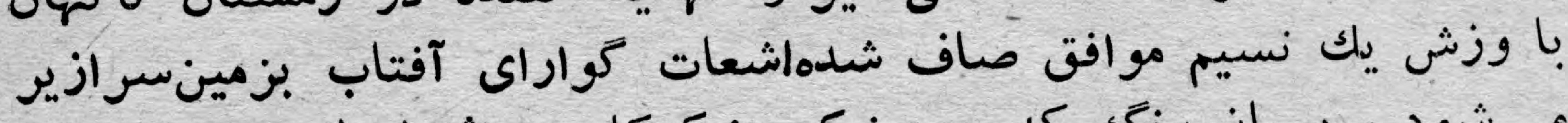

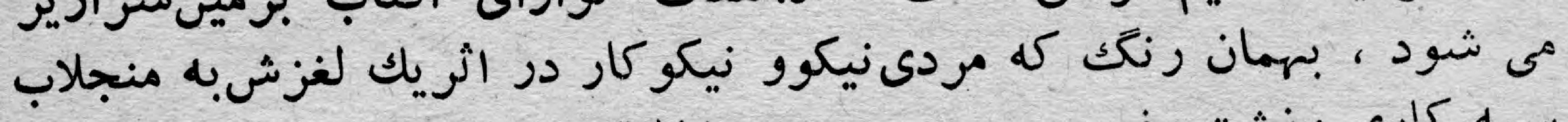

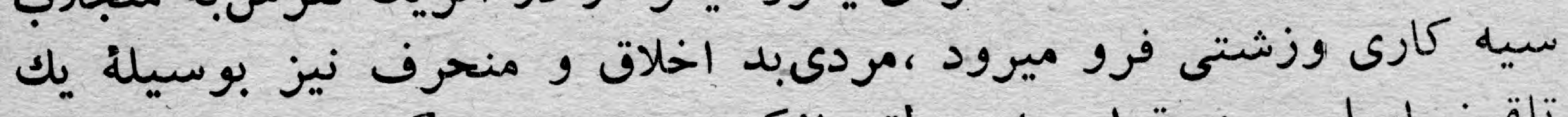

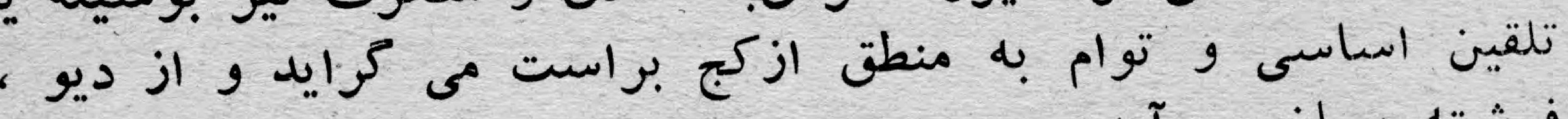

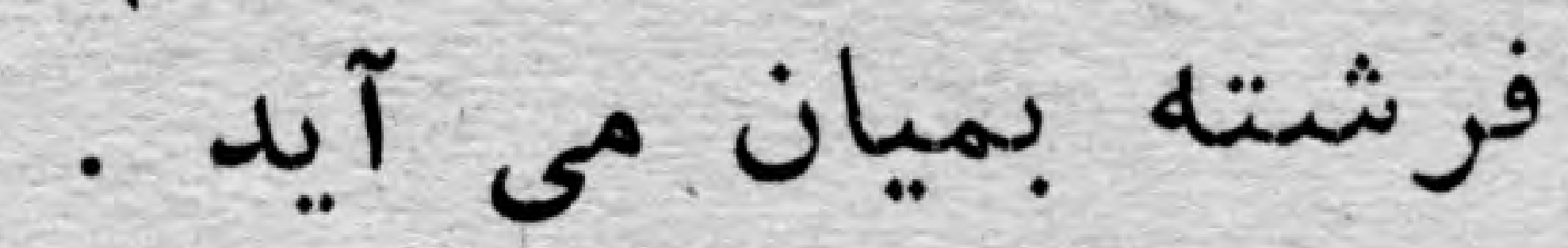
روح ناظر سالخوزده ، ناظرى آند كلهمرى منحرف ون بود و ظروف وامكانات

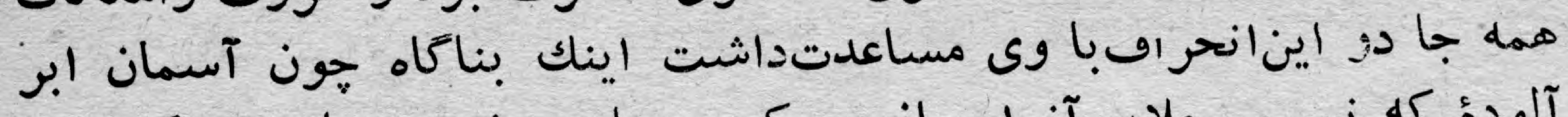

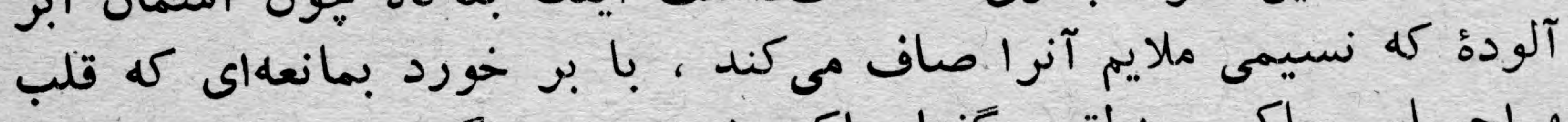

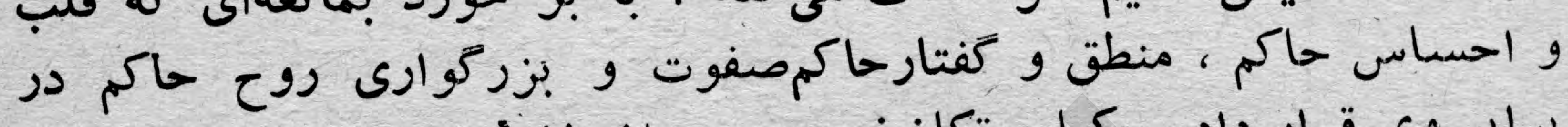

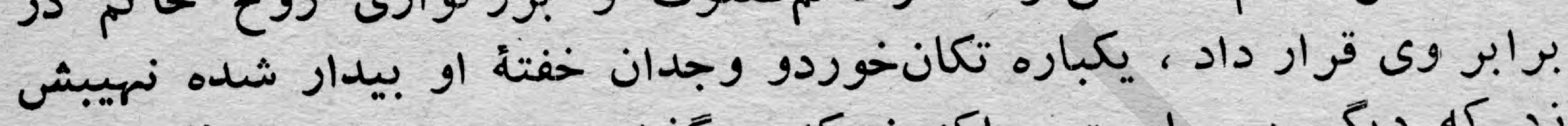

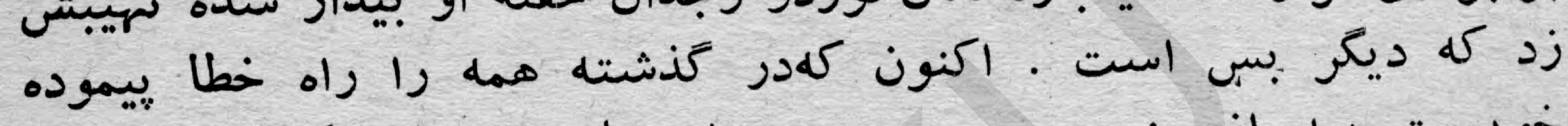

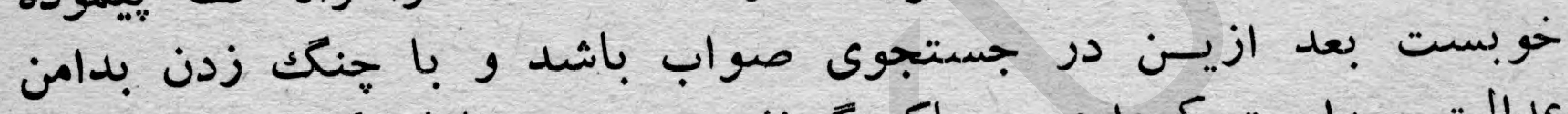

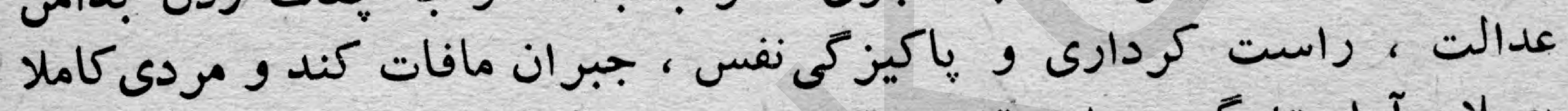

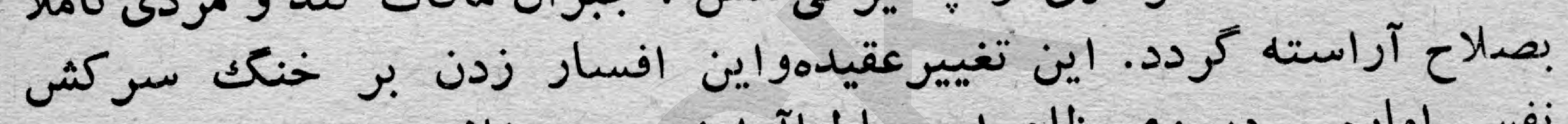

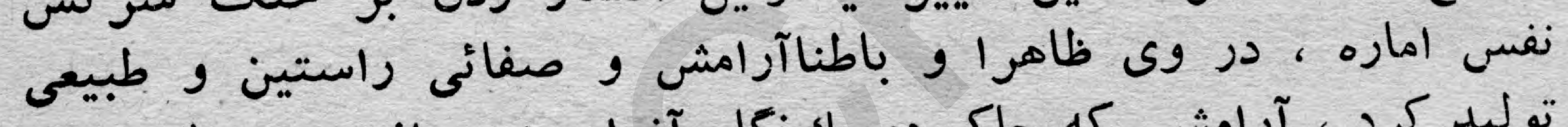

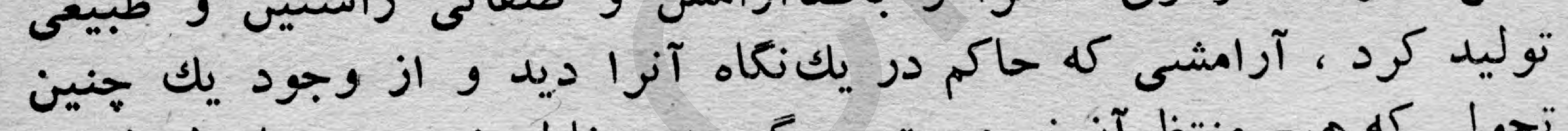

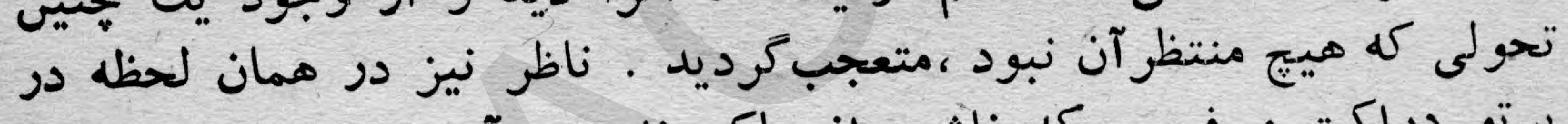

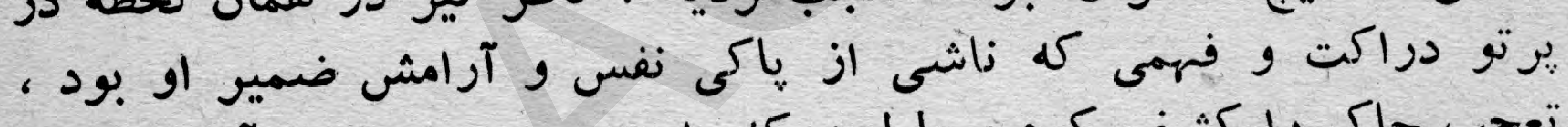

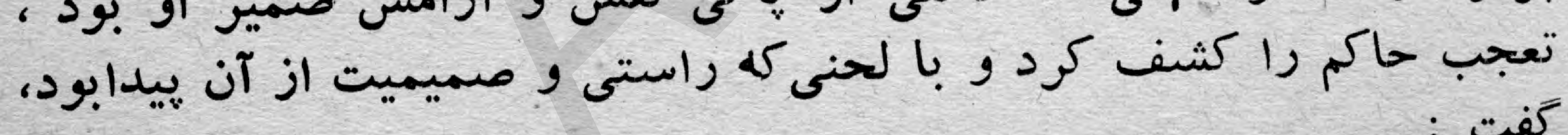

كفت : كنج

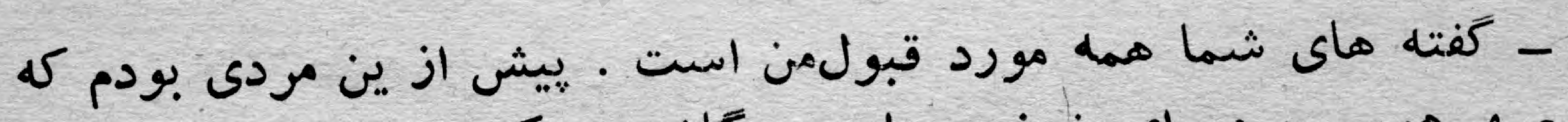

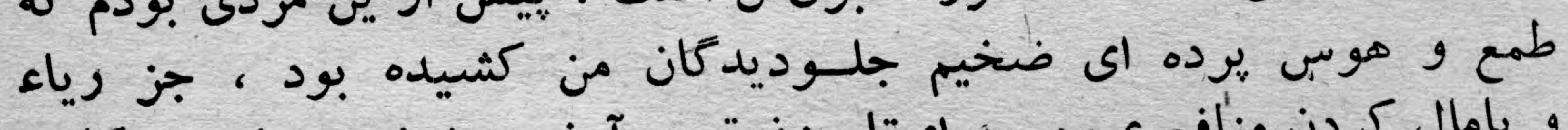

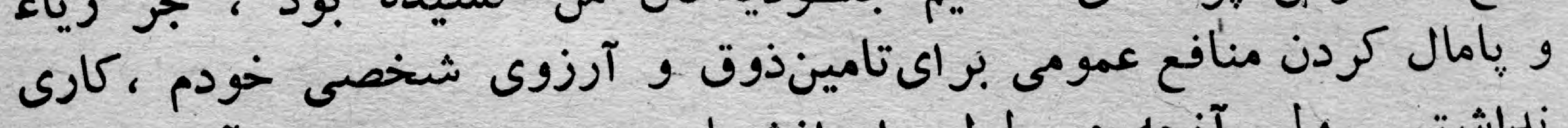

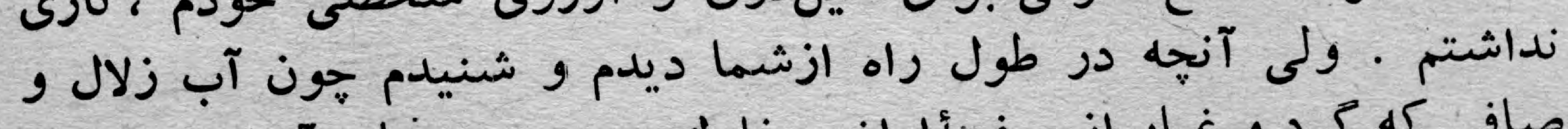

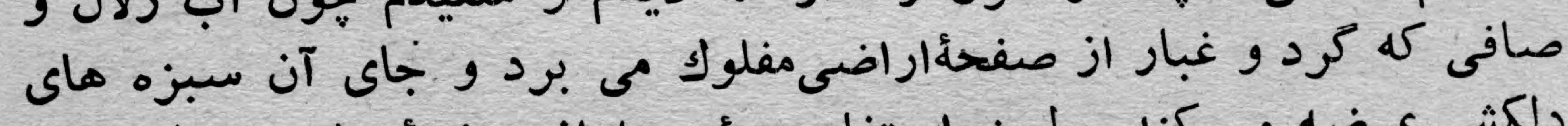

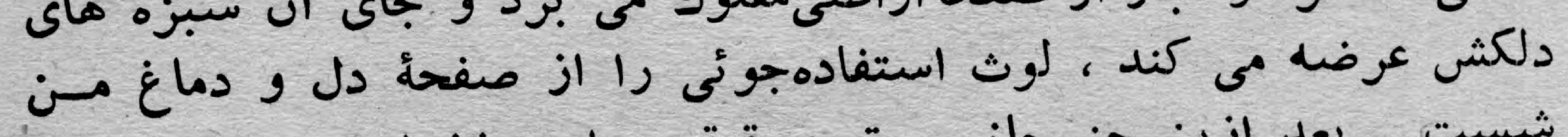

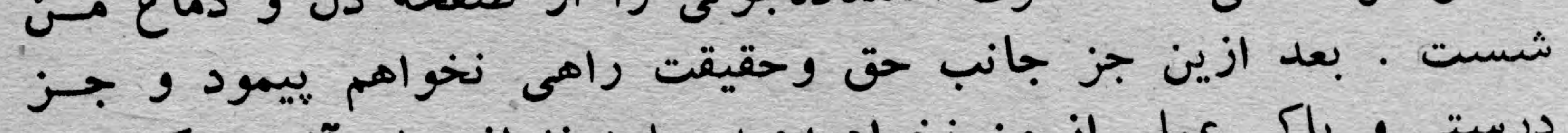

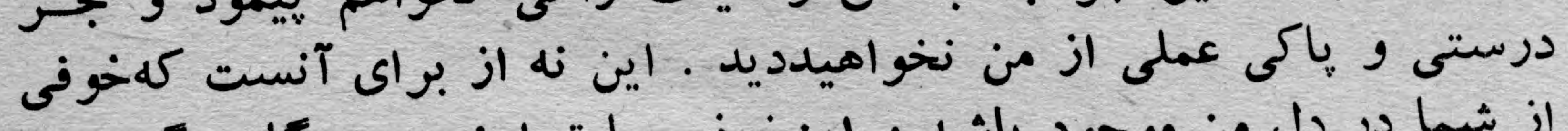

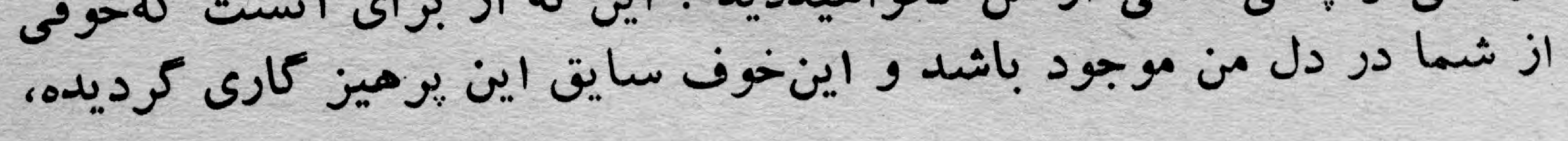

aron 


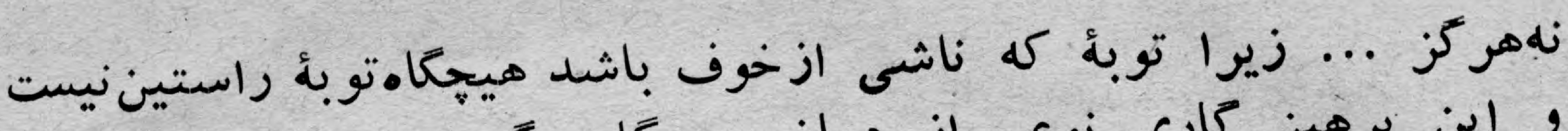

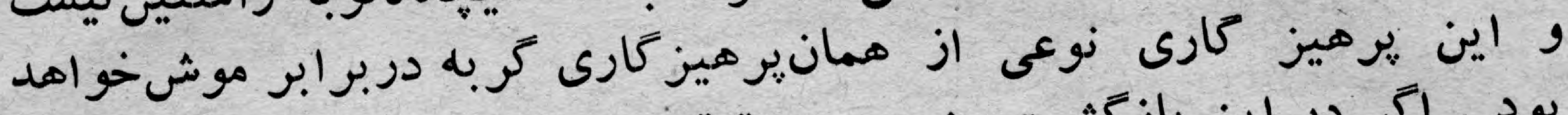

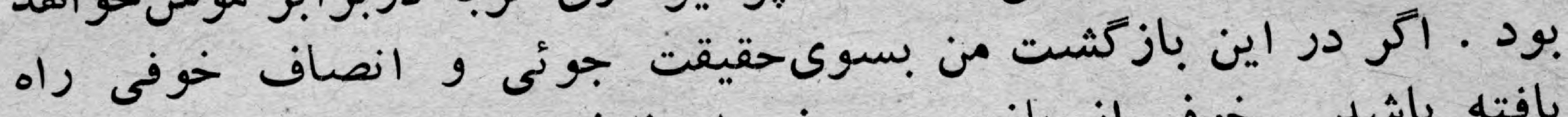

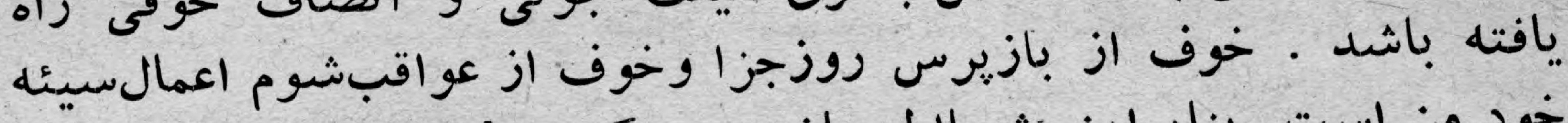

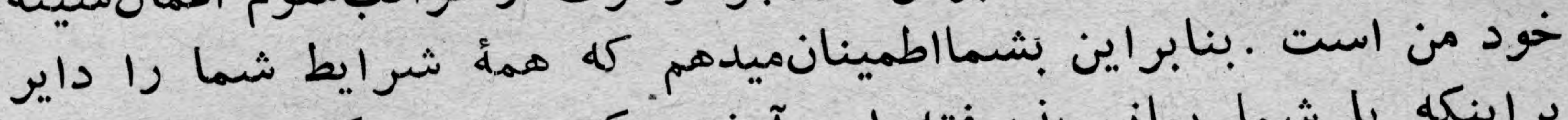

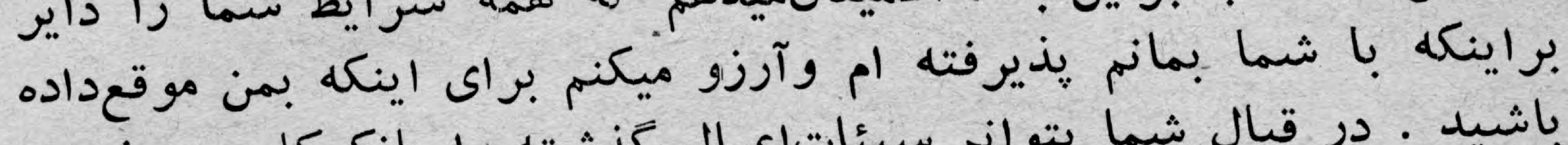

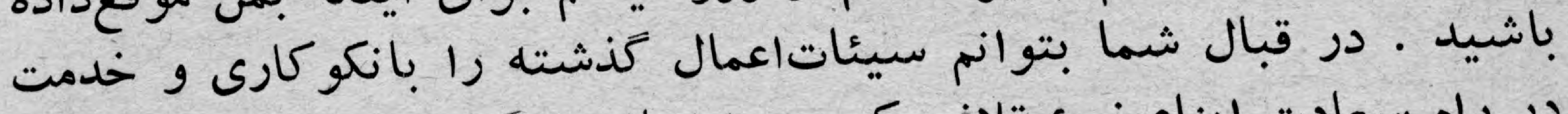

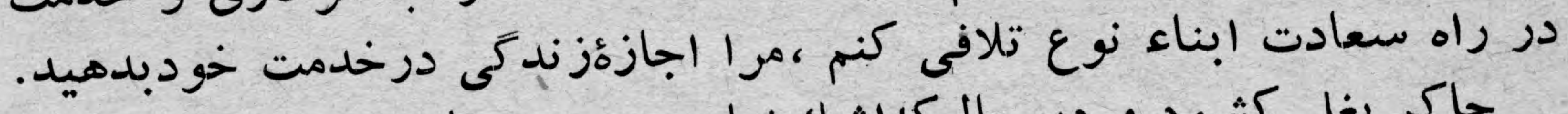

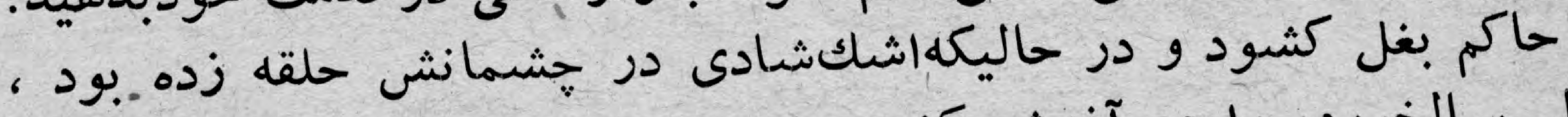

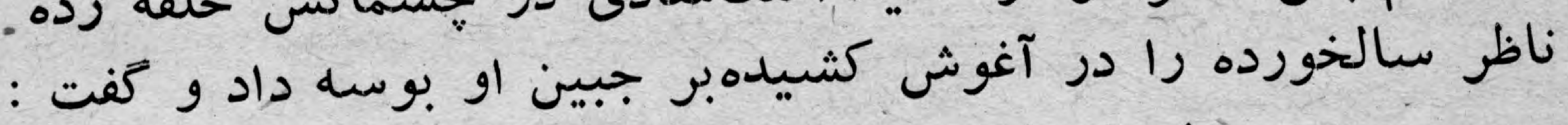

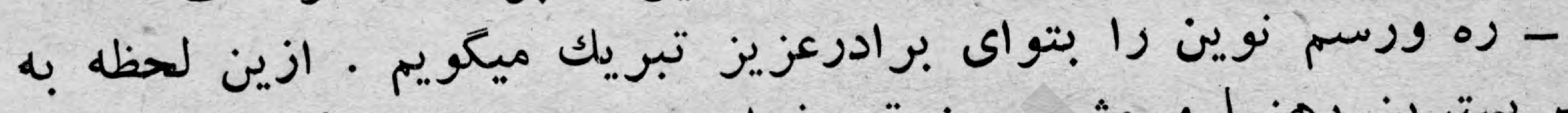

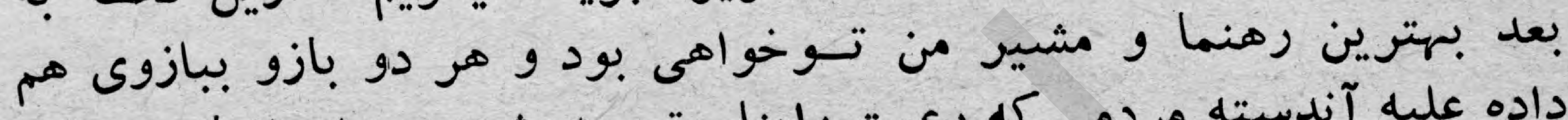

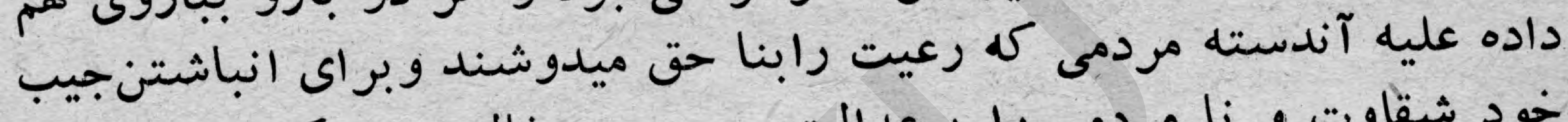

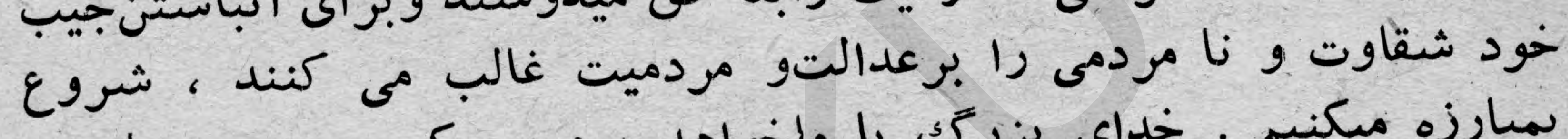

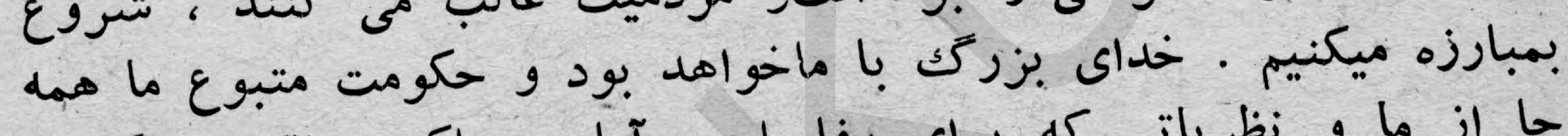

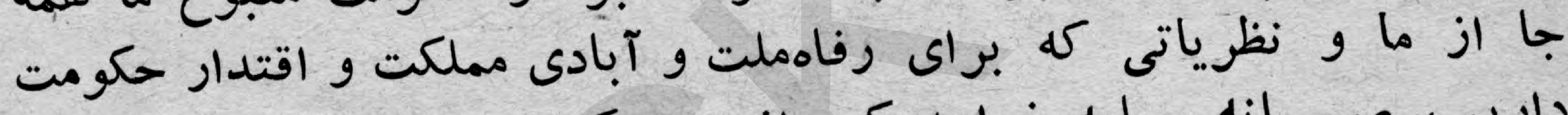

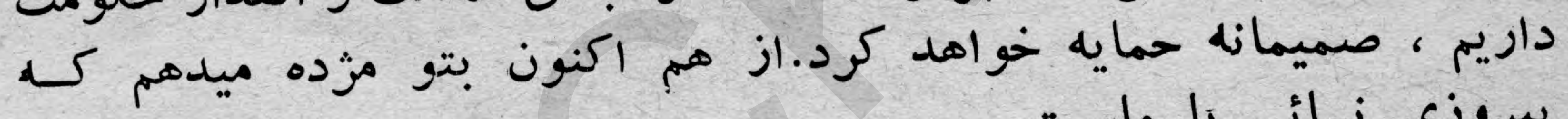

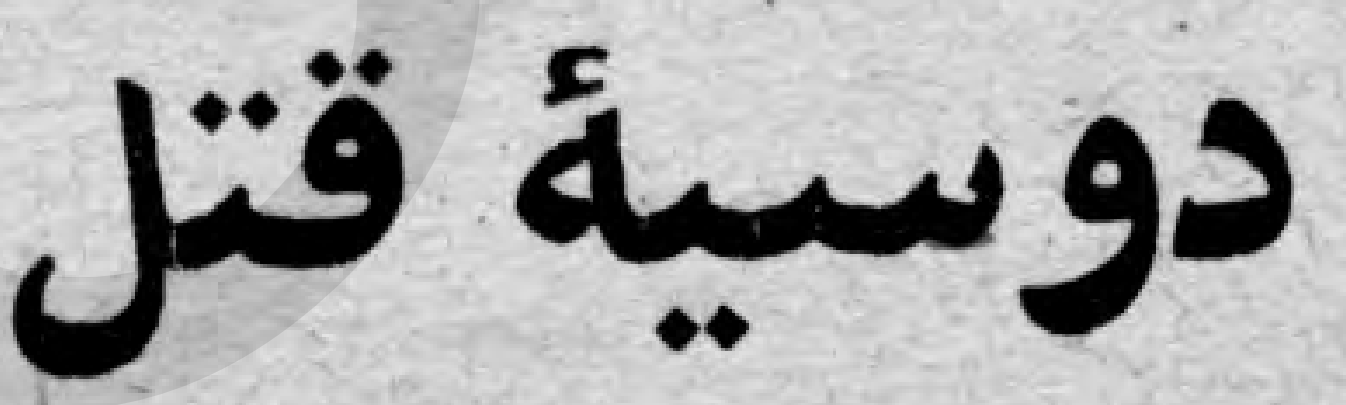

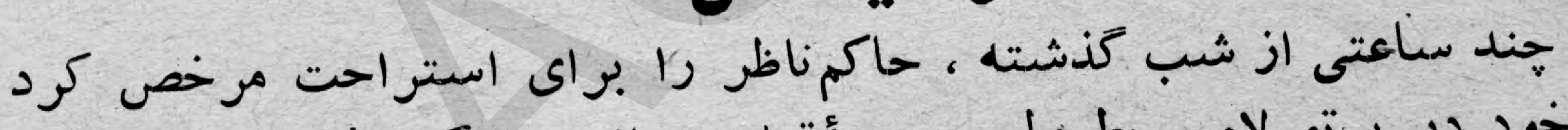

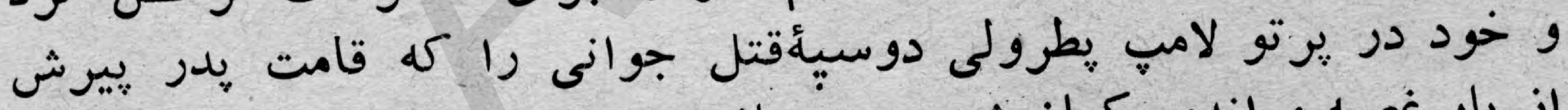

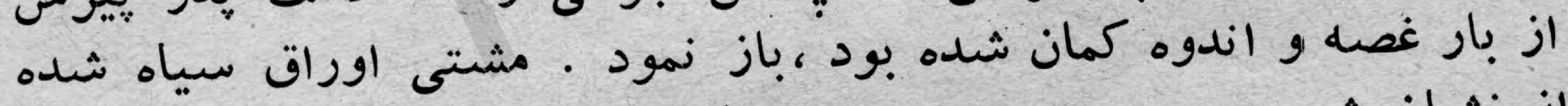

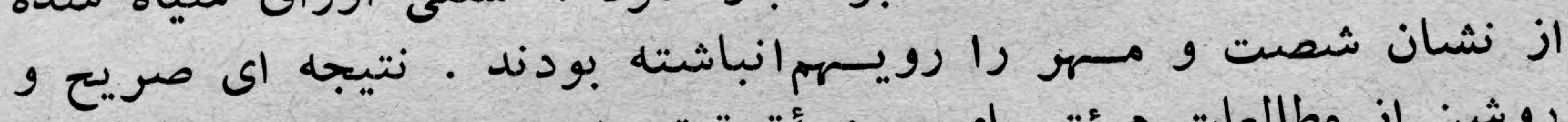

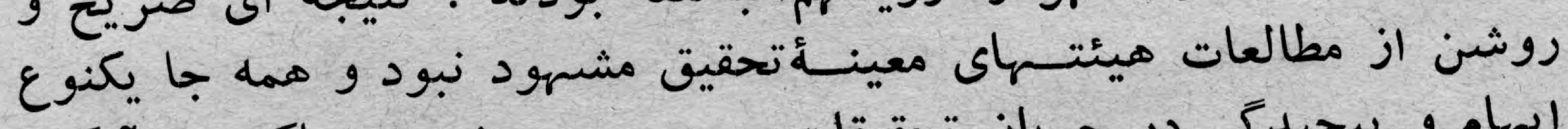

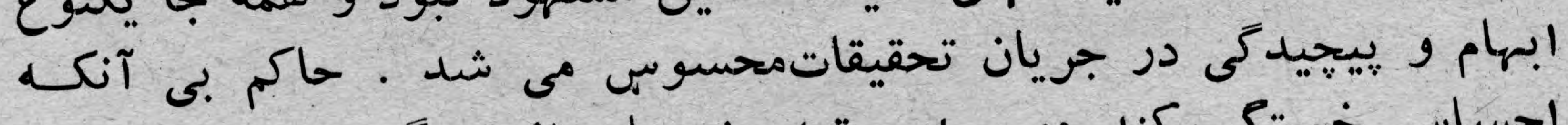

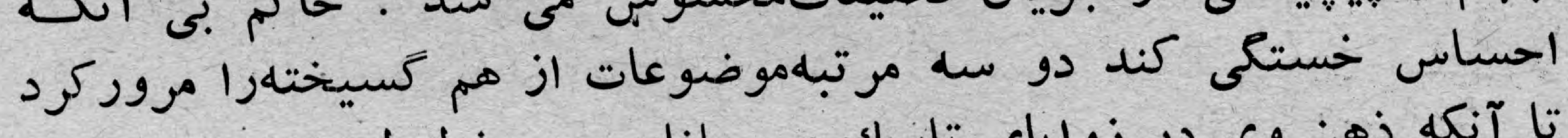

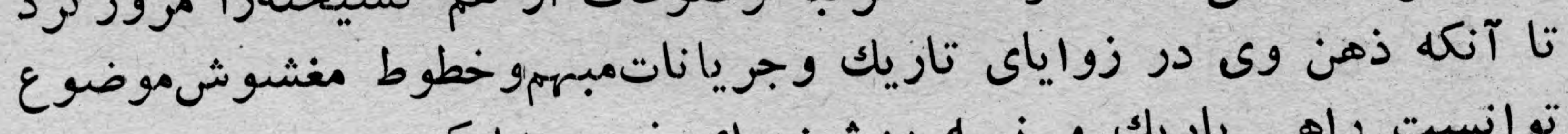

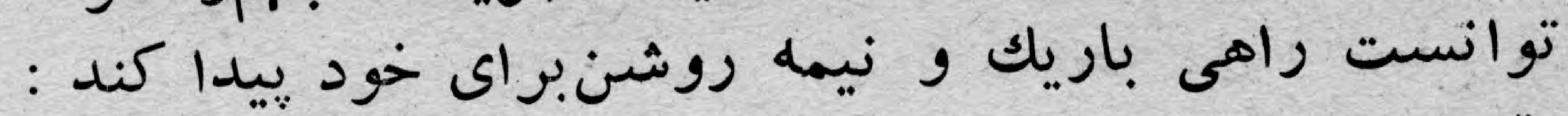

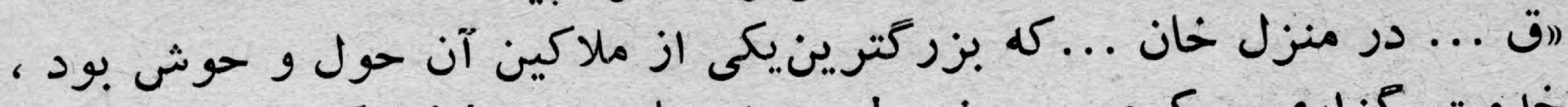

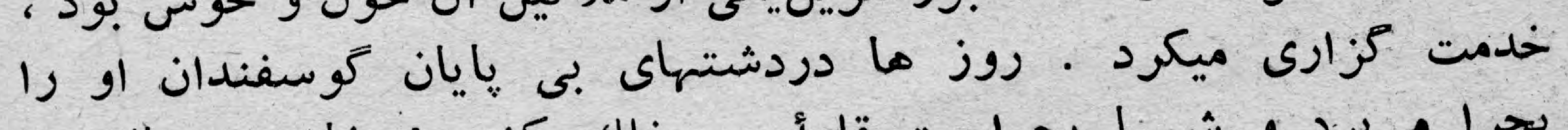

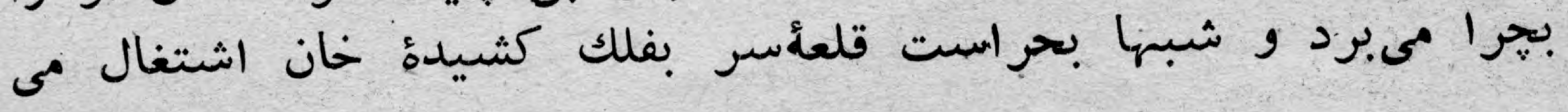




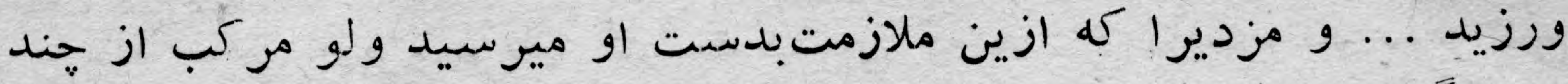

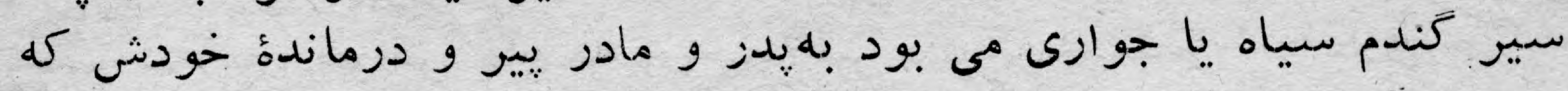

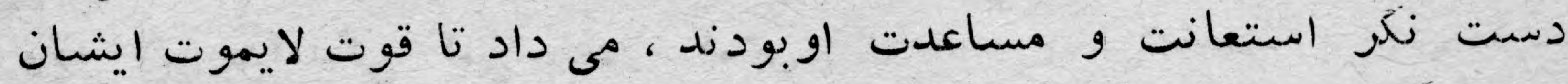

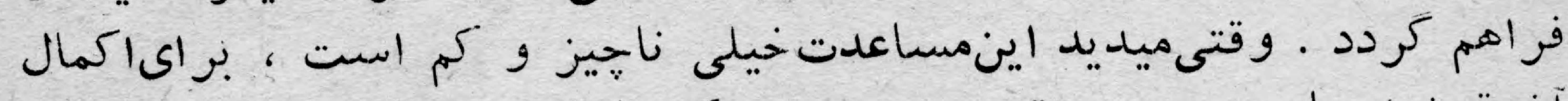

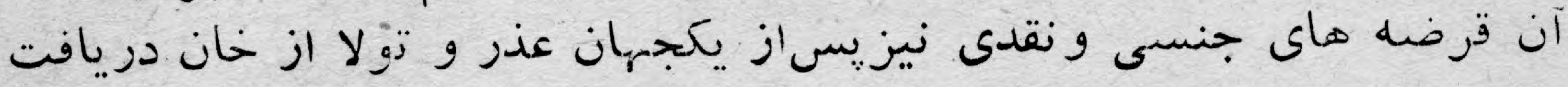

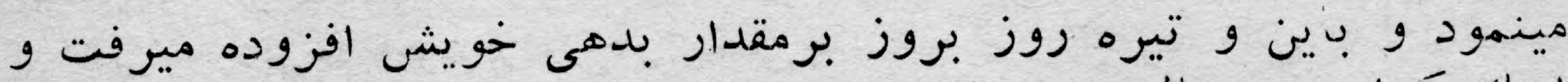

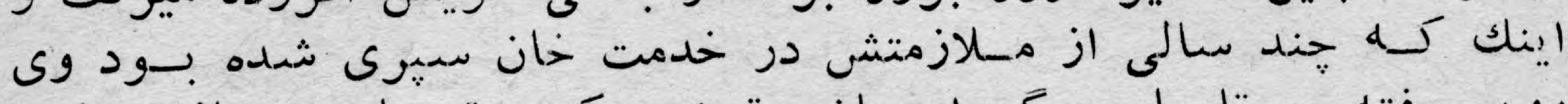

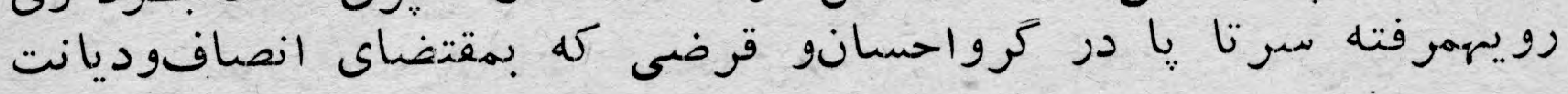

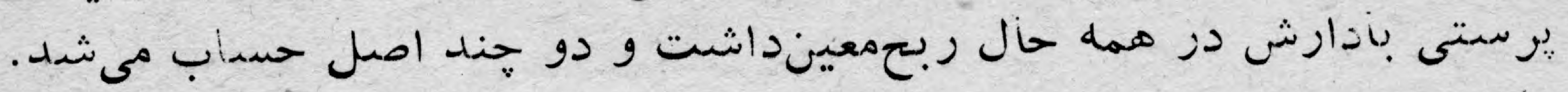

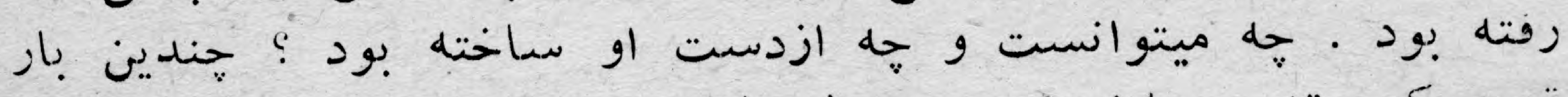

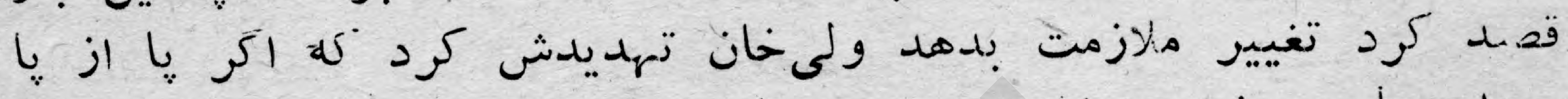

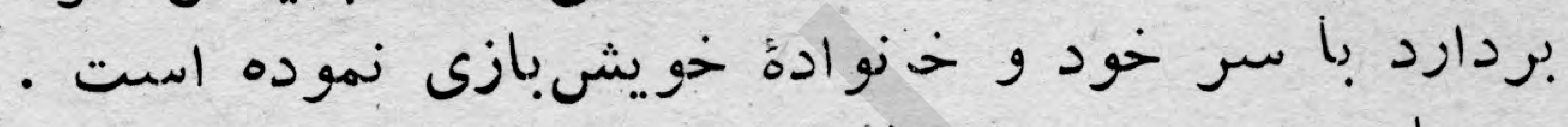

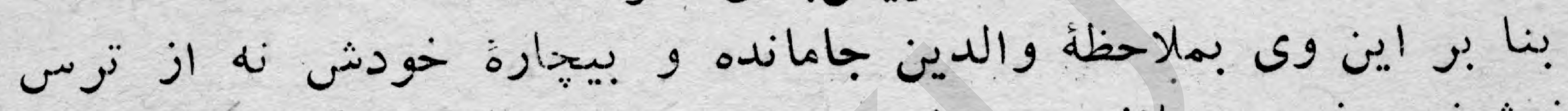

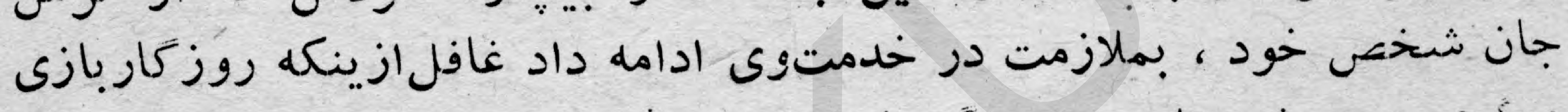

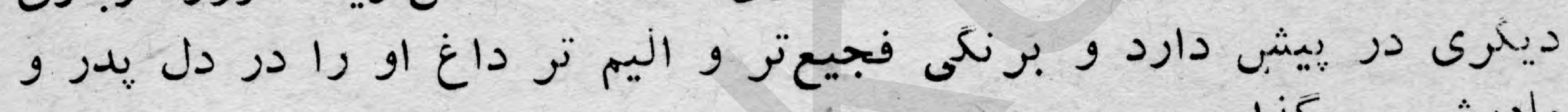

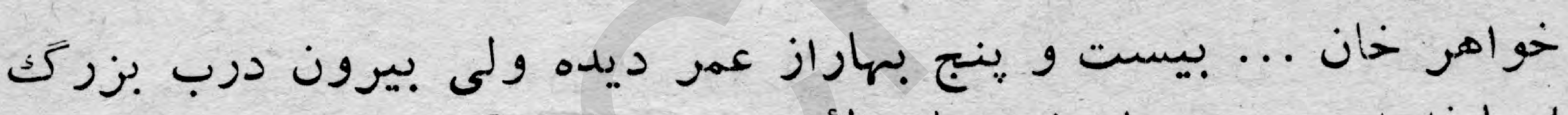

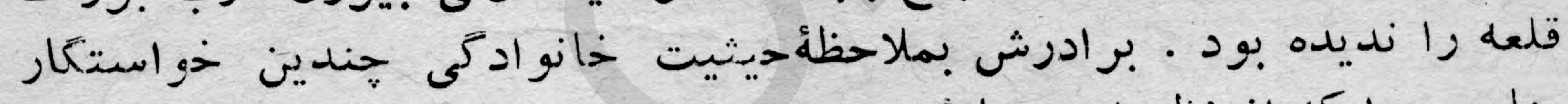

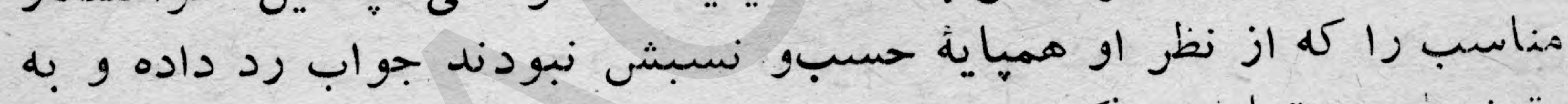

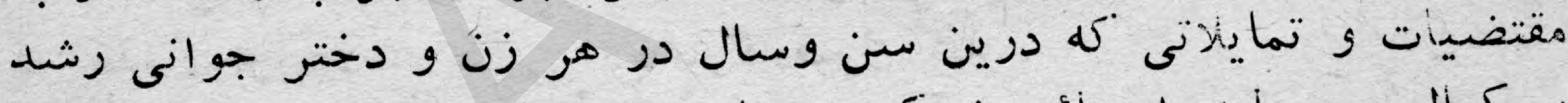

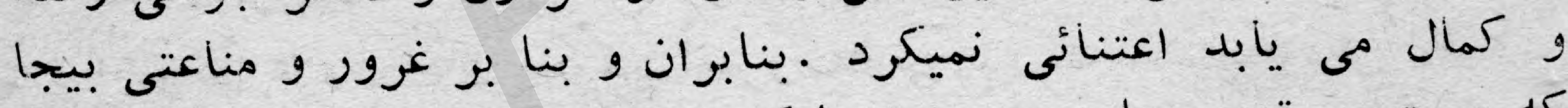

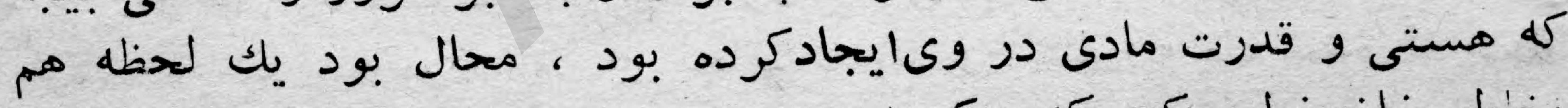

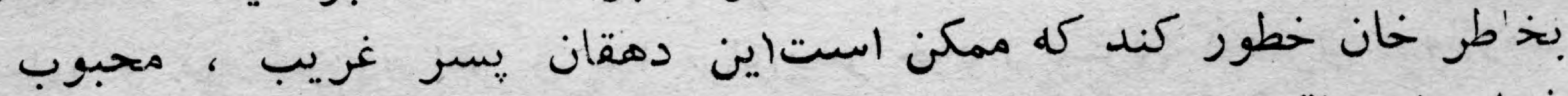

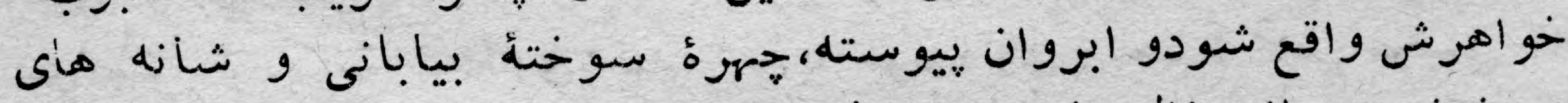

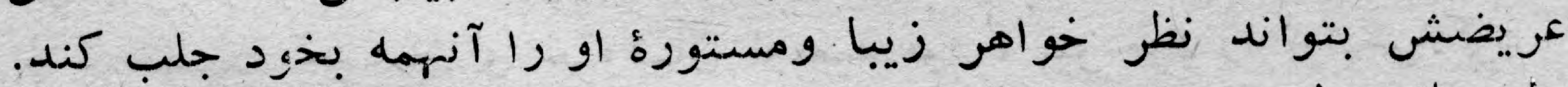

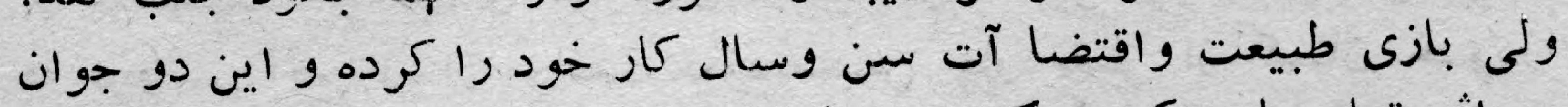

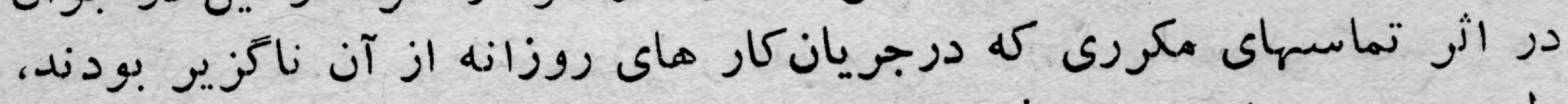

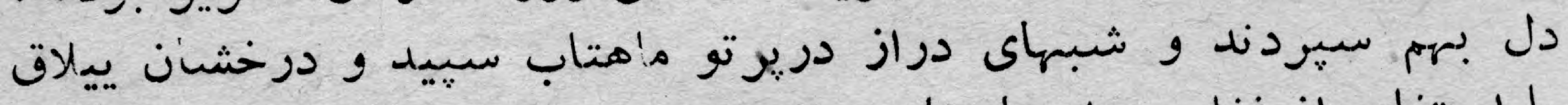

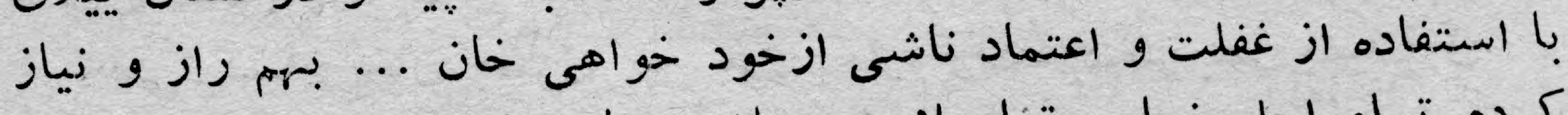

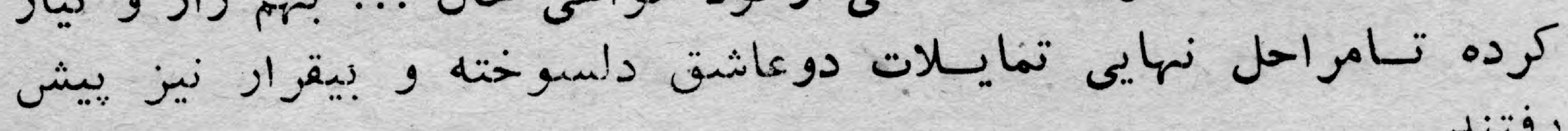
رفتند (... 


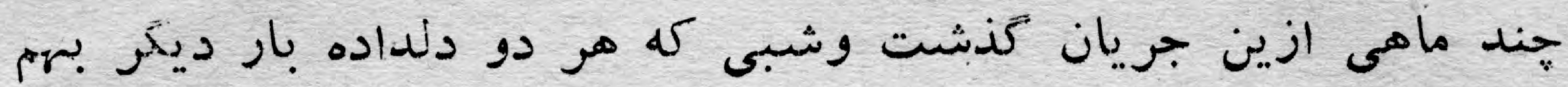

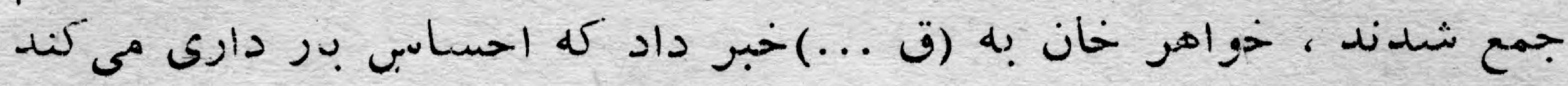

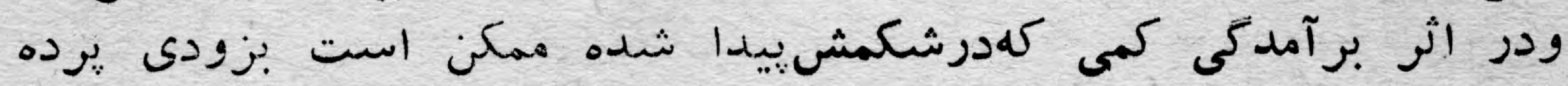

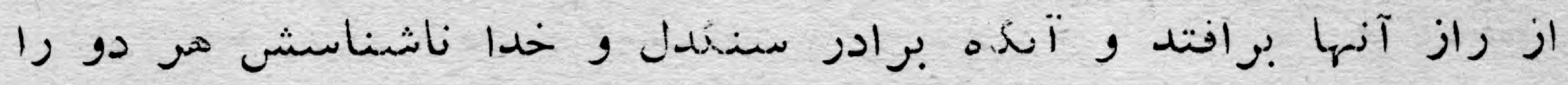

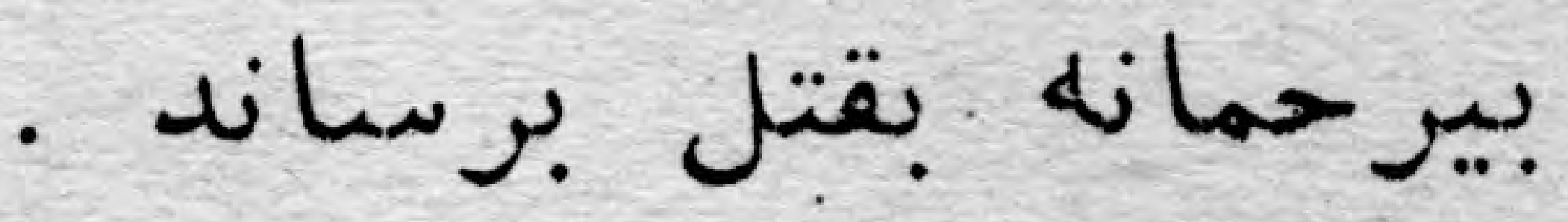

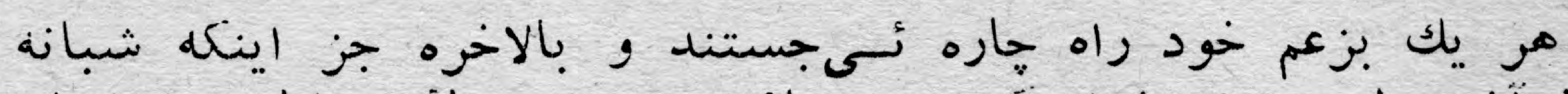

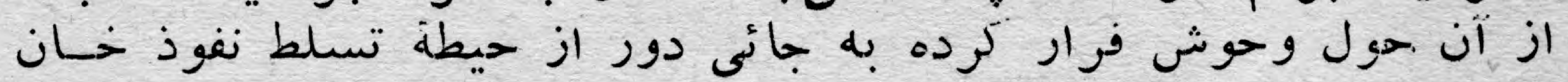

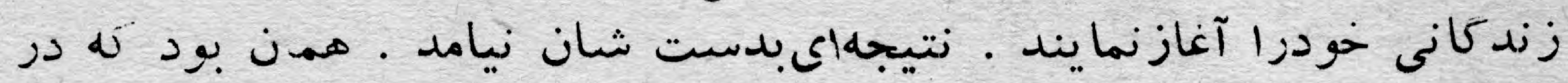

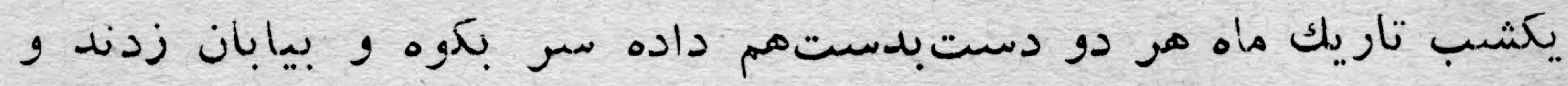

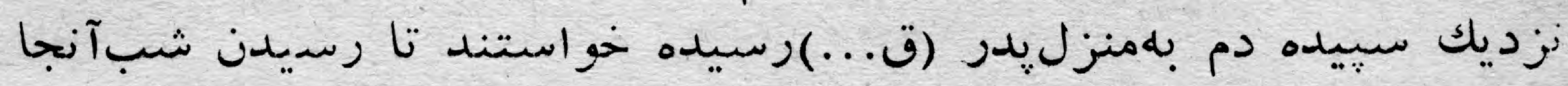

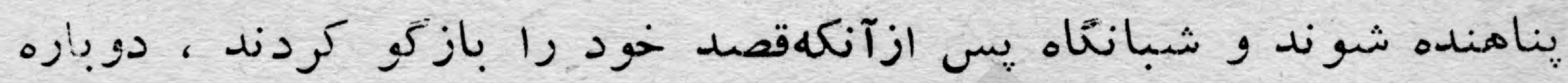

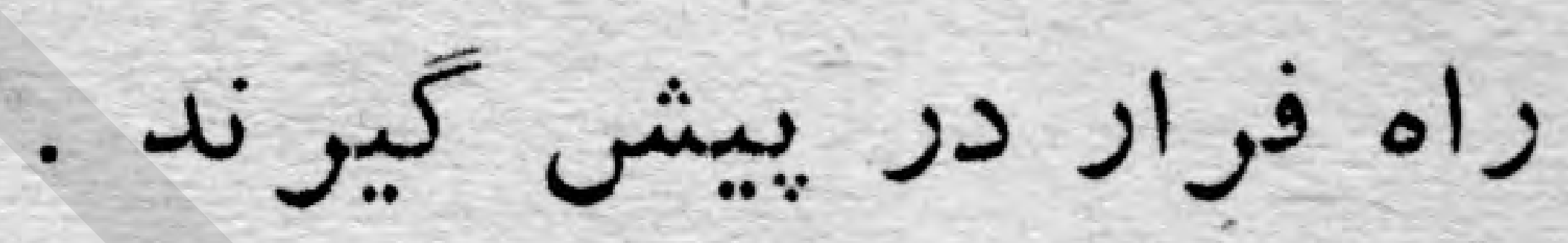

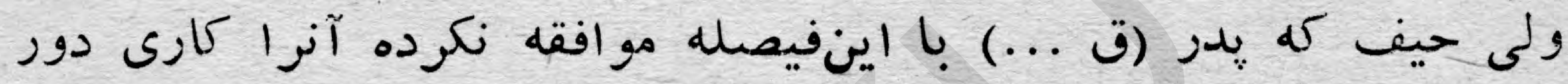

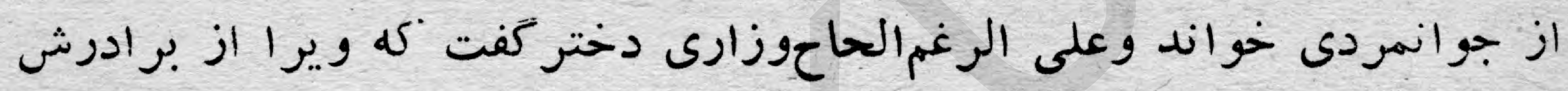

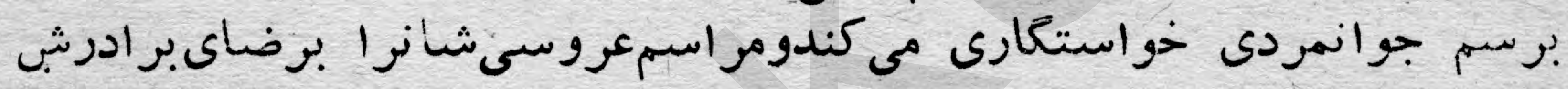

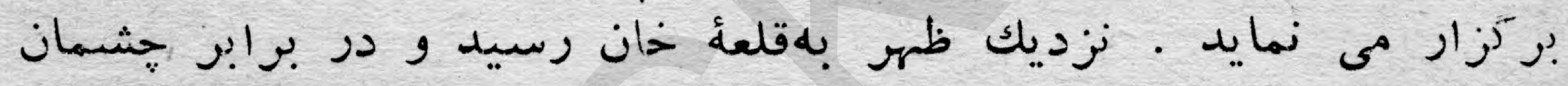

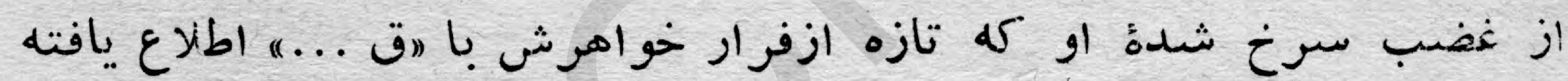

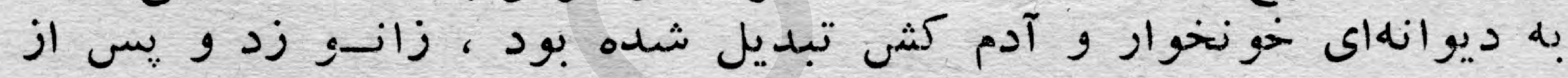

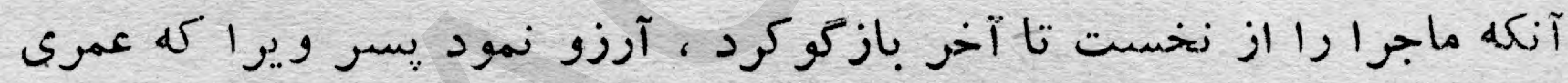

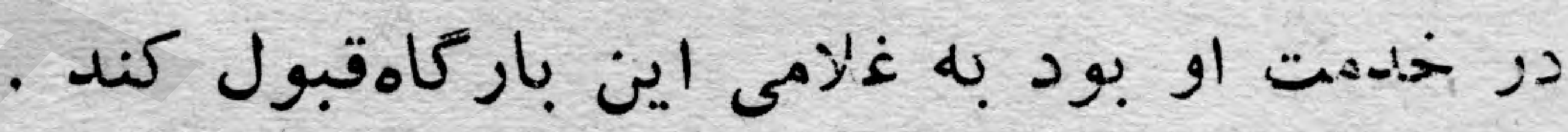

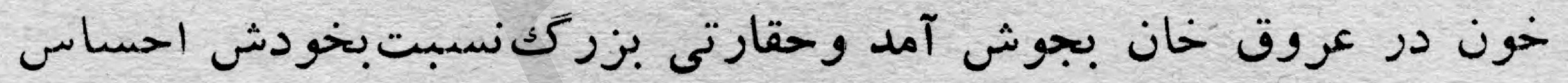

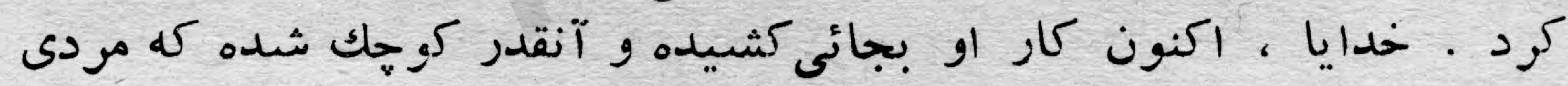

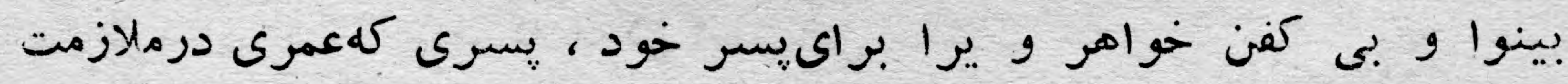

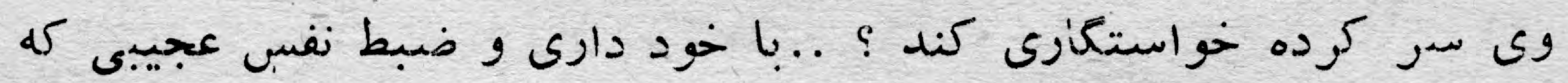

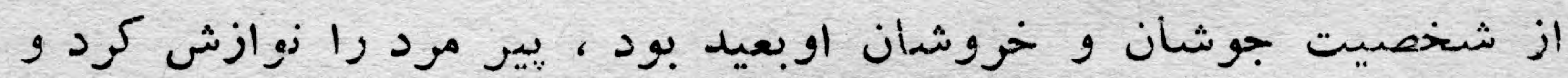

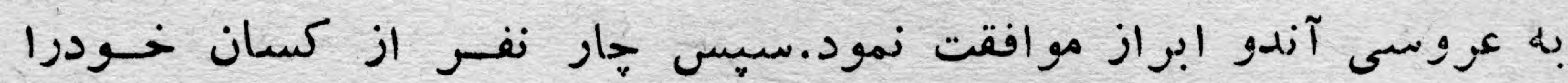

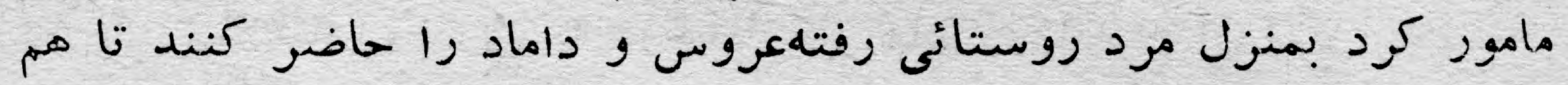

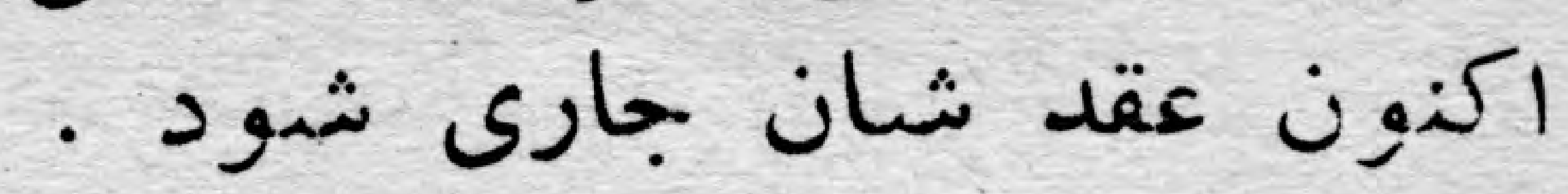

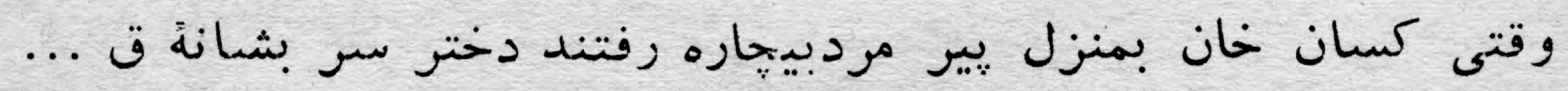

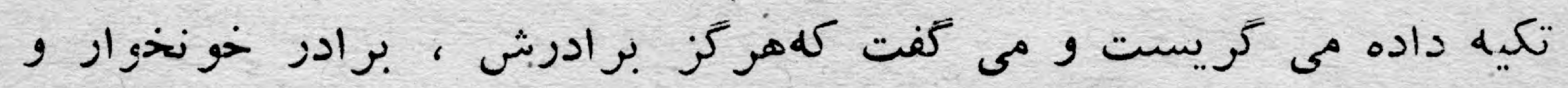

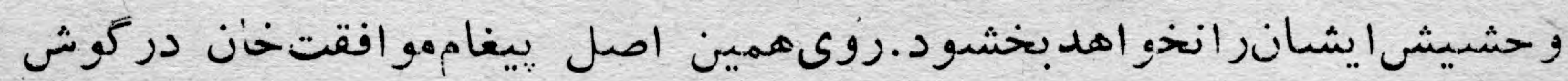


وى جون نواى مركك رسيد و بهت...هم كه از شادى نزديك بود ديوانه

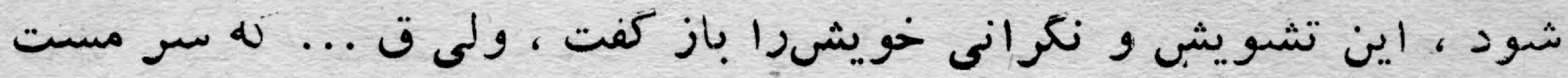

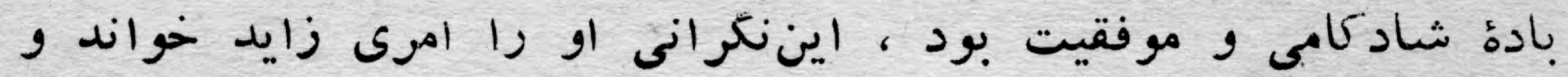

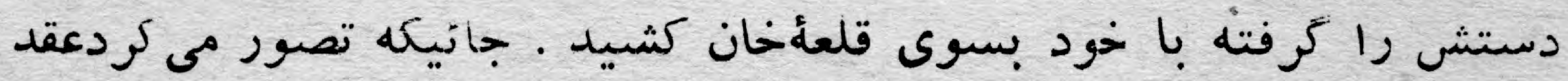

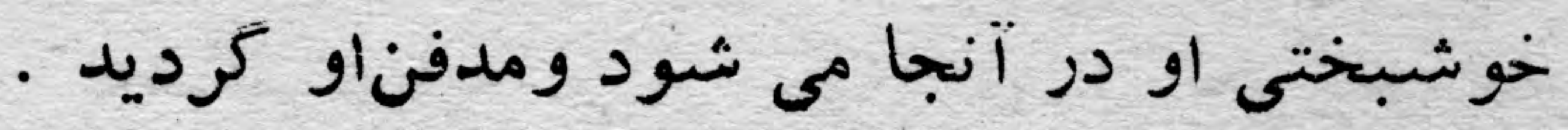

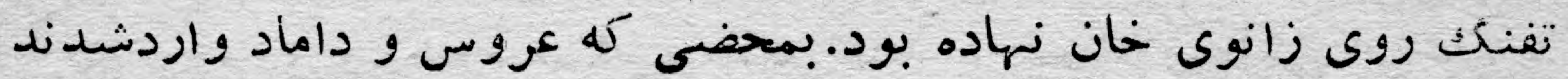

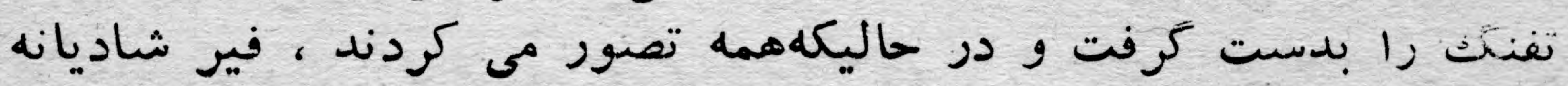

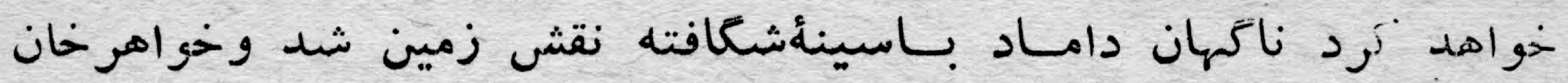

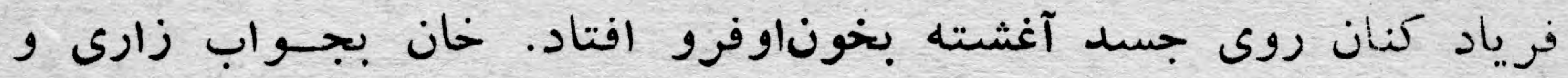

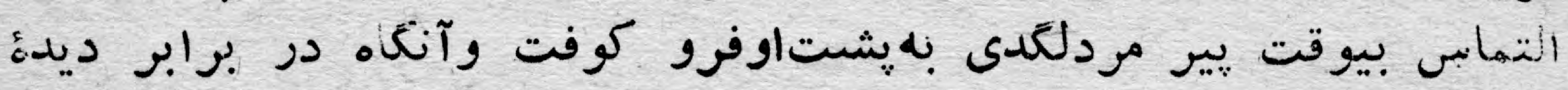

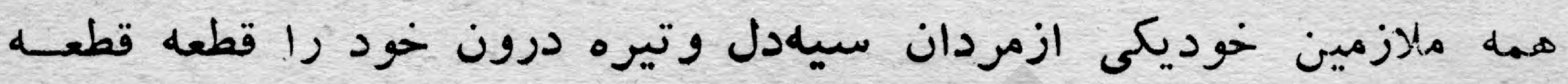

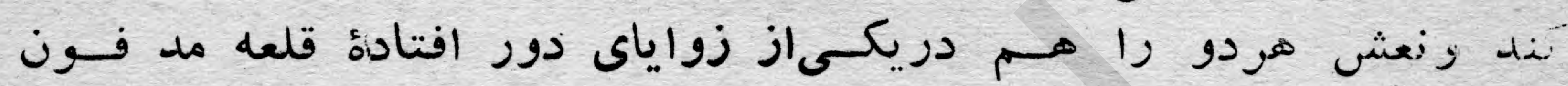
سازند

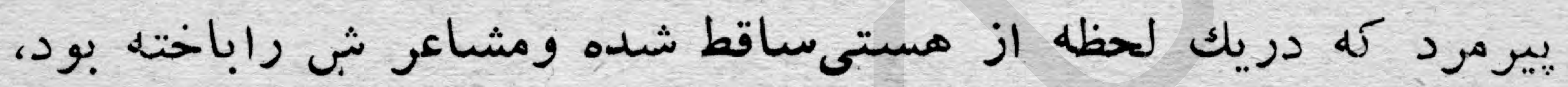

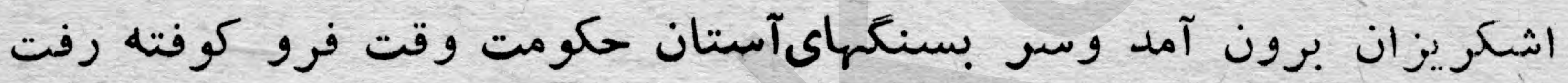

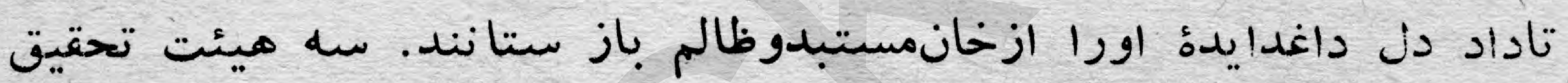

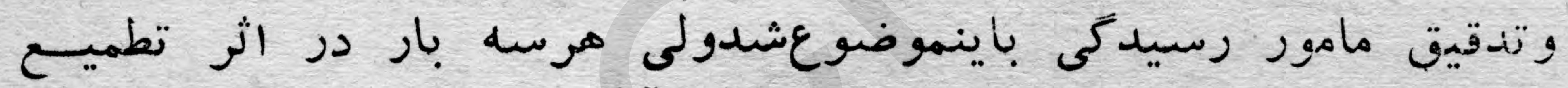

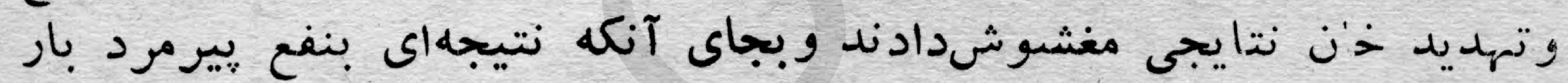

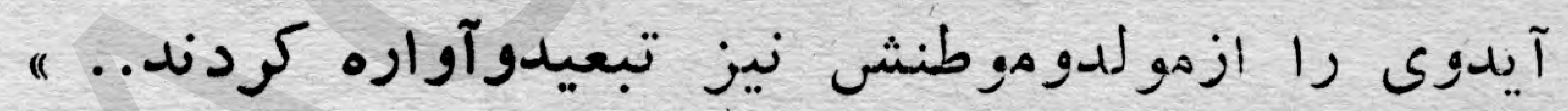

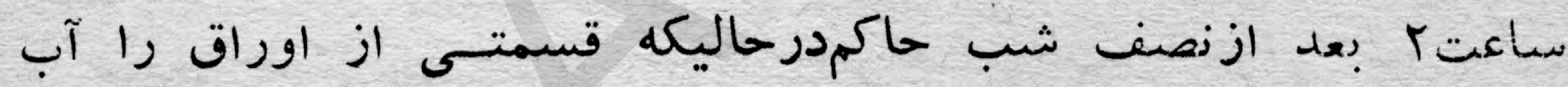

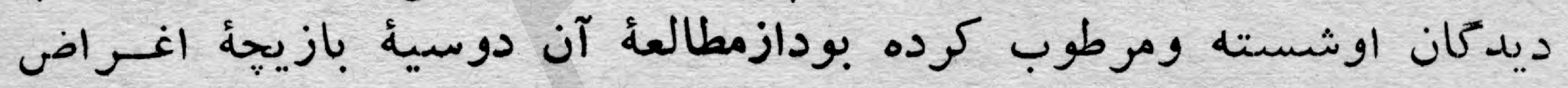

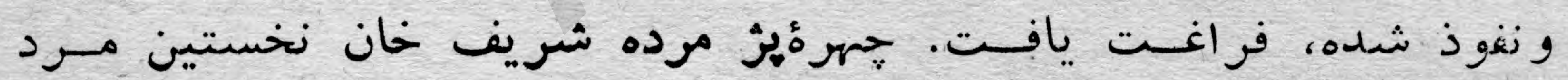

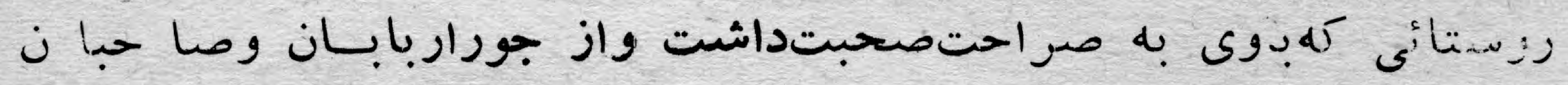

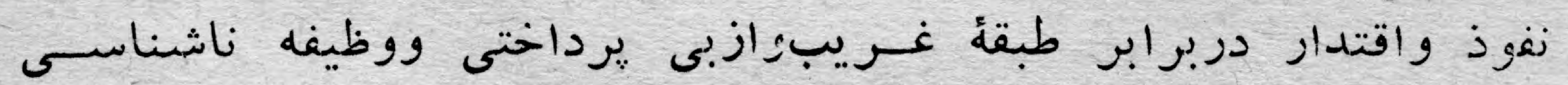

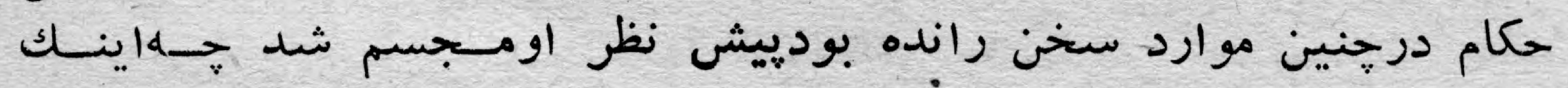

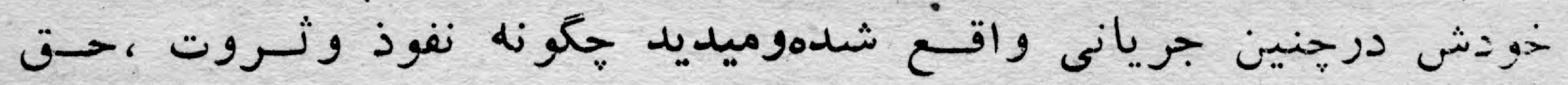

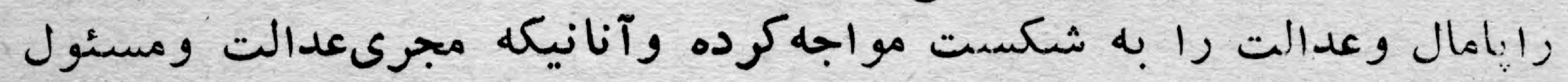

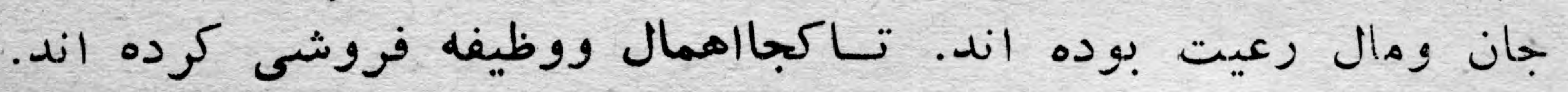

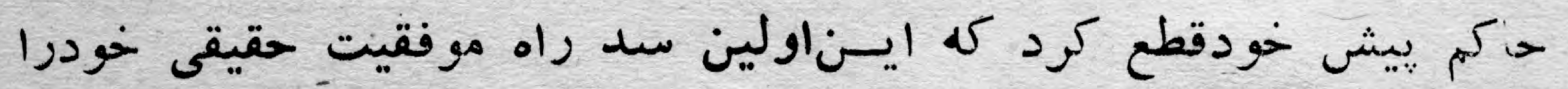

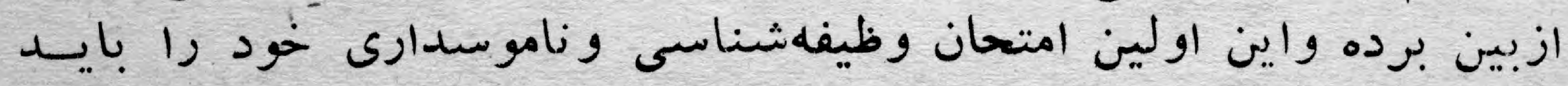

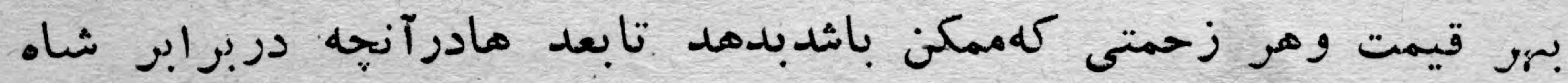




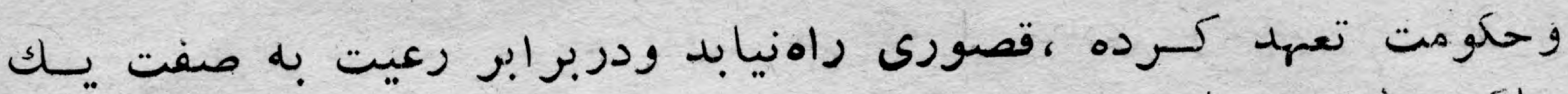

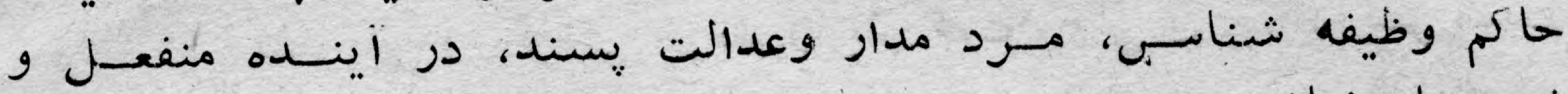
شومسار نباشد.

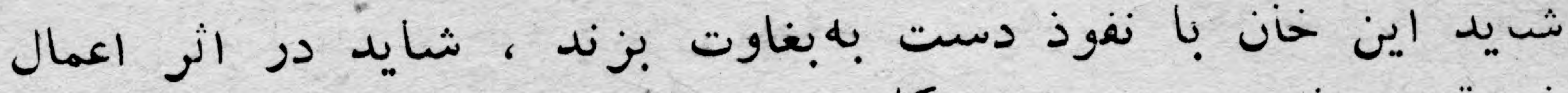

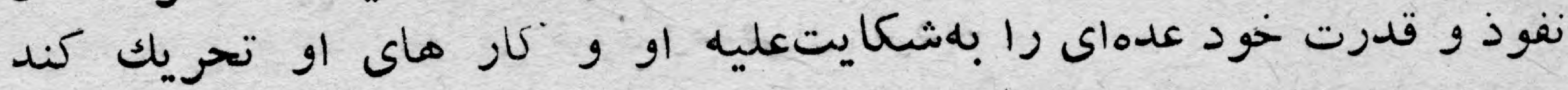

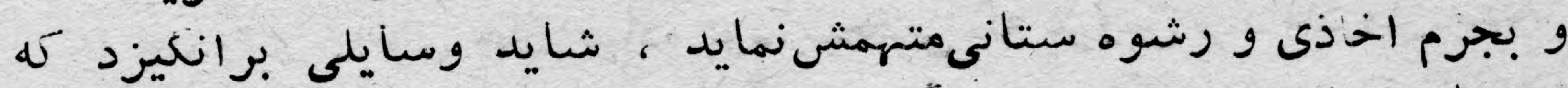

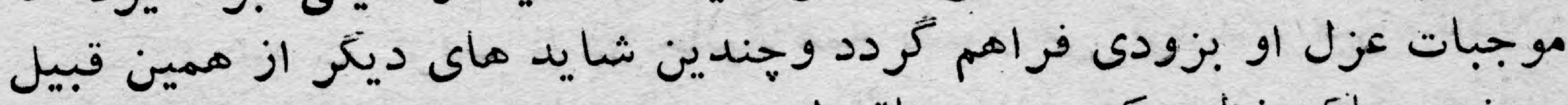

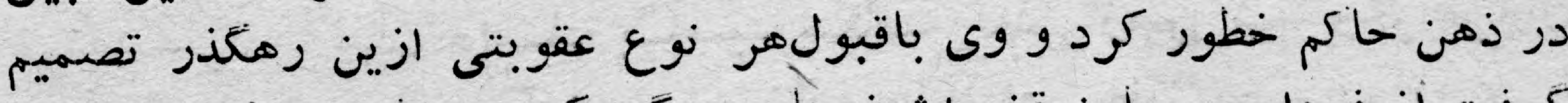

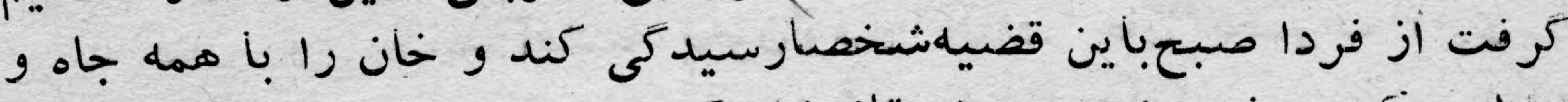

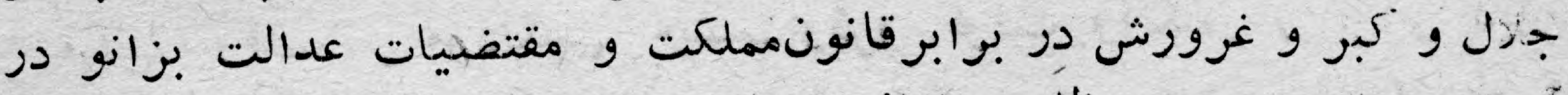

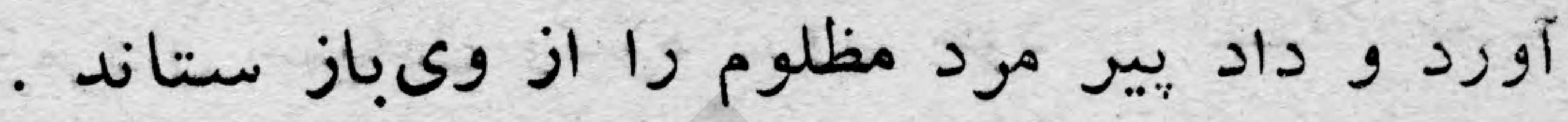

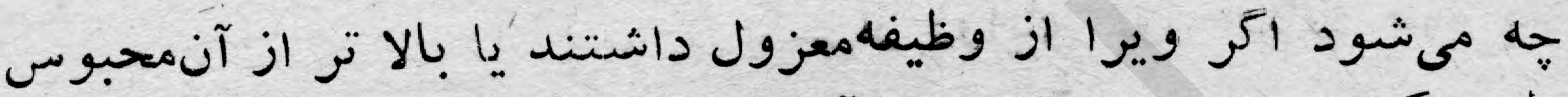

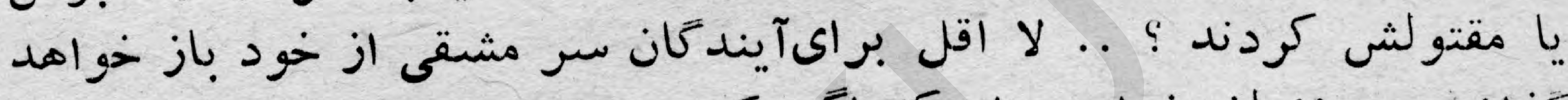

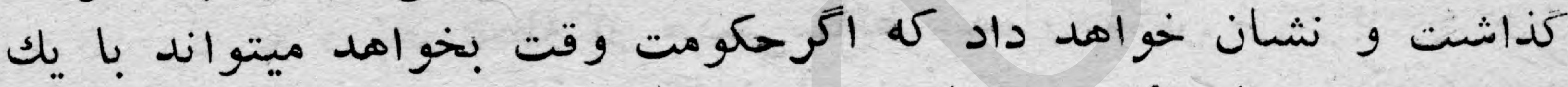

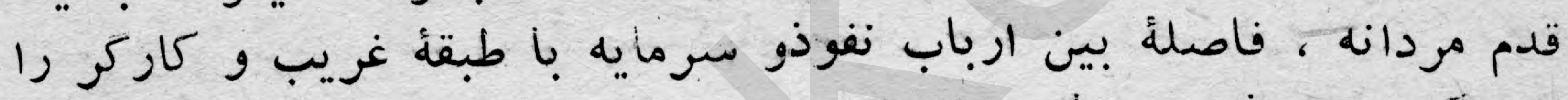

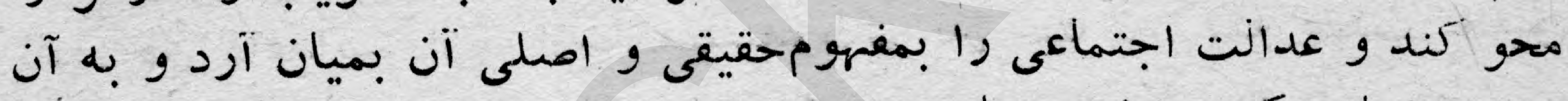

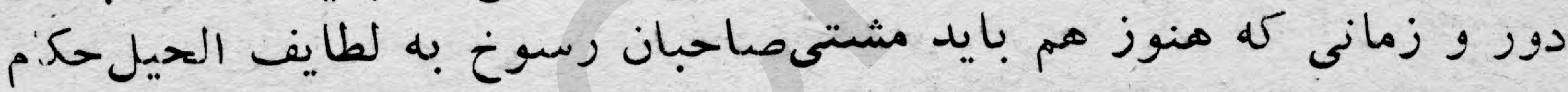

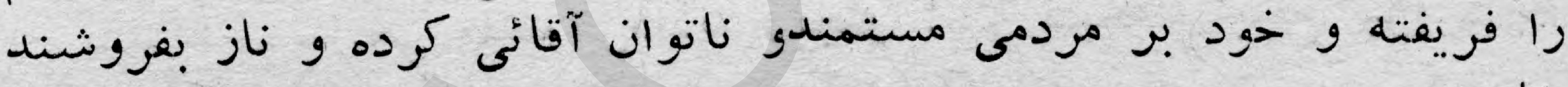
خاتمه دها

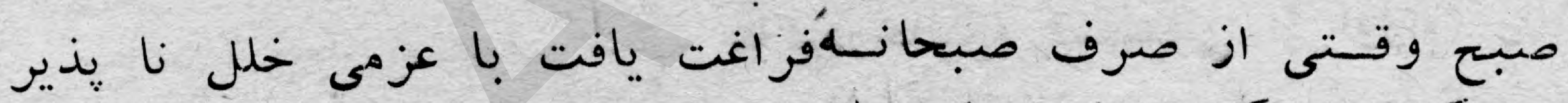

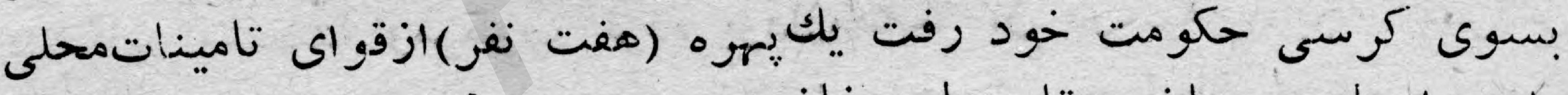

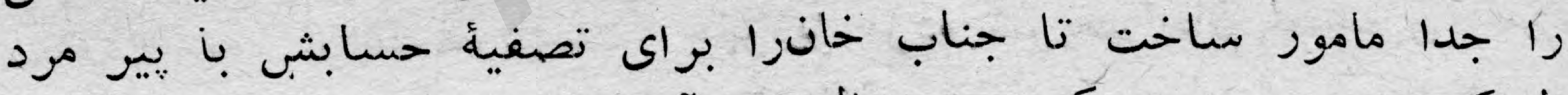

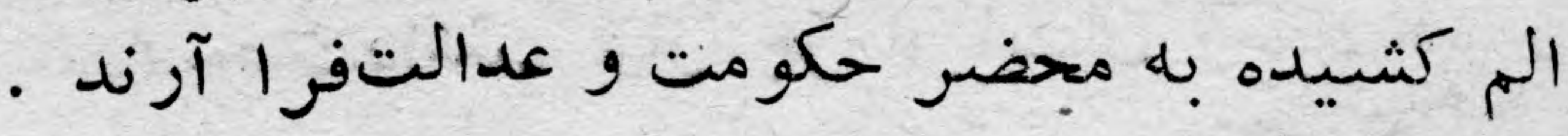

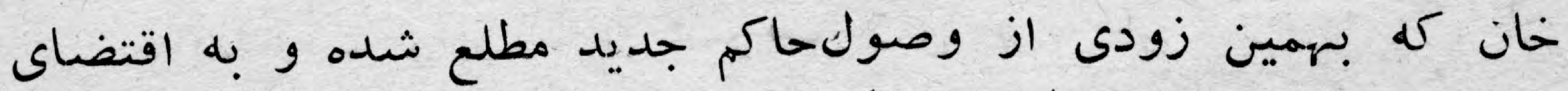

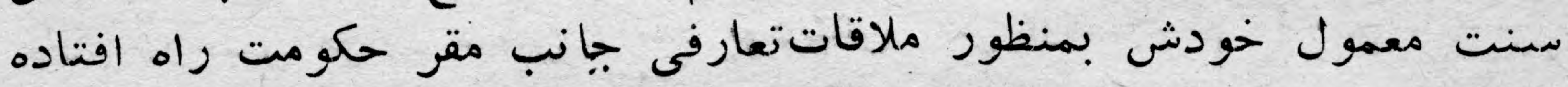

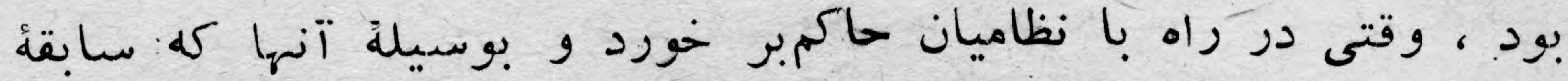

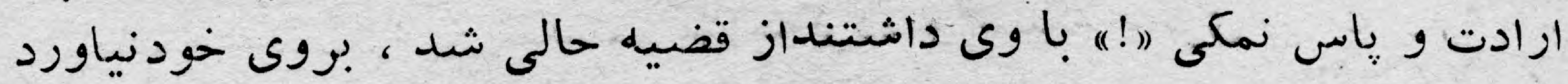

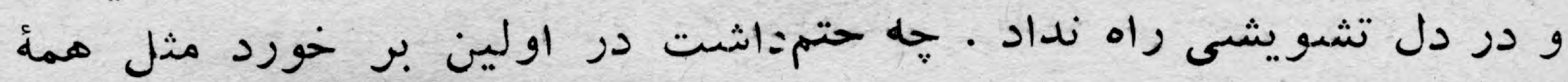

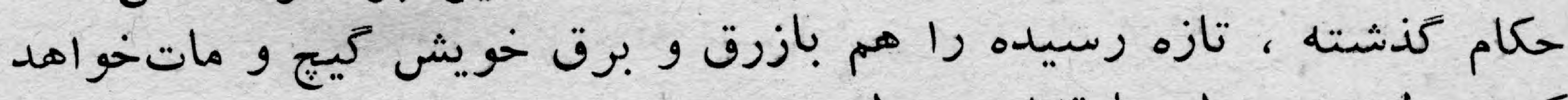

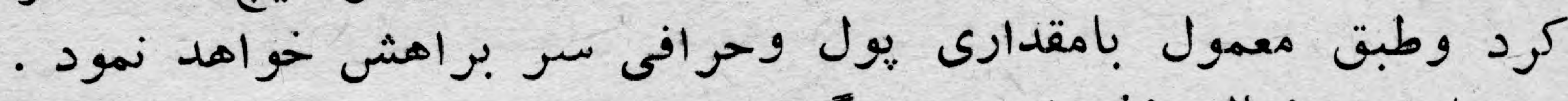

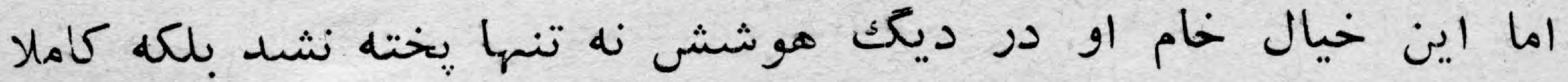




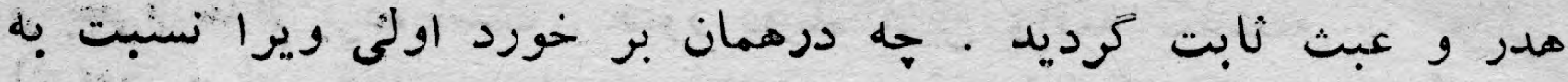

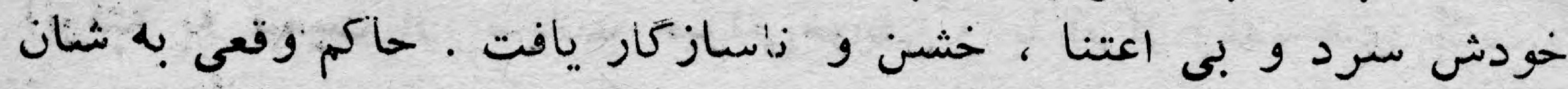

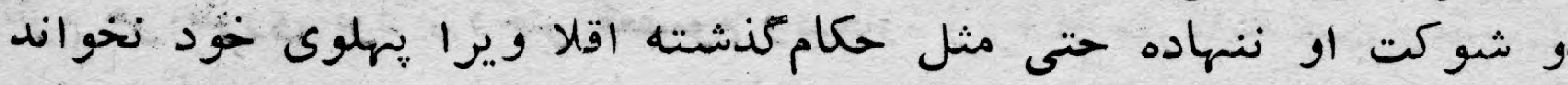

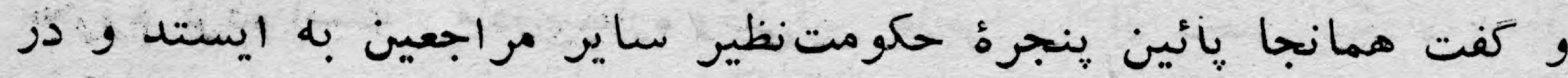

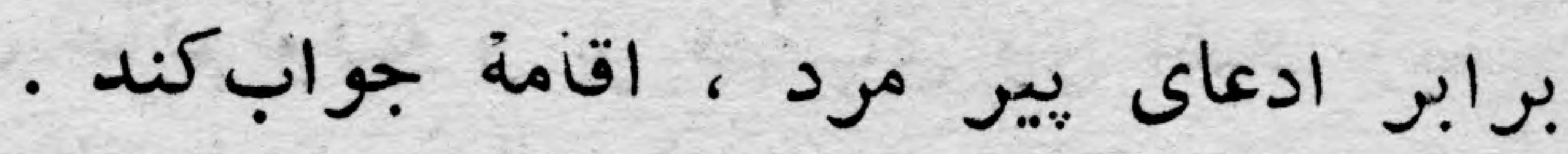

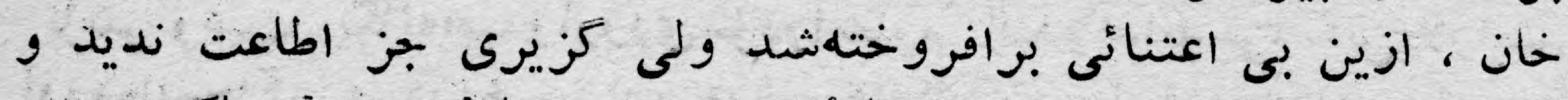

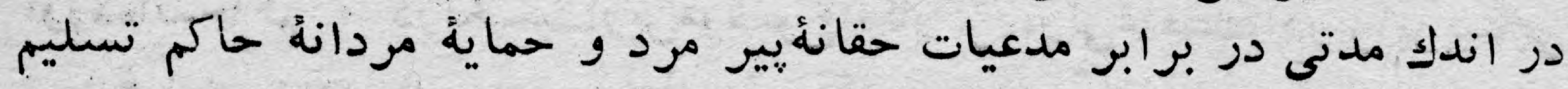

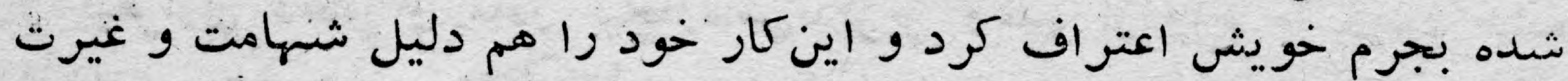

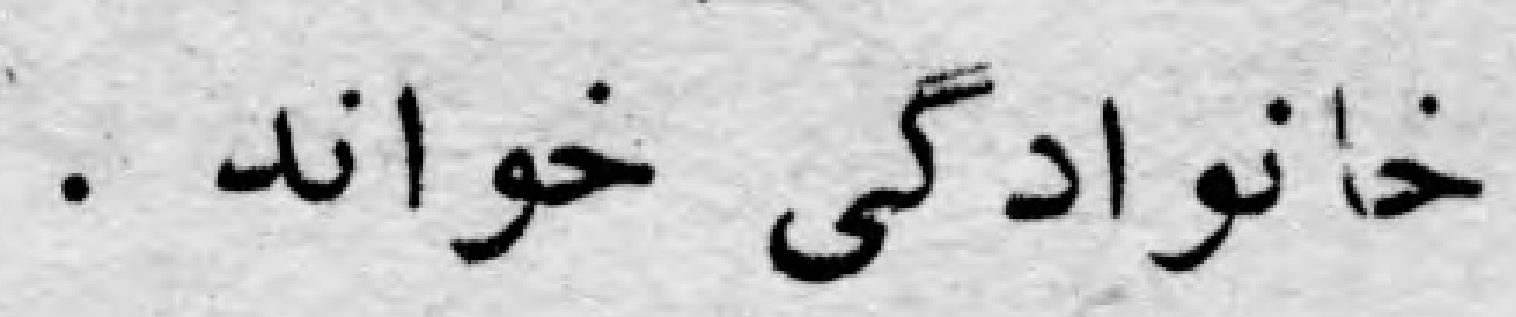

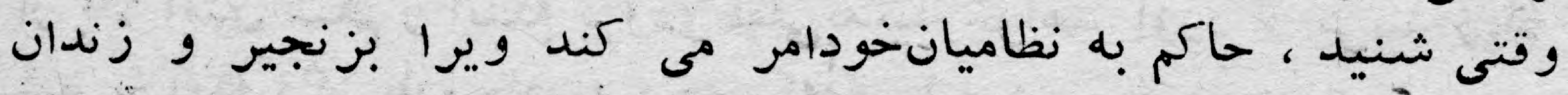

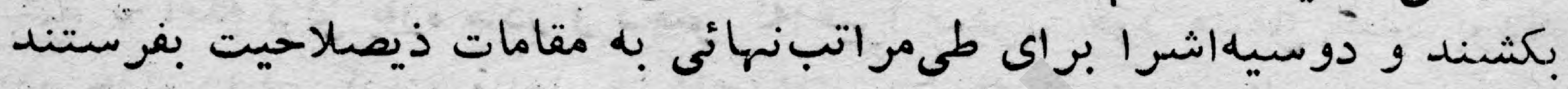

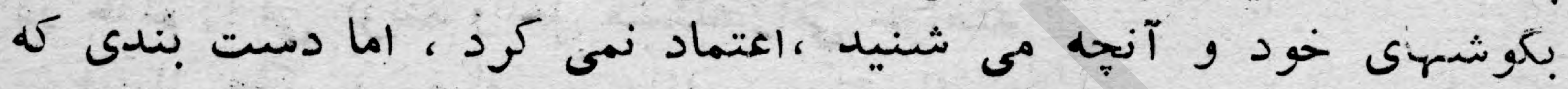

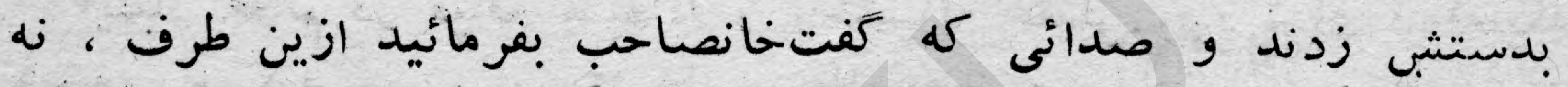

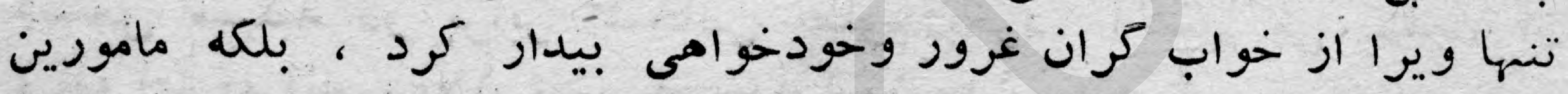

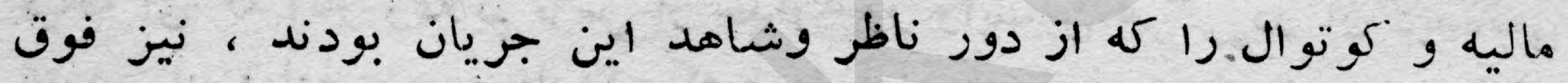

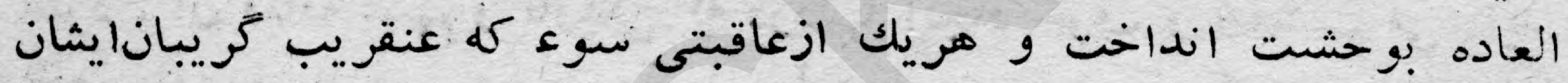

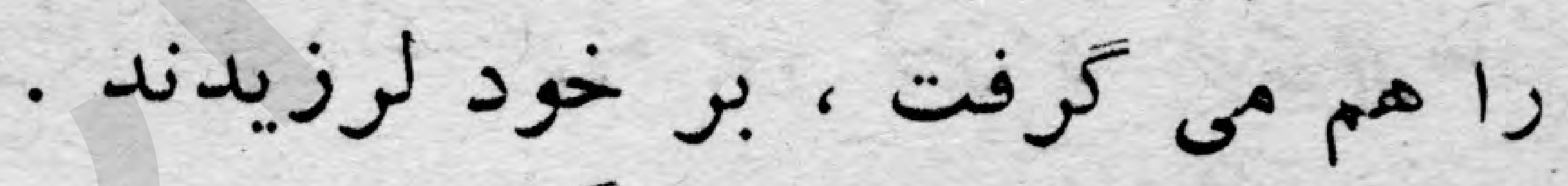

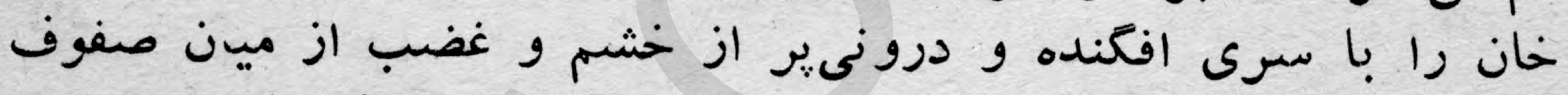

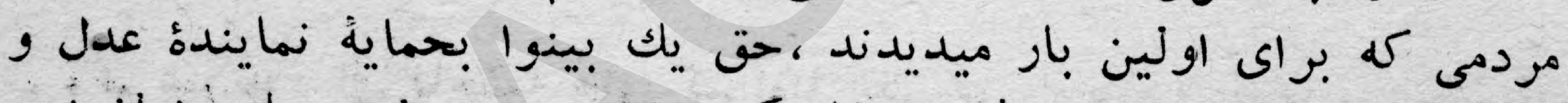

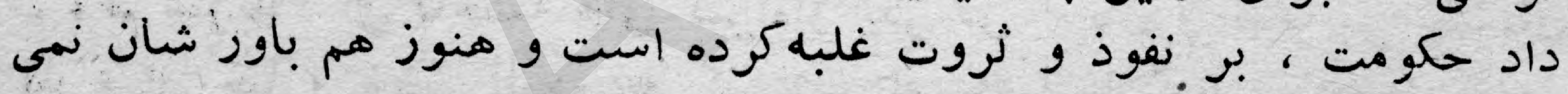

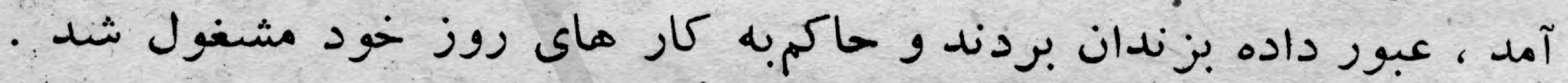

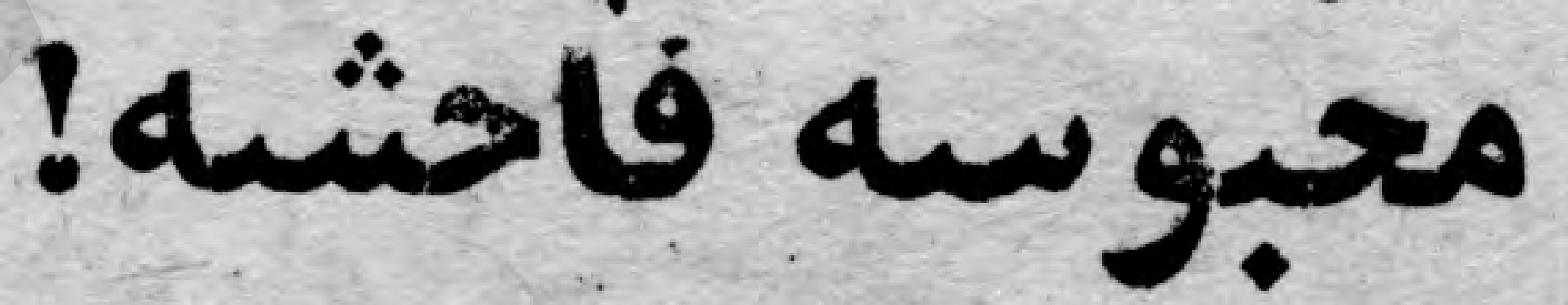

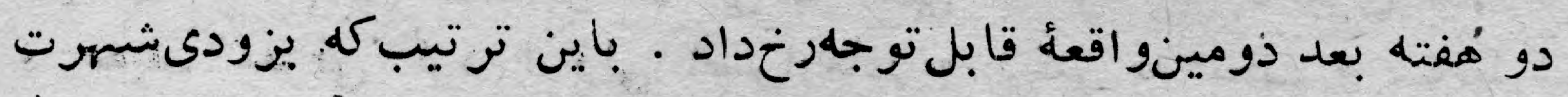

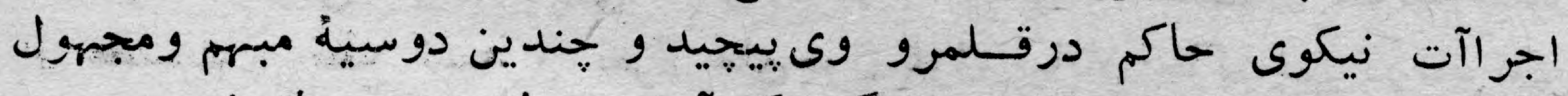

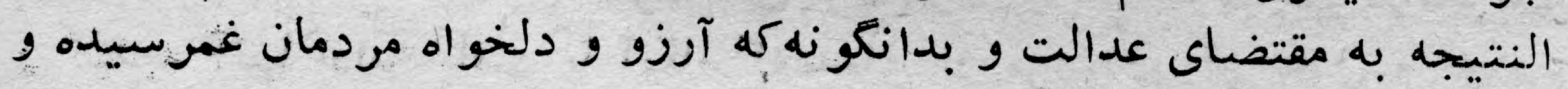

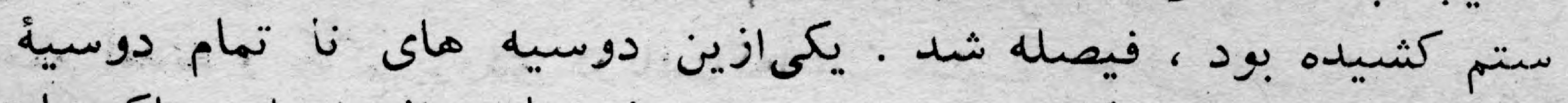

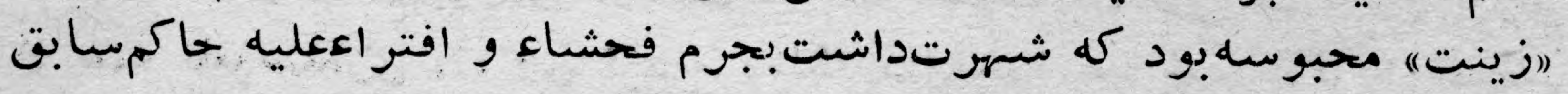

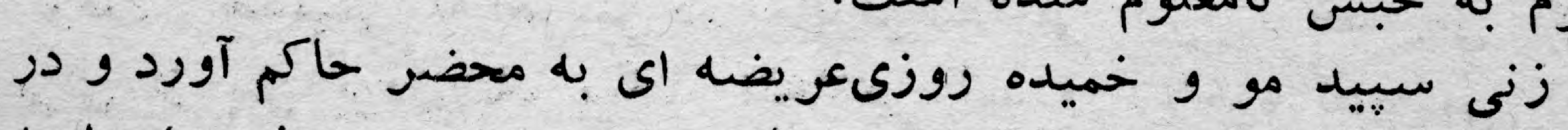

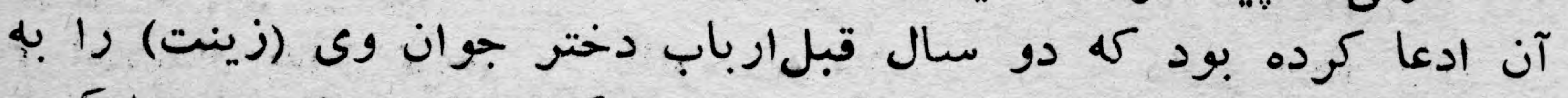

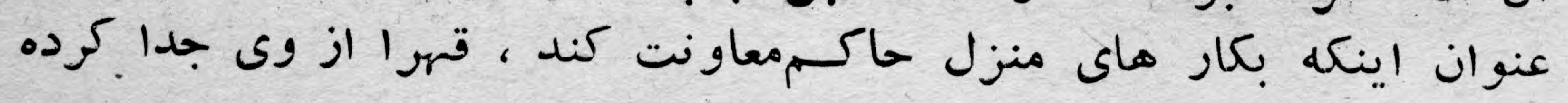




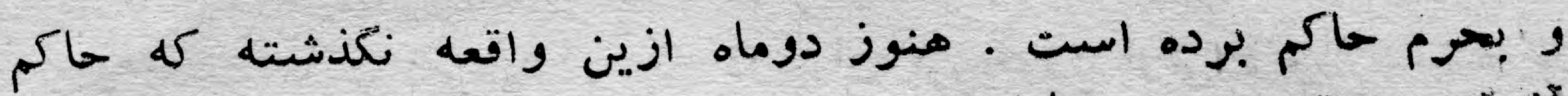

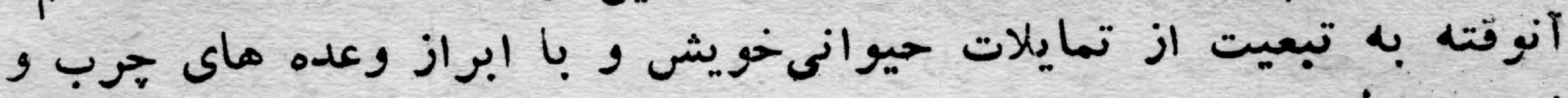

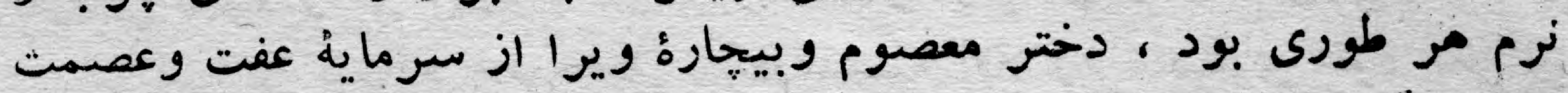

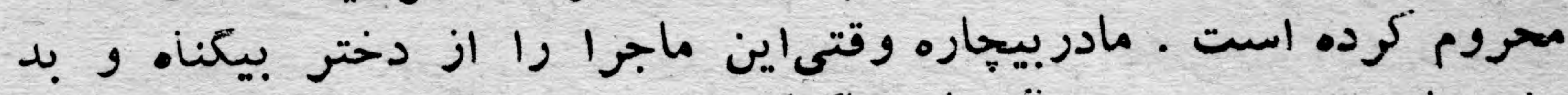

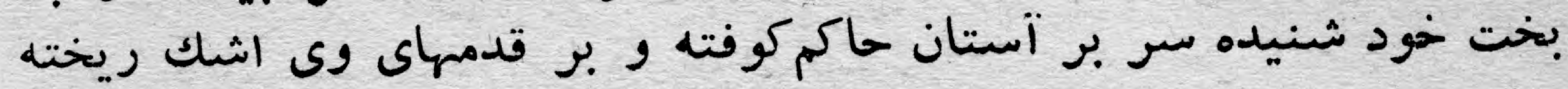

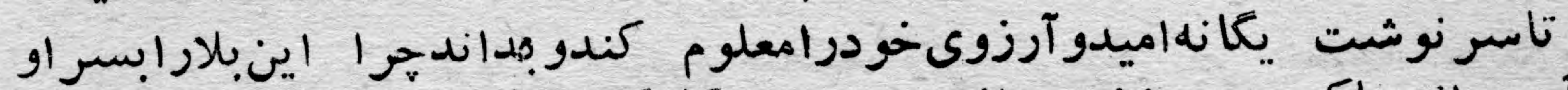

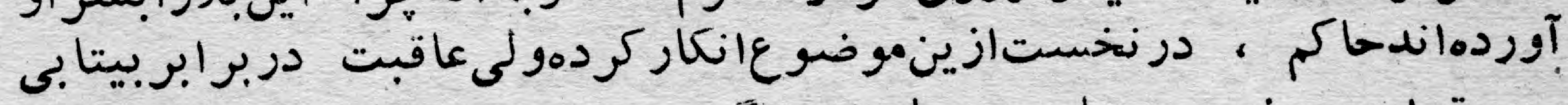

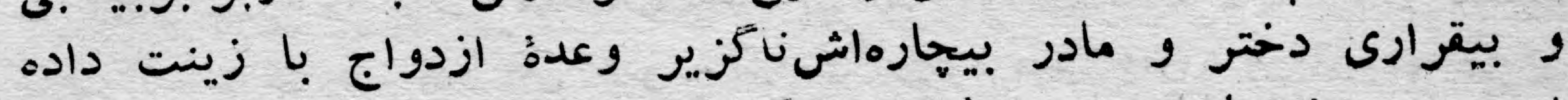

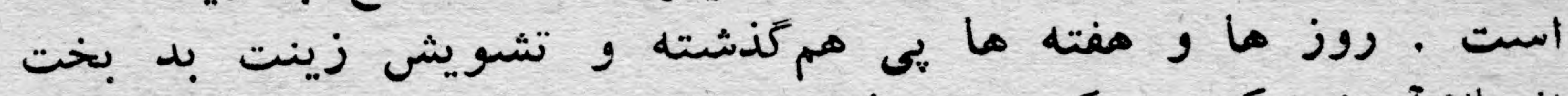

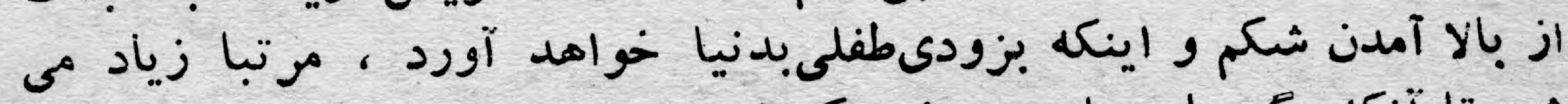

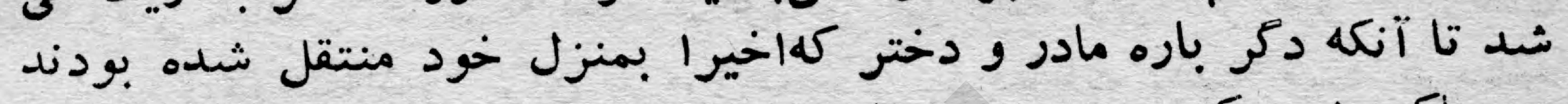

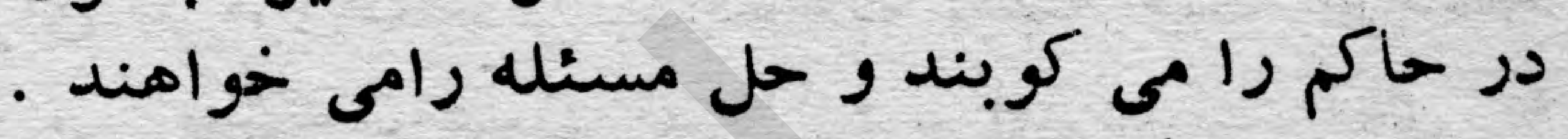

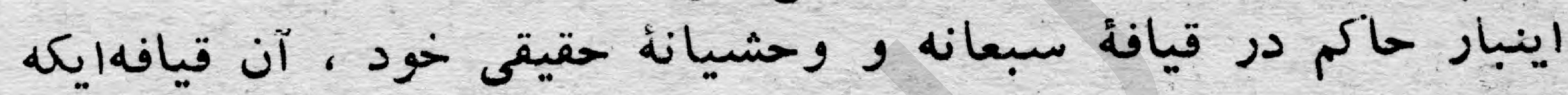

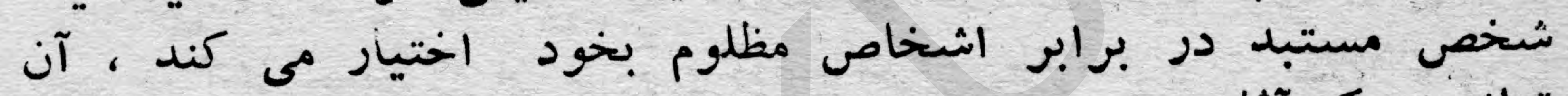

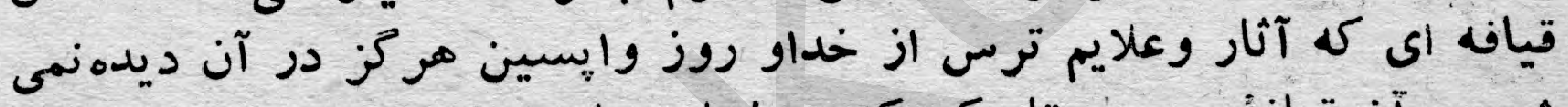

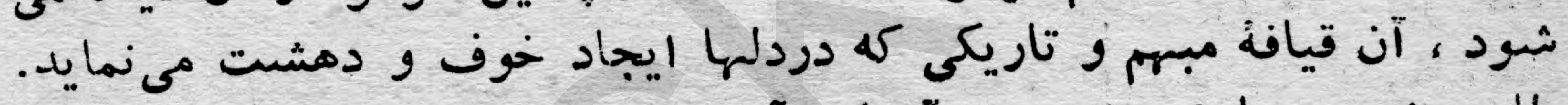

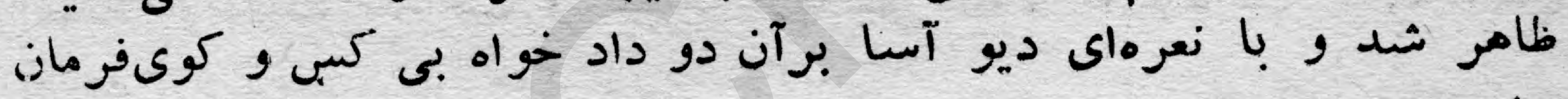
: 213

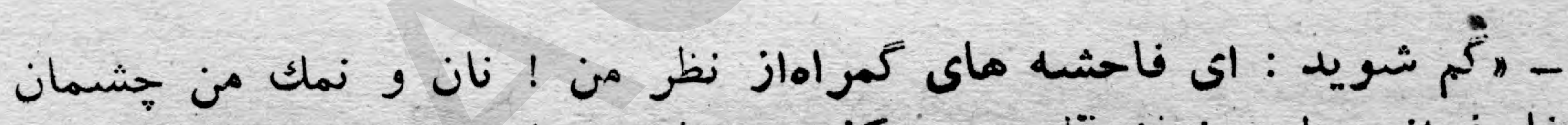

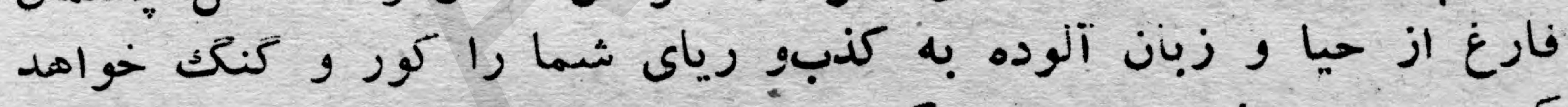

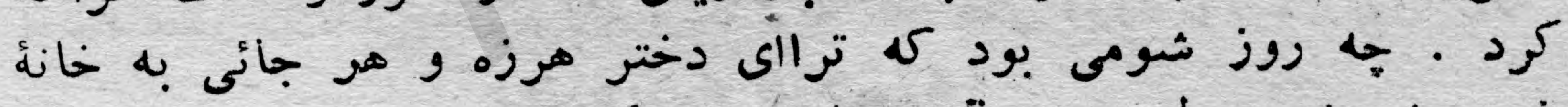

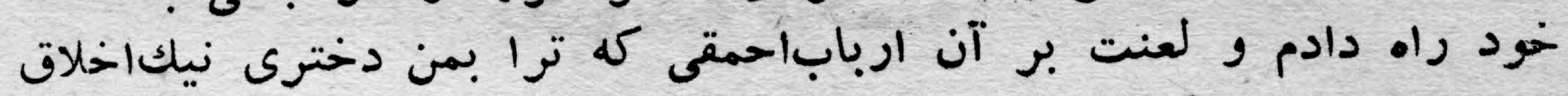

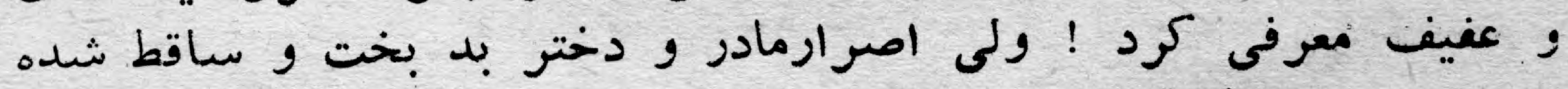

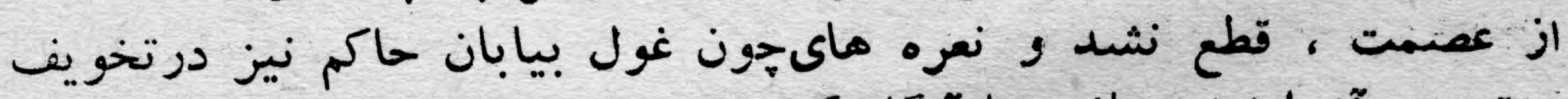

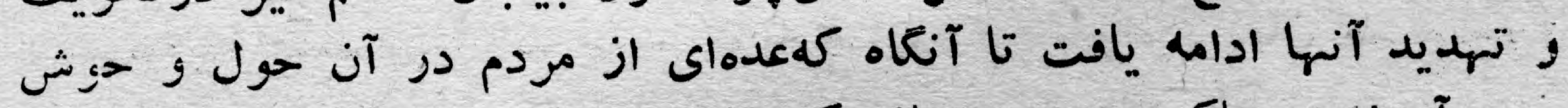

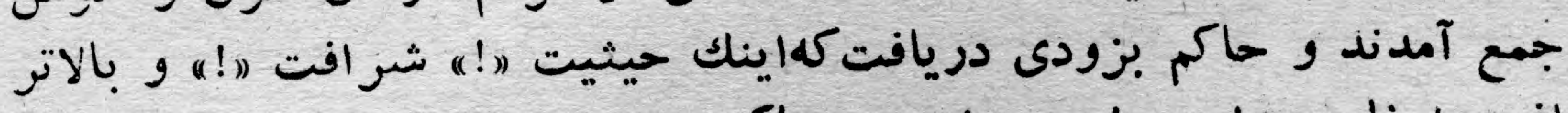

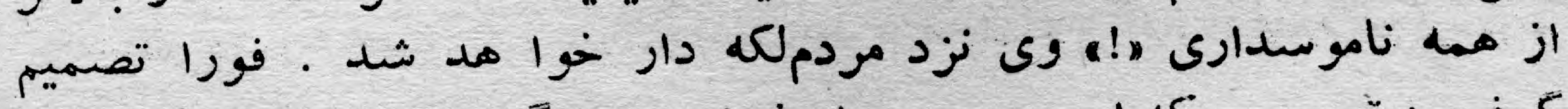

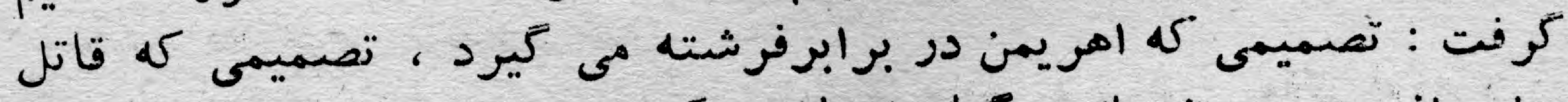

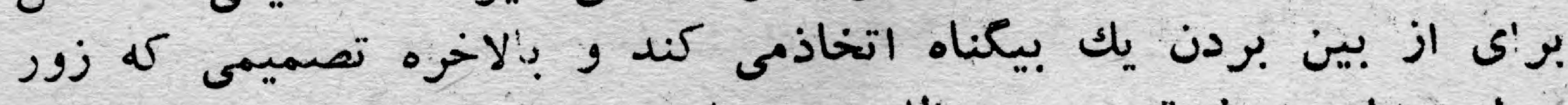

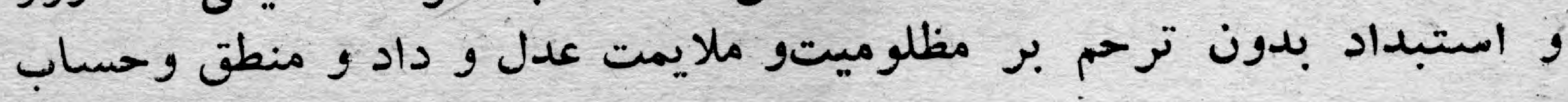


نشان ميدهد و با صدائيكه يك ذرهاز ندامت وجدان ور خوف خدا در آن راه نداشت فريده وياد زد :

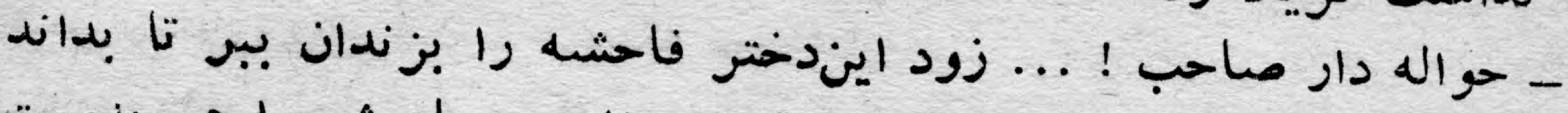

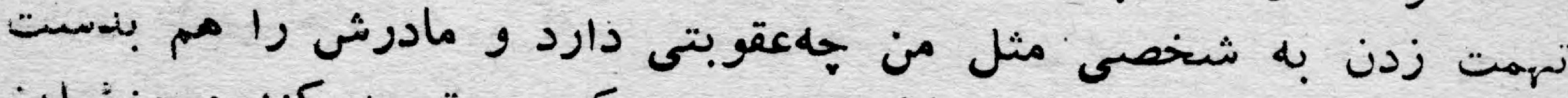

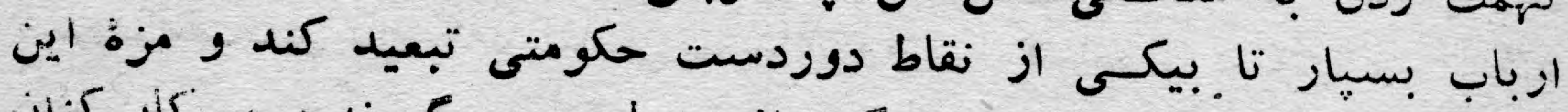

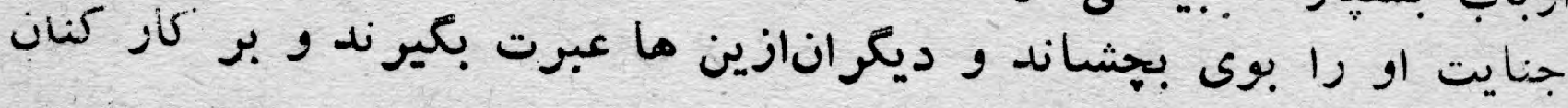

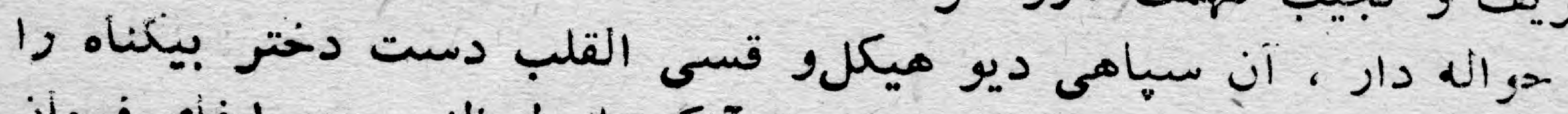

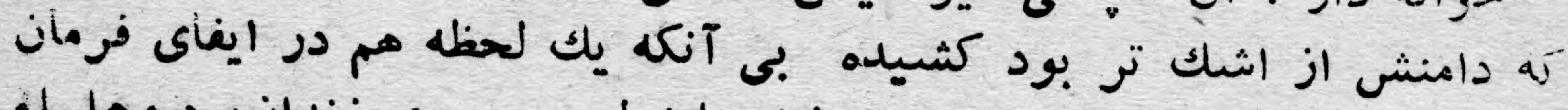

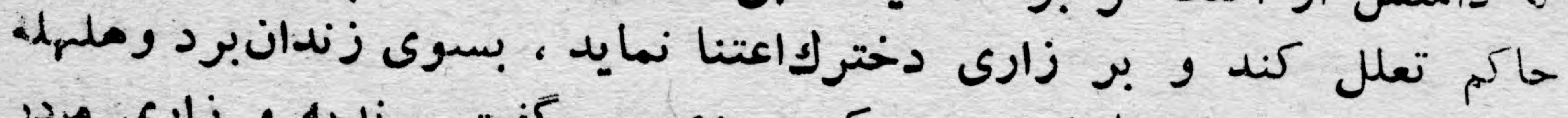

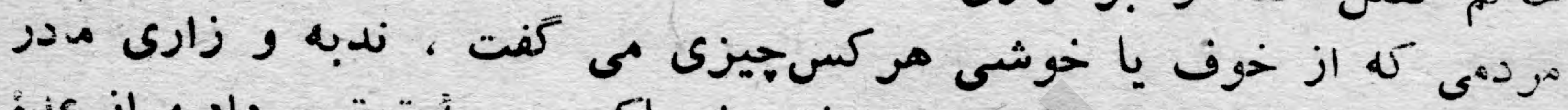

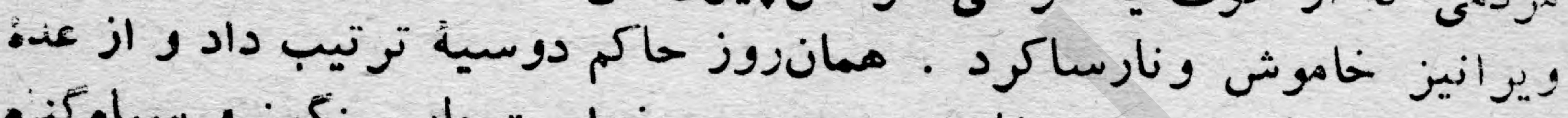

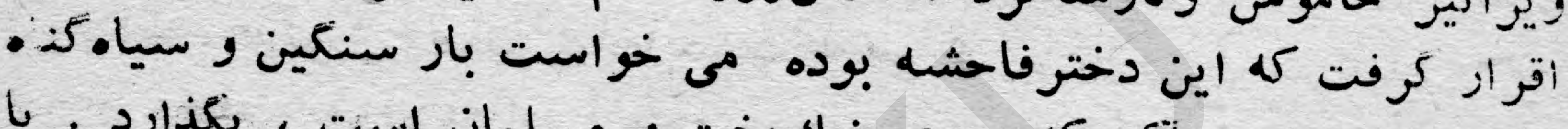

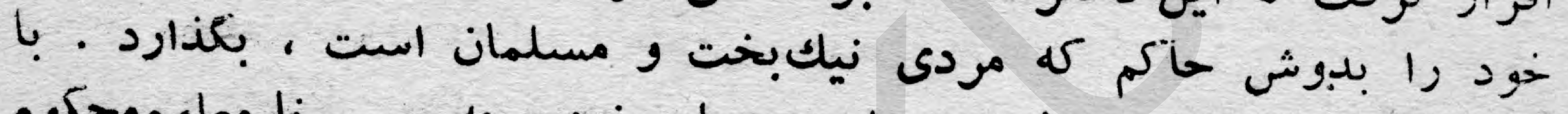

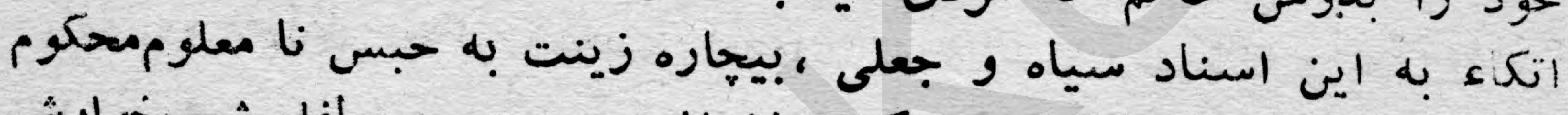

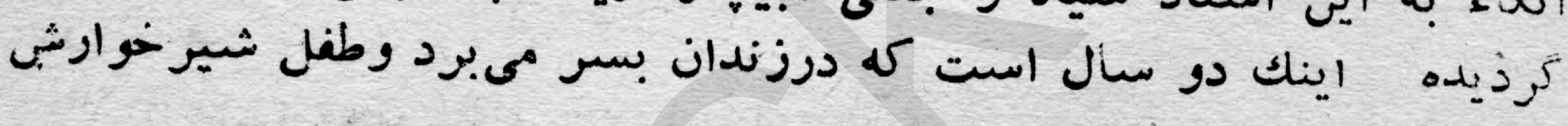

ينز با وى است.

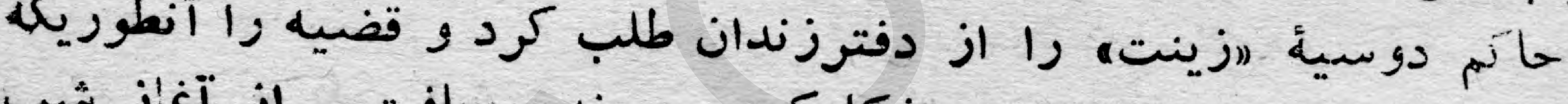

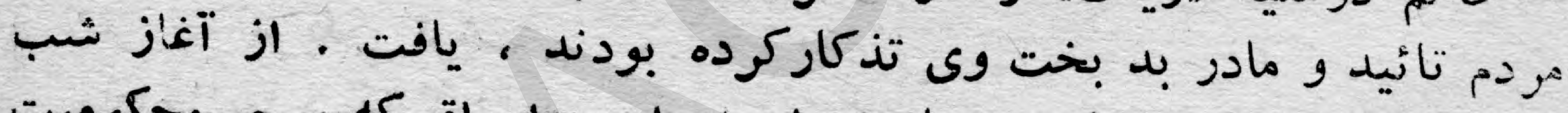

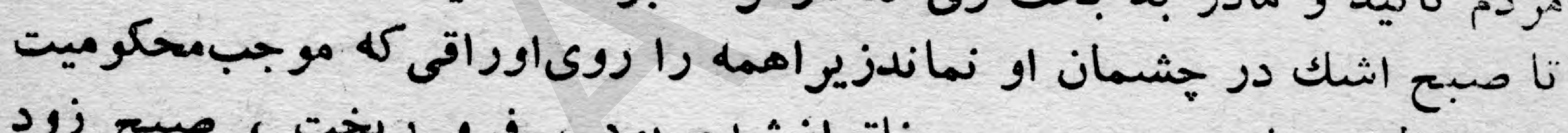

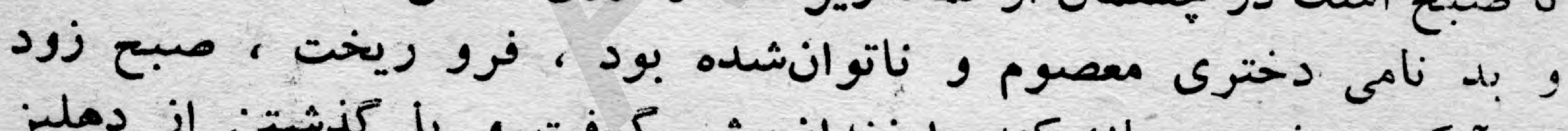

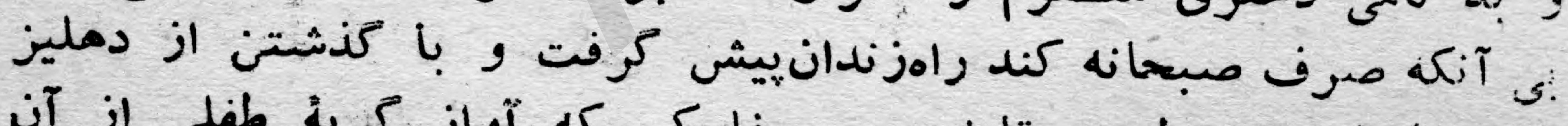

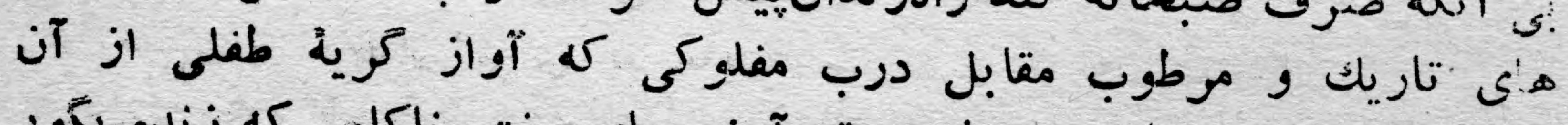

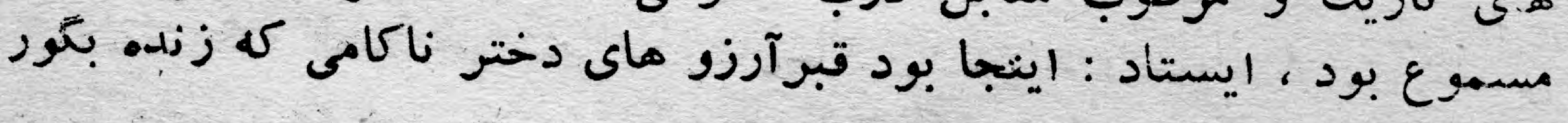

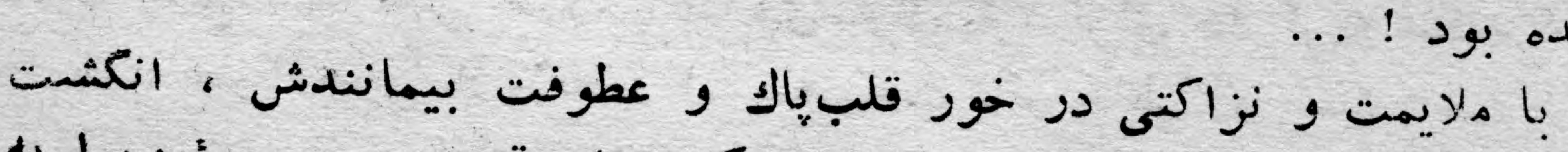

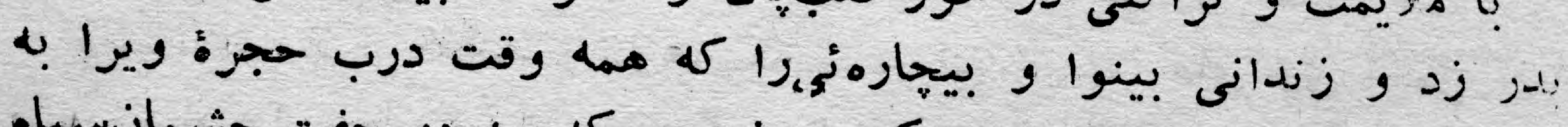

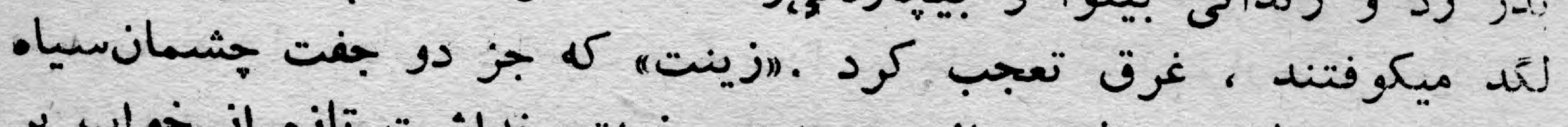

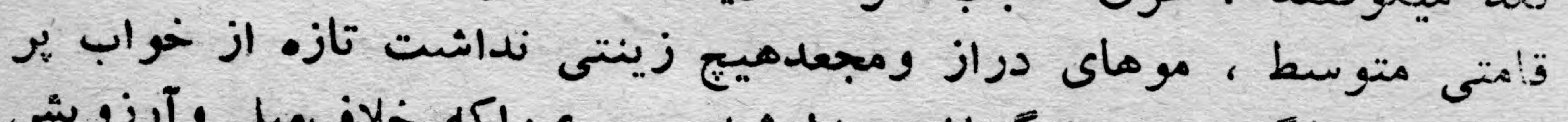

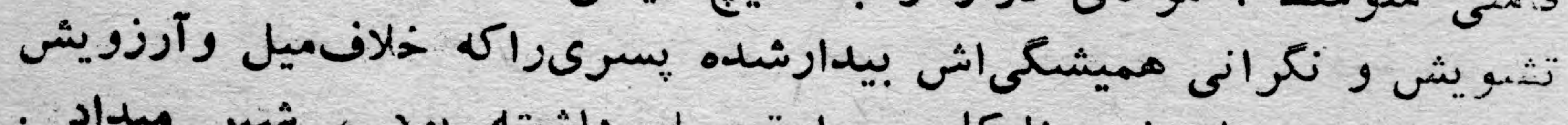

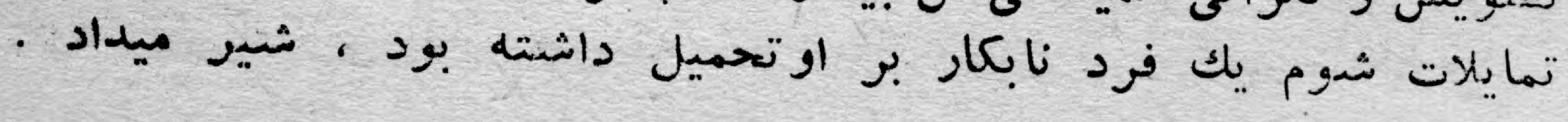




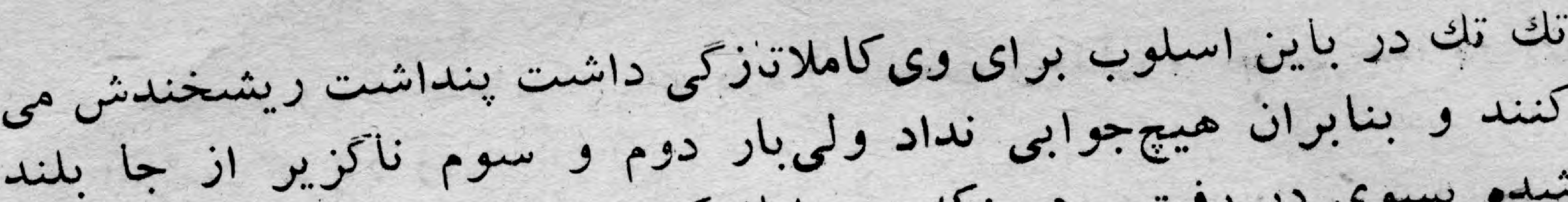

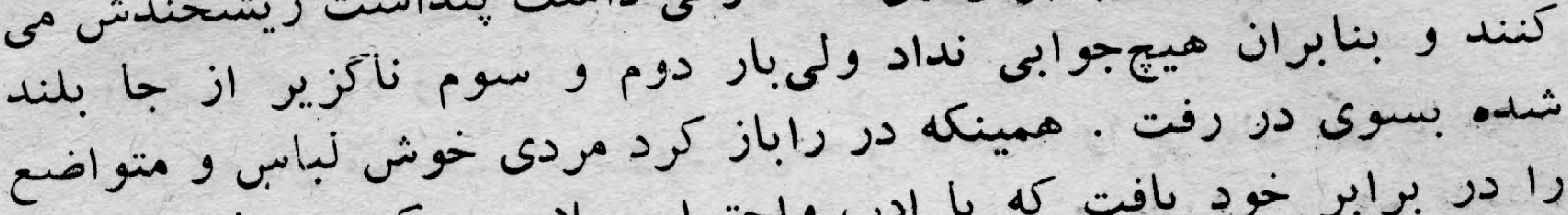

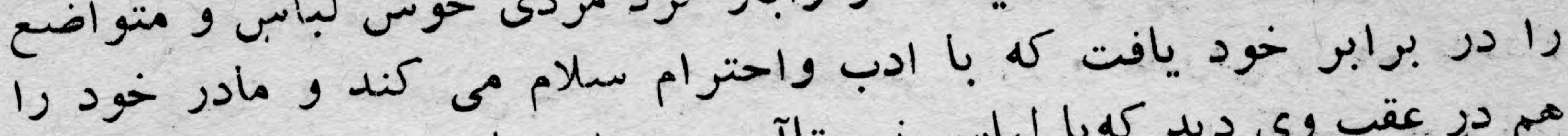

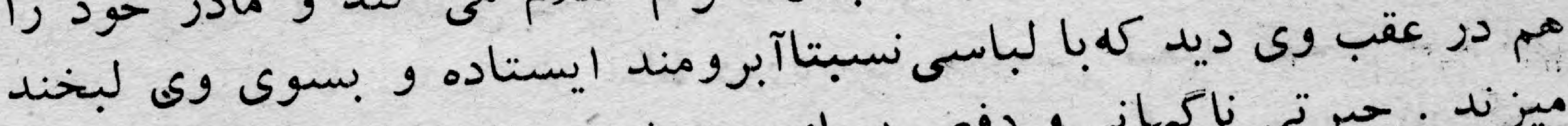

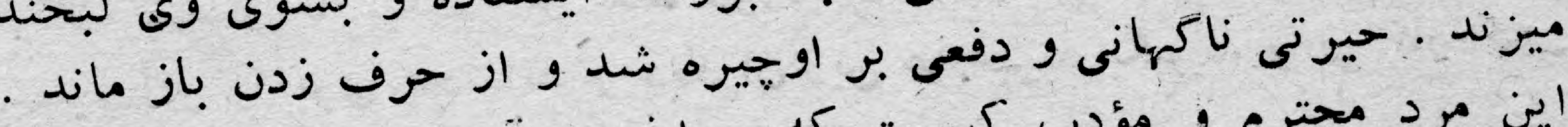

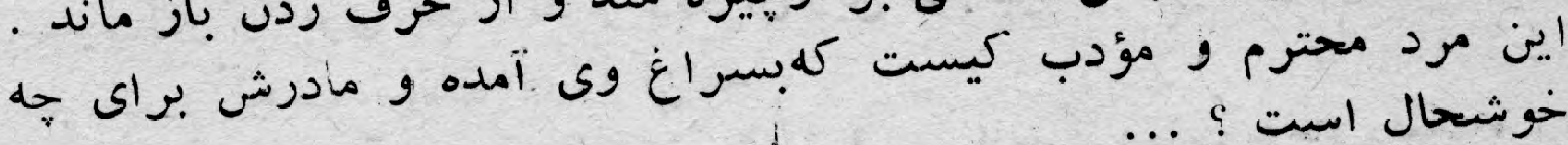

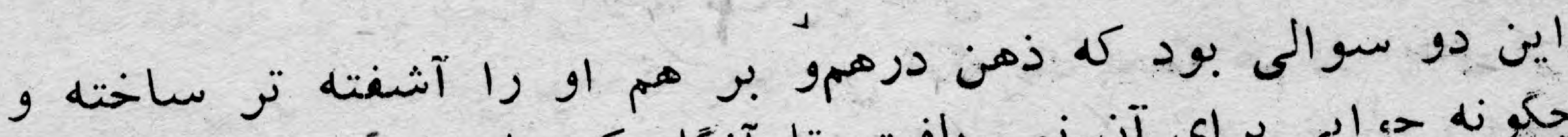

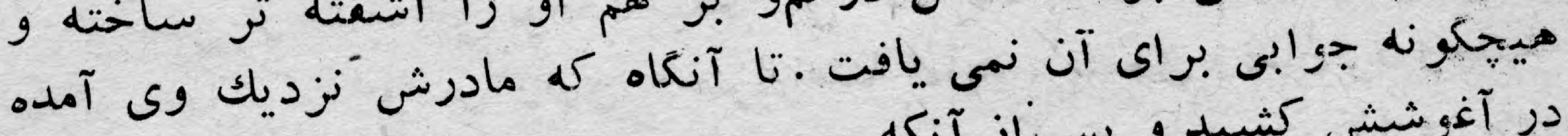

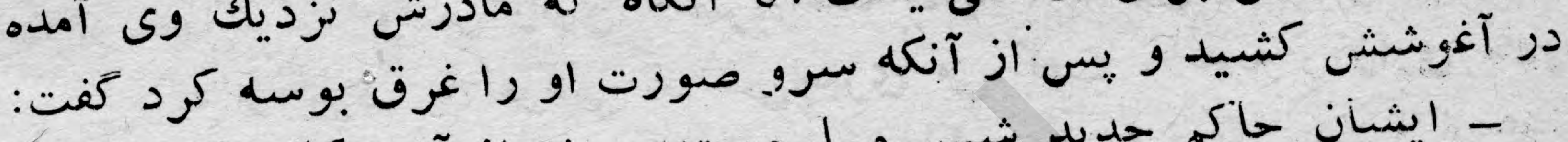

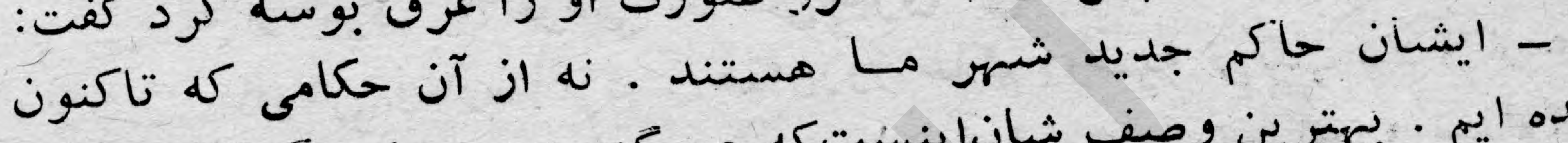

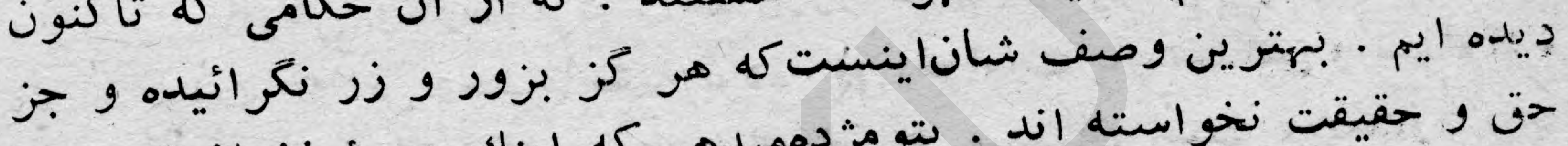

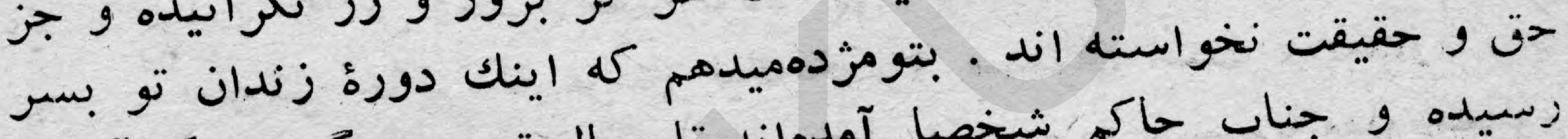

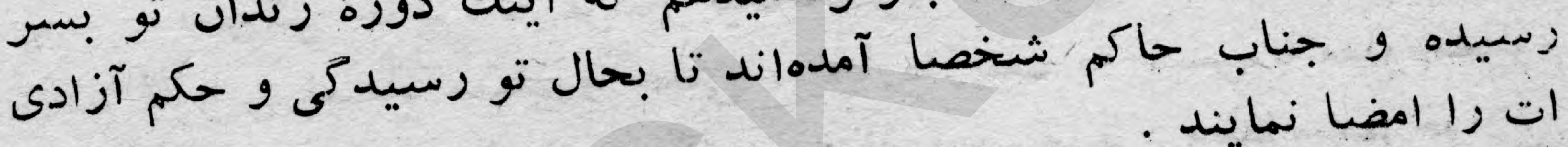

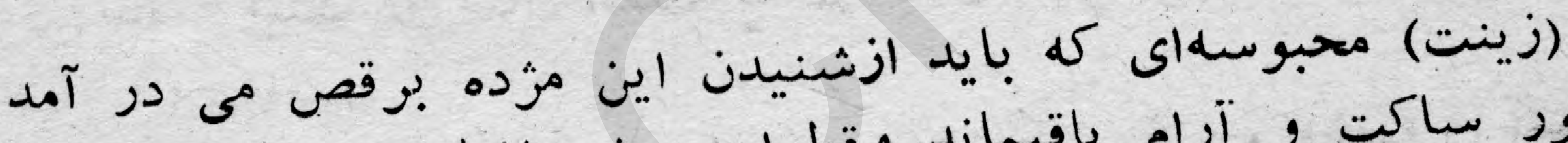

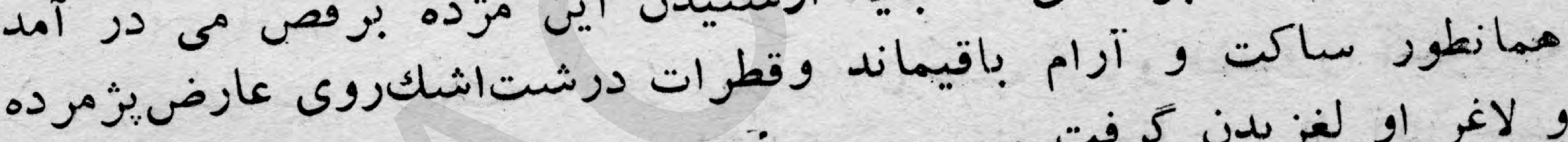

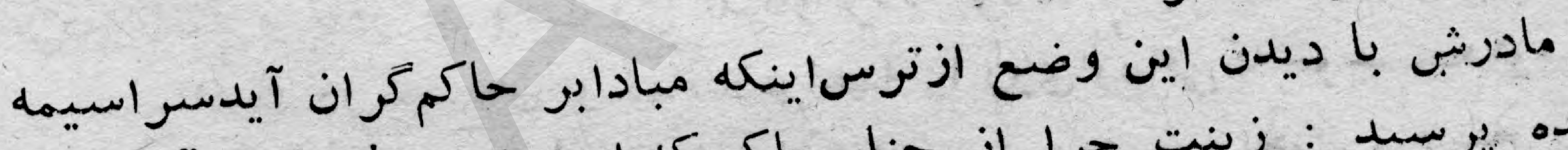

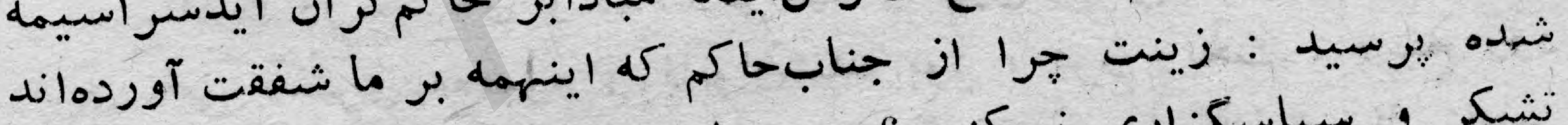

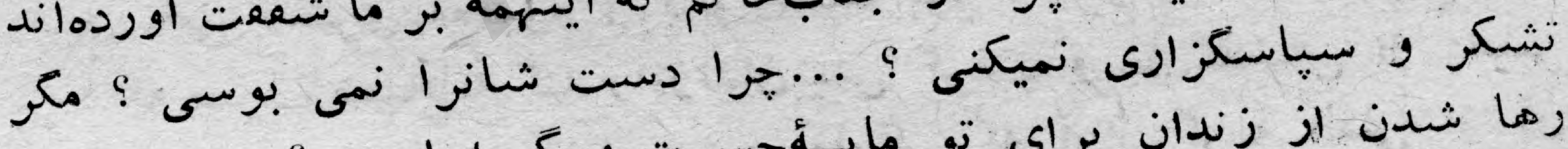

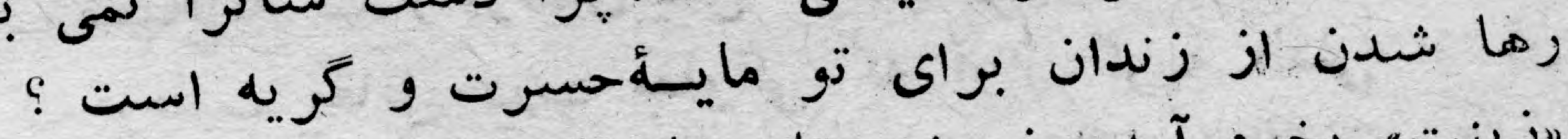

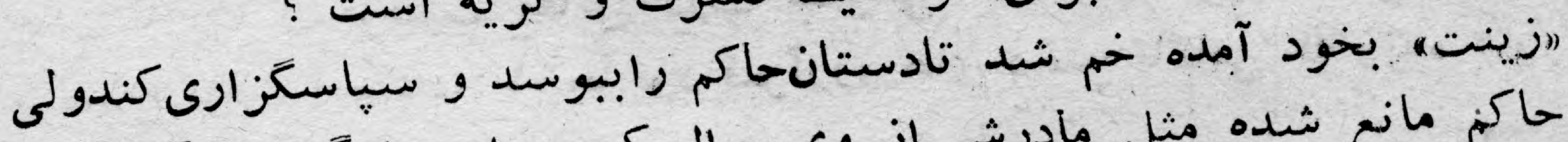

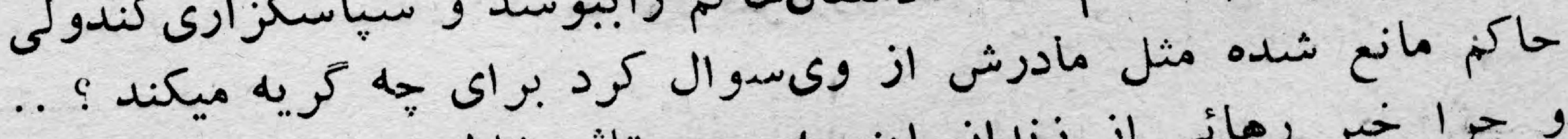

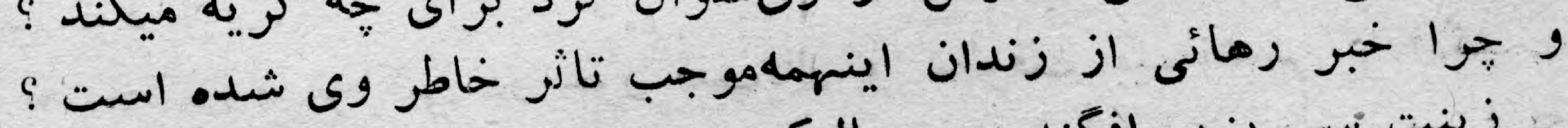

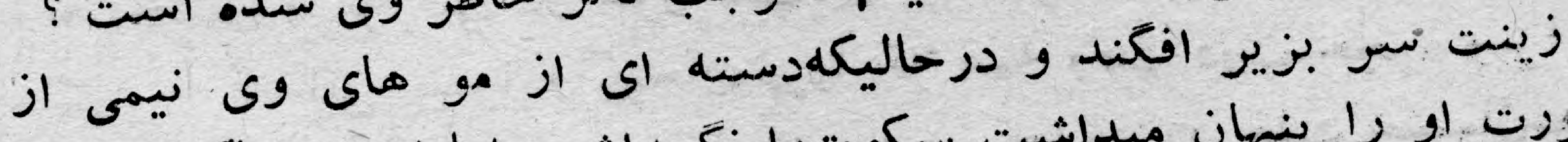

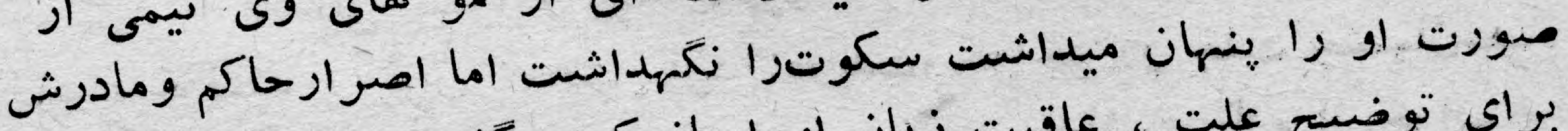

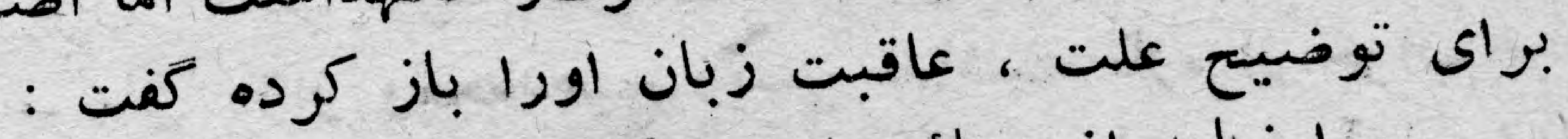

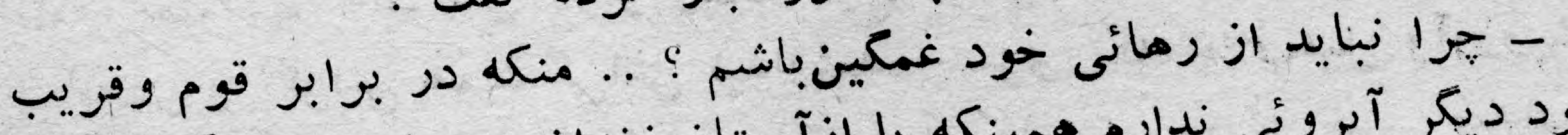

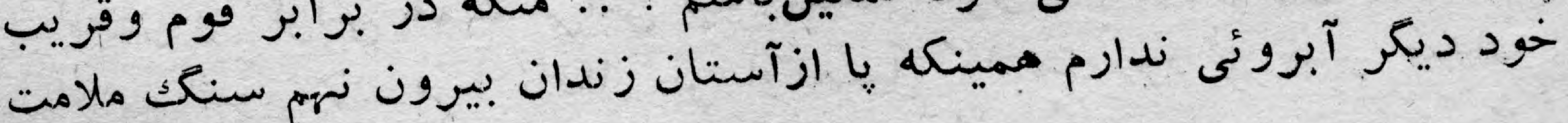




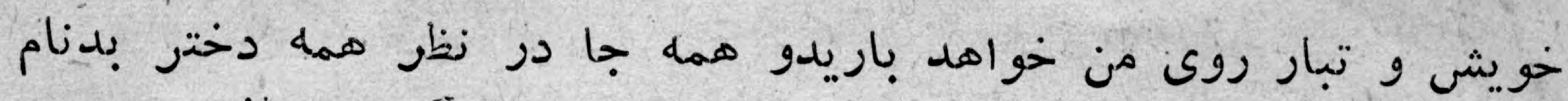

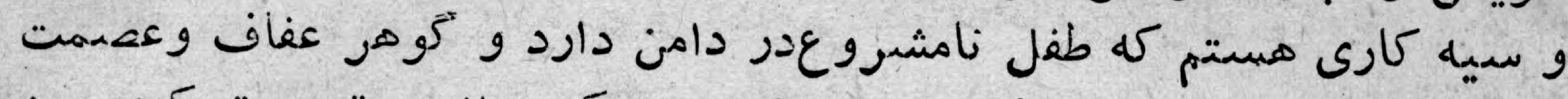

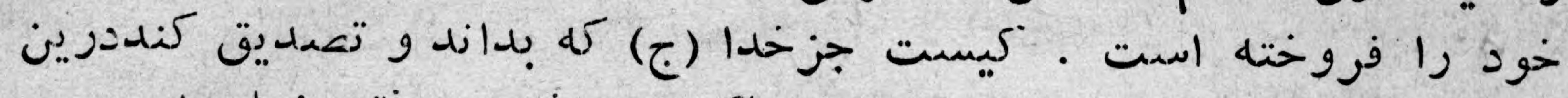

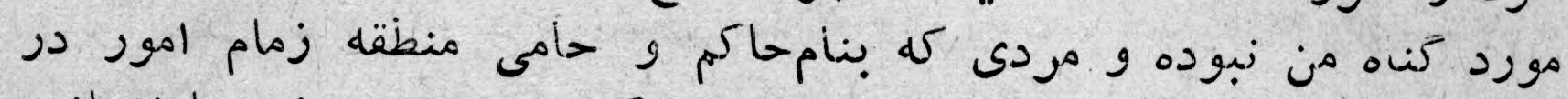

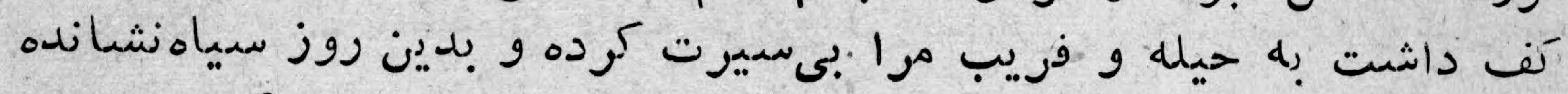

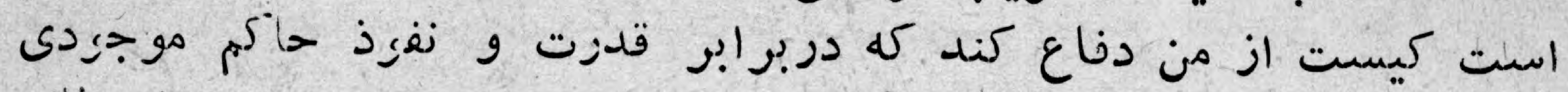

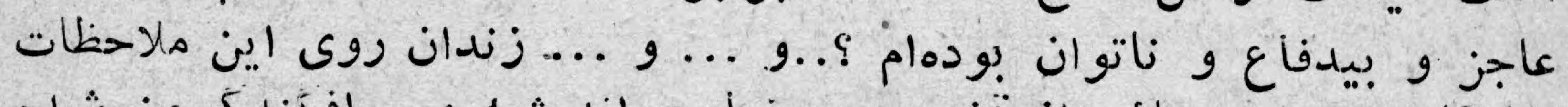

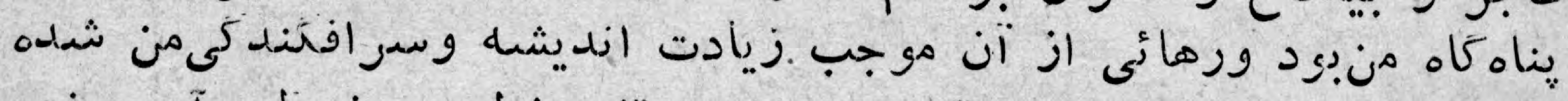

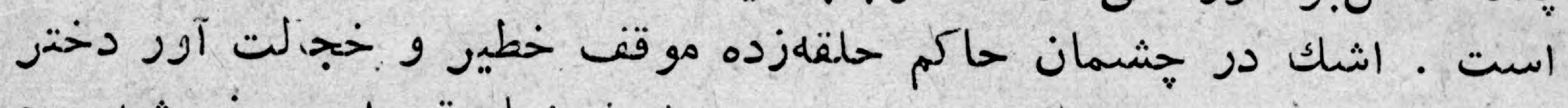

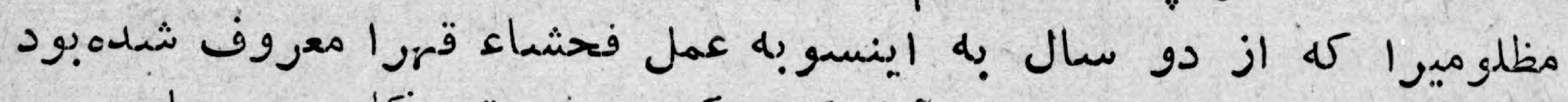

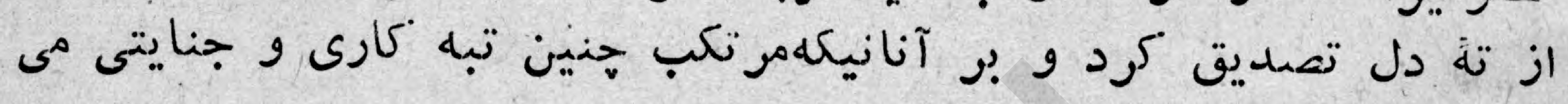

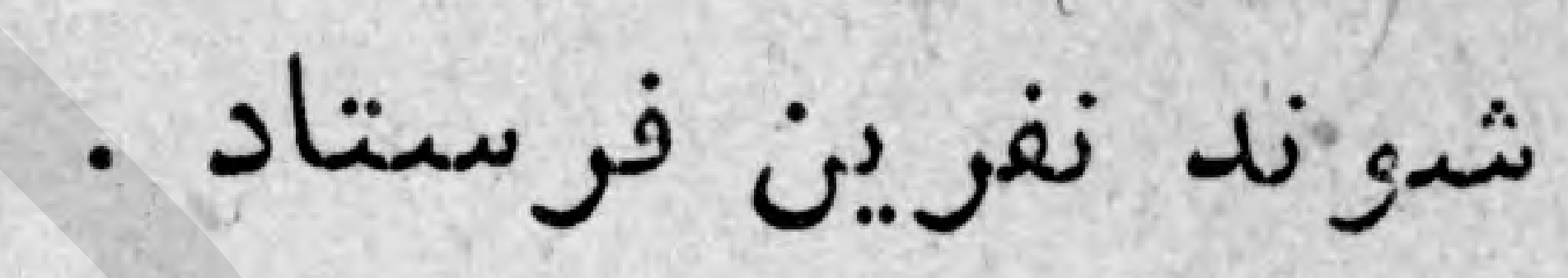

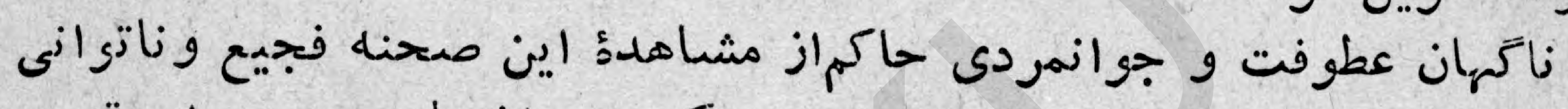

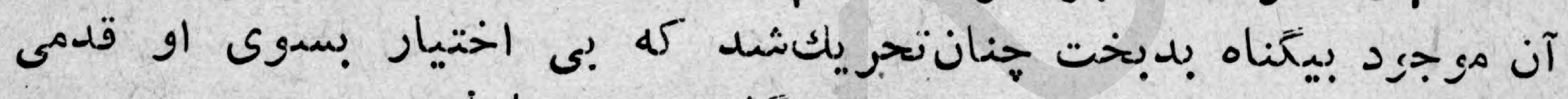

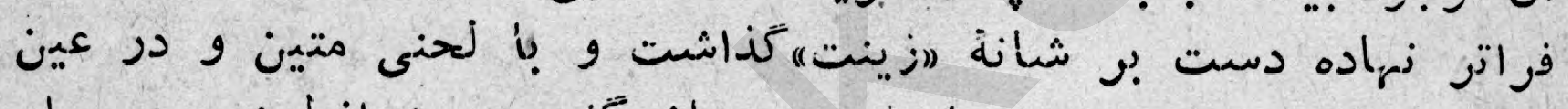

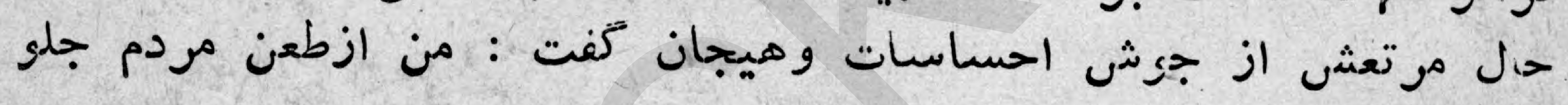

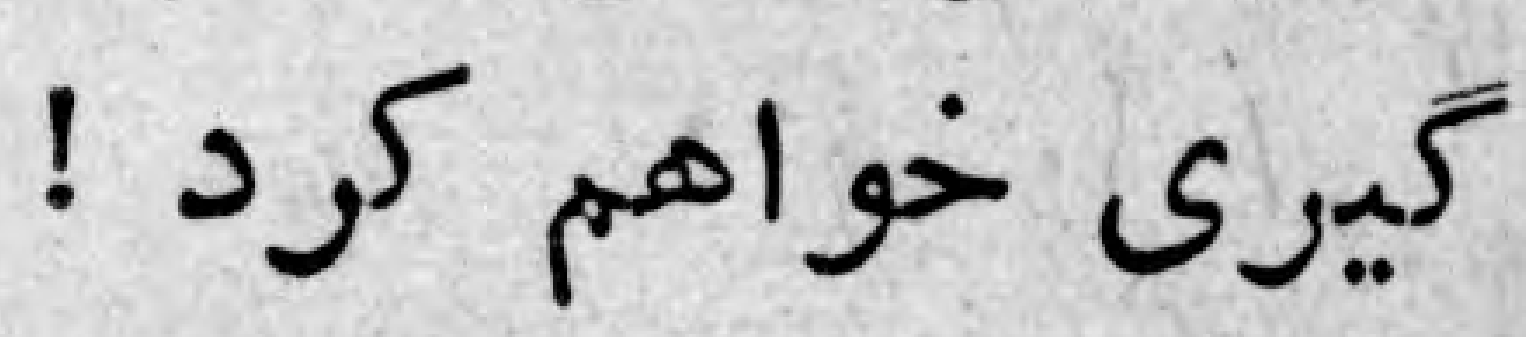

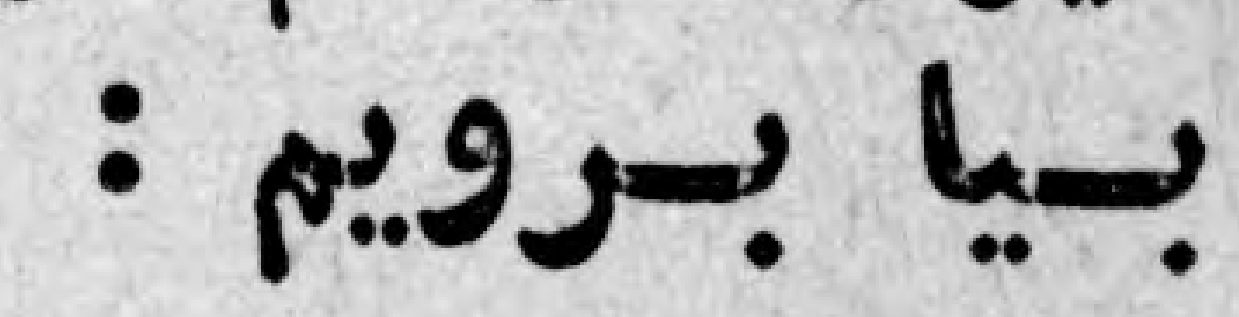$$
\text { doils }
$$

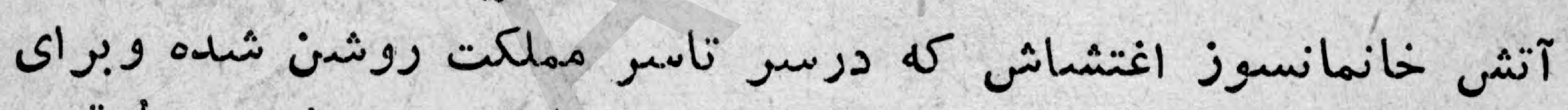

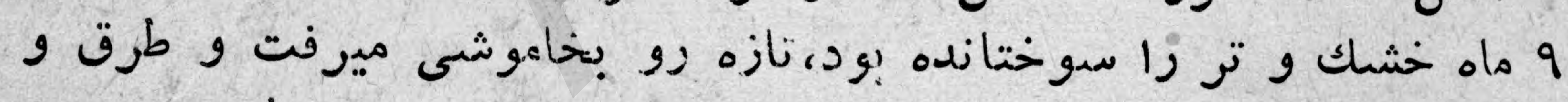

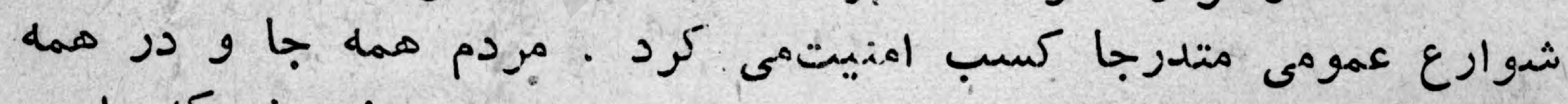

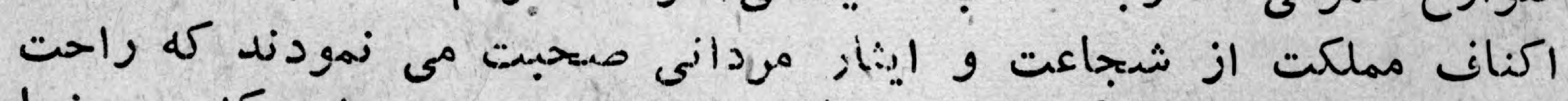

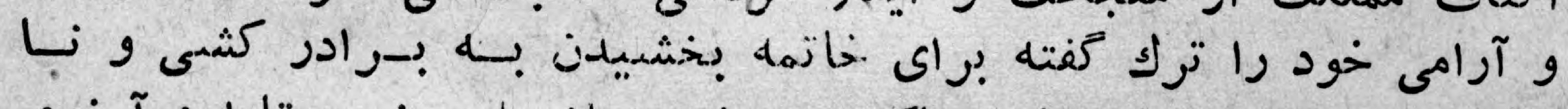

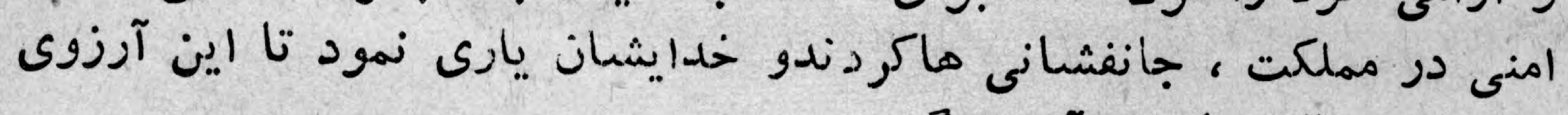

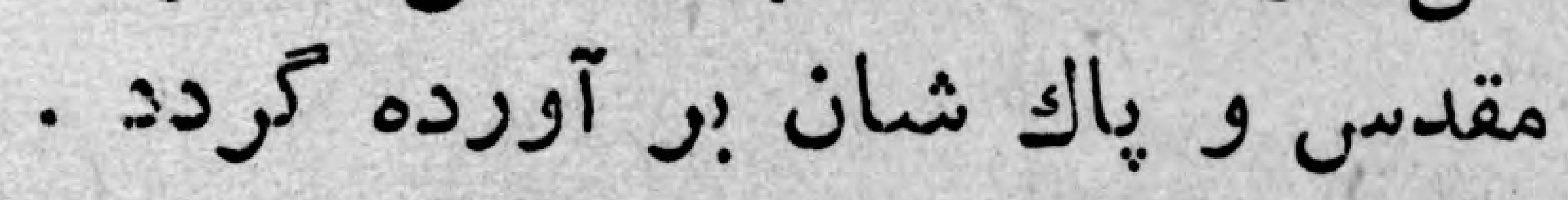

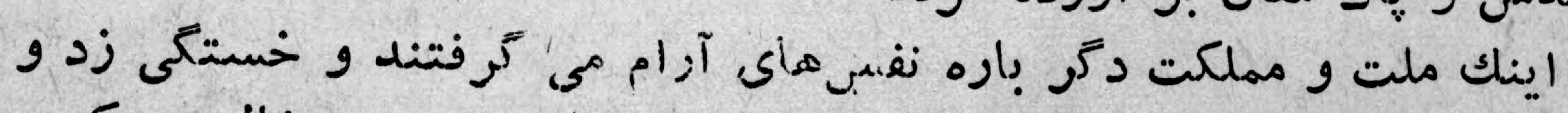

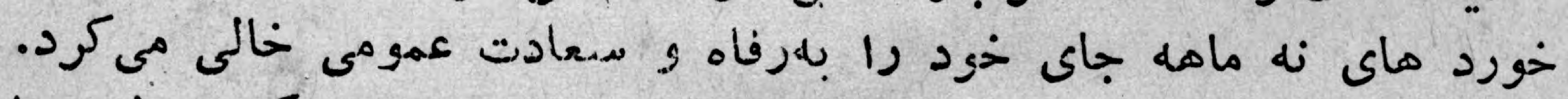

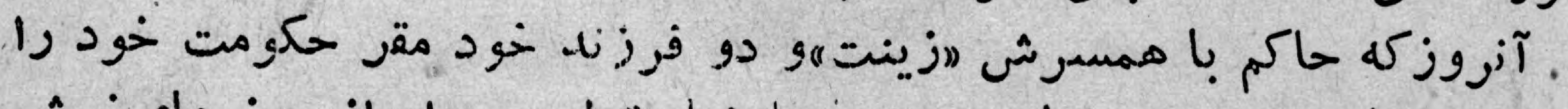

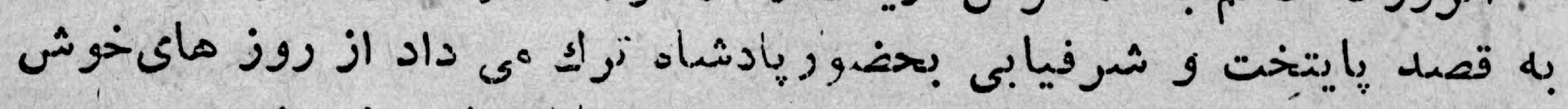

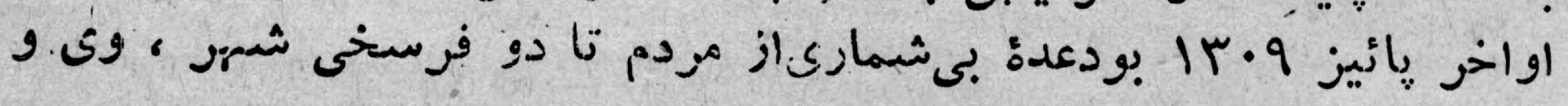




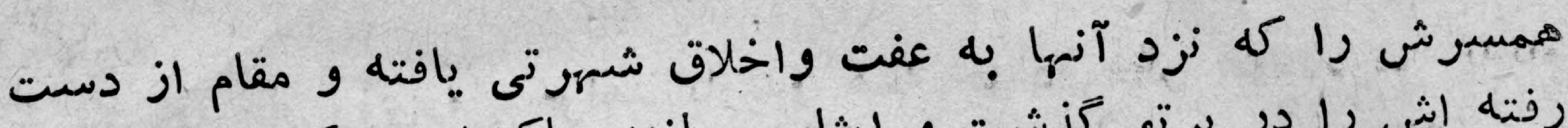

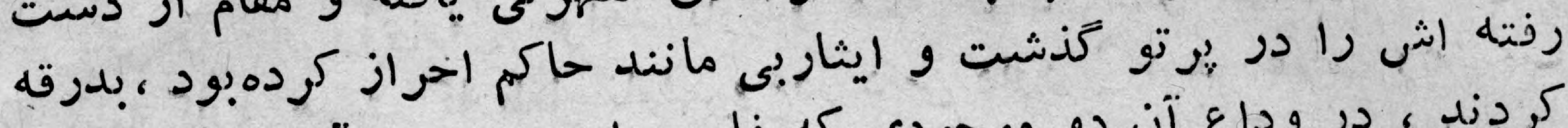

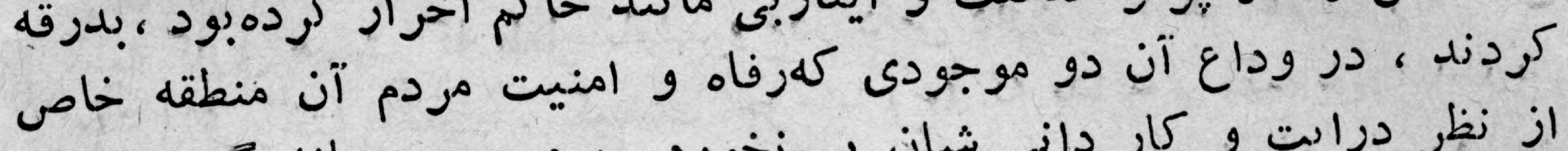

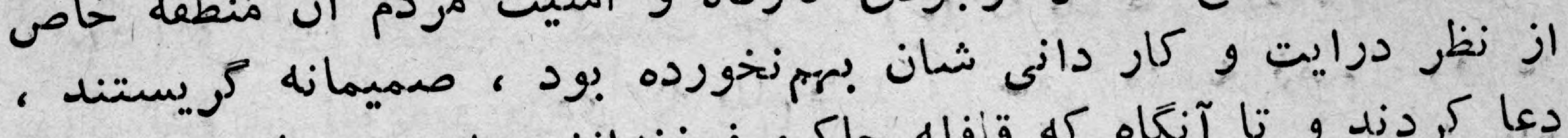

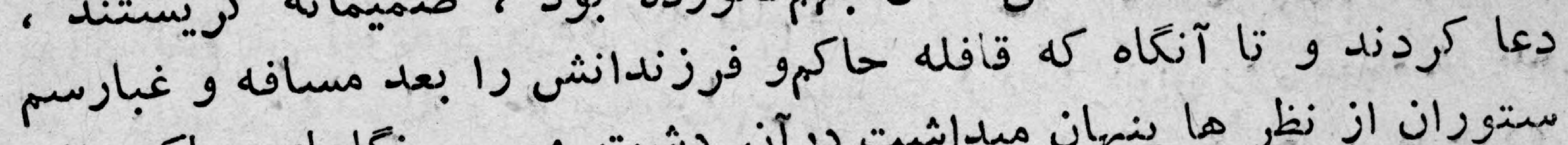

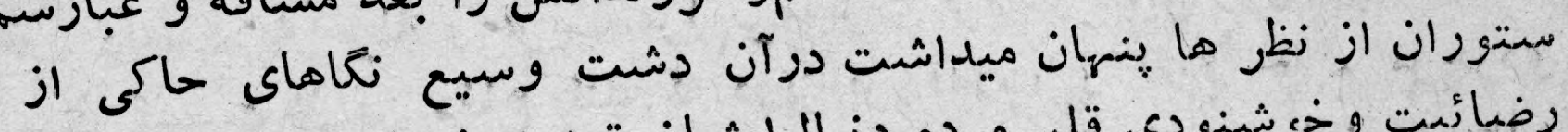

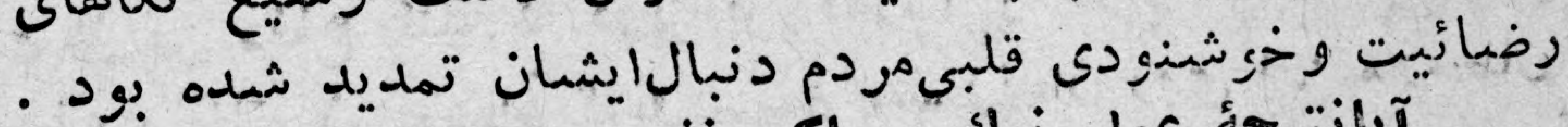

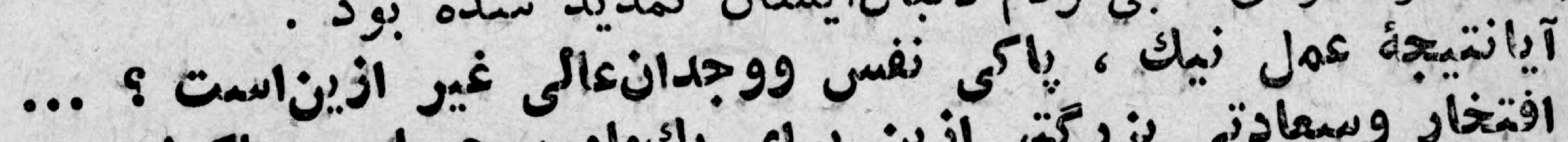

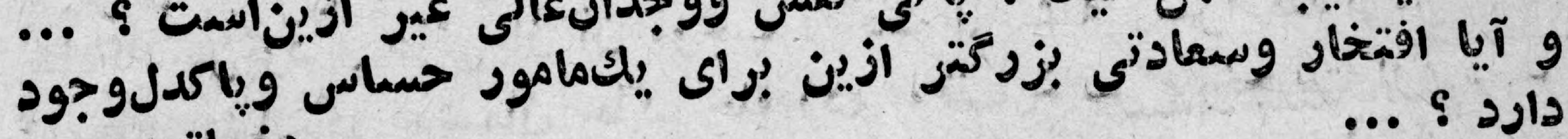

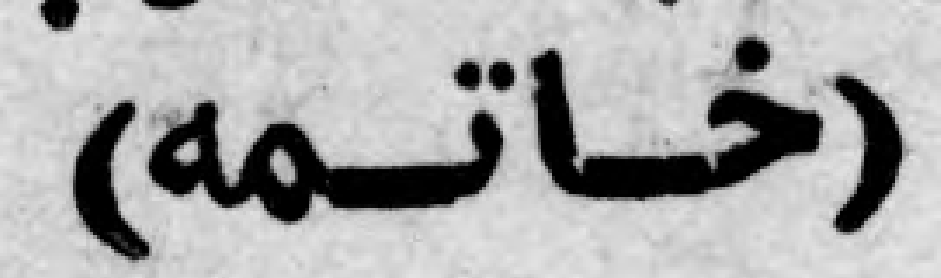
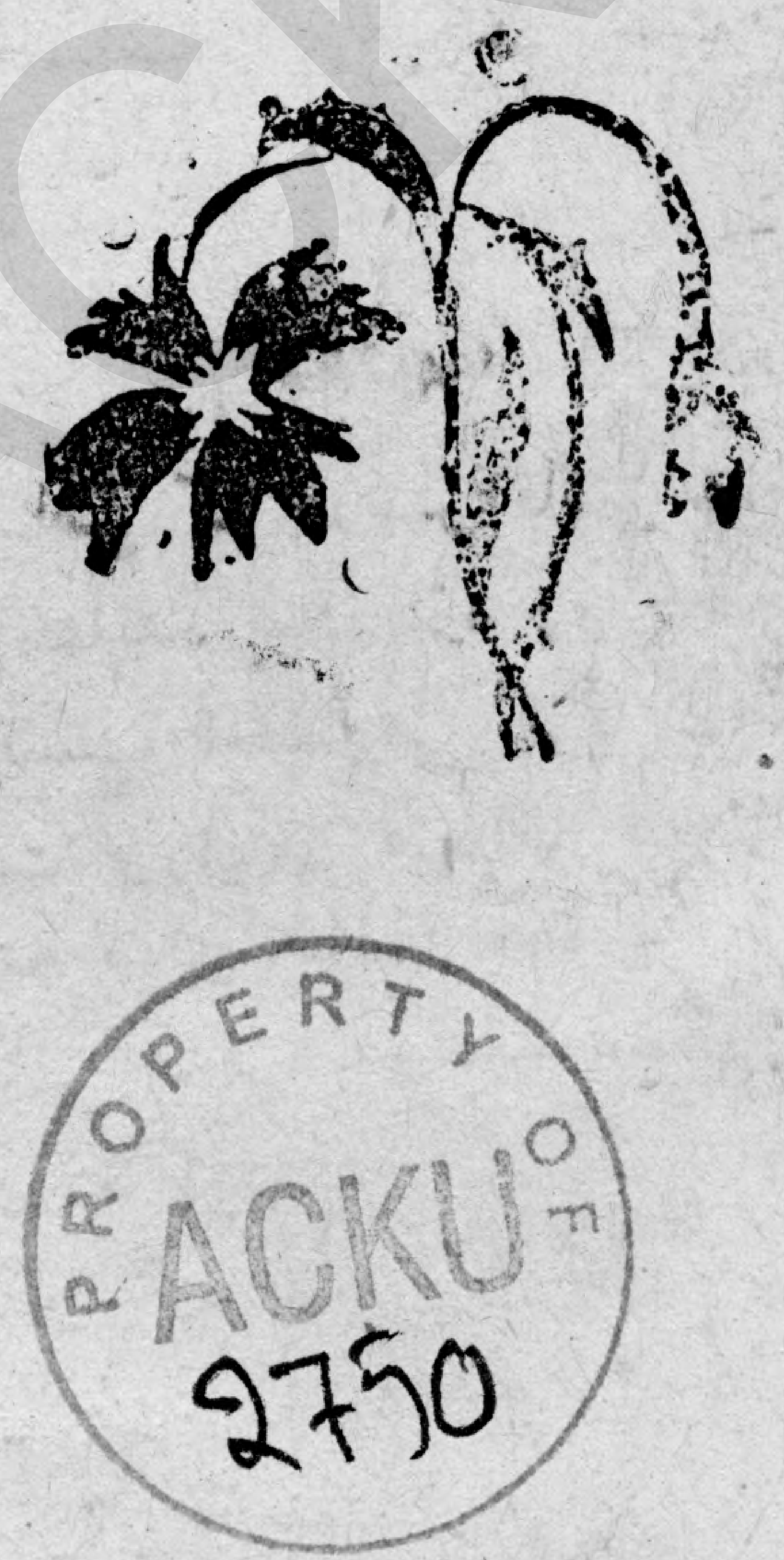
كتبيكه تـاكنون ازطـرف الينهوسسه

بطبع رسيده است

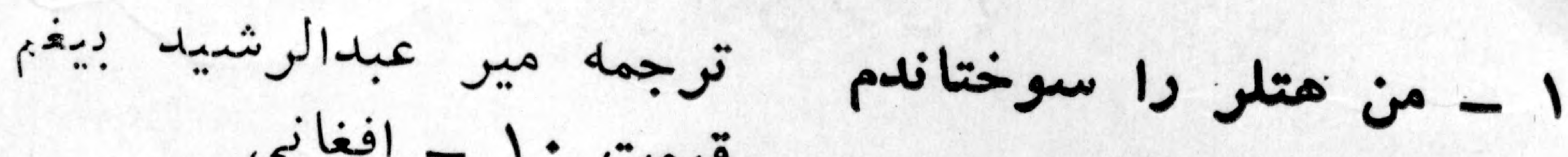

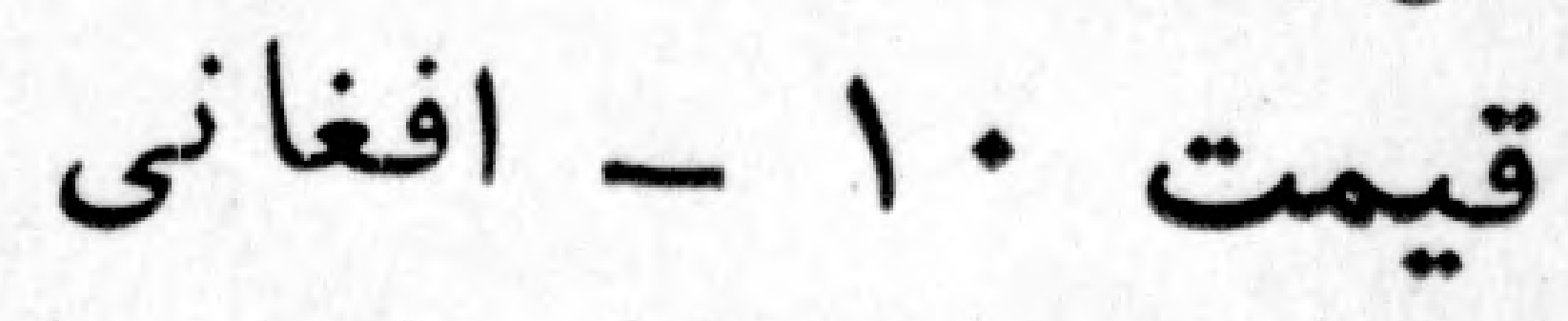

$$
\begin{aligned}
& \text { اثر عبدالرؤف بينوا } \\
& \text { قيمت · } 1 \text { - افغنانى }
\end{aligned}
$$

ترجمه امين برين

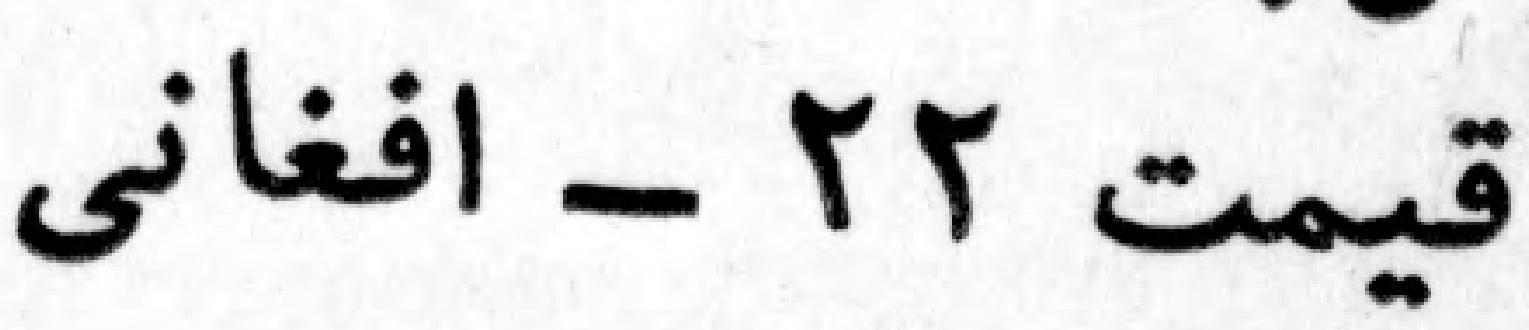

r - r مهيرى

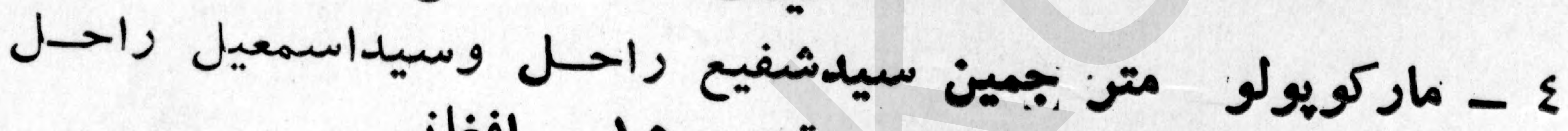
قيمت الحيد 10 - افغانى

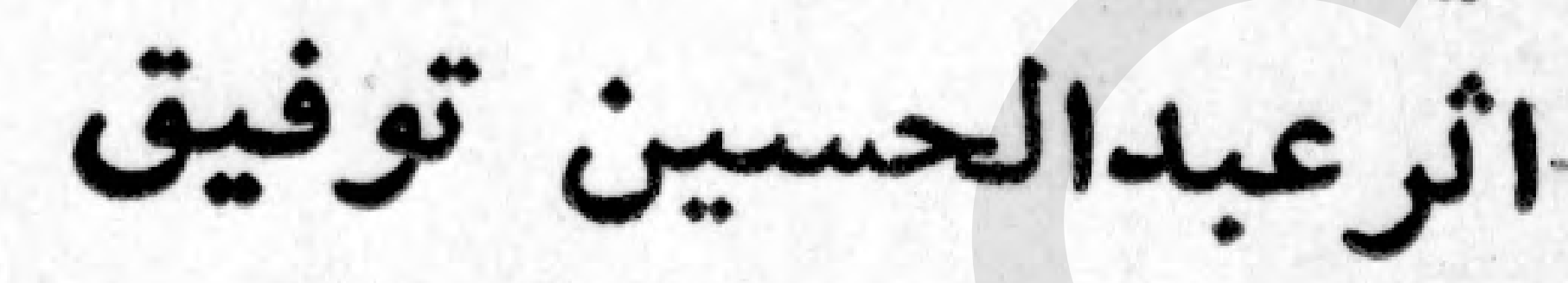

$$
\text { قيمت } 1 \text { - افرغانى تريد }
$$

- م - مرقه ما

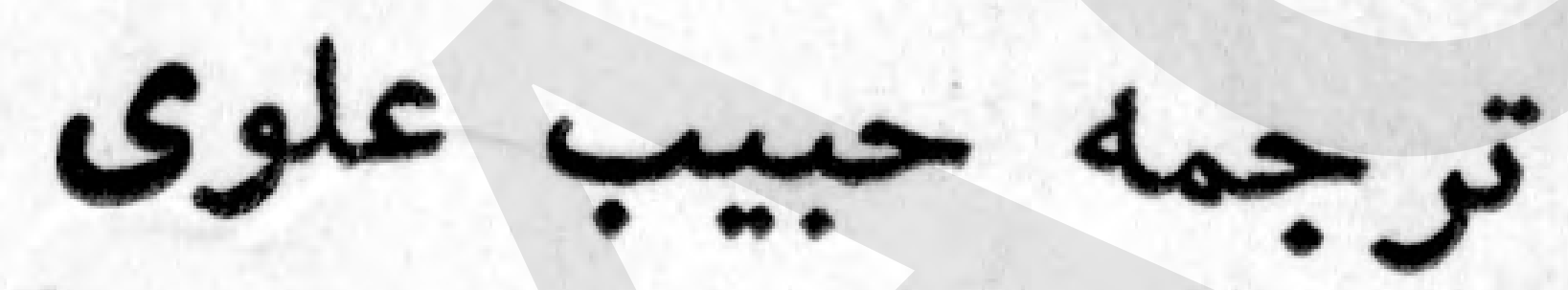

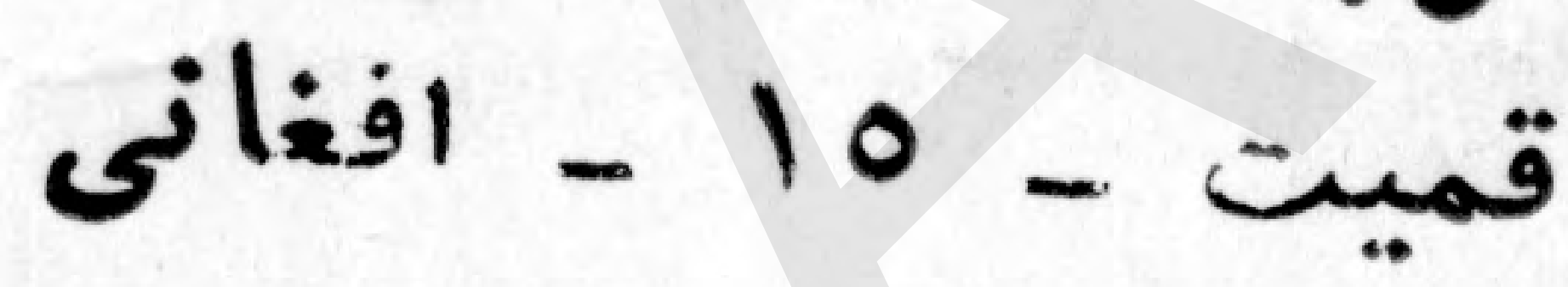

7 - در جستجوى قاتل

$$
\begin{aligned}
& \text { قيمت -1 - افيتانى } \\
& \text { ترجها بشير دال افيق } \\
& \text { قميت } 10 \text { - افغانى }
\end{aligned}
$$

$$
\text { 1- } 1 \text { - نوبهاد آخرينبد }
$$

$$
\text { كتاب هاىزيرضِ }
$$

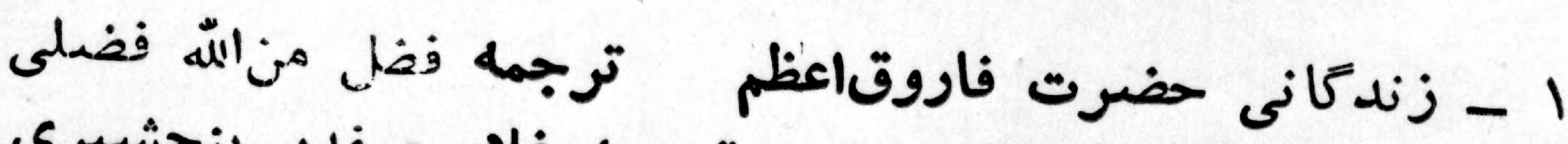

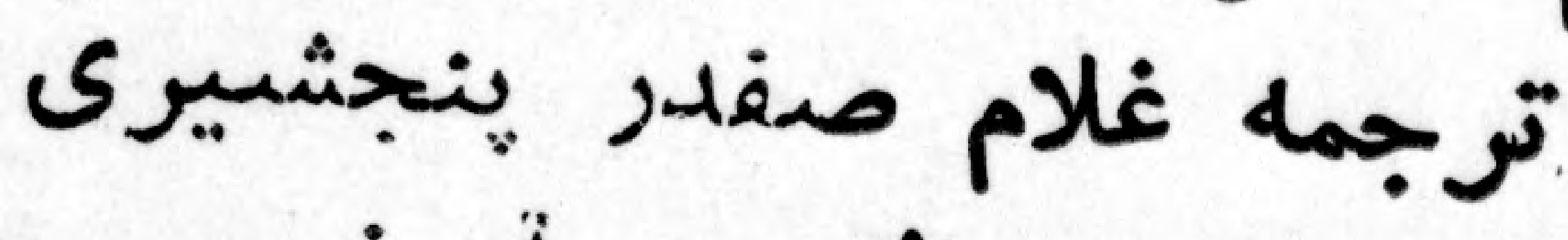

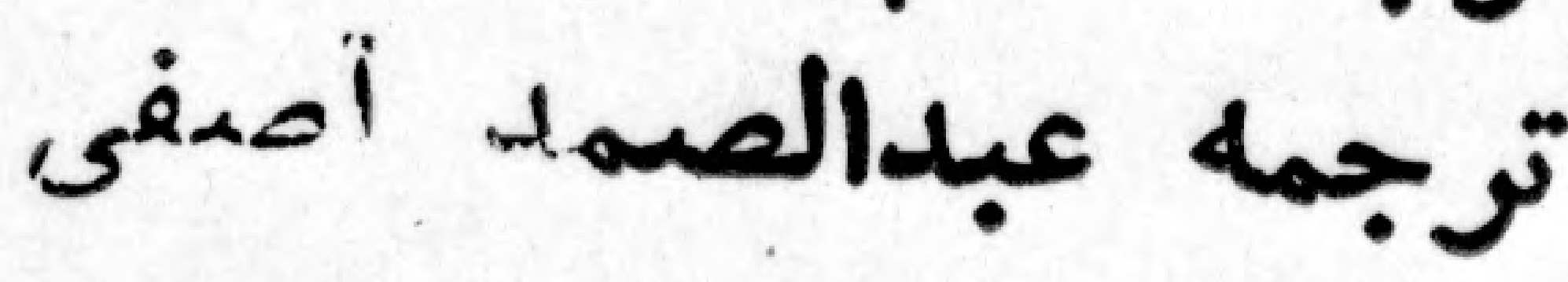

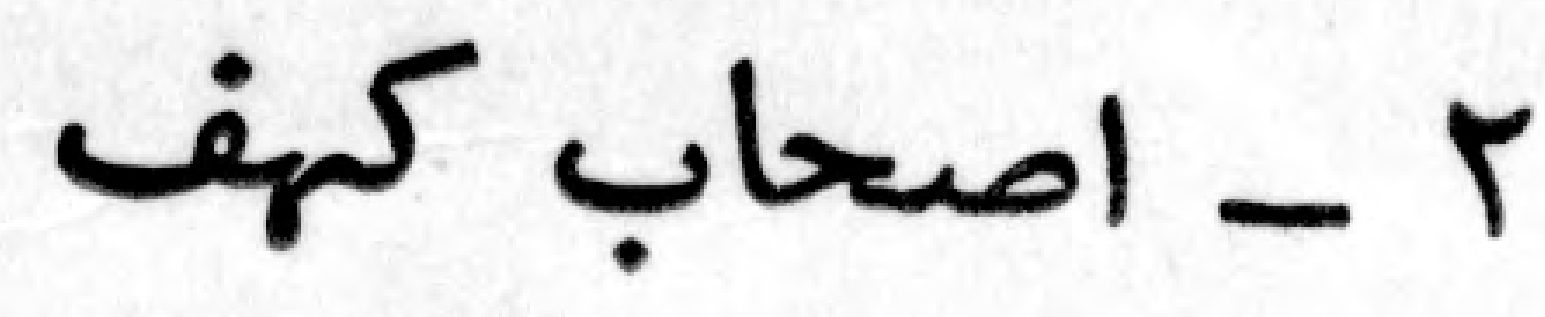

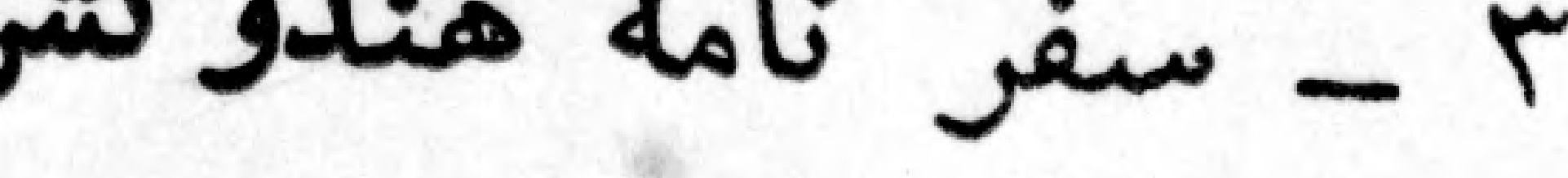
ـ - مركى يك رئيس إمبهود ترجمه امين بوين 
1 - a cis 4 $y-\operatorname{lig}_{0} \cdot \sec 1 t$

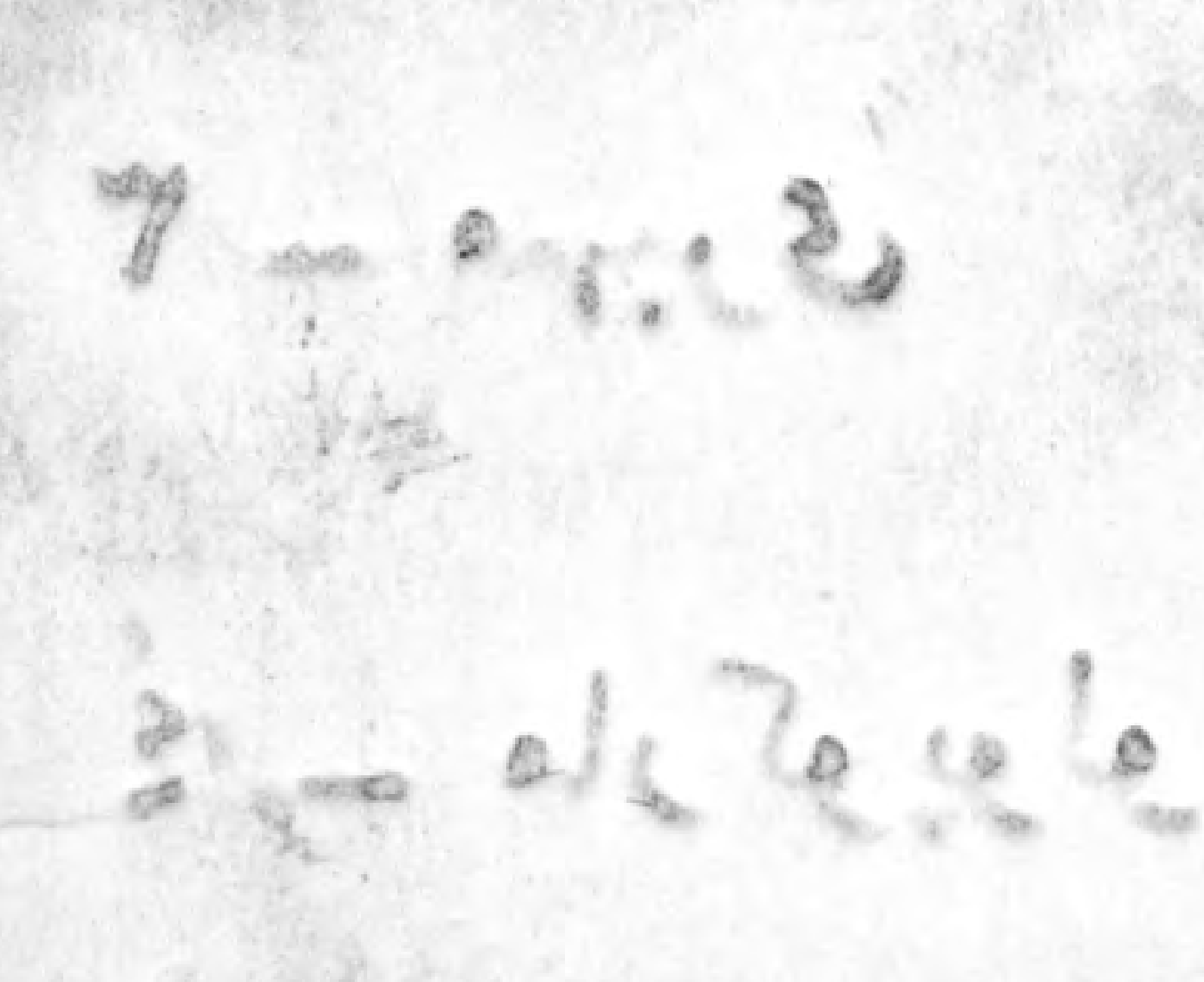

$0-\frac{2}{4}$

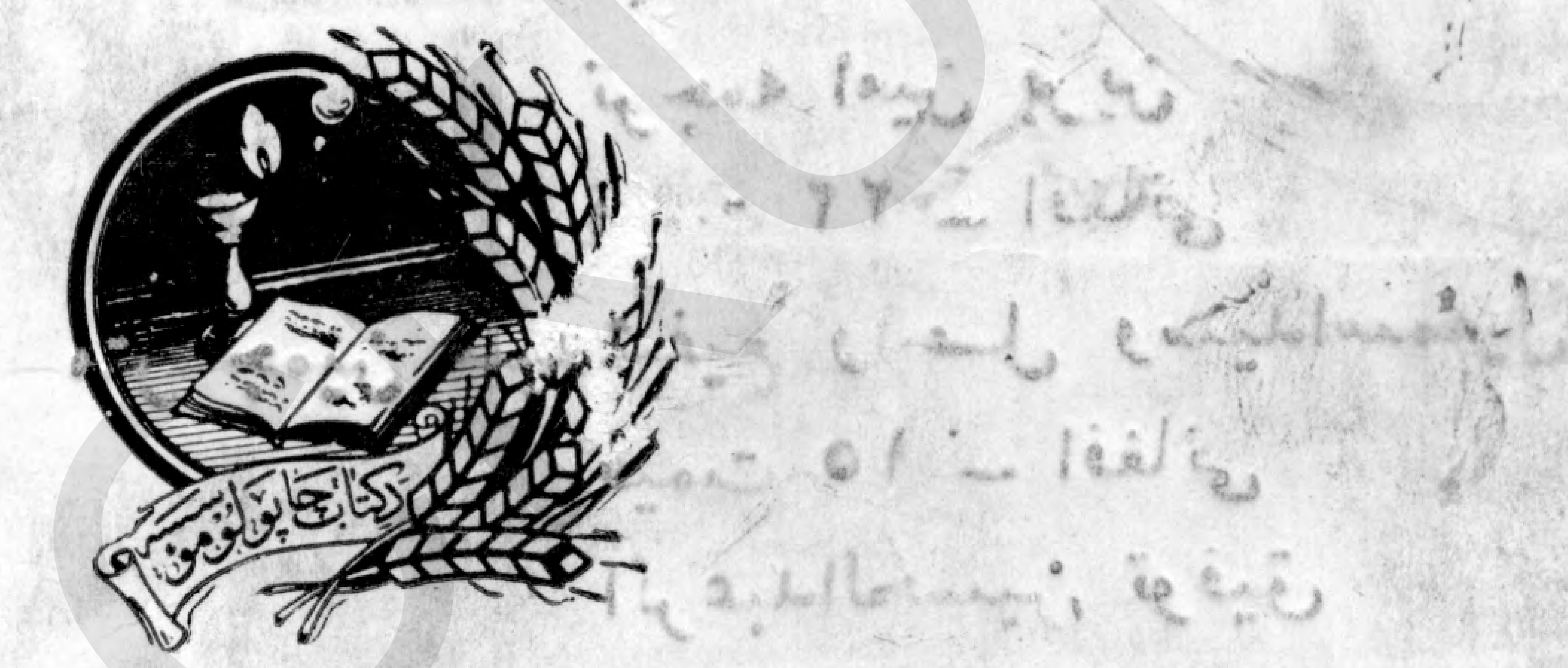

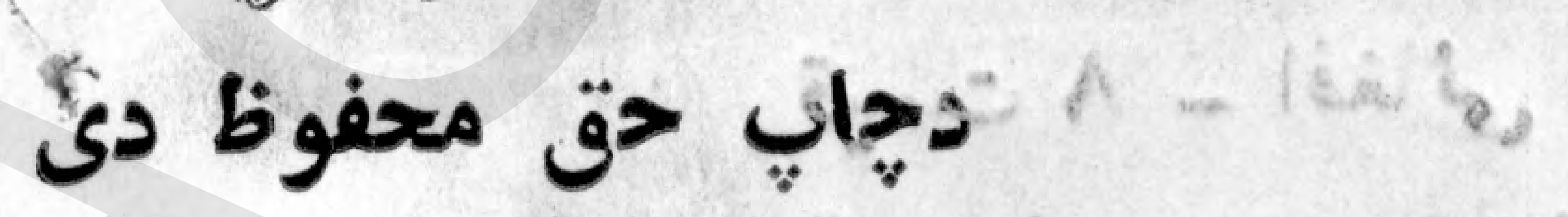

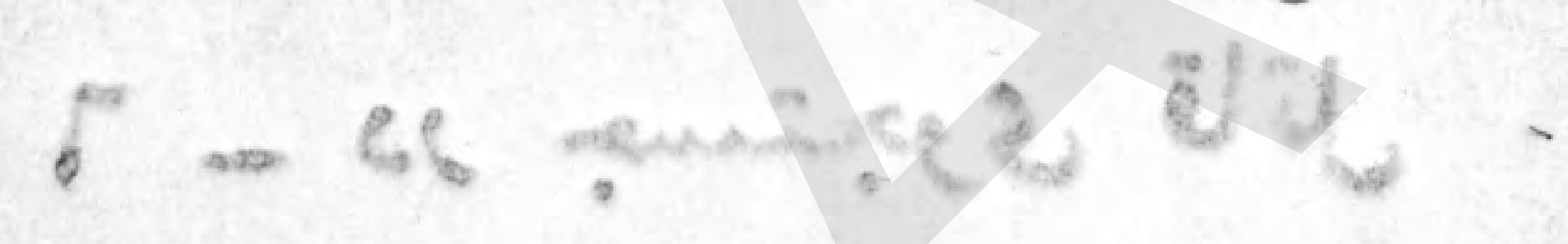

c.

$y-$ ie 4 's

- Pिद्ध一िक

$\operatorname{lom}_{n}$,

$2 a b, a b i a c$

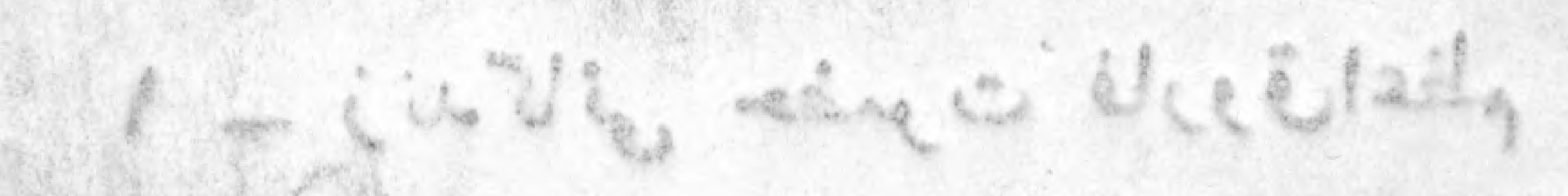

स $1: 1 \operatorname{lom} x+2 ;$

if not sley a

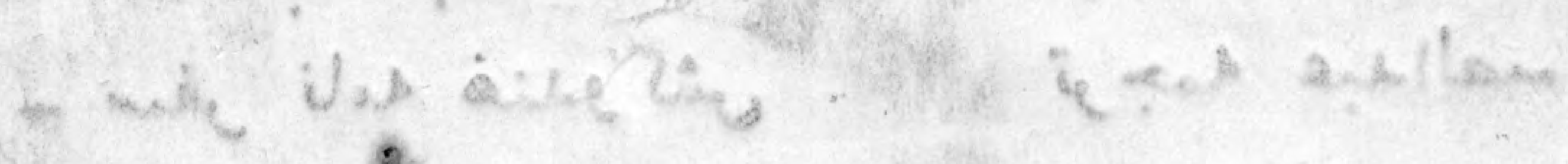

دولى مطبعه

(قيمت - ا- افغانى) 